\title{
Liberdade e indiferença: a "experiência-modelo" jesuítica \\ em cartas de jovens indipetentes espanhóis dos séculos XVI e XVII
}

\author{
Paulo Roberto de Andrada Pacheco
}

Tese apresentada junto ao Programa de Pós-Graduação em Psicologia, do Departamento de Psicologia e Educação da FFCLRP-USP para obtenção do título de Doutor em Ciências. Área: Psicologia.

Ribeirão Preto 


\title{
Liberdade e indiferença: a "experiência-modelo" jesuítica \\ em cartas de jovens indipetentes espanhóis dos séculos XVI e XVII
}

\author{
Paulo Roberto de Andrada Pacheco
}

Orientadora: Marina Massimi

Tese apresentada junto ao Programa de Pós-Graduação em Psicologia, do Departamento de Psicologia e Educação da FFCLRP-USP para obtenção do título de Doutor em Ciências. Área: Psicologia.

Ribeirão Preto 
Autorizo a reprodução e divulgação total ou parcial deste trabalho, por qualquer meio convencional ou eletrônico para fins de estudo e pesquisa, desde que citada a fonte.

Pacheco, Paulo Roberto de Andrada.

Liberdade e indiferença: a "experiência-modelo" jesuítica em cartas de jovens indipetentes espanhóis dos séculos XVI e XVII / Paulo Roberto de Andrada Pacheco; orientadora Marina Massimi. - Ribeirão Preto, 2004. 359 p. : il. $29,7 \mathrm{~cm}$.

Tese, apresentada à Faculdade de Filosofia, Ciências e Letras de Ribeirão Preto / USP - Dep. de Psicologia e Educação..

1. "Experiência de Liberdade". 2. Psicologia Filosófica AristotélicoTomista. 3. Litterae Indipetae - Correspondência Epistolar. 
Para Luigi Giussani 


\section{AGRADECIMENTOS}

É preciso dizer que este trabalho não se teria realizado sem a companhia de amigos que, como pais e mães, me foram guiando desde um distante princípio.

Minha gratidão a Marina Massimi;

a Miguel Mahfoud;

a Pierre-Antoine Fabre e Antonella Romano;

a Alcir Pécora;

a Massimo Cassinari, Cristiano R. A. Barreira, Douglas Pimenta, Sandro Gontijo, Laura Vilela, Mariana Leal, Geisa R. Freitas, Angelita Z. Nedel, Érico e Gabriela Firmino;

a Denise Cremonezi;

ao Grupo de Pesquisa em História das Idéias Psicológicas;

aos colegas da pós-graduação que, na convivência e na liberdade, me foram dados como amigos;

aos funcionários dos arquivos e bibliotecas nos quais trabalhei; aos companheiros da "caverna" - Marcela, Felipe e Anderson;

à CAPES e ao Programa de Pós-Graduação em Psicologia;

e sobretudo a meus pais que, de longe, tudo acompanharam com aquela atenção cheia de querer bem - José Arnoldo Pacheco Ruiz e Anna Maria Andrada de Pacheco.

Non nobis Domine, sed nomini tuo da Gloriam. 


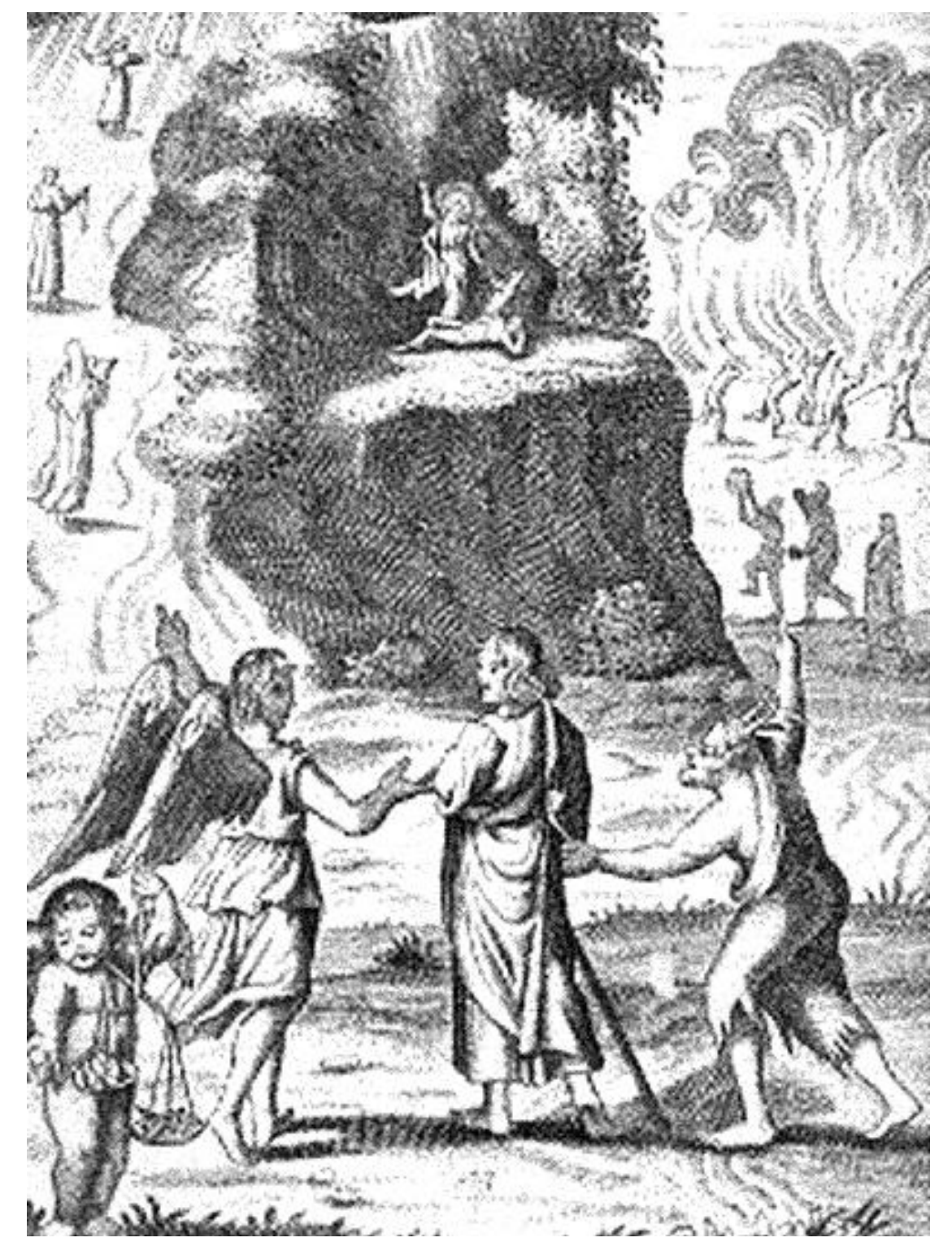

... vea si esto me conviene, que io estoi dispuesto con el favor de

Dios, para obedeçer plenamente en todo. Estando con la indiferençia que mi Instituto me pide, y tiniendo por mas acertado lo que se me mandare, pues sera ordenaçion cierta de Dios, que no quiere ni puede engañarme. Antonio Perez (ARSI, Indipetæ Hispanæ, FG 758, carta n. 43)

Es muy diffiçil con renglones explicar lo que el hombre siente, y lo que el Señor le da a conoçer a ratos Juan Bravo (ARSI, Indipetæ Hispanæ, FG 758, carta n.404)

\footnotetext{
${ }^{1}$ Ilustração dos Exercícios Espirituais de Santo Inácio de Loyola, referente ao momento da "eleição". A ilustração foi retiradas no dia 15 de janeiro de 2003 do site "The Spiritual Exercises in Pictures - Some assistance for the composition of place", no World Wide Web http:// www.faculty.fairfield.edu/ jmac/ SEPICT/ SEPICT.htm.
} 


\section{RESUMO}

\section{Liberdade e indiferença: a "experiência-modelo" jesuítica em cartas de jovens indipetentes espanhóis dos séculos XVI e XVII}

Esta pesquisa tem por objeto as Litterae Indipetae espanholas. As Indipetae são cartas nas quais jovens jesuítas dos séculos XVI e XVII solicitavam ao Padre Geral da Companhia de Jesus o envio em missão nas chamadas "Índias" (como eram genericamente designados os territórios de missão). Estas cartas foram redigidas a partir de normas jurídicas e retóricas estabelecidas pela Ordem e, portanto, são marcadas por diversos topoi cultural e institucionalmente determinados. O objetivo geral é evidenciar as categorias filosóficoretóricas, espirituais, jurídico-institucionais e "psicológicas" que sustentam - nas cartas - o que denominamos uma "experiência de liberdade". Também interessa localizar as raízes históricas dos conceitos de "liberdade" e "experiência" na cultura jesuítica, no período do Generalato do Padre Cláudio Aquaviva (1581-1615), a partir do estudo de documentos representativos do modus cogitandi próprio dos jesuítas (basicamente a filosofia moral e a retórica do XVI-XVII), do modus operandi (sobretudo as normas espiritual e institucional) e do que descreveu-se como a prescrição de uma "experiência-modelo" (os textos de espiritualidade). Interessa também descrever a "experiência de liberdade" a partir de três grupos de lugares-comuns identificados nas cartas: "conhecimento de si", "obediência" e "consolação". As demais fontes utilizadas foram: o Manual Conimbricense sobre a Ética a Nicômaco, escrito em 1593, pelo padre jesuíta Manuel de Góis, com vistas ao ensino de filosofia moral no Colégio das Artes de Coimbra e nos colégios da Companhia no Brasil; os Exercícios Espirituais, o Diário de Moções Interiores e o Relato de Santo Inácio de Loyola; o texto das Constituições jesuíticas, Documentos de Fundação e algumas das Cartas de Inácio; e, finalmente, alguns textos de espiritualidade, escritos por padres jesuítas entre os anos de 1583 e final da década de 1630. A escolha do recorte histórico - o período de influência do Generalato do Padre Cláudio Aquaviva - justifica-se pela importância desse governo no que se refere ao estabelecimento gradual de uma espiritualidade com traços propriamente 
jesuíticos e de uma legislação unificadora e atenta à manutenção do ideal e do espírito autênticos de Inácio de Loyola. O método utilizado pode ser assim descrito: 1) transcrição do corpus documental de 26 Indipetae (todas espanholas, escritas entre 1583 e 1609), sendo 23 cartas de autores diferentes, distribuídas no período referido e 3 de um mesmo autor; 2) levantamento bibliográfico e documental no Brasil e na Europa; 3) leitura e análise dos documentos, a fim de localizar as referências aos conceitos de "liberdade" e "experiência"; 4) leitura e análise das cartas com os critérios "aristotélico-tomistas" fornecidos pelos demais documentos, descrevendo as cartas num primeiro momento estruturalmente, em seguida dinamicamente. Pela análise desses documentos, pode-se dizer que o aparelho filosófico jesuítico fornece um conceito de "liberdade" que é atualizado como "indiferença" e dado como elaboração individual nas cartas Indipetae. A leitura dessas cartas permite compreender como os jesuítas utilizavam os instrumentos de ordenação da vida interior, na medida em que, tendo se apropriado de uma tradição recebida através dos textos de espiritualidade expressamna num ato como o de escrever a carta Indipeta. Para além dos aspectos retórico e institucional que regravam o ato de escrever, as Indipetae podem ser descritas como o espelho que reflete aquele indivíduo que assumiu para si um modus vivendi particular. Também a partir da leitura desses documentos, foi possível compreender o conceito de "experiência" tal como a tradição jesuítica dos séculos XVI e XVII a entende e que pode ser exemplificado pela frase de Inácio: "gustar de las cosas internamente", considerando-se o homem como uma totalidade, isto é, sem solução de continuidade entre fé e razão, entre condição espiritual e psicológica.

Palavras-chave: experiência, liberdade, Companhia de Jesus, Indipetae - correspondência epistolar. 


\section{ABSTRACT}

\section{Liberty and indifference: the Jesuitical "experience-model" in letters of young Spanish indipetentes of $16^{\text {th }}$ and $17^{\text {th }}$ Centuries}

This research has for object the Spanish Litterae Indipetae. Indipetae are letters in which young Jesuits of $16^{\text {th }}$ and $17^{\text {th }}$ Centuries have requested the General Priest of the Society of Jesus the sending in mission to the called "India" (namely, mission territories that they were assigned). These letters were written from legal and rhetorical norms established by the Order and thus marked by diverse topoi culturally and institutionally determined. The general objective is to evidence the philosophical-rhetorical, spirituals, legal-institucional and "psychological" categories that support - in the letters - what we call a "experience of liberty". Also it interests to locate the historical basis of the concepts of "liberty" and "experience" in the Jesuitical culture, in the period of the Govern of the General Priest Claudio Aquaviva (1581-1615), from the representative document study of the proper modus cogitandi of the Jesuits (basically the moral philosophy and the rhetoric of $16^{\text {th }}$ and $17^{\text {th }}$ Centuries), of the modus operandi (over all the norms institucional and spiritual) and of that one described as the prescription of a "experience-model" (the spiritual texts). It also interests to describe the "experience of liberty" from three identified groups of common-place in the letters: "knowledge of itself", "obedience" and "consolation". The used sources had been the following ones: Manual Conimbricense sobre a Ética a Nicômaco, writing in 1593, by the Jesuit Priest Manuel de Góis, with the intent of the education of moral philosophy in the Coimbra College of Arts and in the colleges of the Society in Brazil; Spirituals Exercises, Daily of Interior Motions and the The Story of the Pilgrim by Saint Ignatius of Loyola; text of the Jesuitical Constitutions, Documents of Fondation and some of the Letters by Ignatius; and, finally, some texts of spirituality, written by Jesuit priests between the years of 1583 and final one of the decade of 1630. The choice of the historical clipping - the period of influence of the Govern of the General Priest Aquaviva - is justified for the importance of this government related to the gradual establishment of a spirituality with properly Jesuitical 
traces, and an unifying legislation that intent to the maintenance of the authentic ideal and spirit of Ignatius of Loyola. The used method can thus be described: 1) transcription of the corpus of 26 Indipetae (all Spaniard, writings between 1583 and 1609), being 23 letters of different authors, distributed in the cited period, and 3 of one same author; 2) bibliographical and documentary survey in Brazil and the Europe; 3) reading and analysis of documents, in order to locate the references to the concepts of "liberty" and "experience"; 4) reading and analysis of the letters with the criteria "Aristotelic-Thomists" supplied by the same documents, describing the letters at a first moment structurally, after that dynamically. From the analysis of these documents, it can be said that the Jesuitical philosophical device supplies a concept of "liberty" that is brought up to date as "indifference" and considered as individual elaboration in the Indipetae letters. The reading of these letters allows to understand as the Jesuits used the instruments of ordinance of the interior life, as that, having appropriated from a tradition received through the texts of the literature of spirituality, they express it in an act as the one of writing the Indipeta letter. For beyond the institutional and rhetorical aspects, that controlled the act of writing, the Indipetae can be described as a mirror reflecting a subject that assumed for himself a particular modus vivendi. Also from the reading of these documents, it was possible to comprehend the concept of "experience" such as the Jesuitical tradition of $16^{\text {th }}$ and $17^{\text {th }}$ Centuries understands it and can be exemplified by the phrase of Ignatius: "gustar de las cosas internamente", considering the man as a totality, that is, without broken of continuity between faith and reason, between psychological and spiritual condition.

Key-words: experience, freedom, Company of Jesus, Indipetae. 


\section{LISTA DE SIGLAS E ABREVIAÇÕES}

AIRE - Association Interdisciplinaire de Recherche sur l'Épistolaire

AMDG - Ad maiorem Dei gloriam

ARSI - Archivum Romanum Societatis Iesu

BCE - Biblioteca Casa de Escritores de la Compañía de Jesús (Roma)

BCR - Biblioteca Casanatense di Roma (Roma)

BCS - Bibliotèque du Centre Sèvres (Paris)

BNF - Bibliotèque Nationale de France (Paris)

CARE - Centre d'Anthropologie Religieuse Européenne

CG - Congregação Geral

Const. - Constituições

CULSEC - Centre Universitaire de Lecture Sociopoétique de l'Épistolaire et des Correspondances

DEE - Diretório dos Exercícios Espirituais

DF - Documentos da Fundação

DME - Diário de Moções Espirituais

ED - Bulla Exposcit Debitum

EE - Exercícios Espirituais

FG - Fondo Gesuitico

FS - Formula scribendi 
IHSI - Instituti Historici Societatis Iesu

MHSI - Monumenta Historica Societatis Iesu

RAISSI - Ratio atque institutio studiorum Societatis Iesu

RM - Bulla Regimini Militantis

RP - Relato do Peregrino

SHSI - Subsidia ad Historiam Societatis Iesu 
SUMMA LOGICAE

INTRODUÇÃO

PRIMEIRA PARTE

AS INDIPETAE: O QUE SÃO?

CAPÍTULO 1 Indipetae: sua produção

CAPÍTULO 2 Indipetae: um gênero

CAPÍTULO 3 Indipetae: um corpus documental

SEGUNDA PARTE

AS INDIPETAE: "LIBERDADE" E "EXPERIÊNCIA"

CAPÍTULO 4 Premissa, pólos e eixos de análise

CAPITULO 5 A liberdade e as Indipetae 
TERCEIRA PARTE

AS INDIPETAE: UMA ANÁLISE

CAPÍTULO 7 Introdução: as Indipetae no seu dinamismo

CAPÍTULO $8 \quad 0$ "conhecimento de si" nas Indipetae

CAPÍTULO 9 A “obediência" nas Indipetae

ANEXO 1 Indipetae Hispanae (1583-1609)

ANEXO 2 Indipetae Hispanae - Juan Bravo (1603-1605)

ANEXO 3 Quadro 01 - Estrutura argumentativa

ANEXO 4 Quadro 02 - Estrutura retórica (ars dictaminis)

ANEXO 5 Tabelas 03 e 04 - Lugares-comuns nas Indipetae Hispanae

ANEXO 6 Quadros 03 e 04 - Lugares-comuns nas Indipetae Hispanae 


\section{INTRODUÇÃO}

\section{1) Por que? O que? Como?}

Nós, seres humanos, somos ontologicamente carentes. Condição que nos coloca em anseio permanente do Outro e põe em marcha nosso caminhar em direção ao transcendente. Viver é experimentar o encontro que nos constitui e nos leva, sempre para o mais além. (...) Peregrinos desejosos do além-mar! Gilberto Safra (2002)

Prefácio de Um incendido desejo das Índias...

Liberdade: o que é isso? Um conceito simplesmente relativo? Uma experiência absurda? Uma "condenação"? Nada? Uma impossibilidade para os homens de qualquer tempo, cultura ou lugar? Fazer o que se quer? Conformar-se, com tolerância, à realidade que se apresenta? Resignação? Uma utopia democrática? Ideal? Um gozo momentâneo? Indeterminação absoluta? Voluntarismo? Viver sem opressões e resistências? Afinal, o que é a liberdade? Interessa se debruçar sobre isso? Por que se perguntar sobre ela num âmbito como o da psicologia? Mais: por que a opção pelas sendas da história? Ainda mais: por que dirigir a pergunta aos jovens jesuítas espanhóis dos séculos XVI e XVII ansiosos de serem enviados ao Além-Mar? 
No mais das vezes, damos por óbvia a compreensão que temos de certas palavras, o que, dependendo de seu valor para a constituição do sujeito, pode determinar nossa escravidão a uma ideologia da "mentalidade comum" e, conseqüentemente, definir mesmo nossa "alienação total" .

Escapar dessa alienação é tarefa de um "intellectus cogitabundus", ou seja, de uma inteligência viva, que dá passos em direção àquilo que lhe interessa. Nesse sentido, "a

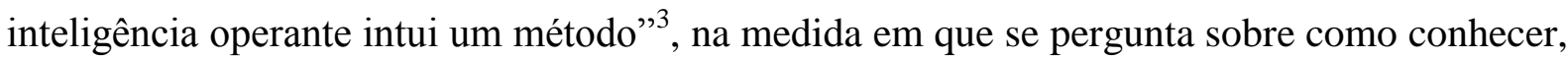
de fato, aquele objeto. Tratando do tema da liberdade, Giussani (2000) nos ajuda de forma bastante significativa, quando escreve: "para compreendermos o que é a liberdade, devemos partir da experiência que fazemos do sentirmo-nos livres". . Dois termos ("experiência" e "liberdade") e uma só questão de fundo: se tratamos da liberdade, e a fim de compreendê-la lançamos mão do método de observação do "eu-em-ação", , ou nos termos propostos, na atenção à própria experiência, a pergunta se resolve na medida em que se responde a uma questão mais radical - o que é o homem?

Evidentemente, não pretendemos aqui responder a essa que é considerada a crux de inúmeros pensadores e correntes de pensamento dos mais variados âmbitos de saber. Certamente, esta é também uma questão por demais genérica para o nosso interesse preciso acerca da liberdade. No entanto, lembramos apenas que, modernamente, em meio às tentativas de resposta, ergueu-se a psicologia que, apesar de seu ainda frágil estatuto

\footnotetext{
${ }^{1}$ Cf. Giussani, L. (2000). O Senso Religioso. Rio de Janeiro: Nova Fronteira, p. 124.

${ }^{2}$ Cf. entre outros Agostinho (1991). A cidade de Deus (2 vols.). Lisboa: Fundação Calouste Gulbenkian, (Livro XIX 1,3).

${ }^{3}$ Giussani, 2000, op. cit., p. 126.

${ }^{4}$ Ibid., p. 127.

${ }^{5}$ Cf. Capítulo IV, Ibid., pp. 57-71. Nesse capítulo, Giussani (2000) propõe como ponto de partida para todo conhecimento (apesar de estar tratando especificamente do "senso religioso", fica claro que o percurso de conhecimento proposto se aplica, razoável, realística e moralmente a toda a realidade), a observação do "eu-emação": "Partir de si quer dizer partir da própria pessoa surpreendida na experiência quotidiana. Então, o 'material' de partida não será mais um preconceito sobre si mesmo, uma imagem artificiosa de si; não será mais uma definição de si talvez emprestada das idéias correntes e da ideologia dominante" (p. 58). E, mais à frente, continua: "Os fatores constitutivos do humano são percebidos quando estão empenhados na ação - de outro modo, não são encontráveis, mas sim obliterados como se não existissem” (p. 60).
} 
epistemológico, tem procurado pensar, às vezes isoladamente, às vezes de mãos dadas à filosofia e/ou à história, chaves de compreensão para o tema.

Se pensarmos, nesse sentido, que a questão proposta - o que é homem? -, se observada sob o prisma da história, pode obter respostas muito diferentes, e que, mesmo o método da atenção à experiência como tentativa de compreensão do que seja a liberdade, historicamente, pode variar sobremaneira: basta lembrarmos que o século XVI, por exemplo, é marcado por uma importante mudança de perspectiva entre uma compreensão do mundo baseada na experientia para uma baseada no experimentum... Ao considerarmos este problema, deparamo-nos com uma questão de método: que passos dar no sentido de uma resposta à pergunta que nos estimulou inicialmente? Qual o caminho razoável para se chegar a compreender o que seja a liberdade - não uma liberdade genericamente compreendida, mas uma liberdade cujos limites histórico e institucional estejam bem delimitados?

Assim recortada, nossa questão (e mesmo aquela mais geral sobre o homem) passa a ser examinada a partir de um campo semântico particular, e será na medida em que recuperamos uma gramática verossímil dos termos de uma época, de uma instituição ou de uma cultura, que seremos capazes de ver se desenhando, paulatinamente, a descrição mesma de um vivido com características muito peculiares e, quem sabe, ler com justiça o relato de uma "experiência de liberdade".

Como, portanto, a história ou a filosofia podem favorecer à psicologia um olhar mais adequado sobre o tema da liberdade do homem?

No nosso caso, não se trata tanto de uma opção por um saber em detrimento de outro: não se trata de apostar na história em detrimento da psicologia. Tampouco, fizemos opções quanto à meta de compreensão simplesmente por uma curiosidade, um exotismo, ou 
partindo de um psicologismo interpretativo. Certeau (2002) afirma que o pesquisador deve partir do presente:

toda pesquisa historiográfica se articula com um lugar de produção sócioeconômico, político e cultural. Implica um meio de elaboração circunscrito por determinações próprias: uma profissão liberal, um posto de observação ou de ensino, uma categoria de letrados etc. Ela está, pois, submetida a imposições, ligada a privilégios, enraizada em uma particularidade. É em função deste lugar que se instauram os métodos, que se delineia uma topografia de interesses, que os documentos e as questões, que lhes serão propostas, se organizam ${ }^{6}$.

Somos, portanto, sempre sujeitos localizados historicamente no presente, que lançamos uma pergunta num espaço-tempo muito bem delimitado.

Quanto a nós, escolhemos como termo de compreensão os homens dos séculos XVI e XVII (especificamente os europeus e, ainda mais especificamente, os jesuítas, por serem esses últimos importantes atores culturais na cultura luso-brasileira), a fim de descobrir sua concepção de "experiência" e, mais pontualmente, de "experiência de liberdade".

Nosso objeto são as assim chamadas Litterae Indipetae: cartas nas quais jovens jesuítas dos séculos XVI e XVII solicitavam ao Padre Geral da Companhia de Jesus o envio em missão nas "Índias"”. Atualmente, estas cartas encontram-se conservadas no Archivum Romanum Societatis Iesu (ARSI), em Roma.

Brevemente, podemos dizer que nos interessam, na medida em que contêm exemplos das modalidades de elaboração da experiência pessoal no que respeita ao processo eletivo a que eram educados os jesuítas; também dados sobre o indipetente (como idade, escolaridade, atividade que exercia na Ordem etc.); bem como conteúdos edificantes próprios do gênero de documento que são.

Nosso objetivo geral é evidenciar as categorias filosóficas, teológicas e psicológicas que sustentam - nas cartas - o que denominamos uma "experiência de liberdade". Estas

\footnotetext{
${ }^{6}$ Certeau, Michel de. (2002). A escrita da história. São Paulo: Forense Universitária, pp. 66-67.

${ }^{7}$ Termo com o qual, genericamente, eram designados os territórios de missão, no âmbito cultural e institucional estudados.
} 
categorias poderiam emergir da análise dos topoi cultural e institucionalmente determinantes do protocolo formal de redação das cartas.

Como método optamos, necessariamente, pela história, já que a nossa alteridade está afastada no tempo. No entanto, continuamos falando de um lugar particular - a psicologia -, e instauramos pois um "fazer singular", sem pretensões de "sistematização totalizante". A nossa é uma historiografia (portanto, um fazer que implica dois termos: a "história" propriamente dita e a "escrita" de/sobre a história) que considera aquela "pluralidade" a que chama atenção Certeau $(2002)^{8}$ :

Sublinhar a singularidade de cada análise é questionar a possibilidade de uma sistematização totalizante, e considerar como essencial ao problema a necessidade de uma discussão proporcionada a uma pluralidade de procedimentos científicos, de funções sociais e de convicções fundamentais ${ }^{9}$.

$\mathrm{Na}$ esteira da discussão acerca do real e do discurso sobre o real ${ }^{10}$ a que se dedica Certeau (2002) e, com ele, seus discípulos ${ }^{11}$, inscrevemos - quiçá pretensiosamente! também nosso trabalho, que mais que um "psicologismo" que sobrevaloriza a subjetividade, ou um "historicismo" filo-estruturalista ou - por que não? - um "racionalismo" totalitário, é a tentativa de dar voz ao "outro" afastado no tempo, ao "morto", àquele "fantasma da historiografia": "objeto que ela busca, que ela honra e que ela sepulta. Um trabalho de separação se efetua com respeito a esta inquietante e fascinante proximidade" ${ }^{\prime 2}$. Assim sendo,

\footnotetext{
${ }^{8}$ Certeau, 2002, op. cit., pp. 31-32.

${ }^{9}$ Ibid., pp. 32.

${ }^{10}$ Certeau (2002) afirma: “A historiografia (quer dizer 'história' e 'escrita') traz inscrito no próprio nome o paradoxo - e quase oximoron - do relacionamento de dois termos antinômicos: o real e o discurso. Ela tem a tarefa de articulá-los e, onde este laço não é pensável, fazer como se os articulasse. Da relação que o discurso mantém com o real, do qual trata, nasceu este livro. Que aliança é esta entre escrita e a história? Ela já era fundamental na concepção judaico-cristã das Escrituras. Daí o papel representado por essa arqueologia religiosa na elaboração moderna da historiografia, que transformou os termos e mesmo o tipo de relação passada, para lhe dar aspecto de fabricação e não mais de leitura ou de interpretação. Desse ponto de vista, o reexame da operatividade historiográfica desemboca, por um lado, num problema político (os procedimentos próprios ao 'fazer história') e, por outro lado, na questão do sujeito (do corpo e da palavra enunciadora), questão reprimida ao nível da ficção ou do silêncio pela lei de uma escrita "científica'." (p. 11).

${ }^{11}$ Referimo-nos, especialmente, ao grupo de pesquisa com o qual tivemos a oportunidade de trabalhar na École des Hautes Études en Sciences Sociales, em Paris, durante estágio de pesquisa no exterior, realizado no ano 2003/2004. Aqui, devemos nos lembrar de modo particular de Pierre-Antoine Fabre, Antonella Romano e Luce Giard, além daqueles que, por intermédio desses últimos, vêm se debruçando sobre o "fazer história" dentro do mesmo horizonte de preocupação de Michel de Certeau.

${ }^{12}$ Ibid., p. 14.
} 
o nosso "discurso sobre o real", a nossa "escrita da história", o nosso "fazer história" singular é mais a transcrição, o relato, de um diálogo que foi se constituindo no dinamismo aparentemente paradoxal da estraneidade à intimidade e vice-versa.

Esta é a história. Um jogo de vida e de morte prossegue no calmo desdobramento de um relato, ressurgência e denegação da origem, desvelamento de um passado morto e resultado de uma prática presente. Ela reitera, um regime diferente, os mitos que se constróem sobre um assassinato ou uma morte originária, e que fazem da linguagem o vestígio sempre remanescente de um começo tão impossível de reencontrar quanto de esquecer ${ }^{13}$.

Nossa pesquisa quer esclarecer um aspecto da história de um grupo social e religioso cuja contribuição foi muito significativa para a história cultural do Brasil. Trata-se propriamente de um sujeito cultural responsável pela construção, transmissão e preservação da cultura brasileira nos níveis antropológico-filosóficos ou teológicos: os jesuítas.

O’Malley (1999b) lembra que os membros da Companhia de Jesus foram, na história, “injuriados como demônios, venerados como santos" $" 14$. Dessa forma, o olhar sobre esta ordem religiosa sempre foi marcado pela "posição cultural e religiosa de seus observadores"15. Hoje em dia, no entanto, a historiografia sobre os jesuítas vem sendo marcada por um "désenclavement" "16 de forma que se pode dizer que passou o tempo da "escritura polêmica", das simples injúria ou veneração, e chegamos mesmo a uma história que "não se reduz mais àquela de uma ordem religiosa susceptível de interesse apenas aos especialistas de história religiosa clássica (...); a Companhia, no presente, entrou no patrimônio coletivo de todos aqueles que têm algo a interrogar sobre a modernidade" ${ }^{, 17}$.

\footnotetext{
${ }^{13}$ Ibid., p. 57.

${ }^{14}$ O’Malley, J. W. (1999b). I primi gesuiti. Milano: Vita e Pensiero, p. 5 (tradução nossa).

15 Ibid., p. 5 (tradução nossa). O que, sem dúvida nenhuma, não é algo de se estranhar, especialmente se consideramos a observação anteriormente feita por Certeau (2002), acerca da produção a partir de um lugar de conhecimento. No entanto, que se compreenda que, nesse caso, o que nos interessa é o argumento em favor do "désenclavement" a que vem se submetendo a historiografia da Companhia de Jesus, nos últimos anos.

${ }^{16}$ Cf. Giard, L. (1995). Le devoir d'intelligence ou l'insertion des jésuites dans le monde du savoir. Em Giard, L. (dir.) (1995). Les jésuites à la Renaissance: système educatif et production du savoir (pp. XI-LXXIX). Paris: PUF, p. XXV. ${ }^{17}$ Fabre, P.-A. e Romano, A. (1999). Presentation. Revue de synthèse 2-3(120), 247-260, p. 247 (tradução nossa).
} 
Por isso, podemos encontrar uma quantidade profícua de produções intelectuais acerca da antiga Companhia de Jesus (1540-1773), que vão, pouco a pouco, constituindo o quadro de uma renovação historiográfica importante: desde edições comentadas das obras da primeira Companhia, passando por textos científicos que se dedicam às mais variadas produções dessa ordem religiosa, até debates, seminários, encontros internacionais e coletâneas de trabalhos sobre a inserção da Companhia de Jesus no âmbito da assim chamada renascença etc. ${ }^{18}$. E, some-se a isto a variedade de campos de investigação interessados pelos jesuítas: arquitetura, artes visuais, música, matemática, literatura, teatro, filosofia, teologia, espiritualidade, política, missão, economia, sociologia, psicologia ${ }^{19}$.

É justamente no âmbito do saber sistematizado em torno do que comumente chamamos de "psicologia filosófica" aristotélico-tomista, bem como dos estudos dos diferentes gêneros de documentos produzidos neste ambiente (manuais de filosofia, tratados de espiritualidade, cartas etc.) e das pesquisas abrangendo esse $\operatorname{saber}^{20}$ que se assenta esta pesquisa.

Conforme O’Malley (1999b) sugere, a nós o interesse por compreender melhor quem são os jesuítas se resolverá a partir da compreensão que eles tinham de si mesmos ${ }^{21}$. Especificamente, abordaremos o estudo de um tipo específico de correspondência epistolar próprio desta Ordem Religiosa: as chamadas Litterae Indipetae. Esses documentos, que vêm

\footnotetext{
${ }^{18}$ Cf. especialmente a Revue de synthèse 2-3(120), que dedicou esse número a apresentar algumas das principais obras da atualidade acerca da Companhia de Jesus. Mas, cf. também Brizzi, G. P. (org.) (1981). La "Ratio Studiorum": modelli culturali e pratiche educative dei gesuiti in Italia tra Cinque e Seicento. Roma: Bulzoni Editore; Giard, L. (org.) (1995). Les jésuites à la Renaissance: système éducatif et production du savoir. Paris: PUF; e outros.

${ }^{19}$ Para uma lista detalhada, cf. os vários artigos agrupados na Revue de synthèse 2-3(4). Neste volume encontramos uma extensa revisão bibliográfica da recente produção acerca da Antiga Companhia de Jesus, desde a história das missões, até história da espiritualidade, passando pelo campo das artes.

${ }^{20}$ Cf., por exemplo, O'Malley, J. W. (1999a). The Jesuits: Culture, Sciences and the Arts. 1540-1773. Toronto/Buffalo/London: University of Toronto Press; Silva, P. J. C. (2000). A tristeza na cultura lusobrasileira: os sermões do padre Antônio Vieira. São Paulo: EDUC/FAPESP; Massimi, M. e Silva, P. J. C. (orgs.) (2001). Os olhos vêem pelo coração: conhecimentos psicológicos das paixões na cultura luso-brasileira dos séculos XVI e XVII. Ribeirão Preto: Holos; e Massimi, M. e Prudente, A. B. (2002). Um incendido desejo das Índias... São Paulo: Loyola.

${ }^{21}$ Assim escreve ele: é preciso "compreender os primeiros jesuítas tal como eles compreendiam a si mesmos" (O’Malley, 1999b, op. cit., p. 7, tradução nossa).
} 
sendo objeto de pesquisas ${ }^{22}$, trazem significativos conteúdos de elaboração pessoal, o que nos permite, para além de uma discussão acerca do uso individual dos instrumentos pedagógicos e formativos utilizados pelos jesuítas, compreender a eficácia formativa desses instrumentos mesmos. Assim, o domínio a que nos dedicamos é aquele que busca descrever a história de determinados conceitos no âmbito cultural e institucional próprios da Companhia de Jesus nos seus inícios, em especial, no período do Generalato do Padre Cláudio Aquaviva (1583-1615).

Trabalhamos com um total de 26 cartas, que primeiramente foram transcritas e, de uma primeira leitura, elaboramos um quadro descritivo, com os principais elementos delas extraídos: nome do indipetente, idade, tempo em que estava na Companhia, ofício a que se dedicava, estudos que havia concluído ou que estava fazendo, cidade solicitada, cidade ou colégio de onde escreveu, topoi utilizados, estrutura argumentativa, número de palavras, codificação do AHSI, nomes a que fez referência, língua em que escreveu, caligrafia etc. Em seguida, partimos para uma compreensão e descrição desse gênero de documento (a história de sua produção, suas especificidades, suas relações com outros gêneros do mesmo período, etc.). A partir desse primeiro nível de análise, e de posse dos topoi utilizados, realizamos um levantamento de outras fontes ${ }^{23}$ que pudessem fundamentar o uso desses e não de outros loci argumentorum ou loci communes.

\footnotetext{
22 Do ponto de vista do estudo da "correspondência epistolar" em geral ou da Companhia de Jesus particularmente, pode-se verificar, por exemplo: Pécora, A. (1999). Cartas à Segunda Escolástica (pp. 373-414). Em: Novaes, A. (org.) (1999). A outra margem do Ocidente. São Paulo: Companhia das Letras; Pécora, A. (2001). Máquina de gêneros: novamente descoberta e aplicada a Castiglione, Della Casa, Nóbrega, Camões, Vieira, La Rochefoucauld, Gonzaga, Silva Alvarenga e Bocage. São Paulo: Editora da Universidade de São Paulo; Assunção, P. (2001). "A Terra dos Brasis”. A natureza da América Portuguesa vista pelos primeiros Jesuítas (1549-1596). São Paulo: Annablume; Hébrard, J. (1990). La correspondance au XIXe siècle: approche historique. Extrait du Colloque "L'Épistolarité a travers les siècles: geste de communication et/ou d'écriture (pp. 162-168). Centre Culturel International de Cerisy la Salle France. Stuttgart: Franz Steiner Verlag; Longo, N. (1981). De epistola condenda: L'arte di “componer lettere” nel Cinquecento. Em: Quondam, A. (org.) (1981). Le "carte messaggiere": retorica e modelli di comunicazione epistolare: per un indice dei libri di lettere del Cinquecento. Roma: Bulzoni Editor; Massimi, 2002, op. cit.; Chartier, R. (dir.) (1991). La correspondance: les usages de la lettre au XIXe siècle. Paris: Fayard, entre outros.

${ }^{23}$ Optamos por nomear como "fontes primárias" apenas as Indipetae e, como "fontes secundárias", os demais documentos utilizados para a análise das cartas.
} 
Basicamente, trabalhamos com três eixos de análise, aparentemente bastante distintos e que, no entanto, descrevem um dinamismo que se sustenta sobre o vivido de uma “experiência-modelo" evidente - a de Inácio de Loyola (1491-1556), o fundador da Companhia de Jesus. Para cada um desses eixos de análise, analisamos diferentes gêneros de documentos, divididos, estes também, em cinco grupos distintos ${ }^{24}$.

Os eixos com os quais trabalhamos são: a ação, ou, para usar um conceito mais próximo do período em questão, o modus operandi (que respeita ao relacionamento do homem com o mundo exterior, ou seja, sua capacidade de transformação do entorno: o aspecto mais imediatamente visível); o pensamento, ou modus cogitandi (relacionado especificamente ao mundo interior: o aspecto invisível); e um eixo sintético que ficou denominado como per experientia (o eixo onde o homem, no contato com a realidade exterior, se deixa tocar e transformar: o aspecto invisível-visível, compreendido através de mediações outras, como a linguagem, por exemplo).

A partir desses eixos de análise, buscamos documentos que os representassem adequadamente: do ponto de vista do cogitare, trabalhamos com documentos do que denominamos representantes do scholicorum (textos de filosofia moral e retórica, sempre aristotélico-tomistas); do ponto de vista do operari, lidamos basicamente com textos do que chamamos de ratio spiritualis (fontes normativas de uma espiritualidade de caráter propriamente jesuítico) e ratio institutorum (os documentos jurídicos da Companhia de Jesus); e, finalmente, para o eixo da experientia, que sintetiza ação e pensamento, trabalhamos com alguns textos de espiritualidade produzidos pelos jesuítas no período do referido generalato, bem como com as Indipetae propriamente ditas.

\footnotetext{
${ }^{24}$ Estas divisões e subdivisões internas que aparecerão ao longo de todo o trabalho - como se verá - não podem ser compreendidas isolada e estaticamente. Sua utilização aqui, deve ser entendida somente na medida em que nos foram úteis do ponto de vista da estruturação do método de análise dos documentos. Durante o percurso que seguimos, ficou-nos claro, pouco a pouco, que essa era uma compartimentação estritamente metodológica e nada estanque. Foi-nos necessário agrupar as fontes dessa forma para que, inicialmente, tivéssemos claros os diferentes campos semânticos com o quais lidávamos. No entanto, posteriormente, essas campos semânticos diversificados descreveram uma gramática bastante particular e dinâmica, viva.
} 
Esse levantamento de fontes foi feito em dois momentos distintos. Uma primeira fase, no Brasil, onde recolhemos, em acervos da Companhia de Jesus, aquelas obras de referência para uma compreensão do horizonte antropológico-filosófico e teológico das cartas (principalmente, literatura de referência; mas também algumas coletâneas de documentos publicadas no Brasil). Nessa primeira fase, nos dedicamos sobretudo ao estudo de suas bases filosóficas $^{25}$. E uma segunda fase, na Europa, na qual tivemos acesso, seja em arquivos franceses, seja em arquivos italianos, às obras fundamentais para essa pesquisa (algumas das fontes primárias e a maior parte das fontes secundárias): textos de Inácio de Loyola (cartas, Relato, Diário de Moções Interiores, Exercícios Espirituais, Constituições, Documentos de Fundação etc.); textos do Padre Geral Cláudio Aquaviva (1542-1615), no período de seu governo na Ordem; e vários textos de espiritualidade da Companhia, produzidos no período de influência do generalato do Padre Aquaviva ${ }^{26}$.

Apesar das evidentes diferenças de gênero entre as fontes primárias (correspondência epistolar) e as secundárias (documentos jurídicos, textos de espiritualidade, tratados filosóficos), foi, na medida de sua confluência na análise de um só desses gêneros - as

\footnotetext{
${ }^{25}$ O principal documento com o qual trabalhamos foi: Góis, M. (1593). Disputas do Curso Conimbricense sobre os livros de Moral a Nicómaco de Aristóteles em que se contêm alguns dos principais capítulos da moral. Lisboa: Oficina de Simão Lopes.

${ }^{26}$ Aquaviva, C. (1583). Lettera del Nostro Padre Generale Claudio Acquaviva. Sopra la Rinovatione dello spirito à Padri \& Fratelli della Compagnie. 29/09/1583. Roma. BCS W12/441; Aquaviva, C. (1586). Lettera del Nostro Padre Generale Claudio Acquaviva. Dello studio della perfettione, \& carità fraterna. 19/05/1586. Roma. BCS W12/441; Fazio, G. (1596). Trattato utilissimo della mortificatione delle nostre passioni, \& affetti disordinati. Composto nuovamente per il molto R. P. Giulio Fatio, della Compagnia di Giesu. Brescia: Pietro Maria Marchetti. BCS W12/274; Nieremberg, J. E. (1657). L'art de conduire la volonté selon les precepts de la morale ancienne \& Moderne, tirez de Philosophes Payens \& Chrestiens. Traduit du latin de Jean Eusebe de Nieremberg, Paraphrase \& de beaucoup enrichy par Loü̈s Videl, de Dauphiné. Dedié à Monsieur de Lionne, Conseiller d'Estat ordinaire \& secretaire des Commandemets de la Reyne Regente. Paris: Chez Jean Pocquet. BNF R-6222; Rodriguez, A. (1834). Ejercicio de perfeccion y virtudes cristianas, su autor el Padre Alonso Rodriguez de la Compañía de Jesus, natural de Valladolid. Dividido en tres partes. Parte tercera. De varios medios para alcanzar la virtud y perfeccion. Nueva Impression. Barcelona: Imprenta de D. Valero Siena y Marti. BCS W10/141; Sanchez, P. (1607). Le Royaume de Dieu, et le vray chemin pour y parvenir. Composé en Espagnol par le Pere P. Sanchez, Docteur de la Compagnie de Iesus. Traduit en François, par F. Guillaume Levite, de l'Ordre des Predicateurs. Paris: Chez Adrian Beys. BCS W12/259; Villanueva, M. (1608). Libro de oracion mental. Compuesto por el Padre Melchior de Villanueva, de la Compañia de Iesus. Toledo: Pedro Rodriguez impressor del Rey nuestro Señor. BCS W12/267; Nieremberg, J. E. (1957). Obras escogidas del R. P. Juan Eusebio Nieremberg (E. Zepeda-Henriquez, ed.). Biblioteca de Autores Españoles, desde la formación del lenguaje hasta nuestros dias (continuación). Tomo 103. Madrid: Ediciones Atlas. BNF 4-Z-3501 (103).
} 
Indipetae - e, acima de tudo, pela unidade própria da Companhia de Jesus (de forma muito especial no período de Aquaviva - nosso recorte histórico mais preciso), que o presente trabalho não perdeu em coesão.

\section{2) Estrutura do trabalho}

O presente trabalho encontra-se dividido em três grandes partes. Na primeira parte “As Indipetae: o que são?" - nos dedicamos a descrever nossas cartas segundo três critérios básicos $^{27}:$ 1) sua produção (primeiro capítulo); 2) o gênero a que pertencem (segundo capítulo); 3) e, finalmente, a especificidade do corpus documental com o qual trabalhamos (terceiro capítulo).

A segunda parte deste estudo - "As Indipetae: liberdade e experiência" - contém os resultados de uma primeira análise, mais estrutural, dos termos "liberdade" e "experiência", a partir das fontes secundárias: 1) um exame do conceito de liberdade (capítulo cinco); 2) outro do conceito de experiência (capítulo seis). O início dessa segunda parte (capítulo quatro) se dedica a apresentar uma premissa básica que será usada ao longo dos capítulos que se seguem e descrever as fontes utilizadas para a análise das Indipetae.

A terceira parte - "As Indipetae no seu dinamismo" - se dedica ao estudo do dinamismo identificado na produção das cartas Indipetae: 1) uma introdução, na qual explicitamos brevemente os conjuntos de lugares-comuns que serão analisados, segundo o seu dinamismo (capítulo sete); 2) uma análise dos topoi relativos ao "conhecimento de si" presentes nas cartas estudadas (capítulo oito); 3) uma análise daqueles relativos à “obediência" (capítulo nove); e 4) uma análise dos que se referem à experiência de “consolação" (capítulo dez).

\footnotetext{
${ }^{27}$ Descritos por Chartier [apud. Assis, Raquel Martins (2004). Tese de doutorado não publicada. Universidade Federal de Minas Gerais, pp. 20-21].
} 


\section{PRIMEIRA PARTE}

AS INDIPETAE: 0 QUE SÃO? 


\section{CAPÍTULO 1 Indipetae : sua produção}

De sua janela era possível ver - naquela manhã especialmente límpida -, para além dos muros, o escarpado monte Zulema: o mesmo horizonte vislumbrado, há milênios atrás pelos cartagineses e depois pelos romanos. O mesmo lugar onde, por séculos, os mouros mantiveram uma fortificação que defendia, às margens do Henares, a importante planície estrategicamente localizada, no caminho de Zaragoza. Sob essa mesma sombra e banhada pelo mesmo rio, mais tarde, se ergueu aquela que seria o centro da renovação científica e da espiritualidade européia. De Iplacéia a Compluto. De Compluto a Al-Khala en Nahr. Cartagineses, romanos, mouros e cristãos: uma história talhada a ferro e sangue ${ }^{1}$.

\footnotetext{
${ }^{1}$ Iplacéia era uma cidade habitada por cartagineses, que foram expulsos, no início da conquista romana, pelos romanos, passando a se denominar Complutum, que significa "ajuntamento de águas". O domínio romano durou até o ano de 749 d.C., quando foi invadida pelos árabes. Em 03 de maio de 1114, o exército de D. Alonso, rei espanhol, vence os mouros da fortaleza de Al-Khala en Nahr, numa batalha sangrenta, comandada pelo arcebispo D. Bernardo. Entre 1444 e 1454, Alcalá é dominada pelo rei de Navarra. A partir de 1454 retorna às mãos do rei de Castilla. Sobre a história de Alcalá de Henares, cf., por exemplo: Azaña, D. E. (1882). História de la Ciudad de Alcalá de Henares (Antigua Compluto). Adicionada con una reseña histórico-geográfica de los pueblos de sua partido judicial. Tomo I. Alcalá de Henares: Imprenta de F. Garcia C.; também Azaña, D. E. (1883). História de la Ciudad de Alcalá de Henares (Antigua Compluto). Adicionada con una reseña histórico-geográfica de los pueblos de sua partido judicial. Tomo II. Alcalá de Henares: Imprenta de F. Garcia C.; e Tormo y Monzó, E. (s.d.). Alcalá de Henares. Madrid: Gráficas Marinas.
} 
Os montes ao fundo e sua história, e as inúmeras cúpulas e torres de aspecto oriental espalhadas em toda a cidade, sempre o faziam pensar nos perigos enfrentados por tantos cristãos, no combate pela fé: desde os santos meninos, Justo e Pastor - decapitados pelas mãos de Daciano, em 296 d.C. -, passando pelos inúmeros e incógnitos mártires dos anos de domínio árabe, até chegar a São Félix... Um imensurável exército de homens e mulheres, tendo por estandarte a Cruz, deu de seu sangue ad maiorem Dei gloriam.

Há apenas alguns dias, havia ajudado seus companheiros do Colegio Máximoª a preparar o altar "poliglota"3 que renderia homenagem a San Diego de Alcalá ${ }^{4}$, recentemente canonizado pelas mãos de Sua Santidade, o Papa Sixto V.

Olhando para a Calle de Libreros se estendendo desde a Puerta de Guadalajara até a Calle Mayor, onde se erguia, na Plaza de la Picota, a Iglesia de los Santos Niños Justo y Pastor, não podia deixar de se lembrar também da enorme procissão que tomou conta da cidade naquele dia; mas, sobretudo, da vida daquele franciscano observante, que havia pisado aquele chão, apenas há algumas décadas atrás: “quantas vezes não passara por aqui ou por ali, seguindo pela Calle de lo Justo, em direção ao convento; ou pela Calle del Homo-quemado, para visitar os doentes no Hospital de Estudiantes, aqui, tão perto?”.

Ainda trazia, anotadas numa pequena folha de papel sobre a escrivaninha, as palavras da bula de canonização, tantas vezes repetidas naquele dia de festa:

\footnotetext{
${ }^{2}$ Chamava-se "Colégio Máximo", porque era considerado o primeiro colégio da Companhia, na Espanha. Para a sua construção, contou com a ajuda econômica de Dona Leonor de Mascareñas, camareira de D. Felipe II, e de Dona Maria e Dona Joana da Áustria. Além da cooperação do Duque de Gandía, São Francisco de Borja. Cf. Institucion de Estudios Complutenses (s.d.). La Compañía de Jesús en Alcalá de Henares (1546-1989). Alcalá de Henares: IEC.

${ }^{3}$ Havia, em Alcalá, na Universidade Complutense, um importante centro de línguas, denominado "Trilingüe", onde se estudavam o hebraico, o latim e o grego. No entanto, o Colégio Máximo, da Companhia de Jesus era ainda mais conhecido pela sua dedicação ao estudo das línguas. O altar preparado pelo colégio da Companhia, por ocasião dos festejos de canonização de São Diego, continha frases que rendiam homenagem ao santo nas mais diversas línguas, disputando claramente com o "Trilingüe".

${ }^{4}$ Dos primeiros anos de São Diego de Alcalá, ou São Diego de San Nicolás del Puerto, se sabe muito pouco. Nascido em San Nicolás del Puerto, na província da Sevilla, de família humilde. Consagrou-se no convento dos frades Menores da Observância Franciscana, de Córdoba, de onde parte, em seguida, para uma longa peregrinação de esmolas e missão. Após passar por várias cidades, finalmente, se instala em Alcalá, onde permanece até sua morte, aos 13 de novembro de 1463. Sua canonização se deu sob o pontificado de Sixto V, em julho de 1588. Mais detalhes, cf. Andrés-Avelino, E. R. (1960). San Diego de San Nícolás. Año Cristiano, IV (BAC 186).
} 
El Todopoderoso Dios, en el siglo pasado, muy vecino y cercano a la memoria de los nuestros, de la humilde familia de los frailes menores, eligió al humilde y bienaventurado Diego, nacido en España, no excelente en doctrina, sino 'idiota' [...], mostrándole claramente que lo que es menos sabio de Dios, es más sabio que todos los hombres, y lo más enfermo y flaco, más fuerte que todos los hombres [...]. Dios, que hace solo grandes maravillas, a este su siervo pequeñito y abandonado, con sus celestiales dones de tal manera adornó y con tanto fuego del Espíritu Santo le encendió, dándole su mano para hacer tales y tantas señales y prodigios así en vida como después de muerto, que no sólo esclareció con ellos los reinos de España, sino aun los extraños, por donde su nombre es divulgado con grande honra y gloria suya ${ }^{5}$.

Ainda trazia na memória as palavras que compunham aquela história singular: “obediente até o milagre", "simplicidade", "humildade", "servo sem limites", "caridade heróica", "peregrino"; era como descreviam aquele homem. Era como, naquela manhã, o Padre Superior, durante a missa, havia falado daquele homem, comparando-o a tantos de seus companheiros e irmãos próximos ou distantes no tempo ou no espaço.

Para as sete horas daquela manhã de início de verão faltavam somente alguns minutos. Passara por seu quarto, após a missa, para buscar papel e pena. Um átimo à janela: memória e pedido se fizeram presentes, antes de se dirigir para uma das salas do Colegio Máximo, onde, até as sete e meia, ouviria algumas "exortações de coisas espirituais, perfeição e virtudes" de Cristóbal de Castro (1551-1615) ${ }^{6}$.

Da Páscoa de Nosso Senhor Jesus Cristo já se haviam passado pouco mais de sete semanas: era uma sexta-feira do ano de 1588.

Lá fora, quem viesse caminhando pela Calle Mayor, quando chegasse à Plaza del Mercado, veria, hoje, mais que nunca, como numa pintura iluminada, a fachada do antigo

\footnotetext{
${ }^{5}$ Ibid., p. 367.

${ }^{6}$ O P.e Cristóbal de Castro (1551-1615), nascido em Ocaña e falecido em Madrid aos dois dias de dezembro de 1615, entrou na Companhia de Jesus em 1569, fazendo profissão dos quatro votos em 1588. Ensinou gramática durante quatro anos, teologia moral durante seis anos e Escritura Sacra durante 21 anos, no Colegio Máximo, de Alcalá, bem como no colégio de Salamanca. Foi secretário da Província de Castilla, e reitor do colégio de Toledo. Além dos seus comentários bíblicos, escreveu uma história do colégio de Alcalá.
} 


\section{Colegio Mayor que deu lugar à Universidade Complutense ${ }^{7}$, cuja construção só terminara 80} anos atrás: obra do empenho do Cardeal Francisco Jiménez de Cisneros (1436-1517) ${ }^{8}$, e que, pouco a pouco, foi mudando o aspecto da cidade. Ouviria também o burburinho da cidade, com seus milhares de estudantes, entrando e saindo dos colégios, dirigindo-se seja para um dos hospitais, seja para uma das igrejas, seja para a Universidade. Quem sabe - se se aguçasse o ouvido -, poderia escutar mesmo alguns comentários de um ou outro estudante acerca do ainda não tão ilustre alcalaíno, Miguel de Cervantes y Saavedra $(1547-1616)^{9}$, que acabara de se mudar para Sevilla, depois de publicada a obra que começou a lhe dar renome - La Galatea - e depois de ter lutado na famosa Batalha de Lepanto ${ }^{10}$. Se se aventurasse por aquelas ruas, um pouco mais tarde, veria também alguns pares de jovens estudantes jesuítas (seria possível reconhecê-los? Diferenciá-los dos demais?) em período de provação ${ }^{11}$, fazendo a "repetição"

\footnotetext{
${ }^{7}$ Obra do Cardeal Cisneros, iniciada após recebidas as bulas de autorização assinadas pelo papa Leão X, em 28 de fevereiro de 1498. As obras terminaram 10 anos mais tarde.

${ }^{8}$ Nascido em Torrelaguna (Madrid), Francisco Jiménez de Cisneros, ingressou na ordem franciscana em 1484, no convento de San Juan de los Reyes, em Toledo. Nomeado confessor e conselheiro de Isabel I, a Católica, atingiu renome que lhe permitiu, em fins de 1494, assumir a arquidiocese de Toledo. Em 1507, recebeu as ordens cardenalícias. Em 1516, pelas mãos de Fernando, o Católico, torna-se governador da Castilla, León, Granada e Navarra.

${ }^{9}$ Nascido em 1547, em Alcalá de Henares, Cervantes acompanha até 1569 o Cardeal Acquaviva, legado pontifício, em Roma, e serve como soldado. Participa da Batalha de Lepanto, em 1571, onde perde o uso da mão esquerda. Prisioneiro dos turcos entre 1575 e 1580, na Argélia, é resgatado pelos Frades Trinitários, regressando para a Espanha. Em 1584, se casa com Catalina de Salazar y Palacios e, um ano depois, escreve La Galatea. Em 1605, publica a primeira parte de El Ingenioso Hidalgo don Quijote de la Mancha, sendo acolhido pela Espanha com grande entusiasmo, decidindo-se dedicar por inteiro à criação literária. Morre em 1616, em data desconhecida, sendo enterrado no dia 23 de abril, do mesmo ano, no Convento dos Trinitários, em Madrid.

${ }^{10}$ A sete de outubro de 1571 tem início a Batalha de Lepanto, quando a liga de cristãos e os mouros se enfrentaram em alto mar. Cervantes lutou como soldado voluntário na galera "Marquesa", sob o comando de Miguel de Mocada (veterano da Guerra do Alpujarras contra os mouriscos). A batalha começada, o capitão Diego de Urdino, deu a Cervantes um papel que demonstrava "quanto il giovane letterato e poeta, benché semplice soldato, fosse stimato": "una tattica diversiva, talvolta praticata dopo che una galea nemica era stata uncinata e arrembata, consisteva in un'azione di aggiramento: una dozzina di uomini scelti montati su una scialuppa raggiungevano la faccia opposta della galea e di là si arrampicavano in coperta sorprendendo il nemico alle spalle. La vita di Cervantes è stata sviscerata nei più piccolli particolari - non ultimo il suo esatto incarico a Lepanto - e si può affermare pressoché con certezza che egli comandasse gli uomini della scialuppa della Marquesa: è certo che ebbe due ferite, al petto e alla mano ('Le ferite al volto o al petto' scriverà molto tempo dopo 'sono le stelle che ti guidano, attraverso l'onore, ai cieli'). Cervantes definì sintenticamente la battaglia come la mayor jornada que vieron los siglos" (p. 258). Trinta anos mais tardes, Cervantes destilaria "azione, intenzione, fede, illusione" (p. 269) vividos naquela batalha em sua mais importante obra - El Ingenioso Hidalgo don Quijote de la Mancha. Cf. sobre a Batalha de Lepanto e a participação de Cervantes: Beeching, J. (2000). La Battaglia di Lepanto. Milano: Bonpiani.

${ }^{11}$ Segundo Ruiz Jurado (1980), o Colegio Máximo de Alcalá de Henares foi o mais importante centro de provação e formação da Companhia de Jesus, na Espanha, durante o Generalato de Inácio de Loyola. Nesse mesmo período, os outros centros de provação eram Mesina, Coimbra, Goa, Córdoba, Granada e Viena. Em 1554, com a criação do noviciado de Simancas, Alcalá deixou de ser um centro significativo para a Companhia de Jesus. Para mais detalhes sobre o colégio jesuíta em Alcalá, cf. Ruiz Jurado, M. (1980). Origenes del noviciado en la Compañía de Jesus. Bibliotheca Instituto Historici Societatis Iesu, XLII. Romae: IHSI.
} 
da exortação para a qual deveria se dirigir naquele instante em que descia as escadas, rumo a uma das aulas do colégio.

Alcalá de Henares, o modelo original da Civitas Dei, a comunidade urbana espanhola ideal, escolhida pelas mais diversas ordens missionárias européias, como centro de formação e desenvolvimento intelectual. Aqui, trinta e nove anos atrás, depois de duas mudanças ${ }^{12}$, se instalou definitivamente, nas proximidades da Puerta de Guadalajara, em propriedade do Doctor Don Alonso Ramirez de Vergara, o Colégio Jesuíta de Alcalá: fruto, sobretudo, do trabalho do então irmão coadjutor - "rústico, pobrecito, pequeño de cuerpo, morenillo de rostro, idiota y sin letras humanas, vil y menospreciado en los ojos de los hombres"13 - Francisco de Villanueva $(1509-1557)^{14}$, da generosidade de Francisco de Borja (1510-1572), Duque de Gandía ${ }^{15}$, que ofereceu mil ducados para a fundação do colégio, e da cooperação das sereníssimas Doña Leonor Mazcareñas, camareira de Felipe II, e da Infanta Doña Maria, Imperatriz ${ }^{16}$.

\footnotetext{
${ }^{12}$ Em 1546, iniciam a fundação do colégio, numa propriedade próxima ao pátio de Mataperros. Entre 1547 e 1548 instalam-se nas proximidades da Puerta de Santiago. E, finalmente, em 1549, alugam a casa em Puerta de Guadalajara, comprando-a alguns meses mais tarde com a ajuda do duque de Gandía.

${ }^{13}$ Citado por De la Escalera, M. (s.d.). Fundación Complutense de la Compañía de Jesús (pp. 05-25). Em: Institucion de Estudios Complutenses, s.d., op. cit., p. 17.

${ }^{14}$ Francisco de Villanueva conheceu a Companhia em 1541, quando foi enviado de Cáceres como procurador a Roma. Ali conheceu Inácio e fez os Exercícios Espirituais com Salmerón. Entrou na CJ nesse mesmo ano de 1541, aos 32 anos de idade e foi enviado para Portugal por Inácio. Doente, com os trabalhos de fundação de uma casa em Coimbra, Inácio o envia a Alcalá para recobrar o ar da terra natal e estudar na universidade. Chega em 1543. Fica amigo de Pedro Sevillano, a quem dá os Exercícios Espirituais. Em 1545, com Maximiliano Chapelle e Manuel Lopes, inicia fundação do colégio. Já em 1548 ajuntam-se aos "fundadores" Juan de Valderrábana, Juan Alvarez (discípulo de São João D’Ávila), o Padre Pedro Tablares (escritor, músico e poeta) e Duarte Pereira (pajem de Dona Leonor de Mascarenhas e que seria, mais tarde, mestre de noviços). Em 1549 novas entradas importantes: o médico Martín Gutiérrez, o político Gil González Dávila, o teólogo Jerónimo de Ripalda, Juan Bautista de Barma, Pedro da Silva (também discípulo de São João D’Ávila), Fernando Jaén (professor de grego), Dionísio Vázquez (conhecido poliglota), Diego Carrillo, Bartolomé de Bustamarte, Juan de Castillo (mais tarde mártir no Paraguai) e Alonso Carrillo (mais tarde chamado de Apóstolo da Transilvânia). Em 1550 é ordenado sacerdote. Nas obras pesquisadas, não há referências quanto ao ano de nascimento. Sabe-se apenas que, quando de sua entrada na Companhia de Jesus (1541) tinha por volta dos trinta anos. Cf. Astrain, A. (1905). Historia de la Compañía de Jesús en la Asistencia de España. Tomo II: Laínez-Borja (1556-1572). Madrid: Est. Tipográfico "Sucesores de Rivadeneyra".

${ }^{15}$ Francisco de Borja, primogênito do Duque Juan de Borja, nasceu em Gandia, no reino de Valencia, no ano de 1510. Foi educado na corte do Imperador Carlos V e, em 1529, casou-se com D. Leonar de Castro, com a qual teve oito filhos. Assumiu o ducado em 1542, mas com a morte de sua esposa, renunciou e, terminados os estudos em teologia, ordenou-se sacerdote (1551) na Companhia de Jesus, sendo eleito Padre Geral em 1565. Morreu em Roma, no dia 30 de setembro de 1572 e foi canonizado por Clemente X, em 1671. Cf. Ibid.

${ }^{16}$ Cf. Azaña, 1883, op. cit., p. 12.
} 
Ao longo dos anos, o colégio cresceu na extensão da Calle de Libreros, chegando a acolher cerca de oitenta estudantes: "abundantes e escolhidas vocações", vindas das diversas províncias dos arredores - “Toledo, Córdoba, Madrid” - se instalaram entre aquelas paredes ${ }^{17}$.

Atentos, se poderiam descobrir os sinais do fundador da casa, P.e Villanueva, ou as palavras virtuosas do P.e Francisco de Borja, que visitara o colégio dois anos antes da morte precoce do fundador; ou as fortes do Padre Jerônimo de Nadal ${ }^{18}$. Semana após semana, nas leituras durante as refeições, se poderia mesmo "ouvir a voz" de Nuestro Padre Maestro Inácio de Loyola (149?-1556) ${ }^{19}$, ou, agora, a do P.e Superior Aquaviva ${ }^{20}(1543-1615)$ e a dos inúmeros padres e irmãos missionários espalhados pelas Índias em leituras periódicas de cartas, nas refeições.

\footnotetext{
${ }^{17}$ Alguns dos mais importantes escritores de espiritualidade dos séculos XVI e XVII jesuítico passaram pelo colégio de Alcalá: Juan Eusebio Nieremberg, Luis de Guzman, Juan de la Plaza, Balthasar Alvarez. Cf. Ruiz Jurado, 1980, op. cit., passim.

${ }^{18}$ Villanueva faleceu no de 1557. Em 1554 (entre fevereiro e março), o Padre Jerônimo de Nadal, que para fins de exortação sobre o Instituto S.I., resolução de problemas e publicação das Constituições, começava a visita aos Colégios e Casas da Companhia, passa um mês no Colégio de Alcalá. Em 1555, em virtude de uma peste, no verão, que toma conta de várias cidades da Espanha e assola o Colégio Máximo, em Alcalá, o Padre Francisco de Borja faz uma visita de alguns dias, para consolar e cuidar dos doentes.

${ }_{19}$ Último dos 11 filhos de Beltrán Yáñez de Oñaz y Loyola e de Marina Sánez de Locona, Iñigo (nome de batismo de Inácio de Loyola) nasceu no castelo de Loyola (Guipúzcoa), provavelmente em 1491. De família nobre, Inácio teve formação civil e religiosa, marcadamente militar (cortesão e cavalheiro espanhol): seu tutor foi Juan Velázquez de Cuéllar, tesoureiro maior da corte real espanhola. Dedicou-se, na juventude, à vida militar. Era aficcionado por literatura de cavalaria, chegando a aspirar - como um exemplar cavaleiro andante das narrativas ficcionais de então - o amor da Infanta Catalina, irmã de Carlos I. Com 30 anos, depois de ferido na guerra de Pamplona, pelas tropas francesas, tendo que guardar longa convalescência, leu o Flos Sanctorum, o Vita Christi e o De imitatione Christi, o que marca sua conversão: romper com sua vida anterior e peregrinar rumo à Terra Santa. Em 1522, abandona a casa, onde se recuperava, e parte para Montserrat, em seguida para Manresa. Em 1524, visita, enfim, a Terra Santa, por dezenove dias. Em 1525, inicia seus estudos, numa escola de gramática, ingressando, dois anos mais tarde, na Universidade de Alcalá. De 1528 a 1535 morou e estudou em Paris, onde conheceu Pedro Fabro, Francisco Xavier, Diego Laínez, Alfonso Salmerón, Bobadilla, Rodrigues e Jay, homens que se constituiriam nos futuros pilares da Companhia de Jesus. No dia 15 de agosto de 1534, Inácio e esse pequeno grupo, em Montemartre, fazem os votos de pobreza e castidade e decidem partir para a Terra Santa. Fracassado o projeto, rumam para Roma, onde se põem a serviço do Papa. Embora conhecidos como a Companhia de Jesus desde 1538, a ordem só foi reconhecida em 1540, pela bula Regimini militantes ecclesias, do Papa Paulo III. Assumiu o generalato da Companhia em 1541, onde permaneceu, apesar de sua constante insistência em abandonar o cargo, até o dia de sua morte, em 31 de julho de 1556.

${ }^{20}$ Filho do Duque d'Atri, Cláudio Acquaviva nasceu em 1543, na região do Abruzzo. Jovem, ingressou no ambiente eclesiástico, tornando-se notável pelas suas capacidades nas ciências humanas, filosofia, teologia e leis. Começou o noviciato na Companhia de Jesus, em 1567, quando já era sacerdote. Ensinou filosofia por um tempo, em seguida foi nomeado reitor em Nápoles, superior da Província Napolitana e, em seguida, da Província Romana. Em 1581, foi eleito superior geral da Companhia. Seu longo generalato (1581-1615) foi um período de grande desenvolvimento e de novas empresas: dedicou-se ao sistema educativo, à espiritualidade inaciana e às missões dentro e fora da Europa. Padre Acquaviva morreu em 1615.
} 
Finda a exortação do P.e Castro e a repetição com seu companheiro, encaminhara-se para a hora e meia de trabalhos manuais e exercícios corporais. O sineiro já anunciara o início do primeiro período de exame de consciência. Já no seu quarto, assentado diante da janela, de onde se podia ver o Convento dos Franciscanos Observantes, retirara da gaveta um pequeno bloco de papéis, onde anotava sistematicamente, conforme aprendera nos Exercícios Espirituais ${ }^{21}$ que realizou em Toledo, os pontos examinados e aqueles a que se propusera emendar. Deixara o maço de papéis ali, e fora se ajoelhar, do lado de sua cama, diante de um crucifixo que pendia da parede: “Obrigado, ó Divina Majestade, por me haveres concedido a graça de ter para quem olhar, de me teres colocado nessa companhia e por me permitires, estando aqui, mudar minha vida e trabalhar por vossa Glória no mundo e salvação daqueles que mais necessitam de vosso socorro. Peço-vos, seguro de vosso auxílio, a graça de me recordar das vezes em que caí no pecado do amor próprio e covardia e, especialmente, a graça de me emendar desse erro". De volta à mesa, instante por instante daquele dia que iniciara às quatro, foi recordando tudo o que pensara, dissera e fizera; anotando na primeira linha do lado do "g" que correspondia àquela sexta-feira, um ponto para cada vez em que incorrera no erro a que se propusera, algumas semanas atrás, de emendar. Lembrara-se, vivamente, daquele breve instante, após a missa, em que, pensando as palavras do Padre Superior, olhando a cidade e o monte, fazendo memória dos homens que deram sua vida, sentira um tremor e chegara a dizer internamente um "mas".

Naquele dia, nos instantes finais da exortação, Castro falou a respeito do P.e Villanueva: falava com tamanha familiaridade que se poderia mesmo pensar que o tivesse conhecido. Mas, não era difícil se falar assim do fundador daquela casa: sua doutrina e estilo espiritual eram a alma do Colégio de Alcalá... o ritmo de vida era o que ele aprendera nos

\footnotetext{
${ }^{21}$ Os Exercícios Espirituais são uma série de notas práticas, de métodos de exame de consciência, de oração, de deliberação ou eleição, de planos de meditação e de contemplação, divididos em partes que indicam quatro semanas, além de algumas regras ao final etc.; é um conjunto de instruções diversas destinadas a dirigir o cumprimento de um certo número de exercícios interiores sistematicamente ordenados, de forma que se trata de um livro não para ser lido, mas para ser "vivido"; trata-se, pois, de uma obra destinada a um guia. No capítulo 4, a obra será analisada com mais vagar.
} 
colégios de Roma e de Coimbra, por onde passara; as regras internas e o cuidado com a formação foram seguidos pelo P.e Manuel Lopes ${ }^{22}$, que o substituíra e por cada um dos seguintes superiores da casa. Muito se falava do P.e Villanueva: como um perfeito jesuíta, filho dileto de P.e Inácio de Loyola, ensinava a abnegação de si mesmo e o desapego das coisas, a indiferença que liberta o homem para seguir em tudo a vontade de Deus; fazia exortações a isso sempre depois das refeições; aconselhava que cada um tivesse alguém que lhe apontasse as faltas com amor e caridade; dava mortificações públicas, mas não era áspero; apreciava muito o exame particular, que considerava o instrumento imediato para alcançar a pureza de coração. E ali estava ele: de novo, olhando, com os olhos da alma, o exemplo de quem alcançara maior perfeição na vida e que não impusera objeções à vontade de Deus.

Não demorou e tocou o horário do almoço. Desceu as escadas rumo ao refeitório, tendo presente à memória homens como Inácio de Loyola, Francisco Xavier, Villanueva, Diego, Justo e Pastor... Já na porta do refeitório, lembrou-se também da leitura da semana anterior - litterae annuae $^{23}$ vindas do Peru... e trouxe, então, para a memória a vida daqueles seus companheiros que se dirigiam para as "Índias" ${ }^{24}$, levando na alma a certeza da realização da própria vida na entrega de tudo o que fosse para a maior Glória de Cristo e para a salvação das almas dos gentios.

Naquele dia, durante a refeição, foram lidas umas regras que Inácio deixara escrita de próprio punho no início da Companhia ${ }^{25}$, quando ainda não estavam completamente redigidas

\footnotetext{
${ }^{22}$ Em 1545, em visita a Francisco de Villanueva (que viera a Alcalá para estudar, conforme indicação de Santo Inácio de Loyola) e seu companheiro, o estudante Pedro Sevillano, Pedro Fabro (1506-1546) sugere a abertura de um colégio da Companhia de Jesus, em Alcalá. Para tanto, vindos de Coimbra, se ajuntaram a eles, o holandês Maximiliano Chapelle e o português Manuel Lopes. A partir de 1554, com as constantes ausências do então já padre Francisco de Villanueva, assume o cargo de Superior do Colegio Máximo, Padre Manuel Lopes. Até essa data, Lopes era encarregado da superintendência de oração do colégio.

${ }^{23}$ Com o crescimento da Companhia de Jesus, alguns tipos de correspondência que se mantinham (semestrais e quadrimestrais), foram substituídas pelas litterae annuae, que eram crônicas das Províncias enviadas anualmente seja para a Casa Generalícia, em Roma, seja para outras Províncias e/ou Assistências. Cf. Lamalle, E. (19811982). L'archivio di um grande Ordine religioso: L'Archivio Generale della Compagnia di Gesù. Archiva Ecclesiae, 24-25, 89-120.

24 "Índias" era como se designavam, genericamente, os territórios de missão. Podiam ser as "Índias ocidentais", as "Índias orientais", as "Índias internas" ou "externas".

${ }^{25}$ Os "Avisos que N. P.e Ignacio de buena memoria dava a los suyos al principio de la Compañía, que se leyan em las casas por que no avía otras regras" foram recolhidos da "Historia del colegio de la Compañía de Jesús em Alcalá de Henares", do P.e Cristóbal Castro, por Ruiz Jurado, 1980, op. cit., pp. 151-153. Havia, além desses “avisos", regras
} 
as Constituições $^{26}:$ 1) guardar o coração no amor de Deus; 2) não falar sem necessidade; 3) não querer se ter como orgulhoso; 4) não querer fazer ou ver coisas que não possam ser feitas ou vistas diante de Deus; 5) tratar com paciência uns aos outros; 6) afastar o que afasta do amor aos irmãos; 7) pedir perdão àqueles a quem deu mau exemplo e se penitenciar conforme ordem do superior; 8) contemplar a Cristo; 9) comunicar as tentações ao confessor ou ao superior; 10) conversar modestamente sem estar triste e grave, nem alegre; 11) não buscar obras maiores em detrimento de menores; 12) perseverar na vocação na qual o Senhor o colocou.

Terminada a refeição, durante a hora de siesta a que tinham direito, sonhara com um fato acontecido quando ainda estava em Toledo, rezando aos pés de Nossa Senhora e fora tomado por um forte desejo de ajudar às almas de gentios em algum lugar por onde estivessem andando seus companheiros jesuítas. Mas, no seu sonho, a Virgem estava viva e era ela mesma quem lhe dizia que deveria ir entregar a vida e padecer muitos trabalhos por amor a Cristo. Acordara sobressaltado, e já atrasado para a aula de "doutrina cristã e regras gerais comuns". Atravessou apressado o corredor do segundo andar, e desceu as escadas em direção à sala, repetindo dentro de si: "que seja para maior Glória de Cristo! Que seja para maior Glória de Cristo!...”. Na sala, todos já esperavam silenciosos a chegada do professor.

Durante todo o dia, permanecera com a lembrança do sonho; retomara cada experiência dos últimos seis anos de sua vida; recordara o momento exato de sua entrada na Companhia: um olhar que mudou para sempre a sua vida e que acendeu um desejo sincero de entregar a vida, como muitos amigos seus fizeram e como o próprio Cristo o fez. Pouco a pouco, foi se deixando tomar por aquele desejo, que já não era novo - ele bem o sabia - mas, que, por muito tempo, tivera medo de encarar - covarde que vinha sendo -, e por outro tanto

introduzidas por Villanueva (trazidas de Roma e Coimbra). No entanto, essas regras e "avisos" se mantiveram apenas até a visita do P.e Jerónimo de Nadal, em 1554; passando, em seguida, a vigorarem as Constituições.

26 Texto jurídico de "fundação" e "constituição" da Companhia de Jesus: compõe, dá a essência, descreve, estabelece um modo de agir que é o espelho da vida de Inácio e de seus primeiros companheiros. O capítulo 4 desse trabalho analisará com mais cuidado a obra. 
de tempo, tivera medo de revelar ao seu superior. Após o período de aulas da tarde, procurou seu confessor ${ }^{27}$, explicou-lhe tudo o que se passara em sua alma naquele dia e ao longo dos seis anos que estava na Companhia de Jesus; explicou como entendia e vivia aquele desejo, porque tivera medo de o revelar e perguntou o que devia fazer. "Reza - disse o padre -, medita diante de Nosso Senhor... É Ele quem te deu este desejo... É Ele a consistência desse teu desejo cheio de medo e 'poréns'. Reza, te encomenda e lembra-te que, como disse nosso pai Inácio, 'a Divina Providência pede a cooperação de suas criaturas'... Ela pede a tua cooperação para que a Glória de Cristo continue presente e se espalhe no mundo às almas que O desconhecem. Reza, Sanchez, reza".

Às cinco da tarde, passou na capela, assentou-se diante do altar simples com a imagem de Nossa Senhora e ficou, ali, olhando e pensando nas mesmas coisas que pensara há cinco anos atrás diante de um altar em Toledo. "Pode acontecer que eu morra logo - pensava. Posso morrer... mas que pena, que dor, que tristeza é essa que trago no coração?... Ainda não Vos servi de verdade... sou covarde, Senhor... sou covarde e sinto vergonha diante de Vossa Divina Majestade, que tanto fez e sofreu por mim".

Até que o sineiro tocou a hora da ceia. Dirigindo-se para o refeitório, apressadamente, tentava esconder as lágrimas... mas os olhos vermelhos não permitiam. Estava confuso: uma tristeza grande pelos próprios limites, uma alegria profunda pela certeza do chamado. Já à mesa, desatento à leitura que estava sendo feita naquele momento, lembrou-se de algo que ouvia todas as semanas, no almoço das sextas-feiras: nas regras deixadas por P.e Inácio ${ }^{28}$, havia uma frase que já decorara: não buscar obras maiores em detrimento de menores, “porque tentación es muy común del enemigo ponernos siempre la perfección en las cosas

\footnotetext{
${ }^{27}$ A regra jesuítica estabelece como prática a confissão sistemática. Nesse sentido, nos colégios e casas era imprescindível a existência de um padre confessor. Em Alcalá, na medida em que se constituía como "casa de provação", o confessor era um dos responsáveis pela formação dos noviços.

${ }^{28}$ Cf. nota 25 supra.
} 
futuras y inducirnos al desprecio de las presentes"29. Naquele instante, não conseguiu esconder a tristeza de se ver desatento e distraído e chorou. Terminada a refeição, antes de se dirigir para a capela para a meditação com o superior da casa, tendo pedido permissão para lhe falar brevemente, suplicou a mais baixa tarefa que pudesse para realizar no dia seguinte. Cônscio de seus deveres, o padre pediu-lhe as razões e ouvindo atentamente o que tinha para dizer, explicou: "Diego, não se trata de realizar tarefas baixas ou não... mas se trata de trazer um coração marcado pelo desejo justo de padecer por amor de Cristo, Nosso Senhor; se trata de realizar tudo o que realizares na vida com a marca desse desejo... toda a tua vida, todas as tuas tarefas, cada passo teu, cada refeição que tomares, cada vez que acordares, cada vez que dormires, toda a tua ação, por menor que seja, é para a maior Glória de Cristo... Agora, vai: estão nos esperando na capela, para o Rosário". Antes de sair, ainda à porta, o superior lhe chamou e disse: "Diego... Reza, meu filho".

Domingo, Ascensão de Nosso Senhor Jesus Cristo, do ano de 1588. Os sinos de Alcalá já se revezavam, tocando quase ininterruptamente a festa daquele dia. No colégio dos jesuítas, era quase hora da oração da manhã. Sanchez acordara mais cedo, quando o dia ainda era silêncio, acendera a lamparina de azeite e, olhando pela janela, vira a silhueta alta da torre da Igreja de los Santos Niños no horizonte ainda escuro àquela hora. Tomara papel, pena e tinteiro e, em silêncio, permanecera diante do papel, elaborando cuidadosamente sua experiência nos últimos anos, motivado pelos acontecimentos dos últimos dias. Rezou. Releu alguns trechos significativos das Constituições. Foi se lembrando das conversas que tivera e das indicações de seu confessor. "Esta covardia, Senhor... esta covardia não me impeça de me entregar para a ajuda das almas. Vós me chamais, mas eu sou fraco, cuidai de mim. Não seja esta carta uma prova de confiança na força das minhas mãos, mas a certeza

\footnotetext{
${ }^{29}$ Ruiz Jurado, 1980, op. cit., p. 153
} 
na vossa ajuda". Molhou, então, a pena no tinteiro e, diligentemente, desenhou no alto da

folha o nome de Cristo - JHS. Começara a escrever a saudação - Pax -, quando tocou a

hora. Ficou tentado a continuar escrevendo, mas se lembrou de que a regra era uma ajuda

para entender e viver mais adequada e verdadeiramente o ideal a que fora chamado. Rezou, fez suas anotações pessoais num pequeno diário ${ }^{30}$, tudo naquela hora e meia antes da missa. “O mistério da Ascensão: Cristo ressuscitado dos mortos, subindo aos céus, assenta-se à direita de Deus Pai e entra, definitivamente, na raiz do tempo, do espaço, da realidade, de tudo. Cristo tudo em todos".

Mais tarde, durante a missa, voltou a considerar o conteúdo de sua meditação. Terminada a celebração, preferiu não tomar o café da manhã. Voltou para o quarto, onde a lamparina ainda acesa deixara um cheiro forte e quente no ar. Assentou-se à escrivaninha, apagou a lamparina e retomou a escritura:

\begin{abstract}
Pax Christi
Considerando aquellas palabras que Nuestro padre Ignaçio dize en el principio de las constitutiones (que la divina providençia pide cooperaçion de sus criaturas), sali de una duda en la qual avia estado çinco anos de seis que ha que Nuestro Señor me hizo modo de traherme a su compañia. Y la duda era si seria açertado, o no, dar parte a V.P. de mis tibios deseos que tenia de yr a qualquiera parte de las que nuestros padres andan en missiones. Y haziame dudar el pensar que, si yo lo pedia por este medio, y V.P. me lo conçediesse, que en qualquiera tentaçion que en el camino (o estando alla) me viniesse, faltaria; y que Dios no me favoresçeria por averme yo puesto en tales peligros, y tomarlos con mis proprias manos. Y assi, todo este tiempo a sido desear y pedir a Nuestro Señor inspirar a V.P. para que, sin yo pedirlo, me siñalase para que desta manera quedasse yo sin temor, y en qualquier peligro pudiesse acudir a Dios Nuestro Señor, pidiendole su ayuda con gran confianza, y alegarle que El me enviara. Considerando pues la palabra que dixe, y reconoçiendo a V.P. en lugar de Christo Nuestro Señor, me determine de cooperar con lo que yo puedo, que es hazer saber a V.P. como abra çinco años que tengo deseo de yr a padeçer a qualquiera parte de las que arriba dixe. La primeira vez que senti en mi estos deseos fue estando en Toledo, sirviendo en la casa profesa donde me avian enviado desde el noviçiado. Estando pues un dia en oraçion, delante de la altar de Nuestra Senõra, senti en mi un animo y deseo de yr a ayudar a los animas a qualquiera parte de las que nuestros padres andan. Y la rason que, entre otras, mas me movio fue ver que tarde (o temprano) yo me avia de morir. $\mathrm{Y}$ considerandome en aquella hora preguntavame a mi mismo: que te da pena? Y que quisiera aver hecho? $\mathrm{Y}$ offreçierame que quisiera aver servido de verdad a Dios Nuestro Senõr y aver padecido muchas cosas por amor de aquel Señor que tantas padeçio por mi. Y offreçierame tambien que me veya en aquella hora corcido y avergonzado delante de
\end{abstract}

$J H S$

\footnotetext{
${ }^{30}$ Era comum que os jesuítas fizessem notas de suas moções interiores em pequenos diários. Em pesquisa realizada em Roma, encontramos, inclusive, a referência a um Librito de apuntamientos espirituales de um certo Diego Sanchez. Cf. Iparraguirre, I. (1961). Répertoire de Spiritualité Ignatienne: de la mort de S. Ignace à celle du P. Aquaviva (1556-1615). Subsidia ad Historiam Societatis Iesu, 4. Roma: IHSI.
} 
Nuestro Señor por aver sido tan covarde, y flexo en cosas de su serviçio, y assi me determine por verme en aquella hora de algo para offreçerle: mi salud y vida en serviçio de los animas.Esta razon es la que he traido delante de los ojos todo este tiempo, y oyendo, los dias pasados, leer en este collegio el Annua del Pyru, se renovo en mi y creçio el deseo de yr a servir y ayudar en lo que yo pudiesse a los Padres y gente de aquella provinçia. Y finalmente la razon dicha es la que me hizo oy, dia de la Ascension de Nuestro Redemptor, determinarme de escrivir a V.P.; y assi, despues de aver comulgado, estando considerando a Christo a la diestra se su Padre tan Glorioso y resplandeçiente, se me offreçio pensar por que medios El avia ganado aquel lugar, y viendo que era por trabajos de 33 años, y que ya se avian pasado, y el premio dura, y durara mientras Dios fuere Dios, cobré en mi nuevos deseos de padeçer el poco tiempo que tubiese de vida por verme a la hora de la muerte, alegre y, en alguna manera, aver sido compañero de Christo en esta vida por trabajos, para serlo tambien en su Gloria por eternos consuelos. Esto es, Padre Nuestro, lo que en mi siento, y solo he querido apresentarlo a V.P. para que, como amoroso Padre y Dios en la tierra, fosse por donde V.P. vea que mas conviene; que yendo quedando lo tomare todo como cosa que viene de mano de Dios Nuestro Señor, al qual yo pido siempre, y pedire en mis pobres oraçiones, guarde a V.P. muchos años, y inspire lo que mas sea para honrra y gloria suya, y pelo provecho especial de mi alma. Mi edad es veinte y çinco años y ahora acabo el quarto año de Theologia en este collegio di Alcala. En los sanctos sacrifiçios y oraçiones de V.P. mucho me encomiendo.

De Alcala, oy, dia de la Ascension, de 1588 años.

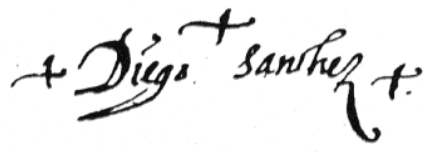

31

\section{1) Litterae Indipetae}

História de uma cidade? História de uma Ordem Religiosa? História de um Colégio?

História de um jovem religioso? Não, história da produção de "um" documento. É bem verdade, no entanto, que como essa carta de Diego Sanchez, se podem encontrar milhares ${ }^{32}$ no Arquivo da Cúria Geral da Companhia de Jesus - o Archivum Romanum Societatis Iesu (ARSI), em Roma: são as chamadas Litterae Indipetae. O que são? Quem as escreveu? Por que motivo? Estas são apenas algumas das perguntas que se podem fazer diante destes documentos. Porém, não podemos nos furtar a outras tantas que, como veremos, inevitavelmente, emergem, quando pensamos a história de sua produção.

${ }^{31}$ Carta de Diego Sanchez ao Padre Geral Claudio Aquaviva, Alcalá, Ascensão de 1588 (ARSI, Indipetae Hispanae, FG 758, carta n. 106).

${ }^{32}$ O ARSI conserva, desde 1871 no Fondo Gesuitico (FG), um total de 14.067 cartas escritas entre os anos de 1583 a 1770, por 5.167. No entanto, é sabido que, cerca de outras 5.000 cartas, que também podem ser classificadas como Indipetae, estão espalhadas no restante do Arquivo (classificadas seja como correspondência ordinária, seja nos arquivos de Províncias; além daquelas desaparecidas das quais se pode ter notícia tanto através das antigas relações de documentos, como através das respostas encaminhadas). Cf. Lamalle, 1981-82, op. cit. 
Sabe-se que, desde o período do generalato do Padre Inácio de Loyola (1541-1556), fundador da Companhia de Jesus, já era comum e mesmo incentivada a correspondência constante entre os vários membros da Ordem e seu Superior Geral ${ }^{33}$. Entre as inúmeras cartas que chegavam à Roma, não era estranho que algumas recebessem, no alto, à margem, traçada pela mão do secretário (quantas não devem ter sido assinaladas por Padre Juan Alfonso de Polanco $^{34}$ !?), a inscrição Indipeta ou Indipetarum, para designar aquelas que solicitavam ao padre geral o envio em missão no além-mar.

As Indi-petae (literalmente, petição das "Índias") são cartas de natureza privada, ainda que nascidas de uma medida oficial ${ }^{35}$, ou mesmo que formalizadas por uma estrutura retórica própria, que reservavam à aprovação do padre geral o envio às missões ${ }^{36}$. Mas, sobretudo, são fruto de

\footnotetext{
${ }^{33}$ No próximo capítulo, nos dedicaremos a melhor compreender o uso das correspondências no âmbito particular da Companhia de Jesus, bem como no âmbito histórico-cultural referente à emergência desta ordem religiosa - os séculos XVI e XVII. Apenas para um breve aceno, lembramos, com Pécora (2001), que "desde os anos de noviciado até o exercício dos principais cargos de governo, passando naturalmente pelos ministérios e missões, tudo é lugar onde a arte epistolar encontra funções bem definidas e relevantes a cumprir" (p. 26). Cf. Pécora, Alcir (2001). Máquina de gêneros: novamente descoberta e aplicada a Castiglione, Della Casa, Nóbrega, Camões, Vieira, La Rochefoucauld, Gonzaga, Silva Alvarenga e Bocage. São Paulo: Editora da Universidade de São Paulo.

${ }^{34}$ Depois de experimentar alguns secretários, Inácio de Loyola chamou a Roma, em março de 1547, para o ofício o jovem espanhol Juan Alfonso de Polanco (1516-1577) que, antes de entrar na Companhia, trabalhara como scriptor apostolicus, adquirindo grande experiência em burocracia pontifícia. Polanco foi ainda secretário dos dois Superiores Gerais que se seguiram a Inácio - Laínez e Borja. Responsável pela tradução das Constituições para o latim. Como secretário, Polanco era quem recebia as cartas dirigidas aos superiores, encaminhava umas e respondia outras (conforme o pedido do geral). Foi o responsável por uma primeira organização dos arquivos da Companhia de Jesus. Cf. Lamalle (1981-1982), op. cit. Scaduto (1992), diz ainda de Polanco: "Il settore di sua competenza fu insieme di raccordo ed evasione di un ingente carteggio internazionale, archivio, centro statistico, ufficio stampa. Ivi maturarono, o almeno furono condizionate, tante decisioni di governo, in particolare nomine e dislocazione del personale. In quei lasellari e registri si conteneva il preciso specchio dei contingenti gesuitici, secondo il numero, le attitudini, le disponibilità, le eventuali mende, le segnalate prestazioni. Fu quella la prima fonte della storiografia dell'Ordine. Polanco vi operò per circa cinque lustri, affiancando e alleggerendo le fatiche dei primi tre Generali" (64-65). Polanco era, segundo o Catálogo do Colégio de Pádua, de "parvae staturae, sed compositae et venustae faciei, debilis visus, aptus ad labores". Cf. Scaduto, M. (1992). Storia della Compagnia di Gesù in Italia. Vol V: L'epoca di Francesco de Borgia (1556-1565). Roma: Edizioni "La civiltà cattolica".

${ }^{35}$ Ou seja, anteriormente à regra ratificada pelo então Padre Geral Diego Laínez, as cartas de petição para o envio em missão não eram ainda institucionalizadas. Tem-se notícia, por exemplo, de cartas enviadas pelo Padre Francisco de Borja ao Padre Inácio de Loyola, nas quais ele manifesta seu desejo de dar a vida pela "maior glória de Deus" em terra de infiéis. Segundo Imbruglia (1992), a "idéia de escrever diretamente ao Geral o pedido de missão, já desejada por Inácio, foi mais tarde ratificada pelo então padre geral Diego Laínez, no dia 18 de dezembro de 1558". Cf. Imbruglia, G. (1992). Ideali di civilizzazione: la Compagnia di Gesù e le missioni (1550-1600) (287-308). Em: Prosperi, A. e Reinhard, W. (ed.) (1992). Il nuovo mondo nella coscienza italiana e tedesca del Cinquecento: Annali dell'Istituto storico italo-germanico. Quaderno 33. Bologna: Il Mulino.

${ }^{36}$ Cf. principalmente, o texto das Constituiç̃es, por exemplo, os \$§ 618-632. Mas também Groupe de Recherches sur les Missions Religieuses Ibériques Modernes (1999). Politique missionaire sous le pontificat de Paul IV: un document interne de la Compagnie de Jésus en 1558. Mélanges de l'École Française de Rome: Italie et Méditerranée, 111(1), pp. 277-344; ou Lamalle, 1981-82, op. cit.; ou Prosperi, A. (1996). Tribunali della coscienza: inquisitori, confessori, missionari. Torino: Giulio Einaudi editore; ou Pizzorusso, G. (1997). Le choix indifférent: mentalités et attentes des jésuites aspirants missionnaires dans l'Amérique française au XVIIe siècle. Mélanges de l'École Française de Rome: Italie et Méditerranée, 109(2), pp. 881-894; entre outros.
} 
uma dinâmica eletiva pessoal, ou resultado de uma elaboração de experiência. Os jovens que as escreveram o fizeram após um trabalho de investigação acerca de si mesmo ${ }^{37}$.

Porém, é preciso dizer, há também uma dinâmica institucional, do ponto de vista das políticas missionárias, dos interesses políticos tanto da cúria geral da Companhia, quanto das mais diversas províncias, assim como nos relacionamentos com a Cúria Romana e com as coroas dos Estados europeus de então; todas questões que precisam ser desvendadas e melhor explicitadas; cabendo, no entanto, a quem trabalhe com história das missões e afins.

Não se pode desconsiderar tampouco as outras motivações pessoais que poderiam estar subjacentes ao imperioso “desejo das Índias”: relacionamentos familiares (como se verá, por exemplo, na carta de Thomas Haward ${ }^{38}$ ), amizades com superiores ou padres importantes, interesses individuais, etc. Movidos por um desejo que variava de objeto mediador imitação, martírio, padecimento de trabalhos, cumprimento da vontade de Deus, ajuda das almas etc. -, os jovens aspirantes jesuítas escreviam suas cartas de petição usando expressões "comuns e que se sabiam mais aceitas no âmbito da Companhia", carregadas de tensão, a fim de verem acolhido mais fácil e rapidamente o seu pedido. No entanto, não se permanecia no ordinário, muitos insistiam sobre suas "atitudes e qualidades particulares" 39 , bem como sobre suas virtudes, grau de instrução, temperamento, saúde, ou experiência.

O interesse consistia, sabendo que quem escolheria era o Superior Geral, em demonstrar todo o real "desejo" 40 das missões e relatar o trabalho pessoal realizado no sentido de descobrir, no dinamismo do desejo experimentado, a vontade de Deus e, ao mesmo tempo, demonstrar suas virtudes pessoais. $\mathrm{O}$ interesse era falar de uma motivação que fora objeto de eleição ${ }^{41}$, de

\footnotetext{
${ }^{37}$ Cf., entre outros, Massimi, M. e Prudente, A. B. (2002). Um incendido desejo das Índias... São Paulo: Edições Loyola. ${ }^{38}$ ARSI, Indipetae Hispanae, FG 759, carta n. 5, de Thomas Hhavvard, Valladolid, 12/03/1605. Ao que tudo indica, o indipetente não é espanhol. Optamos por mantê-lo, ainda assim, entre as fontes primárias, pelas demais características de sua Indipeta: escrita em espanhol, a partir de um colégio jesuítico na Espanha.

${ }^{39}$ Prosperi, 1996, op. cit., passim (tradução nossa).

${ }^{40}$ Cf. nota 34.

${ }^{41}$ Os jesuítas eram educados, através dos diversos instrumentos de ordenação da vida interior e exterior (os Exercícios Espirituais, as Regras, as Constituições, os textos de espiritualidade a que tinham acesso etc.), a eleger aquilo que mais se adequasse à vontade de Deus ou, em outras palavras, o que fosse realmente ad maiorem Dei gloriam. Esse processo
} 
oração e expressar seu zelo pelas missões, por nuestra madre la minima Compañía, a confiança na graça consoladora de Dios Nuestro Señor, ou na intercessão de la Beatissima Virgen Maria, ou de algum outro santo, a exigência de seguir o exemplo de um mártir, de um missionário, de um santo. E, sobretudo, tratava-se de explicitar a decisão de trabalhar para lo que más convenga al Divino Servicio, já que se sabia, pelas Constituições e pelo Documento de $1558^{42}$, que entre os critérios de escolha para o envio se dizia: "se escolherá aqueles que foram dotados de (...) grandes virtudes morais" $"$, mas finalmente o critério maior era sempre "que se faça sempre aquilo que é para o maior serviço divino e um bem mais universal"44.

implicava o "discernimento dos espíritos", prática que consistia, basicamente, na busca do profundo conhecimento de si mesmos, afim de escolher conforme a sua vocação. Em carta enviada no dia 29 de maio de 1555 ("Instrução sobre a maneira de tratar ou de regrar um negócio com um superior”) para toda a Companhia de Jesus, Inácio - então Prepósito Geral - escreve logo no início: "Primeiramente. Que aquele que deve tratar com um superior lhe apresente as coisas maduramente refletidas, examinadas pessoalmente ou discutidas com outros, segundo sua maior ou menor importância" (p. 940), descrevendo assim o básico do processo de eleição e a conseqüente apresentação do resultado. Cf. Loyola, I. (1991). Écrits. Paris: Desclée de Brouwer, Bellarmin, p. 940 (tradução nossa).

${ }^{42} \mathrm{O}$ "Documento de 1558" - como é referido - trata dos critérios de envio em missão. É um texto normativo escrito por Padre Juan Alfonso de Polanco. Para saber mais sobre o documento, cf. Groupe de Recherches sur les Missions Religieuses Ibériques Modernes, 1999, op. cit.

${ }^{43}$ Ibid., p. 341 (tradução nossa).

${ }^{44}$ Loyola, 1991, op. cit., p. 547, Const. $§ 618$ (tradução nossa). 


\section{CAPÍTULO 2 Indipetae: um gênero}

Passo entre outros - a partir do último onde pudemos ver como, por quem e por que se produziram os documentos com os quais lidamos -, devemos dar um segundo de compreensão do lugar que estes documentos ocupam no interior de um gênero específico: quais as suas peculiaridades, suas relações com outros gêneros e documentos da mesma época, qual sua estrutura argumentativa? Perguntas, cujas respostas nos ajudarão a localizar as Indipetae no seu contexto genético ${ }^{1}$.

Cabe lembrar, inicialmente, o valor heurístico da correspondência epistolar, seja para historiadores, sociólogos ou literatos. Atualmente existem, pelo menos, dois reconhecidos centros de estudos e pesquisas trabalhando com documentos do tipo: o Centre Universitaire de Lecture Sociopoétique de l'Épistolaire et des Correspondances (CULSEC), da Université de Montréal (Canadá); e a Association Interdisciplinaire de Recherche sur l'Épistolaire (AIRE), da Université Paris 7 - Jussieu (França). Além desses importantes centros de pesquisa,

\footnotetext{
${ }^{1}$ Cf. Pécora, Alcir (1999). Cartas à Segunda Escolástica (pp. 373-414). Em: Novaes, Adauto (org.) (1999). A outra margem do Ocidente. São Paulo: Companhia das Letras.
} 
vale apontar a contribuição do Centre de correspondance et journaux intimes des XIX et XXe siècles, da Université de Bretagne Occidentale, em Brest (França), bem como os trabalhos do Centre d'Anthropologie Religieuse Européenne ${ }^{2}$ (CARE), que ao longo dos últimos anos tem dedicado especial atenção às cartas Indipetae. Atenção deve ser dada também às pesquisas sobre correspondências particulares e, especialmente as não poucas revistas e encontros científicos $^{3}$ em todo o mundo que vêm se dedicando a publicações sobre epistolários os mais variados, nas últimas décadas.

Do ponto de vista do valor documental, o historiador Jean Hébrard (1990) aponta duas importantes características da correspondência epistolar produzida no século XIX: 1) o fato de, em sendo textos da esfera pública, terem significativa função de troca de informações; 2) e o fato de serem documentos expressivos da construção da subjetividade de quem escreve $e^{4}$. Numa transposição para a análise da correspondência epistolar produzida nos séculos XVI e XVII, podemos fazer referência, com Massimi (1995), ao cunho "expressivo no que diz

\footnotetext{
${ }^{2}$ Em 07 de fevereiro de 2004, alguns dos integrantes do CARE - que compõem o Groupe de Recherches sur les missions religieuses ibériques des XVI-XVIII ${ }^{e m e}$ siècles - propuseram a Journée d'études sur les Indipetae: Demander les Indes, Paris (França).

${ }^{3}$ Seja o CULSEC, sejam alguns de seus membros coordenaram colóquios em 1993 (Montréal), 1994 (Montréal), 1995 (Ottawa), 1995 (Montréal), 1997 (Montréal) e 1998 (Montréal), no Canadá, além de ter publicado em 1994, na revista Spiral (o número 135, de set/1994), o Dossier "L'épistolaire au Québec" O AIRE, por sua vez, publica a revista anual Révue de l'AIRE, totalmente destinada às produções científicas sobre epistolários. Também o Centre Méridional de Rencontres sur le XVII ${ }^{\mathrm{eme}}$ siècle (CMR 17), que organizou colóquios sobre o assunto em 1987 (Tübingen) e recentemente em 2004 (Paris). O Institut de Recherches et Prospective Postales (IREPP), em Paris, que se dedica aos epistolários modernos e, especialmente, ao uso dos recurso informáticos na troca de correspondências e que publica a revista Mille Millard d'e-mail. Também a Fundation La Poste francesa dedica largo espaço a este assunto. Há também alguns centros que se dedicam a publicação de epistolários particulares: a Societé Diderot (cartas de Diderot), a Association Néerlandaise (cartas de Isabelle de Charrière) da Universiteit Leiden, a University of Toronto (cartas de Mme. de Graffigny), as Éditions Louis Conard (cartas de Flaubert). No Brasil, recentemente (2002) a revista eletrônica Memorandum: memória e história em psicologia publicou no seu número 2 (mar/2002) artigo onde Massimi entre outras coisas discute o valor das cartas como documentos históricos; também a revista eletrônica Rever da PUC/SP publicou em 2001 resenha comentando a obra de Assunção, Paulo de (2001). "A Terra dos Brasis". A natureza da América Portuguesa vista pelos primeiros Jesuitas (1549-1596). São Paulo: Annablume, onde o autor não deixa de dar importante destaque às correspondências jesuíticas. Também a obra: Massimi, Marina; Mahfoud, Miguel; Silva, Paulo José Carvalho da e Avanci, Sílvia Helena Sarti (1997). Navegadores, colonos e missionários na Terra de Santa Cruz: um estudo psicológico da correspondência epistolar. São Paulo: Edições Loyola. Outra importante obra no assunto foi publicada em 2002: Massimi, Marina e Prudente, André Barreto (2002). Um incendido desejo das Índias. São Paulo: Edições Loyola. Evidentemente, esta nossa lista está longe de ser exaustiva.

${ }^{4}$ Cf. Hébrard, Jean (1990). La correspondance au XIXe siècle: approche historique. Extrait du Colloque "L'Épistolarité a travers les siècles: geste de communication et/ou d'écriture. Centre Culturel International de Cerisy la Salle France. Stuttgart: Franz Steiner Verlag, pp. 162-168.
} 
respeito às vivências de caráter psicológico e ao reconhecimento das redes de relações sociais presentes no universo de vida dos autores", lugar de prestígio no campo das história das mentalidades.

Estamos na passagem do século XVI para o XVII: um importante período de transição. Culturalmente, o fenômeno que dita as regras do pensar e do agir do homem da época é o que hoje denominamos "humanismo" e "renascimento". Vale lembrar que neste período ocorre um avanço na longa tradição da ars dictaminis de origem medieval ${ }^{6}$ : a arte de escrever cartas; o que implica fazer uso da retórica não apenas no falar, mas também no escrever. $\mathrm{Na}$ "renascença" européia essa tradição ganha nova importância, sobretudo dado o fato de que, com o advento da imprensa com caracteres móveis, firmou-se poderosamente o costume de se publicarem epistolários privados. Nesse sentido, não é mesmo demais afirmar que os humanistas são os sucessores diretos dos dictatores medievais ${ }^{7}$.

É importante darmo-nos conta do valor da retórica nesse período: ela preside não somente o estilo da epistolografia, quando determina os aspectos formais de uma correspondência epistolar, mas a própria gestão da coisa pública, na medida em que cunha “o modo de ser, de pensar e de agir do intelectual humanista" ${ }^{\text {. }}$.

$\mathrm{Na}$ "renascença" - de forma bem evidente nas instituições de ensino dirigidas por jesuítas -, o sistema pedagógico utilizado nas escolas e universidades era o medieval, fundado

\footnotetext{
5 Massimi, Marina (1995). Descoberta, ação, conhecimento e poder no Brasil Colonial: estudos históricopsicológicos. Tese de Livre Docência, Faculdade de Filosofia, Ciências e Letras de Ribeirão Preto, Universidade de São Paulo, São Paulo, SP, p. 43.

${ }^{6}$ Cf. Longo, Nicola (1981). De epistola condenda: L'arte di "componer lettere" nel Cinquecento. Em: Quondam, Amedeo (org.) (1981). Le "carte messaggiere": retorica e modelli di comunicazione epistolare: per un indice dei libri di lettere del Cinquecento. Roma: Bulzoni Editor.

${ }^{7}$ Cf. Pécora, 1999, op. cit.

${ }^{8}$ Longo, 1981, op. cit., p. 187. Longo (1981) cita ainda como exemplo dessa aliança entre cultura e vida civil a obra dos Salutati, onde se misturam documentos de chancelaria e missivas privadas, de forma que podemos ter a "medida exata da transformação da técnica retórica em humanidade" (p. 191).
} 
sobre as sete artes liberais: gramática, retórica, dialética, aritmética, geometria, música e astronomia. No entanto, um significativo destaque era dado à dialética e à retórica ${ }^{9}$.

Concentremo-nos um pouco mais na retórica - nosso foco de interesse no momento -

para melhor entender, de maneira ainda geral, o que dava corpo à produção de documentos

designados como "cartas".

Em retórica, os principais autores estudados eram Cícero e Quintiliano ${ }^{10}$. Aprender a

\begin{abstract}
${ }^{9}$ A Ratio studiorum era o documento que norteava a pedagogia dos colégios jesuíticos. Ela "apresentava um modelo pedagógico construído com base na pesquisa, na prática e nas adaptações decorrentes da experimentação" [Da Cás, Danilo (1996). A universidade luso-brasileira: universidade de fato (1572-1822). Tese de Doutorado não publicada, Universidade Estadual Paulista, Marília, SP, p. 38]. Tratava-se de uma espécie de guia didático-administrativo para as instituições de ensino da Companhia de Jesus, onde estavam estabelecidas regras de atuação a todo o corpo docente dos cursos, estruturas curriculares e, entre outros, procedimentos didáticos e formais. Após a fundação da Companhia de Jesus, e mais especificamente quando a Companhia começou a assumir colégios e universidades, Inácio sentiu a necessidade de se uniformizar o sistema de ensino. Baseado na experiência por que passou na Universidade de Paris, toma como referência o modelo pedagógico dessa instituição. Somente em 1560 é editada uma primeira versão desse "método de estudo", a assim chamada Ratio borgiana, que não é adotada em todas as escolas. Em 1583, o então Padre Geral Cláudio Aquaviva solicita a elaboração de um plano de estudos comum, para garantir a uniformidade da doutrina e do método de ensino. Em 1586 foi escrita então a primeira versão que seria depois encaminhada para todos os colégios para uma revisão cuidadosa. Finalmente, em 1591, essa versão revisada, é editada em forma de regra Regulae officiorum -, e em 1599 é editada a forma definitiva, denominada Ratio atque institutio studiorum Societatis Iesu, que fica em vigor em todos os colégios jesuíticos do mundo, até o ano da supressão da Companhia de Jesus, em 1773. A Ratio studiorum, enquanto documento normativo e "manual pedagógico" para o ensino nas universidades, colégios e seminários da Companhia de Jesus, tornou possível uma influência uniforme em todas as instituições em que os jesuítas eram professores, mesmo em realidades tão díspares da Europa como a realidade do Brasil Colônia, por exemplo. Num período marcado pela necessidade de se formarem "espíritos segundo as diretrizes da ortodoxia mais rígida", um período em que urgia à Igreja Católica a formação de um pensamento coeso e unânime (especialmente em filosofia e teologia), um período de renovação das ciências eclesiásticas e da vida religiosa, sem dúvida era de grande relevância e mesmo indispensável que se estabelecessem certas instruções que norteassem o ensino das humanidades, bem como da filosofia e da teologia, a fim de se evitar contendas e maiores divisões. A eclosão, na chamada "renascença", do movimento Reformista Protestante, exigia uma postura da Igreja Católica: é no século XVI que surge, então, a Reforma Católica, marcada pela reafirmação das tradições; especialmente no campo da filosofia, a retomada da Escolástica. A Ratio studiorum era um documento que chamava a atenção dos jesuítas para a necessidade de se respeitarem as Constituições quanto ao programa de estudos, o que implicava o seguimento de Aristóteles corretamente interpretado, ou para sermos mais conformes às palavras de Inácio: "na lógica, na filosofia natural e moral e na metafísica, bem como nas artes liberais, seguir-se-á a doutrina de Aristóteles" Cf. também Caeiro, Francisco da Gama (1989). El problema de las raíces historicas. Em Barba, Enrique M. et al. (dir.) (1989). Ibero-américa, una comunidad. Tomo I. Separata. Madrid: Ediciones de Cultura Hispánica; Rodrigues, Manuel Augusto (1985). Do Humanismo à Contra-Reforma em Portugal. In: Revista de História das Idéias. Coimbra; Raffo, Giuliano (a cura di) (1989) La "ratio studiorum": il metodo degli studi umanistici nel collegi dei gesuiti alla fine del secolo XVI. Milano: Gesuiti San Fedele; Giard, Luce (1995). Le devoir d'intelligence ou l'insertion des jésuites dans le monde du savoir (XI-LXXIX). Em Giard, Luce (dir.) (1995). Les jésuites à la Renaissance: système éducatif et production du savoir. Paris: PUF; García Mateo, Rogelio (2000). Ignacio de Loyola: su espiritualidad y su mundo cultural. Bilbao: Instituto Ignacio de Loyola/Universidad de Deusto/Ediciones Mensajero..

${ }^{10}$ Mas, no caso da Companhia de Jesus, é importante lembrar que, dado o fato de a filosofia de fundo dos jesuítas ser de bases aristotélico-tomistas, a teoria ciceroniana sobre os argumenta, por exemplo, estava intimamente associada à teoria dos tópicos e da dialética aristotélica. Cf. García-Mateo, Rogelio (1998). Fuentes filosófico-teológicas de los ejercicios según el currículum académico de su autor. Em: Plazaola, Juan (ed.) (1998). Las fuentes de los Ejercicios Espirituales de San Ignacio. Actas del Simposio Internacional (Loyola, 1519 septiembre 1997). Bilbao: Ediciones Mensajero.
\end{abstract}


retórica era mais que aprender a beleza de um estilo literário da comunicação escrita ou oral, mas se tratava propriamente do aprendizado da capacidade argumentativa. A retórica era dividida em cinco partes: inventio ("inventar", descobrir na realidade elementos - coisas ou palavras - em prol de uma plausibilidade), dispositio (ordenar os elementos descobertos), elocutio (adaptar uns aos outros os elementos descobertos), memoria (perceber sensivelmente, na alma, esses elementos) e pronuntiatio (controlar voz e corpo a fim de adaptá-los bem à dignidade dos elementos) $)^{11}$.

O papel da retórica era, pois, dar àquele que a usasse bem, uma capacidade de persuasão sobre o interlocutor, a fim de convencê-lo com argumentos justos e verdadeiros. No momento da fala ou da escrita, o homem deveria ter bem claros para si os elementos todos de sua argumentação: dados da realidade (seja interna, seja externa) bem ordenados e adaptados uns aos outros, somados a uma experiência sensível daqueles dados, atenção ao valor dos dados e, sobretudo, atenção ao interlocutor (seu lugar social, por exemplo).

Deste modo, quase podemos falar de um estilo retórico-poético ${ }^{12}$, certos de que "a carta é um produto puro da capacidade de escrever do autor" ${ }^{\prime 1}$. É, pois, quase imediato se pensar em uma tipologia dos gêneros de cartas: diferentes qualidades de dados, diferentes formas de ordenação e adaptação, diferentes experiências, diferentes interlocutores, designariam, necessariamente, diferentes tipos de carta.

Segundo Longo (1981), podemos descrever, pelo menos, quatro tipos diferentes de

\footnotetext{
${ }^{11}$ Cf., entre outros, o importante trabalho de Yates, Frances A. (1975). L'art de la mémoire (D. Arasse, trad.). Paris: Gallimard (original publicado em 1966). Nessa obra de referência no assunto, a autora refaz a história da ars memoriae, desde as tradições clássicas até o século XVIII. Mas também Cicéron, M. T. (1966 e 1967). De l'orateur. Livres deuxième et troisième. (E. Courbaud, Trad.). Paris: Société d'édition "Les Belles Lettres" (original de 55 a.C.), onde Cícero explica minuciosamente cada uma dessas partes.

${ }_{12}$ Baseamo-nos na tese de Pécora (1999) sobre as implicações epistemológicas da correspondência epistolar, segundo a qual a carta não é absolutamente uma "tábua em branco, impressionada pelos acontecimentos vividos (...), mas deve ser vista como um mapa retórico em progresso da própria conversão" (p. 373), cujos sentidos devem ser "adequados aos roteiros plausíveis desse mapa" (p. 374). Daqui o necessário passo de compreensão dos aspectos retóricos que sustentam a escritura das cartas.

${ }^{13}$ Longo, 1981, op. cit., p. 186.
} 
cartas $^{14}$ nesse período: suasório (ou deliberativo: é o estilo da carta que concilia, exorta, dissuade, consola, questiona ou recomenda), demonstrativo (é aquela que descreve pessoas, países, campos, fortalezas, fontes, tempestades, viagens e fatos ou eventos semelhantes), judicial (que expõe uma acusação, uma querela, uma repreensão, uma ameaça ou uma inventiva) e narrativo (é a carta que dá um aviso, comunica uma alegria ou um lamento, uma carta de gratidão, de louvor, seja oficial ou burlesca).

Além disso, as próprias composições, já que se adequavam a uma fórmula retórica bem determinada e estudada, possuíam uma divisão interna (conformada às normas retóricas da ars dictaminis): 1) uma primeira parte chamada salutatio, normalmente breve, onde é expresso o sentimento com relação ao receptor, é o lugar do "decoro" e, não poucas vezes, adquiria um caráter protocolar, servindo mesmo de preâmbulo preparatório para o restante da carta $^{15}$; 2) na seqüência, uma segunda parte denominada captatio benevolentiae, ou exórdio, na qual o remetente, ordenando adequadamente as palavras, procura influir de maneira eficaz

\footnotetext{
${ }^{14}$ Essa tipologia corresponde exatamente aos gêneros do discurso retórico. No entanto, Cícero (1936) reconhece apenas três gêneros de cartas: cartas de informação, cartas familiares ou jocosas (privadas) e cartas severas e graves (públicas): "Há, tu não o ignoras, mais de um gênero de cartas; mas entre todos aquele que julgo ser o mais autêntico é o que se deve a própria invenção das cartas, o que nasceu do desejo de informar os ausentes, quando era interessante para eles ou para nós que fossem informados de alguma coisa. (...) Há dois outros gêneros de cartas, e que me deliciam, um familiar e jocoso, outro severo e grave" (pp. 170-171). Cf. Cicéron, M. T. (1936). Correspondance Tome III. (L.-A. Constans, Trad.). Paris: Les Belles Lettres (original latino do séc. I a.C.). Pécora (2001) lembra que também na Idade Mëdia e conforme diferentes autores, essa tipologia poderia variar: por exemplo, o tratado de C. Julius Victor, no século IV, reconhecia basicamente dois gêneros de correspondências, as "negotiales (oficiais, com matéria argumentativa séria, em que é possível escrever com erudição ou polêmica, além de usar linguagem figurada) e familiares (cujas principais diferenças virtudes são a brevidade e a claridade)" (p. 19). De qualquer forma, Pécora (2001) lembra também que o século XVI é marcado pela "descoberta das cartas de Cícero por Petrarca" o que trouxe consigo a "moda de imitação clássica que culminou no ciceronianismo do início do XVI" (p. 23), de forma que a oratio ciceroniana será referencial importante nesse período; o que confirma a divisão dos gêneros de cartas conforme os gêneros da retórica que mais tarde influenciou tanto os manuais de epistolografia humanistas e mesmo a Companhia de Jesus, como se verá à frente. Cf. Pécora, Alcir (2001). Máquina de gêneros: novamente descoberta e aplicada a Castiglione, Della Casa, Nóbrega, Camões, Vieira, La Rochefoucauld, Gonzaga, Silva Alvarenga e Bocage. São Paulo: Editora da Universidade de São Paulo.

${ }^{15}$ Cf. Tin, Emerson (2003). "Familiar del Universo": arte epistolar e lugar-comum nas cartas familiares (1664) de d. Francisco Manuel de Melo. Dissertação de Mestrado, Curso de Teoria Literária do Instituto de Estudos da Linguagem da Universidade Estadual de Campinas, UNICAMP, Campinas, SP. Segundo Tin (2003), a salutatio "adquiria uma importância fundamental, pois nela espelhavam-se as relações sociais entre remetente e destinatário, além de servir como uma espécie de prêambulo, preparando e dispondo o destinatário para os assuntos veiculados ao longo da carta. Nas artes epistolares do período renascentista, as prescrições sobre a salutatio se simplificam, reduzindo-se as regras fixas para conferir maior ênfase ao decoro, à adequação da carta ao seu destinatário" (pp. 39-40).
} 
na mente do destinatário, buscando sua disposição favorável $^{16}$; 3) em seguida, vem a narratio, trecho da carta onde o escritor informa a matéria em discussão e relata um ocorrido à pessoa ausente, ao destinatário, é a parte mais extensa da carta, onde é apresentado não somente o caso, mas também os argumentos empregados em torno do caso e as eventuais digressões ${ }^{17}$; 4) em quarto lugar, aparece a petitio, que consiste, tautologicamente falando, no desenvolvimento do discurso do pedido (esta parte pode ser classificada a partir de nove categorias: suplicatória, didática, cominativa, exortativa, incitativa, admonitória, de conselho autorizado, reprovativa ou $\operatorname{direta}^{18}$ ), no entanto, é importante lembrar que a petição, em alguns casos, "não ocupa apenas um lugar fixo nas cartas mas permeia toda a narração e, na quase totalidade delas, participa da sua conclusão, seja como retomada de um pedido já expresso antes, seja como enunciado do 'remédio' para o que antes se deu a conhecer" ${ }^{\text {"19; }}$ 5) finalmente, a última parte é denominada conclusio, e corresponde ao trecho da carta onde o autor resume “os argumentos e (...) enfatiza a súplica para que fique impressa na mente do destinatário" 20 ,é a amarração final, o remate da narratio, sendo basicamente composta de cinco partes (valedictio $^{21}$, indicação de lugar, indicação de tempo, fecho complementar e assinatura $)^{22}$.

Mas, e quanto ao papel das cartas na Companhia de Jesus? Até aqui, vimos como, nos séculos XVI e XVII, estes eram documentos regidos por regras que nos permitem identificar sua produção com a produção retórico-poética de tradição medieval. No entanto, além desse valor geral, existe o fato de que a correspondência na dita "renascença" era concebida como

\footnotetext{
${ }^{16}$ Cf. Ibid., pp. 46-63. Também Pécora, 2001, op. cit., pp. 35-39.

${ }^{17}$ Cf. Ibid., pp. 64-114. Também Pécora, 2001, op. cit., pp. 39-60.

${ }^{18}$ Cf. Pécora, 2001, op. cit., pp. 21 e 61-62.

${ }^{19}$ Ibid., p. 62. Neste trecho, Pécora (2001) trata especificamente das cartas do padre jesuíta Manuel da Nóbrega. No entanto, como as Indipetae se caracterizam pelo fato de serem cartas de tipo suasório de petitio suplicatória, esta observação as descreve adequadamente, como veremos à frente.

${ }^{20}$ Massimi, Marina e Prudente, André Barreto (2002). Um incendido desejo das Índias... São Paulo: Ed. Loyola, p. 18.

${ }^{21}$ Segundo Tin (2003), a valedictio é a despedida formal da carta (literalmente, vale - dictio: dizendo adeus).

${ }^{22}$ Cf. Ibid., pp. 122-129.
} 
uma das formas de "manutenção de relações sociais"23, e há também um aspecto que respeita especificamente aos jesuítas e que, no nosso caso, precisa ser bem compreendido ${ }^{24}$.

Pécora (1999) lembra que as cartas, no seio da Companhia de Jesus, cumpriam uma tríplice função: informar, reunir em um só corpo e comunicar experiência mística ou devocional $^{25}$. De fato, essa é uma codificação que se pode encontrar nos documentos da ordenação institucional jesuítica.

Por exemplo, no início das Constituições jesuíticas, especificamente na Parte Terceira (A conservação e o progresso daqueles que estão em provação), se diz que um dos exercícios para a "conservação do que concerne à alma" é a "leitura de cartas edificantes" 26 durante as refeições. Mais à frente, na Parte Quarta (A formação nas letras e nos outros meios de ajudar o próximo daqueles que se guarda na Companhia), no capítulo décimo sétimo que trata dos "encarregados do ofício ou ministros da universidade", diz-se que o reitor, ou "seus síndicos particulares", deve escrever cada ano, ao Prepósito Geral e ao Provincial (duas vezes por ano), uma carta acerca de todos os professores e outras pessoas pertencentes à Companhia, "inteirando-os do que lhes convêm, para que se aja em tudo com mais circunspecção e com o cuidado de que cada um faça o que deve ser feito" ${ }^{27}$. No mesmo capítulo, em seguida, as Constituições determinam que as cartas devem ser enviadas "fechadas, de modo que ninguém

\footnotetext{
${ }^{23}$ Ibid., p. 13.

${ }^{24}$ Cf. a esse respeito: O’Malley, John W. (1999). I primi gesuiti. Milano: Vita e Pensiero (original em inglês de 1993). Nessa obra, o autor dedica algumas páginas a descrever o uso da correspondência para os jesuítas, nos inícios da Companhia de Jesus.

${ }^{25}$ Cf. também Pécora, 2001, op. cit. Nesta obra, o autor afirma: "Com efeito, o primeiro deles [informação] fica logo claro quando se conhece que a correspondência é muitas vezes o único meio de relato dos sucessos passados nas várias frentes de ação jesuítica espalhada ao longo do vastíssimo novo orbe. (...) O segundo aspecto [reunião de todos em um] justamente manifesta-se aí, quando os acontecimentos enfeixados em linhas de informação, reforçam igualmente a rede espiritual dos irmãos dispersos no mundo, de cuja solidariedade de ação e unidade de propósito depende a sobrevivência do corpo inteiro da Companhia e a eficácia global de sua intervenção na história, enquanto co-autora da Providência. Contudo, este único corpo, em que todos agem como um só, ainda não se compreende verossimilmente enquanto a unidade não se traduz como experiência mística, isto é, como êxtase da participação na plenitude de uma vida espiritual, que, no limite, exige a perda do cuidado de si" (p. 28).

${ }^{26}$ Loyola, Ignace (1991). Écrits (M. Giuliani, trad., apres. e dir.). Paris: Desclée de Brouwer, Bellarmin (Collection Christus n ${ }^{\circ}$ 76, Textes), p. 457, Const., § 252 (tradução nossa)

${ }^{27}$ Ibid., pp. 513-514, Const., § 504 (tradução nossa).
} 
saiba o que o outro escreve",28.

Assim reza o parágrafo 673, capítulo primeiro, Parte Oitava ( $O$ que ajuda a unir com a cabeça e entre si aqueles que estão dispersos), das Constituições jesuítas:

"A troca de cartas" entre inferiores e superiores será também de ajuda toda especial, fazendo saber freqüentemente a uns o que a outros acontece e conhecer "as novas" e "as informações" que provêem de diversas regiões. Os superiores serão encarregados disso, em particular o geral e os provinciais que darão ordens de tal sorte que em cada região se possa saber o que se passa nas outras para a consolação e edificação mútuas em nosso Senhor ${ }^{29}$.

O parágrafo 675, em seguida, é uma descrição de como deve ser regrado o envio das cartas: "no início de cada período de quatro meses uma carta (...) contendo apenas coisas edificantes"; "duas cópias"; "o provincial fará, do segundo exemplar, cópias suficientes para dar ao conhecimento de toda a Província”; "o Geral dará ordens para que se façam cópias suficientes das cartas enviadas pelas Províncias, para fornecer a todos os outros provinciais $" 30$.

Pécora (2001) lembra também que o texto das Constituições "expressa a obrigação de o Geral manter a observância estrita" das regras, "informando-se do que se passa em todas as províncias, e escrevendo assiduamente aos provinciais a propósito do que pensa das coisas que lhe comunicam, fazendo sempre que se proceda como convém"31.

Além do que está expressamente regulamentado nas Constituições, existem outras várias referências às regras de como escrever - conteúdo, forma, periodicidade etc. - em cartas que o próprio Inácio de Loyola deixou. De fato, um dos maiores legados deixados por Inácio, em tudo coerente aos ideais medievais e embebida no mais legítimo espírito renascentista, é o corpus de suas cartas: 6.813 correspondências, reunidas nos 12 grossos volumes da Monumenta Historica Societatis Iesu (MHSI), que nos ajudam a ter uma idéia

\footnotetext{
${ }^{28}$ Ibid., p. 514, Const., § 507 (tradução nossa).

${ }^{29}$ Ibid., p. 565, Const., § 673 (tradução nossa).

${ }^{30}$ Ibid., passim (tradução nossa).

${ }^{31}$ Pécora, 2001, op. cit., pp. 27-28. Cf. também Const., § 790.
} 
completa tanto da espiritualidade jesuítica quanto de sua ordem institucional ${ }^{32}$.

Em carta enviada a Pedro Fabro, em 10 de dezembro de 1542, Inácio pedia que "em nossas correspondências, ajamos de maneira a assegurar o maior serviço de sua divina bondade e a maior utilidade do próximo (...), para a maior edificação dos ouvintes ${ }^{33}$ ou dos leitores" ${ }^{34}$. E relata, nessa mesma carta, como ele faz para escrever: escrevia uma vez, examinava o que tinha escrito, corrigia levando em conta que todos a leriam, e, enfim, a reescrevia (ou dava ao secretário Polanco para re-escrevê-la), "porque o que se escreve deve ser mais amadurecido do que o que se diz. O escrito permanece"35.

Um ano depois, escrevendo a Nicolás Bobadilla, que havia respondido a uma carta enviada por Inácio, onde esse chamava a atenção para a importância do cuidado com a redação das correspondências ${ }^{36}$, Inácio volta a chamar a atenção para uma série de aspectos importantes a serem levados em consideração no momento da escritura: trata-se de um texto, onde Inácio leva às últimas conseqüências sua disposição de se "abaixar totalmente" mais que se "desculpar parcialmente, julgando que será para a maior glória"37. Na carta, Inácio insiste na atenção à correspondência que será enviada, na necessidade de lê-la e corrigi-la antes.

Durante alguns anos, Inácio - Prepósito Geral desde 1541 - não teve bons secretários. Em 1547, ele traz para perto de si Juan Alfonso Polanco. Essa escolha será importante para a organização de todas as correspondências enviadas e recebidas. Uma de suas primeiras iniciativas foi escrever uma longa carta/regra, em 27 de julho de 1547, sobre a

\footnotetext{
${ }^{32}$ Cardoso, Armando (org.) (1990). Cartas de Santo Inácio de Loyola. Volume 2. São Paulo: Ed. Loyola, p. 6.

33 As cartas enviadas para o Padre Geral, como se pode ler no $§ 675$ das Constituições, eram copiadas e enviadas aos provinciais. Nas Províncias - conforme o costume estabelecido em cada casa -, as cartas eram lidas em voz alta em momentos como nas refeições, por exemplo. Cf. a esse respeito, por exemplo Ruiz Jurado, Manuel (1980). Origenes del noviciado en la Compañía de Jesus. Bibliotheca Instituto Historici Societatis Iesu, XLII. Romae: IHSI.

${ }^{34}$ Loyola, 1991, op. cit., p. 670 (tradução nossa).

${ }^{35}$ Ibid., p. 671 (tradução nossa).

${ }^{36}$ Bobadilla, nesse período, se encontrava na Alemanha desenvolvendo "um enorme labor apostólico" (p. 676) e, dado o seu temperamento "fogoso" corria o risco de um ativismo pessoal que não interessava à Companhia de maneira geral e ao amigo Inácio particularmente. De fato, na carta de Bobadilla - a qual só conhecemos a partir das referências que Inácio faz a ela na tréplica - fica claro o temperamento hispânico de Bobadilla: a dureza e secura da resposta, algumas vezes chega à ironia. No entanto, a resposta de Inácio é doce, mas "não sem humor" (p. 676), e retoma uma por uma cada nota de Bobadilla e "chama a si a justiça e, aceitando discutir e ser repreendido, termina por comandar firmemente" (p. 676). Cf. Ibid., p. 676 (tradução nossa).

${ }^{37}$ Ibid., p. 677 (tradução nossa).
} 
correspondência na Companhia (cartas enviadas, cartas recebidas, maneira, freqüência etc.), constituindo-se num documento importante sobre a função orgânica da relação epistolar para uma comunidade "dispersa em diversas regiões" 38 , como a ainda jovem Companhia de Jesus:

Essa troca de cartas, tanto as que vêm daqui quanto as que vêm de lá, é em si uma tão boa coisa e deve ser tão estimada que seria irracional não levá-la muito a sério, enquanto coisa muito importante para o bem desta Companhia e, conseqüentemente, de todo o próximo, bem como para a honra e a glória de Deus ${ }^{39}$.

Em seguida, enumera vinte "importantes coisas" acerca da ajuda que se pode encontrar no exercício dessa troca de correspondência regida por normas. Entre elas, diz: "a primeira razão é a união da Companhia"40; "a solidez e firmeza da Companhia"41; "amor mútuo, que naturalmente se resfria pela ausência e pelo esquecimento" "42; "crescimento da boa reputação da Companhia"43; "crescimento do número de membros da Companhia"44; "o próximo é edificado e encorajado a fazer o bem" ${ }^{45}$; “o bem universal da Igreja"46; “crescimento da glória e louvor de Deus"

Com esses - e outros tantos exemplos que se podem recolher nos textos inacianos - se pode entender a grande importância dada à correspondência sobretudo como fator de unidade e proximidade com "seus filhos dispersos" 48 .

Lamalle (1981-82) lembra também que, com o rápido crescimento da Companhia, foi necessário adaptar as regras contidas nas Constituições acerca da correspondência particularmente, e da produção de documentos de maneira geral:

Naturalmente spinte a tale minuzia, le norme hanno avuto molto presto bisogno di adattarsi alla rapida crescita dell'Ordine e all'evoluzione dei tempi. Le prescrizioni iniziali hanno ceduto il posto ad una piccola guida

\footnotetext{
${ }^{38}$ Ibid., p. 708 (tradução nossa).

${ }^{39}$ Ibid., p. 708 (tradução nossa).

${ }^{40}$ Ibid., p. 708 (tradução nossa).

${ }^{41}$ Ibid., p. 708 (tradução nossa).

${ }^{42}$ Ibid., p. 708 (tradução nossa).

${ }^{43}$ Ibid., p. 708 (tradução nossa).

${ }^{44}$ Ibid., p. 709 (tradução nossa).

45 Ibid., p. 709 (tradução nossa).

${ }^{46}$ Ibid., p. 709 (tradução nossa).

${ }^{47}$ Ibid., p. 710 (tradução nossa). Cf. também, pp. 711-716.

${ }^{48}$ Cardoso, 1990, op. cit., p. 26.
} 
pratica, la Formula scribendi, inscrita già dal 1580 nel libretto delle Regulae Societatis Iesu e ritoccata nelle edizione seguenti ${ }^{49}$. Lo sviluppo della burocrazia farà completare questo nucleo com varie ordinazioni, od istruzioni dei Generali, specialmente del P. Claudio Aquaviva, per categorie determinate d'informazioni ${ }^{50}$.

Pécora (2001) aponta outro importante fator a se considerar no momento da compreensão da epistolografia inaciana: o chamado de atenção de Inácio para o estilo douto e ornado, cheio de adorno e lima:

Considera que uma coisa é a "eloqüência, atrativo e gala da linguagem profana", outra, bem distinta, é aquela que cabe ao "religioso". Neste, o estilo conveniente deve assemelhar-se ao uso dos adornos e atavios recomendáveis para uma "matrona", que sempre deve "respirar gravidade e modéstia". A elocução entre os jesuítas deve possuir uma facúndia "grave e madura" e jamais "exuberante e juvenil", e isto "sobretudo nas cartas, onde o estilo deve ser, por si, conciso e trabalhado". Assim, quando tiver que ser copioso, que o seja "mais por abundância de idéias que de palavras" 51 .

Nesse sentido, percebe-se que a regra para a composição de cartas na Companhia de Jesus em nada se afasta da longa tradição retórica anterior: desde Aristóteles, passando por Cícero e Quintiliano, ao ciceronianismo do chamado "renascimento" resumindo e concluindo esta trajetória iniciada -, o caráter estudado, determinado por regras jurídicas e de composição retórica muito precisas, não se constitui nunca num obstáculo ou impedimento para a conservação do corpo institucional, mas é exatamente por causa dele

\footnotetext{
49 A primeira edição da Formula Scribendi foi preparada por Everardo Mercuriano (1515-1580), o quarto Prepósito Geral da Companhia de Jesus (ele ocupou o cargo entre os anos de 1573 e 1580). Mercuriano era belga da nascença, da pequena cidade de Marcourt. Ordenou-se padre em 1546 e só entrou na Companhia de Jesus dois anos mais tarde. Em 1551, morando em Roma, se torna um dos principais colaboradores de Inácio de Loyola. Entre 1558 e 1564 assume o provincialato da Renânia e Países Baixos. Em 1565, de volta à Roma, torna-se assistente de Francisco de Borja. Assume o generalato, aos 58 anos de idade. Cf. Fouqueray, Henri (1910). Histoire de la Compagnie de Jésus en France - Vol 1: Les origines et les premières luttes (1528-1575). Paris: A. Picard et fils.

50 Lamalle, Edmond (1981-82). L'Archivio di um grande Ordine religioso. L'Archivio Generale della Compagnia di Gesù. Estratto da Archiva Ecclesiae, 24-25(1), pp. 94-95 (Naturalmente impulsionadas a tais minúcias, as normas tiveram, muito cedo, necessidade de se adaptarem ao rápido crescimento da Ordem e à evolução dos tempos. As prescrições iniciais deram lugar a um pequeno guia prático, a Formula scribendi, inscrita desde 1580 no livreto das Regulae Societatis Iesu e retocada nas edições subseqüentes. O desenvolvimento da burocracia fará completar este núcleo com várias ordens, ou instruções dos Padres Gerais, especialmente do P.e Cláudio Aquaviva, por categorias determinadas de informações”).

${ }^{51}$ Pécora, 2001, op. cit., p. 32. O autor cita trechos da carta enviada por Inácio ao Padre Roberto Claysson, de Roma, em março de 1555, localizada à página 969, das Obras Completas de Inácio de Loyola.

52 Pécora (2001) é quem lembra que "este procedimento [ajustar a gravidade do assunto à simplicidade das palavras] se articula com a construção de argumentos favoráveis ao caráter do escritor - as provas morais de que fala Quintiliano retomando Aristóteles - compreendido sobretudo como a demonstração de sua autoridade virtuosa para produzir o discurso da edificação" (p. 32).
} 
que existe informação que permite unidade entre os membros dispersos no imenso novo orbe que, naquele período, começa a se estabelecer, e experiência mística/devocional; fazendo do jesuíta não um orgulhoso retórico, mas um virtuoso homem.

\section{1) Litterae Indipetae}

Neste trabalho, estamos, pois, falando de uma correspondência epistolar com características particulares: obedece a um modelo formal e retórico próprio da tradição de formação intelectual de um longo período que se estende do século XI ao XVI (como tais, as Indipetae podem ser classificadas, portanto, como cartas de tipo suasório, na medida em que têm como objetivo solicitar, pedir, persuadir ${ }^{53}$ ) e tem também uma tríplice função institucional ("esclarecer o desejo a quem escreve e a seus interlocutores"; "reforçar as ligações entre os membros e os superiores" e "submeter o desejo individual à vontade de Deus, confiando-se à decisão do padre geral, cuja autoridade é sinal do querer divino",54). Mas, também, devemos assinalar que, como correspondência epistolar que são, as Indipetae possuem ainda certas peculiaridades que devem ser levadas em conta.

O primeiro aspecto importante a considerar foi já acenado no capítulo anterior, quando descrevemos a dinâmica envolvida na produção desses documentos: como cartas de pedido que são - apesar de toda a codificação e estereotipia pertinente a este tipo de relação "comandada",55 - as Indipetae contêm expressões bastante significativas do trabalho de investigação acerca de si mesmos, para o qual os jesuítas eram treinados em sua formação ${ }^{56}$. Podemos dizer, neste sentido, que o motivo mesmo de existir uma regra, uma forma muito

\footnotetext{
${ }^{53}$ Cf. Massimi e Prudente, 2002, op. cit., p. 18.

${ }^{54}$ Ibid., p. 17.

55 É, de novo, Chartier (1991) quem nos apresenta a questão que tomamos como provocação para a análise de nossas correspondência, dado que há uma distância de três séculos entre nossos documentos e aqueles acerca dos quais Chartier escreve: "La correspondance comandée (...) produit l'écriture la plus codifiée et la plus stéréotypée qui soit, mais elle n'exclut nullement des lettres spontanées, originales et personnelles, puisque rien n'empêche les relations obligées d'être aussi des relations amicales (ou de le devenir)" (p. 458).

${ }^{56}$ Cf. Massimi e Prudente, 2002, op. cit.
} 
bem estabelecida e estudada, revela, nas Indipetae, "o espaço da pessoa, do indivíduo que por meio delas (...), expressa seu desejo, sua vivência pessoal" ${ }^{, 57}$ : regra, protocolo formal, estilo retórico não se contrapõem ao indivíduo e à expressão de sua vivência pessoal; tampouco um se constitui sem o outro; é exatamente porque obedece a este protocolo, que o jesuíta é não só um jesuíta (porque adere ao corpo institucional e seu instituto, em última instância), mas um homem que, conhecendo-se e conhecendo suas moções interiores, os movimentos de sua alma e de suas paixões, pode expressar um desejo, porque o reconhece como ordenado ao fim último para o qual foi criado, e fazê-lo conforme regras (já que toda a realidade é cosmológica, é ordenada).

Aqui, emerge, portanto, uma importante questão levantada por Chartier (1991):

La correspondance (...) suggère que la variable pertinent pour classer et comprendre les écrits de l'homme sans qualité n'est pas leur forme même, mais l'espace dans lequel se situent tant leur production que leur réception, supposée ou véritable. Parce que (...) elle suppose un lecteur qui n'est pas celui qui écrit, parce que, contrairement à la parole vive, elle n'exige pas le face-à-face, la correspondance institue un ordre paradoxal qui est construction d'un lien social à partir d'un geste subjectif et singulier ${ }^{58}$.

Classificar as Indipetae simplesmente a partir do aspecto retórico em que se inscrevem além de não ser suficiente para o nosso objetivo, não nos interessa do ponto de vista da compreensão do dinamismo profundo que sustenta essa produção. É preciso pensá-las, de fato, no espaço tanto institucional quanto cultural em que foram produzidas, pensá-las não como objetos privados (ou, para usarmos a expressão de Hébrard acerca da correspondência epistolar do século XIX, "subjetividade privada",59), mas como objetos

\footnotetext{
${ }^{57}$ Ibid., p. 19.

${ }^{58}$ Chartier, 1991, op. cit., p. 458 (“A correspondência (...) sugere que a variável pertinente para classificar e compreender os escritos do homem sem qualidade não é sua forma mesma, mas o espaço no qual se situam tanto sua produção quanto sua recepção, suposta ou verdadeira. Porque (...) ela supõe um leitor que não é aquele que escreve, porque, contrariamente à palavra viva, ela não exige o face-a-face, a correspondência institui uma ordem paradoxal que é construção de um vínculo social a partir de um gesto subjetivo e singular"). Importa esclarecer, mais uma vez, que Chartier, aqui, trata de um período muito específico e diverso do nosso - o século XIX. Nesse sentido, que fique claro que nosso interesse pela posição de Chartier é o que respeita à intuição do caráter diríamos - "aparentemente" paradoxal da produção desses documentos também nos séculos XVI e XVII jesuíticos. Os aspectos vinculados à gramática de uso hodierno - como "subjetividade" e "sociabilidade" - não nos ocuparão.

${ }^{59}$ Cf. Hébrard, 1990, op. cit., p. 168.
} 
que pertencem a uma instituição que faz uso de uma gramática bastante peculiar e, coeva e paradoxalmente, expressão de homens particularmente concebidos. 


\section{CAPÍTLO 3 Indipetae : um corpus documental}

Sabemos já que, ao analisarmos a história de produção do documento, as cartas Indipetae emergem de uma dinâmica que integra aquela ordenação institucional, que incentivava a escrita da carta no interior de um modelo retórico e pedagógico estabelecido; com uma ordenação pessoal, expressa na comunicação do resultado de um trabalho individual de identificação da origem de um desejo específico - as missões no Além-Mar.

Ainda mais, para além desses dois grandes fatores indissolúveis e inseparáveis, pudemos igualmente identificar as cartas Indipetae como representantes de um gênero retórico próprio, que obedece às regras da ars dictaminis, até o ponto de entender também que aquela produção particular não pode ser compreendida isoladamente, mas dentro de um contexto sociocultural claramente distinto de outros.

Outrossim, sabemos que no Archivum Romanum Societatis Iesu (ARSI) existem 14.067 cartas Indipetae do período que vai do ano de 1583 ao ano de 1770 , escritas por 5.167 jesuítas europeus das mais diversas nacionalidades. Com um universo assim grande de cartas, foram-nos necessários alguns recortes significativos: alguns impostos pela própria limitação 
de documentos a que tivemos acesso, outros impostos pelos limites do método.

Diante desse universo, optamos por trabalhar com um número reduzido de cartas espanholas, escritas no período do generalato do Padre Cláudio Aquaviva - entre 1581 e 1615. Além disso, optamos por trabalhar em duas vertentes de análise: uma macrohistórica, interessada em avaliar as mudanças no tempo, do ponto de vista institucional, do uso de topoi tais como indiferença, vocação, desejo, martírio etc., analisando 23 correspondências enviadas da Espanha por 23 diferentes jesuítas no período do referido generalato (uma por ano e de acordo com a disponibilidade de fontes referentes ao recorte escolhido); e uma micro-histórica, interessada em avaliar essa mesma mudança no nível pessoal, analisando 3 correspondências enviadas por um mesmo jesuíta espanhol, dentro do supradito período histórico.

As tabelas abaixo nos dão uma primeira panorâmica acerca dos principais dados encontrados no corpus documental com o qual trabalhamos. Importa esclarecer, de antemão, que faltam-nos cartas referentes a quatro períodos: 1581-1582 (não há qualquer documento que revele a existências de Indipetae - propriamente ditas - nesses dois $\operatorname{anos}^{1}$ ), 1595-1596, 1600-1601 (as cartas do FG 758 às quais tivemos acesso através de coleta de dados realizada pela Prof.a Marina Massimi nos anos de 1998 e 1999 - um total de 185 cartas - não contêm documentos desses dois períodos) e 1610-1615 (apesar de possuirmos cópia de todo a pasta FG 759, que reúne mais de 500 correspondências dos

\footnotetext{
${ }^{1}$ É bem verdade que o costume de escrever ao superior comunicando o desejo de ser enviado existe desde os tempos de Inácio de Loyola (por exemplo, Francisco de Borja escrevia a Padre Laínez, então Prepósito Geral, sobre o seu desejo de "morrer derramando o sangue pela verdade católica da Igreja Romana", nas Índias); no entanto, a organização das Indipetae nos catálogos do Fondo Gesuitico (FG) só começa a partir de 1583. Scaduto, Mario (1992). Storia della Compagnia di Gesù in Italia. Vol V: L'epoca di Francesco de Borgia (15561565). Roma: Edizioni "La civiltà cattolica", p. 116. Sem dúvida, esta diferença temporal entre o já citado "Documento de 1558" (cf. nota 40, p. 37) e o início da generalização das Indipetae, traz à baila uma série de importantes questões: por que esta diferença de mais de vinte anos? Que fatores institucionais estão em jogo neste processo? Que dinâmicas pessoais? Que políticas missionárias? Tratam-se, sem dúvida, de questões importantíssimas a serem estudadas; no entanto, como se verá na sequiência, elas só nos interessam acessoriamente, dado que nos ocuparemos de descrever um dinamismo de experiência, a partir da gramática de uso presente naquelas cartas a que tivemos acesso, entre as tantas Indipetae produzidas no espaço de quase dois séculos preservadas no ARSI (Roma/Itália).
} 
anos de 1605 até 1634, exatamente nesse período existe uma lacuna). Essa ausência se deve, sobretudo, a dificuldades encontradas no acesso à documentação no ARSI, em Roma $^{2}$. No entanto, essas lacunas serão preenchidas por dados achados em fontes de outros gêneros com os quais trabalhamos na análise das cartas.

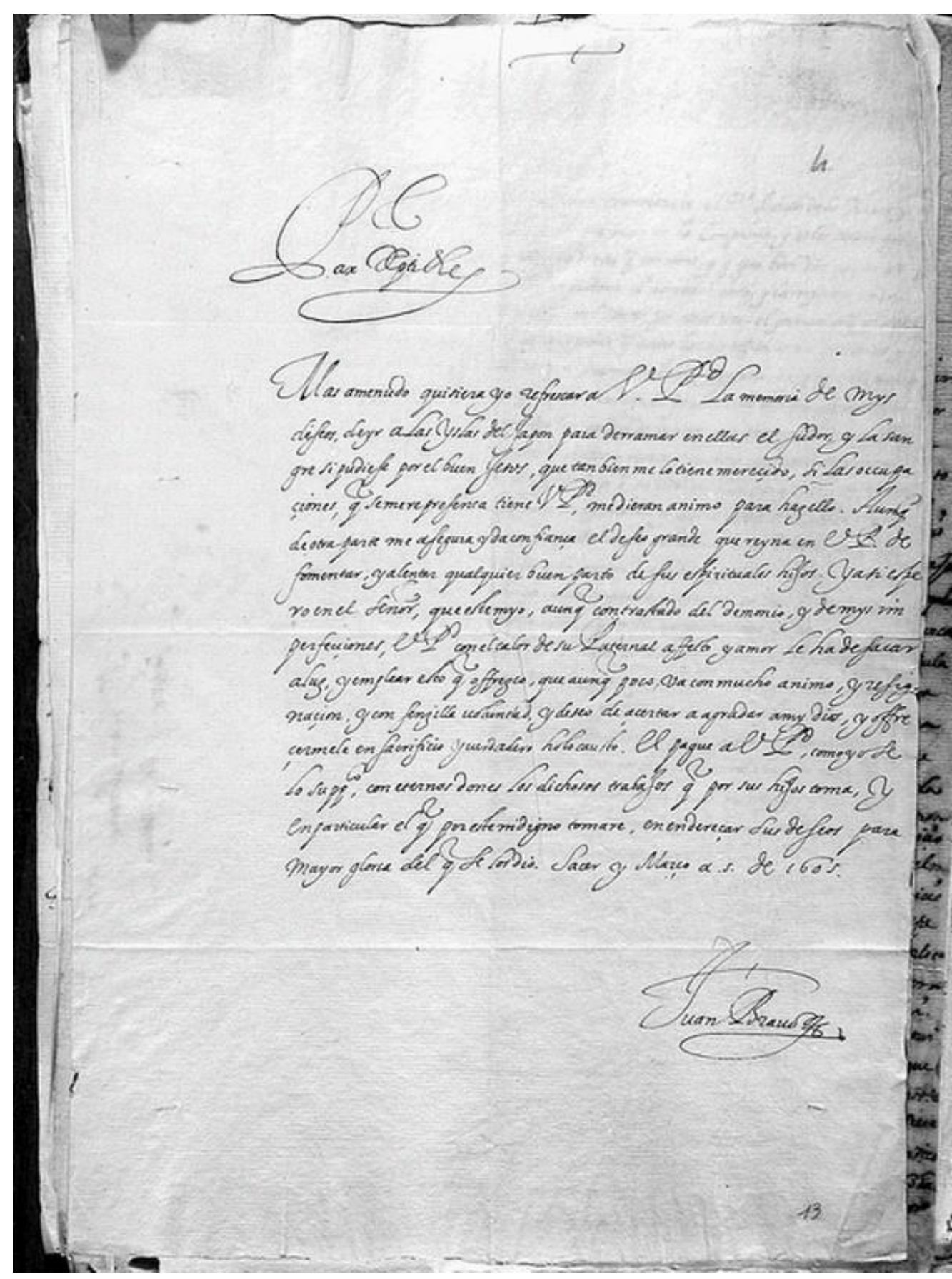

Fig. 01 - Fax símile de Indipeta, FG 759, Fl. 13, 4.

\footnotetext{
${ }^{2}$ Devido a reformas realizadas nos arquivos jesuíticos de Roma, não nos foi possível ter acesso às fontes
} documentais a fim de sanar esse problema. 


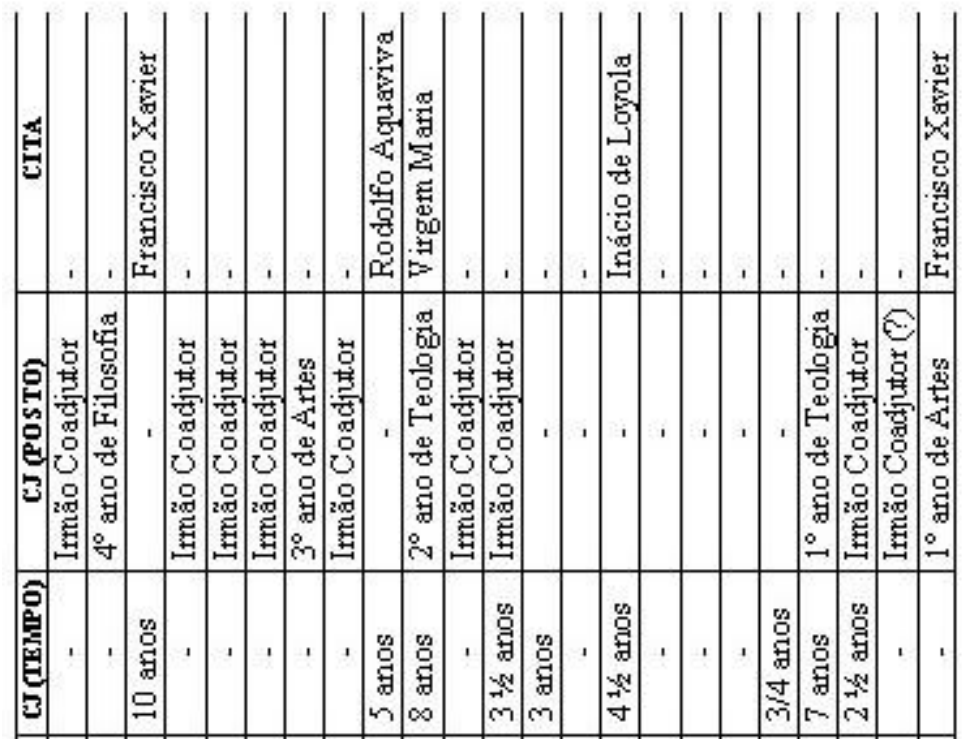

\section{窇}

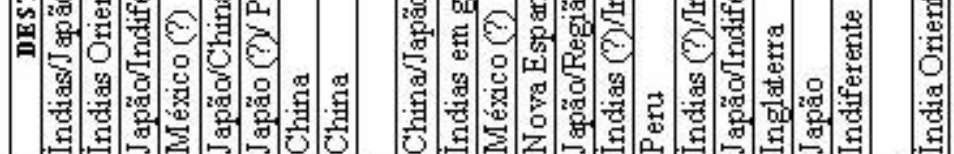

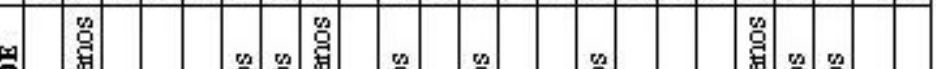

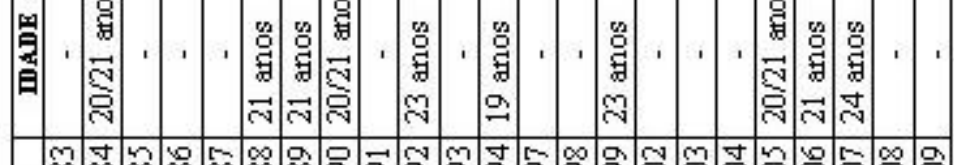

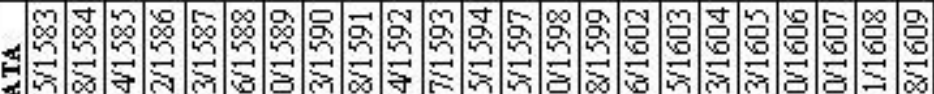

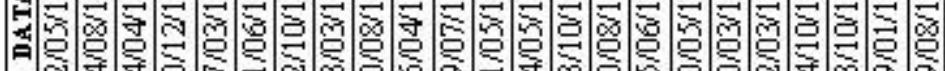

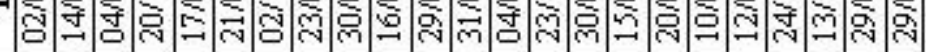

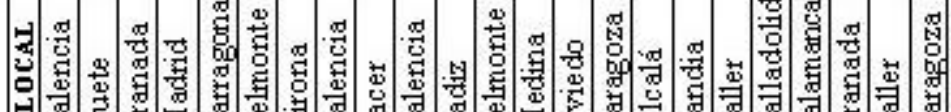

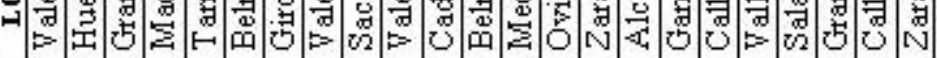

总

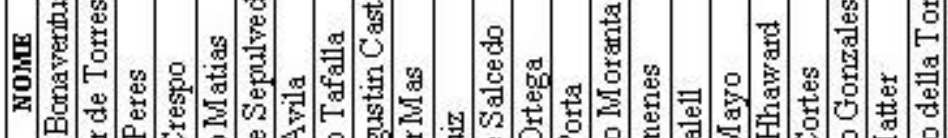

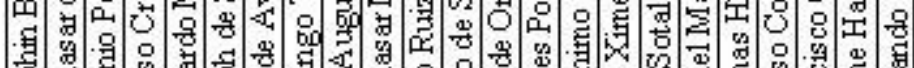

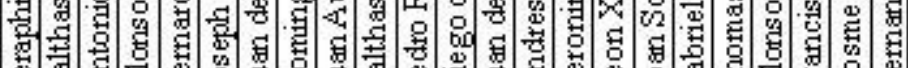

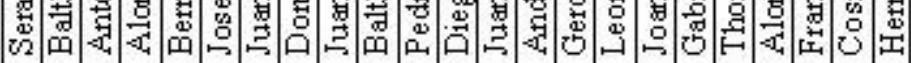

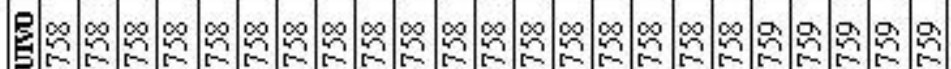

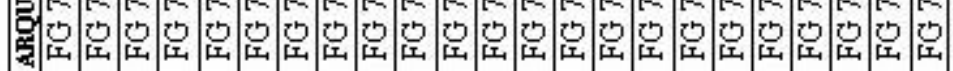

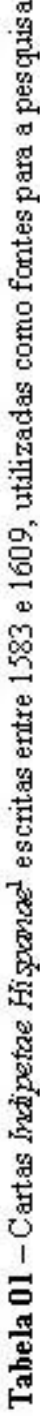

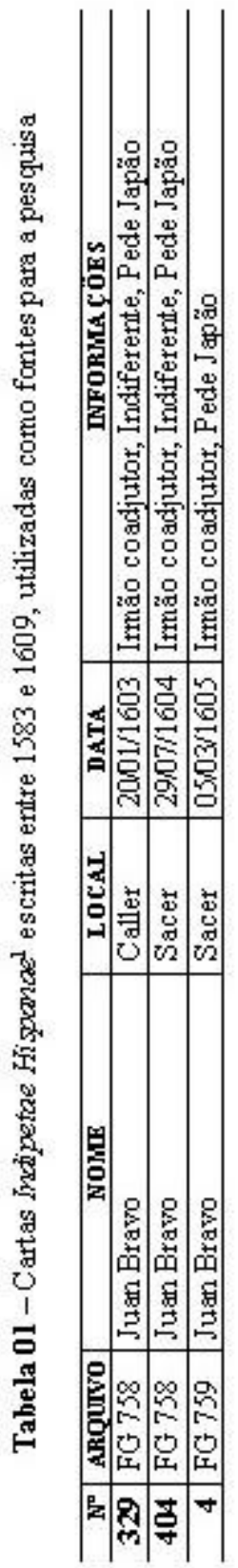

$\overbrace{\forall}^{\infty} \infty$

象语

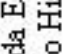

葛.

善

要

要要

㻤鱼

近

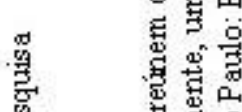

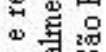

急

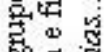

का. 율

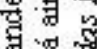

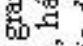

象哭䨔

茛它

g

记

불

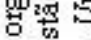

事

牙哭

붑 응

总嵒

证

병

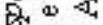

㲧

ov

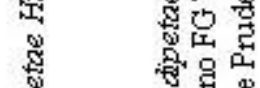

番

을 은

s.

造

总守

s

这电

$8 \stackrel{8}{2}$

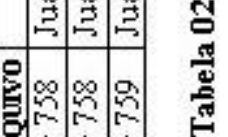

氙

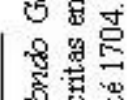

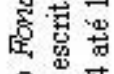

马 巻

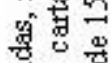

密腾

嵒总热

뭉

㐘焉

음

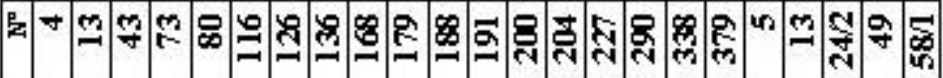

$\checkmark$ 䓌总 
Antes de avançarmos numa primeira análise dessas fontes, entendamos o motivo da escolha desse recorte histórico.

Tendo durado 34 anos, o Generalato do Padre Cláudio Aquaviva é um dos mais extensos da história dos Jesuítas; constituindo-se num período rico em matéria para uma historiografia que tenha como objeto a Companhia de Jesus.

Nessas três décadas de generalato, foram realizadas três Congregações Gerais ${ }^{3}$, além de terem sido promulgadas várias ordens, instruções, explicações e avisos. Corresponde também a esse período, a publicação da forma definitiva da Ratio Studiorum, bem como do Diretório dos Exercícios Espirituais;

además, en su tiempo se vió atacada la Compañía por los enemigos de dentro y de fuera en los puntos más vitales de su santo Instituto, y combatida, no sólo con las armas de la teología y jurisprudencia, sino, lo que era más peligroso, con las de la política, de la intriga y hasta de la calumnia ${ }^{4}$.

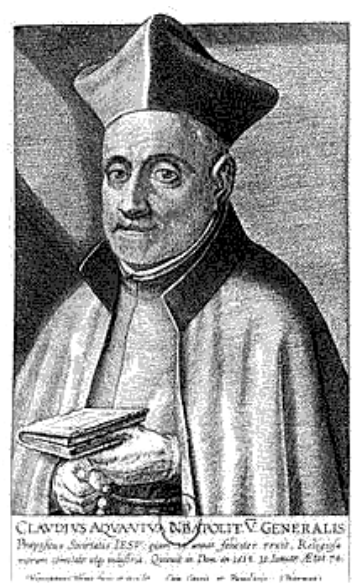

Fig. 02 - Padre Claudio Aquaviva (1543-1615)

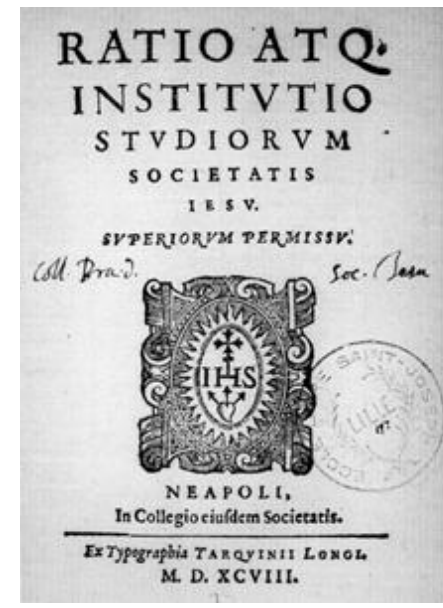

Fig. 03 - Frontispício da edição de 1598 da Ratio Studiorum

\footnotetext{
3 Aquaviva participou da $4^{\text {a }}$ Congregação Geral $(\mathrm{CG})$ da Companhia, que foi convocada pelo padre vigário Oliverio Manare, para o dia 07/02/1581. Foi nessa CG, no dia 19/02/1581, que ocorreu a eleição do Padre Cláudio Aquaviva por 32 dos 57 votos para novo Prepósito Geral. A $4^{\mathrm{a}} \mathrm{CG}$ teve fim no dia 22/04/1581. A $5^{\mathrm{a}} \mathrm{CG}$ que teve início no dia 03/11/1593 e terminou em 18/01/1594. E finalmente, a $6^{a}$ CG que havia sido pensada para setembro de 1607, mas que só teve seu início no dia 20/02/1608, terminando no dia 29/03/1608. Essa última congregação contava com a participação de 64 padre jesuítas. Cf. Ruiz Jurado, Manuel (1976). La espiritualidad de la Compañía de Jesús en sus Congragaciones Generales. AHSI, XLV(90). Romae, pp. 233-290 e Astrain, Antonio (1909). Historia de la Compañía de Jesús en la Asistencia de España. Tomo III: Mercurian-Aquaviva (Primera Parte) (1573-1615). Madrid: Est. Tipográfico "Sucesores de Rivadeneyra".

${ }^{4}$ Astrain, 1909, op. cit., pp. V-VI ("Além do mais, no seu tempo, a Companhia se viu atacada pelos inimigos de dentro e de fora nos pontos mais vitais de seu santo Instituto, e combatida, não somente com as armas da teologia e jurisprudência, mas, o que era mais perigoso, com as da política, da intriga e até da calúnia").
} 
Aquaviva era filho de Giovanni Antonio Aquaviva e de Isabella Spinelli, duques de

Atri. Nasceu em Atri, no reino de Nápoles, no dia 14/09/1543. Aos 20 anos, seu irmão, Giovanni Geronimo, encaminhou Cláudio para um posto em Roma, como camareiro secreto do Papa Pio IV (1559-1565) ${ }^{5}$. Trabalhou para este pontífice e para o Papa Pio V $(1566-1572)^{6}$. No palácio pontifício ele trabalhou por 3 anos, quando, tendo conhecido os padres Cristóbal Rodrigues, Francisco de Borja e Juan Alfonso Polanco, se sentiu movido a entrar na Companhia de Jesus. "Algun tiempo vaciló (...); pero, al fin, no pudiendo resistir á la voz interior del espíritu, por Julio de 1567 presentóse resolutamente á San Francisco de Borja y le pidió con instancias ser admitido entre sus hijos”7 . Após conversar com o Papa Pio V, a quem Francisco de Borja informara do pedido, Cláudio Aquaviva, tendo ouvido as palavras do Pontífice, não hesitou:

Satisfizo punto por punto Aquaviva á todas las dificultades propuestas, y

\footnotetext{
${ }^{5}$ Giovanni Angelo Medici foi eleito papa aos 62 anos de idade, na noite de Natal de 1559, sob o nome de Pio IV, a fim de indicar a humildade com a qual se propunha a governar a Igreja. Nascido em Milão, no dia 31 de março de 1499, de família humilde, iniciou seus estudos em Pavia, depois em Bologna, dedicando-se à filosofia, medicina e direito, tendo conquistado o título de Doutor em Leis e alguma fama como jurista. Aos 28 anos de idade, resolveu-se por abraçar a carreira eclesiástica e dirigiu-se a Roma, onde conseguiu, do Papa Clemente VII, o cargo de protonotário. Mais tarde, no pontificado de Paulo III, ficou responsável pelo governo de várias cidades dos estados pontifícios. Alguns anos depois, após disputa acirrada pelo trono papal, com o apoio do Cardeal Farnesio, Medici é eleito papa, sendo coroado no dia 06 de janeiro de 1560. Apenas eleito, chama para junto de si alguns de seus parentes, entre os quais o sobrinho Carlos Borromeu que é feito cardeal por suas mãos. Entre os principais feitos de Pio IV destacamos: a continuidade nos trabalhos iniciados e o fechamento do Concílio de Trento, no dia 04 de dezembro de 1563. Não obstante a vigorosa luta contra o protestantismo, a benevolência de Pio IV no trato com alguns suspeitos de heresia, tão diferente do rigor de seu predecessor, o deixou em dificuldades, quando um fanático chamado Benedetto Ascolti tentou matá-lo. Pio IV morreu no dia 09 de dezembro de 1565, vítima de febre romana, tendo São Felipe Neri e São Carlos Borromeu à sua cabeceira. Foi enterrado em São Pedro, depois trasladado em 1583, para a igreja de Santa Maria dei Angeli, em Roma.

${ }^{6}$ Antonio Ghisleri, eleito papa em 1566 sob o nome de Pio V, nasceu em Bosco Marengo, em 1504. Aos 14 anos entrou para a Ordem dos Dominicanos, onde fez carreira relâmpago: em seguida à sua ordenação sacerdotal, foi feito professor, em seguida, prior do convento, superior provincial, inquisidor em Corno e em Bergamo, bispo de Sutri e Nepi, cardeal, grande inquisidor, bispo de Mondovi e papa. Como inquisidor, debelou a simonia da Cúria romana e o nepotismo. Como papa reformador, foi uma figura incômoda na Cúria romana. Entre as reformas no campo pastoral promovidas por ele, lembramos a obrigação de residências para bispos, clausura para os religiosos, celibato e a santidade de vida dos sacerdotes, a visita pastoral dos bispos, o incremento das missões, a correção dos livros litúrgicos, a censura sobre publicações etc. A rígida disciplina que o santo pontífice impôs à Igreja era norma constante na sua vida: o ideal ascético dos frades mendicantes era seu ideal pessoal. Homem severo, não hesitou, por exemplo, de excomungar a rainha da Inglaterra, Elisabeth I, mesmo sabendo das consequiências disso para os católicos ingleses. O Papa Pio V é lembrado principalmente como o papa da vitória de Lepanto, não porque fosse belicoso, mas porque com a sua autoridade e com o seu prestígio pessoal conseguiu impor uma trégua entre os Estados europeus e impulsioná-los à "santa aliança" contra a ameaça turca. No dia 07 de outubro de 1571, a frota cristã derrota a turca definitivamente. Naquele mesmo dia, Pio V, que não dispunha de rápidos meios de comunicação, ordenou que soassem todos os sinos de Roma, convidando os fiéis a agradecer a Deus pela vitória obtida. Pio V morreu no dia primeiro de maio de 1572. Foi canonizado em 1712. ${ }^{7}$ Ibid., p. 213.
} 
enla claridad con que las resolvía y en la convicción con que el joven se expresaba, reconoció San Pio V que aquella vocación era verdaderamente de lo alto. 'Puesto que Dios os llama, dijo el Santo, yo no quiero detenerlos; id en paz', y con muestras de ternura paternal le dió su benedición. Alegre salió Aquaviva de la presencia de Su Santidad, y juntándose con San Francisco de Borja, que le esperaba en la antesala, fuése con él derechamente al noviciado de San Andrés. Era el 22 de Julio de $1567^{8}$.

Em 1575 foi nomeado reitor do Colégio de Nápoles. No dia 01 de abril de 1576 fez os quatro votos e foi declarado Provincial de Nápoles. Até que, na primavera de 1580, o Padre Mercurian, então Prepósito Geral, o declara Provincial de Roma. Pouco menos de um ano mais tarde, é eleito Geral, cargo que exerce até sua morte, no dia 31 de janeiro de 1615.

Aquaviva assumiu o generalato, quando a Companhia de Jesus havia iniciado um rápido crescimento em número de sujeitos e de fundações (seja de colégios que de casas, seja na Europa que nas "Índias")9 . E essa "marcha progressiva" continuou: de cerca de 5.000 membros, em 1581, a Companhia de Jesus saltou para mais de 13.000, em 1615; 12 novas províncias foram criadas no período; 228 colégios foram abertos em todo o mundo. Ao final de seu generalato, a Companhia de Jesus contava com mais de 550 comunidades espalhadas por todos os continentes ${ }^{10}$.

Com tanto crescimento, de fundamental importância foi o papel uniformizador exercido pelo Padre Cláudio Aquaviva, na história da Companhia. Como seus antecessores, continuou e aprofundou o trabalho de criar uma legislação unificadora, com um governo eficaz na execução e sobretudo atento à manutenção do ideal e do espírito autênticos de Inácio de Loyola.

Ao mesmo tempo, seu generalato foi marcado - como já se disse - por inúmeras

\footnotetext{
${ }^{8}$ Ibid., p. 214 ("Aquaviva satisfez ponto por ponto a todas as dificuldades propostas, e na clareza com que as resolvia e na convicção com que o jovem se expressava, São Pio V reconheceu que aquela vocação era verdadeiramente do alto. 'Dado que Deus os chama, disse o Santo, eu não quero detê-los; ide em paz', e com mostras de ternura paternal lhe deu sua benção. Aquaviva saiu alegre da presença de Sua Santidade, e juntandose com São Francisco de Borja, que o esperava na ante-sala, foi-se com ele direto para o noviciado de São André. Era o dia 22 de julho de 1567 ").

${ }^{9}$ Cf. dados desse crescimento em Astrain, Antonio (1913). Historia de la Compañía de Jesús en la Asistencia de España. Tomo IV: Aquaviva (Segunda Parte) (1581-1615). Madrid: Est. Tipográfico "Sucesores de Rivadeneyra".

${ }^{10}$ Cf. Ruiz Jurado, 1976, op. cit.
} 
crises que ameaçaram de todos os lados a vida da Sociedade criada por Inácio. Uma das primeiras crises enfrentadas veio da Sede Apostólica: o então Papa, Six to V (1585-1590) ${ }^{11}$ solicitou o exame das Constituições da Companhia pela Inquisição Romana. Aquaviva, na ocasião, pediu o testemunho dos Bispos e Príncipes com quem a Companhia tinha relacionamentos. Com as cartas desses homens em mãos, e sua inteligência e clareza, respondeu a todas as perguntas do inquisidor, deixando satisfeito o Papa.

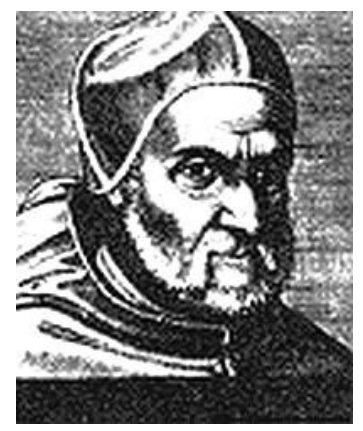

Fig. 04 - Papa Pio IV (1499-1565). Pontificado entre 1559-1565

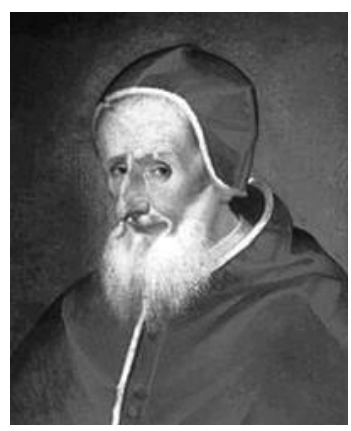

Fig. 05 - Papa Pio V (1504-1572). Pontificado entre 1566-1572

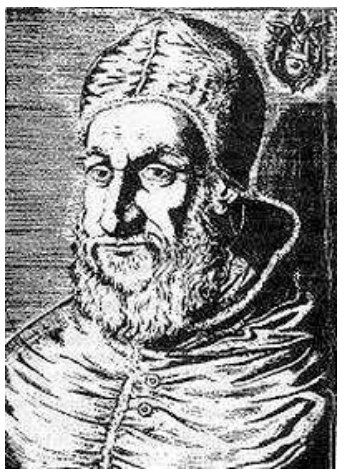

Fig. 06 - Papa Sixto V (1521-1590). Pontificado entre 1585-1590

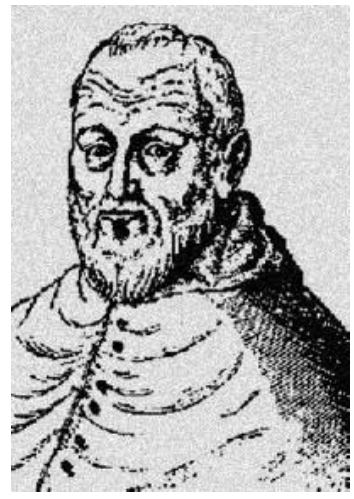

Fig. 07 - Papa Clemente VIII (1535-1605).

Pontificado entre 15921605

Mais tarde, em 1593, nova crise irrompe dessa vez de dentro da própria Companhia, quando alguns jesuítas propuseram graves mudanças nas Constituições. Era o momento da $5^{\text {a }}$ Congregação Geral, quando importantes modificações estavam sendo aprovadas ${ }^{12}$. Descoberta a "raiz" do problema - 25 dos 27 padres a favor das modificações

\footnotetext{
${ }^{11}$ Sixto V, nasceu no dia 13 de dezembro de 1521, em Grottamare, sob o nome de Felice Peretti. Ainda jovem, entrou na Ordem dos Frades Menores conventuais, no convento de Montalto. Sua formação se deu nos colégios da ordem, em Fermo, Ferrara e Bologna. Em setembro de 1544, em Rimini, consegue o título de Bacharel em Teologia e, quatro anos depois, em Fermo, o de Doutor em Teologia. Em 17 de janeiro de 1557 foi nomeado consultor do Santo Ofício, em Roma. Foi confiada a ele a reforma de numerosos conventos da ordem. Em 1561 foi nomeado Procurador Geral da Ordem. Como teólogo, participou das discussões da Congregação para o Concílio de Trento. Promovido bispo de Sant'Agata dei Goti, é consagrado em Nápoles, no dia 12 de maio de 1567. Três anos mais tarde, torna-se cardeal. No dia 24 de abril de 1585 foi eleito papa. Morreu, em Roma, no dia 27 de agosto de 1590 e foi sepultado em São Pedro. No ano seguinte, seu corpo foi trasladado para a tumba monumental, que se encontra na capela do presépio, na Igreja de Santa Maria Maggiore, em Roma.

${ }^{12}$ Astrain (1909) relata que, no dia 03 de novembro de 1593, pela manhã, Aquaviva e outros três padres foram pedir a bênção de Clemente VIII que lhes disse essas palavras: "Desde el principio de mi pontificado (...) he oído á personas prudentes que vuestra Compañía ha decaído de su primitivo fervor, y por eso he mandado reunir esta Congregación para que remediéis ese daño. Vosotros lo podéis hacer mejor que nadie. De ocho partes del pueblo cristiano, las siete las tenéis vosotros, y gracias á vosotros perservera en ellas la religión de Cristo. Yo soy testigo ocular, y sé cuán bien trabajáis por la religión de Cristo en Polonia y en Germania. Ea, pues; si flaquea vuestra Orden por algún lado, aplicad el remedio. Ved si se difieren demasiado las profesiones, si conviene continuar
} 
eram de origem judaica ou mourisca -, a Congregação decretou o "principio de limpieza de la sangre", que impedia a admissão de homens com origens judaicas ou mouriscas no seio da Companhia, seguindo uma tendência que se instalara na Espanha desde 1491.

Um outro ataque enfrentado, veio mais uma vez de Roma: Clemente VIII (1592$1605)^{13}$, recentemente eleito Papa, coloca em questão o fato de que o cargo de Prepósito Geral seja vitalício e propõe um termo fixo para os generalatos. Golpe entre outros, Aquaviva o enfrentou inteligentemente, renunciando tanto à proposta de ser feito Bispo de Nápoles, como à de ser eleito Cardeal (“convites" que tinham como intencionalidade escondida a renúncia do cargo de Geral).

Some-se a essas crises de ordem geral, a recalcitrante inimizade do Rei Felipe III da Espanha e de alguns de seus importantes súditos, as querelas intelectuais enfrentadas seja por Aquaviva pessoalmente, seja pela Companhia de Jesus e se terá um quadro, mais ou menos, ilustrativo dos anos que se passaram sob seu controle. E, sobretudo, se compreenderá que os anos finais do generalato foram marcados por uma saúde bastante fragilizada.

De maneira geral, podemos dizer que o Generalato do Padre Aquaviva é um momento de importante consolidação dos ideais inacianos: tanto do ponto de vista legislativo e

tanto tiempo algunos hombres en el cargo de superior. En cuanto á la doctrina, es mi deseo que sigáis á Santo Tomás, doctor insigne, cuyas obras aprobó y abrazó el Concílio Tridentino” (pp. 580-581). A Congregação se reuniu até 18 de janeiro de 1584, quando foram eleitos os novos padres assistentes da Companhia de Jesus. Astrain, Antonio (1909). Historia de la Compañía de Jesús en la Asistencia de España. Tomo III: MercurianAquaviva (Primera Parte) (1573-1615). Madrid: Est. Tipográfico "Sucesores de Rivadeneyra".

${ }^{13}$ Ippolito Aldobrandini, nascido em Faso, no dia 24 de fevereiro de 1535, estudou em Padova, Perugia e Bologna. Tendo se dedicado ao estudo das leis. Era ótimo jurista, por isso foi nomeado Advogado Concistorial e Auditor de Rota. Em 1585 é nomeado cardeal e, no ano seguinte, foi enviado como Legado Papal à Polônia. O conclave que o elegeu, após a morte de Inocêncio IX, durou cerca de um mês; e, no dia 30 de janeiro de 1592 é eleito papa, escolhendo se chamar Clemente VIII. Uma das maiores preocupação do novo papa foi organizar uma cruzada contra os turcos que voltavam a ameaçar a Europa. É da época de seu pontificado, a querela aberta por Luis de Molina com respeito aos efeitos da graça divina. A controvérsia ganhou proporções muito grandes, e o Papa se viu obrigado a publicar, em 1597, a Instrução De auxiliis, a fim de apaziguar a polêmica e decidir sobre o assunto. Clemente VIII era partidário da tese dominicana, que coincidia com a tradição tomista, no entanto não viu o desenlace da controvérsia; somente com Paulo V terminaram-se as discussões, tendo sido proibida qualquer publicação sem a permissão do Santo Oficio e da Inquisição. É também de seu pontificado a condenação à fogueira da Inquisição de Giordano Bruno, antigo monge dominicano, queimado vivo no dia 17 de fevereiro de 1600. Outra trágica condenação de seu pontificado foi a da conhecida e muito explorada trama familiar de Beatriz Cenci. Clemente VIII morreu no ano de 1605. 
administrativo geral, quanto do ponto de vista da espiritualidade:

Con el impulso dado al cultivo del espíritu por el padre Aquaviva, y con su visión más amplia de lo que debe ser la vida de oración en la Compañía, ha logrado equilibrar y unificar las fuerzas. En los últimos años de su largo gobierno parece notarse la cátarsis de las tensiones superadas. La Compañía marcha ya con rumbo seguro en una espiritualidad conscientemente propia ${ }^{14}$.

É essa característica, acima de tudo, que nos fez optar por esse recorte histórico: os passos rumo a uma "espiritualidade conscientemente própria".

\section{1) Litterae Indipetae}

É dentro desse panorama histórico e contexto institucional com características tão peculiares que se encontram as cartas com as quais trabalhamos, de forma que o conteúdo que será descrito a partir desse ponto deverá ser lido tendo como pano de fundo esse cenário ${ }^{15}$. Nas descrições que se seguirão, analisaremos as Indipetae, uma a uma, sob a ótica da retórica epistolar, a partir das cinco partes mais comuns da carta que acabaram se fixando, na tradição da $\operatorname{ars~dictaminis~}^{16}$.

Aos 02 de maio de 1583, o irmão coadjutor Seraphin Bonaventura Coçar ${ }^{17}$, escreve do Colégio de Valência, pedindo para ser enviado ao Japão. A Indipeta traz uma nota, ao final, dizendo "Copia de otra de 11 de Abril": tratar-se-á do próprio Seraphin o copista, ou foi escrita por uma outra mão? A carta possui salutatio mais completa, contendo além da tradicional saudação Pax Christi \&c, referência ao destinatário. Na captatio benevolentiae, o autor relata que é a segunda vez que escreve; sendo que dessa vez foi principalmente

\footnotetext{
${ }^{14}$ Ruiz Jurado, 1976, op. cit., p. 245 ("Com o impulso dado pelo Padre Aquaviva ao cultivo do espírito, e com sua visão mais ampla do que deve ser a vida de oração na Companhia, conseguiu equilibrar e unificar as forças. Nos últimos anos de seu longo governo parece notar-se a catarse das tensões superadas. A Companhia caminha já como rumo seguro em uma espiritualidade conscientemente própria").

${ }^{15}$ Vide cartas transcritas em anexo.

${ }^{16}$ Importa observar, de antemão, que apesar da rigidez notarial, típica da corte papal na chamada "idade média", a partir de Erasmo, Lípsio e outros humanistas do XVI-XVII, encontramos uma flexibilização da ars dictaminis.

${ }_{17}$ ARSI, Indipetae Hispanae, FG 758, carta n. 4, de Seraphin Bonaventura Coçar, Valencia, 02/05/1583.
} 
incentivado pelo Padre Hieronimo Domenech $(1516-1592)^{18}$, e procura mostrar ao padre geral que não descuidou do trabalho de discernimento dos espíritos necessário para a perfeita eleição e reconhecimento da vontade de Deus, além de reafirmar sua "resignacion que en todas las cosas y obediencias pide Nuestro Santo Instituto”. Inicia a narratio afirmando a força dos desejos e de como, algumas vezes, preferiu fazer-se de surdo "diziendome, que son fervores de caçuela, y que Dios no me llama”. Em seguida, declara quais são os desejos que sente e as conseqüências desses desejos na sua vida: "ahora me es grande espuela para caminar ala perfeccion". Relata, então, o processo de discernimento dos espíritos a que se dedicou, afim de saber a origem dos desejos: por um lado o desejo arredava as dúvidas, o deixava consolado e com alegria, além de afastar dele todas as possíveis dificuldades que sentiria diante de um trabalho mais árduo; por outro lado o desejo causava cegueira e inquietude, restringindo suas forças. E, já na petitio, concluindo que "solo puede ser estorvo desto mi poca virtud, la qual tengo bien conocida", faz sua súplica certo de tudo o que narrou lhe obriga a, "con resignacion, pida a Vuestra Paternidad me enbie al Japon buscando en esto la mayor honra y gloria de su divina Magestad a quien humilmente suplico con desseo de mi aprovechamiento y de aquellos indios inspire a Vuestra Paternidad lo que fuere mas para su S.to Servicio. Amen". A conclusio possui valedictio típica, onde o indipetente se encomenda às orações e sacrifícios do prepósito geral, local e data, e assinatura precedida da fórmula de humildade e filiação: "De Vuestra Paternidad [D.V.P.] servo indigno y hijo en el Señor".

Balthasar de Torres ${ }^{19}$, de 20/21 anos de idade, escreve do Colégio de Huete, no dia 14 de agosto de 1584. O quartanista de filosofia, escreve uma salutatio, como a anterior, completa, com referência ao destinatário e com a tradicional fórmula de saudação. $\mathrm{Na}$

\footnotetext{
${ }^{18}$ Geronimo Domenech nasceu em Valencia, Espanha, em 1516, fez-se padre quando encontrou Pedro Fabro em Parma, Itália, em 1539. Nesse ano, fez os Exercícios e foi aceito na Companhia de Jesus em setembro. Foi reitor da casa de Paris (1540-1542), trabalhou como secretário de Inácio em Roma (1544-1545), foi Provincial da Sićlila (1553-1561, 1562-1568, 1570-1576), e reitor do Colégio Romano (1568-1570). Voltou para a Espanha e morreu em Valencia no dia 20 de dezembro de 1592.

${ }^{19}$ ARSI, Indipetae Hispanae, FG 758, carta n. 13, de Balthasar de Torres, Huete, 14/08/1584.
} 
captatio benevolentiae descreve a "tan buena occasion" da visita do padre procurador do Japão para "dar parte a Vuestra Paternidad de los deseos que Nuestro Señor ha sido servido communicar a este su siervo indignissimo"; reafirma seu sentimento com relação ao padre geral e seu respeito à autoridade, mostrando-se resignado à vontade de Deus manifesta na vontade do superior. Já na narratio, relata que deseja as Índias há dois anos, desde que teve a oportunidade de ler "lo que nuestros padres hacen en las Indias orientales, specialmente en el Japon". O texto faz uso de topoi tais como: consolação, obediência e paixões da alma. Aproveitando a ocasião da visita do Padre Procurador do Japão, Balthasar diz que faz questão de escrever pessoalmente (ao invés de somente se bastar do relato que certamente o padre procurador faria) para "corresponder a las inspirationes de Nuestro Señor". Contando a história de como nasceu o desejo, afirma que foi movido pelo desejo de imitação dos padres que foram para o Oriente. No entanto, "cesavan aquellos deseos, parte por verme tan inhabil (como ahora) por mi poca virtud; parte por no tener certidumbre bastante de la voluntad de Nuestro Señor". Assim, durante 5 ou 6 meses, resolveu perseverar "en el mesmo exercicio delas cosas de el Japon", experimentando um incender-se dos desejos e uma mudança na qualidade da manifestação dos desejos (de "interpollados" para "continuos"). Com isso, explicita como se deu o processo de discernimento dos espíritos até o ponto de chegar a dizer: “creo ser llamammiento de Nuestro Señor porque estos deseos me son espuelas, y ayuda, para aprovechar en virtud". Em seguida, na petitio, declara que isso era tudo o que queria escrever: "no para pedir esta mision, sino para declarar llanamente lo que por mi anima pasa". Interessante observar esta dinâmica: exatamente na parte da carta destinada à manifestação do pedido, o autor diz que não quis pedir: trata-se, conforme se verá mais à frente, da manifestação de sua indiferença. Ainda nesta parte da correspondência, o indipetente faz questão de explicitar qual é o seu desejo: chegar à hora da morte certo de "aver travajado siempre solo por obediencia, y bien de las animas; sin mescla de propria voluntad". $\mathrm{Na}$ 
salutatio, diz qual a sua situação pessoal naquele momento, dentro da Companhia de Jesus, faz uso da valedictio tradicional, escreve data e local e, junto à assinatura, se diz filho muito indigno do padre geral.

Antonio Perez ${ }^{20}$, com dez anos de vida na Companhia de Jesus, escreve de Granada, aos quatro de abril de 1585. A correspondência possui salutatio simples: constando apenas da fórmula tradicional Pax Christi \&c. Em seguida, na captatio benevolentiae, o indipetente justifica o fato de estar "representando" outra vez os "eficazes deseos" que sente. Já na narratio, se diz indiferente quanto ao destino para onde quer ser enviado, apesar de referir o Japão como destino preferido, já que sentiu o desejo de entrar para a Companhia depois de ouvir a história de Francisco Xavier, quando estudava Artes em Cordona. Segundo o indipetente, quando era noviço, seguindo a ordem do Superior Geral de "que quien tuviesse deseos de ir al Japon, lo representase", pediu para ser enviado ao Japão e, é só por entender a seriedade do assunto e por continuar experimentando o mesmo desejo durante os dez anos que o separam do momento em que ouviu pela primeira vez a história de Xavier, que resolveu pedir mais uma vez. Relata a história de sua entrada na Companhia e de como "todo este tiempo vivio en mi un eficaz deseo de este trabajoso viaje, costandome hartas lagrimas por verme privado de el y temiendo perdello". Finalmente, na petitio, começa escrevendo que "mucho he deseado siempre en este negoçio, ser embiado sin peticion mia; pero pues es tan permitido el representar los deseos, me determine a hazerlo", em seguida, no entanto, deixa claro que apesar de representar o desejo, continua fiel à obediência devida ao padre geral e ao Instituto, manifestando sua indiferença, "tiniendo por mas acertado lo que se me mandare, pues sera ordenaçion cierta de Dios, que no quiere ni puede engañarme”. Na conclusio, antes da valedictio comum a quase todas as Indipetae, o autor relata que, a fim de discernir bem os espíritos, se encomendou a Deus, fazendo uma confissão geral, oração, missas e jejuns por 50

\footnotetext{
${ }^{20}$ ARSI, Indipetae Hispanae, FG 758, carta n. 43, de Antonio Perez, Granada, 04/04/1585.
} 
dias. No documento, a palavra "yhesnos" (jejuns?) encontra-se grifada não se sabe por que mão ${ }^{21}$. Há local, data e assinatura, precedida, como as demais, da fórmula de filiação e humildade tradicional.

De Madrid, Alonso Crespo ${ }^{22}$ escreve sua carta no dia 20 de dezembro de 1586. A salutatio da correspondência possui destinatário, além da saudação usual. Aspecto interessante a se observar nesta Indipeta é seu tamanho comparado ao das demais: possui apenas 196 palavras, enquanto que a média geral de palavras é de 486. A captatio benevolentiae, bastante curta, apenas avisa que havia escrito uma correspondência anteriormente e que não sabia da visita do padre procurador do México, Padre Pedro Ortigosa $^{23}$. Na narratio, o indipetente relata que conversou com o padre Ortigosa e, por isso, escreve outra vez ao padre superior geral, "para que sirva de acordar a Vuestra Paternidad la charidad que he pedido mucho ha". Na petitio, então, repete a petição feita antes: "pido por amor de Nuestro Señor y que no me lo niegue por que es justa petiçion". Na conclusio, retoma o pedido e se declara expectante de ser "obediente y hijo verdadero de la Compañia" e de que o padre superior encaminhe seus desejos para aquilo que "mas me conviene". Acrescenta local, data e assinatura com o ordinário "De Vuestra Paternidad indigno hijo y siervo en Christo".

Em 17 de março de 1587, o irmão coadjutor Bernardo Matias ${ }^{24}$ escreve sua carta de Tarragona, pedindo para ser enviado para o Japão, China ou Índias de Portugal. A carta possui salutatio com referência ao destinatário e saudação usual. A captatio benevolentiae faz referência ao fato de já ter escrito duas outras cartas, justificando a escrita desta terceira pelo fato de estar experimentando grande consolação depois de ter ouvido falar "de las muertes o por mejor desir de la nueva vida de tantos martires" da Companhia. Na narratio, o indipetente

\footnotetext{
${ }^{21}$ Talvez a mão do Superior Geral.

${ }^{22}$ ARSI, Indipetae Hispanae, FG 758, carta n. 73, de Alonso Crespo, Madrid, 20/12/1586.

${ }^{23}$ Não conseguimos encontrar referências acerca de Padre Pedro Ortigosa, do México, no período referido.

${ }^{24}$ ARSI, Indipetae Hispanae, FG 758, carta n. 80, de Bernardo Matias, Tarragona, 17/03/1587.
} 
relata como trabalhou a fim de discernir bem os espíritos, dizendo que tratou do assunto com o padre provincial, com o padre reitor e com um certo Padre Morales; sendo que o Provincial lhe garantiu que havia comunicado ao Geral do seu desejo particular. No entanto, na petitio, diz que insiste em escrever de novo "por no saber si Vuestra Paternidad ha rescebido ninguna mia", voltando a apontar seu desejo. Na conclusio, o autor faz um descrição de si mesmo: diz ser alegre quanto ao exterior, mas que não se atreve a dizer nada do interior porque se tiver que escrever sobre alguma virtude, teria que tentar achar alguma em si, mas confia "en el que me da estos deseos me dara lo que es menester para cumplirlos". Há a ordinária valedictio, referência a local e data, além da assinatura com a manifestação de sua filiação.

O jovem Joseph de Sepulveda ${ }^{25}$, de 21 anos de idade, escreve do Colégio de Belmonte, em 21 de junho de 1588. A salutatio de sua correspondência não tem referência a destinatário. Em seguida, na captatio benevolentiae, o autor diz escrever outra vez por não saber se a anterior chegou às mãos do padre geral, declarando-se indiferente e com desejos de ser enviado "al Japon, o a otra qualquiera parte que la obediençia ordenase, donde pudiese servir mas a su Magestad y padeçer algo por su nombre, y amor”. Na narratio, declara ter se encomendado a Deus antes de escrever, demonstrando assim como seguiu a regra de discernimento dos espíritos, já que até então achava que era apenas tentação o que sentia e que ria de quem falava em ir para o Japão: o incômodo que experimentava ao ver que aqueles que iam estavam dando "buen exemplo" o convenceu de se encomendar, pedindo para "no resistir a su Magestad si de mi se quisiese servir". O resultado foi que o desejo aumentou e se esclareceu: "mas en el Japon alli parese me llama nuestro Señor y me da gusto particular". Na petitio, porém, diz que iria também para o Peru ou a outro lugar "con summo gozo a ello entendiendo ser la voluntad de Nuestro Señor por quien aunque indigno queria padecer mucho", terminando por dizer que "esta nonada que soy la offreço a su magestad puniendola

\footnotetext{
${ }^{25}$ ARSI, Indipetae Hispanae, FG 758, carta n. 116, de Joseph de Sepulveda, Belmonte, 21/06/1588.
} 
en manos de Vuestra Paternidad que es mi Dios en la tierra para que de mi disponga como mejor a V.P. pareciere”. Finalmente, na conclusio, descreve sua situação pessoal no momento da escrita e relata que o conteúdo desta carta foi tirada do mata-borrão, onde ficaram impressos trechos da carta anteriormente enviada. Não há valedictio, mas, como é comum, há referência a local, data e assinatura.

Em 02 de outubro de 1589, de Girona, escreve o jovem Juan de Avila ${ }^{26}$ ao padre geral seu segundo pedido de ser enviado à China. A partir desta carta, nenhuma das seguintes possui, na salutatio, referência ao destinatário e, praticamente todas, possuem a usual saudação Pax Christi \&c, de forma que, daqui em diante, a não ser nos casos extraordinários, faremos referência a esta parte da correspondência epistolar. A captatio benevolentiae preparada por este indipetente faz referência a uma carta escrita um ano antes, onde se relatavam os desejos que sentia de ir para as Índias, para trabalhar "por amor de Christo"; relata também que, apesar de ter sido indicado de não voltar a escrever, se resolve pelo contrário após ter conversado com o padre provincial que lhe disse "ser conveniente, dar razon de lo que el Señor me a comunicado en esta parte"; finalmente, diz que o simples fato de poder voltar a escrever foi para ele motivo de "tanto alivio, quanto era el dolor, q rescebia por haverseme quitado el acudir a Vuestra Paternidad con carta". Em seguida, na narratio, descreve o desejo que vem sentindo e relata o trabalho de discernimento dos espíritos a que se dedicou (mortificação das paixões, encomendas), deixando bem claro que o lugar a que mais se sente movido a ir é para a China - "que tengo metida en lo intimo de mi coraçon". Também aqui, o autor diz que o desejo que sente é tão grande que, quando pensa nele, "rebiento em lagrimas"; além de dizer que o desejo se tornou remédio para a mortificação das paixões e para as dificuldades no caminho da perfeição. Na petitio, suplica "con lagrimas" que o superior não lhe negue tal consolação a este "minimo hijo (pues estos suelen ser mas

\footnotetext{
${ }^{26}$ ARSI, Indipetae Hispanae, FG 758, carta n. 126, de Juan de Avila, Girona, 02/10/1589.
} 
tiernamente amados y regalados)". Na conclusio, descreve sua situação pessoal e reafirma sua confiança de que "su Magestad me lo concedera presto [o desejo de padecer por Cristo], y dexara ver a Vuestra Paternidad enel cielo, como yo se lo supplico"; faz referência ao local e à data, e assina.

A carta do irmão coadjutor Domingo Tafalla ${ }^{27}$, de 21 anos, aos 23 dias de março de 1590, é bastante peculiar do ponto de vista da estruturação retórica: além da salutatio e da conclusio, a carta parece não estar organizada nas três partes internas necessárias. Toda a carta parece ser uma petitio, entremeada de trechos em que o autor claramente busca captar a benevolência do superior geral da Companhia. De maneira geral, dadas as características da carta, podemos dizer que este é o típico ineptus a que se refere Cícero, no De Oratore ${ }^{28}$, demonstrando não uma falta de preparo psicológico, mas de falta de domínio do modelo retórico; o que não é de se estranhar - ainda que esta estrutura retórica seja uma preocupação corrente entre os jesuítas -, dado que algumas das cartas eram escritas por jesuítas sem um preparo intelectual adequado. $\mathrm{O}$ indipetente afirma que escreve aproveitando a visita de um certo Padre Rogério, para pedir a "charidad de consolarme", enviando-o para a China junto com outros que estão indo numa próxima "empressa". Argumentando a seu favor, depois de ter declarado seu trabalho de discernimento dos espíritos, demonstra como tem saúde, forças e qualidades necessárias para quem deseja ir

\footnotetext{
${ }^{27}$ ARSI, Indipetae Hispanae, FG 758, carta n. 136, de Domingo Tafalla, Valencia, 23/03/1590.

${ }^{28}$ Assim se refere Cícero (1966), na descrição do diálogo entre Crassus e César: "Tum ille: Ego mehercule, inquit, Caesar, ex omnibus Latinis verbis huius verbi vim vel maximam semper putavi. Quem enim nos ineptum vocamus, is mihi videtur ab hoc nomen habere ductum, quod non sit aptus, idque in sermonis nostri consuetudine perlate patet. Nam qui aut tempus quid postulet non videt aut plura loquitur aut se ostentat aut eorum quibuscum est vel dignitatis vel commodi rationem non habet aut denique in aliquo genere aut inconcinnus aut multus est, is ineptus esse dicitur. Hoc vitio cumulata est eruditissima illa Graecorum natio" (IV, 17-18, p. 14). ["Retomou Crassus: Para dizer a verdade, César, de todas as palavras latinas ineptus é aquela que sempre me pareceu ter talvez maior força. Dizer de alguém que é "inepto", é dizer, segundo a etimologia da palavra, que ele é "não apto" e, nos hábitos da nossa língua, este significado vai muito mais longe. Quem, com efeito, não vê o que pedem as circunstâncias, ou fala mais que o necessário, ou se estende ostensivamente, ou não tem nenhum respeito nem à dignidade nem aos interesses das pessoas com as quais ele se encontra, quem é assim, em poucas palavras, não tem conveniência ou medida, nós o chamamos "inepto". Defeito que infecta a raça grega com todo o seu saber" (tradução nossa)]. Cf. Cicéron, M. T. (1966). De l'orateur. Livre deuxième. (E. Courbaud, Trad.). Paris: Société d'édition "Les Belles Lettres" (original de 55 a.C.).
} 
para a China: "El Padre Rogerio me ha animado mucho, ý me ha dicho que era el mejor tiempo de mi edad para ýr ý aprender la lengua china que no tengo mas de veynte o veynte un años". Na conclusio, reafirma a confiança no padre geral que, como pai, "me ha de consolar", faz a valedictio ordinária, refere lugar e data e assina. Outro aspecto interessante a notar é o tamanho da carta: possui apenas 235 palavras. Parece-nos que seja mais uma carta para cumprir a normativa do pedido - quase como que comunicando a próxima partida - que uma carta na qual se espera a benevolência do prepósito geral.

Juan Augustin Castangia ${ }^{29}$, que já havia escrito em 29 de novembro de 1591, escreve essa segunda carta, aos 30 de agosto de 1591, de Sacer. O documento relata, na captatio benevolentiae, que só escreve outra carta "por estar dudoso si Vuestra Paternidad ha recebido una que con el Padre Superior escrivi a 29 de Noviembre de 1590"; resume, então, o conteúdo da primeira carta antes de iniciar a narratio. Nela, demonstra o trabalho que fez de discernimento dos espíritos: "exortaciones ordinarias, lectiones, y otros exercicios espirituales (...), comuniones, diciplinas mortificaciones y trabajos ordinarios (...) por espacio de cinco años"; e diz que os desejos aumentaram de tal forma "que me parece hechar con esto leño al fuego". Falando de si mesmo, na petitio, lembra que não tem o necessário em virtudes para ir, mas confia que Deus, que lhe deu os desejos, lhe suprirá com graça suficiente; então suplica ao prepósito geral "no me prive deste consuelo, graçia y misericordia que Dios Nuestro Señor me quiere hazer de padecer por sua divino amor y reverencia de su sanctissimo nombre para que assi alcance el fin para el qual he sido criado y he entrado en la Compañia”. Na conclusio escreve a seguinte valedictio: "Y Nuestro Señor sea servido que se aga en todo su sanctissima y divina voluntad y de a Vuestra Paternidad mucha vida quanta sus hijos tenemos menester"; refere local e data, e assina.

Pedindo para ser enviado para o Japão ou para a China, Balthasar Mas ${ }^{30}$, de 23 anos de

\footnotetext{
${ }^{29}$ ARSI, Indipetae Hispanae, FG 758, carta n. 168, de Juan Augustin Castangia, Sacer, 29/11/1591.

${ }^{30}$ ARSI, Indipetae Hispanae, FG 758, carta n. 179, de Balthasar Mas, Valencia, 16/04/1592.
} 
idade, e 8 anos na Companhia, escreve uma pequena carta (apenas 230 palavras) quando estava morando no Colégio de Valencia, no dia 16 de abril de 1592. Na captatio benevolentiae, o autor afirma escrever com o interesse de "descubrir mi pecho con toda resignacion como es verdad". Em seguida, na narratio, explicita seu desejo de ser enviado e de que o "Señor se servira de mi vida miserable en lo que fuere de maior gloria suya"; para, em seguida, relatar a história da origem do desejo: “oyer el exemplo de los nuestros en Japon”. Tendo discernido os espíritos, diz que tem recebido "muchos beneficios de Dios por medio dela sacratissima Virgem", afirmando também que coloca sua esperança “en esta Señora”. A peculiaridade de sua petitio é que, nela, o indipetente, ao invés de pedir diretamente ao superior geral, se confia a Nossa Senhora para que ela o console, dispondo-se, indiferentemente, para o que for servir no Japão ou China (como afirmou anteriormente) ou "servirse de mi en otro". Na conclusio, bem brevemente declara sua situação pessoal no momento da escrita ${ }^{31}$; refere local e data, e assina.

O irmão coadjutor Pedro Ruiz ${ }^{32}$ escreve de Cádiz, no dia 29 de julho de 1593. A captatio benevolentiae de sua correspondência dá conta de uma carta escrita um ano antes e resume brevemente o conteúdo desta anterior; além do mais, é aqui que o autor procura captar a benevolência do padre geral, dizendo que como "Nuestro Señor a puesto para que me enderecen y encaminem asi superiores como confisores me parecio guiado por su parecer escribir segundo vez a Vuestra Paternidad”. Em sua Indipeta, o autor parece inverter de lugar a petitio, que aparece em seguida à captatio benevolentiae, e diz o seguinte: “y pedirle con todas las veras que puedo tenga por bien si juzgare ser para maior servicio y gloria de Dios concederme esta peticion que sin duda ninguna sera para mi de mucho consuelo si por ordem de Vuestra Paternidad Nuestro Señor me hiciese esta Merced”. Na narratio que se segue, o indipetente relata brevemente a história do desejo e do trabalho de discernimento de espíritos a que se

\footnotetext{
${ }^{31}$ No rodapé dessa carta, um certo Hernando Ponçe aproveita para escrever o seu pedido. Não usaremos o texto dele nas análises que se seguirão nos próximos capítulos. No entanto, transcrevemos sua "carta" nos anexos.

${ }^{32}$ ARSI, Indipetae Hispanae, FG 758, carta n. 188, de Pedro Ruiz, Cadiz, 29/07/1593.
} 
dedicou neste tempo. Finalmente, na conclusio, descreve sua situação na Companhia de Jesus e diz que fica confiante "en la paternal charidad de Vuestra Paternidad que mirara mis deseos como de hijo que desea obedecer en todo". A valedictio diz "Nuestro Señor guarde a Vuestra Paternidad"; ao final, anota o local, a data e assina.

O irmão coadjutor Diego de Salcedo ${ }^{33}$ - de 19 anos de idade e 3 anos e dois meses na Companhia de Jesus - escreve do Colégio de Belmonte, no dia 31 de maio de 1594. Na carta, sem salutatio, Diego diz, logo na captatio benevolentiae, que mandou notícias suas, antes, pelo Padre Provincial (do México) Esteban Paez ${ }^{34}$; além disso, a fim de melhor conquistar a docilidade do destinatário, se diz "uno delos minimos desta Compañia". Na narratio que se segue, o autor relata que o próprio padre provincial com quem conversara lhe "dixo que escriviese a Vuestra Paternidad y mostrase los deseos que Dios Nuestro Señor me avia dado, y que Nuestro Señor lo negociaria". Segundo ele o desejo de "ir alas Indias" nasceu depois de ouvir a leitura das cartas do Japão "y otras partes", quando, então, "regozijava interiormente pareciendome que yo me hallava alla con ellos conviviendo, y me crecian los deseos". Diz então que, "aora que esta movida el agua son muy grandes" os desejos; tão fortes que "si me viniera una suia, que me significase que me fuese, me fuera luego sin duda muy contento y regozixado", do contrário, diz que não sabe se ficaria "tan contento, pero alo menos procurara conformarme con la voluntad de Nuestro Señor entendiendo ser aquello lo que mas conviene”. Em seguida, faz sua petitio: “Asy yo supplico y pido humilmente a V.P. hincadas las rodillas, que aunque bien apartado, con todo eso lo pido como si estubiera muy cerca, que si no hallare que ay algun grande inconveniente en mi ida, o que si sirviere mas Dios Nuestro Señor de que me quede por aca, que aiude a mis

\footnotetext{
${ }^{33}$ ARSI, Indipetae Hispanae, FG 758, carta n. 191, de Diego de Salcedo, Belmonte, 31/05/1594.

${ }^{34}$ Acerca de P.e Esteban Páez conseguimos poucas informações: sabe-se que foi provincial do México e do Peru. $\mathrm{Na}$ época da carta de Diego Salcedo, seguramente era provincial do México, o que nos faz crer que a petição do indipetente se dirige para as missões no México. Cf. Pacheco, Juan Manuel (1959). Los Jesuitas en Colombia. Bogotá: T.I. Editorial San Juan Eudes. Nesse texto, o autor relata a origem da Província da Colômbia, quando o então bispo de Santafé, D. Bartolomé Lobo Guerrero, solicitou, em 1596, ao P.e Esteban Páez dois jesuítas de sua província para a fundação em Cartagena. Eram esses jesuítas P.e Alonso de Medrano (Marchena, España) e P.e Francisco de Figueroa (Fregenal, España). Eles chegaram no dia 05 de outubro de 1598.
} 
deseos, y me los cumpla, pues esta en sus manos, si como he dicho no viere ser outra la voluntad de Dios". Finalmente, na conclusio, repete o pedido feito e entrega-se nas mãos do padre geral esperando, que se cumpra a vontade de "Dios Nuestro Señor". Não há valedictio, mas há referência a local e data, além da assinatura sem nenhum acréscimo especial.

A carta de Juan de Ortega $^{35}$ foi escrita no dia 04 de maio de 1597 , em Medina del Campo, não tem captatio benevolentiae ${ }^{36}$ e relata, logo de entrada, seu desejo de servir a Deus na Companhia de Jesus e de ir às Índias. Diz que, há três anos, Deus concedeu-lhe o primeiro desejo, permitindo que fizesse parte da Companhia, na Província de Castilla, “y agora se a ofrecido buena ocasion que el padre procurador de la Nueva España a de llevar algunos, me parecio representarlo a Vuestra Paternidad para que me de licencia que vaya con el y me lleve con los demas". Em seguida, na parte que corresponde à petitio, o indipetente pede "licençia que vaya con el y me lleve con los demas". Na conclusio, ele afirma que não tem o necessário para ir em missão, mas confia "en la divina bondad que ofreciendome yo a los trabajos que se an de padecer en la navegacion y por alla, me dara su favor y ayuda para que en aquellas partes seade algun probecho en lo que se me mandare". Faz a valedictio usual, refere local e data, e assina. Trata-se de uma das cartas mais curtas das que temos em mãos (apenas 195 palavras).

Na carta seguinte, escrita por Andres Porta ${ }^{37}$, em 23 de outubro de 1598, na cidade de Oviedo, a captatio benevolentiae e a narratio parecem se misturar, sobretudo dado o fato de que o autor inicia o texto relatando a história do desejo: "Muchos años ha me da Nuestro

\footnotetext{
${ }^{35}$ ARSI, Indipetae Hispanae, FG 758, carta n. 200, de Juan de Ortega, Medina del Campo, 04/05/1597.

${ }^{36}$ A captatio benevolentiae, como dissemos, existe para conseguir a atenção e a benevolência do leitor que, no nosso caso específico, trata-se do superior geral da Companhia de Jesus. Trata-se, ainda, neste caso, de uma relação também muito claramente determinada: a carta Indipeta tem a função de "persuasão" para um objetivo que, se não for bem justificado (ou seja, justificado com os loci argumentorum adequados), pode não ser efetivo. Em princípio, a captatio é uma parte da carta que nunca seria dispensável; e se se pensam essas características do documento com o qual trabalhamos, muito menos neles poder-se-ia dispensá-la. Mas se essa carta, bem como uma outra que se verá mais à frente (ARSI, Indipetae Hispanae, FG 759, carta n. 24/2), respondendo a aspectos específicos - a petição do envio -, quando o pedido já foi, digamos assim, atendido, pode ser que a captatio perca relevância. É como se a carta, ao final, cumprisse simplesmente o papel puramente formal de encaminhamento de pedido; não servindo, necessariamente, para avaliação do superior geral. A fim de verificar essa hipótese, seria necessário o acesso, no ARSI, aos Catálogos da Companhia de Jesus, referentes aos colégios dos autores, ou às províncias pedidas.

${ }^{37}$ ARSI, Indipetae Hispanae, FG 758, carta n. 204, de Andres Porta, Oviedo, 23/10/1598.
} 
Señor deseos" etc. Ainda nesta parte, manifesta, pouco antes do início da petitio, sua "determinadissima indifferensia a eso o a qualquier otra cosa que a la obediencia pareciesse". Em seguida, então, vem a súplica: “pido y supplico humilmente a Vuestra Paternidad que ora sea para el Japon ora para alguna parte delas regiones septentrionales donde reyna la heregia, ora en qualquier otra del mondo donde mas aya que padeçer por amor de JesuCristo". Já na conclusio, afirma que as demais notícias a seu respeito serão dadas pelo P.e Cristobal de los Cabos $^{38}$, acrescenta uma valedictio, local, data e assinatura.

Em 30 de agosto de 1599, de Zaragoza, Geronimo Moranta ${ }^{39}$ (23 anos de idade) escreve declarando ao padre geral principalmente sua indiferença. O texto começa, já na captatio benevolentiae, justificando que por confiar no "paternal pecho de Vuestra Paternidad" se atreve a escrever "breves ringlones, dando razon de mis antiguos deseos" (há 10 anos deseja). Em seguida, narrando a história de seu desejo, explica que apesar de ter apenas quatro anos e meio que está na Companhia, esses desejos o acompanham desde antes de entrar: "comence a pedir la Compañia seis años antes que entrasse en ella; y luego que me determine de entrar [...] mi principal motivo fue para yr a las Indias a emplearme en lo que alli se emplean los nuestros; y entonces aca no se ha apartado de mi coraçon un punto este deseo". Diz que conheceu a Companhia quando ainda era uma criança, graças ao relacionamento de sua família com o Padre Jerônimo Nadal. Desde então, ouve a histórias dos que iam para as missões, passando a desejar ardentemente imitar "a los Padres en esta parte". Tendo entrado na Companhia, imediatamente começou a pedir para ser enviado - pediu ao Padre Provincial e ao Mestre de Noviços -, "procurando de ponerme con indiferencia antes y despues de averlo propuesto". Na petitio que se segue, o autor apenas diz que lhe pareceu conveniente, após conversar com um e outro de seus superiores, representar os desejos que sente "a Vuestra Paternidad para que entendiendo mis antiguos deseos disponga de mi (...) como mas fuere a gloria de Dios; porque nil mihi gratia quam

\footnotetext{
${ }^{38}$ Não encontramos referências acerca do P.e Cristobal de los Cabos.

${ }^{39}$ ARSI, Indipetae Hispanae, FG 758, carta n. 227, de Geronimo Moranta, Zaragoza, 30/08/1599.
} 
vivere in est mundi plaga ubi maius Dei obsequium at animarum auxilium speratur" ${ }^{, 40}$. A conclusio, bastante concisa, apenas refere local e data, além da assinatura.

De Alcalá de Henares, no dia 15 de junho de 1602, escreve Leon Ximenes ${ }^{41}$. Logo na captatio benevolentiae, o autor declara a certeza da origem divina do desejo, a partir da "tan extraordinaria" mudança que vem sentindo em sua vida. Na narratio, então, descreve a história deste desejo e do trabalho de discernimento dos espíritos a que se dedicou para chegar a tal conclusão. Relata que seu desejo é particularmente dirigido para o Peru, porque é onde se padecem mais trabalhos e incômodos na comida, habitação e relacionamentos. Completa, dizendo que confia em Deus que suprirá nele o que lhe falta de forças e perseverança. Na petitio, diz que "si a Vuestra Paternidad le pareciere sera mayor gloria de Dios Nuestro Señor que yo vaya al Piru, el si de Vuestra Paternidad lo tomare como si fuera de la boca del mismo Cristo, y como por obediencia suya". Na última parte da carta, a conclusio, escreve a valedictio formal: "Guarde Nuestro Señor muchos años a Vuestra Paternidad en cuyas oraciones y santos sacrificios este su minimo hijo muy deveras se encomienda"; refere local e data, e assina a carta.

Joan Sotalell $^{42}$, de Gandia, escreve aos 20 dias de maio de 1603 ao Padre Geral, para dar notícias diretamente de seus grandes desejos. Diz, na captatio benevolentiae, que, já que em outros momentos havia escrito por via seja do Padre Gaspar Moro ${ }^{43}$ seja do Padre Diego

\footnotetext{
${ }^{40}$ Apesar do latim mal escrito, se pode, mais ou menos, traduzir o trecho assim: "nada me é de maior graça do que viver neste mundo buscando o maior obséquio de Deus e esperando seu auxílio para alma".

${ }^{41}$ ARSI, Indipetae Hispanae, FG 758, carta n. 290, de Leon Ximenes, Alcalá de Henares, 15/06/1602.

${ }^{42}$ ARSI, Indipetae Hispanae, FG 758, carta n. 338, de Joan Sotalell, Gandía, 20/05/1603.

${ }^{43}$ Encontramos uma referência ao P.e Gaspar Moro em Sánchez, Javier Burrieza (2003). La recompensa de la eternidad. Los fundadores de los colegios de la Compañía de Jesús en el ámbito vallisoletano. Revista de Historia Moderna Anales de la Universidad de Alicante, 21, 7-74: "El obispo de Tlaxcala siempre ejerció una protección muy especial sobre este matrimonio. El prelado empezó a pensar en la posibilidad de establecer en su Valladolid natal una casa de la Compañía de Jesús que se iba a dedicar al sabio arzobispo de Milán San Ambrosio. Para ello, su contacto en la provincia de Castilla sería el padre Gaspar Moro, jesuita con no excesiva buena prensa, pues era diestro en manejos económicos dentro de la orden. Si las primeras ideas se oyeron en 1585, no se hicieron efectivas hasta diez años después. Era muy importante lo que Luis Fernández Martín ha conceptualizado como «raíces loyoleas», el parentesco con la familia del fundador de la Compañía de Jesús"(p. 15). O que nos leva a crer que se tratava do ecônomo da Província de Castilla.
} 
Torres $^{44}$, sentiu necessidade de enviar a carta sem intermediários; além do mais, esclarece que volta a escrever também por que o "desseo grande que mi alma tiene de ir a las Indias, hora sena orientales, hora occidentales, me fuerça a que buelva a escrivir". Explica também que o desejo lhe foi comunicado um ano antes, quando fazia os Exercícios Espirituais, no mês de agosto: “mi alma [...] se renovo [...] deseando el martirio". Em seguida, quando começa a narrativa da história do desejo, relata que tem experimentado um desfazer-se "como humo" das tentações, simplesmente pensando na ida para as Índias. Depois, conta duas histórias para exemplificar isso. E, mais à frente, relata o trabalho de discernimento dos espíritos que fez: "conosco en mi alma grande ventaja en mortificar los vicios y passiones desordenadas", "exercicios espirituales", oferecimentos etc. Diz ainda que "cuando siento hablar dellas Indias, yo hablo con algunos, es muy grande el consuelo que mi alma recibe con aquella platica, y esto en qualquiera hora del dia, lo qual me firme para que yr fervor en todas las cosas que hago". Em seguida, na petitio, após dizer-se indigno de tal empresa, explicita seu pedido: "que Vuestra Paternidad me quiera oyrme lo mas presto que fuere possible". Já na conclusio, antes de se despedir formalmente, relata um sonho que teve quando ainda era secular: "me parecia que me enbiaron a las Indias a predicar, y a los que no se querian convertir a nuestra Santa fe, yo con mi propia mano les dava la muerte"; segue-se a valedictio, a referência ao local e à data, e a assinatura.

Na carta de Gabriel Mayo ${ }^{45}$, escrita no Colégio de Caller, no dia 10 de março de 1604, o autor escreve, logo na captatio benevolentiae, que durante mais de um ano esteve considerando "lo que pretendia comunicar", por saber que se tratava de coisa séria. Em seguida, explica que,

\footnotetext{
${ }^{44}$ P.e Diego Torres Bollo, com a fundação da Província do Paraguai, em 09 de fevereiro de 1604, foi escolhido pelo então Prepósito Geral, P.e Claudio Aquaviva, como seu primeiro Padre Provincial, permanecendo no cargo até 1615. Não conseguimos outros dados além desses. Cf. Rondon, Víctor (1997). Música jesuita en Chile en los siglos XVII y XVIII: primera aproximación. Revista musical chilena [online], 188(51), 7-39, jul/1997. Retirado no dia 13/06/2003, do World Wide Web: http://www.scielo.cl/scielo.php?script=sci_arttext\&pid=S0716$27901997018800001 \& \operatorname{lng}=$ es\&nrm=iso.

${ }^{45}$ ARSI, Indipetae Hispanae, FG 758, carta n. 379, de Gabriel Mayo, Caller, 10/03/1604.
} 
nesses casos, é muito importante discernir bem os espíritos; e diz que pretende ser breve e sincero, "por no ser fastidioso a Vuestra Paternidad". Ainda aqui, relata, com poucas palavras, o trabalho de discernimento que fez: diz que se encomendou a Deus conforme pede a Regra da Companhia, e descobriu que Deus lhe deu "un muy encendido desseo de emplear mis fuerças sirviendo al Señor en la conversion de las almas de Japon”. Só então, na narratio, diz que sente desejo de salvar também as almas de outras pessoas de quaisquer outras partes do mundo, declarando, nesse sentido, sua indiferença. Explica que o desejo não nasceu de suas capacidades, pois é "inhabilissimo"; mas nasce "de sola la immensa bondad de Dios, que en mi lo despierta que me tira sin yo merecello ni pretendello". Diz também que quer entregar a vida e o próprio sangue por amor de Cristo que também se entregou e derramou seu sangue. Numa quarta parte da carta, a assim chamada petitio, explicita as suas motivações para a escrita: "una de las cosas que mas me mueven a pedir esto a Vuestra Paternidad es el entender que serviendo al Señor deste modo, le agradare muchissimo y passando por obediencia a partes tan remotas en alguna manera me assemejare mas a mi dulce Jesus”. Finalmente, na conclusio, repete a suplica que fez anteriormente - "Supplico a Vuestra Paternidad que no desprecie estos mis desseos"-, se despede formalmente, acrescenta local e data, e assina a carta.

O pedido expresso por Thomas Hhaward ${ }^{46}$ em carta escrita no dia 12 de março de 1605 , em Valladolid, foi tratado antes mesmo de entrar na Companhia de Jesus com o Padre Luis de la Puente (1554-1624) ${ }^{47}$ e com o Padre Francisco Lavata ${ }^{48}$, segundo o indipetente explica na captatio benevolentiae. Também aí, o autor, a fim de conquistar mais facilmente a benevolência do padre geral, pede desculpas pelo "atrevemiento" e completa dizendo que a resposta "tendra

\footnotetext{
${ }^{46}$ ARSI, Indipetae Hispanae, FG 759, carta n. 5, de Thomas Hhavvard, Valladolid, 12/03/1605.

${ }^{47}$ P.e Luis de la Puente, importante teólogo jesuíta e escritor ascético do chamado "Século de Ouro" espanhol (XVI-XVII). Nasceu em Valladolid, em 1554, e morreu em 1624. Entre seus trabalhos se destaca "Guía Espiritual" e "Meditaciones sobre los misterios con la práctica de la oración mental", livros dedicados à prática da perfeição espiritual. P.e de la Puente pode ser considerado, juntamente com P.e Álvarez de Paz e P.e Alonso Rodríguez, um dos responsáveis pela progressiva "criação" de uma espiritualidade propriamente jesuítica. Cf. Abad, Camilo Maria (1957). Vida y escritos del V.P. Luis de la Puente de la Compañía de Jesus (1554-1624). Comillas: Universidad Pontificia.

${ }^{48}$ Quanto a este padre, não encontramos referências.
} 
conmigo la condicion del manà". É interessante notar também que nesta parte, ele procura fazer referência a outros jesuítas que, seguramente, são personalidades importantes na Companhia e, portanto, bons intercessores. Na narratio, ele ter basicamente três desejos: 1) "desseo derramar mi sangre por la fee", 2) "desseo la conversion de mis parrientes y deudos", que, segundo ele, são "caze todos [...] sismatticos" e 3) "desseo de tener una muerte buena y segura". Explica também aí que, antes de entrar, o Padre John Blacfan ${ }^{49}$ (Blackfan?) prometeu levá-lo para a Província da Inglaterra, mas que, no entanto, era preciso que permanecesse em Valladolid, por seis meses, até que se decidisse seu envio. Segundo Hhaward, a proposta de que permanecesse partiu dos padres Luis de la Puente, Francisco Lavata e Joseph Creswello ${ }^{50}$ (Creswell). No entanto, se queixa que já se passaram “quasi 3 años y no me imbian y muchas vezes yo lo ha pedido del Padre Creswello y el me responde que no conviene porque yo no soy sacerdote". Termina esta parte dizendo: "entonces me dixeron una cosa y agora otra". A petitio breve apenas reafirma a expectativa de uma resposta do padre geral: "qualquira cosa que Vuestra Paternidad respondiere para mi sera grande consuello”. Sua conclusio apenas faz referência a local e data, além da assinatura precedida da usual fórmula de filiação ${ }^{51}$.

Alonso Cortes $^{52}$ - 21 anos de idade e, então, há 7 anos na Companhia -, de Salamanca, escreve no dia 24 de outubro de 1606 sua carta dizendo, já na captatio benevolentiae, que "el deseo de corresponder a los deseos y inspiraciones que yo no dudo ser de Dios Nuestro Señor, me fuerza a manifestarlos a Vuestra Paternidad para que sabiendolos Vuestra Paternidad este yo

\footnotetext{
${ }^{49}$ Não encontramos referências a P.e John Blacfan (nem mesmo Blackfan).

${ }^{50}$ P.e Joseph Creswell (1577-1623), juntou-se à Companhia de Jesus em 11 de outubro de 1583, tendo estudado em Reims e no Colégio de Roma. Foi reitor do Colégio Inglês, entre 1589 e 1592, em Roma. Homem de caráter difícil, foi muito criticado pela controversa intervenção em Sevilha e Valladolid com relação às vocações beneditinas. Em 1614 foi enviado para a Bélgica e em 1621 eleito reitor do Colégio de Ghent. Escreveu várias e importantes obras de espiritualidade e hagiografia. Cf. Loomie, A. J. (1994). Fr Joseph Creswell's Informacion for Philip II and the Archduke Ernest ca August 1594. Recusant History, 22(1994), 465-481.

${ }^{51}$ Apesar de o autor ser claramente um inglês - e não um "jesuíta espanhol" - consideramos esta Indipeta como parte do nosso corpus, porque além de estar escrita em espanhol, é enviada de um colégio espanhol. Há um aspecto a mais que nos interessa nesta carta: o fato de o pedido de envio para a Inglaterra ser movido não só pelo desejo de martírio, mas também pelo relacionamento anterior com o P.e John Blackfan e pelo envolvimento direto de seu desejo com a família cismática. Nesse sentido, a presente carta representa algumas das importantes questões que estavam em jogo no processo de "discernimento dos espíritos" a que eram educados os jesuítas, no momento da eleição.

${ }^{52}$ ARSI, Indipetae Hispanae, FG 759, carta n. 13, de Alonso Cortes, Valladolid, 24/10/1606.
} 
contento con lo que de mi ordenare". Afirma também que fez tudo o que devia ter sido feito para cumprir com o trabalho de discernimento dos espíritos, de reconhecimento das razões. Diz então, na narratio, que quer ser enviado para o Japão, mesmo que se saiba indigno e insuficiente "de tan alta empresa", confiando "en la divina bondad suplira em mi lo mucho que de virtud y letras para ella me falta". A petitio que escreve é bastante interessante: o autor, não manifesta explicitamente seu pedido, mas apenas se diz disponível para aquilo que o padre geral decidir; dizendo, ao final desta parte, que o padre procurador de Portugal fará, de voz, o pedido formal " $\mathrm{y}$ facilitara la difficultad que puede aver". A conclusio é marcada pela expressão de sua confiança no discernimento do padre geral; há uma valedictio - que "Dios Nuestro Señor [se digne] gardarnos [Vuestra Paternidad] por muchos años"-, referência a local e data, e assinatura.

De Granada, no dia 13 de outubro de 1607, escreve o jovem irmão coadjutor, de 24 anos, Francisco Gonzales ${ }^{53}$. A carta sem captatio benevolentiae ${ }^{54}$, começa com a narrativa da história de seu desejo e a manifestação de sua indiferença, além de descrever o trabalho de discernimento dos espíritos ("he hecho los votos y he encomendado este negocio muy deveras a Dios"). Em seguida, na petitio, pede ao Padre Geral "haga caridad de concederme que yo vaya alas indias, porque entiendo según es el fervor que siento quando pienso em esso que Nuestro Señor se quiere servir de mi enllas indias y el deseo de servirle me mueve a pedirlo con grande instancia", sem nem mesmo se preocupar com as dificuldades que se podem oferecer. A conclusio, por sua vez, traz uma breve descrição de sua situação no momento da escrita e de suas capacidades. Há também a afirmação da confiança na boa decisão do padre geral, uma valedictio, referência a local e data, e assinatura.

\footnotetext{
${ }^{53}$ ARSI, Indipetae Hispanae, FG 759, carta n. 24/2, de Francisco Gonzales, Granada, 13/10/1607.

${ }^{54}$ Cf. nota 34 supra. Acrescentamos apenas uma observação: se alguma parte da carta está ausente, ou se trata de inaptidão no uso das regras, ou dificilmente seria um erro ou esquecimento, já que se trata de um padrão, de uma regra. A falta de partes nas Indipetae será interpretada (a não ser em caso de evidente inaptidão) e associada a alguma pragmática particular. Neste caso, como no caso anterior, da carta 200 (FG 758), entendemos por "pragmática particular" a hipótese de que os autores, na verdade, apenas cumpriam a regra da petição por escrito, estando ambos já designados para as missões solicitadas por eles, ou a eles indicadas pelos padres procuradores a que fazem referência em suas cartas. Repetimos: esta hipótese, para ser verificada, deverá ser confrontada com os dados fornecidos pelos Catálogos da Companhia de Jesus.
} 
Aos 29 dias de janeiro do ano de 1608, em Caller, Cosme Hatter ${ }^{55}$ escreve pedindo genericamente as Índias, onde gostaria de "dar la vida, ý derramar la sangre de mis venas en servicio de Nuestro buen Jesus", conforme explicita na captatio benevolentiae. Em seguida, na narratio, o indipetente diz que se motivou a escrever porque ouviu "unas nuevas de Indias" e soube de "un aviso que por orden de Vuestra Paternidad se ha dado en general que todos los que piden ýr a las Indias esten con buen animo, ý se pongam a punto por que Vuestra Paternidad en esta sazon los consolarà". Explica que só isso já foi suficiente para que o desejo se incendesse ainda mais. Na petitio, então, o autor explica que se encomendou a Deus e considerou cuidadosamente o desejo para "bien dar dello razon a Vuestra Paternidad", demonstrando assim seu trabalho de discernimento dos espíritos, antes de suplicar "humildissimamente ý con toda resignacion, que Vuestra Paternidad siempre que iusgare ser assi conveniente a maýor gloria divina, ý provecho de mi Alma, me conceda esto que pido". Na conclusio, retoma as causas para persuadir ao padre geral e as tira do trabalho de discernimento feito; descreve a si mesmo e suas atividades partindo da tópica do desejo: diz que, às vezes, o desejo é tão forte que já chegou a desmaiar, ao considerar sua juventude, suas tão poucas letras e virtudes e por mesmo assim “entender que el Señor me llama”. Propõe-se também de não abandonar os estudos de todas as virtudes e, para isso, já na valedictio, se encomenda às orações e aos sacrifícios do prepósito geral; finalmente, diz de onde escreve, quando escreve e assina a carta.

Hernando dela Torre ${ }^{56}$, escrevendo em Zaragoza, no dia 29 de agosto de 1609, começa explicando, na captatio benevolentiae, que anda experimentando "una cosa que hasta aquí no avia podido alcançar": a alegria de se dar conta do fato de que um religioso tenha superiores que regem a vida de todos e a endereçam para o que é "mayor provecho suyo y gloria de su divina magestad". Aproveitando esse fato mesmo, Hernando, após ter facilitado com este argumento a benevolência do padre geral, quer manifestar na carta

\footnotetext{
${ }_{55}$ ARSI, Indipetae Hispanae, FG 759, carta n. 49, de Cosme Hatter, Caller, 29/01/1608.

${ }^{56}$ ARSI, Indipetae Hispanae, FG 759, carta n. 58/1, de Hernando de la Torre, Zaragoza, 29/08/1609.
} 
"parte delos desseos que Nuestro Señor me da, para que jusgando Vuestra Paternidad que son tales los endereçe y guia aquello que sea de serbiçio de Nuestro Señor”. Em seguida, na narratio, conta a história da origem do seu desejo de ser enviado às Índias Orientais, mais especificamente ao Japão ou Etiópia, além de apresentar os resultados do trabalho de discernimento a que se dedicou: quer ser enviado porque entrou "en la Compañia no solo para me aprobechar a mi sino tambien a otros"; também porque em terra de missões os religiosos costumam ser mais "desapegados y desavidos de todas las cosas temporales para estar mas dependentes de Dios", o que lhe parece mais difícil "que aquí"; e finalmente porque quer imitar "Nuestro Padre Francisco Jabier", que abriu a porta "para que entrase em aquella ciega gentilidad la luz del Santo Evangelio”. Em seguida, escreve uma curta petitio, onde, na verdade, solicita ao padre geral apenas que verifique "si mi vocaçion es de Dios". Na última parte da carta - a conclusio -, descreve sua situação pessoal na Companhia de Jesus; escreve a valedictio usual, refere lugar de escrita, data, e assina.

As três seguintes cartas foram todas escritas pelo mesmo jesuíta - Juan Bravo - em datas, no entanto, diferentes: a primeira escrita, em Caller, no dia 20 de janeiro de $1603^{57}$; a segunda escrita, em Sacer, no dia 29 de julho de $1604^{58}$; e a terceira escrita também em Sacer, no dia 05 de março de $1605^{59}$.

Do ponto de vista da estruturação retórica, as cartas oferecem elementos bastante interessantes: enquanto a primeira, mais extensa que as demais, está muito bem dividida, contando com as cinco partes tradicionais; a segunda e a terceira são marcadas seja por uma atenção excessiva à captação da benevolência do padre geral (como é o caso mais evidente da segunda; mas também presente na terceira), seja por um cuidado cada vez maior à humildade

\footnotetext{
${ }^{57}$ ARSI, Indipetae Hispanae, FG 758, carta n. 329, de Juan Bravo, Caller, 20/01/1603.

${ }^{58}$ ARSI, Indipetae Hispanae, FG 758, carta n. 404, de Juan Bravo, Sacer, 29/07/1604.

${ }^{59}$ ARSI, Indipetae Hispanae, FG 759, carta n. 4, de Juan Bravo, Sacer, 05/03/1605.
} 
da petição (como é o caso da terceira ${ }^{60}$. Além do fato de esta estrutura formal ser conhecida dos jesuítas e mesmo estudada e aplicada rigorosamente, um fator a se considerar aqui é a presença de argumentos e vocabulário bastante eruditos na estrutura dos três textos, o que nos leva a pensar que, seguramente, o indipetente só "descuida" da forma propositadamente.

Outro aspecto a que se ater: é notável como, na primeira carta, o autor praticamente não faz uso de abreviações, recorrendo apenas à usual abreviação de "Vuestra Paternidad" e a algumas outras também não pouco incomuns; no entanto, nas seguintes, o uso de abreviações aumenta progressivamente.

É interessante notar também a maneira como o autor utiliza a argumentação nos três momentos, distintamente. Na primeira carta, por exemplo, o indipetente, após a captatio benevolentiae separada do restante da carta, declara, já na narratio, seu “encendido deseo de emplear mys pocas fuerças en ayuda de la Gentilidad de Japon", mas não deixa de declarar também que "siento indifferencia grande para lo que es yr, o quedar sin perder por esto un punto el fervor y desseo de servile aca en Europa, antes creçiendo mas". Nessa mesma carta, explica que achou que era um disparate tal desejo porque não via em si virtudes para tão grande empresa, no entanto considerou que "siempre Dios en empresas grandes se sierve de instrumentos viles dando su Magestad todo lo que es menester para que alcançe lo que con ellos pretende". Só não tinha certeza de que era vontade de Deus e, para sabê-lo, ajudou-se de orações e de reflexões acerca de si mesmo. Somente depois de alguns meses, se resolveu por escrever ao Padre Geral. Sente que são de Deus os desejos porque, desde que os tem, suas imperfeições têm desaparecido; além do mais, sabe que só está na

\footnotetext{
${ }^{60}$ É preciso lembrar que muitos preceptistas acreditavam que a captatio era realmente a parte mais importante da carta. Sabe-se também que, em geral, ela se articula com a petitio. O que, talvez, explique essa pragmática particular adotada por Juan Bravo nas suas cartas. Apenas para esclarecimento: preceptistas eram os teóricos neo-classicistas que recuperaram o modelo clássico de Aristóteles quanto ao que respeita à retórica especialmente, impondo uma estética normatizada conforme a teoria aristotélica. Cf. Pécora, 2001, op. cit.
} 
Companhia de Jesus por chamado de Deus. Termina dizendo que está firme no desejo “como peña dura entre las olas del mar", o que para ele é confirmação de que "rayz de donde brotan tales ramas [no] puede ser o malas, o antonjadiza". Faz uma petitio breve: “supplico a Vuestra Paternidad que mirando este negocio con ojos de Padre disponga de my segun juzgare ser mas conveniente para la gloria del Señor y bien de my alma". Na seqüência, declara que, enquanto espera uma resposta do padre geral, fará mortificação, “porque me da a entender Nuestro Señor que ella es una de las mayores alas con que puede un verdadero hijo dela Compañia atravesar el imenso occeano, y andar seguro entre los mayores trabajos que en la Gentilidad se offreçen"; e segue com a valedictio, o local, a data e assinatura. Na segunda carta, por sua vez - que mais parece ser uma longa captatio benevolentiae -, o autor argumenta que só escreve de novo porque os desejos, após um ano, continuam fortes e vigorosos e sente que precisava "renovar a Vuestra Paternidad la memoria" desses seus desejos de empregar-se "en la empresa que nuestra Compañia ha emprendido en los reynos del Japon”. Segundo ele, a misericórdia de Deus com ele - que só merece "muchos açotes y castigos" - é motivo suficiente para que se sinta obrigado a "no desistir de hazer lo que con esta hago, y supplicar instantemente a Vuestra Paternidad se dignasse hechar los ojos a lo que embado del Señor (segun pienso) le llego a pedir". Justifica-se argumentando que é muito difícil explicar em poucas linhas o que o homem sente e o que Deus dá a conhecer aos poucos, por isso sua impaciência e sua vontade de poder falar sobre isso pessoalmente. E termina - no que parece ser uma petitio - dizendo que ainda se encontra com "sufficiente indiferençia" para "o, en Japon, o en Europa procurar ser hijo de nuestra Sancta Compañia", suplicando do padre geral the alcance esse desejo de ser filho verdadeiro. Sua conclusio apenas refere local e data, além da assinatura. A terceira carta - muito concisa e direta - é um novo "refresco" para a memória do padre geral dos seus "deseos, de yr a las Yslas del Japon para derramar en ellas el sudor y la 
sangre si pudiese por el buen Jesus". Nesta carta, que, como a segunda, também não tem as partes muito distintas - mais parecendo uma grande petitio -, diz também que espera que o superior saiba "sacar a luz" o desejo que tem para que seja empregado "con mucho animo, y resignaçion, y con senzilla voluntad, y deseo de acertar a agradar a my Dios, y offrecermele en sacrificio y verdadero holocausto". E, contrariamente ao que estava presente nas demais cartas, nesta última, Juan já nada comenta acerca de sua indiferença. A conclusio é marcada pela expectativa de que o padre geral lhe alcance a graça suplicada ao longo dos três últimos anos, afirmando, logo de início, que ele espera que Deus "pague a Vuestra Paternidad como yo se lo supplico, con eternos dones los dichosos trabajos que por sus hijos toma, y en particular el que por este indigno tomare, en endereçar sus deseos para mayor gloria del que se los dio". Impressiona esse trecho pelo uso do argumento em favor pessoal: que Deus lhe pague tudo que fez por todos, mas especialmente aquilo que pode fazer por ele no sentido de permitir que a glória de Deus se cumpra através de sua vida, através da vida de alguém a quem Deus deu um desejo tão particular. Termina a conclusio, referindo local e data, e assinando a carta.

Infelizmente, não sabemos se existem outras cartas de Juan Bravo, porém, julgamos que existem nessas cartas elementos suficientes para uma primeira análise do ponto de vista da evolução do desejo num âmbito mais reduzido, como o é o de um indipetente tomado individualmente.

O que até aqui fizemos foi uma apresentação e simples descrição canônica do corpus documental com o qual trabalhamos. Nos capítulos que se seguirão será oferecida uma análise detalhada de alguns aspectos implícitos ao conteúdo desse material, a partir de critérios oferecidos pelo contexto institucional de produção desses documentos. 


\section{SEGUNDA PARTE}

AS INDIPETAE: "LBERDADE” E “EXPERIÊNCIA" 


\section{CAPÍTULO 4 Premissa e pólos de análise}

\section{1) Premissa}

É preciso dizer que estes documentos que descrevemos nos capítulos anteriores podem ser olhados segundo múltiplas perspectivas. No nosso caso, entretanto, o focus de análise das Litterae Indipetae é a "experiência".

Tomadas como lugar da expressão de uma "experiência", a correspondência epistolar produzida no âmbito da Companhia de Jesus, nos séculos XVI e XVII, especialmente as Indipetae, se tornam, como vimos, fonte significativa para o estudo que estamos empreendendo.

Para dar continuidade, é preciso que o termo "experiência" seja descrito dentro da gramática de uso a que vimos nos referindo desde o princípio. Sobretudo em se sabendo que, nos capítulos que se seguirão, premissa importante a se considerar é a que respeita ao lugar desta categoria nas análises feitas, e sobretudo no ambiente histórico, cultural e institucional com o qual trabalhamos. 
A julgar simplesmente pelo uso repetido da palavra já desde séculos anteriores - como se vê, por exemplo, no trecho extraído de um hino composto por São Bernardo de Claraval, no século XIII -, a experientia já passa a ser fator de interesse bastante significativo.

\section{Jesu, dulcis memoria / Dans vera cordis gaudia \\ Sed super mel et omnia / Eius dulcis presentia. (...) \\ Nec lingua valet dicere / Nec littera exprimere \\ Expertus potest credere / Quid sit Jesum diligere ${ }^{1}$}

Se se pensa, então, a discussão que começa a tomar corpo nos séculos XVI e XVII experientia $\mathrm{x}$ experimentum ${ }^{2}$-, vê-se configurado um cenário cada vez mais significativo. Considerar, finalmente, essa mesma categoria no contexto institucional específico com o qual trabalhamos - a Companhia de Jesus -, onde a experiência é fator de conhecimento, fator de relacionamento com Deus e mesmo fator de unidade com o corpo institucional, se nos apresenta como premissa de trabalho importante. Vejamos passo a passo.

A fim de bem distinguir o uso que se fazia dessa categoria no período estudado e no ambiente considerado, do uso que se faz hodiernamente nos mais variados âmbitos, propomos uma brevíssima e apenas inicial descrição do conceito ${ }^{3}$.

Tal como é empregado entre os jesuítas, o termo "experiência" deve ser entendido a partir de um complexo feixe de influências: além da assumida posição filosófica aristotélicotomista, é preciso dizer que parece existir também uma influência agostiniana. E, para além do aspecto puramente filosófico, quando se fala de "experiência" na Companhia de Jesus, se está tratando com uma categoria que também pertence ao universo da regulação tanto espiritual quanto jurídica. Assim, para bem compreender o termo, será preciso um trabalho mais delicado, que será desenvolvido em capítulo posterior.

Dizer que expertus potest credere, como o diz São Bernardo para declarar que o conhecimento do amor de Jesus não se dá através de lingua ou littera; ou dizer que

\footnotetext{
${ }^{1}$ O livro das horas (1998). São Paulo: Companhia Ilimitada, p. 248 (grifo nosso).

${ }^{2}$ Mais à frente se esclarecerá bem esta querela.

${ }^{3} \mathrm{O}$ capítulo 6 será dedicado a um aprofundamento da questão.
} 
experientia docet, como repete algumas vezes o Doutor Angélico; ou ainda probatur autem eius veritas tum ipsa experientia, como aparece não poucas vezes na obra de Manuel de Góis (1593) que iremos apresentar mais à frente; enfim, dizer experientia nesse âmbito histórico-cultural e institucionalmente bem definido pode ser bem compreendido ao ler o que o padre jesuíta Alexandre de Gusmão (nascido em Lisboa em 14/8/1629 e falecido em Belém da Cachoeira, na Bahia, em 15/3/1724) escreveu no prólogo de sua obra Eleyçam entre o bem e o mal eterno:

Se fosse consideravel hum homem tão simples ou tão ignorante, que duvidasse, se o fogo queymava, y a agua esfriava, este tal, com nenhuma outra razão se poderia desenganar melhor, que com a experiência, pondo huma mão no fogo e outra na agua. Logo se desenganaria, e veria por experiência, que o fogo queymava e a agua esfriava.

Pois has de saber, que deste homens ha muytos neste mundo, e sempre os houve. Não fallo dos Atheistas, os Epicureos, que da outra vida nada curão; fallo dos christãos, que sabendo, e confessando que ha Ceo para bons e Inferno para maos, vivem como se ignorassem, que o fogo do Inferno queymava e a agua do Ceo refugiava. Estes tais, de ordinario se não desenganam nesta vida, até que na outra fazem a experiencia, que o Santo Job diz se costuma fazer no Inferno, que he passar da agua de neve para o calor do fogo. Então com seu mal eterno experimentão, quanto queyma aquelle fogo, e quanto esfria aquella agua. O que importa logo, he fazer nesta vida a experiência que o Espírito Santo nos manda fazer, pelo Ecclesiastico... ${ }^{4}$

Experientia é pois modo de conhecer, que não se dá simplesmente per modum cogitandi ou somente per modum operandi. A experiência, assim dada a entender, deve ser compreendida como o conhecimento que se adquire após o operari e todas as potências de alma aí envolvidas, e o precedente (e/ou consecutivo) cogitare com suas devidas implicações anímicas. Sabendo-se que o "agir" do homem (conforme essa antropologia filosófica específica sobre a qual nos debruçamos) - seu operar, seu proceder - só se dá na medida em que seja "para conseguir a coisa desejada intencionada", vê-se uma importante diferença para o que se possa descrever como "ação" contemporaneamente: não se trata do simples movimento verificado apenas

\footnotetext{
${ }^{4}$ Gusmão, Alexandre (1720). Eleyçam entre o Bem e o Mal Eterno, Lisboa: Officina da Musica, prólogo, s/p.

${ }^{5}$ Aquino, Tomás de (1947). Suma Teológica, I Parte, Questões 75-83: Do homem considerado na sua alma (A. Correa, trad.). São Paulo: Gráfica Siqueira, p. 166 (q. LXXVIII, a. I).
} 
externamente - um "comportamento" -, mas da conjugação de uma série longa de fatores, tais como a intencionalidade, que só é colocada em jogo se se considera a vontade e o intelecto, os apetites e as faculdades da alma sensitiva (tanto externas quanto internas). Sabendo-se também que o "cogitar" humano - seu modo de pensar, de inteligir - envolve toda uma gama de faculdades anímicas influenciando umas nas outras... percebe-se que a visão de homem aqui envolvida, quando se fala de experientia é digamos assim uma visão totalizante: não há solução de continuidade entre uma e outra operação, trata-se de um contínuo, onde per experientia implica o conhecimento obtido pelo homem total - todos os seus cinco gêneros de potências da alma, suas três almas distintas e seus quatro modos de viver diferentes, e suas devidas implicações ${ }^{6}$.

\section{2) O corpus documental}

Antes de avançarmos na análise das Litterae Indipetae - nosso ativo histórico principal -, importa elencar e descrever as fontes secundárias que nos forneceram os critérios de base a partir dos quais demos seqüência ao trabalho.

A fim de melhor sistematizar essas fontes e visualizar e organizar os diferentes dados que cada uma delas poderia nos fornecer, elas foram divididas, inicialmente, em três grupos que nos permitiram identificar mais claramente os diferentes critérios fornecidos por cada fonte: 1) aqueles documentos do universo filosófico de formação dos jesuítas, que nos forneceram dados da formação do ponto de vista da filosofia moral e da retórica seiscentista no âmbito da Companhia de Jesus; 2) as fontes referentes à ordenação e formação da vida espiritual nesta

\footnotetext{
${ }^{6}$ Tomás de Aquino é quem assim divide: cinco categorias de potências (vegetativas, sensitivas, apetitivas, motora e intelectivas), três almas (vegetativa, sensitiva e racional) e quatro modos de viver (vegetativo, sensitivo, motivo e intelectivo). Cf. Ibid., pp. 159-194 (q. LXXVIII). E ele diz ainda: "ao teólogo pertence indagar, especialmente, só das potências intelectivas e apetitivas, susceptíveis de virtude. Mas, como o conhecimento dessas potências depende de certo modo das outras, por isso a nossa consideração sobre as potências da alma, em especial, será tripartida. Pois, primeiro, devem-se considerar cousas que servem de preâmbulo ao intelecto. Segundo, as potências intelectivas. Terceiro, as potências apetitivas" (pp. 159-160).
} 
ordem religiosa, que nos indicaram os critérios especificamente vinculados à normatização da vida de espiritualidade; e 3) os documentos descritivos da ordenação e formação da vida institucional, cujos critérios jurídicos eram os que mais interessavam. A cada um desses grupos corresponde um dado do modus vivendi dos jesuítas, e cada um deles foi, respectivamente, designado de scholicorum, ratio spiritualis e ratio institutorum ${ }^{7}$.

No primeiro grupo estão localizados os Manuais do Curso Conimbricense, mas no caso da nossa pesquisa ocupamo-nos especial e unicamente o Comentário à Ética a Nicômaco de Aristóteles, escrito pelo padre Manuel de Góis, e publicado em 1593; além de textos clássicos da formação em retórica a que tinham acesso os jesuítas estudados (basicamente os textos de Cícero e a análise realizada por Zanlonghi, 2003). Ao segundo grupo pertencem o texto dos Exercícios Espirituais (utilizamos o texto dos Exercícios nas suas três versões - o texto Autógrafo, de perto dos anos de 1544; o Versio Prima, escrito em latim, de cerca de 1530; e a Vulgata, de cerca de 1547 - em versão sinóptica, comentado por Claude Viard ${ }^{8}$ ), o Diário de Moções Interiores $^{9}$ (escrito por Inácio entre 1544 e 1545 , e publicado apenas em 1934) e o Relato $^{10}$ de Inácio (ditado por Inácio ao Padre Luiz Gonçalves da Câmara entre os anos de 1553 e 1555). E, finalmente, foram agrupadas ao terceiro conjunto de fontes as Constituições ${ }^{11}$ (utilizamos a versão francesa, traduzida do texto de 1556, acrescentada do Exame Geral - um preâmbulo das Constituições - e das Declarações -

\footnotetext{
${ }^{7}$ Apesar da divisão aparentemente estanque entre estes aspectos, ficou-nos claro que há um dinamismo de influência que quase confunde esses pólos compreensivos. A pergunta que pode ser feita aqui e que será respondida nos capítulos subseqüentes é, portanto, o que confere unidade a esse dinamismo?

${ }^{8}$ Esta versão apareceu em língua francesa no ano de 1991, sob a iniciativa de um grupo de padres jesuítas Jean-Noël Aletti, Adrien Demoustier, Jean-Claude Dhôtel, Gervais Dumeige, François Évain, Édouard Gueydan, Antoine Lauras, Luc Pareydt e Claude Viard -, dirigidos pelo P.e Maurice Giuliani, sj, com a colaboração de Pierre-Antoine Fabre (da EHESS) e de Luce Giard (do CNRS). Cf. Loyola, Ignace de (1991). Écrits (M. Giuliani, dir., pres. et dir). Paris: Desclée de Brouwer/Bellarmin (Collection Christus, n. ${ }^{\circ}$ 76, Textes), pp. 35-268.

${ }^{9}$ Usaremos a expressão "de moções interiores" em substituição a "espiritual" (que consta na maior parte das traduções portuguesas da obra), conforme a tradução francesa organizada e comentada por Pierre-Antoine Fabre e Maurice Giuliani. Cf. Ibid., pp. 313-384.

${ }^{10}$ Usaremos o termo "Relato" em lugar de "Autobiografia", conformes à tradução francesa de Antoine Lauras. Cf. o texto completo com notas de Jean-Claude Dhôtel em Ibid., pp. 1011-1076.

${ }^{11}$ Cf. o texto traduzido por Édouard Gueydan e Antoine Lauras, e comentado por Pierre-Antoine Fabre em Ibid., pp. 385-618.
} 
que nada mais são que comentários ao texto das Constituições), os chamados Documentos de Fundação (utilizamos a seleção realizada por Pierre-Antoine Fabre e Maurice Giuliani, que consta dos seguintes documentos: o relatório 1539. Durante três meses. A maneira como se instituiu a Companhia, o Atestado concernente à decisão de fazer voto de obediência, o relatório Determinações da Companhia, a transcrição do Voto de Inácio, o relatório Forma e Oblação da Companhia, e o texto da Summa em versão sinóptica com os dois documentos pontificais de aprovação da Companhia de Jesus, Regimini Militantis, de 1540 e Exposcit Debitum, de $1550^{12}$ ) e algumas das $\operatorname{Cartas}^{13}$ de Inácio.

Além desses três grupos de documentos que descrevem, como já mencionamos, pólos muito precisos e fundamentos do universo peculiar aos jesuítas - seu modus operandi, por um lado, e seu modus cogitandi, por outro -, aos nossos conjuntos de fontes elencados, acrescentamos alguns textos de espiritualidade a que tinham acesso os jesuítas do período referente ao generalato do Padre Cláudio Aquaviva. Esses textos exprimem os três aspectos fundamentais que, uma vez encarnados num modus vivendi, puderam ser novamente formulados num texto escrito e tornado prescrição de um modelo descritivo legível.

Mas "prescrição de um modelo descritivo" de quê e dirigido a quem? Prescrição de um modus vivendi imitado de uma "experiência-modelo" fundante - a de Inácio -, que toma corpo no período do referido generalato e que vai se estabelecendo, paulatinamente, ao longo dos anos que se seguem: tipo de espiritualidade que começa a tomar uma forma propriamente jesuítica, inaciana. Portanto, uma prescrição dirigida aos próprios jesuítas.

\footnotetext{
${ }^{12}$ Cf. os documentos traduzidos por Maurice Giuliani e Antoine Lauras, e comentado por Pierre-Antoine Fabre em Ibid., pp. 269-312

${ }^{13}$ Usamos a seleção feita por Luce Giard em Ibid., pp. 619-1010; bem como a seleção de Cardoso, Armando (org.) (1988-93). Cartas de Santo Inácio de Loyola. Volumes 1-3. São Paulo: Ed. Loyola.
} 
Exemplos desses "modelos descritivos" particulares que ganham corpo naquele período são alguns diários espirituais produzidos na época (como o de Francisco de Borja ${ }^{14}$ e outros $^{15}$ ) e, por que não?, apesar de pertencerem a um gênero bastante diverso daquele onde podem se enquadrar tantos os diários, como os textos de espiritualidade, as cartas Indipetae que são, como se sabe, nossa fonte principal.

\section{1) O Scholicorum}

O trabalho de descrição de um período histórico dado, implica sempre a consideração dos elementos transicionais presentes nos mais diversos âmbitos de produção de cultura, de formação de mentalidade. De tal forma que, ao falar de séculos XVI e XVII e do que comumente vem designado sob o título de "humanismo" ou de "renascimento", precisamos ter claro que não estamos diante de um fenômeno histórico isolado e puro, abstraído da realidade, a priorístico e/ou compreensível de per se, ou que tem suas raízes afundadas em si mesmo. É preciso, nesse sentido, uma atenção a fatores que não são imediatamente reconhecíveis.

Pécora (1994), por exemplo, ao definir o "humanismo" cristão do padre jesuíta e conhecido pregador Antônio Vieira, diz que, no caso dele, este "humanismo" - que não é usado por Pécora no sentido "técnico" com que é ordinariamente utilizado - é marcado por uma "concepção segura do alto sentido da Criatura Humana, na inteireza cristã do termo"16, e acrescenta que se trata de uma visão de homem que o considera como

um homem mergulhado em vícios e imperfeições, mas capaz de arrancar do fundo de sua natureza a vontade inabalável de um Bem que essa vontade torna possível; capaz, igualmente, de encontrar a razão que

\footnotetext{
${ }^{14}$ Um importante trabalho de análise e comentário do diário de Borja, pode ser encontrado na obra Borja, San Francisco de (1997). Diario Espiritual (1564-1570) (M. R. Jurado, ed.). Bilbao: Ediciones Mensajero/Sal Terrae (original publicado em 1578).

${ }^{15}$ A se julgar pelas indicações oferecidas pelo Diretório dos Exercícios Espirituais: nas "notas transmitidas oralmente", $\S 8$ da II parte, diz-se que "se pode aconselhar àquele que se exercita de anotar por escrito seus pensamentos e suas moções" (Loyola, 1991, op. cit., p. 265, tradução nossa), obedecendo à tradição iniciada por Inácio e certamente conhecida através do seu Relato.

${ }^{16}$ Pécora, Alcir (1994). Teatro do Sacramento. São Paulo: EDUSP, p. 72.
} 
descobre nessas imperfeições as marcas indestrutíveis que as podem reverter e saltar ${ }^{17}$.

Estamos falando de "valorização do humano" e "antropocentrismo", como usualmente se designa este período do XVI-XVII europeu ${ }^{18}$; no entanto, se falamos da Companhia de Jesus, estas mesmas características devem ser compreendidas com um “a mais”: essa apologia do humano preserva algo do sentido cristão.

O solo sobre o qual se ergue essa "concepção segura" é aquele aristotelismo de "tendência escolástica"19 que teve seus principais representantes entre os pensadores da Península Ibérica, sobretudo da Espanha: assim se designa a retomada da predominância da via antiqua do Tomismo no pensamento da Igreja, levada a cabo durante os anos da Reforma Católica, inclusive por pensadores da Companhia de Jesus ${ }^{20}$; sendo o próprio

${ }^{17}$ Ibid., p. 73.

18 O "humanismo" tout court mais conhecido é aquele que ordinariamente denominamos florentino. É bem verdade, que, geograficamente falando, o "humanismo" se caracteriza pela diversidade de centros e focos culturais europeus. Entretanto, o primeiro "humanismo", historicamente falando, é o italiano. E Florencia pode não só ser entendida como o berço do "humanismo", como também do "renascimento". Os florentinos do século XV sabiam que os studia humanitatis - a gramática, a poesia, a eloqüência, a pintura, a escultura, a arquitetura - renasciam ali graças a Dante, Petrarca e Giotto, basicamente. No entanto, a figura dominante de Florencia desta "renovação clássica" foi Coluccio Salutati. Graças a ele, o movimento "humanista" deixaria de ser exclusivamente erudito e literário. Para Salutati, os studia humanitatis, isto é, o conhecimento da história, da ética e da retórica, poderiam ser utilizados também com fins políticos, como um serviço civil permanente para a cidade. Herdeiro intelectual de Petrarca, Salutati foi mestre de uma geração de florentinos. Pode-se resumir o que comumente se chama "humanismo cívico florentino" assim: gosto pelo cultivo do latim, paixão pela arte antiga, amor pela liberdade, adaptação dos métodos da crítica de textos para a análise de fontes históricas, busca da verdade no mister historiográfico. Entre os studia humanitatis dever-se-ia prestar uma atenção especial à filosofia moral; além de ser igualmente necessária uma combinação harmoniosa da vida ativa com a vida de estudo. Além do mais, o "humanista", como guia moral e intelectual, conhecedor dos studia humanitatis e dos ideais éticos que estes inspiravam, tinham a obrigação de perseguir a felicidade dos homens, dos cidadãos, através do trabalho político. Com a progressiva concentração de poder nas mãos da família Medicis, os "humanistas" florentinos começaram a valorizar mais a vida contemplativa que a ativa, como resposta à decadência das instituições republicanas. Neste período também, vê-se ressurgir a filosofia platônica, através das obras de Marsilio Ficino. Cf. a este respeito, além da obra de Pécora, obras tais como a de Kristeller, Paul Oskar (1995). Tradição clássica e pensamento do Renascimento. Lisboa: Edições 70; Mayeur, Jean-Marie et col. (dir.s) (1994). Histoire du Christianisme: des origines à nos jours. Tome VII - De la Réforme à la Réformation (1450-1530). Sèvres: Desclée; Morse, Richard M. (1988). O espelho de Próspero: cultura e idéias nas Américas. São Paulo: Companhia das Letras.

${ }^{19}$ Estamos falando dos fundamentos lançados pela Segunda Escolástica

${ }^{20}$ No texto autógrafo dos Exercícios Espirituais há, por exemplo, uma regra (EE. 363) que diz: "Louvar a doutrina positiva e escolástica. É, com efeito, mais próprio dos doutores positivos, como São Jerônimo, Santo Agostinho, São Gregório etc., mover os sentimentos para amar e servir em tudo a Deus nosso Senhor, e é mais próprio dos escolásticos, por exemplo Santo Tomás, São Boaventura, e o Mestre das Sentenças etc., definir e explicar para nossa época as coisas necessárias à salvação eterna, e refutar e explicar melhor todos os erros e todos os sofismas. Com efeito, como os doutores escolásticos são mais modernos, não somente aproveitam a verdadeira inteligência da Santa Escritura e dos santos doutores positivos, mas ainda, sendo eles iluminados e esclarecidos pela graça divina, encontram uma ajuda nos concílios, cânones e constituições da nossa santa Mãe a Igreja”. Loyola, 1991, op. cit., p. 250, tradução e grifos nossos. 
Inácio - "le champion de 1'homme"21 - um importante representante:

Revela-se aí, como característica desse humanismo, a perspectiva inaciana fundamental de que a salvação não apenas não pode ser entendida como exclusivamente decorrente da Graça de Deus, como, além disso, não o poderia como constituindo um privilégio da devoção especial de santos, contemplativos e mártires, dotados, portanto, de potencialidades extraordinárias. A visio Dei na devotio moderna pretendida por Inácio não era absolutamente reservada aos inspirados, ao contrário, estava ao alcance de todos os que se dispusessem a praticar determinados exercícios da alma que, uma vez bem conduzidos e realizados, segundo um acompanhamento rigoroso a que não faltariam gráficos dos mais prosaicos, levariam certamente a ela. Mas ainda é preciso compreender que esses exercícios não visam encerrar-se ensaisticamente, como mero aperfeiçoamento de representações dramáticas mentais: eles terão necessariamente de prolongar-se em uma ação afirmativa no mundo dos acontecimentos, este sim uma forma eficaz de busca da perfeição cristão. Diferentemente da mística tradicional, para Inácio, o homem não precisaria, e nem mesmo deveria, renunciar a ser causa e agente no mundo criado para participar com êxito da economia da salvação; dessa sua atividade, aliás, dependeria a reforma cristã do mundo, este espaço humano irredutível, como irredutíveis são os sentidos externos do homem. Só o homem completo, sem renunciar a quaisquer de seus dotes, intelectuais, sensíveis e ativos, poderia esperar encontrar o caminho para aquele que o criou nessa inteireza ${ }^{22}$.

Trata-se, portanto, neste caso peculiar, de um humanismo "aristotélico-tomista e inaciano", que compreende o homem como analogia de Deus, partícipe da divindade de Deus, como efeito da Causa Primeira. Assim, até mesmo aquele "amor pela liberdade" que caracteriza o "humanista" é, em Inácio, um aspecto relevante: a liberdade é a imagem adequada, no homem, do Ser de Deus ${ }^{23}$.

Um exemplo marcante da difusão da Segunda Escolástica - pedagógica e filosoficamente falando - é o Colégio das Artes de Coimbra ${ }^{24}$ que, em 10 de setembro de 1555,

\footnotetext{
${ }^{21}$ Dominique, Pierre (1965). La politique des jésuites. Paris: CAL.

${ }^{22}$ Pécora, 1999, op. cit., pp. 75-76.

23 Pécora (1999) lembra também que “o 'humano' qualifica-se, portanto, como o que é voluntariamente pretendido por Deus; enquanto tal, dito de outra maneira, haveria, para Antônio Vieira, uma glória que é exclusiva da humanidade: a de ser objeto de uma escolha amorosa do Ser, a que nada obriga senão o mesmo amor, e que se manifestaria de forma plena, inicialmente, na Criação ex nihilo, que a resgataria de sua condição de contingência radical, depois, na Encarnação, dando a ela a substância divina do próprio Filho, e, após a Paixão e Morte, na Consagração Eucarística, que preserva a sua presença real em meio humano" (p. 80).

${ }^{24}$ Em primeiro de março de 1290, sob o reinado de D. Dinis, é fundada em Lisboa a Universidade que hoje existe em Coimbra. Ao longo de quase trezentos anos, a sede dessa universidade portuguesa foi transferida de Lisboa para Coimbra e vice-versa por duas vezes, até que em 1537, no reinado de D. João III, transferiu-se definitivamente para Coimbra. Com essa mudança, operou-se também uma ampla reforma no sistema de ensino, fundando-se uma rede de colégios, "muitos deles ligados a ordens religiosas, que tinham funções de pensionato, assistência e ensino". Data do ano de 1548 a fundação de um dos mais importantes desses colégios, o Colégios das Artes, que funcionava como um centro de ensino preparatório para a entrada nas faculdades da Universidade de Coimbra. A partir de 1552 estabeleceu-se nesse Colégio um plano de estudo de Filosofia baseado nos textos do Corpus Aristotelicum. Cf. Torgal, Luís Reis (2001). Nota Histórica. Retirado em 09/08/2001, da Universidade de Coimbra, no World Wide Web http:// www.ci.uc.pt/ sdp/ prospecto9798/ his.historia.html; Rodrigues, Manuel Augusto (1985). Do Humanismo à Contra-Refoma em Portugal. Revista de História das Idéias., e Tavares, Severiano (1948). O Colégio das Artes e a Filosofia em Portugal. Revista Portuguesa de Filosofia, 4/3, jul/set.
} 
foi entregue às mãos dos jesuítas ${ }^{25}$. Nele, o estudo das humanidades, que já seguia o modelo da Universidade de Paris - o modus parisiensis ${ }^{26}$-, era constituído não só como "acesso à filosofia e à teologia, mas também como disciplina do espírito e cultura do homem ilustrado"27.

Em 1561, estando em visita a Portugal, o jesuíta Jerônimo de Nadal indicou ao P.e Pedro da Fonseca (1528-1599) ${ }^{28}$ a redação e publicação de um curso de filosofia que servisse de texto nos colégios da Companhia. No entanto, dadas as inúmeras incumbências de

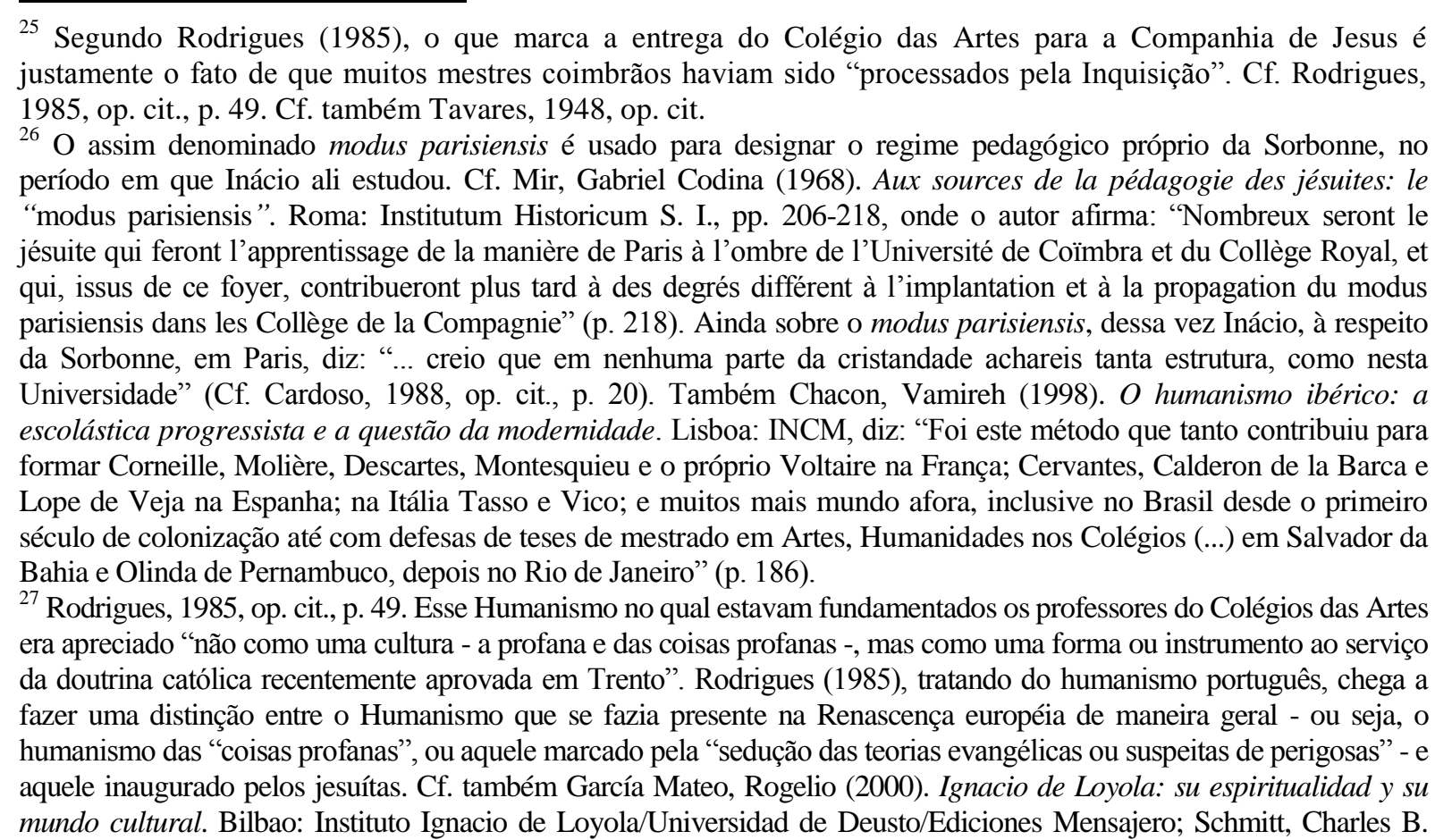
mundo cultural. Bilbao: Instituto Ignacio de Loyola/Universidad de Deusto/Edcic
(1992). Aristote et la Renaissance (L. Giard, trad.) Paris: PUF (original de 1983).

${ }^{28}$ O P.e Pedro da Fonseca, nascido em Cortizada (Portugal) e morto em Lisboa, foi um filósofo e teólogo jesuíta. Ingressou na Companhia de Jesus, em Coimbra, no ano de 1548, e em 1551 foi para a Universidade de Évora, onde, após completar seus estudos, leu filosofia brilhantemente (valendo-lhe o título de "O Aristóteles Português"). Seus principais trabalhos atravessaram os séculos como referência em filosofia: Institutionum Dialecticarum Libri Octo (Lisboa, 1564); Commentariorum em Libros Metaphysicorum Aristotelis Stagirite (Roma, 1577); Isagoge Philosophica (Lisboa, 1591). Fonseca também compartilha a fama dos Conimbricenses, dado que foi um dos professores jesuítas da Universidade de Coimbra. Ocupou vários postos importantes na Companhia de Jesus: Assistente para Portugal do Padre Geral, Padre Visitador de Portugal e Padre Superior da Casa dos Professos de Lisboa. Credita-se também a ele um importante papel na criação da Ratio studiorum. Porém, seu maior crédito e onde perdura sua reputação deve-se ao fato de ter solucionado, por meio da scientia media em Deus, o complexo problema da reconciliação entre graça e liberdade. Não obstante sua fama nesta matéria, Luis de Molina (seu discípulo) o superou, obscurecendo sua importância, tendo aperfeiçoado e desenvolvido a idéia do mestre no seu livro Concordia Liberi Arbitrii cum Gratice Donis etc., sendo gradualmente considerado como o criador da doutrina. Cf., entre outros, Rodrigues, Francisco (1938). História da Companhia de Jesus na Assistência de Portugal. Tomo II, Vol. II. Porto: Livraria Apostolado da Imprensa; Carvalho, José Vaz de (1991). Jesuítas portugueses com obras filosóficas impressas nos séculos XVI-XVII. Revista Portuguesa de Filosofia, 47. Braga: Faculdade de Filosofia, 651-659; Martins, António Manuel (1989). Verbete "Conimbricense". Enciclopédia Logos II. Lisboa, 1112-1126; Lewalter, Ernst (1998). Metafisica ispanico-gesuitica e tedesco-luterana del XVII secolo: un contributo alla storia dei rapporti culturali iberotedeschi e alla preistoria dell'idealismo tedesco. Em: Mozzarelli, Cesare (org.) (1998). Chiesa romana e cultura europea in Antico Regime. Roma: Bulzoni Editore; Tavares, 1948, op. cit. 
Fonseca, somente a partir de 1579, quando já assumira como Geral da Companhia o P.e Everardo Mercuriano ${ }^{29}$, é que efetivamente, dessa vez sob a coordenação do P.e Manuel de Góis, o curso de filosofia começava a ser pensado mais concretamente. A edição definitiva dos Comentários só começou em 1592, quando P.e Cláudio Aquaviva já assumira o Generalato da Companhia, com o primeiro volume denominado Commentarii Collegii Conimbricensis Societatis Iesu in octo libros Physicorum Aristotelis Stagiritae...

Assim, quando falamos de Conimbricenses ou de Curso Conimbricense, referimo-nos ao conjunto de textos publicados entre 1592 e 1606 com o título genérico de Comentários do Colégio Conimbricense da Companhia de Jesus. Discute-se freqüentemente a que autores se deve atribuir a responsabilidade da redação dos volumes: sabe-se que a maior parte dos títulos é de autoria do P.e Manuel de Góis; cabendo aos P.es Sebastião Couto e Baltazar Álvares a redação de dois dos seus oito volumes ${ }^{30}$. De forma que as obras do P.e Pedro da Fonseca, especialmente o Comentário à Metafísica de Aristóteles, não podem ser consideradas como parte de sua estrutura ${ }^{31}$.

Observando-se o conjunto da obra, é interessante notar que excetuando o pequeno volume

\footnotetext{
29 A Congregação Provincial de 1579 enviou um pedido ao então Prepósito Geral justificando que com a publicação "evitava-se o interminável trabalho de escrever nas escolas, notavelmente prejudicial à saúde de tantos Irmãos da Companhia, como dos alunos externos. Podia empregar-se com menos fadiga e mais utilidade em disputas e outros exercícios escolares o tempo de duas horas, que tantas se gastavam nos ditados de cada dia. Arredava-se o perigo que certamente havia de que pessoas estranhas ou, o que era mais doloroso, apóstatas da Companhia, publicassem os Comentários, que eram fruto de muito estudo e assíduo trabalho dos professores do Colégio (...). Por fim, com esse Curso se alcançaria finalmente a tão desejada uniformidade nas opiniões entre os Padres da Companhia" (Rodrigues, 1985, op. cit., pp. 110-111).

${ }^{30}$ O Curso Conimbricense é constituído pelas seguintes obras: 1) Commentarii Collegii Conimbricensis S. J. in octo libros Physicorum Aristotelis Stagiritae, Coimbra: A. Mariz, 1592; 2) Commentarii Collegii Conimbricensis S. J. in quattuor libros De Coelo Aristotelis Stagiritae, Lisboa: S. Lopes, 1593; 3) Commentarii Collegii Conimbrincesis S. J. in libros Meteororum Aristotelis Stagiritae, Lisboa: S. Lopes, 1593; 4) Commentarii Collegii Conimbricensis S. J. in libros Aristotelis qui Parva Naturalia appellantur, Lisboa: S. Lopes, 1593; 5) In libros Ethicorum Aristotelis ad Nicomachum aliquot Conimbricensis Cursus disputationes in quibus praecipua quaedam Ethicae disciplinae capita continentur, Lisboa: S. Lopes, 1593; 6) Commentarii Collegii Conimbricensis S. J. in duos libros De Generatione et Corruptione Aristotelis Stagiritae, Coimbra: A. Maris, 1597; 7) Commentarii Collegii Conimbricensis S. J. in tres libros De Anima Aristotelis Stagiritae, Coimbra: A. Mariz, 1598; 8) Commentarii Collegii Conimbricensis S. J. in universum Dialectam Aristotelis, Coimbra: D. G. Loureiro, 1606.

${ }^{31}$ Martins (1996), em artigo publicado na Revista Portuguesa de Filosofia, discute essa questão, ao apresentar a obra do Padre Manuel de Góis. Cf., Martins, António Manuel (1996). O conimbricense Manuel de Góis e a eternidade do mundo. Revista Portuguesa de Filosofia, 52. Coimbra: Faculdade de Filosofia, 487-499 entre outros dos textos já citados em notas anteriores.
} 
sobre a Ética a Nicômaco e o volume dedicado à lógica aristotélica, todo o Curso gira em torno do domínio disciplinar próprio da física (filosofia natural). De maneira geral, podemos dizer que os comentários estão estruturados em torno do texto aristotélico, sendo que a parte mais significativa é a dedicada às quaestiones: onde é possível ver um desenvolvimento dos temas propostos pela obra aristotélica, mas sem se fixar à "letra do texto". Martins (1996) comenta mesmo que "mais do que no comentário propriamente dito (...), é aqui que podemos encontrar as posições doutrinais mais importantes dos Conimbricenses" ${ }^{32}$.

Especificamente quanto a esse pequeno volume dedicado ao comentário da Ética a Nicômaco, podemos dizer que não se ocupa de todo o texto aristotélico, mas apenas de "algumas das melhores questões que foram tratadas dispersamente por Aristóteles nos livros da Moral a Nicómaco"33. De fato, este tratado está organizado em torno de nove Disputationes que abordam, sumariamente, apenas alguns dos temas da obra de Aristóteles: as três primeiras giram em torno das noções centrais de Bem, Fim e Felicidade. A quarta se ocupa dos Princípios dos atos humanos, ou seja, da Vontade, do Intelecto e do Apetite Sensitivo. A quinta analisa, genericamente, a questão da bondade e da malícia dos atos humanos. A sexta trata das Paixões e a sétima das Virtudes em geral. A oitava e a nona Disputationes dividem a análise de algumas virtudes em particular: a Prudência, a Justiça, a Temperança e a Fortaleza.

Mas é retomando o Proêmio deste Comentário que podemos localizar um dos por quês da escolha dessa fonte para o tema que nos interessa. Assim se refere Góis (1593) ao apresentar o sujeito a quem se dirige a obra: "é o homem enquanto atua livremente e se pode aperfeiçoar com os bons costumes e alcançar a felicidade humana"34, que é o Bem e o Fim últimos da vida.

\footnotetext{
${ }^{32}$ Ibid., p. 489. Também a esse respeito, cf. Lohr, Charles H. (1995). Les jésuites et l'aristotelisme du XVIe siècle (8191). Em Giard, Luce (dir.) (1995). Les jésuites à la Renaissance: système educatif et production du savoir. Paris: PUF. 33 Góis, Manuel de (1593). Disputas do Curso Conimbricense sobre os livros de Moral a Nicómaco de Aristóteles em que se contém alguns dos principais capítulos da moral. Lisboa: Oficina de Simão Lopes, p. 59.

${ }^{34}$ Ibid., p. 61.
} 
Finalmente, não podemos deixar de mencionar a importância desses manuais para a cultura européia e mesmo a formação intelectual das colônias, bem como sua difusão no período que estende até os fins do século XVII.

De toda essa descrição se podem colher os aspectos que fazem dos tratados produzido no Colégio das Artes de Coimbra documentos fundamentais para a compreensão do projeto jesuítico: primeiro, por serem os Comentários bastante representativos das matrizes do pensamento jesuítico e fundamentarem a assim chamada "psicologia filosófica" da Companhia de Jesus; segundo, porque, na busca das bases que sustentam a cultura brasileira, é preciso que sejam considerados os sujeitos culturais, responsáveis pela construção de tais fundamentos, ou seja, os "sujeitos que

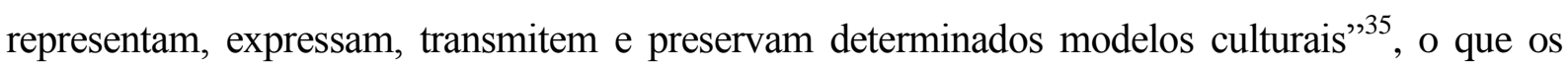
jesuítas o são na medida em que influenciaram enormemente a difusão e a construção de idéias no Brasil; basta olhar para sua preocupação com a educação ${ }^{36}$, por exemplo, o veio por onde entraram “idéias, sonhos e desilusões, riquezas e contradições do Velho Mundo no terreno fecundo, virgem e desconhecido do Mundo Novo" ${ }^{37}$.

Num período marcado pela necessidade de se formarem "espíritos segundo as diretrizes da ortodoxia mais rígida" ${ }^{38}$, um período em que urgia à Igreja Católica a formação de um pensamento coeso e unânime (especialmente em filosofia e teologia), um período de renovação das ciências eclesiásticas e da vida religiosa, sem dúvida era de grande relevância e mesmo indispensável que se estabelecessem certas instruções que

\footnotetext{
${ }^{35}$ Massimi, Marina (1999a). O lugar dos conhecimentos psicológicos na cultura luso-brasileira do século XVI ao século XVII. Estudos em História da Psicologia, 1. São Paulo: EDUC, p. 2.

${ }^{36}$ Cf. Caeiro, Francisco da Gama (1989). El Problema de las raíces historicas. In: Barba, Enrique M. et al. (dir.) (1989). Ibero-américa, una comunidad. Tomo I. Separata. Madrid: Ediciones de Cultura Hispánica. Neste livro, o autor retomando um trecho de uma carta do P.e Manuel da Nóbrega, diz: "hay un dato significativo a retener por la prioridad que origina: no habían pasado dos semanas desde el desembarco en Bahía el 29 de marzo de 1549 y ya el padre Nobrega, por carta, informa de uno de los jesuitas que lo acompañaba: 'el hermano Vicente Rijo enseña cada día a los niños y tiene también escuela de leer y escribir; pareceme buen modo para atraer a los indios de esta tierra, los cuales tienen grandes deseos de aprender'. De ahí Ne adelante, hasta 1604, en forma regular, llegaron desde Portugal a Brasil veintiocho expediciones de misioneros jesuitas, que consolidaron y desenvolvieron la empresa iniciada" (p. 379).

${ }^{37}$ Massimi, 1999a, op. cit., p. 3.

${ }^{38}$ Rodrigues, 1985, op. cit., p. 42.
} 
norteassem o ensino das humanidades, bem como da filosofia e da teologia - como foi o caso da Ratio Studiorum, na Companhia de Jesus - a fim de se evitar contendas e maiores divisões. A eclosão, na Renascença, do movimento Reformista Protestante, exigia uma postura da Igreja Católica: é no século XVI que surge, então, a Reforma Católica, marcada pela reafirmação das tradições; especialmente, no campo da filosofia, a retomada da Escolástica.

Essa retomada, foi é freqüentemente entendida como um "desastre para o cultivo dos estudos filosóficos em Portugal"39, no entanto, não se trata de "falta de originalidade, de seguidismo em relação à tradição aristotélico-tomista" ou de fechamento numa "cega rigidez de sistema"40. Severiano Tavares (1948), por exemplo, pode nos ajudar a entender a verdadeira dimensão da retomada da tradição escolástica na história da filosofia não só portuguesa e brasileira (por conseqüência), mas mesmo européia; quando diz:

Só no (...) período do Colégio das Artes, Portugal entrou de pleno e próprio direito no domínio da História da Filosofia Mundial, conduzindo, de mãos dadas com a Espanha, o movimento filosófico europeu. As nossas obras de metafísica, lógica, psicologia, ultrapassando os limites da pátria, foram então avidamente procuradas, profusamente espalhadas em numerosas edições feitas no estrangeiro, encontrando elas por toda a parte leitores assíduos e entusiastas. A Lógica de Pedro da Fonseca tomou nas Universidades o lugar das Summula Logicales de Pedro Hispano. Descartes, Leibniz e tantos outros filósofos leram assiduamente as obras dos mestres coimbrões e sofreram-lhe o influxo ${ }^{41}$.

Para quem não se deixa levar por juízos preestabelecidos, o reconhecimento do valor das produções dos mestres da Segunda Escolástica Ibérica vai se evidenciando aos poucos. Ernst Lewalter (1998), filósofo alemão interessado na história do idealismo germânico, não se furta a este reconhecimento: segundo ele, para poder compreender Descartes, Leibniz e Spinoza é preciso antes deixar-se imergir na vasta corrente escolástica daquele período ${ }^{42}$. A

\footnotetext{
${ }^{39}$ Tavares, 1948, op. cit., p. 227.

${ }^{40}$ Dinis, Alfredo (1991). Tradição e transição no Curso Conimbricense. Revista Portuguesa de Filosofia, 47. Braga: Faculdade de Filosofia., p. 535.

${ }^{41}$ Tavares, 1948, op. cit., p. 230.

${ }^{42}$ Cf. Lewalter, 1998, op. cit., p. 263.
} 
construção de toda a filosofia alemã, especialmente de sua metafísica, tornou-se plenamente possível a partir da leitura cuidadosa da obras de filósofos como Pedro da Fonseca e Francisco Suárez, grandes representantes da também chamada Neo-Escolástica. Outro exemplo disso pode ser visto no Dicionário de História da Filosofia ${ }^{43}$ de Rittier e Gründer (1998), onde volta a se afirmar o papel decisivo da obra de Francisco Suárez no desenvolvimento do pensamento alemão, seja no que concerne à filosofia ou ao protestantismo. Alfredo Dinis (1991), num estudo quase "filológico" de uma das obras do P.e Manuel de Góis, busca resposta para a seguinte pergunta: até que ponto os mestres de Coimbra "se limitaram a adotar posições Escolásticas tradicionais e em que aspectos se mostraram abertos às inovações que começavam a anunciar-se um pouco por todo o lado a um ritmo surpreendente" ${ }^{44}$ ? É a partir da análise do comentário às obras De caelo e Physica de Aristóteles e sua comparação com o livro de Copérnico De revolutionibus orbium calestium, que ele chega a concluir:

O Curso Conimbricense foi elaborado num período de crescente transformação da cosmovisão aristotélica, e os seus autores foram, consciente ou inconscientemente, influenciados por este clima de mudança. (...) De qualquer modo, não é possível afirmar que os Conimbricenses se opuseram a tudo o que fosse novidade, e se limitaram a repetir a tradição aristotélica que tinham recebido. Há, pelo contrário, no Curso Conimbricense uma abertura a um pluralismo de opiniões. Aliás o mesmo clima de pluralismo de opiniões e de transição se verifica na Companhia de Jesus em geral nos séculos XVI e XVII. Só uma leitura desatenta e preconceituosa das obras dos autores jesuítas deste período pode não ver nelas mais do que uma monótona e rígida defesa da tradição aristotélica. Só colocado neste complexo contexto tanto doutrinal como histórico, dominado pela tensão entre um duplo movimento: de fidelidade à tradição aristotélica, por um lado, e de transição progressiva para teses inovadoras, por outro, o Curso Conimbricense se compreende corretamente ${ }^{45}$.

De fato, essa querela entre tradição aristotélico-tomista e inovação humanista e renascentista permeia grande parte do pensamento europeu desde o final do século XVI; e podemos ir ainda mais além se falarmos na filosofia produzida na Península Ibérica, em

\footnotetext{
${ }^{43}$ Rittier, Joachim e Gründer, Karlfried (1998). Historisches Wörterbuch der Philosophie. Vol. 10. Berlin: Wissenschaftliche Buchgesellschaft Darmstadt.

${ }^{44}$ Dinis, 1991, op. cit., p. 540.

${ }^{45}$ Ibid., p. 559.
} 
centros como Salamanca, Alcalá e Coimbra, onde até o final do século XVII todo o "ensino universitário das disciplinas filosóficas continuou a basear-se (...) nas obras de Aristóteles”46. Kristeller (1995) chega mesmo a dizer que não é possível se falar do Renascimento sem entender que esse período é dominado pelo Corpus Aristotelicum, que, em parte continuou as correntes medievais, mas em outra grande parte (talvez mesmo a mais significativa) se deixou influenciar pelo humanismo clássico e por outras idéias diversas; de onde se pode dizer sem qualquer receio de erro que autores como Erasmo de Roterdam, Pico della Mirandola, Giordano Bruno entre outros não tinham “um corpo doutrinal realmente novo em todos os domínios do saber, de forma a poder competir em termos de completude e consistência com o Corpus Aristotelicum"47.

\section{2) A Ratio Spiritualis}

Falar de espiritualidade nos séculos XVI e XVII, especialmente falar da Devotio moderna $^{48}$, sem dúvida é considerar fatores tais como a retórica, a ética, a política, a teologia

${ }^{46}$ Cf. Kristeller, 1995, op. cit., p. 40.

${ }^{47}$ Martins, 1996, op.cit., p. 490.

${ }^{48}$ Alguns séculos antes da Reforma Católica, a Igreja já entendia a necessidade de reformas internas, dado que há muito se apontavam as dificuldades com o nepotismo dos Papas, as queixas contra os Bispos e Padres, a queda da qualidade das universidades administradas pela Igreja, os monges sem vocação e a desatenção com o povo cristão. É conhecida, nesse sentido, por exemplo, a atuação do Cardeal Cisneros na Espanha, a iniciativa de D’Amboise na França, as reformas convetuais, o "afan misionero de esta Iglesia poco edificante: evangelización de la America es un ejemplo eximio" [Cf. Diego, Rafael Maria Sanz de (1991). La novedad de Ignacio de Loyola ante un mundo nuevo. Em Plazaola, Juan (Ed.) (1991). Ignacio de Loyola y su tiempo: Congresso Internacional de Historia. Bilbao: Mensajero e Universidad de Deusto, p. 919], ou a iniciativa dos monges alemães Gerd Groote e Florent Radewjns, no século XIV. Por volta do ano de 1370, Gerd Groote abandonou a clausura e a erudição para se tornar um pregador itinerante e viver no meio do povo. Era uma reação contra a vida segregada e privilegiada que os monges levavam em seus mosteiros. Entendeu que todo o clero deveria ser muito bem instruído e que o povo deveria ter acesso ao saber. Por essa razão, traduziu trechos da Bíblia e alguns hinos para o vernáculo. Logo surgiram os "Irmãos e Irmãs da Vida Comum" e os "Canônicos Regulares de Windesheim”, um grupo de homens e mulheres com o propósito de reformar a igreja oficial através da educação da juventude, da instrução religiosa transmitida ao povo e da caridade ao próximo. Foram essas atitudes que deram início ao que se denominou devotio moderna, que rapidamente se espalhou por toda a Europa cristã. A Imitatio Christi (cuja a autoria é discutida, mas tradicionalmente é devida a Thomas Kempis), é um exemplo da literatura devocional própria desse movimento. Ela se destinava a todos, sem exceção, mas principalmente àqueles desejosos de transformar e santificar o seu cotidiano [Cf. Melloni, Xavier (2002). Los Ejercicios en la Tradición de Occidente. Cuadernos EIDES, 23. Retirado em 01/02/2002, do site Cristianisme i Justícia, no World Wide Web: http://www.fespinal.com/espinal/castellano/eides/eies23.htm e também o texto do World Wide Web http://www.magma.ca/ gcsfred/ cap3.html; extraído em 01/02/2002]. Ainda sobre a Devotio moderna, e especificamente para uma história mais detalhada do movimento dos "observacionistas" e as principais obras escritas no período, cf. Mayeur, 1994, op. cit.. Guibert (1953) elenca alguns dos "principais centros" de divulgação espiritual do século XVI: o Exercitatório do abade Cisneros e a Imitação de Cristo são os principais representantes do mais importante desses centros: a Devotio moderna dos Países Baixos. Inácio sofreu a influência dessas e de outras obras a partir dos mais variados meios. Após enumerar uma série de representantes nos mais diversos países da Europa, Guibert diz: "Telle sont 
etc. Hansen, no prefácio à obra de Pécora (1994) - Teatro do Sacramento - define a Devotio moderna como "metafísica neo-escolástica da Luz difusa" que funda a "história como história sacra"49, como lugar da epifania da "Luz". Segundo ele, espiritualidade, experiência religiosa, mística e fé, são re-elaborações ou retomadas de conceitos tomistas, apenas revestidos de roupagens modernas; o que significa uma devoção em nada desvinculada da realidade ${ }^{50}$.

Porém, é Guibert (1953) quem melhor define o que seja espiritualidade, quando explica o que significa uma "espiritualidade inaciana": segundo ele, o termo designa tanto a vida interior pessoal de um homem, como a maneira como esse homem exerce certas práticas genericamente entendidas como espirituais, ou mesmo uma doutrina espiritual presente em escritos desse mesmo homem. No entanto, quando se trata da "espiritualidade" de uma ordem religiosa, por exemplo, na maioria das vezes

cette spiritualité du groupe aura pour point de départ la spiritualité d'un homme, d'un fondateur ou d'un maître, telle qu'elle ressort de sa vie, de ses enseignements et de sa parole, de ses écrits, de tel écrit considéré comme normatif par la tradition vivante du groupe ${ }^{51}$

Por isso, pela expressão "espiritualidade inaciana", se quer designar esse conjunto de características próprias da experiência pessoal de Inácio, presente em determinados documentos - que serão aqui analisados - que funda um modo próprio de um grupo, no caso a Companhia de Jesus.

très sommairement les lignes maîtresses de l'ensemble riche et mouvant au milieu duquel va se constituer la spiritualité de la Compagnie de Jésus, suivant certaines de tendances qui s'y manifestent, résistant à d'autres, s'inspirant par exemple largement de la piété à la fois affective et méthodique de la Dévotion moderne, mais restant réservée en face de l'enthousiasme des milieux espagnols pour les très longues oraisons". Guibert, Joseph de (1953). La spiritualité de la Compagnie de Jésus: esquisse historique. Bibliotheca Instituti Historici Societatis Iesu, vol.IV. Roma: IHSI, p. XXXIII.

${ }^{49}$ Cf. Pécora, 1994, op. cit., p. 16.

${ }^{50}$ Em poucas palavras, podemos apontar pelo menos quatro características importantes da tradição pedagógicoespiritual da Devotio moderna: uma tendência anti-especulativa com relação à mística, preocupando-se com a contemplação da vida de Cristo, Deus feito homem; o que explica a atenção aos exercícios espirituais, que lidavam especialmente com a ação e a afeição, propondo contemplar, imitar e seguir a Cristo; a existência desses exercícios espirituais e piedosos, trouxe a necessidade de uma preocupação com o método, sistematizando a vida de oração; finalmente, podemos falar de uma piedade subjetiva e intimista, por exemplo presente na idéia de "peregrinação interior" tão fomentada e prestigiada na época. Cf. Du Jourdin, Michel Mollat (1991). Saint Ignace et les pèlegrinages de son temps. In: Plazaola, Juan (Ed.) (1991). Ignacio de Loyola y su tiempo: Congresso Internacional de Historia.. Bilbao: Mensajero e Universidad de Deusto, p. 177, e Melloni, 2002, op. cit.

${ }^{51}$ Guibert, 1953, op. cit., p. XVIII ("Esta espiritualidade do grupo terá por ponto de partida a espiritualidade de um homem, de um fundador ou de um mestre, tal como ela sai de sua vida, de seus ensinamentos e de sua palavra, de seus escritos, de tal escrito considerado como normativo para a tradição viva do grupo"). Cf. também acerca dessa categoria - "espiritualidade" - Bergamo, Mino (1994). L'anatomie de l'âme: de François de Sales à Fénelon (M. Bonneval, trad.). Paris: Jérôme Millon (original de 1991). 
Retomemos, no entanto, algo que já foi mencionado acima, mas que nos interessa como descritivo da experiência espiritual própria do período histórico no qual encontramos a figura de Inácio e a nascente Companhia de Jesus.

Lembremo-nos de que a Segunda Escolástica teve um impacto e uma importância capitais na reordenação católica dos séculos XVI e XVII ${ }^{52}$, quando a Igreja enfrentava o processo de reforma de suas bases doutrinais e institucionais, com o Concílio de Trento. Esta importância funda-se sobretudo no fato de a Segunda Escolástica ter conseguido empreender a conciliação entre a exigência de racionalidade do Estado moderno emergente e uma certa nova ordem do mundo ocidental ${ }^{53}$. Além disso, é preciso ainda lembrar o fato de que a Segunda Escolástica manteve a afirmação tomista da unidade entre fé e razão, graça e natureza, de forma complementar.

Filha de um homem de transição, como o foi Inácio de Loyola, a Companhia de Jesus deve ser apontada como representante bastante significativa de uma visio Dei diferente (e até mesmo, e sobretudo, no contra-rumo) de tudo o que as tentativas "modernizantes" da filosofia emergente ${ }^{54}$ apregoavam, mas, ao mesmo tempo, em tudo "humanista": o carisma

\footnotetext{
52 Morse (1988), diz que os ibéricos foram mais cautelosos no momento da "revolução moderna", pois "acompanharam as questões-chaves durante o final da Idade Média e então, no umbral da modernidade, mantiveram suas posições" (p. 29), contrariamente à dinâmica anglo-saxônica, por exemplo. "Ao retrocederem (...), os ibéricos estavam muito conscientes de que os tempos impunham uma revisão das orientações da última parte da Idade Média. A adoção do tomismo não era uma conclusão antecipada, nem sequer era viável sem uma significativa modernização. Os neo-escolásticos ibéricos do século XVI não eram de modo algum reacionários cegos, pois lhe devemos reconhecer o fato de terem assentado as bases da jurisprudência internacional, fornecido uma metafísica inicial para a moderna filosofia européia e criado uma racionalidade e normas para as conquistas no ultramar mais humanas do que aquelas que as sucederam" (p. 29). Cf. Morse, 1988, op. cit.

${ }^{53}$ Segundo Morse (1988), deveu-se à adaptação dos “requisitos da vida cristã à tarefa de 'incorporar' povos não cristãos à civilização européia" (Ibid., p. 42).

${ }^{54}$ Entre as figuras do humanismo renascentista, é preciso mencionar Francesco Petrarca (1304-1374) e Giovanni Bocaccio (1313-1375), como precursores, Gianozzo Manetti (1396-1459) e Giovanni Pico della Mirandola (14631494), autores de tratados sobre a dignidade humana, Erasmo de Rotterdam (1467-1536) e Michel Eyguem de Montaigne (1533-1592), por sua afirmação da centralidade do sujeito (posição, mais tarde, assumida por Martinho Lutero no que respeita à relação entre o homem e Deus). Também é preciso mencionar, ainda que arriscando de sermos muito simplistas os principais fatos e características do período que abriu as portas para a Modernidade: 1) o "humanismo" e a unidade cultural e de pensamento; 2) o fim do domínio turco em Constantinopla (1453) e a conquista de Granada (1492), que selam o fim do secular domínio islâmico na península ibérica; 3) as navegações portuguesas (1418) e o descobrimento da América (1492); 4) a publicação de De revolutionibus orbium caelestium (1543), de Nicolas Copérnico (1473-1543), fazendo triunfar o heliocentrismo; 5) o homem - descobridor, cientista, racional passa ao centro da questão; 6) a Reforma protestante, cujo protagonista foi Martinho Lutero (1486-1546); 7) a Reforma católica; 8) e as querelas daí nascentes acerca da liberdade, predestinação e graça; 9) o reconhecimento da
} 


\section{jesuítico revela uma perspectiva salvífica onde Graça e Liberdade ${ }^{55}$ se complementam, numa}

autonomia de certas realidades humanas em relação à transcendência (a política e a economia); 10) os Estados Nacionais; 11) o surgimento do capitalismo; 12) mas também uma retomada especulativa da tradição medieval, como o testemunha a Segunda Escolástica Ibérica, com Francisco de Vitoria (1492-1546) e Francisco Suárez (1548-1617), pensadores que se debruçaram sobre questões tanto teológico-filosóficas, quanto metafísicas e direito internacional; 13) o ressurgimento do platonismo, especialmente na Itália (a partir do século XV), com pensadores como Felipe Aureólo Teofrasto, vulgo Paracelso (1493-1541), Bernardino Telesio (1508-1588), Yehudá Abrabanel, vulgo León Hebreo (1465-1521), Giordano Bruno (1548-1600), Thomas More (1478-1535) e o já citado Erasmo de Rotterdam; 14) mas também autores com posições ortodoxas mais tradicionais, fora do âmbito propriamente da Segunda Escolástica, tais como Nicolau de Cusa (1401-1464), o já mencionado Pico della Mirandola, Girolamo Savonarola (1452-1498), Frei Bartolomeu de las Casas (1474-1566); 15) o ceticismo do já citado Montaigne. Evidentemente essa lista de eventos e autores não quer ser exaustiva, mas apenas dar uma pequena descrição do estado de coisas no período em questão, especialmente quanto ao que tratamos. Tudo isso para dizer que, exatamente nesse período histórico em que viveu Inácio, é que surge René Descartes (1596-1650) que é considerado o pai da filosofia moderna, quando afirma o valor da razão ancorada no descobrimento da subjetividade. Suas principais obras são Le discours de la méthode pour bien conduire as raison et chercher la vérité dans les sciences (1637) e Méditations Métaphysiques (1641). É também desse período o filósofo político Nicolau Machiavel (1469-1527), cuja mais importante obra é Il Principe (1531). É preciso acrescentar à lista personagens como: Francis Bacon (1561-1626), considerado o pai da razão dedutiva; Thomas Hobbes (1588-1679) filósofo da política que desenvolveu o materialismo; Blaise Pascal (1623-1662), filósofo e matemático que se dedicou, no século XVII, à questão da experiência religiosa humana; Baruch Spinoza (1632-1677), filósofo panteísta; Nicolas Malebranche (1638-1715), filósofo e teólogo francês, discípulo de Descartes, cuja obra mais significativa foi Entretiens sur la métaphysique et la religion (1688); Gottfried Wilhelm von Leibniz (1646-1716), matemático e filósofo alemão, e crítico de Descartes.

${ }^{55}$ Para falar de "graça" e "liberdade", nesta perspectiva, é preciso remontar a Tomás de Aquino: é de seu exame acerca da graça que vem a compreensão adotada pela Segunda Escolástica em geral, e pela Companhia de Jesus, em particular. Tomás de Aquino, para falar de "graça" lança mão do já mencionado conceito de "participação": "Na linguagem comum, 'participar' significa - e deriva de - 'tomar parte' (partem capere). Ora, há diversos sentidos e modos desse 'tomar parte'. Um primeiro é o de 'participar' de modo quantitativo, caso em que o todo 'participado' é materialmente subdividido e deixa de existir (...). Num segundo sentido, 'participar' indica 'ter em comum' algo imaterial, uma realidade que não se desfaz nem se altera quando participada (...). O terceiro sentido, mais profundo, é o que é expresso pela palavra grega metékhein, que indica um 'ter com', um 'co-ter', ou simplesmente um 'ter' em oposição a 'ser'; um ‘ter' pela união (participação) com outro que 'é'. Já ao tratar da Criação, Tomás havia utilizado este conceito, que é platônico e não aristotélico, mas que foi pouco trabalhado por Agostinho. O ser criado tem o ser, por participar do ser de Deus, que é ser. Lembramo-nos de que Tomás comparava o ato de ser das criaturas à luz e ao fogo: um ferro em brasa tem calor porque participa do fogo, que ‘é calor'; um objeto iluminado 'tem luz' por participar do brilho que emana de uma fonte luminosa. Ora, quando Tomás fala da graça, vale-se exatamente das mesmas comparações. O próprio conceito de participação, utilizado neste sentido, encontra-o em textos do Novo Testamento, por exemplo em Heb 3, 14: 'somos participantes de Cristo'.” (p. 19-20). Cf. Lauand, Jean (2003). Razão, Natureza e Graça - Tomás de Aquino em Sentenças: Estudos introdutórios e tradução. Mirandum Plus, 3. 1-51. Retirado em 12/08/2003, do World Wide Web http://www.hottopos.com/mp3/sentom.htm. Tanto no plano natural, como no plano sobrenatural, portanto, há "participação", mas apenas no plano sobrenatural há o que São Pedro denomina o tornar-se divinae naturae consortes $(2 \mathrm{Pe} 1,4)$ - participantes da própria vida íntima de Deus -, e a isto Tomás dá o nome de "graça". Compreender-se-á, porém, o que é a "liberdade" na medida em que se entender a "moral" de Tomás. Antes de mais nada, fique claro que a moral do Aquinate deriva de sua concepção do ser do homem: uma unidade corpo e alma. "Ele nem sequer poderia conceber a moral como algo imposto, nem como 'assunto reservado a religiosos' e, menos ainda, como algo constrangedor ou repressivo da liberdade humana! O que, sim ele diz, é que a moral é o ser do homem, doutrina sobre o que o homem é e está chamado a ser" (Ibid., p. 15). Isto se dá, na medida em que moral é entendida como auto-realização do homem; como um processo no qual o homem se lança com liberdade e responsabilidade no caminho inexorável de sua felicidade: "por criação está indelevelmente inscrito em seu coração o desejo de ser feliz" (Ibid., p. 17). Aqui entram, então, conceitos tais como ordo, ratio e natura, que são fundamentais para melhor se compreender a relação entre "graça" e "liberdade". Tomás compreende ordo como uma relação, como algo dinâmico e não estanque, que indica uma direção: "O sentido de ordo que se aplica à moral é, pois, o de boa integração e estruturação dinâmica. (...) O homem e todas as coisas do mundo (cada qual a seu modo) ordenam-se, dirigem-se a Deus, seu fim último: Tomás vê no movimento de cada coisa criada (e na interação dos entes) um processo de 'retorno' ao Criador. No vértice do mundo material, o homem - que se assemelha a Deus pelas suas duas potências espirituais: a inteligência e a vontade - é a cabeça deste processo, levando consigo as outras realidades da Criação" (p. 22). Por sua vez, ratio, em Tomás, é mais do que o "racionalismo" moderno: designa, por um lado, algo intrínseco à realidade das coisas, e, por outro lado, um peculiar relacionamento da razão humana com a realidade (cf. 
mística de passividade e atividade. Nele, é o homem completo - "sem renunciar a quaisquer

de seus dotes, intelectivos, sensíveis e ativos" ${ }^{\text {- }}$ - que é solicitado a viver uma "mística do

serviço de Deus por amor" ${ }^{, 5}$, ou uma "mística de apostolado" ${ }^{\text {. }}$. É um carisma também

"realista",59 , na medida em que possui instrumentos e propõe práticas específicas que ajudam a

trilhar um caminho de "progressiva incorporação da realidade"

É essa paixão pelo real que fez da espiritualidade inaciana, ou seja, do percurso de

Ibid., p. 22); portanto, ratio, descreve tanto a estruturação interna de um ente, quanto a capacidade de relação com a ratio das outras coisas todas. Esta concepção de ratio é em tudo coerente com a noção cristã de Logos, a que São João se refere tanto no prólogo de seu evangelho - "e o Verbo se fez carne" -, quanto no seu Apocalipse, quando designa o Logos como princípio da Criação (Ap, 3,14): “Assim, para Tomás, a criação é também 'fala' de Deus: as coisas criadas são pensadas e 'proferidas' por Deus: daí decorre a possibilidade de conhecimento do ente pela inteligência humana" (Ibid., p. 23). Natura, por outro lado, indica o ser enquanto princípio de operações: aquele aspecto da natureza que distingue operativamente dos demais entes. De forma que podemos dizer: "A 'natureza', especialmente no caso da natureza humana, não é entendida por Tomás como algo rígido, como uma camisa de força metafísica, mas como um projeto vivo, um impulso ontológico inicial (ou melhor, 'principial'), um 'lançamento no ser', cujas diretrizes fundamentais são dadas precisamente pelo ato criador que, no entanto, tem de ser completado pelo agir livre e responsável do homem. Assim, todo o agir humano (o trabalho, a educação, o amor, etc.) constitui uma colaboração do homem com o agir divino, precisamente porque Deus - cuja ordem conta com as causas segundas - quis contar com essa cooperação. Esse caminho moral é percorrido, exercendo a liberdade de praticar o bem e, assim realizando sua própria natureza. Mas, o bem remete à verdade: à ratio da realidade que a razão capta, propondo à vontade sua realização" (Ibid., p. 24). "Graça" e "liberdade", portanto, não se podem conceber separadamente: a "graça" fez do homem divinae naturae consortes, e esta participação mesma na natureza divina, esta relação amorosa que o homem pode viver com a divindade, que permite ao homem de, ordenando-se virtuosa e dinamicamente, e com liberdade, na realidade inteira, chegar à sua natureza original, não negando nada nem de sua ratio nem de sua natura.

${ }^{56}$ Pécora, 1994, op. cit., p.76.

${ }^{57}$ Cardoso, Armando (1977). Introdução. Em: Loyola, Inácio (1977). Diário Espiritual. São Paulo: Ed. Loyola, p. 10.

58 Cf. Monteiro, Miguel Corrêa (1998). Finalidade Teística e Humanismo no Primitivo Ideal Pedagógico Jesuítico. Millenium Internet, 12, Outubro. Retirado em 01/02/2002, da Revista Eletrônica Millenium, no World Wide Web: http://www.ipv.pt / millenium / pers12_jesuit.htm, p. 01.

${ }^{59}$ O que é esse realismo em Inácio? Fernández-Martos (1991) apresenta quatro precisões do termo: 1) realidade como oposto a ilusório, isto é, Inácio entende e procura ajudar a entender que o real é tudo o que não está circunscrito às nossas fantasias de onipotência ou de impotência, à ilusão do nosso pecado, portanto; 2) é realidade também não só o mundo visível das pessoas e das coisas, mas o que há de sentido por trás do visível, o que está para além do visível; 3) entende-se realidade também como tudo com o que, relacionando-nos com seu aspecto de sentido, estabelecemos um olhar ético, ou seja, é real se relacionar de forma adequada com o real, segundo sua "verdadeira utilidade", e não de forma trivial, reativa ou puramente prazerosa; 4) uma última delimitação do termo, é a respectividade do real, segundo a qual, toda a realidade é algo mais do que ela mesma, é um "tear onde Deus tece o "mistério divino", trata-se de um olhar que é capaz de ver o real como teológica e teleologicamente orientado. Lendo o Princípio e Fundamento dos Exercícios Espirituais ["1 $O$ homem é criado para louvar, reverenciar e servir a Deus Nosso Senhor, e assim salvar a sua alma. E as outras coisas sobre a face da terra 2 são criadas para o homem, para que o ajudem a alcançar o fim para que é criado. Donde se segue que há de 3 usar delas tanto quanto o ajudem a atingir o seu fim, e há de privar-se delas tanto quanto dele o afastem. Pelo que é necessário tornar-nos indiferentes a respeito de todas as coisas criadas em tudo aquilo que depende da escolha do nosso livre-arbítrio, e não lhe é proibido. De tal maneira que, de nossa parte, não queiramos mais saúde que doença, riqueza que pobreza, honra que desonra, vida longa que breve, e assim por diante em tudo o mais, 4 desejando $e$ escolhendo apenas o que mais nos conduz ao fim para que fomos criados". Loyola, 1991, op. cit., pp. 62 e 64 . (tradução nossa. Os grifos e a numeração também são nossos e auxiliam a identificar a precisão descrita)], é possível identificar cada uma dessas quatro precisões do termo "realidade". Cf. Fernández-Martos, J. M. (1991). La incorporación de la realidad como clave del cambio en los Ejercicios Espirituales. Em Alemany, Carlos e Garcia-Monge, José A. (ed.) (1991). Psicologia y Ejercicios Ignacianos (vol I): la transformación del yo en la experiencia de Ejercicios Espirituales. Bilbao: Mensajero e Sal Terrae, p. 243 (tradução nossa)

${ }^{60}$ Ibid., p. 241 (tradução nossa). 
experiência espiritual trilhado por Inácio e sua proposta para os membros da Companhia de Jesus - seja através dos Exercícios Espirituais, seu Relato ou seu Diário de Moções Interiores - um passo a mais na experiência religiosa de relação com Deus que a Devotio moderna inaugurara alguns séculos antes: trata-se de um olhar para o real que é capaz de identificar lá onde toda a contingência parece determinar tudo, onde o não-ser, o pecado, o limite, a fraqueza humana e suas imperfeições parecem não deixar saídas, os sinais da Graça que não somente é "negação do pecado", mas "estabelecimento da Liberdade",61 "libertação divina dos módulos ordinários do homem"62 que escravizam e iludem, que impedem de viver o espaço e o tempo de maneira razoável e totalizante (isto é, viver com um sentido, com uma tarefa, com uma missão ${ }^{63}$ ). Para Inácio, que viveu a busca permanente de conhecer e fazer a vontade de Deus (o que implica o reconhecimento da necessidade de um discernimento contínuo e uma disposição de escuta constante), o mundo se transforma em teofania, ou seja, lugar de revelação de Deus ${ }^{64}$.

Quantos aos Exercícios Espirituais, são - à primeira vista - uma série de notas práticas, de métodos de exame de consciência, de oração, de deliberação ou eleição, de planos de meditação e de contemplação, divididos em partes que indicam quatro semanas, além de regras etc.; é um conjunto de instruções diversas destinadas a dirigir o cumprimento de um certo número de exercícios interiores sistematicamente ordenados, de forma que se trata de um livro não para ser

\footnotetext{
${ }^{61} \mathrm{E}$ “liberdade real: nem a ilusão da onipotência fantástica, nem a da impotência que crê não poder chegar a algum lugar" (Ibid., p. 265, tradução nossa).

${ }^{62}$ Ibid., p. 264 (tradução nossa).

${ }^{63}$ A este respeito, Fernández-Martos (1991) diz que a escolha dessa missão (futuro) se dá na "eleição", que é um kairós, onde o homem, num "agora" de decisão (presente) e se vendo diante da história (passado), entra na eternidade de Deus, anulando toda a temporalidade. Inácio "ataca com 'opróbrios' a fantasia da 'fama' eternizante que me prolongaria no tempo. Pulveriza a riqueza que amplia meus espaços na posse, com a estreiteza da pobreza" (Ibid., p. 264, tradução nossa).

${ }^{64}$ Era comum que Inácio terminasse suas cartas com fórmulas do tipo "que em sua infinita bondade, ele se digne nos dar a graça perfeita para tenhamos o sentido de sua santíssima vontade e a cumpramos inteiramente" (Carta enviada, de Roma, no dia 15 de março de 1545, ao Rei João III, de Portugal. Loyola, 1991, op. cit., p. 681, tradução nossa). E, P.e Câmara, no final do Relato, relata como Inácio sentia facilidade "para encontrar Deus, e agora mais do que nunca antes em toda a sua vida. Todas as vezes e a toda hora em que ele queria encontrar Deus, ele $\mathrm{O}$ encontrava. E ele diz que, ainda agora, ele tinha muito freqüentemente visões, sobretudo aquelas das quais falou antes: ver Cristo como um sol. E isso lhe acontecia sobretudo quando falava de coisas importantes; e isso lhe fazia venire in confirmatione" (Ibid., p. 1072).
} 
lido, mas para ser vivido; mas, sobretudo, trata-se de uma obra destinada a quem guia o exercitante $^{65}$. Quanto à compreensão de como este texto nasceu, qual o seu objetivo e portanto seu lugar na vida de espiritualidade da Companhia de Jesus, é o próprio Inácio quem narra - no seu Relato - como os Exercícios foram escritos: não de uma só vez, "mas, na medida em que observava algumas coisas na sua alma e as achava úteis, e lhe parecia que poderiam ser também úteis aos outros; então as punha por escrito" ${ }^{\text {, }}$. De forma que o texto dos Exercícios Espirituais é produzido como uma experiência pessoal, marcada por acontecimentos que são sinais da presença e da ação de Deus ${ }^{67}$, descrita de maneira a ser útil para que outros homens fossem capazes de trilhar um caminho de experiência de encontro com Deus ${ }^{68}$. O objetivo da obra é suscitar e sustentar uma experiência ${ }^{69}$ de eleição da vontade de Deus - "sempre conhecer e cumprir sua divina vontade"70 -; uma "escola de oração"71, para usar a expressão de Guibert (1953). Podemos também dizer que os Exercícios são mesmo o ponto de partida fecundo, no sentido de "princípio de orientação e de desenvolvimento de toda esta espiritualidade nascida da experiência de Santo Inácio"72. E finalmente, segundo O’Malley (1999), "não se pode compreender os jesuítas sem fazer referência” aos Exercícios Espirituais ${ }^{73}$.

\footnotetext{
${ }^{65}$ Cf. Guibert, 1953, op. cit., e Giuliani, Maurice (1991). Introduction aux Exercices (pp. 35-42). Em Loyola, 1991, op. cit.

${ }^{66}$ Loyola, 1991, op. cit., p. 1072 (tradução nossa).

${ }^{67}$ Ao apresentar o texto dos Exercícios Espirituais, Pousset (1992) comenta exatamente o valor de "inspiração" do texto inaciano. Cf. Pousset, Edouard (1992). Foi et liberté: présentation des Exercices spirituels de saint Ignace de Loyola. Paris: Vie Chrétienne/CERF.

68 "Nous nous trouvons toujours devant une expérience qui se livre et se dérobe à la fois et qui, introduisant l'utilité de l'autre comme critère de choix dans l'expression, accepté de ne jamais se référer à elle seule. Il ne faut donc chercher, dans les Exercices, aucun témoignage direct sur la vie spirituelle d'Ignace. Celui qui écrit ne cherche pas à raconter ce qui est le secret de sa vie, mais à être 'utile' à d'autres. (...)Ainsi le discernement opéré par Ignace affirme-t-il un tri essentiel: ce qui est 'utile', c'est le chemin qui mène à l'expérience ou, pour employer son langage habituel, la 'manière de procéder' qui donne à chacun le moyen de se disposer à la rencontre de Dieu". Giuliani, 1991, op. cit., p. 39.

${ }^{69}$ Cf. Giuliani, 1991, op. cit., p. 40: "Tout d'abord, par sa fonction, le texte ne vise qu'à susciter et soutenir une expérience. Cette intention d'utilité, exprimée par Ignace dans ses déclarations sur la genèse des Exercices se retrouve en chaque note, remarque, conseil pour prier, règle, point d'oraison. (...) Rien n'est imposé au nom de quelque conviction théorique, mais au contraire toute intervention et toute proposition n'a de pertinence que si elle favorise l'attitude qui est recherchée, au moment précis où se trouve l'exercitant dans son évolution ou dans son combat intérieur".

${ }^{70}$ Cf., por exemplo, a carta enviada a Juan Alfonso de Polanco, de Roma, entre fevereiro e março de 1547. Cf. Loyola, 1991, op. cit., p. 693.

${ }^{71}$ Guibert, 1953, op. cit., p. 529 (tradução nossa).

${ }^{72}$ Ibid., p. 537 (tradução nossa).

${ }^{73}$ O’Malley, John (1999). I primi gesuiti. Milano: Vita e Pensiero, p. 9 (tradução nossa).
} 
A respeito do Diário de Inácio, podemos dizer que aquilo que temos publicado atualmente é apenas um pequeno fragmento do "grande maço de manuscritos" nos quais Inácio "escrevia cada dia o que se passava em sua alma"74, especialmente com respeito à escrita das Constituições. Esse fragmento equivale a dois cadernos inteiramente escritos pela mão de Inácio: o primeiro vai de 02 de fevereiro a 12 de março de 1544, e o segundo se refere aos dias de 13 de março de 1544 à 27 de fevereiro de 1545. Esses manuscritos só foram publicados pela primeira vez em $1934^{75}$. O Diário, por ser a descrição do que se "passava na alma” de Inácio, descreve a dinâmica da vida mística do fundador.

Finalmente, quanto ao que concerne ao Relato, o que mais nos interessa é seu caráter "testamentário" "76 , que ajuda a entender como a experiência espiritual de Inácio constituiu-se fundamento da Companhia de Jesus. No Relato, a vida de Inácio é mais que uma sequiência de acontecimentos: é uma vida marcada, constituída e formada pela graça de Deus ${ }^{77}$; a vida de Inácio se torna, pois, uma "experiência-modelo"78, de forma que ler seu relato significa "reviver a vida do fundador, repetir a vida do fundador como fundador, quer dizer refundar o corpo, reinstituir o instituto que ele fundou a partir de sua conversão" ${ }^{79}$, ou seja, finalmente, é imitar Inácio.

\section{3) A Ratio institutorum}

Falar dos trabalhos de fundação institucional da Companhia de Jesus implica um

\footnotetext{
${ }_{75}^{74}$ Conforme descreve o P.e Gonçalves da Câmara. Loyola, 1991, op. cit., p.1072.

${ }^{75}$ Cf. Fabre, Pierre-Antoine (1991). Introduction aux Journal des motions intérieures (pp. 313-318). Em Loyola, 1991, op. cit.

${ }^{76}$ Nadal, no prefácio ao Relato diz que o pedido feito a Inácio foi de relatar sua vida "desde o início de sua conversão", com o objetivo de "servir para nós como um testamento e um ensinamento": "L'intention est donc claire: vers la fin de sa vie, les compagnons ont demandé au fondateur de la Compagnie de Jésus un testament spirituel en forme de récit. Toujours selon Nadal, d'après un propos rapporté dans la préface de Louis Gonçalves da Câmara, 'c'était fonder vraiment la Compagnie'. Celle-ci, en effet, ne repose pas seulement sur sa reconnaissance para l'Église et sur les textes fondateurs que sont en particulier les Exercices et les Constitutions, mais plus encore sur le fondateur lui-même et son expérience dont les compagnons auront à recueillir l'esprit". Dhôtel, J. C. (1991). Introduction aux Récit (pp. 1011-1018). Em Loyola, 1991, op. cit., p. 1011.

${ }^{77}$ Marin, Louis (1996). Le Récit, réflexion sur un testament (pp. 137-155). Em Marin, Louis (1999). L'écriture de soi: Ignace de Loyola, Montaigne, Stendhal, Roland Barthes. Paris: PUF.

${ }^{78}$ Cf. Ibid., pp. 145-146.

${ }^{79}$ Ibid., pp. 147 (tradução nossa).
} 
percurso que começa com a preparação do solo onde se enraizará "a crença dos primeiros companheiros em um vínculo de unidade" $" 80$, passando pela fundação do "Instituto" (1539), na medida em que se iniciam as discussões que fornecerão os "critérios de visibilidade, de distinção, os argumentos de seu reconhecimento"81, até chegar ao texto final das Constituições $(1577)^{82}$. Compreender esse percurso fundacional também não pode prescindir das inúmeras Cartas enviadas “por” Inácio ao longo dos primeiros anos da jovem Companhia de Jesus e, especialmente, ao longo dos anos em que esteve à sua frente como Padre Geral.

Desde os votos em Montmartre, em 15 de agosto de 1534, os primeiros jesuítas deram início ao longo trabalho de preparação do texto institucional que dará a forma de uma congregação religiosa reconhecida pela autoridade pontifical àquele ainda pequeno grupo de companheiros unidos pelo ideal de "buscar 'a vontade de Deus, o que é bom, o que Lhe dá prazer, o que é perfeito', segundo o objetivo de nossa vocação"

Em 1539, reunidos em Roma, iniciam-se os primeiros debates sobre a fundação. Somente em 1550, com a Bula de confirmação da Ordem, assinada pelo Papa Júlio III Exposcit debitum - se considerará definitivamente fundada e aceita a nova Ordem Religiosa.

Desses 11 anos de trabalhos, conservaram-se dois relatos de debates entre os primeiros companheiros - um de 1539 (1539 - Durante três meses - A maneira como se instituiu a Companhia) e um de 1541 (Forma e oblação da Companhia) -, o Atestado concernente a decisão de fazer voto de obediência (emitido em 15 de abril de 1539, após aquele primeiro debate), o texto das primeiras Determinações da Companhia, o Voto de Inácio para a eleição do prepósito geral (escrito no dia 05 de abril de 1541, após o segundo debate), a Summa de 1539 e as duas Bulas Pontificais - a de 27 de setembro de 1540, assinada por Paulo III (Regimini militantis) e a de 21 de julho de 1550, assinada por Júlio III (Exposcit debitum).

\footnotetext{
${ }^{80}$ Fabre, Pierre-Antoine (1991). Introduction aux Documents de Fondation (pp. 269-273). Em Loyola, 1991, op. cit., p. 269 (tradução nossa).

${ }^{81}$ Ibid., p. 269 (tradução nossa).

${ }^{82} \mathrm{O}$ texto atual das Constituições equivale ao estado em que se encontrava em 1577. Cf. Ibid., pp. 385-391.
} 
Apesar de escritos em períodos distintos, os documentos, quando lidos no conjunto, revelam uma cadeia contínua de progressiva legitimidade da Ordem: sua instituição, a eleição do Prepósito, a Summa - texto oficial do "Instituto" - que deverá ser aprovada, mais tarde, pelo Papa Paulo III e, posteriormente, confirmada por Júlio III.

A produção desses documentos nada mais é que uma "articulação coletiva do ato fundador, como vínculo, no gesto de uma escritura comum" ${ }^{83}$, onde o ponto de unidade do grupo que começa a se dispersar é o próprio Inácio, que aceita se tornar Geral: é justamente porque eles se dispersarão pelas missões "que a união em um Corpo deve ser considerada" ${ }^{4}$, daí a necessidade de um selo unitivo - a obediência (que vimos ser uma das questões debatidas no primeiro encontro fundante, entre metade de março e 24 de junho de 1539, em Roma).

Quanto ao texto das Constituições, tentar responder a algumas perguntas pode nos ajudar a melhor compreender esse documento: o que são? Como nasceram? Quem as escreveu? O que descrevem? Essas questões ajudam também a entender as demais regras que Inácio deixou, especialmente, em algumas de suas cartas, e a descrever o modus operandi propriamente jesuíta.

A gênese das Constituições se confunde com o nascimento da Companhia de Jesus. Não é inaugural ${ }^{85}$ (no sentido de que só aparece como necessidade cerca de cinco anos depois dos votos em Montmartre), mas é fundante da Ordem (na medida em que organiza, define, legisla em nome de uma unidade).

Em junho de 1539, os primeiros companheiros de Inácio deliberam o que dá origem à Summa, um conjunto de decisões que fornecerão ao Papa Paulo III o essencial para a edição da bula Regimini Militantis que, em 1540, reconhece a nova Ordem

\footnotetext{
${ }^{83}$ Ibid., p. 269 (tradução nossa).

${ }^{84}$ Ibid., p. 270 (tradução nossa).

${ }^{85}$ Como bem o lembra Fabre (1991), na introdução das Constitutions. Cf. Fabre, Pierre-Antoine (1991). Introduction Constitutions et Règles (pp. 385-391). Em Loyola, 1991, op. cit., p. 387.
} 
religiosa. Da deliberação de 1539 à versão final das Constituições são passados 19 anos, nos quais o texto é revisado, enriquecido, retomado. A esse período correspondem os Generalatos de Inácio, Laínez e Borgia e o Pontificado de Paulo III e Júlio III. Cada um desses personagens contribuiu de alguma forma com a gênese do texto definitivo, de forma que falar de um autor é sempre uma questão problemática; especialmente quando sabemos também que é a Polanco - secretário dos três primeiros Padres Gerais - que se deve a maior parte do trabalho jurídico ${ }^{86}$.

No entanto, é preciso ter claro que, para além das inúmeras contribuições ao texto das Constituições, o ponto de unidade é a experiência pessoal de Inácio ${ }^{87}$. Fabre (1991) lembra que ainda no texto "B" (a última versão, que foi editada em 1558), Inácio teve a oportunidade de deixar várias notas marginais, atestando assim seu trabalho de fundador ${ }^{88}$. Leite (1938) também diz que as Constituições são "a melhor fonte para se conhecer o pensamento explícito e direto de Inácio" $"$.

Através desse texto fundamental, conhece-se, pois, mais que um sistema jurídico, um texto que tem a característica de constituir a Companhia de Jesus, na medida em que compõe, dá a essência, descreve, estabelece um modo de agir que pretende ser o espelho da vida de Inácio e de seus primeiros companheiros.

\footnotetext{
${ }^{86}$ Para uma ampla compreensão do papel de Juan Alfonso de Polanco no trabalho jurídico de composição das Constituições, bem como nos trabalhos legislativos e organizativos da Companhia de Jesus durante os três primeiros generalatos, cf. Giard, Luce (dir.) (1995). Les jésuites à la Renaissance: système éducatif et production du savoir. Paris: PUF; Astrain, Antonio (1905). Historia de la Compañía de Jesús en la Asistencia de España. Tomo II: Laínez-Borja (1556-1572). Madrid: Est. Tipográfico "Sucesores de Rivadeneyra"; Bangert, E. V (1990). Storia della Compagnia de Gesú. Genova: Marietti; Giard, Luce et Vaucelles, Louis de (1996). Les jésuites à l'âge baroque (1540-1640). Grenoble: Jérôme Millon; Lacouture, Jean (1994). Os jesuitas: 1. Os conquistadores. Porto Alegre: L\&PM; Scaduto, Mario (1964). Storia della Compagnia di Gesù in Italia. Vol III: L'epoca di Giacomo Lainez (1556-1565) - Il governo. Roma: Edizioni "La civiltà cattolica"; Scaduto, Mario (1974). Storia della Compagnia di Gesù in Italia. Vol IV: L'epoca di Giacomo Lainez (1556-1565) - L'azione. Roma: Edizioni "La civiltà cattolica" e Scaduto, Mario (1992). Storia della Compagnia di Gesù in Italia. Vol V: L'epoca di Francesco de Borgia (1556-1565). Roma: Edizioni "La civiltà cattolica".

${ }^{87}$ Cf. Guibert, 1953, op. cit.

${ }^{88}$ Cf. Fabre, 1991, op. cit., p. 389.

${ }^{89}$ Leite, Serafim (1938-1950). História da Companhia de Jesus no Brasil, 10 vols. Lisboa-Rio de Janeiro: Portugália-Civilização Brasileira.
} 


\section{4) Os escritos espirituais}

Até aqui, vimos descritos cada um dos três primeiros grupos de fontes, de forma a compreender como cada um daqueles pólos integrava a formação de um jesuíta. A vida, através da particularidade de cada um dos documentos analisados até aqui, era regrada (tanto a alma quanto o corpo, tanto individual quanto coletivamente) e ordenada a um fim - ad maiorem Dei gloriam.

Um aparelho filosófico moral fundado sobre as relações entre a Liberdade intrínseca ao homem e sua Razão não menos inerente. Uma norma espiritual construída sobre a experiência de um homem, que se dá como modelo. Uma regra institucional que estabelece um "dever ser" a partir da descrição da vida de um fundador. Pensamento e normas de ação. Se queremos, então, ler esse pensamento e essa ação encarnados e descritos como experiência, numa síntese inicial, realizada no período histórico abordado pela nossa pesquisa, será necessário estudar um quarto tipo de fontes: os textos de espiritualidade, especialmente aqueles produzidos no período que vai de 1581 à 1633.

É nesse período, com já vimos, que começa a tomar corpo a realização prática do programa pedagógico ${ }^{90}$ traçado pelas Constituições; é aprovado o Diretório dos Exercícios Espirituais $^{91}$ em 1599, o que permite um trabalho aprofundado e sério sobre o texto inaciano;

\footnotetext{
${ }^{90}$ P.e Aquaviva, por exemplo, definiu com precisão as etapas de formação dos noviços, colocando num mesmo plano contemplação e meditação. Como se sabe, no centro das práticas cotidianas que são exigidas dos jesuítas, se encontram o exame de consciência, a leitura espiritual e a missa. Para mais informações acerca de Aquaviva e sua profícua produção, cf. Guerra, Alessandro (2003). Un generale fra le milizie del papa. La vita di Claudio Acquaviva. AHSI, 72, Romae, 199-203.

${ }^{91}$ O P.e Luis Gonçalves da Câmara, em seu Mémorial, afirma: "Nosso pai disse que queria fazer um Diretório sobre a maneira de dar os Exercícios, e que Polanco poderia lhe propor dúvidas quando se quisesse, porque, em matéria dos Exercícios, não lhe seria necessário refletir muito para responder" (apud Giuliani, Maurice (1991). Introduction aux "Notes pour un Directoire des Exercices". Em Loyola, 1991, op. cit., p. 259, tradução nossa), demonstrando assim que era desejo de Inácio a composição de um diretório para os Exercícios. O próprio Polanco - que redigiu o texto do Diretório - afirma que Inácio "tinha começado mas não terminou" (apud Ibid., p. 259), além de mencionar, entre as obrigações pedidas por Inácio a ele, "terminar o Diretório dos Exercícios, que é tão necessário" (apud Ibid., p. 259). Não resta dúvida, no entanto, que o próprio Inácio deu início àquilo que, mais tarde, seria o Diretório: “L'auteur en est Polanco, mais, comme nous l'avons déjà dit à propos de leur collaboration, c'est Ignace qui parle, qui présente la formule, qui répond à la question et qui, finalement, assume la responsabilité de ce qu'écrit le secrétaire" (p. 259). Finalmente, Giuliani (1991) lembra: "Il reste que les points d'insistance de ces 'Notes', les vues d'ensemble qui se révèlent à travers des détails très liés à la culture du temps, la pédagogie qui s'affirme autour du discernement des esprits, sont pour nous de précieux témoignages de la manière dont procédait Ignace avec ses exercitants. Beaucoup de formules de ces pages ont été recueillies et intégrées dans le Directoire élaboré para la Compagnie au cours des quarante ans qui ont suivi la mort d'Ignace” (p. 260).
} 
são publicadas inúmeras cartas de Aquaviva (sobre a oração ${ }^{92}$, sobre a renovação do espírito $^{93}$, sobre o estudo da perfeição ${ }^{94}$ e outras tantas destinadas a particulares); são editados os primeiros tratados espirituais e instruções sobre oração, aproveitamento espiritual etc. ${ }^{95}$; os debates nas Congregações Gerais e seus decretos sobre tempo dedicado à oração, noviciado etc. Todos exemplos de uma profícua preocupação com o estabelecimento de uma Espiritualidade "verdadeira, sólida e eficaz" $"$, com traços propriamente jesuíticos.

Entre os textos editados no período, selecionamos apenas alguns obedecendo basicamente a três critérios: 1) autores e obras mais lidas nos colégios e casas da Companhia de Jesus, conforme o inventário de Gilmont (1961) e o esboço histórico da espiritualidade jesuítica feita por Guibert (1953); 2) disponibilidade de obras nos arquivos pesquisados (basicamente BCS, mas também BCE, BNF e BCR); 3) e, finalmente, aquelas obras, entre as recolhidas, que melhor sintetizassem o conteúdo daqueles três pólos de análise anteriormente

\footnotetext{
92 Para mais informações acerca, cf. Gilmont, Jean-François (1961). Les écrits spirituels des premiers jésuites: inventaire commenté. Subsidia ad Historiam Societatis Iesu, 3. Romae: IHSI.

93 Aquaviva, Claudio (1583). Lettera del Nostro Padre Generale Claudio Acquaviva. Sopra la Rinovatione dello spirito à Padri \& Fratelli della Compagnie. 29/09/1583. Roma. BCS W12/441.

94 Aquaviva, Claudio (1586). Lettera del Nostro Padre Generale Claudio Acquaviva. Dello studio della perfettione, \& carità fraterna. 19/05/1586. Roma. BCS W12/441

${ }^{95}$ Lamalle (2004), afirma: "l'Acquaviva sapeva evitare quello che avrebbe potuto essere una pericolosa crisi di crescenza. Infatti, in 34 anni, vide i suoi sudditi passare da 5.000 a 13.000, eresse undici nuove province ed accettò più di 200 nuovi collegi. La C. penetrò in Cina con il p. Matteo Ricci, nelle Filippine, nell'Indocina, a Costantinopoli, nel Canada, nel Paraguay, dove nel 1606 si fondò la prima della famose riduzioni; nel Giappone sembravano legittime le più rosee speranze. In Europa, si assicurava con i suoi collegi una posizione di prima importanza nell'insegnamento umanistico ed ecclesiastico, mentre spingeva le sue conquiste verso il Nord, dove si fiancheggiavano le nazioni protestanti con i cosiddetti 'seminari apostolici', ad opera, fra altri, del p. Antonio Possevino. Ispirando e regolando questo intenso dinamismo, Acquaviva assicurò l'osservanza religiosa mediante l'invio di visitatori e d'importanti lettere circolari; molto notevole la preoccupazione costante dell'Acquaviva per mantenere in piena vitalità lo spirito primitivo. La C. di G. fu allora allietata da copiosi frutti di santità (Pietro Canisio, Luigi Gonzaga, Roberto Bellarmino, Pietro Claver, Bernardino Realino ecc.) e specialmente la grazia del martirio le fu largamente concessa: nel Giappone i tre Santi crocefissi di Nagasaki (1597) e parecchi beati, nell'India un cugino del generale, il b. Rodolfo Acquaviva e compagni, in Francia i bb. Martiri d'Aubenas (1593), in Inghilterra i bb. Campion (1583), Southwell (1591) e compagni, ecc. Sotto il governo dell'Acquaviva e in parte per le sue premure, la C. di G. si costituì una letteratura ascetica e mistica propria, note-vole per il numero di grandi trattati ancora classici, come A. Rodríguez, Alvarez de Paz, Luigi de la Puente, Ant, Le Gaudier, Francesco Suárez, ecc. Con uno sforzo pa-rallelo di grandi pubblicazioni, la scuola teologica dei Gesuiti prendeva contemporaneamente il suo posto nella scolastica post-tridentina; basta accennare agli esegeti Franc. Toledo, Franc. Ribera, Ben. Pereira, Ben. Giu-stiniani, Giov. Villalpando, ecc., ai dommatici o controversisti Rob. Bellarmino, Franc. Suárez, Gabr. Vázquez, Greg. di Valenza, Didaco Ruiz de Montoya, Luigi Molina, Giac. Gretser ed altri”. Lamalle, Edmond (2004). Compagnia di Gesú. Retirado em 15/04/2004, da Totus Tuus Network - Pagine cattoliche, no World Wide Web: http:// www.paginecattoliche.it/ CompagniaDiGesù.htm.

${ }^{96}$ Guibert, 1953, op. cit., p. XXV.
} 
descritos - scholicorum, ratio spiritualis e ratio institutorum.

Optamos, então, pelos seguintes textos: uma carta do P.e Aquaviva (1543-1615), de 29 de setembro de $1583^{97}$, na qual o Padre Geral propõe a "renovação do espírito aos Padres e Irmãos da Companhia" e uma outra carta, do dia 19 de maio de $1586^{98}$, sobre o "estudo da perfeição e da caridade fraterna"; ambas têm um caráter refundador importante, na medida em que julgam o momento histórico vivido e propõem os novos passos a serem dados.

Um texto de Giulio Fazio - Trattato utilissimo della mortificatione delle nostre passioni, \& affetti disordinati - de $1594^{99}$, pela sua importância do ponto de vista da síntese entre conteúdo filosófico aristotélico-tomista e experiência espiritual.

Outro texto do mesmo ano, do espanhol Pedro Sanchez - Libro del Reyno de Dios y del camino por donde se alcanza -, do qual encontramos uma tradução francesa de $1607^{100}$. Dada a significação da obra do ponto de vista da descrição do verdadeiro filho da Companhia de Jesus, demonstrando o valor da obediência como "caminho" para se alcançar o Reino.

O Libro de oracion mental, de Melchior de Villanueva, editado em $1608^{101}$, por ser uma síntese bastante completa do uso de conceitos próprios da psicologia filosófica aristotélico-tomista no âmbito da espiritualidade.

O Ejercicio de perfeccion y virtudes cristianas, de Alonso Rodrigues (1533-1617), publicado pela primeira vez em $1609^{102}$ e que conheceu inúmeras traduções e edições ao longo da história da Companhia de Jesus.

\footnotetext{
${ }^{97}$ Aquaviva, 1583, op. cit., BCS W12/441.

${ }^{98}$ Aquaviva, 1586, op. cit., BCS W12/441.

${ }^{99}$ Fazio, Giulio (1596). Trattato utilissimo della mortificatione delle nostre passioni, \& affetti disordinati. Composto nuovamente per il molto R. P. Giulio Fatio, della Compagnia di Giesu. Brescia: Pietro Maria Marchetti. BCS W12/274.

${ }^{100}$ Sanchez, Pedro (1607). Le Royaume de Dieu, et le vray chemin pour y parvenir. Composé en Espagnol par le Pere P. Sanchez, Docteur de la Compagnie de Iesus. Traduit en François, par F. Guillaume Levite, de l'Ordre des Predicateurs. Paris: Chez Adrian Beys. BCS W12/259

${ }^{101}$ Villanueva, Melchior de (1608). Libro de oracion mental. Compuesto por el Padre Melchior de Villanueva, de la Compañia de Iesus. Toledo: Pedro Rodriguez impressor del Rey nuestro Señor. BCS W12/267.

${ }^{102}$ Rodriguez, Alonso (1834). Ejercicio de perfeccion y virtudes cristianas, su autor el Padre Alonso Rodriguez de la Compañía de Jesus, natural de Valladolid. Dividido en tres partes. Parte tercera. De varios medios para alcanzar la virtud y perfeccion. Nueva Impression. Barcelona: Imprenta de D. Valero Siena y Marti. BCS W10/141
} 
Finalmente, como representante de uma espiritualidade completa - um todo orgânico - que amadureceu no tempo, escolhemos algumas obras de Juan Eusebio Nieremberg (1595-1658): o seu De Artes Voluntatis, de 1631 (tivemos acesso a uma tradução francesa de $1657^{103}$ ) e o Vida divina y camino real de grande atajo para la perfeccion, de $1633^{104}$.

Esses oito textos são uma síntese daquilo que descrevemos a partir dos três pólos representativos do pensamento e da ação jesuíticos, na medida em que, imersos num ambiente filosófico, pedagógico, espiritual e institucional específicos, se preocupam em estruturar aquilo que se configurará um corpus de textos de espiritualidade com características próprias. Trata-se, nesse caso, de uma genealogia positiva: são textos que só podem ter nascido de um ambiente sustentado minimamente por aquele tripé.

Um fator interessante a notar é que nunca, nestes textos, o aspecto filosófico ou o institucional aparecem sozinhos ${ }^{105}$ : são sempre marcados por aquela "experiência espiritual modelo", retomando a expressão de Marin (1996) ${ }^{106}$. Na carta de 1583 , de P.e Claudio Aquaviva, o autor escreve que

tutti gli affetti, che ci fanno cercar noi stessi, che ci attaccano à qualche cosa del mondo, che c'impediscono la vera libertà del puro servitio divino, \& ci rendono men pronti ad esser da lui maneggiati, sono dell'huomo vecchio nostro. Onde la rinovatione per contrario sará posta, non solo nel rinovare al primo vigore, et stato gli antichi proponimenti, \& fervori; ma nell'andarsi spogliando di questo huomo; in guisa, che si vada riducendo la volontà nostra (secondo lo stato di questa vida di esilio), à quella piena subordinatione, \& unione con Dio, che quanto egli

\footnotetext{
${ }^{103}$ Nieremberg, Juan Eusebio (1657). L'art de conduire la volonté selon les precepts de la morale ancienne \& Moderne, tirez de Philosophes Payens \& Chrestiens. Traduit du latin de Jean Eusebe de Nieremberg, Paraphrase \& de beaucoup enrichy par Louÿs Videl, de Dauphiné. Dedié à Monsieur de Lionne, Conseiller d'Estat ordinaire \& secretaire des Commandemets de la Reyne Regente. Paris: Chez Jean Pocquet. BNF R-6222. ${ }^{104}$ Nieremberg, Juan Eusebio (1957). Obras escogidas del R. P. Juan Eusebio Nieremberg (E. ZepedaHenriquez, ed.). Biblioteca de Autores Españoles, desde la formación del lenguaje hasta nuestros dias (continuación). Tomo 103. Madrid: Ediciones Atlas. BNF 4-Z-3501 (103).

${ }^{105}$ Cf. Bergamo, Mino (1994). L'anatomie de l'âme: de François de Sales à Fénelon (M. Bonneval, trad.). Paris: Jérôme Millon (original de 1991).

${ }^{106}$ Cf. Marin, Louis (1996). Le Récit, réflexion sur un testament (pp. 137-155). Em Marin, Louis (1999). L'écriture de soi: Ignace de Loyola, Montaigne, Stendhal, Roland Barthes. Paris: PUF.
} 
vuole, \& ella efficacemente voglia; et quanto egli no vuole, ella constantissimamente rifiuti ${ }^{107}$.

Aqui, Aquaviva faz uso de termos que são próprios do âmbito filosófico (paixões, liberdade e vontade, por exemplo), unindo-os a termos próprios da experiência espiritual (serviço divino, homem velho, união com Deus). Na carta sobre o "estudo da perfeição", de 1586, Aquaviva, fazendo uso de categorias que são desenvolvidas, por exemplo, naqueles documentos descritos no grupo da ratio institutorum, para mostrar como são eficientes para que os membros da companhia se dêem ao estudo da perfeição, lembra a seus subordinados que

questo in somma hà da esser il nostro studio, e l'obligo della nostra vocatione: ne siamo venuti ad altro alla Compagnia, che per far la volontà del nostro padre \& signore. Et credetemi (padri \& fratelli diletissimi) che'l forzarsi di farlo, \& darsi da vero alla essecutione di questo studio, mettendo in opera quel, che (...) le nostre costitutioni gridano \& fin dal principio del novitiato ci fù inculcato di far sua la volontà di Dio, interpretata dal superiore, è gran principio per rendercela ogni giorno più dolce ${ }^{108}$.

Também Fazio (1596), no seu tratado, apresenta inúmeros exemplos desse uso de categorias filosóficas e institucionais (sobretudo a categoria obediência) para descrever uma experiência espiritual (fazer a vontade de Deus). Por exemplo, no capítulo VI, onde trata de considerações particulares quanto à mortificação de cada uma das potências da alma, das paixões e dos sentidos do corpo, ao falar da mortificação da vontade, escreve:

Considera, come la volontà tua, è una potenza di sua natura cieca: Et perciò hà bisogno grandissimo di guida per non errare; Ma perché l'esperienza t'hà pur troppo, \& con gran danno tuo mostrato, che non sei buono tu per guida di lei; è necessario, che ti risolui di soggetarla

\footnotetext{
107 Aquaviva, 1583, op. cit., p. 5. "Todos os afetos que nos fazem buscar a nós mesmos, que nos ligam a qualquer coisa do mundo, que nos impedem a verdadeira liberdade do puro serviço divino, e nos tornam menos prontos a sermos por Ele manejados, são do nosso homem velho. Onde a renovação, pelo contrário, será não somente retornar ao primeiro vigor e aos antigos fervores e propostas; mas no ir se desfazendo deste homem; de forma que se vá reduzindo a nossa vontade própria (segundo o estado desta vida de exílio), para se encher daquela plena subordinação e união com Deus, de tal forma que o quanto Ele queira, ela também queira, e o quanto Ele não queira, ela de forma muito constante refute" (tradução nossa).

${ }^{108}$ Aquaviva, 1586, op. cit., p. 8. "Este, em suma, a de ser o nosso estudo e a obrigação da nossa vocação: estamos na Companhia apenas para fazer a vontade de nosso Pai e Senhor. E creiam-me (padres e irmãos muito diletos) que o forçar-se a fazê-lo e dar-se verdadeiramente à execução deste estudo, colocando em obra aquilo que (...) as nossas Constituições gritam e desde o princípio do noviciado nos foi inculcado - fazer a vontade de Deus interpretada por nossos Superiores - é grande princípio para torná-lo cada dia mais doce" (tradução nossa).
} 
con la Mortificatione santa, all'indrizzo, \& guida della volontà di Dio, $\&$ di quelli, che in luogo di lui ti governano ${ }^{109}$.

A obra de Sanchez (1607), como as demais, na medida em que se propõe a descrever o melhor caminho para chegar ao "Reino de Deus", também faz uso de termos peculiares à ratio institutorum. O capítulo IV do livro $\mathrm{V}$, por exemplo, trata da "obediência que é devida aos superiores", e nele Sanchez (1607) explica que "l'obeissance est une vertu, qui nous incline à obeyr au commandement du superieur, qui commande au nom de Dieu, (...) car ainsi le dict le vray superieur, fils de Dieu"110

No Libro de oracion mental, de Villanueva (1608), os exemplos se multiplicam, na medida em que o autor pretende ir apresentando cada tipo de oração: começa dizendo que a "consideração" é o modo próprio de orar dos principiantes e trata disso; em seguida diferencia oração mental de oral, e diz que a primeira é a mais perfeita e mais verdadeiramente oração; depois, divide a oração mental em oração "de vontade" (dividida em petição, ação de graças, louvor a Deus e amor de Deus) e "de entendimento" (que pode ser cogitação, meditação, especulação e contemplação); nos capítulos que se seguem, trata, então, de cada um dos tipos de oração, dando, inclusive, exercícios para ir se aperfeiçoando. Ao longo da obra, termos como memória, entendimento, vontade, liberdade, paixões da alma são lidos e dados à compreensão seja através de expressões tais como "santa obediência", "vontade de Deus", "suma virtude", "mortificação das paixões", “nosso espírito" etc.

Rodriguez (1834) também segue a mesma dinâmica, atendo-se sobretudo a categorias que aparecem no regrado jurídico da Companhia de Jesus. Todo o primeiro tratado da parte

\footnotetext{
${ }^{109}$ Fazio, 1596, op. cit., pp. 48-49. "Considera como tua vontade é uma potência naturalmente cega. E, por isso, tem muita necessidade de um guia para não errar. Mas porque a experiência te mostrou com grande dano para ti que não és bom para ser um guia da vontade, é necessário que te resolvas a sujeitá-la com a Mortificação santa ao lugar e guia da vontade de Deus e daqueles que no lugar dEle te governam" (tradução nossa).

${ }^{110}$ Sanchez, 1607, op. cit., pp. 562-563. "a obediência é uma virtude que nos inclina a obedecer à ordem do superior, que comanda em nome de Deus, (...) porque assim nos disse o verdadeiro superior, filho de Deus" (tradução nossa).
} 
terceiro do Ejercicio de perfeccion se dedica a explicar qual o fim da Companhia de Jesus e qual os meios para alcançar esse fim. O segundo tratado, por sua vez, se dedica a analisar cada um dos votos essenciais da Companhia e os descreve de forma a mostrar sua importância para que se alcance a perfeição pessoal e o fim da Companhia: "Pues los medios principales que la Religion tiene para alcanzar la perfeccion, son los três votos esenciales que hacemos, de pobreza, castidad y obediencia"111.

Quanto à primeira obra de Nieremberg (1657) - que trata da "arte da vontade" pode-se dizer que talvez seja uma das mais ricas do ponto de vista do uso de conceitos advindos do arcabouço filosófico aristotélico-tomista, sobretudo os próprios da filosofia moral: página após página, vemos Nieremberg (1607) falando de liberdade, vontade, razão, bens, virtudes, paixões etc.; mas também de "bens do espírito", "glória de Deus", "graça”, "família do Céu” etc. Assim, por exemplo, já perto do final da obra, ele escreve: "Par qui l'inconstance \& l'impetuosité des passions sçauroit elle mieux estre arrestée que par la Raison? C'est d'elle que la Verité tire son Estre; Elle vient du Ciel, elle procede de Dieu, comme de sa premiere \& naturelle Origine" ${ }^{112}$. Também em Vida Divina, Nieremberg (1957), por exemplo no capítulo V, que trata do "fazer a vontade de Deus", explica que

No hay cosa que nos sea más prejudicial y dañosa que hacer la propia voluntad, que nunca se cumple sin gran daño nuestro. Que con razón es común sentencia de los santos, que la propia voluntad es raíz y origen de todos los males. Aun Aristóteles, para que uno fuese prudente y no errase en el juício de las cosas, requiere en el tal, por fundamento de la prudencia, una buena voluntad libre de amor próprio y desembarazada de afectos ${ }^{113}$.

\footnotetext{
${ }^{111}$ Rodriguez, 1834, op. cit., p. 99. "Pois os meios principais que a Religião tem para alcançar a perfeição são os três votos essenciais que fazemos, de pobreza, castidade e obediência" (tradução nossa).

112 Nieremberg, 1657, op. cit., p. 473. "Por quem a inconstância e a impetuosidade das paixões serão melhor vencidas que pela Razão? É dela que a Verdade tira seu Ser; Ela vem do Céu, ela procede de Deus, como de sua primeira e natural Origem" (tradução nossa).

${ }^{113}$ Nieremberg, 1957, op. cit., p. 16. "Não existe coisa que nos seja mais prejudicial e danosa que fazer a própria vontade, que nunca se cumpre sem grande dano nosso. Com razão é sentença comum dos santos que a própria vontade é raiz e origem de todos os males. Também Aristóteles diz que para que uma pessoa seja prudente e não erre no juízo das coisas, se requer nele, por fundamento da prudência, uma boa vontade livre de amor próprio e desembaraçada de afetos" (tradução nossa).
} 
Em seguida a isso, começa a falar da necessidade de mortificação das paixões.

Podemos perceber daí que a experiência-modelo de Inácio, dada como prescrição nos textos normativos da espiritualidade, assim como naqueles que ordenam a estrutura institucional desta ordem religiosa, é atualizada na própria vida de quem escreve. Aparelho filosófico e regras são atualizados, e vividos como experiência espiritual e, em seguida, depois de comparados aos textos normativos da espiritualidade jesuítica, são dados ao conhecimento, como passos-modelares - como prescrição, como prática levada a um fim e testemunhada.

Temos portanto, todo o processo de análise - tal como se verificará nos capítulos subseqüentes a esse - assim desenhado: de um lado aqueles pólos compreensivos (dinamicamente interligados), de outro as Indipetae $\mathrm{e}$, entre eles, os textos de espiritualidade. As Indipetae, como fonte documental pouco estruturada do ponto de vista dos aspectos de análise até aqui descritos, não podem ser interpretadas de maneira imediata. São, sim, documentos marcados por aquele aparelho pedagógico de ordenação do homem, mas para identificar os fundamentos desse aparelho é necessário um revelador, algo que torne presente, que represente, que transpareça essa estrutura subterrânea. Certo, há, nas Indipetae, uma elaboração da experiência, no entanto, não se trata de uma elaboração sistemática, reveladora. O grau de elaboração - se podemos dizer assim presente nos textos de espiritualidade, é de uma profundidade tal que permite, se colocado entre um e outro dos tipos de documentos, vir à tona aquela estrutura profunda. Como são documentos que se propõem ao leitor como prescrição de uma espiritualidade com traços jesuíticos, revelam com maior clareza os fundamentos do aparelho pedagógico de ordenação do homem que o sustenta. 
Esses textos são uma espécie de espelho translúcido: ao mesmo tempo em que revelam a estrutura subterrânea das Indipetae, desvelam a si mesmos, ao espelharem aqueles pólos. 


\section{CAPÍTULO 5 A liberdade e as Indipetae}

Lendo nas Indipetae frases tais como, a memória dos desejos "me ayuda [...] para la resignacion que en todas las cosas y obediencia pide Nuestro Santo Instituto", ou resolvi "hacer lo que sentia ser obligado, para corresponder a las inspirationes de Nuestro Señor", ou "mucho he deseado siempre en este negoçio, ser embiado sin petiçion mia"3... poderíamos nos perguntar: se realizar uma escolha é um ato da liberdade, como uma escolha necessária, ou uma escolha por subordinação - "ser obligado" - pode ser um ato livre? Ou, em outros termos, como é possível experimentar consolação, numa escolha "obediente"4 ou "obrigada" ? Em que medida um desejo e a resignação ou a obediência podem ser colocados numa mesma expressão? Que dinâmica subterrânea sustenta o desejo destes sujeitos - suas escolhas possíveis - a ponto de esperar "ser embiado sin petiçion" ${ }^{6}$ ?

\footnotetext{
${ }^{1}$ ARSI, Indipetae Hispanae, FG 758, carta n. 4.

${ }^{2}$ ARSI, Indipetae Hispanae, FG 758, carta n. 13.

${ }^{3}$ ARSI, Indipetae Hispanae, FG 758, carta n. 43.

${ }^{4}$ Cf. ARSI, Indipetae Hispanae, FG 758, carta n. 4, no anexo 1.

${ }^{5}$ Cf. ARSI, Indipetae Hispanae, FG 758, carta n. 13, no anexo 1.

${ }^{6}$ Cf. ARSI, Indipetae Hispanae, FG 758, carta n. 43, no anexo 1.
} 
O que propomos nesse capítulo é justamente trazer à luz esse subterrâneo, analisando a concepção de liberdade que está por trás de um tal dinamismo. Descreveremos, nesse sentido, esta categoria, analisando cada um daqueles documentos que compõem nosso corpus documental. A análise será feita, a princípio, obedecendo àquela divisão entre os documentos do ponto de vista de seus conteúdos: os carregados de conteúdo da casuística aristotélicotomista e da retórica (scholicorum), os que trazem conteúdo propriamente normativo da vida de espiritualidade (ratio spiritualis), os textos jurídicos em geral (ratio institutorum) e, finalmente, os escritos espirituais produzidos na Companhia de Jesus no período do generalato do P.e Cláudio Aquaviva, que fundamentam a formação destes indipetentes.

\section{1) A liberdade e o scholicorum}

Antes de adentrarmos o texto representativo da formação filosófico-retórica, importa lançar mão de algumas premissas teóricas que sustentam a visão de homem subjacente ao documento analisado.

Já sabemos que os Manuais Conimbricenses são um importante representante da filosofia, que nos séculos XVI e XVII, foi denominada de Segunda Escolástica ${ }^{7}$. Assim sendo, a concepção de homem que está por trás da produção desses manuais é aquela que nasce da releitura tomista da obra aristotélica. Podemos descrever o modelo aristotélico-tomista da topografia da alma da seguinte maneira: a alma é dividida em três graus de perfeição - do mais baixo para o mais alto - em alma vegetativa, alma sensitiva e alma racional. A cada um

\footnotetext{
${ }^{7}$ A também assim chamada Escolástica tardia é "um dos mais importantes movimentos culturais da Europa dos séculos XVI e XVII” (p. 3). Massimi, Marina (1999b). O lugar dos conhecimentos psicológicos na cultura lusobrasileira do século XVI ao século XVII. Estudos em História da Psicologia 1. São Paulo: EDUC. Zanlonghi (2003), em estudo sobre a retórica jesuítica afirma que o "renascimento da escolástica iniciada pelo domenicando Francisco de Vitoria, em Salamanca, 'a universidade que foi no século XVII aquilo que Paris foi no século XIII', se irradiava nas universidades espanholas, portuguesas e alemãs e chegava, em particular, à de Coimbra, que se tornou no final do século XVI sede privilegiada de instalação dos grandes mestres da Companhia de Jesus” (p. 63). Cf. Zanlonghi, Giovanna (2003). La psicologia e il teatro nella riflessione gesuitica europea del Cinque-Seicento. Memorandum, 4, 61-85. Retirado em 12/08/2003, do World Wide Web: http:// www.fafich.ufmg.br/ memorandum/ artigos04/ zanlonghi01.htm (tradução nossa).
} 
desses graus, correspondem potências específicas ${ }^{8}$; assim, temos: as potências da alma vegetativa, que são se nutrir, crescer e se multiplicar; as potências da alma sensitiva que são externas (visão, audição, olfato, paladar e tato) ou internas (senso comum, imaginação, pensamento e memória), além das chamadas potências sensitivas apetitivas gerais (apetite irascível e apetite concupiscível); e, finalmente, as potências da alma racional que são o intelecto (potência racional cognitiva) e a vontade (potência racional apetitiva) ${ }^{9}$.

Ainda dentro dessa visão de homem, podemos apresentar também uma importante questão - própria da Casuística (Casos ou Filosofia Moral) escolástica - que se encontra discutida e difundida nesse modelo: como é possível à retórica, que trabalha preferentemente com os sentidos - agindo sobre a alma sensitiva -, interferir na alma racional, movendo, por exemplo, a vontade? Se retomarmos uma das máximas da Patrística que, junto com os “doutores escolásticos"10, guiava o projeto pedagógico jesuítico, começaremos a ver se delinear uma resposta: nada é objeto de volição se não for antes objeto da razão. A vontade, pois, enquanto potência daquela alma que define o humano, pressupõe um conhecimento prévio do objeto. Mas a vontade - potência de substância igual à da alma - age sobre o apetite sensitivo (sejam os sentidos externos ou internos), que é uma faculdade corpórea. É fácil ver se resolver a aparente contradição: inúmeras vezes, na experiência cotidiana, podemos identificar momentos em que os apetites e as paixões interferem sobre o conhecimento e sobre o livre-arbítrio, como veremos mais detalhadamente adiante. O que não significa que a vontade também não aja sobre os apetites.

$\mathrm{Na}$ perspectiva dos Comentários Conimbricenses, as paixões (como eram denominados os apetites sensitivos) não são apenas um aspecto desordenado, perturbado e

\footnotetext{
${ }^{8}$ Lembremo-nos ainda que "potentia est principium per quod anima operatur" (Saint-Paul, Eustache de (1611), Summa philosophiae quadrapartita. Cit. por Bergamo, Mino (1994). L'anatomie de l'âme: de François de Sales à Fénelon. Grenoble: Jérôme Millon, p. 38).

${ }^{9}$ Cf. Ibid., pp. 35-39.

${ }^{10}$ Loyola, Ignace de (1991). Écrits (M. Giuliani, trad., pres. et dir.). Paris: Desclée de Brouwer, p. 250, tradução nossa.
} 
indigno do homem; as paixões são reconhecidamente neutras, ou seja, a desordem não é inerente à paixão, mas aos objetos para os quais, por vezes, elas se voltam: voltando-se para um mal fim, estão desordenadas e precisam, portanto, ser exercitadas, reordenadas para um fim adequado, para um Bem, da mesma maneira que - usando uma metáfora celeste - as esferas inferiores se ordenam pelas esferas superiores dos céus ${ }^{11}$.

O homem, nessa concepção, é imago do Corpo de Cristo, o Verbo Encarnado. A Encarnação de Cristo - assim como a alma racional encarnada no corpo - não significa uma mortificação da plenitude do Verbo, mas sim uma valorização do humano. O que define o homem é antes sua analogia com o Verbo Divino, ou seja, sua alma racional. Trata-se pois, em poucas palavras, de uma antropologia que se apoia sobre a confiança na capacidade de construção da pessoa através da experiência sensível/intelectiva ${ }^{12}$ : ao mesmo tempo em que reconhece a infinita potencialidade cognoscitiva do homem, a reconduz realisticamente à sua finitude, na medida em que afirma a necessidade de que se parta dos dados sensíveis, ou seja, tanto do que os sentidos externos recolhem quanto das phantasmata construídas a partir do ambiente cultural ${ }^{13}$.

Finalmente, e sabido que de forma geral a pedagogia jesuítica praticada nos colégios dedicava a maior parte do espaço curricular a Aristóteles ${ }^{14}$, importa esclarecer que o principal

\footnotetext{
${ }^{11}$ Essa não é uma imagem incomum; de fato, nessa concepção de homem, ele é um microcosmos, um espelho do macrocosmos, conforme Platão descreve no Timeu. Delumeau (2003), de fato, escreve: "A perfeição do círculo serviu muito tempo para evocar e explicar a correspondência entre o homem e o mundo, o microcosmo e o macrocosmo: concepção dos antigos sobre o homem como resumo do universo, que a Idade Média transmitiu à Renascença. Proclus (falecido em 485), comentando o Timeu de Platão, escreve: 'O homem é um microcosmo e tudo o que está no cosmo, sob forma divina e total, encontra-se parcialmente no homem' (Proclus, Commentaire du Timée, prólogo, Paris, Vrin, 1966, 28-29). Portanto, se o mundo é uma esfera, o homem, que o resume, inscreve-se logicamente em um círculo”. Delumeau, Jean (2003). O que sobrou do paraíso? (M. L. Machado, Trad.). São Paulo: Companhia das Letras (original francês de 2000), p. 285.

12 Assim se refere Zanlonghi (2003): "a pedagogia jesuítica, na procura de um equilíbrio entre as exigências do intelecto e da sensibilidade, pretendia forjar a pessoa segundo o princípio moral da moderação: mas educar à moderação significava não apenas, em negativo, censurar mas também promover o substrato humano da comunicação, ensinando a dar corpo à palavra: a virtude não destrói a natureza, mas a corrige" (Zanlonghi, 2003,, op. cit., p. 73, tradução nossa).

${ }^{13}$ Cf. Ibid., pp. 74-75.

14 As Constituições dizem claramente: “em lógica, em filosofia natural e moral, seguir-se-á a doutrina de Aristóteles, assim como nas outras Artes liberaris” (Loyola, 1991, p. 507, tradução nossa).
} 
método de aprendizagem utilizando em suas instituições de ensino universitário eram as disputas filosóficas, que seguiam uma dinâmica muito semelhante à didática platônicoaristotélica. As quaestiones disputatae nada mais eram que uma análise dialética de uma determinada afirmação ${ }^{15}$ : um diálogo com a intenção de encontrar a Verdade.

Assim introduzidos, passemos ao Manual Conimbricense sobre a Ética a Nicômaco, de autoria do Padre Manuel de Góis. No proêmio da obra, o autor justifica a necessidade de "ver o que é honesto, o que é desonesto, o que se deve aceitar ou repelir"16 para "filosofar rectamente, tal como para se viver bem e felizmente"17. Segundo ele, o Curso Conimbricense tem um papel muito específico: não se trata tanto de propor as diversas interpretações feitas à obra aristotélica, mas de apresentar aos alunos de filosofia, "no espaço dos anos que lhes está prescrito" ${ }^{\prime 18}$ a obra do Estagirita.

Especificamente sobre a obra em questão, Góis (1593) afirma que seu objetivo é "ensinar o modo de viver honestamente, instruir na probidade dos costumes e levar ao feliz estado da vida"19. Nesse sentido, estabelece uma divisão importante no que concerne aos âmbitos no qual influencia e age esse felicem vitae statum: o do homem considerado em si mesmo (Ethicam), o da família (Oeconomicam) e o da "República ideal” $(\text { Politicam })^{20}$, de tal forma que a Ethica é considerado o saber que precede a todos os outros dois "porque disputa acerca de cousa mais simples, a saber, a conformação do homem individual"21 .

\footnotetext{
${ }^{15}$ García-Mateo (1998) assim descreve: "se começava por examinar as razões que estavam a favor de una sentença; depois, todas as que se pudessem propor contra. Uma vez que o auditório estava na presença de ambas as posições, o defensor de uma delas explica sua eleição, a defende e refuta as contrárias. A argumentação tinha sempre, como base formal de discussão, o silogismo". García-Mateo, Rogelio (1998). Fuentes filosóficoteológicas de los ejercicios según el currículum académico de su autor. Em Plazaola, Juan (1998) (ed.). Las fuentes de los Ejercicios Espirituales de San Ignacio. Actas del Simposio Internacional (Loyola, 15-19 septiembre 1997). Bilbao: Ediciones Mensajero, p. 474, tradução nossa.

${ }^{16}$ Góis, Manuel de (1593). Disputas do Curso Conimbricense sobre os livros de Moral a Nicómaco de Aristóteles em que se contêm alguns dos principais capítulos da moral. Lisboa: Oficina de Simão Lopes, p. 59.

${ }^{17}$ Ibid., p. 59.

${ }^{18}$ Ibid., p. 59.

${ }^{19}$ Ibid., p. 59.

${ }^{20}$ Ibid., p. 61.

${ }^{21}$ Ibid., p. 61.
} 
Em seguida, Góis (1593) fala acerca da obra que será objeto do comentário e procura tirar toda dúvida acerca de sua autoria: argumentação importante se se pensa o lugar ocupado por Aristóteles na Segunda Escolástica ibérica.

Deve, porém, afirmar-se com a opinião comum de outros intérpretes, que estes livros são aristotélicos, como o justifica a harmonia da doutrina, a brevidade e o peso das sentenças, o aguilhão dos argumentos, o contexto da dicção e todo o modo de ensinar. Igualmente porque no fim desta obra o Autor remete o leitor para os seus livros da República ou da Política e no livro sexto, capítulo 3, para os seus Analíticos - obra esta que consta ser aristotélica. Denominamse, pois, esses livros, nicómacos, não porque tenham sido compostos por Nicómaco, mas porque são de Nicómaco, isto é, não só intitulados a Nicómaco, mas também presenteados pela afeição paternal ${ }^{22}$.

Finalmente, antes ainda de dar início às disputas, apresenta o texto aristotélico, elencando brevemente o conteúdo de cada livro da Ética a Nicômaco.

A primeira disputa procura esclarecer o que seja o Bem. As quaestiones discutidas encaminham o leitor a concluir que Bem é aquilo a que todos os seres apetecem, por ser honesto, útil e/ou agradável; de forma que o apetite mais perfeito será aquele que tende para o Sumo Bem - qual seja: o amor de Deus -, que assume ao mesmo tempo as características de honesto, útil e agradável.

A disputatio secunda, que procura esclarecer o que seja o Fim, afirma que este é aquilo por cuja causa tudo se faz. Interessante notar também que nessa disputatio se discute qual seja o papel da alma racional humana: segundo a obra, a natureza intelectual do homem se define pela ação dirigida a um fim, ou seja, uma ação só pode ser designada com o genitivo "do homem" na medida em que é necessariamente teleológica.

Ao falar da felicidade, Góis (1593) discute, inicialmente, que tipo de bem é a felicidade: um bem externo ou interno? Do corpo ou da alma? As conclusiones que se seguem afirmam que a felicidade é um bem da alma, ou seja, é um Bem próprio da operação da alma

\footnotetext{
${ }^{22}$ Ibid., p. 65.
} 
racional, produzida pela potência intelectiva, conforme à reta razão, praticada ao longo de uma vida que busca a perfeição ${ }^{23}$. De tal forma que a contemplação, na medida em que é uma operação da alma racional, é mais perfeita que a ação. O que não implica dizer que as ações do homem não estejam também dirigidas para a felicidade, enquanto que buscam igualmente o Bem e o Fim últimos da vida. Com isso, o autor chega a afirmar que a ação é a manifestação formal da liberdade do homem.

É bem verdade que o filósofo conimbricense parte da seguinte premissa aristotélica: “o modo próprio de operar do homem, enquanto se distingue dos animais, é agir de tal forma que gere o domínio e a liberdade de suas ações" ${ }^{24}$. No entanto, fazendo uso do método escolástico, ele se pergunta: será livre a ação humana? E conclui, finalmente, que sim, o afirmando a partir do seguinte argumento: o homem age conforme uma deliberação anterior, ou seja, conforme sua vontade deliberada que deve sempre ser regida pela razão ${ }^{25}$.

Continuando a dinâmica de questão e resposta, ele se pergunta: será a vontade do homem livre? Não será ela movida pelo intelecto ou pelos apetites? Góis (1593) explica a controvérsia da seguinte forma: a vontade vive uma espécie de relação dialética com o intelecto e com o apetite sensitivo. No caso da relação com o intelecto ${ }^{26}$, é este que propõe o objeto de deliberação da vontade - o Bem e o Fim últimos. À vontade cabe ser o movente da ação. Assim, a vontade move e é movida pelo intelecto: o intelecto move a vontade quanto ao exercício, mas a vontade move o intelecto quanto à espécie. Segundo Góis (1593), é preciso que fique claro que a vontade move ativamente todas as faculdades da alma, algumas com poder despótico, outras com poder político. O que isso significa?

\footnotetext{
${ }^{23}$ Cf., ibid., pp. 127-131.

${ }^{24}$ Ibid., p. 139.

${ }^{25}$ Assim diz o texto: "todos os actos humanos partem da vontade livre do homem - o que se mostra porque, embora a raiz da liberdade esteja no intelecto, contudo a liberdade formal é só da vontade (...). Torna-se evidente, pelo fato de se dizer liberdade, enquanto elegemos alguma coisa na medida em que agrada. A eleição, porém, dirige-se para o bem, o qual como é objeto da vontade, traz como conseqüência que a liberdade formal pertence à vontade. (...) Por isso, não haverá absolutamente nenhum ato humano que não nasça da vontade" (Ibid., p. 139).

${ }^{26}$ Cf. ibid., pp. 141-145.
} 
Poder despótico é aquele com que o senhor dá ordens aos escravos, que não têm possibilidades de resistir, visto não possuírem nenhum direito. Poder político é aquele com que o Príncipe impera aos cidadãos que lhe obedecem às ordens. Mas como são livres, têm alguma coisa de seu com que possam resistir ao poder dele ${ }^{27}$.

Essa questão se esclarece melhor quando o autor discute a relação entre a vontade e o apetite sensitivo. Em diversos momentos ao longo do texto, fazendo uso do método de construção do saber a partir da atenção à experiência, Góis (1593) apela:

que o apetite seja movido pela vontade demonstra-o a experiência, visto que muitas vezes provocamos ou reprimimos os movimentos dele, segundo o nosso arbítrio, [no entanto] que tal sujeição não é despótica, aparece claramente no fato de a cada passo o apetite ser levado para o bem sensível contra o juízo da razão e o afeto da vontade ${ }^{28}$.

Entretanto, levando-se em consideração uma determinada escala hierárquica de moventes e movidos - a vontade move o apetite, que move o corpo -, é mais excelente e virtuoso, mais perfeito, mais de acordo com a natureza do homem, deixar-se mover pelo mais nobre do que desejar mover o inferior, assim como é mais excelente "obedecer ao Rei no Paço, do que mandar no tugúrio"29.

Sem nos determos mais à descrição dos passos que se seguem ao longo da obra e já apresentando uma conclusão, podemos dizer que a liberdade pressupõe o uso da razão: todos os atos humanos nascem da vontade, que só é livre na medida em que é precedida de deliberação do intelecto, ou seja, pressupõe-se o uso reto da razão - que sempre, por sua natureza mesma, busca o Bem e o Fim últimos da vida. Ao contrário, não é livre e conseqüentemente menos humano - vicioso - aquele ato que se deixa mover apenas pelos apetites sensitivos, especialmente quando estes, de tão veementes, perturbam a vontade e a impedem de deliberar retamente. O homem será mais excelente, mais virtuoso, na medida em que se deixar conduzir por sua razão, e não na medida em que tentar dominar seus apetites.

Essa definição da categoria filosófica "liberdade" nos termos em que aparecem no

\footnotetext{
${ }^{27}$ Ibid., p. 151

${ }^{28}$ Ibid., p. 153.

${ }^{29}$ Ibid., p. 157.
} 
Curso Conimbricense não é apenas uma abstração, com a qual nossos jovens indipetentes lidavam como conteúdo de discussão ou de Disputationes em suas classes de Casos ou Teologia Moral. Como a liberdade, aqui entendida e dada a entender apenas categoricamente, é sustentada como experiência, é parte do modus vivendi dos jovens jesuítas em formação? Para responder a esta questão, procuramos as fontes do segundo tipo.

\section{2) A liberdade na ratio spiritualis}

Na terça-feira dia 26 de fevereiro de 1544, em seu Diário de Moções Espirituais, Inácio relata estar "mais satisfeito e mais contente de deixar-me governar pela divina Majestade ${ }^{, 30}$. O que ele quer dizer com isso?

Se entendemos que essa, assim chamada, moção espiritual ou interior é o "movimento ou inclinação da vontade pela graça de Deus, que não suprime a liberdade humana, mas a move pelo bem que lhe mostra" 31 , fica claro que tal "deixar-se governar" está estreitamente vinculado à realização da pessoa, tanto é verdade que o próprio Inácio, dias mais tarde, afirma: "Seguindo-vos, meu Senhor, eu não poderei me perder" ${ }^{32}$. Esta alegria é, pois, a alegria de encontrar e ver realizada sua próprio humanidade. Mas, fica ainda uma pergunta: em que sentido "buscar a vontade de Deus em toda a sua perfeição e beneplácito",33 ou não afirmar nada "de nossa própria cabeça e entendimento, mas só o que o Senhor nos inspirar" 34 é capaz de realizar a humanidade de uma pessoa? Ou, em outras palavras: em que sentido, obedecendo me torno livre realmente, ou seja, realizado $?^{35}$

\footnotetext{
${ }^{30}$ Loyola, 1991, op. cit., p. 344 (tradução nossa).

${ }^{31}$ Cardoso, Armando (1977). Introdução. Em Loyola, Inácio de (1977). Diário Espiritual (A. Cardoso, trad. e org.). São Paulo: Ed. Loyola, p. 19.

32 Loyola, 1991, op. cit., p. 350 (tradução e grifo nossos).

${ }^{33}$ Do anexo à Loyola, 1977, op. cit., p. 86.

${ }^{34}$ Ibid., p. 88.

35 Apesar de essas perguntas nos permitirem (e mesmo nos exigirem) uma discussão que adentre o texto das Constituições (especialmente o capítulo primeiro da sexta parte, denominado "Quanto ao que concerne à obediência"), permaneceremos ainda no âmbito estritamente delimitado por aquilo que compreendemos como os textos da ratio spiritualis. Importa esclarecer outra vez que esta divisão é apenas metodológica.
} 
Lembremo-nos que o caminho proposto por Inácio - em tudo coerente com a tradição aristotélico-tomista da Segunda Escolástica dos séculos XVI e XVII - é um caminho que leva à "liberdade real" "36: deixando-se governar pela Graça Divina, obedecendo à Sua Vontade, adere-se ao Ser, participa-se dEle como "um só espírito", deixa-se causar livremente por Aquele que é a consistência última e inexorável da humanidade e do homem individual.

A tópica da "eleição por conformidade" ou da "obediência" se esclarece neste horizonte apenas esboçado. Para dar forma mais clara a este horizonte, será preciso considerar uma outra tópica comum dos anos quinhetos e seiscentos ibéricos: o "desengano" ou "desconcerto do mundo". Trata-se daquele lugar comum que buscava descrever a inconsistência de per se da realidade: a brevidade da vida, a efemeridade da existência e da passagem do tempo. Tema já presente, por exemplo, no chamado de atenção do apóstolo Paulo, na carta enviada aos cristãos de Corinto: "passa a figura deste mundo" ${ }^{37}$, ou seja, toda a realidade corre para o nada, as coisas todas são instáveis, fugazes, mutáveis. Se as coisas do mundo são assim inconsistentes, o sentido do tempo é cuidar do que é consistente, imutável, estável, eterno: temporal X eterno; onde o temporal só tem valor se usado em função dos bens eternos.

O "desengano" - este trabalho pessoal de fugir do engano a que se é induzido pela aparência do mundo - coincide exatamente com este juízo acerca do uso do temporal:

não corresponde apenas a um sentimento psicológico da vida, mas sugere uma modalidade de uso das coisas e dos relacionamentos na consciência de sua paradoxal dimensão passageira e definitiva. Em suma o significado temporal de cada coisa e pessoa só pode ser adequadamente afirmado na consideração de seu sentido último ${ }^{38}$.

Trata-se, portanto, de um verdadeiro conhecimento da realidade, onde o indivíduo é

\footnotetext{
${ }^{36}$ Fernández-Martos, J. M. (1991). La incorporación de la realidad como clave del cambio en los Ejercicios Espirituales. Em Alemany, Carlos e Garcia-Monge, José A. (ed.) (1991). Psicologia y Ejercicios Ignacianos (vol I): la transformación del yo en la experiencia de Ejercicios Espirituales. Bilbao: Mensajero e Sal Terrae, p. 265 (tradução nossa).

37 Cor 7,29.

${ }^{38}$ Massimi, M. (2001) Identidade, Tempo, Profecia na visão de Padre Antônio Vieira. Memorandum, 1, 13-32. Retirado em 10/10/01, do World Wide Web: http:// www.fafich.ufmg.br/ memorandum/ artigos01/ massimi01.htm, p. 23.
} 
chamado a apreender o sentido das coisas, pessoas e fatos presente, ainda que velado pelas aparências, imagens, "figuras" do mundo.

Se o temporal é enganador, a atitude razoável, a atitude adequada à ordo na qual ratio e natura humana se realizam perfeitamente, é aquela da subordinação à Verdade Eterna, ou de uma escolha conformada à Providência Divina: obediência, portanto ${ }^{39}$.

Pécora (1998) explica que a Providência, segundo o pregador jesuíta Padre Antônio Vieira, é uma "disposição ordenada dos decretos divinos", assim "ela pode se conciliar perfeitamente com a escolha humana, em virtude da 'conformidade', quer dizer, em virtude de nossa capacidade de nos conformarmos voluntariamente às ordens de Deus" ${ }^{\text {40 }}$. De maneira que, "pela obediência, participamos da Providência" ${ }^{41}$ : através da obediência, o ato humano se conforma à vontade de Deus, sendo, portanto, a obediência de conformidade mais perfeita que a obediência de deliberação, porque pela conformidade, o ato além de humano é divino:

On remarque, en premier lieu, que le providentiel, dont la mort serait l'outil privilégié, ne se soucie ni du mondain ni du passager, mais seulement du spirituel et de l'éternel. On en tire la conclusion, jésuitique par excellence, que se conformer à la Providence, sans révolte, fait de celle-ci un véritable bien de l'homme. Ce qui veut dire qu'en acceptant la mort, on atteint la véritable réalité de ce qu'elle semblait nier: la vie bienheureuse de laquelle jeunesse, beauté et intelligence n'étaient que faux-semblants ${ }^{42}$.

Percebe-se que, aqui, a pergunta que está por trás desta dinâmica que o homem vive

\footnotetext{
${ }^{39}$ Pécora (1998), tratando dos sermões fúnebres do Padre Antônio Vieira, descreve o que o pregador jesuíta diz em seu sermão das exéquias de D. Maria: "Dans le seconde moitié du sermon, élaborée comme une réfutation de la première, Vieira fait parler la Providence pour mieux répondre aux plaintes antérieurement formulées contre elle. Ainsi, en ce qui concerne la morte prématurée, le jésuite n'y voit aucune négligence, mais, au contraire, une concession de grâce faite à $\mathrm{D}$. Maria afin d'éterniser son âge'. Il existe donc une préoccupation divine pour que, en perdant des jours en ce monde, elle puisse 'les multiplier' dans la vie éternelle des bienheureux. Il réfute, de même, la plainte motivée par la perte de la beauté: D. Maria n'a fait que troquer une beauté mineure pour une plus grande, celle du corps contre celle de l'esprit. En associant l'argument aux lieux de détrompement et vanitas, Vieira remarque encore que, outre l'avantage de cet échange d'une beauté physique pour une beauté spirituelle, la mort précoce l'a sauvée de l'inexorable ruine de cette beauté au long des années. Pour finir, la 'discrétion', n'aurait pas non plus de raison de se plaindre puisque la plus grande discrétion consiste en 'savoir mourir' et non pas en 'savoir dire'. La mort seule permet de distinguer le discret véritable: ce n'est qu'au moment des choix définitifs qu'on en observe la réussite ou l'erreur". Pécora, Alcir (1998). Les sermons funèbres du padre Vieira. Em Mattoso, Katia de Queiroz (org.) (1998). Naissance du Brésil moderne (pp. 194202). Paris: Presses de l'Université de Paris-Sorbonne, pp. 194-195.

${ }^{40}$ Ibid., p. 195.

${ }^{41}$ Ibid., p. 195.

${ }^{42}$ Ibid., p. 196.
} 
diante da aparência do mundo e da Providência, diante da sorte e da morte em oposição à eternidade, é a pergunta que o salmista faz: "quando vejo o céu, obra dos teus dedos, a lua e as estrelas que fixastes, que é o homem para dele te lembrares, e o filho do homem para que o visites?" ${ }^{43}$. De fato, diante da "presença divina oculta no visível do mundo" ${ }^{44}$, a experiência da auto-consciência pode não ser óbvia e imediata, mas é, mediada pela Igreja, uma experiência possível, direta, individual e extática. E a experiência-modelo de Inácio parece responder àquela pergunta, como escreve o P.e Câmara no Relato do Santo, quando diz que

a maior consolação que recebia era olhar o céu e as estrelas, o que ele fazia freqüentemente e durante um bom espaço de tempo, porque com isto ele sentia em si um muito grande esforço para servir nosso Senhor ${ }^{45}$.

O que Inácio entende por esta ação muito específica - "servir a Nosso Senhor”? Não se trata de um puro ato voluntarista, sem objetivo ou finalidade, mas o dinamismo vital de fazer a vontade de Deus, num movimento ascensional em direção a Ele, e impulsionado por Ele mesmo. Mas, onde está o lugar da liberdade nessa ação aparentemente "escrava" da Graça Divina? Para falarmos disso, é preciso trazer à baila as categorias de consolação e desolação: corolários de um tal "agir” ou "não agir".

Inácio, nas Regras para sentir e reconhecer de algum modo as diversas moções que se produzem na alma, as boas para as receber e as más para as rejeitar, explica que consolação é aquele inflamar da alma "no amor do seu Criador e Senhor; e não poder mais amar coisa alguma criada sobre a face da terra por si, mas somente no Criador de todas essas coisas" 46 .

Desolação, por sua vez, é exatamente o movimento contrário, de afastamento do Amor e da Vontade de Deus, portanto.

Chamo desolação (...) escuridão da alma, perturbação nela, moção a coisas baixas e terrenas, ausência de paz proveniente de diversas agitações e tentações

\footnotetext{
${ }^{43}$ S1 8, 3-4 (grifo nosso).

${ }^{44}$ Pécora, 1999, op. cit., p. 99.

${ }^{45}$ Loyola, 1991, op. cit., p. 1023 (tradução e grifo nossos).

${ }^{46}$ Ibid., p. 224 (EE. 316, tradução nossa).
} 
que levam à falta de confiança; sem esperança, sem amor a alma achando-se toda preguiçosa, tíbia, triste e como que separada do seu Criador e Senhor ${ }^{47}$.

Segundo Inácio, nas mesmas regras, a desolação tem sua fonte em Satanás - o "Inimigo da natureza humana" - que procura impedir nossa liberdade de aderir ao Sumo e Verdadeiro Bem. É aqui, justamente, onde entra a resposta àquela pergunta - onde está o homem entendido como ontologicamente livre nessa aparente "ação escrava"?

Inácio nos lembra que, mesmo sendo obra do "Inimigo da natureza humana", devemos nos servir da desolação - com a ajuda da graça -, bem como de todo o sofrimento, para progredir e nos abrir mais à ação de Deus e à consolação que Ele promete àqueles que fazem Sua Vontade. Nessa iniciativa do homem - que passa basicamente pelo tripé oração-examepenitência - o homem age não mais como "escravo"; porque então se trata de uma iniciativa que nasce do juízo acerca da própria experiência, onde "usamos dos atos da inteligência, quando refletimos e dos da vontade, quando experimentamos sentimentos" que é solicitado nessa iniciativa, é o homem internamente ordenado ${ }^{49}$.

Isso fica ainda mais claro se nos remetemos ao título dos Exercícios Espirituais Exercícios Espirituais para se vencer a si mesmo e ordenar sua vida sem se determinar por nenhuma afeição desordenada ${ }^{50}$-, que aponta para a sua intencionalidade última: o restabelecimento da ordem interna do homem, o retorno à consciência do bem real a que todo homem deseja, a partir da supressão de todo o apego aos bens aparentes que dificulta a livre atividade de suas forças e as impedem de se submeter à Vontade Divina. Nesse sentido, os Exercícios Espirituais são um método para encontrar a Deus que se revela, uma possibilidade concreta na qual o homem, libertado pela Graça de Cristo, aprende a aderir, por uma escolha

\footnotetext{
${ }^{47}$ Ibid., p. 224 (EE. 317, tradução nossa).

${ }^{48}$ Ibid., p. 48 (EE. 3, tradução nossa).

${ }^{49}$ Ou seja, o homem livre das afeições desordenadas, que são aqueles desejos (conscientes ou inconscientes) do homem, que o levam a se afastar de Deus, e pelos quais tende a se desviar e a sair da ordem estabelecida por Deus, na qual tudo converge para Cristo, e nEle para o Pai. É importante lembrar que a ordenação é um processo, como já foi dito, que envolve o entendimento e a vontade: o entendimento para reconhecer o Verdadeiro Bem que orienta a vida; a vontade para mobilizar o afeto no sentido desse Bem.

${ }^{50}$ Ibid., p. 62 (EE. 21, tradução nossa).
} 
cada vez mais lúcida, esclarecida e livre, à ação do Espírito Santo.

Desse modo, se o homem considera o fim para que foi criado, se se torna indiferente, se afasta as afeições desordenadas, é então capaz de escolher aquilo que é ad maiorem Dei gloriam:

É preciso ter por objetivo o fim para que fui criado: louvar a Deus nosso Senhor e salvar minha alma; além disso, eu devo me encontrar indiferente, sem nenhuma afeição desordenada, de tal maneira que eu não seja mais inclinado ou afeiçoado a me prender à coisa visada que a perdê-la, nem mais a deixá-la que a mantê-la. Mas que eu me atenha ao meio, como numa balança, para seguir aquilo que eu sentirei ser mais para a glória e o louvor de Deus nosso Senhor e salvação de minha alma ${ }^{51}$.

Inácio faz uso da categoria da "indiferença" para designar esse passo de diferenciação entre o homem e a realidade ${ }^{52}$. Caberá à indiferença permitir ao homem, na distância, vislumbrar o verdadeiro sentido do real, de modo que se possa melhor inteligir o que o circunda.

Assim entendida e descrita, a indiferença se torna fator fundamental para uma experiência de liberdade. Sem a indiferença, parece impossível o perfeito uso das faculdades da alma, o que torna remoto todo sentido, pensamento e oração. No entanto, é preciso ter claro que o homem é uma dinâmica de emersão e imersão da e na realidade, de forma que a experiência definitiva de liberdade é ainda e somente promessa evangélica: a perfeição e a consolação eterna são prometidas àqueles que forem radicalmente fiéis a Deus e o seguirem, esvaziando-se de si mesmos, e se dispuserem a realizar Sua Vontade. Por isso, já no início dos Exercícios Espirituais, Inácio lembra que

Muito se aproveita ao exercitante entrar neles com um coração largo $e$ grande generosidade para com seu Criador e Senhor, oferecendo-lhe todo o seu querer e toda a sua liberdade, para que sua divina Majestade se sirva de sua pessoa bem como de tudo o que possui, conforme a sua santíssima vontade ${ }^{53}$.

Mais à frente, na Contemplação para Alcançar o Amor, Inácio insiste na oferta da

\footnotetext{
${ }^{51}$ Ibid., p. 144 (EE. 179, tradução nossa).

${ }^{52}$ Cf. Fernández-Martos, 1991, op. cit., pp. 246-247.

${ }^{53}$ Loyola, 1991, op. cit., p. 50 (EE. 5, tradução nossa).
} 
própria vida como pedido para ser disponível à Vontade de Deus:

Tomai, Senhor, e recebei toda minha liberdade, minha memória, minha inteligência e toda minha vontade; tudo o que tenho e tudo o que possuo; Vós me destes; a vós, Senhor, o restituo. Tudo é vosso, de tudo disponde segundo a vossa inteira vontade. Permiti-me vos amar, dai-me a vossa graça, que isso me basta ${ }^{54}$.

Outro aspecto importante para ser considerado na análise dos Exercícios Espirituais é o que se refere à proposta da Primeira Semana: a meditação dos pecados e de suas consequiências. A dinâmica sugerida passa pela meditação do pecado dos anjos, do pecado de Adão e Eva e, finalmente, dos pecados particulares dos homens ${ }^{55}$.

Olhando para o próprio pecado e limitação, o homem é capaz de reconhecer-se participante de uma mesma dinâmica universal - a da queda. Além disso, meditando o amor de Cristo que pagou o preço do resgate do seu pecado, se entregando à morte de Cruz, para recolocála na sua posição original, para fazer emergir sua humanidade verdadeira ("imagem e semelhança"), o homem então, partindo da justa pergunta "o que fiz por Cristo, o que faço por Cristo e o que devo fazer por Cristo?" ${ }^{56}$, é capaz de um compromisso apostólico e missionário com a realidade baseado na eleição e oblação que nasce de uma identificação com Cristo.

E é justamente essa identificação o objetivo da Segunda Semana: onde Inácio propõe "amar e seguir mais" a Cristo ${ }^{57}$, imitá-Lo ${ }^{58}$, “assemelhar-se a Ele mais efetivamente" ${ }^{, 59}$, servi-Lo ${ }^{60}$, participar de Seus sentimentos ${ }^{61}$, ter um "conhecimento interior do Senhor" ${ }^{\prime 2}$, visando, com fórmulas como essas, dar instrumentos para quem faz

\footnotetext{
${ }^{54}$ Ibid., p. 172 (EE. 234, tradução nossa).

${ }^{55}$ Assim diz a letra do texto: "Trazer à memória o pecado dos anjos: como, tendo sido criados na graça, não querendo ajudar-se da sua liberdade para render reverência e obediência a seu Criador e Senhor, caíram no orgulho, passaram da graça à malícia e foram cassados do céu para o inferno. Percorrer em seguida o tema mais detalhadamente com a inteligência; em seguida mover mais os sentimentos com a vontade". Ibid., p. 82 (EE. 50, tradução e grifo nossos).

${ }^{56}$ Ibid., p. 84 (EE. 53, tradução nossa).

${ }^{57}$ Ibid., p. 108 (EE. 104), entre outros.

${ }^{58}$ Ibid., p. 106 (EE. 98), entre outros.

${ }^{59}$ Ibid., p. 136 (EE. 167), entre outros.

${ }^{60}$ Ibid., p. 136 (EE. 168), entre outros.

${ }^{61}$ No EE. 203, por exemplo, Inácio diz: "Pedir o que eu quero; o que é próprio da Paixão é pedir a dor com o Cristo doloroso" (Ibid., p. 154, tradução nossa).

${ }^{62}$ Ibid., p. 108 (EE. 104), entre outros.
} 
os Exercícios Espirituais que permitam a união da sua vontade à Vontade de Deus ${ }^{63}$ : o termo e o meio do verdadeiro amor.

Assim, tendo reconhecido o pecado, a queda da posição original, surge no homem o desejo de um novo nascimento, de uma mudança radical, de uma conversão. Esse nascimento implica também que se identifique um novo modelo para a imitação. Mas qual? Com quem? Como localizar esse "alguém" com quem se identificar para o novo nascimento?

Nesse ponto, a experiência-modelo de Inácio ajuda o "exercitante" a dar passos significativos no rumo de uma resposta. Começa, ajudando a localizar na realidade, na experiência pessoal, uma presença com quem se viva um relacionamento de identificação: alguém a quem se sirva cotidianamente. Por isso, na primeira parte desta semana, Inácio propõe meditar o serviço a um rei cristão, humano e temporal, o que era próprio dos homens de sua época. Já na segunda parte, a proposta é que se medite o serviço a Cristo, o Rei eterno, Aquele que diz ao homem:

Minha vontade é conquistar o mundo inteiro e todos os inimigos e assim entrar na glória de meu Pai; conseqüentemente quem quiser vir comigo deve penar comigo, a fim de que, seguindo-me nas penas, siga-me também na glória ${ }^{64}$.

O fundador da Companhia de Jesus quer imergir o homem na pessoa de Cristo (depois de o ter feito emergir da realidade), para que, seduzidos pela "suavidade e doçura infinitas da divindade"65, se torne óbvio no homem a rapidez e diligência "para cumprir sua santíssima vontade" ${ }^{, 66}$. Imergir na pessoa de Cristo é, finalmente, tê-Lo como modelo de imitação.

É a identificação que permite que um homem se converta em um outro, passando a sentir e se comportar do mesmo modo que o segundo: olha-se para a realidade, vive-se na realidade como esse outro - mais perfeito e realizado. Daí, se se passa a desejar mais a

\footnotetext{
${ }^{63}$ No EE. 180, Inácio diz: "Pedir a Deus nosso Senhor que ele queira mover minha vontade e colocar na minha alma aquilo que devo fazer em relação àquilo que verifiquei na meditação, que seja mais para o seu louvor e para a sua glória; refletindo bem e fielmente com minha inteligência e escolhendo conforme à sua santíssima e bondosa vontade" (Ibid., p. 144, tradução nossa).

${ }^{64}$ Loyola, 1991, op. cit., p. 104 (EE. 95, tradução nossa).

${ }^{65}$ Ibid., p. 116 (EE. 124).

${ }^{66}$ Ibid., p. 102 (EE. 91).
} 
pobreza, as injúrias, ou a estima de ignorante e louco, é porque já se iniciou definitiva e irremediavelmente o processo de identificação com Cristo, que é pobre de riquezas, cheio de injúrias e que primeiro foi tratado como ignorante e louco ${ }^{67}$.

Assim, a determinação de realizar "sua santíssima vontade" não é mais fruto de uma "vontade hercúlea" ou de uma capacidade especial de uns poucos, mas é tão somente fruto da percepção do que é, em última instância, a nossa realidade limitada.

Ainda na Segunda Semana, no Preâmbulo para Fazer Eleição, Inácio retoma os termos do Princípio e Fundamento para nos lembrar qual é o verdadeiro objetivo da vida do homem:

Em toda boa eleição, na medida em que isso dependa de nós, o olho de nossa intenção deve ser simples, olhando unicamente aquilo para que fui criado: para o louvor de Deus nosso Senhor e a salvação de minha alma. (...) Porque nós devemos nos propor em primeiro lugar, como objetivo, querer servir a Deus, que é o fim ${ }^{68}$.

Eis aqui, mais uma vez, aquela dinâmica descrita nas fontes definidas anteriormente como pertencentes ao pólo scholicorum: uma atitude iluminada pela razão e deliberada pela vontade é aquela dirigida a um fim. Mas, o que é razão ${ }^{69}$, conforme a entende Inácio e, especialmente, como aparece nos Exercícios Espirituais? Trata-se de uma faculdade espiritual que participa do dinamismo que nos impele a agir na direção do Bem. Não é exatamente a sensibilidade (sensualidad) e deve-se distinguir também do entendimento, faculdade discursiva, que de si mesma não indica nenhum impulso para o Sumo Bem. Um exemplo do uso da razão aparece nos Exercícios 97 e 98, quando Inácio diz:

\footnotetext{
${ }^{67}$ Cf. Loyola, 1991, op. cit., p. 136 (EE. 167).

${ }^{68}$ Ibid., pp. 137-138 (EE. 169, tradução nossa).

${ }^{69}$ Pécora (1999) lembra que, para um jesuíta, razão é sempre entendida do ponto de vista tomista, ou seja, é "sempre 'razão natural', isto é, potência humana que participa da lex naturalis que Deus inscreve em todo o criado e cujo funcionamento, por ter tal Causa, tende a tal Fim" (op. cit., p. 145). De novo, uma ponte com o "desengano" e com a "obediência" (e, portanto, nada paradoxalmente, com a "liberdade"): "O "engano do mundo’ é um lugar-comum do XVI e XVII - mas é preciso notar que, numa perspectiva cristã, esse engano se refere não à atribuição maniqueísta do mal ao mundo e a recusa do sensível ou da matéria, que, para os tomistas (...), participa da essência mesma do homem. O 'engano' refere-se sempre à ilusão de perpetuidade ou de autonomia substancial daquilo que apenas é ou significa na relação participada do divino. Atribuir eternidade ao temporal, estabilidade ao provisório, descuidando de que o ser, na contingência, é sobretudo analogia, eis aí a essência do engano barroco. Propõe-se, assim, a retomada do tema da vanitas (Eclesiastes 1,2), e a contrapartida dele é o desengano, sobretudo promovido pelo tempo que torna escarmentado o sujeito de suas fantasias de autonomia e independência" (p. 160).
} 
Os que quiserem mais se ligar e se distinguir em todo serviço junto de seu rei eterno e Senhor universal, não somente oferecerão suas pessoas à pena, mas ainda, agindo contra sua própria sensualidade e contra seu amor carnal e mundano, farão oferta de maior valor e maior importância, dizendo: "Eterno Senhor de todas as coisas, faço a minha oferta, com vosso favor e vossa ajuda, em presença de vossa infinita bondade e em presença de vossa mãe gloriosa e de todos os santos e santas da corte celeste: quero e desejo, e é minha decisão determinada, contanto que seja vosso maior serviço e vosso maior louvor, vos imitar suportando todos os ultrajes, todas as humilhações e toda pobreza, seja efetiva que espiritual, se vossa santíssima Majestade me quiser escolher e receber nessa vida e nesse estado" ${ }^{\text {"70 }}$.

Ou seja, são as faculdades da alma racional - razão e vontade agindo juntas -, ou melhor dizendo, é a "decisão deliberada" ou a "liberdade" (entendidas em estreita relação com a razão, como vimos na análise dos textos do scholicorum) as responsáveis por, no olhar para a realidade, tendo identificado o Bem e o Fim últimos da vida, deliberar em favor de sua aplicação para cumprir esse objetivo final. Literalmente, a razão dá - ou localiza, ou ilumina as razões da ação humana.

Esses documentos são, pois, fontes que nos permitem conhecer, por um lado, os fundamentos teológicos da doutrina da Companhia - em geral - e por outro lado a fundação da sua espiritualidade - em particular -, na medida em que são instrumentos que servem à ordenação da vida espiritual dos jesuítas. Podemos então dizer que se trata de documentos prescritivos de uma "ação" com características genericamente entendidas como "espirituais". A liberdade aqui dada a entender é uma adesão à vontade de Deus: livre de sua vontade pessoal, livre das paixões desordenadas, o homem vai, aos poucos, se identificando com Cristo que obedecia ao Pai.

\section{3) A liberdade na ratio institutorum}

“A quaresma estando quase a terminar, quando se aproximava o momento onde seria necessário nos dividir e nos separar (...),decidimos nos reunir durante todos os dias que

\footnotetext{
${ }^{70}$ Ibid., p 106 (EE. 97 e 98, tradução e grifo nossos).
} 
precedem nossa separação e discutir nossa vocação e regra de vida" ${ }^{\text {71 }}$. É bastante significativo que o primeiro texto fundador da Companhia de Jesus comece assim e avance relatando como foi-se decidindo pela união "em um só corpo"72 e pelo voto de obediência (além dos dois outros já emitidos em Montmartre - pobreza e castidade).

Se lemos os argumentos utilizados contra e a favor a emissão de um terceiro voto que permitisse "cumprir em tudo a vontade de Deus nosso Senhor, ao mesmo tempo que a livre vontade e os mandados de Sua Santidade" ${ }^{\text {,3 }}$, vamos descobrindo a estreiteza de laços entre a obediência e o tema em questão - liberdade.

Pedro Fabro, no relato, descreve apenas três objeções, apesar de dizer que todos os companheiros reunidos trouxeram, cada um, um argumento contra: que a obediência não é bem vista pelo povo cristão; que a obediência os forçará a viver apenas o que o Soberano Pontífice decidir, podendo ir contra a regra estabelecida pela Companhia e, sobretudo, contra o desejo de unidade; e que pela obediência diminuir-se-ia o interesse em fazer parte dessa Companhia de Jesus.

Em seguida, apresenta todas as "vantagens e todos os frutos da obediência" trazidos por cada um dos que estavam reunidos em torno do tema: que a obediência permite que todos, indiscriminadamente, carreguem qualquer fardo difícil; que a obediência é a virtude que mantém a unidade do grupo para sempre; que a obediência é a origem de todos os atos heróicos; que a obediência abate o orgulho e a arrogância, e é associada estreitissimamente à humildade; a obediência ao Pontífice e Pastor da Igreja não impedirá que se ocupem de seus "negócios pessoais cotidianos"74. Resultado do debate?

Ao fim, o Senhor nos tendo dado seu socorro, concluímos não por maioria de votos mas sem que ninguém fosse de opinião contrária: para nós, conviria mais e seria mais necessário obedecer a um dentre nós, para que pudéssemos realizar melhor e mais exatamente nossos primeiros desejos de

\footnotetext{
${ }^{71}$ Ibid., p. 277 (1539. Durante três meses. A maneira como se instituiu a Companhia, tradução nossa).

${ }^{72}$ Ibid., p. 278 (tradução nossa).

${ }^{73}$ Ibid., p. 278 (tradução nossa).

${ }^{74}$ Cf., ibid., pp. 280-281.
} 
cumprir em todas as coisas a vontade divina, e para que a Companhia fosse conservada mais seguramente, e enfim para que se pudesse prover corretamente aos negócios particulares que se apresentarem, tanto espirituais como temporais ${ }^{75}$.

Como é possível, obedecendo a um dentre aqueles primeiros, chegar a realizar os desejos de cumprir a "vontade divina"? "Obediência", "desejos", "vontade divina": fatores de uma mesma expressão que parece - para os olhos modernos que lêem - cheia de contradição. A questão se explica se lemos o Atestado:

Eu, abaixo-assinado, N., atesto em presença de Deus todo-poderoso, da bemaventurada Virgem Maria e de toda a côrte celeste, depois de ter rezado a Deus e pesado de forma madura a coisa, que decidi de pleno acordo, como mais conveniente, segundo meu julgamento, para o louvor de Deus e a manutenção perpétua da Companhia, que haja nela o voto de obediência; e que eu me ofereço resolutamente, fora no entanto de todo voto e de toda obrigação, a entrar nessa mesma Companhia, se o Senhor permite que ela seja confirmada pelo Papa. Para memória desta decisão (que reconheço como dom de Deus), me aproximo agora da santíssima comunhão, ainda que indigníssimo, com esta mesma decisão ${ }^{76}$.

Entra em jogo, aqui um fator muito importante - o "julgamento": aquela mesma atividade da alma racional que, na regra espiritual determinava a escolha mais acertada e que, no filosófico-retórico era responsável por localizar o Bem e o Fim últimos da vida. De tal forma que essa obediência, nascendo de uma deliberação da razão, é instrumento escolhido e adequado para caminhar em direção à liberdade pretendida. $\mathrm{O}$ fruto de uma obediência assim vivida, no nível da experiência pessoal, é a consolação de ver "os desejos de cumprir a vontade divina" se realizando na vida e trabalho cotidianos, na missão, na vocação e, no nível da experiência institucional, a unidade da Companhia de Jesus.

Se passamos ao texto das Constituições, ainda no Exame Geral, falando dos "exames" a que devem passar os que querem entrar na Companhia de Jesus, encontramos pela primeira vez a idéia de liberdade associada à de indiferença. $\mathrm{O}$ documento explica as diferenças entre as quatro categorias de pertencimento à Ordem: 1) os padres de quatro votos (de instrução

\footnotetext{
75 Ibid., p. 281 (tradução e grifos nossos).

${ }^{76}$ Ibid., p. 282 (Atestado concernente a decisão de fazer voto de obediência, tradução e grifos nossos).
} 
suficiente, e provados), 2) os coadjutores temporais ou espirituais de três votos (também provados, mas não necessariamente instruídos), 3) os estudantes (que podem ou não emitir os votos ao final do período de instrução, como padres ou como coadjutores) e 4) finalmente os assim chamados "indiferentes" - "aqueles que se aceita sem que seja determinado aquilo para o que serão aptos com o tempo",77. Acerca desses últimos, no capítulo 80 do Exame Geral - a eles dedicados -, se diz:

abrindo-se a uma total humildade e a uma total obediência, ele deve deixar todo o cuidado de si mesmo, e a escolha de seu emprego ou de seu estado, a seu Criador e Senhor e, em seu nome, e por seu divino amor e respeito, à Companhia ou àquele que será seu superior ${ }^{78}$.

O documento continua, explicando como se deve, por fim, fazer a escolha do emprego e estado de um desses "indiferentes", a começar por saber dele se é "perfeitamente indiferentes (...) para servir seu Criador e Senhor em não importa que emprego ou (...) serviço",79 e, ainda, "se está pronto a passar todos os dias de sua vida em empregos baixos e humildes para o bem e o serviço da Companhia" ${ }^{80}$; estando ele "contente em nosso Senhor" por tudo isso, se lhe informará seu "emprego e serviço", de forma que as "duas partes serão contentes e satisfeitas, e agirão em tudo com uma maior clareza" ${ }^{\text {" }}$.

Analisando a dinâmica que sustenta essa decisão caracterizada como "clara", é possível que compreendamos como essa "indiferença” a que se refere é a que permite uma obediência pronta a aderir àquilo que for "ordenado em vista de um maior serviço e de um maior louvor de Deus nosso Senhor" ${ }^{\wedge 3}$. E se, como vimos acima, "cumprir a vontade divina" é o desejo original de todo homem - conforme notamos também na descrição da ratio spiritualis - ser primeiramente indiferente e depois obediente é o que permite a realização do

\footnotetext{
${ }^{77}$ Ibid., pp. 398-399 (Const. 15, tradução nossa).

${ }^{78}$ Ibid., p. 424 (Const. 131, tradução nossa).

${ }^{79}$ Ibid., p. 424 (Const. 132, tradução nossa).

${ }^{80}$ Ibid., p. 424 (Const. 132, tradução nossa).

${ }^{81}$ Ibid., p. 424 (Const. 133, tradução nossa).

${ }^{82}$ Ibid., p. 424 (Const. 133, tradução nossa).

${ }^{83}$ Ibid., p. 424 (Const. 133, tradução nossa).
} 
desejo que tudo move - do desejo, podemos dizer, do Bem e do Fim últimos.

Ao longo do texto das Constituições, as demais vezes em que essa categoria obediência - aparece será sempre reafirmando todo o conteúdo inicialmente discutido, quando dos primeiros passos de fundação da Companhia de Jesus: a obediência visa a unidade do corpo com a cabeça; deve ser deliberada para ser verdadeira; deve-se obedecer a Cristo na figura do superior (seja que superior for: da Companhia ou de fora dela); é também devida ao Sumo Pontífice, como vigário de Cristo que é.

A liberdade nessa dinâmica, apresentada desde a análise do conteúdo próprio da casuística e da retórica aprendido nas escolas jesuíticas, até aqui, passando pela norma espiritual, aparece como corolário da obediência, como se pode ver, por exemplo, em algumas das inúmeras cartas ${ }^{84}$ que Inácio assinou ao longo do tempo de exercício do cargo de Prepósito Geral da Companhia. Vejamos, passo a passo.

É exatamente na consideração da finalidade de sua vida ${ }^{85}$ que, segundo o espírito inaciano, o homem começa a se deparar com a questão da obediência. Dado que, sendo conhecimento de fé (reconhecimento), exige do homem uma postura justa, uma resposta razoável: o seguimento, a imitação; a obediência - e obediência cega -, portanto.

Entrementes, de antemão, merece consideração o fato de que em nenhum lugar Inácio de Loyola diz que a "obediência cega" ${ }^{\$ 6}$ deve ser alguma coisa sequer semelhante a uma obediência militar, mecânica ou voluntarista. Pelo contrário, Inácio explica que esta "obediência cega" ou a obediência como a de um cadáver (perinde ac cadaver) não é e não

\footnotetext{
${ }^{84} \mathrm{Um}$ dos maiores legados deixados por Inácio, em tudo coerente aos ideais medievais e embebida no mais legítimo espírito renascentista, é o corpus de suas cartas: 6.813 correspondências, reunidas nos 12 grossos volumes da Monumenta Historica Societatis Iesu.

${ }^{85}$ Qual seja? Retomemos o que Inácio diz no Princípio e Fundamento de seus Exercícios Espirituais: "O homem é criado para louvar, reverenciar e servir a Deus Nosso Senhor, e assim salvar a sua alma. E as outras coisas sobre a face da terra são criadas para o homem, para que o ajudem a alcançar o fim para que é criado" (Loyola, 1991, op. cit., EE. 23, pp. 62-64).

${ }^{86}$ Não é Inácio que cunha esse termo, tampouco é o primeiro a usá-lo na história do cristianismo: deve-se, antes, a alguns pensadores da Patrística. Entenda-se, nesse sentido, que "obediência cega" se diz "cega" porque não olha a própria vontade ou o próprio interesse, mas quer unicamente e procura "em tudo e por tudo o maior louvor e glória de Deus", ou seja, é cega à vontade própria.
} 
pode ser, como veremos a seguir, uma obediência irracional, mas se trata sim de uma atitude simples e generosa do homem, que só tem olhos para a vontade de Deus.

É acima de tudo na conhecida “Carta da Obediência” que Inácio de Loyola estabelece o que entende por obediência, enumerando seus graus, ou degraus: obediência de execução, de vontade e de entendimento. Além disso, nesse texto ficam firmadas as verdadeiras e justas motivações para a obediência: o amor a Cristo e a disponibilidade total à missão que Ele confia ao homem. E as boas conseqüências desta "santa virtude", ou melhor, dessa "mãe de todas as virtudes" $"$ : traz "paz e sossego" e "enobrece o homem" $" 88$. Inácio diz que "desnudo de si mesmo, o obediente veste-se de Deus, o qual 'tanto mais enche a nossa alma, quanto mais vazia a encontra da própria vontade" ${ }^{\prime 89}$.

Outro tema recorrente é o que se refere ao mote jesuítico - ad maiorem Dei gloriam -, que aparece diversas vezes no texto das cartas, bem como nas Constituições, nos Exercícios Espirituais e em outras inúmeras produções dos jesuítas. Segundo Cardoso (1993), a espiritualidade inaciana está assentada nesse lema que expressa a "experiência de grandeza e amor de Deus que levou Inácio à purificação das paixões desordenadas e daí ao conhecimento, amor e seguimento de Jesus Cristo" ${ }^{90}$.

Passo importante para se começar a viver a "maior glória de Deus" é fazer sua vontade e obedecê-lo. Antes porém, é preciso reconhecer que a vida e todo o desejo humano vêm de Deus. Esse reconhecimento da graça de Deus e a conseqüente gratidão que nasce daí permitem ao homem o maior e mais perfeito serviço:

\footnotetext{
${ }^{87}$ A obediência entendida como "mãe de todas as virtudes" é uma idéia de S. Gregório, a quem Inácio recorre em algumas cartas. Por exemplo, em carta enviada aos Padres e Irmãos de Gandía, no dia 29 de Julho de 1547, Inácio diz que a obediência ajuda a conseguir todas as virtudes, pois, como diz S. Gregório, "a obediência não é tanto virtude, como mãe de virtudes" (Loyola, 1991, op. cit., p. 716, tradução nossa). Na "Carta da Obediência", enviadas de Roma aos Padres e Irmãos de Portugal, no dia 26 de Março de 1553, o fundador exorta os jesuítas sobre a obediência e diz: “... como diz São Gregório, obedientia sola virtus est quae menti caetera virtutes inserite, insertasque custodit" ("a obediência é uma virtude que por si só enxerta na alma as outras virtudes e, enxertadas, as conserva". Ibid., p. 837, tradução nossa).

${ }^{88}$ Ibid., p. 836 (tradução nossa).

${ }^{89}$ Ibid., p. 836 (tradução nossa).

${ }^{90}$ Cardoso, Armando (org.) (1993). Cartas de Santo Inácio de Loyola. Volume 3. São Paulo: Ed. Loyola, p. 14.
} 
Entre tudo o que se pode imaginar, o desconhecimento dos bens, graças e dons recebidos é a origem, princípio e causa de todos os males e pecados. Pelo contrário, o reconhecimento e gratidão dos bens, graças e dons recebidos, é grandemente estimado e amado, tanto no céu como na terra ${ }^{91}$.

Do contrário, se não se reconhece de quem é o desejo e a vida que se tem, o homem vive preso às afeições desordenadas, ou seja, deixa de ser verdadeiramente livre, deixa de participar da liberdade de Deus: essa é a própria experiência de desconsolo relatada quando tratamos da ratio spiritualis. Na medida em que o homem se dedica a fazer a Vontade de Deus, vê vencidos todos os medos e paixões desordenadas que antes o impediam de agir no rumo do seu destino último. Em carta a Diogo de Gouveia, Inácio escreve: “A distância do país não nos espanta, nem o trabalho de aprender línguas. Faça-se somente o que mais agrada a Cristo" $" 92$.

Ainda dentro dessa dinâmica, falando acerca da condição humana, Inácio - o Peregrino -, diz que os da Companhia peregrinam porque não se pertencem. De fato, é essa a característica do homo viator: o não pertencimento a si mesmo, mas ao Mistério, a participação no Mistério, no Sagrado, através da pertença a uma companhia específica que, como Povo de Deus, também não se pertence a si mesma: povo escolhido, testemunhas, instrumentos nas mãos dEle $\mathrm{e}^{93}$.

A metáfora do peregrino ${ }^{94}$ é bastante ilustrativa desse dinamismo que nos interessa

\footnotetext{
${ }^{91}$ Cardoso, 1993, op. cit., p. 24 (Carta ao Padre Simão Rodrigues, 18/03/1542, de Roma).

92 Cardoso, Armando (org.) (1988). Cartas de Santo Inácio de Loyola. Volume 1. São Paulo: Ed. Loyola, p. 63 (23/11/1538, de Roma).

${ }^{93}$ Em carta a D. João Bernardo Diaz de Lugo, do dia 16/01/1543, Inácio escreve: “... como não nos pertencemos, nem queremos nos pertencer, contentamo-nos em peregrinar por onde o Vigário de Cristo N.S. quiser mandarnos" (Cardoso, 1993, op. cit., p. 32).

${ }^{94}$ Le Goff, Jacques (1989). O Homem Medieval. Lisboa: Editorial Presença, esclarece que essa concepção de homem - homo viator, peregrino - vem de uma antropologia cristão fundada na Idade Média: "o homem em marcha, em viagem permanente nesta terra e na sua vida, que são o espaço/tempo efémeros do seu destino e onde ele caminha, segundo as suas opções, para a vida ou para a morte - para a eternidade. Assim, paradoxalmente, o monge, ligado por vocação a um lugar de clausura, peregrina frequentemente pelas estradas. No século XIII, os frades das ordens mendicantes (...) estarão ora in via, ou seja, pelos caminhos, ora nos seus conventos. O homem da Idade Média é, por essência, por vocação, um peregrino e, nos séculos XII e XIII, sob a forma terrena mais elevada e perigosa da peregrinação, um cruzado" (p. 13). Também Silva, Paulo José Carvalho da e Massimi, Marina (1987). A construção do conhecimento psicológico na obra História do Predestinado Peregrino e seu irmão precito (1682) de Alexandre de Gusmão S.J. Sociedade Brasileira de História da Ciência, 17. Jan/Jun, São Paulo: SBHC, 71-80, falam a cerca dessa concepção, dessa vez explicitando a retomada renascentista do conceito de peregrino, especialmente na Companhia de Jesus: "na busca das matrizes filosóficas e teológicas da estória de Gusmão
} 
aqui, por isso nos deteremos um pouco mais na explicitação do sentido que Inácio atribui a ela ${ }^{95}$.

Na medida em que está em caminho, o peregrino já experimenta o gosto do seu destino.

Segundo o fundador, em carta aos padres e irmãos de Gandía, se se é obediente, o caminho não é duro:

Mas, mesmo enquanto duram os trabalhos da presente peregrinação e desterro, esta forma de vida dá um grande gosto do descanso da pátria, não só porque liberta de perplexidades e dúvidas, mas porque faz ao homem se descarregar do gravíssimo peso da sua própria vontade e de solicitude de si mesmo, colocando-o sob o Superior e trazendo, assim, paz e sossego ${ }^{96}$.

Nesse sentido, quem obedece, se faz peregrino com os pés de Cristo. Caminha, portanto, pelas sendas de Cristo e não se cansa, por isso já vive o consolo do cêntuplo, porque a meta, o destino, é Cristo, que se oferece como o próprio Caminho para o homem. Inácio, então, na mesma carta, acrescenta uma lista de vantagens e boas conseqüências do se aplicar à obediência cega:

Deveis também considerar que vos fará andar descansados e mais rapidamente passar adiante no caminho do céu, como quem anda com pés alheios e não com os próprios do seu entender e querer. E em todas as coisas, como comer, dormir etc., fará com que caminheis por esse caminho em contínuos méritos, como acontece aos navegantes que, enquanto repousam, andam ${ }^{97}$.

Porém, quais são os demais argumentos usados por Inácio, em favor da obediência?

Quais as razões da obediência? Por que desejar esta "virtude"?

Na carta enviada aos jesuítas de Gandía, Inácio, diz que há uma ordem social que prova, por experiência, que é mais acertado, razoável e conveniente viver sob a

\footnotetext{
deparamo-nos com uma clara influência da filosofia neo-escolástica, desenvolvida primeiro por dominicanos e posteriormente assumida pelos jesuítas como a maior referência do pensamento de sua Companhia" (p. 76). Assim, chegam a dizer mais à frente: "a peregrinação implica em escolhas de caminhos, assim como a vida também oferece alternativas de atitudes. Gusmão aponta que o caminho pode ser o mesmo, a eternidade, mas não são os mesmos atalhos e, portanto, são também distintas as sanções. Mais uma vez, aparece o papel da razão na escolha do atalho certo, na busca da verdade" (p. 77).

${ }^{95}$ É importante lembrar, inclusive, que a peregrinação é uma das "provações" porque devem passar todos os jesuítas antes de emitirem os votos: "Antes de entrar no segundo ano de provação, que se faz nas casas ou colégios, todos devem fazer, durante seis meses, essas seis experiências, e durante seis outros meses a diferentes outras experiências" (Loyola, 1991, op. cit., p. 410, Const. 71, tradução nossa). Quais são essas "experiências"? Fazer os Exercícios Espirituais, servir nos hospitais, sair em peregrinação, fazer serviços baixos ou humildes, expor publicamente a doutrina cristã e pregar e confessar em outros lugares (Cf. Const. 65-70).

${ }^{96}$ Loyola, 1991, op. cit., p. 712 (29/07/1547, Roma; tradução nossa).

${ }^{97}$ Ibid., p. 713 (tradução nossa).
} 
obediência. E para mostrar a razoabilidade do argumento, lembra que também Cristo, a Virgem Maria, José e os Apóstolos eram submissos e obedientes: "Portanto, se eles necessitaram de um Superior, quanto mais qualquer outra comunidade"98. Além dos exemplos - a serem imitados - dessas figuras, Inácio lembra que há outras razões,

porque se temos de considerar como melhor modo de viver aquele em que se presta o serviço mais agradável a Deus, teremos por tal aquele em que todos fazem a oblação da obediência, a qual é a mais aceita entre todos os sacrifícios ${ }^{99}$.

A obediência é um sacrifício - sacro officium - da própria vontade e liberdade. É, portanto, a maior de todas as ofertas que o homem pode fazer a Deus. Mas, oferta é pedido, porque oferta é reconhecimento de que a liberdade e a vontade que se têm, em última instância, são dados de Deus, oferecer a Ele o que Ele deu é pedir que Ele realize a liberdade total da qual se tem sede, a vontade última que o coração carrega. E não sem motivo, já que, ofertando o próprio juízo, vontade e liberdade, que são as principais faculdades da alma humana, se oferece "mais do que se lhe fosse ofertada qualquer outra coisa"100.

Outro argumento importante é o que passa pela observação da realidade: há uma ordem em toda a realidade, desde a ordenação natural das coisas, até a social, passando pela nossa ordenação interna, ou a das potências da alma. Todo o universo é cosmológico, tem um sentido ordenado, hierarquicamente estabelecido: obedecer é, antes de tudo, se deixar guiar pela ordem universal, de quem o homem é uma analogia perfeita, microcosmo que é. Em carta ao Padre André d'Oviedo, o fundador da Companhia de Jesus, através de Polanco - seu secretário -, escreve:

Quase todas as criaturas nos ensinam que assim se deve proceder e é conforme à disposição da divina Providência: em todos os seres corporais em movimento vemos a dependência dos inferiores para com os superiores e estes, por sua ordem, para com um que é supremo ${ }^{101}$.

\footnotetext{
${ }^{98}$ Ibid., p. 713 (tradução nossa).

${ }^{99}$ Ibid., p. 713 (tradução nossa).

${ }^{100}$ Cardoso, 1993, op. cit., p. 57.

${ }^{101}$ Loyola, 1991, op. cit., p. 728 (27/03/1548, Roma; tradução nossa).
} 
Lembrando sempre que a hierarquia a que se refere não é uma simples formalidade, mas uma obediência à ordem universal, da qual o homem participa, Inácio afirma, em carta enviada a seus companheiros de Coimbra, no dia 07/05/1547, que aderir à tal evidência traz benefícios espirituais significativos ${ }^{102}$, além de ajudar a manter a unidade do corpo social da Companhia de Jesus particularmente, mas de qualquer grupo que se organize na sociedade: “Assim, se desejamos que se conserve o ser da nossa comunidade, é necessário desejar tenhais a alguém que seja a vossa cabeça"103. E continua, "não há nenhum exercício que (...) considere mais oportuno e mais necessário para o bem da Companhia do que este obedecer muito bem"104.

Ainda sobre a obediência como virtude essencial para o bom andamento da Companhia, Inácio escreve:

a virtude mais necessária e mais essencial que nenhuma outra nesta Companhia (...): o respeito, a reverência e obediência perfeita aos superiores, que ocupam o lugar de Cristo N.S., ou melhor, à sua divina Majestade neles ${ }^{105}$.

A obediência é necessária para a manutenção, pois, não só da ordem interna mas também da externa. Inácio, na "Carta da Obediência"106 aponta duas circunstâncias onde a obediência é especialmente importante: 1) nas decisões ou nas coisas "onde a paixão faz que [os homens] não sejam bons juizes"107 e, novamente lembrando a necessidade da obediência para a unidade da Companhia ${ }^{108}$, diz que, 2) sem obediência o "bom ser e governo da

\footnotetext{
${ }^{102}$ Entre os bens espirituais a que se refere, Inácio lembra a importância da obediência como sustento para o meio-termo e condição para a fecundidade da indiferença, portanto: "Para conservar, pois, o meio termo entre os extremos da tibieza e do fervor indiscreto, aplicai-vos à obediência, e se ardeis de desejos de mortificação durante o tempo dos estudos, empregai-vos mais em quebrar vossa vontade e sujeitar o vosso juízo ao jugo da obediência e não a debilitar o corpo e afligi-lo sem moderação" (Ibid., p. 696, tradução nossa).

${ }^{103}$ Ibid., p. 696 (tradução nossa).

${ }^{104}$ Ibid., p. 697 (tradução nossa).

${ }^{105}$ Ibid., p. 830 (Carta ao Padre Diogo Mirão, 17/12/1552, Roma; tradução nossa).

106 Originalmente, a "Carta da Obediência" foi enviada aos companheiros de Coimbra, no entanto, posteriormente teve cópias enviadas a todas as casas da Companhia de Jesus.

${ }^{107}$ Ibid., p. 696 (tradução nossa).

${ }^{108}$ Madrid, Jairo H. Cifuentes (2002). Momentos de decisión: reflexiones sobre tres momentos en la vida de Ignacio de Loyola. Retirado em 02/05/2002 da Pontificia Universidad Javeriana, no World Wide Web http:// www.puj.edu.co/ pedagogia/ seminario, diz que "El voto de obediencia debe entenderse como el 'medio' más apto y eficaz para realizar el fin fijado o la misión" (p. 02), porque a obediência possibilita "la unión para la dispersión. Ella se expressa en 'un cuerpo' (la unión) para realizar de la mejor manera posible 'una misión' concreta, historica y geográficamente determinada según las necesidades del momento (la dispersión)" (p. 02).
} 
Companhia não se pode conservar, como nem o de outra qualquer Congregação"109.

Nesta carta, o Inácio exorta os membros da Companhia de Jesus sobre a virtude da obediência, e, para tanto, usa várias citações evangélicas e de São Gregório.

Citando São Lucas, por exemplo - Qui vos audit, me audit; qui vos spernit, me spernit $^{110}$-, Inácio aponta o passo para se chegar à perfeição na obediência, lembrando que na obediência, obedece-se a Cristo no superior. E completa com um trecho da carta de São Paulo aos Efésios:

Obedite dominis carnalibus con timore et tremore, in simplicitate cordis vestri, sicut Christo; non ad oculum servientes, quasi hominibus placentes, sed ut servi Christi facientes voluntatem Dei, ex animo cum bona voluntate servientes, sicut Deo et non hominibus ${ }^{11}$.

De novo, Inácio lembra que obedecer é sacrificar a vontade própria, pois só então se há de alcançar a verdadeira liberdade. Então, para falar dos "degraus" da obediência obediência de execução, de vontade e de entendimento - escreve: “... segundo São Gregório, per victimas aliena caro, per obedientiam propria voluntas mactatur." $" 12$. Então, completa, lembrando que a obediência de vontade ainda é um passo aquém na perfeição da "obediência cega":

Mas quem pretende fazer perfeita e inteira oblação de si mesmo, além da vontade, é necessário que ofereça o entendimento, e isto é outro grau e supremo da obediência, que tendo somente um querer, mas também um mesmo sentir com seu Superior, sujeitando o próprio juízo ao dele, enquanto a vontade fervorosa pode inclinar o entendimento ${ }^{113}$.

Para que a obediência seja sincera é preciso que o homem ofereça seu próprio entendimento e razão, seu juízo:

Porque, embora este não tenha a liberdade que tem a vontade, e naturalmente aprove o que se lhe representa como verdadeiro, todavia, em muitas coisas em que não o força a evidência da verdade conhecida, pode com a vontade

\footnotetext{
${ }^{109}$ Loyola, 1991, op. cit., p. 697 (tradução nossa).

${ }^{110}$ Lc, 10, 16: "Quem vos ouve, ouve a mim; e quem vos rejeita, a mim rejeita".

${ }^{111}$ Ef 6, 5ss: "Vós, servos, obedecei a vossos senhores segundo a carne, com temor e tremor, na sinceridade de vosso coração, como a Cristo; não servindo à vista, como para agradar aos homens, mas como servos de Cristo, fazendo de coração a vontade de Deus; servindo de boa vontade como ao Senhor, e não como aos homens".

112 Ibid., p. 696, tradução nossa ("por outros sacrifícios mata-se carne alheia, mas pela obediência sacrifica-se a vontade própria").

${ }^{113}$ Ibid., p. 696, tradução nossa.
} 
inclinar-se mais a uma parte do que à outra; e nas tais todo o obediente verdadeiro deve inclinar-se a sentir o que o Superior sente ${ }^{114}$.

É verdade que a obediência de entendimento é o mais perfeito grau da obediência, no entanto, é preciso que aquele que deseja chegar a essa perfeição, galgue os outros degraus também, procurando resignar a própria vontade inteiramente, "oferecendo literalmente a vosso Criador e Senhor em seus ministros a liberdade que Ele vos deu"115.

Nesse ponto, ele explica como se dá o passo seguinte:

Com efeito a obediência é um holocausto, no qual o homem todo, sem tirar nada de si, se oferece no fogo da caridade a seu Criador e Senhor por mão de seus ministros. E visto ser uma resignação inteira de si mesmo, pela qual se desapossa de si todo, para ser possuído e governado da divina Providência por meio do Superior, não se pode negar que a obediência compreende não somente a execução para efetuar e a vontade para se contentar, mas também o juízo para sentir o que o Superior ordena, enquanto, como se disse, por vigor da vontade se pode inclinar ${ }^{116}$.

Inácio lembra, finalmente que nosso ser segue também a ordem estabelecida no universo, de tal forma que, se não chegarmos ao ponto de oferecer, de fato, nosso entendimento, toda obediência será uma violência:

se não há obediência de juízo, é impossível que a obediência de vontade e execução sejam qual convém. Pois as forças apetitivas da nossa alma seguem naturalmente as apreensivas. E assim será coisa violenta obedecer largo tempo com a vontade contra o próprio juízo ${ }^{117}$.

Todo sacrifício que o homem faça deve ser feito com amor e alegria, do contrário, perde-se a simplicidade, a humildade, a fortaleza e todas as perfeições que podem vir carreadas a esta virtude.

Numa carta enviada à mãe de um jovem que buscara a Companhia de Jesus apesar da insistência dela de que ele não o fizesse, Inácio, volta a lembrar que "é preciso obedecer antes a Deus do que aos homens" $" 118$.

\footnotetext{
114 Ibid., p. 697 (tradução nossa).

115 Ibid., p. 697 (tradução nossa).

116 Ibid., p. 698 (tradução nossa).

${ }^{117}$ Ibid., p. 698 (tradução nossa).

${ }^{118}$ Cardoso, 1993, op. cit., p. 126 (Carta à Mãe de Otávio Césari, 28/01/1554, Roma. Inácio aqui faz uso de um trecho dos Atos do Apóstolos - At 5, 29 -, onde está descrito o que Pedro e os apóstolos responderam, após serem libertados e interrogados pelo sumo sacerdote a cerca da desobediência às suas ordens sobre não pregar usando o nome de Cristo).
} 
Nas Regras de Nosso Pai Mestre Inácio, Polanco, certamente a pedido de Inácio, escreve o seguinte: "Pratica a obediência cega em todas as coisas, tanto grandes como pequenas e ínfimas e pensa que fizeste voto disso"119. E também: "Não fales, não respondas, não medites, não andes, nada faças, enfim, sem antes pensares se aquilo agrada a Deus e serve para exemplo e edificação do próximo" ${ }^{\text {120 }}$. E, finalmente, falando da liberdade de espírito:

Conserva, em toda a parte, a liberdade de espírito; não faças acepção de pessoas perante quem quer que seja; procura reter sempre a liberdade de espírito diante dos casos mais opostos. Não a percas ante obstáculo algum. Neste ponto não desista nunca ${ }^{121}$.

Numa outra carta Inácio lembra os benefícios que a obediência é capaz de trazer àquele que a ela se aplicar:

se considera quão grande é Deus nosso Senhor para fazer coisas muito grandes com instrumentos, por si mesmos, fraquíssimos, mas movidos pela santa obediência, então não se desanimará nem um pouco. Ao contrário, quanto mais se rebaixar considerando a sua pequenez, tanto mais se levantará ao considerar o poder divino que costuma usar de misericórdia servindo-se dos fraquíssimos instrumentos da sua Companhia. De maneira que, enquanto V. Rev.ma tiver de exercer este ministério, faça-o com coragem e confiante no poder da obediência, isto é, de Cristo nosso Senhor, ao qual obedece na pessoa do superior ${ }^{122}$.

É acerca da liberdade que ele trata: a verdadeira liberdade - a que Inácio pretende levar seus filhos -, que é a realização da vontade de Deus. Mais que a satisfação da liberdade das cadeias, essa "verdadeira liberdade" é a única capaz de realizar, de fato, o homem que busca a Deus. Numa carta a um padre preso, Inácio lembra que confiar na Providência Divina ajuda a ser livre, mais livre do que a simples liberdade das cadeias:

Portanto, caríssimo Irmão, esforce-se naquele que o criou e remiu com o seu sangue e confie-se em sua suavíssima providência. Ele, ou o tirará do cativeiro de algum modo, ou pelo menos o fará mais frutuoso em seu favor, não menos que a liberdade, para o fim pretendido, a saber, a divina glória e serviço e com eles a salvação e felicidade perpétua ${ }^{123}$.

\footnotetext{
119 Ibid., p. 149.

${ }^{120}$ Ibid., p. 150.

${ }^{121}$ Ibid., p. 150.

122 Ibid., p. 145 (Carta ao Padre João Batista de Fermo, 06/06/1556, Roma).

${ }^{123}$ Loyola, 1991, op. cit., p. 896 (Carta ao Padre Miguel de Nóbrega, 25/08/1554, Roma; tradução nossa).
} 
O binômio obediência/liberdade bastante presente nos textos inerentes ao aspecto jurídico institucional da vida da Companhia, como vimos é um eco do conteúdo tanto dos documentos do pólo filosófico-retórico quanto do regrado propriamente espiritual. O que demonstra o todo orgânico e vivo que sustenta o modus operandi do jesuíta. Ficou claro, mais uma vez, que a liberdade aqui definida não é o oposto a uma regra, mas a proposta de uma experiência capaz de unidade com a instituição e da instituição, na medida em que, por meio dessa regra se caminha em direção aos destinos individuais, ou seja, conforme a antropologia inaciana de fundo, em direção ao destino de todo homem.

\section{4) A liberdade nos escritos espirituais jesuíticos}

Vejamos, agora, como toda essa discussão que, como já se pôde perceber, faz parte de um contínuo, de um todo muito bem estruturado, encontra uma síntese nos textos de espiritualidade. Os textos serão apresentados por ordem cronológica de publicação, tomandose por referência o ano de publicação da primeira edição.

Nesse sentido, o primeiro texto a que tivemos acesso foi uma carta do Padre Geral Claudio Aquaviva, no início do seu generalato, no dia 29 de setembro de 1583, na qual propõe à toda Companhia de Jesus, uma renovação do espírito, ou seja, um desvestir-se do homem velho, um mortificar-se do amor próprio e das paixões desordenadas, a fim de atingir o verdadeiro fundamento do carisma inaciano:

Tutti gli affetti, che ci fanno cercar noi stessi, che ci attaccano à qualche cosa del mondo, che c'impediscono la vera libertà del puro servitio divino, \& ci rendono men pronti ad esser da lui maneggiati, sono dell'huomo vecchio nostro ${ }^{124}$.

A renovação do espírito coincide também com a consideração do "espírito verdeiro da nossa vocação"125 e permite ao jesuíta experimentar "com a divina graça, magnanimidade por

\footnotetext{
124 Aquaviva, Claudio (1583). Lettera del Nostro Padre Generale Claudio Acquaviva. Sopra la Rinovatione dello spirito à Padri \& Fratelli della Compagnie. 29/09/1583. Roma, p. 5. ("Todos os afetos que nos fazem procurar a nós mesmos, que nos ligam às coisas do mundo, que nos impedem a verdadeira liberdade do puro serviço divino, e nos tornam menos prontos a ser por ele manejados, são do nosso homem velho").

${ }^{125}$ Ibid., p. 15 (tradução nossa).
} 
cada empresa, e ver não ser impossível aquilo que aos sentidos, ou à carne assim parecia" ${ }^{\text {,26. }}$. Mas, o que significa, em termos práticos, essa renovação do espírito? “Colocar as mãos à obra e nas coisas que conhecemos, que nos faltam, colocar toda diligência por sua aquisição; isto é levar, como nota S. Gregório, não só o coração, mas as mãos a Deus" ${ }^{127}$. E ele completa, dizendo ainda, que as paixões da alma - "come per isperienza proviamo" -, podem ser modificadas pelo exercício ordenativo.

Falando do estudo da perfeição e da caridade fraterna, em carta do dia 19 de maio de 1586, Aquaviva propõe aos padres e irmãos da Companhia de Jesus, ainda no mesmo sentindo de uma renovação do espírito, que se considere e se estude o verdadeiro significado da perfeição. Logo no início da carta lembra que "ne trova il servo di Dio altro riposo, ò altro contento, che il far la volontà di colui, la cui volontà è sola regola d'ogni rettitudine, il cui desiderio è, che noi la facciamo solo per nostro bene \& nostra felicità” ${ }^{128}$.

O que significa o estudo da perfeição? Segundo Aquaviva (1586), significa considerar o motivo da vocação - "fazer a vontade de nosso pai e senhor" ${ }^{129}$. E completa:

forzarsi di farlo, \& darsi da vero alla essecutione di questo studio, mettendo in opera quel, che tanto \& le nostre costitutioni gridano \& fin dal principio del novitiato ci fù inculcato di far sua la volontà di Dio, interpretata dal superiore, è gran principio per rendercela ogni giorno più dolce, $\&$ farci con la sperienza gustare, \& con una luce maravigliosa, che non è di lume naturale, conoscere chiaramente, che questà è dottrina del cielo ${ }^{130}$.

E termina, lembrando que, se não desnudarmos nossa vontade de todo amor próprio “como dizem os Filósofos"131 - "ela não poderá, por amor, que é o seu movimento,

\footnotetext{
${ }^{126}$ Ibid., p. 15 (tradução nossa).

${ }^{127}$ Ibid., p. 23 (tradução nossa).

128 Aquaviva, Claudio (1586). Lettera del Nostro Padre Generale Claudio Acquaviva. Dello studio della perfettione, \& carità fraterna. 19/05/1586. Roma, p. 7 ("Nela [na renovação do espírito] encontra o servo de Deus outro repouso, ou outro contentamento, que é o fazer a vontade daquele cuja vontade é a única regra de toda retidão, cujo desejo é que façamos sua vontade somente para o nosso bem e nossa felicidade").

${ }^{129}$ Ibid., p. 8 (tradução nossa).

${ }^{130}$ Ibid., p. 8 ("Forçar-se de fazê-lo e executar de verdade esse estudo, colocando em obra aquilo que tanto as nossas constituições gritam e desde o início do noviciado nos foi inculcado: fazer sua a vontade de Deus, interpretada pelo superior, é grande princípio para que ela se torne cada dia mais doce, e fazer-nos com a experiência degustar, e com uma luz maravilhosa, que não é de luz natural, conhecer claramente, que esta é a doutrina do céu").

${ }^{131}$ Ibid., p. 17 (tradução nossa).
} 
buscar Deus nas criaturas" ${ }^{\prime 132}$.

Já a obra de Fazio (1594) - Trattato utilissimo della mortificatione delle nostre passioni, \& affetti disordinati -, por sua vez, lembra que originalmente as paixões são como os pés de nossa alma - "as potências dadas ao homem para caminhar a Deus"133. No entanto, as potências estão presas aos nosso afetos desordenados que "nos impedem de nos aproximarmos de Deus; e

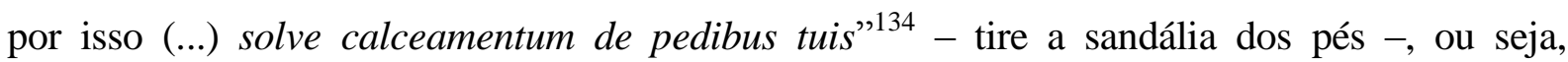
mortifique-se por meio da oração, porque "è proprio di questo santo essercitio della Mortificatione sciorre da piedi dell'anima nostra questi legami di nostri affetti disordinati, \& renderla affatto libera, \& pronta ad inalzarsi con la oratione santa à Dio"135.

Mais à frente, recorda que a vontade é uma potência que, sozinha, é cega, tendo, portanto, necessidade de um guia justo:

Ma perche l'esperienza t'hà pur troppo, \& con gran danno tuo mostrato, che non sei buono tu per guida di lei; è necessario, che ti risolui di soggettarla con la Mortificatione santa, all'indrizzo, \& guida della volontà di Dio, \& di quelli, che in luogo di lui ti governano, se non vuoi incorrere ne gl'inciampi che l'istesso Signore ti predisse dicendo: Si coeco coecus ducatum prestet, ambo in foveam cadunt ${ }^{136}$.

E segue exemplificando, uma a uma, como mortificar as potências da alma, ou seja,

como ordená-las ao fim da vocação jesuítica. Ao final da obra, falando dos mais diversos exercícios de mortificação, fala da indiferença:

Et cominciando dalla diffinitione di essa, dico, che Indifferenza al modo, che di lei si ragiona, non è propriamente altro, ch'una dispositione d'animo acquistata con lungo essercitio di Mortificatione, per laquale un'huomo havendosi determinatamente prefisso il fine della perfettione spirituale, alla quale aspira; nella determinatione poi de mezzi, che secondo lo stato suo, à tal fine s'appartengono, si rende ugualmente pronto ad abbracciare; ò

\footnotetext{
${ }^{132}$ Ibid., p. 17 (tradução nossa).

133 Fazio, Giulio (1596). Trattato utilissimo della mortificatione delle nostre passioni, \& affetti disordinati. Composto nuovamente per il molto R. P. Giulio Fatio, della Compagnia di Giesu. Brescia: Pietro Maria Marchetti, p. 5 (tradução nossa).

${ }^{134}$ Ibid., p. 5 (tradução nossa).

135 Ibid., p. 6 ("É próprio deste santo exercício da Mortificação tirar dos pés da nossa alma estes legâmes dos nossos afetos desordenados, e torná-la de fato livre e pronta a alçar-se com a oração santa a Deus.").

${ }^{136}$ Ibid., p. 48-49 ("Mas como a experiêcia te mostrou tanto e com grande dano teu que não és bom tu por guia dela, é necessário que tu te resolvas a sujeitá-la com a Mortificação santa ao lugar e guia da vontade de Deus e daqueles que, no lugar dele, te governam; se não quiseres incorrer no erro que o mesmo Senhor te predisse dizendo: Si coeco coecus ducatum prestet, ambo in foveam cadunt").
} 
lasciare qualsivoglia di essi, nel tempo, \& modo che da suoi Superiori le verrà semplicemente significativo, $\&$ imposto ${ }^{137}$.

No prólogo da obra - Le Royaume de Dieu, et le vray chemin pour y parvenir -, Pedro Sanchez (1607) escreve que "tendo colocado os olhos (...) sobre as regras de religiões sacratíssimas, descobri que somente a obediência é o grande caminho Real por onde se deve caminhar na vida comum"138. Definindo, portanto, o caminho para se atingir a perfeição na vida: a obediência conforme é definida nas Constituições. Segundo ele, a obediência é uma virtude e, portanto, está de acordo com a razão, enquanto que o vício é contra a razão e a natureza humana.

No Livro V, falando sobre a "obediência que é devida aos superiores", insistindo no fato de que a obediência é uma virtude, diz:

Or l'obeissance est une vertu, qui nous incline à obeyr au commandement du superieur, qui commande au nom de Dieu, (...) / car ainsi le dict le vray superieur, fils de Dieu. Celuy qui vous obeist, il m'obeit aussi, \& celuy qui vous mesprise, aussi me desprise. Et de la façon nous ne devons obeyr à ceux qui commandent, à cause qu'ils sont sçavants, bons, ou puissans, sinon pource qu'ils tiennent ce nom \& authorité de Dieu ${ }^{139}$.

E lembra que é suficiente se considerarmos que a vontade do Superior é, antes, a vontade de Deus. E dá exemplos, tirados da observação da realidade, de como tudo obedece, tudo é hierarquicamente organizado, toda a realidade é cosmológica.

Villanueva (1608) em seu livro sobre a oração mental, faz um verdadeiro tratado filosófico/espiritual sobre esta prática, dividindo a oração mental em oração de entendimento

\footnotetext{
${ }^{137}$ Ibid., p. 140 (“E começando por sua definição, digo que Indiferença - como sobre ela se raciocina - não é outra coisa senão uma disposição do ânimo conquistada com longo exercício de Mortificação, pela qual um homem tendo determinadamente prefixado o fim da perfeição espiritual à qual aspira, e, em seguida, determinado os meios, conforme seu estado e a tal fim pertencem, torna-se igualmente pronto a abraçar ou deixar qualquer um desses meios, no tempo e modo que dos seus Superiores lhe virá simplesmente significado e imposto").

${ }^{138}$ Sanchez, Pedro (1607). Le Royaume de Dieu, et le vray chemin pour y parvenir. Composé en Espagnol par le Pere P. Sanchez, Docteur de la Compagnie de Iesus. Traduit en François, par F. Guillaume Levite, de l'Ordre des Predicateurs. Paris: Chez Adrian Beys, p. iii (tradução nossa).

${ }^{139}$ Ibid., pp. 560-561 ("Ora, a obediência é um virtude que nos inclina a obedecer à ordem do superior, que comanda em nome de Deus, (...) porque assim o disse o verdadeiro superior, filho de Deus: aquele que vos obedece, me obedece também, e aquele que vos despreza, também me despreza. De maneira que não devemos obedecer àquele que comanda porque sejam sábios, bons ou poderosos, mas porque têm esse nome e autoridade por parte de Deus").
} 
e oração de vontade. E cada um dessas em quatro graus distintos: os quatro tipos de oração de entendimento são a cogitação, a meditação, a especulação e a contemplação; e os quatro tipos de oração de vontade são a petição, a ação de graças, o louvor a Deus e o amor a Deus. A partir dessas distinções, dedica-se aos tipos de oração de entendimento, porque "o entendimento costuma abrir caminho à vontade, para que com o maior conhecimento, ela se dilate no desejo e afeto" 140 .

Diz que a oração mental é superior à oração vocal, porque

Dios mas atiende al coraçon, que a las palabras: pero añadimos la palabra, para que quando el alma en la oracion se siente cayda, con la voz exterior se levante: juntandose por este camino la memoria con Dios: atendiendo el entendimiento al sentido de lo que se ora, y el afecto por la devocion inflamado guste quan suave es el Señor ${ }^{141}$.

Segue, portanto, explicando os tipos de oração de entendimento. O primeiro cogitação ou consideração - é designado como um primeiro olhar do nosso entendimento sobre a realidade: "se estende ao que percebemos com os sentidos para conhecer alguns efeitos, e às imaginações que temos, e finalmente aos discursos da razão, com tudo o que pertence à verdade que buscamos com o nosso entendimento" ${ }^{142}$. Segundo ele, esse tipo de oração, tem necessidade, antes de mais nada, de todas as potências tanto da alma sensitiva, quanto da alma racional.

Ainda tratando da cogitação, lembra que, às vezes, acontece que o homem fica distraído na oração; para ele a distração está estreitamente ligada à desordem dos afetos:

es cosa clara, que por mas cuydado que un alma ponga en estar atenta en la oracion, si ay descuydo en la mortificacion de sus apetitos, no ha de salir con ello (...). Abran pues los ojos los que por una parte quieren darse a la oracion, y por otra tienen descuydo en la mortificacion, que por mas que con

\footnotetext{
${ }^{140}$ Villanueva, Melchior de (1608). Libro de oracion mental. Compuesto por el Padre Melchior de Villanueva, de la Compañia de Iesus. Toledo: Pedro Rodriguez impressor del Rey nuestro Señor, p. 12,2 (tradução nossa).

${ }^{141}$ Ibid., p. 7,1 ("Deus atende mais ao coração que às palavras. Porém acrescentamos a palavra para que, quando a alma na oração se sente caída, com a voz exterior se levante, juntando-se, por este caminho, a memória com Deus; atendendo o entendimento ao sentido do que se ora, e o afeto inflamado pela devoção saboreie quão suave é o Senhor").

${ }^{142}$ Ibid., p. 18,1 (tradução nossa).
} 
su libertad trabajen para atar esta bestia, al punto que ellos la atan, la desata la passion, y le da alas para que buele ${ }^{143}$.

Finalmente, o último tratado do livro é dedicado à contemplação. E citando e explicando as coisas que melhor dispõem o homem à contemplação, chega a afirmar que uma das coisas que mais dispõem a alma para a vida contemplativa é a vida ativa,

la qual consiste en el exercicio de las virtudes morales, como son la humildad, paciencia, mansedumbre, y las demas: porque las Theologales, como mas principales, son para la vida contemplativa. La qual, como lo prueva Aristoteles por muchas razones, se aventaja a la activa: que como superior viene a servilla, como criada a señora. Y assi san Gregorio sobre Ezechiel a la activa llama servidumbre, y a la contemplativa libertade ${ }^{144}$.

Por que é livre a contemplação? São duas as explicações expostas por Villanueva, a partir da obra de Ricardo de Santo Victor: a primeira respeita ao fato de que a contemplação não tem nada que a detenha, de tal maneira que se diz - com São Boaventura - que "está livre de pecado e do desejo e cuidado com o temporal"145, assim como o afirma também São Gregório, para quem "nosso espírito vem a estar livre quan do, tendo por pouco o desejo das coisas da terra, se descarrega do apetite do temporal, com a segurança interior da nossa mente" ${ }^{146}$; e a segunda diz:

se nota en esta libertad de la contemplacion, (...) el señorio que tiene el alma contemplativa, para rebolverse (como dezia Ricardo) a todas partes: porque no tiene atadura que le detenga, o porque tiene licencia para yr donde quisiere: como si dixessemos de un hidalgo, que es libre, porque no es tributario: o que es libre, para traer armas ${ }^{147}$.

Explica, já no final da obra, para melhor exemplificar o que seja essa liberdade, a diferença entre o amor forte e o amor livre:

\footnotetext{
${ }^{143}$ Ibid., p. 127,2 (“É coisa clara que, por mais cuidado que uma alma ponha em estar atenta na oração, se há descuido na mortificação de seus apetites, não sairá da desatenção com isso (...). Abram pois os olhos aqueles que, por um lado querem dar-se à oração, e por outro têm descuido na mortificação, porque por mais que com sua liberdade trabalhem para atar essa besta, até o ponto que a atam de fato, a desatará a paixão, e lhe dará asas para que voe”).

${ }^{144}$ Ibid., p. 331,1 ("A qual consiste no exercícios das virtudes morais, como são a humildade, paciência, mansidão e as demais. Porque as Teologias, como mais principais, são para a vida contemplativa que, como o prova Aristóteles com muitas razões, é mais vantajosa que a ativa, que como superior vem a servi-la, como criada à senhora. E também São Gregório, falando de Ezequiel, à vida ativa chama servidão e à contemplativa liberdade").

145 Ibid., p. 339,1 (tradução nossa).

146 Ibid., p. 339,1 (tradução nossa).

${ }^{147}$ Ibid., p. 339,2 ("Se nota nessa liberdade da contemplação (...) o senhorio que tem a alma contemplativa para dirigir-se (como dizia Ricardo) a todas os lugares: porque não tem ataduras que a detenha, ou porque tem licença para ir onde quiser. Como se falássemos de um fidalgo que é livre porque não é tributário, ou que é livre para carregar armas").
} 
El amor libre tiene señorio sobre las tentaciones, muy de otra manera que el amor fuerte: porque este con forças resiste, pero aquel no haziendo caso de ellas, por la compañia de la luz que trae consigo, con que conoce lo que son las cosas, y por el señorio que en si tiene. Tampoco paga tributo al mundo, porque mira la gloria de Dios, y no la de los hombres. Sale con libertad a buscar las almas, que Dios comprò con su sangre, sin que le detengan interesses proprios, aunque sean a vezes espirituales, pidiendolo assi la necessidad, charidad, o la obediencia ${ }^{148}$.

Quando a este amor libre se junta el espiritu de libertad, haze que las sobredichas condiciones, y exercicios deste amor tengan eficacia: que aunque sea assi, que el tal amor estè de assiento enel coraçon, no siempre serà facil al que le tiene, exercitalle: o porque el Señor le mueve a otra cosa, o por poca salud, o por descuydo nuestro, o por contradiciones grandes que se ofrecen. At ubi spiritus, ibi libertas. Mas donde esta el espiritu, alli està la libertad ${ }^{149}$.

Quanto ao que respeita à importante obra de Rodrigues (1609) - Ejercicios de perfeccion y virtudes cristianas -, infelizmente só tivemos acesso à sua terceira parte. No entanto, encontramos ali alguns importantes aspectos, especialmente, por ser essa a parte denominada De varios medios para alcanzar la virtud y la perfeccion. Segundo o autor, logo no início da obra, importante meio para se alcançar a perfeição, são os votos ${ }^{150}$, porque são um exercício no caminho em direção à perfeição; porque tornam o religioso livre dos cuidados com as coisas do mundo e porque o religioso, com votos, se torna um holocausto vivo a tudo o que é de Deus.

No capítulo V, lembra que os votos não tiram a liberdade, pelo contrário, aperfeiçoam a liberdade do homem:

\footnotetext{
${ }^{148}$ Ibid., pp. 419,2-420,1 ("O amor livre tem senhorio sobre as tentações, muito diferentemente do amor forte; porque este com forças resiste, porém aquele, não fazendo caso delas, pela companhia da luz que traz consigo, com que conhece o que são as coisas, e pelo senhorio que em si tem. Tampouco paga tributo ao mundo, porque olha a glória de Deus, e não a dos homens. Sai com liberdade para buscar as almas que Deus comprou com seu sangue, sem que o detenham interesses próprios, ainda que sejam às vezes espirituais, pedindo a ele assim a necessidade, caridade ou a obediência").

149 Ibid., p. 420,2 ("Quando a este amor livre se junta o espírito de liberdade, faz com que as sobreditas condições e exercícios deste amor tenham eficácia. Ainda que seja assim (que tal amor esteja assentado no coração), nem sempre será fácil ao que o tem exercitá-lo; ou porque o Senhor lhe move a outra coisa, ou por pouca saúde, ou por nosso descuido, ou por contradições grandes que se oferecem. At ubi spiritus, ibi libertas. Mas onde está o espírito, ali está a liberdade").

${ }^{150}$ Assim afirma: "Pues los medios principales que la Religion tiene para alcanzar la perfeccion, son los tres votos esenciales que hacemos, de pobreza, castidad y obediencia”. Rodriguez, Alonso (1834). Ejercicio de perfeccion y virtudes cristianas, su autor el Padre Alonso Rodriguez de la Compañía de Jesus, natural de Valladolid. Dividido en tres partes. Parte tercera. De varios medios para alcanzar la virtud y perfeccion. Nueva Impression. Barcelona: Imprenta de D. Valero Siena y Marti, p. 91.
} 
porque lo que hacen los votos, es afirmar y fitar nuestra voluntad en lo bueno, para que esté mas lejos de volver atrás; lo cual no quita, sino antes perficiona mas la libertad, en su modo; como en Dios, y en los bienaveturados que no pueden pecar, y no les quita eso la libertad, antes la tienen perfectísima ${ }^{151}$.

E continua, algumas páginas adiante:

Luego cuanto mas os taparen y cerraren ese camino, para que no useis mal de vuestra libertad, tanto os hacen mayor bien: de manera que sujetar vuestra voluntad al superior por el voto de la obediencia, no es perder la libertad, sino perficionarla y engastarla en oro finísimo de la obediencia y de la voluntad de Dios ${ }^{152}$.

Mais à frente, fala da obediência como uma virtude que, entre todas as outras, é a única que oferece a Deus tudo o que se é, e encerra em si todas as outras virtudes:

De manera que la obediencia es la virtud mas esencial en la Religion, y la que hace á uno ser Religioso: esa es la que agrada á Dios, mas que el sacrificio y las victimas: en esa se incluye y encierra la pobreza, la castidad, y todas las demas virtudes; porque si sois obediente, sereis pobre, casto, humilde, callado, sufrido, mortificado, y alcanzareis todas las virtudes; y esto no es encarecimiento, sino verdad muy llana; porque las virtudes se adquieren y alcanzan con el ejercicio de sus actos, y de esa manera nos las quiere dar Dios. Pues este ejercicio nos da la obediencia: todas las reglas que tenemos, $\mathrm{y}$ todas las obediencias que nos mandam, son ejercicios de virtudes ${ }^{153}$.

A primeira obra de Nieremberg (1631) que apresentamos é também uma de suas primeiras

obras publicadas - De Artes Voluntatis. Ele se propõe dar à compreensão do leitor as maneiras

de conduzir a vontade no sentido do Sumo Bem. Para ele é preciso, antes de mais nada, diferenciar bem as coisas que estão nas mãos do homem daquelas que dependem da Fortuna $^{154}$ : a

\footnotetext{
${ }^{151}$ Ibid., p. 99 ("Porque o que fazem os votos é afirmar e fazer nossa vontade olhar para o bem, para que esteja mais longe de voltar atrás; o que não tira, mas antes aperfeiçoa mais a liberdade em seu modo; como em Deus e nos bem-aventurados que não podem pecar, e isso não lhes tira a liberdade, antes a têm perfeitíssima").

${ }^{152}$ Ibid., p. 101 ("Logo, quanto mais os impedirem e fecharem esse caminho para que não useis mal de vossa liberdade, tanto maior bem vos fazem. De maneira que sujeitar vossa vontade ao superior pelo voto da obediência não é perder a liberdade, mas aperfeiçoá-la e engastá-la no ouro finíssimo da obediência e da vontade de Deus").

${ }^{153}$ Ibid., pp. 214-215 ("De maneira que a obediência é a virtude mais essencial na Religião, e é a que faz a alguém ser Religioso. É a que agrada a Deus, mais que o sacrifício e as vítimas. Nela se inclui e encerra a pobreza, a castidade e todas as demais virtudes; porque se sois obediente, sereis pobre, casto, humilde, calado, sofrido, mortificado, e alcançareis todas as virtudes. E isso não é exagero, mas verdade muito certa, porque as virtudes se adquirem e alcançam com o exercício de seus atos, e dessa maneira Deus nos quer dá-las. Pois este exercício nos dá a obediência; todas as regras que temos e todas as obediências que nos mandam são exercícios de virtudes").

${ }^{154}$ Ele diz: "Il y a donc cette difference entre les choses qui nous appartiennent, \& celles qui dépendent de la Fortune, que celles-là sont libres, $\&$ celles-cy ne sont pas. C'est pourquoy si nous voulons nous conserver ce rare avantage de ne relever que de nous-mesmes, nous devons tenir pour indifferent ce qui n'est point en nostre puissance; autrement certes, nous sçaurions éviter de devenir esclaves; nostre passion fera nostre servitude; elle sera le titre en vertu duquel nous passerons entièrement au pouvoir d'autruy". Nieremberg, Juan Eusebio (1657). L'art de conduire la volonté selon les precepts de la morale ancienne \& Moderne, tirez de Philosophes Payens \& Chrestiens. Traduit du latin de Jean Eusebe de Nieremberg, Paraphrase \& de beaucoup enrichy par Louÿs Videl, de Dauphiné. Dedié à Monsieur de Lionne, Conseiller d'Estat ordinaire \& secretaire des Commandemets de la Reyne Regente. Paris: Chez Jean Pocquet, p. 147.
} 
essas últimas, não dependendo do homem, se deve estar indiferente, do contrário, corre-se o risco

de ficar escravo delas. E quais são, pois, os bens que devemos entender como aqueles a que se dirigirá mais adequadamente a vontade?

Sans doute, ce sont les biens de l'esprit; la bonté, l'innocence, les moeurs; les actions honnestes \& legitimes; les saines affections; les bonnes oeuvres; \& le reste des choses qui appartiennent à la Vertu; qui sont de sa jurisdiction \& de son domaine; En un mot, tout ce qui est sujet à la Volonté tout ce qui luy obeyt, \& en releve souverainement, c'est seulement sur cela que nous avons du pouvoir, mais nous n'en avons point sur les choses qui appartiennent à la Fortune ${ }^{155}$.

Explica, mais à frente, que a vontade, de per se, não se dirige sozinha ao Sumo Bem,

devendo, portanto, ser guiada pela Razão do homem:

Nostre Volonté est de certe sorte, elle ne demeure pas long temps pure; elle se soüille bien-tost de l'ordure des passions. Son partage naturel est la liberté; elle a droit de se porter du costé qu'il luy plaist, \& d'agir raisonnablement, \& de se porter au bien. Or, ce qui l'en détourne $\&$ luy fait prendre en party contraire; c'est le trouble que luy causent les passions; qui la débauchent si fort, \& la pervertissent tellement, qu'elle en devient inhabile à toute sorte d'employs legitimes ${ }^{156}$.

Fica claro, no trecho acima, o que caracteriza o homem, nessa antropologia: sua Razão

e sua Liberdade ${ }^{157}$. No entanto, tantas vezes, o homem abre mão daquilo que o diferencia dos animais $^{158}$. É preciso, nesse sentido, que o Entendimento, esclareça a Vontade. Mas, antes, é preciso que o Entendimento seja esclarecido pela Graça:

${ }^{155}$ Ibid., p. 158 (“Sem dúvida são os bens do espírito: a bondade, a inocências, os valores morais, as ações honestas e legítimas, as afeições sanas, as boas obras, e o resto das coisas que pertencem à Virtude, que são de sua jurisdição e de seu domínio. Numa palavra: tudo o que é sujeito à Vontade, tudo o que lhe obedece soberanamente; é somente sobre isso que nós temos poder, mas sobre as coisas que pertencem à Fortuna não temos nenhum poder").

156 Ibid., p. 316 ("Nossa Vontade é dessa sorte: ela não permanece muito tempo pura; ela se suja rapidamente das sujeiras das paixões. Seu par natural é a liberdade: ela tem o direito de se colocar do lado que lhe apraz e de agir razoavelmente ou bem. Ora, o que a faz mudar o caminho e pegar a parte contrária é o mal que lhe causam as paixões, que a desviam tão fortemente, e a pervertem de tal maneira que ela se torna inábil a todo tipo de empregos legítimos"). ${ }^{157}$ Ele, de fato, na seqüência do pensamento, completa: "Nous avons eu gratuitement la Raison \& la liberté; \& nous en faison si peu d'estat, que nous n'avons pas honte de les vendre pour le mésme prix, auquel les bestes ne refuseroient pas de les acquerir; \& par une mal-heureuse \& brutale émulation, devenants plus déraisonnables, voire, diray-je, plus bestes que les bestes mesmes, nous nous privons volontairemente de deux si excellents avantages; nous nous rendons indignes de la grandeur de nostre condition, \& de tous les privileges qui l'accompagnent, en nous rendans sujets à nos passions; Nous perdons la gloire de tenir rang dans la famille du Ciel; \& au lieu d'estre considerez avec cet auguste titre d'enfants de Dieu, nous ne sçaurions plus passer que pour de miserables esclaves de la Fortune" (p. 320).

158 Ele diz: "Nous avons eu gratuitement la Raison \& la liberté; \& nous en faisons si peu d'estat, que nous n'avons pas honte de les vendre pour le mésme prix, auquel les bestes ne refuseroient pas de les acquerir; \& par une mal-heureuse \& brutale émulation, devenants plus déraisonnables, voire, diray-je, plus bestes que les bestes mesmes, nous nous privons volontairemente de deux si excellents avantages; nous nous rendons indignes de la grandeur de nostre condition, \& de tous les privileges qui l'accompagnent, en nous rendans sujets à nos passions; Nous perdons la gloire de tenir rang dans la famille du Ciel; \& au lieu d'estre considerez avec cet auguste titre d'enfants de Dieu, nous ne sçaurions plus passer que pour de miserables esclaves de la Fortune". Ibid., p. 320. 
Ainsi, quoy que l'opinion luy represente dur y penible, le moyen d'acquerir son repos; elle tirera de la Raison, dequoy n'y trouver que de l'aizance \& de la facilité; \& la connoissance qu'elle aura de la grandeur \& de la dignité de son but, changera toutes ses épines en roses. Mais, avec que l'assistance du Ciel; elle a sans doute besoin de la Grace; c'est d'où luy doit venir son plus grand \& plus asseuré secours; c'est d'où elle doit attendre l'heureux succez de toutes ses entreprises; $\&$ d'autant plus, que c'est-ce qui opere tout ce qu'il y a de bien en nous; que sans cette ayde nous ne ferions que travailler inutilemente; \& qu'errer dans une obscure nuit, quelque effort que face nostre Raison, \& quelque grande lumiere qui d'ailleurs nous éclaire ${ }^{159}$.

Eis a autêntica liberdade do homem: essa "nossa condição" de "membros da família do

Céu" e augustos "filhos de Deus". Mais que "miseráveis escravos da Fortuna", pela "liberdade", e pela "razão", e pela "Graça", os homens se devem conceber como "escravos de Deus"160.

Considerando-se assim, o homem é capaz de atingir a verdadeira Felicidade, que é

un certain silence de l'appetit, à qui la pleine satisfaction de posseder le bien qu'il avoit ardemment souhaitté, ne laisse desormais rien demander, \& ferme comme la bouche pour toutes choses. C'est une retenue, une modestie de l'ambition, qui s'est prescrit de bornes à elle-mesme, \& s'est renfermée dans des limites. C'est une prison de la convoitise, que n'a plus le pouvoir de s'élever contre l'authorité souveraine de la Raison. C'est un rassasiement du coeur sans dégoust; une conqueste, une proye de la Volonté, l'ajustemente de l'esprit avec les choses; l'union, \& pour ainsi dire, le mariage de l'amour avec son object; une heureuse rencontre de ce que l'on cherche, la presence de ce que l'on ayme; l'accomplissement de l'esperannce; l'effect du desir; la possession du bien, \& pour tout comprendre en un mot, un certain Assez ${ }^{161}$.

\footnotetext{
${ }^{159}$ Ibid., p. 377-378 (“Assim, mesmo que a opinião se lhe represente dura e penível, ela tirará da Razão (de onde só se tira comodidade e facilidade) o meio de conseguir repouso; e o conhecimento que ela terá da grandeza e da dignidade de seu objetivo mudará todos os espinhos em rosas. Mas, somente com a assistência do Céu; ela tem, sem dúvida, necessidade da Graça: é de onde lhe vem seu maior e mais seguro socorro, é de onde ela deve esperar o feliz sucesso de todas as empresas, e ainda mais é o que opera tudo o que há de bem em nós. Sem essa ajuda nós só trabalharíamos inutilmente, e erraríamos numa noite escura").

${ }^{160}$ Em outra obra - Vida Divina e camino real de grande atajo para la perfeccíon -, Nieremberg (1957), falando "do direito e justiça que Deus tem para que não façam os homens sua própria vontade, mas a divina" (capítulo segundo), explica: "Añado más: que aunque no fuéramos esclavos de Dios, como lo somos, debiendo por toda ley hacer su voluntad; y aunque no fuéramos hijos suyos, por lo cual le debemos toda obediencia; y aunque no fueran las almas sus esposas, ni El fuera tan infinitamente perfecto, nin le debiéramos de jusiticia, ni piedad, ni religión, ni cosa criada, ni hacer servicio alguno; sólo por lo que por vía de agradecimiento le debemos, estamos obligados a no hacer en nada nuestra voluntad, sino en todo y por todo la suya" (p. 9) (“Acrescento mais: ainda que não fôssemos escravos de Deus, como o somos, devendo por toda lei fazer sua vontade; e ainda que não fôssemos filhos seus, pelo que lhe devemos toda obediência; e ainda que não fossem nossas almas suas esposas, nem Ele fosse tão infinitamente perfeito, nem lhe devêssemos justiça, piedade, religião, coisa criada ou serviço algum; somente pelo que lhe devemos por via de agradecimento, estamos obrigados a não fazer em nada nossa vontade, mas em tudo e por tudo a sua", tradução nossa). 161 Ibid., p. 118-119 ("Um certo silêncio do apetite, a quem a plena satisfação de possuir o bem que ele tinha ardentemente desejado, nada mais pede, e permanece como a boca fechada a todas as coisas. É uma contenção, uma modéstia da ambição, que prescreve limites a si mesma, e se fecha dentro de seus limites. É uma prisão da cobiça, que não tem mais o poder se elevar contra a autoridade soberana da Razão. É uma satisfação do coração sem desgosto algum; uma conquista, uma presa da Vontade, o ajustamento do espírito com as coisas; a união e, por assim dizer, o casamento do amor com seu objeto; um feliz encontro daquilo que se procura com a presença daquilo que se ama; o cumprimento da esperança; o efeito do desejo, a possessão do bem, e para tudo compreender em uma só palavra, um certo Assaz”).
} 
Sua segunda obra analisada - Vida divina y camino real de grande atajo para la perfeccion - fala do caminho que o homem deve seguir para atingir a perfeição. Como Sanches e Rodrigues, Nieremberg (1633) propõe que o caminho da perfeição é fazer a vontade de Deus: "Porque entre todos os exercícios espirituais, que são o sustento da alma, como o que se alimenta a vida de espírito e fervor, o cumprir e conformar-se à vontade de Deus durará por toda a eternidade, e não nos cansaremos desta doce ocupação" ${ }^{\text {"162 }}$.

Fazer a vontade de Deus coincide com uma certa "escravidão" ou obediência. E deve-se agir dessa maneira somente por verdadeira gratidão, que se mostrará “con cosa que sea nuestra propria", porque não se agradece um outro com coisa que não seja sua ou com coisa que já seja dele. Como, no entanto, de nosso só temos o arbítrio, a liberdade e a vontade, é preciso "dar ésta enteramente a Dios" $" 163$.

No fim da obra, Nieremberg diz:

De todo lo dicho hemos de sacar una incomparable estima de la virtud de la obediencia, virtud riquísima y poderosa para llenar un corazón de bienes espirituales y colmarle de grandes merecimientos; virtud poderosa para subir un alma a grande perfección en breve tiempo. Ella es una vida de ángeles que tienen por ocupación hacer la voluntad de Dios, significada por sus superiores; ella es una perfecta imitación del Hijo de Dios; ella es la quietud de las pasiones; ella es el descanso del corazón; ella es el sosiego del alma, ella es el vuelo al Cielo; ella es la causa de aprovechamiento espiritual, ella es el atajo de la perfección ${ }^{164}$.

\section{5) A liberdade, portanto}

Retomemos as perguntas iniciais: se é verdade que realizar uma escolha é um ato da liberdade, como é possível entender que uma escolha necessária seja um ato livre? Em que

\footnotetext{
162 Nieremberg, Juan Eusebio (1957). Vida Divina y camino real de Grande atajo para la perfeccion. Em Nieremberg, Juan Eusebio (1957). Obras escogidas del R. P. Juan Eusebio Nieremberg (E. Zepeda-Henriquez, ed.). Biblioteca de Autores Españoles, desde la formación del lenguaje hasta nuestros dias (continuación). Tomo 103. Madrid: Ediciones Atlas, p. 5 (tradução nossa).

${ }^{163}$ Ibid., p. 9.

${ }^{164}$ Ibid., p. 70 ("De tudo o que foi dito temos que tirar uma incomparável estima da virtude da obediência: virtude riquíssima e poderosa para encher um coração de bens espirituais e grandes merecimentos, virtude poderosa para que uma alma suba a uma grande perfeição em breve tempo. Ela é uma vida de anjos que tem por ocupação fazer a vontade de Deus, significada por seus superiores; ela é uma perfeita imitação do Filho de Deus; ela é a quietude das paixões; ela é o descanso do coração; ela é o sossego da alma, ela é o vôo para o Céu; ela é a causa do aproveitamento espiritual, ela é o atalho da perfeição").
} 
medida elementos como desejo, resignação e obediência podem ser colocados numa mesma expressão? Que dinâmica subterrânea sustenta o desejo dos nossos indipetentes a ponto de muitos deles esperarem ser enviados sem pedido?

E acrescentemos a essas perguntas dados tais como: praticamente todas as cartas Indipetae têm referência seja à obediência, obrigação ou imitação, seja à mortificação das paixões (lembremo-nos que as paixões são os potências sensitivas apetitivas gerais, ou seja, aquelas faculdades da alma sensitiva que dirigem o homem a um objeto qualquer desejado, ou o afastam de um objeto qualquer indesejado). Porém, também está presente na maioria absoluta das cartas alguma referência ao discernimento dos espíritos, ou seja, ao trabalho de conhecimento de si mesmo, a fim de identificar nos desejos sua origem, de tal modo que a dinâmica eletiva seja feita no sentido que melhor se adeqüe à sua vocação, ou ao fim para o qual se foi criado: dar maior glória a Deus, fazendo Sua Vontade.

Vimos também, através dos escritos espirituais da Companhia de Jesus, como aqueles conceitos filosófico-retóricos encontrados nos documentos representativos do scholicorum, bem como o dinamismo expresso nos textos da ratio spiritualis e da ratio institutorum, se encarnam numa prescrição de "experiência-modelo", por meio de uma síntese atenta de todo o conteúdo programático de formação dos jesuítas. Assim, somente entendendo que um ato livre é aquele iluminado adequadamente pela razão e deliberado pela vontade, ou seja, é aquele que se atualiza a partir do reconhecimento do Bem e Fim últimos da vida, que nada mais é do que gozar do Amor de Deus, aderindo à Sua Vontade, e desfazendo-se da vontade pessoal (que, muitas vezes, nada mais é do que uma paixão desordenada, ou seja, uma paixão, um desejo, que se volta para qualquer outra coisa que não seja aquilo que é verdadeiramente honesto, útil e agradável), e se identificando totalmente a Cristo (obediente ao Pai); somente entendendo que essa imitação de Cristo 
obediente, implica na obediência mesma ao "rosto" que Cristo assumiu na história pessoal de cada um dos jesuítas, ou seja, na obediência ao Instituto da Companhia de Jesus e aos Superiores que lhes são dados; somente assim se compreenderá que a liberdade é caminhar em direção ao destino, é se realizar plenamente, é chegar à perfeição.

Não é de se estranhar que tantas das obras de espiritualidade tenham insistido na "obediência": sem dúvida - usando os termos com os quais estamos trabalhando - por obediência à regra institucional que diz que somente a obediência é capaz de conceder unidade ao corpo da Companhia de Jesus, que se dispersa tanto no mundo. Todavia não há dúvida também de que tal insistência nasce da identificação na experiência de adesão ao corpo inaciano de um termo de coesão; nasce, portanto, da elaboração de uma prática.

Tendo esses textos como espelho, é possível compreender a razoabilidade de afirmações como a de Alonso Crespo ${ }^{165}$ que, em sua carta de petição, afirma que quer ser obediente, ou seja, quer ser "hijo verdadero de la Compañía", a fim de que se "cumpla su sancta Voluntad", a Vontade de "Nuestro Señor". Obediência e filiação: termos de uma vida realizada no cumprimento da Vontade de Deus.

Também Joseph Sepulveda ${ }^{166}$ faz uso da tópica da obediência para mostrar o quanto deseja ser "agradable a sua divina Magestad". Segundo ele, que deseja ser enviado para onde a "obediençia ordenasse", oferecer o "nonada" que é a Deus - por intermédio do Prepósito Geral, "que es mi Dios en la tierra" - coincide com uma disposição que lhe permite agora experimentar a consolação de "estar ya obligado a Dios". Aqui, a consolação - "não poder mais amar coisa alguma criada sobre a face da terra por si, mas somente no Criador de todas as coisas" ${ }^{\prime 167}$ - é experimentada no exercício da obediência para ser agradável da Deus, fazendo sua Vontade, estando obrigado a Ele.

\footnotetext{
165 ARSI, Indipetae Hispanae, FG 758, carta n. 73.

${ }^{166}$ ARSI, Indipetae Hispanae, FG 758, carta n. 116.

${ }^{167}$ Loyola, 1991, op. cit., p. 224 (EE. 317, tradução nossa).
} 
Pedro Ruiz ${ }^{168}$, por sua vez, diz que tem se empregado ordinariamente em tudo o que a obediência lhe ordena, demonstrando assim sua filiação, sua identificação com o corpo da Companhia de Jesus - sua identificação com daqueles que se designam como sendo "de Jesus". Ao final de sua carta, o indipetente ainda reafirma seu desejo de obedecer sempre ao Prepósito Geral, como filho que é. Mais uma vez o binômio obediência e filiação se ajuntam a expressões como "maior servicio y gloria de Dios", "sera para mi de mucho consuelo", "el consuelo que Nuestro Señor me comunica”, sempre descrevendo uma dinâmica onde a obediência aparece como termo de uma experiência de deliberação e de satisfação (que é igual à "consolação") e, portanto, de liberdade.

Como os demais, também Andres Porta ${ }^{169}$, no seu pedido, fala de sua indiferença e, nesse sentido, diz que quer ser empregado naquilo "que a la obediencia pareciesse". E, continua mais à frente, assegurando que esse seu desejo, dado por Deus, será cumprido com as graças que dEle há de receber. Segundo ele, seu desejo de uma “extraordinaria mission” é movido por desejo mais original de sofrer "deshonrras y peligros por amor de Nuestro Señor y la salvacion de las almas". Por "salvação das almas" era entendido o reconhecimento de Cristo e de Deus como criador do mundo e a adesão e identificação com o Verbo Encarnado, ou, para usar o Princípio e Fundamento, "louvar, reverenciar e servir a Deus Nosso Senhor" ${ }^{\prime 70}$. Dessa forma, para o indipetente, não interessa tanto em qual extraordinária missão irá trabalhar, mas, por obediência à Vontade de Deus, obedecendo ultimamente ao fim da Companhia de Jesus, trabalhar para que o mundo reconheça a Deus, identificando-se, finalmente, a Cristo que primeiro e definitivamente cumpriu esse papel, também obedecendo.

Leon Ximenes ${ }^{171}$ junta, em sua carta, topoi tais como obediência e consolação. Segundo ele, se ao Padre Geral parecer que seu envio ao Peru será para a maior glória de

\footnotetext{
${ }^{168}$ ARSI, Indipetae Hispanae, FG 758, carta n. 188.

${ }^{169}$ ARSI, Indipetae Hispanae, FG 758, carta n. 204.

${ }^{170}$ Loyola, 1991, op. cit., p. 62 (EE. 23, tradução nossa).

${ }^{171}$ ARSI, Indipetae Hispanae, FG 758, carta n. 290.
} 
Deus, "el si de Vuestra Paternidad lo tomare como si fuera dela voca del mismo Cristo, y como por obediencia suya", e continua pedindo que o Prepósito o envie por que, em indo por obediência, o ato será "mas meritorio" e ele irá "consolado". Fica evidente, aqui, como obedecer é ato da liberdade, porque é mais meritório e concede consolação.

Também Gabriel Mayo ${ }^{172}$ demonstra como, através da obediência, realiza a identificação com Cristo: "passando por obediencia a partes tan remotas en alguna manera me assemejare mas a mi dulce Jesus" que, por obediência, desceu da "Region de la vida, hasta esta nuestra Region de muerte”. E como, com isso, quer fazer aquilo que seja “mayor gloria ý honra del Señor". Lembremo-nos que Cristo, nessa visão, é o homem plenamente realizado, o Novo Homem, em quem se cumpre o destino humano, ou seja, em quem se cumpre a própria liberdade do homem.

Finalmente, Hernando dela Torre ${ }^{173}$ lembra o quão importante é poder ter um superior que lhe aponte e reja naquilo que seja "de mayor provecho suyo y gloria de su divina magestad" e afirma também que deseja imitar aqueles que, com suas vidas, demonstraram como se realiza o homem que vive sob a obediência.

Outros muitos exemplos se podem tirar das cartas, no entanto, avancemos um passo a mais: com o que acabamos de descrever abrem-se as vias para que analisemos com mais vagar o que seja propriamente "experiência” dentro desse horizonte.

\footnotetext{
${ }^{172}$ ARSI, Indipetae Hispanae, FG 758, carta n. 379.
}

${ }^{173}$ ARSI, Indipetae Hispanae, FG 759, carta n. 58/1. 


\section{CAPÍTLL 6 A experiência e as Indipetae}

Ao longo do último capítulo, como já havíamos anunciado anteriormente, vimos como a categoria "experiência" aparece repetidas vezes nos documentos com os quais trabalhamos.

Assim como o conceito de liberdade, a experiência é uma categoria que, ao longo dos séculos, viu seu sentido modificado inúmeras vezes. O que vem a ser experiência? Como, nos nossos documentos, ela aparece? Qual o sentido específico naquele contexto?

Nas Indipetae, lemos, por exemplo, em carta enviada em 02 de maio de 1583, pelo Irmão Coadjutor Seraphin Bonaventura Coçar:

Pero en semejante caso experimento (...) que ades hora me da devero Dios Nuestro Señor un desseo fervoroso, que como luz del cielo deshaze en mi alma aquellas tinieblas y razones, dexandome muy consolado, $\mathrm{y}$ con tal alegria, que me parece bastante para arrostrar a qualquiera dificultad y trabajo que por entonces se me podria ofrecer, y de hecho se me haze todo suave. ${ }^{1}$

Joan Sotalell, de Gandía, no dia 20 de maio de 1603, escreve também: “Tengo experimentado que muchas vezes, quando alguna tentacion, o otra cosa alguna me aflige, el

\footnotetext{
${ }^{1}$ ARSI, Indipetae Hispanae, FG 758, carta n. 4 (grifo nosso).
} 
medio para vencella, es pensar (...) yr a las Indias (...), y siento despues grande consuelo y facilidad en haser lo que antes me parecia muy pesado"2. Ou Gabriel Mayo que, um ano depois (10/03/1604), escreve dizendo que "juntamente al desseo (...) experimento facilidad grandissima para todos los trabajos de corazon, que me paracer en comparacion de aquellos, muy pequeños"3. Também Juan Bravo diz

experimentar muy a la clara que este desseo que me ha dado Nuestro Señor hasta agora ha sido como una lima con la qual gran parte de mys imperfecçiones han desaparecido, y melhorandose my vida notablemente fruto que es argumento claro de que es raiz divina la de donde mana ${ }^{4}$.

A categoria "experiência", nesses trechos, é colocada ao lado de expressões tais como "Dios Nuestro Señor", “alma”, “consolado", “trabajos”, “tentaciones”, “desseo". Como é possível uma "experiência" de Deus? Como é possível conhecer desejos, tentações ou a si mesmo e sua alma a partir da "experiência"? Como o trabalho pode ser lugar de uma "experiência"?

Nossa proposta nesse capítulo é mostrar a concepção de experiência que sustenta essa dinâmica apenas apresentada com exemplos até aqui. Como no capítulo anterior, a categoria será descrita a partir dos eixos do cogitari, do operare e da experientia, analisando documentos dos pólos scholicorum, ratio spiritualis, ratio institutorum e, finalmente, do pólo sintético-encarnado, ou seja, alguns dos principais escritos espirituais produzidos na Companhia de Jesus no período de influência do Generalato do padre Cláudio Aquaviva.

É preciso, pois, compreender bem como era entendida esta categoria no âmbito cultural e institucional específicos com o qual se está lidando aqui: trata-se de descrever a gramática de uso do termo, o campo semântico no qual está imerso.

\footnotetext{
${ }^{2}$ ARSI, Indipetae Hispanae, FG 758, carta n. 338 (grifo nosso).

${ }^{3}$ ARSI, Indipetae Hispanae, FG 758, carta n. 379 (grifo nosso).

${ }^{4}$ ARSI, Indipetae Hispanae, FG 758, carta n. 329 (grifo nosso).
} 


\section{1) A experiência e o scholicorum}

Como a filosofia seiscentista de forma geral, mas especialmente a que se desenvolveu em torno do ponto de vista escolástico retomado no período, abordava a questão da experiência?

É bem verdade que o período histórico com o qual lidamos é determinado por uma transição importante - entre uma realidade social que construía seus conhecimentos retoricamente $^{5}$ e uma outra que passou a construir cientificamente o conhecimento ${ }^{6}-$ onde justamente o debate não só filosófico, mas também científico, quanto ao que respeitava à experiência marcava claramente posições muito distintas ${ }^{7}$ : experientia $\mathrm{X}$ experimentum. Não obstante esta importante transição e as diversas implicações a ela inerentes, aqui nos concentraremos mais agudamente sobre o modelo construído em torno da manutenção de um pensamento propriamente escolástico.

Exatamente por se estar tratando de um período e de uma realidade institucional e cultural que construíram muito de seu conhecimento retoricamente, e sobretudo pelo fato mesmo de a retórica ser disciplina importante no sistema pedagógico jesuítico, se torna necessário assumir, aqui, algumas questões significativas deste âmbito.

\footnotetext{
${ }^{5}$ Segundo Mendiola (2003), essas sociedades são aquelas que se constituíram do século V a.C. ao século XVII d.C. Podemos descrever assim essa realidade retórica: a cognição estava construída sobre a oralidade/escritura, de forma que a leitura da realidade era sempre analógico-metafórica; estando baseada na oralidade/escritura, é uma realidade onde importa a interação entre as pessoas, ou seja, exige comunicação e sociabilidade; ainda por estar baseada na oralidade/escritura, era necessário que se normatizasse o falar, tornando-se o processo de aprendizado um processo moralizante e marcadamente cristão. É uma realidade, por fim, teleologicamente orientada. Cf. Mendiola, Alfonso (2003). Un nuevo reto a la interpretación de las crónicas de la conquista: historzar el concepto de experiencia. Ciudad de Mexico: mimeo.

${ }^{6}$ Para essa assim chamada realidade científica, Mendiola (2003) enumera as seguintes características: se desenvolveu a partir do século XVII e chega aos nossos dias; o processo cognitivo é baseado na depuração da escrita pelas técnicas de impressão, o que faz da leitura da realidade, uma leitura literal-referencial; sendo baseada na escrita/impressão como meio de comunicação, elimina a necessidade de interação e valoriza o discurso analítico e representacional (a palavra suplanta a coisa) e permite a comparação entre textos e opiniões diferenciadas, tornando-se, portanto, uma dinâmica individual e técnico-cognitiva. É uma realidade, por fim, cognitivamente orientada. Cf. Mendiola (2003), op. cit.

${ }^{7}$ Schmitt, em artigo de 1969, discutindo a questão da diferença entre experientia e experimentum em obras de Zabarella e Galileu, diz que "uma das tendências que mais claramente marcam a tendência do século XVII é uma ênfase crescente na experiência" (p. 80, tradução nossa). Uma ênfase que, segundo ele, se encontra tanto no que respeitava à produção filosófica (por exemplo, em Gassendi e Locke), quanto ao que respeitava à produção científica (por exemplo, as obras de Francis Bacon e Newton). Cf. Schmitt, Charles Bernard (1969). Experience and Experiment: a comparison of Zabarella's view with Galileo's in De motu. Studies in the Renaissance. Vol. 16 (1969), 80-138.
} 
É sabido como Cícero e Quintiliano eram os principais autores estudados quando o assunto era retórica: nihil mutare sine ratione, dizia Cipriano Soares em seu manual de retórica - De arte rethorica - defendendo a razoabilidade no uso de suas obras, ainda que pagãs $^{8}$. E, finalmente, vimos que a retórica, nesse contexto Neo-Escolástico, era o aprendizado da capacidade argumentativa ${ }^{9}$.

E, tal como foi assumida pelos jesuítas - segundo a filosofia aristotélico-tomista -, a retórica era estudada de forma que se respeitava uma compreensão da pessoa como unidade, irredutível a uma só dimensão - forma ou substância. Dessa forma, vemos um projeto retórico que não valorizava somente o intelecto em detrimento da paixão ou a racionalidade em detrimento da emotividade. Trata-se de uma antropologia de fundo que compreende o homem como razão encarnada, onde não há solução de continuidade entre matéria e substância e que traz consigo algumas importantes implicações.

Conforme o modelo aristotélico-tomista da topografia da alma ${ }^{10}{ }^{11}$, quatro são os chamados sentidos internos: fantasia, cogitativa, memória e senso comum. A cada um cabe um papel: o senso comum produz a primeira unificação das informações sensíveis, a fantasia inicia o processo de unificação espaço-temporal, a memória armazena e ordena essas informações em imagens, e a cogitativa é responsável pela primeira intelecção dos elementos não sensíveis.

De importante destaque é o papel da cogitativa - ratio particularis - que, além de inteligir os elementos não sensíveis (res non sensatas, como vícios e virtudes), sintetiza as informações sensíveis recolhidas pelos sentidos internos e armazenadas pela memória: é

\footnotetext{
${ }^{8}$ Cf. Zanlonghi, Giovanna (2003). La psicologia e il teatro nella riflessione gesuitica europea del CinqueSeicento. Memorandum, 4, 61-85. Retirado em 12/08/2003, do World Wide Web: http://www.fafich.ufmg.br/ $\sim$ memorandum/ artigos04/ zanlonghi.htm.

${ }^{9}$ Cf. Cap. 2 desta tese.

${ }^{10}$ Cf. Cap. 5 desta tese.

${ }^{11}$ Cf. acerca dessa temática - "topografia da alma" - Bergamo, Mino (1994). L'anatomie de l'âme: de François de Sales à Fénelon (M. Bonneval, trad.). Paris: Jérôme Millon (original de 1991).
} 
portanto o ponto alto da organização da atividade sensitivo-imaginativa. Apesar de ser de âmbito pré-racional, a cogitativa já está ordenada ao Fim Último, na medida em que faz um primeiro reconhecimento, no sensível, do Universal ${ }^{12}$.

Uma importante relação a se compreender é a que existe, nesse projeto retórico, entre memória e prudência: cabe à retórica, como técnica, dar aos elementos recolhidos uma unidade e uma dignidade final, o que só é possível se se compreende que a memória, na medida em que armazena e ordena em loci determinados uma série de phantasmata (o mesmo vale para a representação de elementos invisíveis), e sendo parte da prudência (assim como a escolástica herdou de Cícero), é também um habitus moral que se aperfeiçoa com determinados exercícios de retórica; e que também a prudência, na mesma medida em que tem a memória como uma de suas partes, tem também necessidade de imagens para se exercitar. Conseqüentemente, 1) a prudência se serve da memória como ponto de sustentação, 2) a memória só pode operar com imagens sensíveis e 3) o uso das imagines agentes e, particularmente, das imagens que surpreendem os sentidos acaba sendo vantajoso para o aperfeiçoamento da prudência ${ }^{13}$.

\footnotetext{
${ }^{12}$ Assim, já é possível distinguir um aspecto importante da antropologia que se constrói a partir dessa concepção da alma: os sentidos não são passivos, na medida em que concorrem ativamente no processo intelectivo. Podemos começar a completar a questão, lembrando: o intelecto age a partir das phantasmata. Se se compreende a unidade intelecto/sensibilidade, que está por trás dessa compreensão, não há contradição: "sensibilidade e intelecto interagem até o ponto que a virtus cogitativa apresenta uma estreita afinidade com o espírito; assiste-se a uma espiritualização da sensibilidade" (Zanlonghi, 2003, op. cit., p. 69, tradução nossa). Essa "espiritualização" permite a unidade entre razão e sensibilidade: o homem, enquanto razão encarnada que é, necessita dos sentidos para conhecer; sejam os sentidos externos (que recolhem as impressões), sejam os sentidos internos que formam imagens, depositadas e ordenadas na memória, que cumpre o papel de custodiar as impressões unidas aos juízos do intelecto.

${ }^{13}$ Sobre essa passagem cf. Zanlonghi, 2003, op. cit., pp. 75-76, quando ela afirma: "Todavia, para compreender de que modo a retórica age neste nexo, é preciso refletir sobre a conexão entre prudência e retórica. Muitas, na verdade, são as tangentes e um mesmo estatuto gnosiológico: nem ciência, nem opinião, produzem conhecimento, mas não demonstração, como a retórica desenvolve raciocínios que movem a partir de premissas prováveis e constróem uma razoabilidade orientada para o concreto, assim a prudência é a virtude que, em estreito contato com as paixões, discerne o bem do mal e orienta a escolha do bem concreto. Ambas orientadas para a ação, radicadas nos afetos, mas dirigidas para sua própria normalização, dividem o destino comum de agir naquela zona intermediária entre sentido e intelecto (...). Mesmo a prudência utiliza a cogitativa na sua aplicação na vida cotidiana, recebendo como matéria do raciocínio a variedade das ações possíveis ou a variedade dos aspectos e dos pontos de vista de uma mesma ação. A prudência precisa, para produzir o seu consilium, ver claramente a experiência. De onde tirará o socorro senão pescando da memória, da imaginação e da cogitativa as species que a retórica fundirá em imagens?” (p. . Sobretudo, cf. a obra de referência no assunto - arte da memória: Yates, Frances A. (1975). L'Art de la mémoire (D. Arasse, trad.). Paris: Gallimard (original publicado em 1966).
} 
É bem verdade que a "renascença" é marcada por uma mudança radical na concepção de memória que fora desenvolvida durante a Idade Média ${ }^{14}$. Com a "renascença", a memória sofre um processo de laicização, na mesma medida em que começa a ser lida sob a luz do neo-platonismo "renascentista" $"$. No entanto, vale lembrar que, graças à Segunda Escolástica, a Companhia de Jesus manteve a memória como parte da Prudência, como virtude do homem moral e do orador.

Retornaremos a esta questão mais à frente; antes, nos é necessário avançar alguns passos na compreensão filosófica da questão.

Outro aspecto a se considerar no ponto de vista filosófico quanto ao que respeita à categoria "experiência", antes porém de adentrarmos a análise do documento com o qual vimos trabalhando - o Manual Conimbricense sobre a Ética a Nicômaco -, é o papel da filosofia agostiniana na definição desta categoria.

Para Santo Agostinho (354-430) fé e razão não têm, entre si, fronteiras ou limites de separação: a razão ajuda o homem a alcançar a fé e a esclarecer seus conteúdos, da mesma

\footnotetext{
${ }^{14}$ A chamada arte da memória foi, segundo a tradição ciceroniana, "descoberta" por Simónides de Céos, alguns séculos antes da era cristã. Após entender o papel da visão e da ordem no processo memorativo, criam-se regras para facilitar o desenvolvimento do que passa a ser chamado "memória artificial". Mais tarde, Cícero enquadra a memória entre as disciplinas da Retórica (que, segundo ele, são cinco: inventio, dispositio, elocutio, memoria e pronuntiatio); e Quintiliano descreve o processo. Platão compreende a memória como sinal da divindade e da imortalidade da alma. Aristóteles também trata da memória e a relaciona à formação do conhecimento, apontando o importante papel da imaginação. Cada um desses pensadores da antigüidade, se tornará, na Idade Média e na "renascença", referência para um passo na compreensão dessa arte. Segundo Yates (1975), na antigüidade clássica é elaborado um "modelo arquitetural da memória", onde as coisas (para elas a memoria rerum) e as palavras (para elas a memoria verborum) a serem lembradas são ordenadas num espaço (locus ou topos), a partir de imagens (imaginibus ou phantasmata). É na Idade Média, no entanto, que a arte da memória passa a ter uma importante "intenção religiosa": há uma preocupação por se lembrar das coisas da salvação e da danação da alma, dos artigos da fé, da estrada para o céu (virtudes) e para o inferno (vícios). Essa preocupação com as virtudes e os vícios, faz com que os escolásticos retomem a obra aristotélica, especialmente a Ética à Nicômaco, que enquadra a memória como parte da prudência: "a memória pode ser um habitus moral quando a utilizamos para lembrar das coisas passadas em vista de uma conduta prudente no presente e de um olhar prudente para o futuro" (Ibid., p. 74, tradução nossa). A “memória artificial” é uma memória aperfeiçoada pela arte: eis o papel da Prudência.

${ }^{15}$ Com o advento da impressão, a memória perde seu lugar, porque não é mais necessário saber par coeur as lições aprendidas. Assim, a "arte da memória" torna-se um jogo curioso, ou um artifício mágico: "Tem-se a impressão que no século XVI a arte da memória começa a declinar. O livro impresso destrói os velhos hábitos da memória" (Ibid., p. 143, tradução nossa). Os principais representantes dessa nova áurea ocultista que aparece em torno à arte da memória são as correntes neo-platônicas renascentistas, especialmente de Pico de la Mirandola e Marcilo Ficino. Também Giordano Bruno envereda pelas sendas da memória e desenvolve o conceito a paritr de uma concepção mágica.
} 
forma que a fé orienta e ilumina a razão; os conteúdos da revelação cristã e as verdades acessíveis ao pensamento racional caminham juntos. Sua obra é profundamente enraizada na filosofia de Platão, especialmente nos textos do neo-platônico Plotino, de quem assume, por exemplo o conceito de alma ${ }^{16}$.

Uma de suas mais importantes obras é o De Trinitate, texto onde procura sistematizar a filosofia e a teologia cristãs. Esta obra, divulgada entre os anos 400 e 416, em 15 livros, é um tratado não só sobre a Santíssima Trindade, mas sobre o próprio homem, já que ele é uma analogia - imagem e semelhança - da própria Trindade.

No início do primeiro livro do De Trinitate, Agostinho já lança mão da categoria "experiência":

com a ajuda de Nosso Deus e Senhor e conforme nossa capacidade, empreenderemos a tarefa que nos pedem, e assim demonstraremos que a Trindade é um só e verdadeiro Deus, e quão retamente se diz, se crê e se entende que o Pai, o Filho e o Espírito Santo possuem uma só e mesma substância ou essência. Assim não poderão afirmar, por assim dizer, que enganamos os adversários com nossas pretensões. Mas que se convençam pela própria experiência de que existe aquele sumo Bem, só visível às mentes puras. E se eles não podem compreender, é porque o limitado olhar da inteligência humana não é capaz de se fixar nessa luz sublime, se não for alimentado pela justiça fortalecida pela fé ${ }^{17}$.

No entanto, é preciso entender bem o que ele quer dizer quando faz uso dessa categoria, sobretudo se se considera o uso freqüente de expressões do tipo "há de entender, com a ajuda do Senhor"18 " "a alma, segundo penso, deve humilhar-se, para que possa brilhar, iluminada pela graça de Cristo"19 "fatos em que o Senhor Deus nos anuncia sua ação"20, "Deus nos envia sinais adequados ao nosso caráter de peregrinos",21, "Deus é a verdade!"22 ou

\footnotetext{
${ }^{16}$ Para Agostinho, o homem é uma alma que faz uso de um corpo. Até naqueles conhecimentos adquiridos pelos sentidos, a alma se mantém em atividade e ultrapassa o corpo. Os sentidos só mostram o imediato e o particular, enquanto que a alma é capaz de tocar o universal e atingir a compreensão pura, porque a alma se confunde com o próprio Deus.

${ }_{17}$ Agostinho, Santo (1994). A Trindade (A. Belmonte, trad.). São Paulo: Paulus (original latino de 416), p. 27 (I 2,4).

${ }^{18}$ Ibid., p. 60 (I 13,28).

${ }^{19}$ Ibid., p. 82 (II Prólogo,1).

${ }^{20}$ Ibid., p. 131 (III 10,19)

${ }^{21}$ Ibid., p. 147 (IV 1,2)

${ }^{22}$ Ibid., p. 263 (VIII, 2,3).
} 
ainda "torna-se necessário crer antes de compreender" ${ }^{23}$. Em todas estas expressões, bem como em outras tantas, começa-se a compreender como é possível, em Agostinho, que no conhecimento esteja implicada a fé, que já é uma adesão amorosa: credendo diligere, ele diz.

Mas quem ama o que desconhece? Pode-se conhecer algo e não o amar; pergunto, porém, se é possível amar algo que se ignora, porque se isso for possível, ninguém é capaz de amar a Deus antes de o conhecer. E o que é conhecer a Deus, senão o contemplar e perceber com firmeza, com os olhos da mente? Ele não é um corpo para que possamos divisá-lo e percebê-lo com os olhos corporais ${ }^{24}$.

Mente conspicere (traduzido por "olhos do espírito" no texto que utilizamos) e firmeque percipere (firme percepção) estão juntas na mesma expressão. O que causa impressão é notar o uso de uma categoria que, a rigor, se conjuga às experiências sensíveis de maneira geral - percipere -, no âmbito de uma certa "atenção do espírito". Sobretudo quando sabemos que percipere, para Agostinho, significa muitas vezes o conhecimento experimental de Deus. No entanto, o que esclarece toda possível contradição é entender que esse conhecimento experimental, como vimos nos excertos elencados acima, é dado por uma sabedoria sobrenatural, pela graça da fé, enfim. Certa enim fides, utcumque inchoat cognotionem ${ }^{25}$ :

De fato, é efeito próprio da fé formar em nós uma imagem de Deus, no melhor conceito possível. Confere ele uma existência mental às coisas propostas à nossa adesão pessoal. (...) Mas, [Agostinho] conhecia muito bem os limites impostos pela nossa condição terrestre à busca racional de Deus. E os limites da experiência mística correspondentes aos limites da exploração teológica ${ }^{26}$.

Para Agostinho, o conhecimento das verdades eternas se obtém por meio da iluminação divina: “a iluminação agostiniana é uma luz especial, incorpórea, que nos torna visíveis e compreensíveis as 'verdades eternas'. Luz essa mediante a qual Deus irradia na mente humana essas verdades absolutas e imutáveis"27.

\footnotetext{
${ }^{23}$ Ibid., p. 270 (VIII, 5,8)

${ }^{24}$ Ibid., p. 267 (VIII 4,6).

25 "É a certeza da fé que, de certa maneira, está na origem do conhecimento". Ibid., p. 291 (IX 1,4).

${ }^{26}$ Ibid., p. 624 (nota do tradutor).

${ }^{27}$ Ibid., p. 637 (nota do tradutor).
} 
Em toda essa discussão o que nos interessa sobremaneira é perceber a relação entre conhecimento sensível e graça da fé, que, como veremos a seguir, não é estranha à concepção retomada pela pedagogia inaciana, mesmo quando estamos simplesmente no âmbito da Filosofia Moral, como é o caso do Manual Conimbricense com o qual vimos trabalhando ao longo dos últimos capítulos.

Vejamos, portanto, como o termo "experiência" aparece nesta obra.

Por exemplo na segunda disputa - Acerca do Fim -, Góis (1593) se perguntando se Bem e Fim são iguais, diz que uma coisa só pode ser igual a outra sob dois aspectos: formalmente (ou seja, quando a razão formal de ambas as coisas é idêntica), ou por reciprocidade de fundamento (quando tanto em ato quanto em potências as coisas são iguais). A partir daí, busca responder à pergunta que abriu a disputa, afirmando que: 1) Bem e Fim não são, do ponto de vista formal, idênticos; 2) assim como Bem e Fim não são tampouco idênticos quanto à reciprocidade do fundamento com relação a Deus, quando se tratarem de ações divinas internas; 3) e, finalmente, Bem e Fim, em ato, com relação às criaturas, também não são idênticos quanto a reciprocidade de fundamentos, no entanto, o são, de algum modo, se se consideram segundo a potência. E para provar a segunda parte da asserção, recorrendo à “experiência”, afirma:

A segunda parte da mesma asserção consta do facto de aquilo que pode tornar-se bem e conveniente com respeito a alguém, embora a princípio, com relação a ele, não seja bem em acto e conveniente, pode, por sua natureza, ser por ele apetecido e ter razão de fim com respeito a ele. E ao contrário, aquilo que pode ser experimentado [quid potest ab aliquo experi] por alguém e alcançar a natureza de fim em relação a alguém, pode ser-lhe bem e conveniente ou ao menos ser apreendido como tal ${ }^{28}$.

É interessante notar como, aqui, a categoria "experiência” é utilizada no âmbito de compreensão do que seja o Bem e o Fim, objetos teleológicos daquele felicem vitae statum a

\footnotetext{
${ }^{28}$ Góis, Manuel de (1593). Disputas do Curso Conimbricense sobre os livros de Moral a Nicómaco de Aristóteles em que se contêm alguns dos principais capítulos da moral. Lisboa: Oficina de Simão Lopes, p. 93. $2^{\mathrm{a} D}, 1^{\mathrm{a}} \mathrm{q}, \mathrm{a} 2^{\circ}$ )
} 
que se dedica a obra de Góis (1593). Demonstrando que, além da abordagem intelectual da temática proposta ${ }^{29}$, é possível, com rigor e verdade, compreender diferenças entre as duas categorias, com o uso da experiência; que, neste caso, não tem que ver com experimentum, mas com a reação afetiva e efetiva do "homem como consciência encarnada" 30 diante de uma determinada realidade a ser investigada.

Em seguida, na quarta disputatio, quando discorre acerca dos "três princípios dos actos humanos: vontade, intelecto e apetite sensitivo", argumentando a partir de obras de Santo Agostinho, São Damasceno, Santo Anselmo e Santo Tomás, Góis (1593) pergunta se a vontade move as outras potências da alma humana e responde assim:

Prova-se esta verdade quer pela experiência própria [probatur autem eius veritas tum ipsa experientia], visto que contemplamos, lemos, movemonos de um lugar e fazemos outras obrigações do género quando queremos; quer pela razão, porque é do fim que parte o princípio de moção de qualquer potência ativa, visto que todo o agente opera por causa do fim e do bem em comum que tem a razão de fim, é o objeto da vontade. Donde se conclui que a vontade move todas as outras potências para o exercício dos seus atos ${ }^{31}$.

Nas quaestiones que se seguem a essa, e especialmente naquelas em que a categoria "experiência" aparece, é notável como praticamente sempre ela virá unida ao conceito de "vontade" (com apenas duas exceções). Ainda no artigo apresentado acima $-1^{\circ}$ artigo da $3^{\mathrm{a}}$ questão -, o autor ajuda a compreender o porquê dessa conjunção:

A acção com que a vontade move formalmente as outras potências é transeunte, visto que não permanece na própria vontade. Com efeito, não se distingue realmente da acção das outras potências. Além disso, este mesmo concurso da vontade umas vezes é algo espiritual, visto a vontade concorrer com a potência imaterial como com o intelecto; outras vezes, material, se, por exemplo, concorre com potência inerente a órgão corpóreo, como com a imaginaçã $o^{32}$.

\footnotetext{
${ }^{29}$ Em disputas e questões anteriores, o autor já havia descrito o que os filósofos e o Filósofo entendem por Bem (aquilo a que tudo apetece; e sendo que o bem é aquilo que é honesto, útil e/ou agradável/deleitável, o Sumo Bem será aquilo que é, ao mesmo tempo, honesto, útil e agradável/deleitável, ou seja, o Amor de Deus) e por Fim (aquilo a que potencialmente toda a criatura se dirige, ou age em direção a, e em havendo, portanto, uma finalidade para toda a ação do homem).

${ }^{30}$ Zanlonghi, 2003, op. cit., p. 63 (tradução nossa).

${ }^{31}$ Góis, 1583 , op.cit., p. $147\left(4^{\mathrm{a}} \mathrm{D}, 3^{\mathrm{a}} \mathrm{q}, \mathrm{a} 1^{\mathrm{o}}\right)$.

${ }^{32}$ Ibid., p. $149\left(4^{\mathrm{a} D}, 3^{\mathrm{a}} \mathrm{q}, \mathrm{a} 1^{\circ}\right)$.
} 
É exatamente por agir no "órgão corpóreo" e no "espiritual” ao mesmo tempo ou separadamente, que a Vontade é uma potência que pode ser tanto conhecida do ponto de vista estritamente intelectual, como do ponto de vista da experiência.

Assim, por exemplo, quando se pergunta como é possível à vontade mover os sentidos internos, usando a distinção aristotélica entre poder despótico e político, e argumentando a partir da compreensão tomista da obra do Estagirita, explica que não obstante para Santo Tomás apenas a cogitativa (potência da alma sensitiva, elencada na lista dos sentidos internos) obedecer à razão e à vontade, sendo regida portanto por poder despótico,

a nós, porém, parece-nos que devemos afirmar que não existe nenhum sentido interno que obedeça sempre à vontade. Com efeito, o sentido comum apreende necessariamente o objecto sem mudar a apreensão do sentido externo e, de um modo geral, todos os sentidos internos (sem dúvida, quanto a isso parece ser idêntica a razão de todos). Algumas vezes apreendem o objecto tão tenazmente que a vontade, de nenhum modo ou dificilmente, domina a concepção deles, como ensina a experiência cotidiana [uti docet quotidiana experientia $]^{33}$.

E explica que esta "tenacidade de concepções" se deve a muitas causas, entre elas enumera: 1) pela presença real do objeto que se introduz pelos sentidos externos; 2) pela instigação dos "demônios internos"; 3) pela disposição (affectione) do órgão interno (os melancólicos, por exemplo, por terem temperamento frio e seco, persistem muito mais tempo na apreensão de uma mesma coisa, porque o órgão está mais disposto a isso); 4) pelo afeto do apetite sensitivo, "visto se saber que o sentido interno se fixa mais nas cousas para que o apetite é levado com maior ímpeto" 34 .

Em seguida, Góis (1593) se pergunta como a vontade move os apetites sensitivos. E, logo de início, explica que a vontade move os apetites com poder político. E se baseia em autores tais como Aristóteles, São Damasceno, São Gregório Nisseno e Santo Tomás. Mas, a argumentação final cabe à "experiência":

\footnotetext{
${ }^{33}$ Ibid., p. 151 ( $\left.4^{\mathrm{a}} \mathrm{D}, 3^{\mathrm{a}} \mathrm{q}, \mathrm{a} 2^{\mathrm{o}}\right)$.

${ }^{34}$ Ibid., p. 151 ( $4^{\mathrm{a}} \mathrm{D}, 3^{\mathrm{a}} \mathrm{q}, \mathrm{a} 2^{\mathrm{o}}$ ).
} 
... que o apetite seja movido pela vontade demonstra-o a experiência [quod appetitus a voluntate moveatur, patet experientia], visto que muitas vezes provocamos ou reprimimos os movimentos dele, segundo o nosso arbítrio. (...) Que tal sujeição não é despótica, aparece claramente no facto de a cada passo o apetite ser levado para o bem sensível contra o juízo da razão e o afecto da vontade ${ }^{35}$. (...) Esta repugnância nasce do facto de o apetite sensitivo seguir a apreensão do sentido interino, a qual é de tal modo eficaz que não pode ser coibida pela razão nem pela vontade. Ou ainda porque a moção do apetite sensitivo depende da disposição [dispositione] do órgão (por isso, os que têm temperamento cálido se irritam fàcilmente), a qual disposição [dispositio] ou modificação [sive affectio] não se suborna ao poder ${ }^{36}$.

Todavia, o autor lembra que tanto Aristóteles como Santo Tomás afirmam que seja possível ao apetite ser movido pela vontade, dado que, pela ordem e hierarquia de moventes e movidos, superior move inferior, especialmente sabendo-se que nada é objeto de apetição se não for antes objeto de intelecção: “a vontade só move o apetite, imediatamente e por certa redundância, quando no sentido interno já existe notícia do mesmo objeto, de maneira que, sem nova intenção ou aplicação da notícia, o apetite seja mais incitado por causa da inclinação da vontade"37.

$\mathrm{O}$ artigo $4^{\circ}$ dessa mesma quaestio se dedica a compreender como a vontade pode mover os membros externos. E, apela para a experiência, logo no início do artigo: "Como se prova pela experiência [ut experimento compertum est], a vontade move os membros externos, com que se exerce o movimento arbitrário, com poder servil e sem qualquer

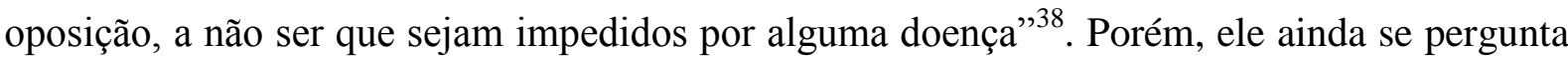
se, na verdade, não seriam os membros externos movidos antes pelos apetites sensitivos. E diz que não, apelando de novo para a experiência: “o contrário disto ensina a experiência nos santos mártires [docet experientia in sanctis martyribus], que ofereciam os membros a tormentos acerbíssimos"39. Aqui, no entanto, é importante entender que a vontade só pode

\footnotetext{
${ }^{35}$ Cf. Rm 7,23.

${ }^{36}$ Ibid., p. $153\left(4^{\mathrm{a}} \mathrm{D}, 3^{\mathrm{a}} \mathrm{q}, \mathrm{a} 3^{\mathrm{o}}\right)$.

${ }^{37}$ Ibid., p. $155\left(4^{\mathrm{a}} \mathrm{D}, 3^{\mathrm{a}} \mathrm{q}, \mathrm{a} 3^{\circ}\right)$.

${ }^{38}$ Ibid., p. $155\left(4^{\mathrm{a}} \mathrm{D}, 3^{\mathrm{a}} \mathrm{q}, \mathrm{a}^{\mathrm{o}}\right)$.

${ }^{39}$ Ibid., p. $155\left(4^{\mathrm{a}} \mathrm{D}, 3^{\mathrm{a}} \mathrm{q}, \mathrm{a} 4^{\mathrm{o}}\right)$.
} 
mover os membros através de alguma potência média, que, neste caso, serão os apetites: “pede a harmonia e a ordem dos moventes que o supremo não mova o extremo senão com a intervenção do médio" ${ }^{40}$. Esclarece finalmente que pode acontecer de os membros serem movidos não pela vontade (mesmo que indeliberada), mas diretamente pelos apetites, como acontece nos movimentos súbitos, entretanto esses não podem ser considerados movimentos humanos, mas "do homem".

Na quarta quaestio dessa mesma disputa sobre os princípios dos atos humanos, Góis (1593) pergunta se o apetite é capaz de mover a vontade. Faz, então, três afirmações, baseando-se em Aristóteles e Santo Tomás de Aquino: 1) é inegável que o apetite mova a vontade de alguma maneira, como se confirma "também pela experiência [confirmatur quoque experientia]. Ninguém existe, com efeito, que não experimente [qui non experiatur] o movimento do apetite ou da ira ou da dor ou da alegria, inclinar a vontade para si $^{\text {"41 }}$; 2) porém o apetite não move a vontade com poder despótico, como a harmonia e a ordem dos moventes o indica; 3) mas a move por intermédio da notícia intelectiva que propõe acerca de determinado objeto que deve ser aceito ou rejeitado, já que a vontade, seguindo a decisão do intelecto, pode querer ou repudiar o mesmo que o apetite, ou o apetite pode mover a vontade por meio da notícia do sentido interno, na medida em que as imagens dos sentidos determinam o intelecto para a contemplação de uma coisa ou de outra.

Até este ponto da obra, praticamente todas as vezes em que se fez uso da "experiência" como método de conhecimento, ela estava de algum modo vinculada à categoria "vontade". Nos dois outros momentos da obra em que a "experiência" aparece será, uma vez vinculada às "paixões" e outra às "virtudes morais". Vejamos.

Na $6^{\mathrm{a}}$ disputa da obra - Dos estados da alma que se chamam paixões - numa certa altura da discussão, o autor se pergunta se os apetites sensitivos (as paixões) têm sede no

\footnotetext{
${ }^{40}$ Ibid., p. $155\left(4^{\mathrm{a}} \mathrm{D}, 3^{\mathrm{a}} \mathrm{q}, \mathrm{a} 4^{\mathrm{o}}\right)$.

${ }^{41}$ Ibid., p. $159\left(4^{\mathrm{a}} \mathrm{D}, 4^{\mathrm{a}} \mathrm{q}, \mathrm{a} 1^{\mathrm{o}}\right)$.
} 
coração. Então, no primeiro artigo desta questão - a segunda -, usando Platão e outros platônicos, diz que apenas o irascível tem sede no coração. No entanto, no segundo artigo, baseando-se em Hipócrates, Zenão, Posidónio, Crisipo, Aristóteles e Teofrasto, afirma "que um e outro apetite tem sede no coração" ${ }^{\text {42 }}$. E diz ainda:

Prova-se a verdade dessa sentença, já pelo facto de todo o afecto, quer de ira quer de cobiça, causar perturbação no coração e nele logo se sentir; já porque o coração, no consenso dos Filósofos, é origem e fonte de todas as operações vitais, no qual, por isso tiveram de se fixar os apetites dados pela natureza para conservar a vida e afastar os perigos ${ }^{43}$.

Esclarece, finalmente, que apesar de os dois apetites residirem no coração, não significa que seja na mesma parte do coração, dado que são de composição muito diferente (a ira é feita de calor e de secura, e a cobiça, por sua vez, de umidade e de calor). E em seguida, rebatendo as teorias que dizem que cada apetite tem residência em um órgão distinto, diz: "os que têm muito sangue não experimentam [experiuntur] mais frequentes insultos das cobiças pelo facto de a concupiscência estar deitada no fígado (...), mas porque são de temperamento cálido e húmido, o que excita o ardor da cobiça" ${ }^{44}$. Dessa forma, explica que os apetites são determinados, de alguma forma, pelos temperamentos, mas que habitam sempre o coração, como pode "logo se sentir" 45 . Experiência e sentimento (trata-se da mesma categoria sensualidad, bastante utilizada por Inácio, como vimos anteriormente) são praticamente sinônimos nessa argumentação.

Finalmente, na $7^{\text {a }}$ disputa - Das virtudes em geral -, se perguntando se as virtudes morais têm conexão entre si, Góis (1593) se serve de Santo Tomás para afirmar que, nesta questão, não trata das virtudes intelectuais que, certamente, não são conectadas entre si; mas estará tratando das virtudes morais que, segundo Aristóteles, podem ser adquiridas de três modos: por continência, por temperança ou por heroísmo.

\footnotetext{
${ }^{42}$ Ibid., p. 189 (6 $\left.{ }^{\mathrm{a} D}, 2^{\mathrm{a}} \mathrm{q}, \mathrm{a} 2^{\mathrm{o}}\right)$.

${ }^{43}$ Ibid., p. $189\left(6^{\mathrm{a}} \mathrm{D}, 2^{\mathrm{a}} \mathrm{q}, \mathrm{a} 2^{\mathrm{o}}\right)$.

${ }^{44}$ Ibid., p. $191\left(6^{\mathrm{a} D}, 2^{\mathrm{a}} \mathrm{q}, \mathrm{a} 2^{\mathrm{o}}\right)$.

${ }^{45}$ Ibid., p. 189 (6 $\left.{ }^{\mathrm{a}} \mathrm{D}, 2^{\mathrm{a}} \mathrm{q}, \mathrm{a} 2^{\mathrm{o}}\right)$.
} 
No primeiro grau obtém-se a virtude, quando as paixões ainda são veementes e contudo lhes resistimos. No segundo quando as paixões não são tão veementes, mas mais calmas. No terceiro, quando já estão de tal modo coibidas e refreadas que, muito raramente, e mal repugnam à razão ${ }^{46}$.

Segundo ele, esses três graus são também chamados, respectivamente de: do principiante, do experimentado (usa, aqui, o termo proficientum) e do perfeito. Para ele, no grau heróico ou do perfeito, as virtudes morais se conectam; e, no grau de continência ou do principiante, não se conectam. No entanto, diz ser necessário entender como se dá no grau de temperança ou do experimentado. Segundo ele, Duns Escoto, Gabriel, Ockham e Almaíno afirmam que não há conexão nesse grau. Entretanto, no segundo artigo, usando Santo Ambrósio, Santo Agostinho, São Gregório, São Jerônimo, Aristóteles, Platão, Crisipo, Plutarco, Cícero, Santo Tomás, Caetano, Durando, Capreolo e Ricardo (estes últimos cinco todos escolásticos), afirma que também no grau de temperança ou dos experimentados as virtudes morais são conectadas. E usa a seguinte argumentação:

Prova-se esta opinião do seguinte modo: a perfeita generosidade coíbe o apetite do dinheiro em toda a ocorrência, porque de outro modo não seria perfeita. Mas isto não se pode fazer sem o apoio das outras virtudes. Logo, a perfeita generosidade requer a união das outras virtudes. Prova-se a menor porque, se se propuser a alguém, por uma parte a morte, por outra o dinheiro, para perpetrar uma injúria à Pátria - certamente sucumbirá com facilidade à cobiça do dinheiro, se não estiver munido da virtude da fortaleza para desprezar a morte, e da justiça para não perpetrar a injúria. Por isso, não se pode encontrar a generosidade sem a fortaleza e a justiça e semelhantemente sem as outras virtudes ${ }^{47}$.

Assim, o experimentado ou temperado é o homem prudente, ou seja, aquele que vive o meio-termo. E a prudência, como vimos, requer um juízo íntegro, portanto, assim como se comprovou acima, requer virtudes conectadas, do contrário agirá sempre imoderadamente. É bem verdade, que o termo "experimentado", aqui usado, não é exatamente o mesmo com o qual vimos tratando ao longo do capítulo. Não obstante a diferença, é bastante interessante notar como a prudência entra em jogo na discussão. Lembremo-nos das relações entre

\footnotetext{
${ }^{46}$ Ibid., p. $229\left(7^{\mathrm{a}} \mathrm{D}, 4^{\mathrm{a}} \mathrm{q}, \mathrm{a} 1^{\mathrm{o}}\right)$.

${ }^{47}$ Ibid., p. $231\left(7^{\mathrm{a}} \mathrm{D}, 4^{\mathrm{a}} \mathrm{q}, \mathrm{a} 2^{\mathrm{o}}\right)$.
} 
retórica e prudência explicitadas no início deste capítulo, e se entenderá como um homem proficientum, nos termos usados para responder à questão proposta, pode muito bem ser considerado um homem "experimentado", no sentido de "perito".

Do debate filosófico, de maneira geral, o que se conclui é que "experiência" é algo que ajuda a conhecer a verdade. Seja do ponto de vista retórico (na medida em que a retórica conduz o homem pelas sendas dos sentidos internos, identificando, organizando, adaptando, armazendo e ordenando e explicitando segundo sua dignidade os elementos colhidos na realidade), seja do ponto de vista dialético (na medida em que, como dinâmica dialógica que é, se volta adequadamente ao fundo mesmo da realidade), a "experiência" é sempre entendida, grosso modo, como um aspecto do indivíduo que pode conduzi-lo mais adequadamente à Verdade, ou, nos termos da casuística, ao Bem Último.

\section{2) A experiência na ratio spiritualis}

Como a espiritualidade seiscentista encarava a questão da "experiência"? E, mais especificamente, como uma espiritualidade com normas muito peculiares - a dos jesuítas compreendia a relação entre "experiência" e vida espiritual?

No início desta Segunda Parte, a fim de apresentar uma premissa importante para a continuidade do trabalho, citamos um trecho de um hino composto no século XIII, por Bernardo de Claraval, monge beneditino - Jesu, dulcis memoria / Dans vera cordis gaudia / Sed super mel et omnia / Eius dulcis presentia. / (...) Nec lingua valet dicere / Nec littera exprimere / Expertus potest credere / Quid sit Jesum diligere ${ }^{48}$.

Esclareçamos, inicialmente, o que pode parecer um anacronismo: como comparar o hino medieval com a então emergente questão renascentista do valor da "experiência"?

\footnotetext{
${ }^{48}$ O livro das horas (1998). São Paulo: Companhia Ilimitada, p. 248.
} 
Certeau (1982) nos chama a atenção para o fato de que a assim chamada "renascença" é marcada pela retomada da fórmula teológica medieval ${ }^{49}$ segundo a qual o relacionamento com Cristo se dá na materialidade da Eucaristia e da Igreja. Ele afirma que, fora dessa objetividade material, corria-se o risco de uma "mystiquerie”. Em poucas palavras: a fé era mais do que a língua podia dizer ou as letras expressarem: somente expertus potest credere. Percebe-se aí que a "experiência" é fundamental nesse relacionamento com o corpo real (Eucaristia) e místico (Igreja) de Jesus Cristo na terra ${ }^{50}$. Temos, portanto, um primeiro aspecto relevante: a relação experiência/espiritualidade, que aparece num debate teológico renascentista e que busca recuperar a carnalidade objetiva da experiência mística.

Entra em jogo, nessa concepção de "experiência", o binômio visível/invisível (e, se o quisermos, do audível/inaudível, palpável/impalpável etc.), que Certeau (1982) explica como sendo o lugar do nascimento de uma nova concepção de "mística"51.

Visível e invisível, fato em si e sentido do fato, experiência e fé, corpo e alma, finito e infinito, acidental e fundamental: a mística renascentista com uma definição

\footnotetext{
49 Também Bergamo (1994) aponta a fascinação pelo mundo da interioridade e pela estrutura da alma, presente especialmente no século XVII, na França, e retomado da tradição medieval. Segundo ele, a questão da estrutura da alma tem suas raízes em um problema bastante discutido por autores de séculos anteriores: "Em particular, a aparição, com o desenvolvimento da escolástica no século XIII, de uma antropologia fortemente estruturada que, modelando-se sobre a filosofia aristotélica, comportava uma classificação rigorosa das faculdades da alma, e uma análise minuciosa de seu funcionamento, abriu a via para uma longa série de transposições, até o ponto que conhecimentos maduros sobre o terreno de discussão filosófico poderiam, a qualquer momento, ser transplantados e aplicados no campo da literatura espiritual. Há, em suma, toda uma história da representação da estrutura da alma, que não somente se articula no interior de uma história da espiritualidade, mas ainda cruza a história das relações da espiritualidade com seu contexto, e em particular com o discurso filosófico" (Bergamo, 1994, op. cit., pp. 32-33, tradução nossa).

${ }^{50}$ Certeau (1982) explica que esta fórmula teológica mantida nos séculos XVI e XVII é no entanto ligeiramente modificada, quando então acontece o temido risco da "mystiquerie". O risco, segundo Certeau é que a crescente individualização das práticas e o aparecimento cada vez maior das experiências privadas, isto é, o progressivo desvincular-se da instituição, produzisse esta "mystiquerie": "Torna-se 'místico' aquilo que se destaca da instituição" (p. 116, tradução nossa). Por isso a necessidade de se retomar, com clareza maior, a certeza de que a Igreja é o sinal do corpo de Cristo. Esta idéia faz trazer a experiência mística para o campo da instituição visível. Cf. Certeau, Michel de (1982). La fable mystique, 1: XVIe - XVIIe siècle. Paris: Gallimard.

${ }^{51}$ Ele, de fato, diz: "O campo religioso se reorganiza também em função da oposição entre o visível e o invisível, de tal maneira que as experiências 'escondidas', que cedo foram reunidas sob o nome de 'mística', adquiriram uma pertinência que não tinham" (Ibid., p. 120, tradução nossa). Ou ainda: "Esta (...) modificação implica uma reestruturação das relações entre o fato e o sentido. Se torna mais difícil pensar que os fatos chamam o sentido um sentido que seria levado à lisibilidade pelas coisas mesmas -, quanto mais era necessário gerar primeiro uma 'razão' por textos, e depois fatos (uma 'experiência' e'/ou um corpo) para esta razão (sintoma: 'produzir' passado do sentido de 'manifestar' para o de 'criar')" (Ibid., p. 121, tradução nossa).
} 
escolástica, especialmente a dos jesuítas, retoma (ou mantém) a experiência do sagrado como algo do nível dos sentidos, mais que de uma formulação teórica, teológica ou filosófica. Além de acrescentar algo novo: a prática, que tem como representante mais significativo, no caso da então nascente Companhia de Jesus, os Exercícios Espirituais. É nítido também o fato de que não há solução de continuidade ${ }^{52}$ entre um e outro aspectos do relacionamento com o Mistério.

Os Exercícios Espirituais, além disso, demonstram como se dá o conhecimento da realidade: através do transcender a dimensão das operações discursivas e do recorrer à arte da memória e da imaginação ${ }^{53}$. O exercitante é convidado a, fazendo uso da memória, construir uma ponte entre o abstrato de uma afirmação e sua imagem concreta na alma. Essa imagem existe na medida em que quem faz os Exercícios, aprende a usar a imaginação. Lendo o Princípio e Fundamento ${ }^{54}$ - que é propriamente um aspecto teológicodoutrinal (ou seja, está dentro de uma perspectiva eminentemente histórico-salvífica) da obra

\footnotetext{
${ }^{52}$ Massimi (1999a) afirma, falando da experiência religiosa dos jesuítas: "não há solução de continuidade entre a experiência psicológica e a experiência religiosa, já que ambas são inerentes ao eu do homem. Nem pode haver autonomia entre a esfera psíquica e a esfera espiritual, assim como hoje nós 'modernos' concebemos" (p. 51). Segundo a tradição da filosofia aristotélico-tomista, conhece-se o fundamental pelo acidental: "conhecemos a alma por seus efeitos, ou seja, por suas funções psicológicas, ou faculdades que se evidenciam no plano dos fenômenos" (p. 53). Cf. Massimi, Marina (1999a). Conhecimentos psicológicos e experiência religiosa na história da cultura luso-brasileira: um sermão de Antônio Vieira. Em Massimi, Marina e Mahfoud, Miguel (orgs.) (1999). Diante do Mistério: psicologia e senso religioso (pp. 47-55). São Paulo: Ed. Loyola.

${ }^{53}$ Como pudemos ver no item anterior a este. Porém, cf. também o texto de García Mateo, Rogelio (2000). Ignacio de Loyola: su espiritualidad y su mundo cultural. Bilbao: Instituto Ignacio de Loyola/Universidad de Deusto/Ediciones Mensajero, que dá uma descrição detalhada do uso que Inácio fazia das categorias de seu ambiente cultural de forma justa e razoável. Assim, por exemplo no EE. 53, Inácio escreve: “Imaginando Cristo nosso Senhor diante de mim e colocado na cruz, fazer um colóquio: como, de Criador, ele veio a se fazer homem, passar da vida eterna à morte temporal, e assim morrer por meus pecados. Da mesma maneira, olhara para mim: o que eu fiz por Cristo, o que eu faço por Cristo, o que devo fazer por Cristo. Depois, vendo-o nesse estado, suspenso na cruz, percorrer o que se me oferecerá" (EE. 53, p. 84, tradução e grifos nossos). Loyola, Ignace de (1991). Écrits (M. Giuliani, trad., apres. e dir.). Paris: Desclée de Brouwer. Percebe-se daí que o uso da imaginação tem que ver com o que, mais a frente explicaremos melhor, será chamado "composição de lugar" e "aplicação dos sentidos".

54 "O homem é criado para louvar, reverenciar e servir a Deus Nosso Senhor, e assim salvar a sua alma. E as outras coisas sobre a face da terra são criadas para o homem, para que o ajudem a alcançar o fim para que é criado. Donde se segue que há de usar delas tanto quanto o ajudem a atingir o seu fim, e há de privar-se delas tanto quanto dele o afastem. Pelo que é necessário tornar-nos indiferentes a respeito de todas as coisas criadas em tudo aquilo que depende da escolha do nosso livre-arbítrio, e não lhe é proibido. De tal maneira que, de nossa parte, não queiramos mais saúde que doença, riqueza que pobreza, honra que desonra, vida longa que breve, e assim por diante em tudo o mais, desejando e escolhendo apenas o que mais nos conduz ao fim para que fomos criados". Ibid., EE. 23, pp. 62-64 (tradução e grifos nossos).
} 
inaciana $^{55}$ - dentro da obra completa que são os Exercícios Espirituais, podemos identificar uma "realidade" $" 56$ descrita como algo mais do que ela mesma, como um "tear onde Deus tece o "mistério divino",57. Nos Exercícios, Inácio aponta para a necessidade de "incorporarmonos ao real”; real entendido como "incorporado ao 'desígnio secreto' de Deus" sentido último de todo o Universo ${ }^{59}$. E isso é ler a realidade de forma teológica e teleologicamente orientada, segundo um princípio cristão ${ }^{60}$.

Mas, com que recursos o homem pode identificar na realidade essa meta final apenas sinalizada? Aqui, podemos apresentar a preocupação de Inácio com a "aplicação dos

\footnotetext{
${ }^{55}$ Segundo García Mateo (1998), os Exercícios Espirituais podem ser compreendidos a partir desses três eixos: teológico-doutrinal, ascético-espiritual e prático-pastoral. Cf. García-Mateo, Rogelio (1998). Fuentes filosóficoteológicas de los ejercicios según el currículum académico de su autor. Em: Plazaola, Juan (ed.) (1998). Las fuentes de los Ejercicios Espirituales de San Ignacio. Actas del Simposio Internacional (Loyola, 15-19 septiembre 1997). Bilbao: Ediciones Mensajero., pp. 473-474.

${ }^{56}$ Podemos dizer que, por "realidade" entende-se tudo que é oposto a ilusório, isto é, o real é tudo o que não está circunscrito às nossas fantasias de onipotência ou de impotência, à ilusão do nosso pecado: não interessam, para Inácio, os limites ou capacidades do homem, interessa que ele se saiba criado para "louvar e reverenciar" o Criador. É "realidade" também não só o mundo visível das pessoas e das "coisas sobre a face da terra", mas o que há de sentido por trás do visível, o que está para além do visível, que ajuda o homem "a alcançar o fim para que é criado". Nesse sentido, é "realidade" aquilo para o que somos capazes de lançar um olhar moral, na medida em que aponta ou não o sentido, o fim. Nessa antropologia, o homem é chamado a se relacionar de forma adequada com o real, segundo sua "verdadeira utilidade", e não de forma trivial, reativa ou puramente prazerosa. Para isso, é preciso que a liberdade esteja exercitada na escolha do Bem e Fim último, da Verdade.

57 Fernández-Martos, José Maria (1991). La incorporación de la realidad como clave del cambio en los Ejercicios Espirituales. Em Alemany, Carlos e Garcia-Monge, José A. (1991) Psicologia y Ejercicios Ignacianos (vol I): la transformación del yo en la experiencia de Ejercicios Espirituales. Bilbao: Mensajero e Sal Terrae, p. 243 (tradução nossa). ${ }^{58}$ Ibid., p. 244 (tradução nossa).

${ }^{59}$ A espiritualidade dos séculos XVI e XVII aponta o Ser presentificado "sob a capa das espécies do mundo" nos mistérios litúrgicos, para Deus sinalizado no universo. Esse universo que "não sendo autônomo, mas, sim, criado, sustentado e dirigido pelo Ser divino, (...) guarda necessariamente em suas múltiplas disposições as marcas daquele que, para os cristãos, o fabricou do nada, ou, da maneira que preferem os tomistas, tudo fez com que emanasse de si”. Cf. Pécora, Alcir (1994). Teatro do Sacramento. São Paulo: EDUSP., p. 141.

${ }^{60}$ A experiência do mundo para o homem seiscentista (especialmente o ibérico) está submetida à moralidade propriamente cristã. $\mathrm{O}$ que significa que esse homem lê a realidade a partir de sua concepção teológico-cristã: conhecer por experiência e agir moralmente coincidem, de forma que o conceito está ligado à concepção do mundo que se tinha. De fato, Mendiola (2003) afirma: "na sociedade espanhola do século XVI, a experiência depende da ação e (...) a ação se observa por meio do esquema binário norma/desviação da norma”(Mendiola, 2003, op. cit., p. 31, tradução nossa). O autor usa ainda um exemplo bastante significativo para ajudar a entender isso: "vejamos um exemplo do século XVI: a comunidade toma a decisão de fazer uma procissão com o Santíssimo à frente com a intenção de fazer chover, se a chuva não vem não significa que a procissão com o Santíssimo não tenha a capacidade de fazer chover, mas que não se fazia a procissão com uma fé verdadeira. O que implicaria para o homem do século XVI modalizar sua expectativa em termos cognitivos? Aceitar que não existe uma relação causal entre a procissão e a chuva. A compreensão de que não existe nenhuma relação entre o ritual do padre e a chuva traria consigo uma estilização cognitiva da expectativa, e isto não é possível no século XVI. Mas ainda que a chuva não chegue, a expectativa se mantém contrafaticamente, porque a carência de chuva se explica por meio do conceito de pecado" (Ibid., p. 33). Em outros termos: a realidade é teológica e teleologicamente orientada, é sinal do Criador e está imersa na História da Salvação. Dessa concepção nasce inevitavelmente uma "paixão pelo real” (Cf. Fernández-Martos, 1991, op. cit., p. 241 tradução nossa), que pode ser encontrada, por exemplo, nos Exercícios Espirituais de Inácio de Loyola.
} 
sentidos"61. Para ele, a consistência última da realidade é apreendida pelos sentidos - ver, tocar, ouvir, degustar, sentir o cheiro ${ }^{62}$, e não por um exercícios de abstração metafísica lingua ou littera. Essa aplicação - intuitiva a princípio e cada vez mais possível na medida em que se simplificam as faculdades espirituais, exercitando-as - ajuda a recolher os frutos da meditação de todo um dia: localizados na experiência sensível, estes frutos são melhor percebidos como pessoais e, portanto, melhor julgados pela razão.

Outros muitos exemplos dessa "experiência sensível”, nos Exercícios Espirituais, podem ser dados: desde a insistência com o pedido de sentir com Cristo sua alegria ou padecimento $^{63}$, até os muitos exemplos de uso da aplicação dos sentidos, nos quais Inácio sempre insiste na necessidade de, em seguida, "refletir em si mesmo e tirar proveito",64, passando inclusive pelos exames e verificações de emenda propostas, por exemplo, logo no início do livro ${ }^{65}$. Todavia, é somente no EE. 176 que aparecerá, pela primeira vez, o termo “experiência”. Trata-se da parte dos Exercícios Espirituais denominada Três tempos para fazer boa eleição, e Inácio, demonstrando como os conhecimentos filosóficos acerca da alma

\footnotetext{
${ }^{61}$ A aplicação dos sentidos na composição de lugar, por exemplo, aparece pela primeira vez, dentro do texto dos Exercícios Espirituais, no EE. 47: “Aqui é preciso remarcar que na contemplação ou meditação do que é visível, como por exemplo a contemplação de Cristo nosso Senhor, o que é visível, a composição será ver com a vista da imaginação o lugar material onde se encontra a coisa que eu quero contemplar. (...) Na contemplação do que é invisível, como é aqui a dos pecados, a composição será ver com a vista da imaginação e considerar minha alma aprisionada nesse corpo corruptível e todo o composto humano neste vale, como que exilado entre animais privados de razão. Eu digo: todo o composto da alma e do corpo" (Loyola, 1991, op. cit., EE. 47, pp. 78-80, tradução nossa). E voltará a aparecer outras muitas vezes. Fabre (1991), comentando esse EE. 47, diz: "A composição de lugar é uma preparação que tem necessidade da imaginação. Explicando-a aqui, Inácio mostra que a imaginação é uma faculdade a ser colocada em ação: fazer um trabalho que não consiste simplesmente em colocar juntas idéias e palavras, mas os elementos de um quadro. O exercitante torna preciso assim o lugar evangélico no qual ele vai se situar durante o exercício" (Ibid., p. 79, nota do tradutor, tradução nossa). Outros exemplos de aplicação dos sentidos podem ser encontrados em EE. 53, EE. 66-70, EE. 122-125, EE. 159, EE. 194, EE. 202, EE. 220.

${ }^{62}$ Alguns exemplos retirados dos Exercícios Espirituais: "Verei com os olhos da imaginação" (Ibid., EE. 122, p. 116, tradução e grifo nossos). "Pelo sentido da audição escutarel" (Ibid., EE. 123, p. 116, tradução e grifo nossos). "Pelo sentido do olfato e do gosto, hei de sentir e saborear a suavidade e a doçura infinitas da divindade, da alma, de suas virtudes e de tudo o mais" (Ibid., EE. 124, p. 116, tradução e grifo nossos). "Exercitarei o sentido do tato, abraçando, por exemplo, e beijando os lugares que estas pessoas tocaram com os pés, ou se detiveram” (Ibid., EE. 125, p. 116, tradução e grifo nossos). Jesu, dulcis memoria: a "doçura infinita da divindade" deve ser experimentada pelos sentidos. Bem como, toda experiência do sagrado passa pelos sentidos: de novo, expertus potest credere, quid sit Jesum diligere.

${ }^{63}$ Cf., por exemplo, EE. 48, EE. 55, EE. 63, EE. 65, EE. 104, EE. 203.

${ }^{64}$ Ibid., EE. 124, p. 116 (tradução nossa).

${ }^{65}$ Nos EE. 29 e 30, por exemplo, logo no Exame Particular, Inácio propõe que se compare, depois que se tenha analisado os gráficos cotidianos e semanais, a evolução de um dia para o outro e de uma semana para a outra, a fim de verificar se houve emenda do pecado a que o exercitante se dispôs a emendar.
} 
são aqui aplicados como experiência, afirma: "Deus nosso Senhor move e atrai a vontade de tal forma que, sem duvidar nem poder duvidar, a alma fiel segue o que lhe é indicado",66. E, em seguida, explicando quando se há de fazer uma boa eleição, enumera como segundo momento propício aquele no qual "se recebe suficiente luz e conhecimento pela experiência das consolações e desolações, e pela experiência do discernimento dos espíritos" "67. Mais à frente, nas Regras para sentir e reconhecer de alguma maneira as diversas moções que se produzem na alma, as boas para as receber as más para as rejeitar, Inácio explicará o que é consolação e desolação, e dirá:

Existem três causas principais pelas quais nós nos encontramos desolados. A primeira é porque somos mornos, preguiçosos ou negligentes nos nossos exercícios espirituais; de forma que é por causa de nossas faltas que a consolação se afasta de nós. A segunda, para nos fazer experimentar quanto valemos e até onde avançamos no serviço e louvor do Senhor sem o salário das consolações e grandes graças. A terceira, para nos dar verdadeiro saber e conhecimento - de modo a sentir interiormente - do que não depende de nós fazer nascer ou conservar uma grande devoção, um amor intenso, lágrimas, nem nenhuma outra consolação espiritual, mas que tudo é bom e graça de Deus nosso Senhor ${ }^{68}$.

Um pouco mais à frente, nas Regras visando mesmo efeito com um maior

discernimento dos espíritos, Inácio explica:

Quando o inimigo da natureza humana tiver sido sentido e reconhecido tanto por sua cauda de serpente quanto pelo fim maldoso em direção ao qual impulsiona, é proveitoso, para aquele que foi tentado por ele, olhar em seguida o desenvolvimento dos pensamentos bons que ele lhe apresentou e seu começo, e como, pouco a pouco, ele tentou fazer descer da suavidade e alegria espiritual onde estava, até chegar a sua intenção depravada. Assim, por esta experiência conhecida, e anotada, se guardará no futuro de suas enganações habituais ${ }^{69}$.

No trecho do EE. 176 que citamos acima, Inácio fala de "experiência de desolação" e "experiência de discernimento dos espíritos", e com a ajuda dos dois trechos seguintes se pode melhor compreender o que é a categoria "experiência" dentro desta perspectiva, a partir destas duas experiências particulares: não se trata apenas de uma sensação ou sentimento

\footnotetext{
${ }^{66}$ Ibid., EE. 175, p. 142 (tradução nossa).

${ }^{67}$ Ibid., EE. 176, p. 142 (tradução nossa).

${ }^{68}$ Ibid., EE. 322, pp. 226-228 (tradução nossa).

${ }^{69}$ Ibid., EE. 334, pp. 234-236 (tradução nossa).
} 
abstrato (de consolação ou desolação), mas também de uma certa sensibilidade específica (um reconhecimento que se dá pela visão), que juntas dão ao homem uma ciência que lhe permitir evitar as "enganações habituais" do "inimigo da natureza humana".

Outro aspecto importante a se considerar quanto ao texto dos Exercícios Espirituais, é o uso que Inácio faz - já mencionado acima - de categorias próprias da psicologia filosófica aristotélico-tomista. Um exemplo bastante significativo é o do EE. 50, quando o autor lança mão das potências da alma sensitiva e da alma racional, especialmente da memória, da inteligência e da vontade, para ajudar o exercitante nos passos a que se propõe. Ele diz:

O primeiro ponto será aplicar a memória sobre o primeiro pecado que foi aquele dos anjos; em seguida, exercer a inteligência sobre este mesmo pecado percorrendo o tema, depois a vontade; querendo lembrar e compreender tudo isso para experimentar bastante vergonha e confusão. Fazer a comparação entre o pecado dos anjos e os meus tão grandes pecados ${ }^{70}$.

Aqui, as três faculdades da alma correspondem, para Inácio, aos três níveis constitutivos do homem: animal, racional e imagem de Deus. Segundo Fabre (1991), neste ponto fica claro o papel que o fundador atribui a cada uma das potências:

A memória é a faculdade que o exercitante opera quando deixa retornar nele mesmo aquilo que lhe foi apresentado como matéria para sua meditação ou sua contemplação. Tendo-o encontrado, ele lhe dá toda a atenção. A inteligência lhe permite percorrer o tema, fazendo sobretudo comparações entre aquilo que vivem os personagens contemplados ou considerados e aquilo que ele mesmo vive, entre aquilo que eles fazem e aquilo que ele faz ou quer fazer. A vontade é uma faculdade afetiva. Ele se deixa tocar pelo tema rememorado e aprofundado. É, portanto, a capacidade de ser afetado e, por outro lado, de sentir e responder com amor. Nesse sentido, pode-se traduzir, hoje, este termo por 'coração'. Mas a vontade aponta também para a capacidade de decidir, de querer: aqui, de tomar a decisão de aplicar a memória ou de fazer trabalhar a inteligência ${ }^{71}$.

O outro documento com o qual trabalhamos, quanto à discussão no nível da ratio spiritualis, é o texto do Diário de Moções Interiores, de Inácio. Sabemos que o Diário, é o resultado do trabalho pessoal de "eleição sobre a pobreza", que o Fundador fez enquanto preparava o texto das Constituições. Para esta eleição, Inácio se utilizou, entre outras coisas,

\footnotetext{
${ }^{70}$ Ibid., EE. 50, p. 80 (tradução nossa).

${ }^{71}$ Ibid., pp. 81-83, nota do tradutor (tradução nossa).
} 
de uma pequena folha de papel dobrada onde anotou uma série de argumentos contra e a favor quanto ao que concerne ao voto de pobreza $^{72}$. No verso da última página, onde se lê "Os inconvenientes em não ter nenhuma renda são as vantagens em ter parcial ou totalmente", encontramos no terceiro argumento a seguinte observação: "com rendas, eles não experimentarão tantos movimentos interiores e problemas que os levem a uma preocupação desordenada procurando dinheiro" ${ }^{73}$.

No entanto, o aspecto mais revelador deste maço de folhas autógrafas a que se deu o nome de Diário, é justamente o fato de que se tratam de notas advindas de uma elaboração da experiência pessoal. Assim, a própria linguagem utilizada no texto se torna objeto da nossa atenção. Não é, pois, de se estranhar que os trechos que se seguem às vezes sejam impessoais, ou se caracterizem por uma simples descrição de um estado emocional, ou de uma consideração feita, ou de um sentimento provado etc. Por exemplo, no dia 4 de fevereiro de 1544, uma segunda-feira, Inácio escrevia: "Mesma coisa [referindo-se ao que havia escrito no dia anterior: "abundância de devoção na missa, lágrimas, grande confiança em Nossa Senhora" ${ }^{, 4}$ ], e também outros sentimentos" ${ }^{, 75}$, sendo que quando ele faz uso do termo "sentimentos", não só aqui mas ao longo de todo o Diário, não está prescindindo de uma compreensão intelectual: sentir, em espanhol, é indissociável do intelecto, do afeto e da sensibilidade envolvidos ${ }^{76}$. E isso se pode comprovar, por exemplo, quando o vemos escrever, alguns dias mais tarde que "depois do despertar, eu não parava de render graças a Deus nosso Senhor muito intensamente, com inteligência e lágrimas, por um tão grande bem e uma tão grande luz recebida, que não podem ser expressas"77. Ou mesmo quando faz uso de jogos de

\footnotetext{
${ }^{72}$ Cf. Ibid., pp. 322-323. Esse pequeno documento que, dobrado, comporta quatro páginas, foi classificado entre os manuscritos do AHSI com os números 38 e 39, de forma que temos as páginas 38f, 38v, 39f e 39v.

${ }^{73}$ Ibid., p. $322,39 v 3^{\circ}$ (tradução nossa).

${ }^{74}$ Ibid., p. 327, 03/02/1544 (tradução nossa).

${ }^{75}$ Ibid., p. 327, 04/02/1544 (tradução nossa).

${ }^{76}$ Cf. nota do tradutor, Ibid., p. 327.

${ }^{77}$ Ibid., pp. 331-332, 12/02/1544 (tradução e grifo nossos).
} 
palavras tais como "inteligência espiritual", "sentindo o Filho muito propício para interceder", "vendo os santos de uma tal maneira que não se pode escrever"78, ou "tão grandes inteligências que não se pode escrever"79, ou ainda "esse sentimento ou essa visão", "sentindo muitas inteligências importantes, saborosas e muito espirituais" ${ }^{\prime 0}$ e, para não estender por demais esta lista, mesmo quando relata que "um conhecimento me veio de que um tal pensamento era também de Deus" ${ }^{\$ 1}$, ou que provou “certo sentimento ou visão pelo entendimento" ${ }^{\prime 2}$ etc.

Encontram-se também referências explícitas à experiência, como é o caso desta nota feita no dia 21 de fevereiro de 1544, na qual Inácio relata que durante a missa daquela segunda-feira

conhecia, sentia ou via, Dominus scit, que falar ao Pai, ver que ele era uma Pessoa da Santíssima Trindade, me levava a amá-lo inteiramente, tanto quanto as outras Pessoas estavam nele essencialmente. Experimentava a mesma coisa durante a oração ao Filho, a mesma coisa durante a oração ao Espírito Santo, gozando indiferentemente de uma ou outra Pessoa durante o tempo em que sentia as consolações, as relacionando a todas as três ${ }^{83}$.

Além de todos estes exemplos, é preciso ao menos apontar as inúmeras referências (anotadas nas margens das folhas, por mão de Inácio) às visões, lágrimas e loquela (palavra, em latim; mas, que no caso das anotações de Inácio, se refere à escuta de uma voz interior ou exterior que lhe significa um momento, lhe ajudando num discernimento qualquer).

Com respeito ao Relato de Inácio, Marin (1999), que denomina o texto de “autobiofonia", explica que se trata de um documento no qual Inácio é dado ao leitor como um "imitável, um modelo" ${ }^{84}$. Este texto permite "reviver a vida do fundador, repetir a vida do

\footnotetext{
${ }^{78}$ Todos estes trechos foram retirados da anotação feita no dia 14/02/1544, Ibid., p. 333 (tradução nossa).

${ }^{79}$ Ibid., p. 334, 15/02/1544 (tradução nossa).

${ }^{80}$ Ibid., p. 335, 16/02/1544 (tradução nossa).

${ }^{81}$ Ibid., p. 337, 18/02/1544 (tradução nossa).

${ }^{82}$ Ibid., p. 342, 23/02/1544 (tradução nossa).

${ }^{83}$ Ibid., pp. 340-341, 21/02/1544 (tradução nossa).

${ }^{84}$ Marin, Louis (1996). Le Récit, réflexion sur un testament (pp. 137-155). Em Marin, Louis (1999). L'écriture de soi: Ignace de Loyola, Montaigne, Stendhal, Roland Barthes. Paris: PUF, p. 140.
} 
fundador" ${ }^{\circ 5}$, que é mais do que uma série de eventos, mas o tecido dos eventos ("tudo o que se passou em sua alma até o dia de hoje ${ }^{\text {"86 }}$ ) dirigidos pelo Senhor "desde a sua conversão":

Mas se o próprio de um modelo é de ser imitável, portanto reiterável e repetível, como repetir uma vida dirigida e formada pelo Senhor? Como repetir as intervenções divinas que (...) constituem a vida do fundador, o legendum singular desta vida? Como fazer da leitura do relato desta vida, um modo de repetição desta vida mesmo depois de seu verdadeiro nascimento até o momento onde ela termina? (...) Trata-se, em uma palavra, de escrever 'o relato' no corpo segundo uma modalidade encarnada de sua leitura, ou (...) descobrir a maneira na qual cada companheiro leitor se apropria singularmente, segundo sua vocação, da experiência do fundador ${ }^{87}$.

Ler o Relato, portanto, tem, segundo Marin (1999), dignidade sacramental, na medida que pode ser descrito como uma espécie de comunhão eucarística, na medida em que o texto se torna corpo em quem lê: é a experiência pessoal de Inácio que é dada como paradigma de identificação e incorporação (dois termos que não nos são mais estranhos). O paradoxo apontado pela pergunta de Marin (1999) - o de ser a vida de Inácio dada à imitação apesar de ter sido uma vida formada e dirigida por Deus - se desfaz na interseção entre Graça Divina e Vontade Humana, que nessa visão de homem é tão presente: a experiência da Graça Divina na vida de Inácio ${ }^{88}$, faz dele um modelo, um imitável, um texto vivo para seus companheiros, que, no entanto, têm a liberdade de colocar em operação sua Vontade pessoal para encarnar em suas vidas (ou não) essa "experiência-modelo"89.

Desse debate, finalmente, pode-se concluir que "experiência" é o contraponto de uma mística do abstrato, onde a experiência de relação com Deus se dá apenas na parte nobre da alma humana - alma racional. Mais uma vez, vemos a afirmação da imprescindibilidade dos sentidos, da experiência sensível. A espiritualidade jesuítica, aqui

\footnotetext{
${ }^{85}$ Ibid., p. 146 (tradução nossa).

${ }^{86}$ Cf. Ibid., p. 147 (tradução nossa).

${ }^{87}$ Ibid., p. 147 (tradução nossa).

${ }^{88}$ Apenas a título de exemplo, citamos uma passagem do Relato, quando Inácio relata sua ida para Alcalá: "uma coisa o embaraçava muito, era que quando ele começava a aprender de cor, como era necessário nos inícios da gramática, lhe vinham novas inteligências de coisas espirituais e novos gostos; e isso de tal maneira que ele não podia aprender de cor e não podia as afastar, ainda que lutasse muito contra elas" (Loyola, 1991, op. cit., p. 1046, § 54).

${ }^{89}$ Cf. Ibid., pp. 147-149.
} 
manifesta especialmente pelo seu texto normativo, reafirma que o conhecimento dedutivo não basta para se chegar a um pleno conhecimento da realidade, ou seja, não basta para chegar a tocar o Sentido, o Bem, a Verdade, o Fim presente, como consistência última, na realidade: é preciso a experiência imediata, é preciso o conhecimento direto proporcionado pelos sentidos e pela consciência de si mesmo, é preciso a experiência das coisas percebidas, que são conhecidas na medida em que as vivemos, as tocamos, ouvimos, experimentamos... "sentir y gustar de las cosas internamente" 90.

\section{3) A experiência na ratio institutorum}

Interessa-nos nesse tópico, responder às seguintes questões: qual o conceito de "experiência" que aparece na norma de um corpo institucional religioso - o da Companhia de Jesus, nos séculos XVI e XVII? Ou, em outras palavras, qual a gramática de uso deste termo em textos particulares, e em uma época específica: documentos basicamente "jurídicos"91 de uma dada instituição? E que papel desempenha a "experiência" no processo de identificação/definição do indivíduo com esse corpo institucional?

Inicialmente, devemos apontar o uso comum, nos primeiros documentos da Companhia de Jesus, da expressão "nossa maneira habitual”, para designar como os primeiros jesuítas agiam em questões muito particulares. Por exemplo, no documento 1539. Durante três meses, A maneira como se instituiu a Companhia, o redator anota que a maneira habitual usada para discutir sobre as questões da fundação era: "refletir e meditar sobre elas durante o dia e as aprofundar em nossas orações"92. Bem como no Atestado concernente à decisão de fazer voto de obediência: “depois de ter rezado a Deus

\footnotetext{
${ }^{90}$ Cf. García Mateo, 1998, op. cit., pp. 478-479.

91 “Jurídicos" mas não somente: como já se pôde verificar e se verificará aqui, estes documentos, bem como os demais, se auto-influenciam e se referem uns aos outros todo o tempo... não há, podemos dizer, solução de continuidade entre o que é do âmbito da regra espiritual e institucional, bem como entre esses âmbitos e o filosófico-retórico.

${ }_{92}$ Loyola, 1991, op. cit., p. 278, § 2 (tradução nossa).
} 
e pesado maduramente a coisa (...), decidi de pleno grado" 93 etc.

A pergunta que se pode fazer a partir daí é: como um indivíduo pode chegar a assumir para si, a se colocar em primeira pessoa nessa "nossa maneira habitual"? Ou: que dinâmica permite a identificação de um indivíduo à essa modus operandi particular?

Lemos nas Determinações da Companhia algo que responde a esta pergunta: "Aqueles que estão para ser admitidos devem, antes de serem experimentados durante o ano de provação, passar três meses em exercícios espirituais, em peregrinação e a serviço dos pobres nos hospitais, ou em outra coisa"94. Aprende-se a ser jesuíta “experimentando" o que seja ser um jesuíta. E o que é ser um jesuíta? Passar por exercícios espirituais, fazer peregrinação, trabalhar a serviço de pobres: o que é isso? É a vida de Inácio: uma experiência-modelo que, aqui, deixa de ser a descrição de uma experiência espiritual, para se tornar a prescrição explícita de um modelo de identificação. É por isso que na Summa os primeiros escrevem: "que ninguém seja recebido nesta Companhia antes que seja, inicialmente, longa e cuidadosamente experimentado, e quando se tiver constatado que é prudente no Cristo e se distingue por sua doutrina ou pela santidade de sua vida"95.

Quanto ao texto das Constituições, importa, primeiro, que fique claro que mais que um texto normativo strictu sensu, elas são, para os jesuítas, a descrição de um caráter particular, bem definido e com traços muito específicos. É bem verdade que é pelo motivo mesmo de ser descritivo, que o texto tem uma virtude prescritiva, na medida em que ao descrever como "é", tangencia o como "deve ser" o jesuíta: o exemplo é o postulado da prescrição. É esta característica do documento que permite compreender porque é indicado que sejam lidas e meditadas com freqüência, até o ponto de serem sabidas de cor ${ }^{96}$.

\footnotetext{
${ }^{93}$ Ibid., p. 282 (tradução nossa).

94 Ibid., p. 285, § 11 (tradução nossa).

${ }^{95}$ Ibid., p. 306, Summa § 9 (tradução nossa).

${ }^{96}$ Nas Regras gerais tiradas das constituições se diz que foi a Divina Providência que permitiu que a Companhia de Jesus existisse e, portanto, mais que qualquer constituição exterior é a Ela que se deve recorrer sempre. No entanto, continua, foi a mesma Providência Divina que "pede a cooperação de suas criaturas" e o Papa que "assim ordenou", que mostraram o quão necessário era "escrever Constituições que ajudem a melhor avançar, conformes ao Instituto da Companhia, na via do serviço divino que começamos a seguir" (Ibid., p. 608, Regras $\S 2$, tradução nossa). No parágrafo seguinte diz: "Assim, e bem mais ainda, é necessário que todos aqueles que entram na
} 
Neste documento aparecem, com freqüência termos diferentes para designar a categoria analisada neste capítulo: "experiência" (que, no texto francês, aparece como expérience, quando designa substantivo ou éprouver, para designar um verbo), "provação" (que aparece no texto francês como probation) ou "prova" (épreuve, em francês).

Assim, encontramos, por exemplo no "Exame" (uma espécie de prólogo ao texto jurídico) das Constituições, após explicar a pertinência dos "seis meses de experiências e provas", a seguinte observação:

Isso para que, de uma e outra partes, aja-se com a maior clareza e conhecimento em nosso Senhor e que, mais sua constância tenha sido experimentada [éprouvée], mais sejam estáveis e firmes no serviço divino e na sua primeira vocação, para a glória e honra de sua divina Majestade ${ }^{97}$.

Em seguida, nos parágrafos 64 a 83 do mesmo "Exame" descrevem-se minuciosamente cada uma das "experiências" que se farão ao longo do período anterior à entrada em casa ou colégio da Companhia de Jesus (trata-se do período denominado “primeiro ano de provação"):

Além disso, antes de entrar na casa ou colégio, ou depois de ter entrado, seis experiências [expériences] principais são exigidas, sem contar muitas outras sobre as quais se falará mais adiante. Essas experiências [expériences] poderão ser avançadas, retardadas ou adaptadas e, em certos casos, modificadas por outras com a autorização do superior, segundo a pessoa, os tempos, os lugares e as circunstâncias ${ }^{98^{3}}$.

Quais são estas “experiências"? Fazer exercícios espirituais durante mais ou menos um mês ( $§ 65)$, servir em hospitais ou em um hospital durante um outro mês (§ 66), fazer peregrinação durante um outro mês ( $§ 67)$, se aplicar em serviços baixos e humildes ( $§ 68)$, expor publicamente a doutrina cristã para crianças ou pessoas ignorantes (§ 69) e pregar e confessar em igrejas indicadas ( $§ 70)$. Nos parágrafos que se seguem, procura-se explicar como cada uma delas ajuda a atestar o candidato e ao final diz: "se esses atestados quanto às

Companhia e vivem nela sejam convencidos em nosso Senhor e desejos de guardar integralmente todas as constituições, as regras e a maneira de viver da Companhia e que com sua divina graça se esforcem, de todo seu coração e de todas as suas forças, por as observar perfeitamente" (Ibid., p. 609, Regras § 3, tradução nossa).

${ }^{97}$ Ibid., p. 400 (Const.18, tradução nossa).

${ }^{98}$ Ibid., p. 409 (Const.64, tradução nossa). 
experiências [expériences] faltam, deve-se procurar a razão com muito cuidado, com o objetivo de saber a verdade sobre tudo, a fim de que se possa melhor prover a tudo, onde convém"99. Isso porque, nas experiências de provação, o candidato se expõe, se revela, e é, portanto, essencial o papel das testemunhas: o candidato está sempre sob os olhos de uma testemunha. Ao final, cabe ao candidato produzir, diante de seus superiores, o atestado de suas experiências, por isso o comentário do $§ 79$, acima transcrito.

Já no texto das Constituições propriamente dito, na Primeira Parte - que trata de "A admissão à provação" - quando fala daqueles que serão recebidos, se diz:

Para falar de uma maneira geral daqueles que se deverá receber, pode-se dizer que mais alguém tenha recebido de Deus nosso Senhor dons naturais e infundidos para ajudar a Companhia naquilo que ela busca, seu divino serviço, e mais tenha feito a experiência [expérience] desses dons, mais será apto a ser recebido na Companhia ${ }^{100}$.

Serão recebidos na Companhia aqueles que são experimentados naqueles dons que ajudam a Companhia, ou sejam, que distinguem a sua ação da ação das demais Ordens. De novo "experiência" pode ser colocada lado a lado com o termo "identificação". Como se confirma no Capítulo III, desta Primeira Parte - denominado "A dispensa daqueles que foram admitidos e não deram satisfação" - onde se enumeram as justificativas para a dispensa de um membro da Companhia: entre elas se diz que será dispensado quem for “contrário ao bem da Companhia", ou seja, "se a experiência mostrar que este é de fato inútil e mais próprio a embaraçar a Companhia que a ajudar"101.

Na Quarta Parte - "A formação nas letras e nos outros meios de ajudar o próximo daqueles que são guardados no seio da Companhia" - das Constituições, mais especificamente no Capítulo III, que trata dos "Estudantes que se deve colocar nos Colégios", por sua vez, lemos o seguinte:

\footnotetext{
${ }^{99}$ Ibid., p. 411 (Const.79, tradução nossa).

${ }^{100}$ Ibid., p. 433 (Const.147, tradução nossa).

${ }^{101}$ Ibid., p. 448 (Const.212, tradução nossa).
} 
No entanto, só serão admitidos como estudantes aprovados aqueles que foram experimentados [éprouvés] nas casas ou nos colégios e que, depois de dois anos de experiências [expériences] e de provação [probation], uma vez feitos os votos e a promessa de entrar na Companhia, são recebidos para nela viver e nela morrer para a glória de Deus nosso Senhor ${ }^{102}$.

Ou então, o que se lê na Quinta Parte - "O que concerne à admissão ou incorporação na Companhia” - quando logo no Capítulo I (“A admissão. Quem a faz e em que momento"), se diz:

Aqueles que foram suficientemente colocados à prova [épreuve] na Companhia e durante bastante tempo para saber, de parte a parte, se convém que eles permaneçam para um maior serviço e uma maior glória de Deus nosso Senhor, devem ser admitidos não mais em provação como antes, mas de uma maneira mais intrínseca, enquanto membros de um mesmo corpo, o da Companhia. É o caso principalmente daqueles que são admitidos para serem professos ou coadjutores formados ${ }^{103}$.

Pela leitura de todos estes excertos fica clara a identidade experiência/provação. O jesuíta é chamado a viver um período de provas, ao final do qual o indivíduo é definitivamente reconhecido ou não como pertencente ao um corpo institucional. A "experiência" aqui pode ser definida, pois, como uma série de atividades que garante 1) a identificação do indivíduo com a instituição e 2) a reprodução/manutenção dessa mesma instituição ${ }^{104}$. Importante destacar, portanto, o papel da "experiência" assim compreendida no processo de individualização x individualismo: quem obedece a essa regra integra um corpo institucional e se torna uma pessoa que vive de uma forma que, se descrita, permite-nos conhecer o jesuíta.

\footnotetext{
102 Ibid., p. 477 (Const. 336, tradução nossa).

${ }^{103}$ Ibid., p. 515 (Const.510, tradução nossa).

${ }^{104}$ Cf. Fabre, Pierre-Antoine (2000). "Ils iront en pèlerinage...": 1"“expérience" du pèlerinage selon 1"“Examen général" des Constitutions de la Compagnie de Jésus et selon les pratiques contemporaines (159-188). Em Boutry, Philippe; Fabre, Pierre-Antoine et Julia, Dominique (2000). Rendre ses voeux: les identités pèlerines dans l'Europe moderne (XVIe-XVIIIe siècles). Paris: EHESS.
} 


\section{4) A experiência nos escritos espirituais jesuíticos}

On peut par deux voies savoir les choses de la vie [mystique] future, c'est à savoir par la foi et par l'expérience. La foi est la voie commune que Dieu a établie pour cela à cause que les choses de Dieu et de la vie future ne nous sont connues que par ouï-dire et par la prédication des apôtres. L'expérience est pour peu de personnes. Les apôtres de Jésus-Christ étaient de ce nombre. Aussi disaient-il: Quod vidimus, quod audivimus, quod manus nostrae contrectaverunt de verbo vitae annuntiamus vobis; et ailleurs: Quod scimus loquimur, quod vidimus testamur.

Jean-Joseph Surin (1660)

Assim inicia sua obra - Science expérimentale des choses de l'autre vie -, o padre jesuíta francês Jean-Joseph Surin (1600-1665), que ganhou celebridade dentro e fora da Companhia de Jesus graças a suas virtudes e talentos como diretor espiritual. Quarenta e cinco anos depois da morte do P.e Cláudio Aquaviva, vê-se (com esta e outras tantas obras espirituais, como vimos anteriormente) muito mais estabelecida sobre bases seguras uma espiritualidade com feições propriamente jesuíticas.

É bem verdade que, no trecho citado, Surin deixa claro que a "experiência" é uma forma de conhecimento das coisas futuras (ou místicas) para poucos, como os apóstolos que - note-se - viram, ouviram e tocaram o "verbo vitae". Mas isso não significa que somente eles puderam fazer uma experiência sensível do Verbo Encarnado ou das coisas futuras ou místicas (para usar os termos que ele usa). Neste ponto, Surin é bastante claro: “os apóstolos de Jesus Cristo eram deste número", porém, mais à frente no texto inicial da obra, ele se diz parte deste número também e afirma ter a "mesma intenção" dos apóstolos: "que essas coisas que conhecemos (...), e na qual a providência de Deus nos engajou, sejam empregadas neste discurso para tornar firme a fé na qual a profissão da religião católica nos

\footnotetext{
${ }^{105}$ Surin, Jean-Joseph (1990). Triomphe de l'Amour divin sur les puissances de l'Enfer en la possession de la Mère Supérieure des Ursulines de Loudun, exorcisée para le Père Jean-Joseph Surin, de la Compagnie de Jésus et Science expérimentales des choses de l'autres vie. Grenoble: Jérôme Millon (originais em francês de 1653 e 1660, respectivamente), p. 127.
} 
engajou, e para nos tornar melhores cristãos"106.

Eis o ponto capital: o texto-testemunho de Surin - que relata os sofrimentos porque passou e as graças que recebeu no período que se seguiu à sua intervenção junto a um caso de possessão demoníaca de algumas irmãs Ursulinas ${ }^{107}$ - ganha estatuto de veracidade porque é uma experiência feita que se comunica com a finalidade de tornar firme a fé de quem leia: annuntiamus vobis, loquimur e testamur que os Demônios existem ${ }^{108}$, mas que há um "Deus, tal como a Igreja acredita e anuncia"109 e um "Deus que é vingador dos crimes"110, e também que "uma vontade boa é toda poderosa, e que contra ela o Inferno é como que um quase-nada que, sem ela, se torna um gigante sem tamanho"111, mas sobretudo que "a providência de Deus foi singular nesta possessão, dando todas as ocasiões e provas suficientes de que eram demônios, e que Deus e a Igreja dominam sobre eles" $" 112$.

Vejamos, porém, como nos textos espirituais com os quais vimos trabalhando, a questão da "experiência" se apresenta, a fim de verificar como, no tempo, vai se estabelecendo esta espiritualidade e, sobretudo, como ela se define, no âmbito discutido até aqui, a partir do assumir-se, numa síntese encarnada, todo um horizonte formativo com as características bastante peculiares descritas.

Por exemplo, na carta enviada no dia 29 de setembro de 1583 pelo P.e Aquaviva à toda a Companhia de Jesus - Lettera del Nostro Padre Generale (...) Sopra la Rinovatione dello spirito etc. - se pode ler, depois que ele exorta os padres e irmãos a "metter la mano all'opera", sua justificativa para este trabalho:

sappiamo con l'esperienza, che le arti non s'imparano, se non facendo; \& pure occupandosi intorno à materia di fuori, non trovano resistenza: perche ne

\footnotetext{
${ }^{106}$ Ibid., p. 128 (tradução nossa).

${ }^{107}$ Cf. sobre a história do P.e Surin, o texto de Certeau, Michel (1990). Les aventures de Jean-Joseph Surin (pp. 421-437). Em Ibid.

${ }^{108}$ No Capítulo I da Primeira Parte do texto Surin mostra as "provas de que existe verdadeiramente demônios", a partir das “pistas que deixaram em sua saída dos corpos das pessoas possuídas”. Cf. Ibid., pp. 131-149.

${ }_{109}$ Surin, 1990, op. cit., p. 343 (tradução nossa).

${ }^{110}$ Ibid., p. 347 (tradução nossa).

111 Ibid., p. 377 (tradução nossa).

112 Ibid., p. 414 (tradução nossa).
} 
all'architetto le pietre, ne à gli altri artefici impediscono le materie i suoi disegni; ma la nostra filosofia che consiste nel moderar gli affetti interni, truova molto maggior ripugnanza, \& mutatione; poi che se bene nel quadrare, la pietra fa alcuna difficoltà, quadrata però non torna alla prima roizessa; ma gli affetti nostri ben spesso si mutano, come per isperienza proviamo ${ }^{113}$.

Aquaviva (1583), aqui, insiste no fato de que se renovará o espírito não somente pela graça de Deus, mas pela prática constante dessa renovação. Constante porque, "como por experiência provamos", os afetos não são como nossas características externas que, quando modificadas não voltam atrás, mas "muito freqüentemente se alteram". "Experiência” é, pois, não somente conhecimento adquirido pela prática, mas um saber indutivo acerca de si mesmos, a que eram educados os jesuítas.

$\mathrm{Na}$ carta seguinte - Lettera del Nostro Padre Generale (...) Dello studio della perfettione, \& carità fraterna -, Aquaviva (1586) explicando o que é este "estudo da perfeição e caridade fraterna", ou seja, o forçar-se a fazer a vontade do "nosso pai e senhor"114, tornará a obediência às Constituições e aos Superiores "cada dia mais doce""115 e, especialmente, “far-nos-á com a experiência saborear e, com uma luz maravilhosa, que não é de lume natural, conhecer claramente, que esta é uma doutrina do céu"116. Fica claro, nesta passagem que, de fato, regra espiritual e regra institucional são análogas; esta analogia, na verdade, é corroboradas pelo conhecimento filosófico - que também deve ser considerado como não-autônomo - das potências da alma ("se nossa vontade não é espoliada de todo amor e afeição particular não poderá buscar a Deus"117, como escreve mais à frente na mesma carta); e a interseção/analogia se dá exatamente no apelo à "experiência".

\footnotetext{
113 Aquaviva, Claudio (1583). Lettera del Nostro Padre Generale Claudio Acquaviva. Sopra la Rinovatione dello spirito à Padri \& Fratelli della Compagnie. 29/09/1583. Roma, pp. 23-24. ("sabemos com a experiência que as artes não se aprendem a não ser praticando-as; e também que se ocupando da matéria externa, não se encontra resistência: porque nem ao arquiteto no trabalho com as pedras, ou aos outros artesãos, impedem a matéria e os seus desenhos; porém a nossa filosofia que consiste em moderar os afetos internos, encontra muita maior repugnância e mudança; dado que se para tornar quadrada uma pedra se encontra alguma dificuldade, já quadrada, no entanto, não volta à primeira forma; mas, os nossos afetos muito freqüentemente se alteram, como por experiência provamos").

114 Aquaviva, Claudio (1586). Lettera del Nostro Padre Generale Claudio Acquaviva. Dello studio della perfettione, \& carità fraterna. 19/05/1586. Roma, p. 8, tradução nossa.

${ }_{115}$ Ibid., p. 8, tradução nossa.

${ }^{116}$ Ibid., p. 8, tradução nossa.

${ }^{117}$ Ibid., p. 18, tradução e grifo nossos.
} 
Também Fazio (1594) faz uso dessa categoria - dentro do mesmo espaço de discussão usado por Aquaviva (1586) - para demonstrar o quão necessário é se aplicar no exercício da "Mortificação santa" das faculdades da alma e, sobretudo, das paixões desordenadas e também no exercício da obediência. Segundo ele, a mortificação e a obediência fazem com que nos deixemos guiar, finalmente, pela vontade de Deus e não pela nossa, que, "por sua natureza é cega" e, dessa forma guiados, não corremos o risco de incorrer no erro "que o Senhor mesmo predisse dizendo: Si coeco coecus ducatum prestet, ambo in foveam cadunt" ${ }^{\text {"118. }}$.

Sanchez (1607), fazendo uso de questões próprias da Filosofia Moral, acaba por prescrever a obediência como ajuda para a manutenção da prudência, que, sabidamente, é a virtude dos experimentados. Assim escreve ele, no Capítulo IV, Livro V - que trata da “obediência que é devida aos superiores" - de seu Le Royaume de Dieu et le vray chemin pour y parvenir:

Apres qu'un homme aura prins des estudes \& exercices suffisans en sa vacation \& estat, il a necessité d'une prudence \& discretion, par laquelle il se regle, \& conduise, car d'autre maniere, les vertus se convertiroient en vices. Et pource que la prudence, est celle-là, qui met le frain \& ordonne toutes vertus, parfoy elle est appellée vertu des anciens, qui d'ordinaire s'obtient fort tard, \& avec grande experience (à raison de quoy les jeunes superieurs, font tant de folies, \& injures mal a propos) pourtant il est três-evident qu'il faut prendre l'obeissance pour bride \& guide, qui supplee à la prudence ${ }^{119}$.

Um a um, todos os padres espirituais apresentados vão se servindo da "experiência" para prescrever exercícios que auxiliem no engajamento à "religião católica" e no se tornarem "melhores cristãos": Villanueva (1608), depois de dizer que a oração mental é mais oração

\footnotetext{
118 Fazio, Giulio (1596). Trattato utilissimo della mortificatione delle nostre passioni, \& affetti disordinati. Composto nuovamente per il molto R. P. Giulio Fatio, della Compagnia di Giesu. Brescia: Pietro Maria Marchetti, p. 49 (tradução nossa).

${ }^{119}$ Sanchez, Pedro (1607). Le Royaume de Dieu, et le vray chemin pour y parvenir. Composé en Espagnol par le Pere P. Sanchez, Docteur de la Compagnie de Iesus. Traduit en François, par F. Guillaume Levite, de l'Ordre des Predicateurs. Paris: Chez Adrian Beys, p. 560 ("Depois que um homem tiver estudado e se exercitado suficientemente no seu trabalho e estado, ele tem necessidade de uma prudência e discrição, pela qual se regrar e conduzir, porque de outra maneira, as virtudes se convertem em vícios. E porque a prudência é aquele que freia e ordena todas as virtudes, às vezes ela é chamada de virtude dos antigos, que ordinariamente se obtém bastante tarde e com grande experiência (por isso os jovens superiores fazem tantas loucuras e injúrias a este respeito), no entanto, é muito evidente a necessidade de ter a obediência como freio e guia, que supre a prudência").
} 
que a vocal, lembra, por exemplo, que no entanto se acrescentam as palavras à oração mental quando a alma "se sente caída"120 e afirma que "este aviso (...), cada dia nos é ensinado pela experiência, que vendo caído o nosso espírito na oração, com a voz exterior o reaviva" ${ }^{121}$; e segue com suas considerações sobre as potências da alma humana. À frente, na mesma obra, Villanueva (1608), falando acerca da especulação e da contemplação, como formas de oração de entendimento, retoma conteúdos próprios dos Exercícios Espirituais de Santo Inácio de Loyola: aplicação dos sentidos, composição de lugar, uso da memória, etc. Rodriguez (1834) também, no Ejercicio de perfeccion y virtudes cristianas $^{122}$, apela para a "experiência" com o fim de comprovar como são importantes os votos para a ordenação pessoal e institucional. Assim como Nieremberg (1657 e 1957), o qual também faz uso desta categoria para mostrar como a vontade precisa ser bem conduzida pelos preceitos da moral ${ }^{123}$, ou pela ordem institucional $^{124}$. De tal forma que, nestes textos, podemos encontrar o teórico, o institucional e

\footnotetext{
${ }^{120}$ Villanueva, Melchior de (1608). Libro de oracion mental. Compuesto por el Padre Melchior de Villanueva, de la Compañia de Iesus. Toledo: Pedro Rodriguez impressor del Rey nuestro Señor, p. 7,1 (tradução nossa).

${ }^{121}$ Ibid., p. 7,2 (tradução nossa).

${ }^{122}$ É bem verdade que não se trata de uso explícito, como nos demais exemplos, no entanto, Rodriguez (1834) recorre a exemplos de santos, apóstolos e mártires para mostrar, por exemplo, como é verdade que os votos não tiram a liberdade, pelo contrário a aperfeiçoam, como é o caso deste trecho: "não se tira a liberdade pelos votos, antes se aperfeiçoa mais (...); porque o que fazem os votos é afirmar e fitar nossa vontade no bem (...); como em Deus, e nos bem aventurados que não podem pecar (...) e os apóstolos que foram confirmados em graça e não podiam pecar mortalmente, não por isso perderam a liberdade, antes com isso se aperfeiçoou; porque se afirmou e fixou mas o bem para que foi criada". Cf. Rodriguez, Alonso (1834). Ejercicio de perfeccion y virtudes cristianas, su autor el Padre Alonso Rodriguez de la Compañía de Jesus, natural de Valladolid. Dividido en tres partes. Parte tercera. De varios medios para alcanzar la virtud y perfeccion. Nueva Impression. Barcelona: Imprenta de D. Valero Siena y Marti, p. 100 (tradução nossa).

${ }^{123}$ Nieremberg (1657), no decorrer do seu De arte voluntatis, se auxilia de conceitos vindos da psicologia filosófica aristotélico-tomista com a clara finalidade de demostrar como as potência da alma racional têm necessidade dos preceitos morais para se bem ordenarem. Assim, não poucas vezes, fará uso de termos e expressões que implicam um conhecimento por experiência: "a felicidade é um certo silêncio" (p. 118, tradução nossa), "as ações honestas e legítimas, as afeições sãs, as boas obras" (p. 158, tradução nossa), "nós nos privamos voluntariamente dessas duas tão excelentes vantagens" (p. 320, tradução nossa), "lhe represente duro e penível" (p. 377, tradução nossa), "quem ama a paz e deseja adquirir repouso" (p. 475, tradução nossa) etc. Cf. Nieremberg, Juan Eusebio (1657). L'art de conduire la volonté selon les precepts de la morale ancienne \& Moderne, tirez de Philosophes Payens \& Chrestiens. Traduit du latin de Jean Eusebe de Nieremberg, Paraphrase \& de beaucoup enrichy par Louÿs Videl, de Dauphiné. Dedié à Monsieur de Lionne, Conseiller d'Estat ordinaire \& secretaire des Commandemets de la Reyne Regente. Paris: Chez Jean Pocquet

${ }^{124} \mathrm{Na}$ obra seguinte (a edição que usamos é aquela de 1957), Nieremberg segue as veredas da regra institucional sob a qual se encontra determinado para mostrar também, pela experiência, como este é um caminho facilitado para chegar a uma "vida divina". Nieremberg, Juan Eusebio (1957). Vida Divina y camino real de Grande atajo para la perfeccion. Em Nieremberg, Juan Eusebio (1957). Obras escogidas del R. P. Juan Eusebio Nieremberg (E. Zepeda-Henriquez, ed.). Biblioteca de Autores Españoles, desde la formación del lenguaje hasta nuestros dias (continuación). Tomo 103. Madrid: Ediciones Atlas.
} 
o espiritual tornados prescrição não porque sejam documentos normativos, mas porque fazem legível a descrição de um modus operandi e de um modus cogitandi encarnados numa experiência de caráter necessariamente jesuítico. "Necessariamente" porque se trata de um caráter fundado sobre aquele tripé formativo muito peculiar desta ordem religiosa.

\section{5) A experiência, portanto}

No início deste capítulo, nos perguntávamos como era possível que termos tão diversos e, sobretudo, tão distantes do horizonte cognoscitivo da "experiência" pudessem ser usados, numa mesma frase, juntos: Deus, a alma, as paixões da alma, os sentimentos etc. Tendo seguido este percurso que vimos descrevendo até este ponto, a questão parece esclarecer-se. Senão, vejamos.

Escrever que se experimenta que Deus dá um "desejo fervoroso" que, como luz do céu, desfaz as trevas e as falsas razões da alma; ou que se experimenta que, na medida em que os desejos são considerados a partir das falsas razões, parecem vir do demônio, como o afirma Seraphin Bonaventura Coçar ${ }^{125}$, é descrever o resultado de um trabalho de discernimento dos espíritos, ou seja, o trabalho do juízo a fim de bem localizar de quem partiu o desejo, quem o concedeu; é também comprovar o trabalho de elaboração pessoal acerca da experiência de "sentir um incendido desejo". De fato, em sua carta, Seraphin procura deixar claro ao Padre Geral o quão seriamente trabalhou para conhecer a origem desse desejo e sobretudo o quão certo é de que quem o dá é "Dios Nuestro Señor", já que tem experimentado uma atenção maior na "observância das regras", depois de se ter encomendado a Deus, nas orações. Vê-se que, a "experiência", neste caso, está intimamente ligada a um conhecimento de si mesmo e de Deus, bem como de virtudes morais, indissociavelmente: se o desejo é um desejo honesto, útil e agradável, é um movimento em

\footnotetext{
${ }^{125}$ Cf. ARSI, Indipetae Hispanae, FG 758, carta n. 4.
} 
direção ao sumo Bem; mas não basta a confirmação teórica, é preciso uma experiência sensível de sua honestidade, utilidade e benignidade: "un desseo fervoroso, que como luz del cielo deshaze en mi alma aquellas tinieblas y razones, dexandome muy consolado, y con tal alegria, que me parece arrostrar a qualquiera dificultad y trabajo”.

Joan Sotalell experimenta paciência grande diante das tentações, pelo simples pensar "yr a las Indias"126, além de experimentar consolação e facilidade para fazer o que antes era difícil. No texto que escreve, o jovem jesuíta relata, como os demais indipetentes, o trabalho de discernimento dos espíritos a que se dedicou - oferecimentos, obediências, abnegações, exercícios espirituais, mortificações -, bem como procura demonstrar e comprovar como conhece bem a si mesmo, seus limites, suas virtudes, as graças recebidas. Tudo utilizado como argumento a favor e prova da origem divina de um tal desejo. Além disso, Sotalell explicita seu desejo de fazer sua a vontade de Deus: "davame grande molestia el ver que no podia ser luego, pero conformeme con la voluntad de Dios Nuestro Señor que fuesse quando el quiziesse"; como, por exemplo, Aquaviva (1586) lembrava em sua carta dirigida à Companhia de Jesus: "ne trova il servo di Dio altro riposo, ò altro contento, che il far la volontà di colui, la cui volontà è sola regola d'ogni rettitudine",127.

A experiência de facilidade para os "trabajos de corazon" a que se refere Gabriel Mayo $^{128}$ em sua Indipeta, unida à certeza de sua falta de habilidades que justifiquem o pedido, não se contradizem, porque: "no nace este desseo que tengo de ver en mi algo delo que han de tener los Predicadores", mas "nace de la sola immensa bondad de Dios, que en mi lo despierta y me tira sin ýo mereçello ni pretendello". Porém, a comprovação maior é que, junto com o desejo de ir para o Japão para trabalhar na conversão das almas, sente também um “desseo de dar la vida por amor del Señor”. Como pode ser possível que um

\footnotetext{
${ }^{126}$ Cf. ARSI, Indipetae Hispanae, FG 758, carta n. 338.

${ }^{127}$ Aquaviva, 1586, op. cit., p. 7.

${ }^{128}$ Cf. ARSI, Indipetae Hispanae, FG 758, carta n. 379.
} 
Bem honesto, útil e agradável dê origem a um desejo de morte? Se e somente se esse desejo é o desejo do Amor de Deus, o desejo do Sumo Bem, da realização da vida a que foi chamado no seio da Companhia de Jesus.

Também Juan Bravo comprova, a partir da experiência, a origem divina do seu desejo, quando apresenta as justificativas nascidas da elaboração pessoal: o desejo corrige suas imperfeições e lhe permite viver firme nas "cosas de Instituto". E, finalmente, diz: "No creo que rayz de donde brotan tales ramas puede ser o malas, o antojadiza" ${ }^{129}$. Em outra carta sua ${ }^{130}$, Juan Bravo relata o desejo de dizer à voz tudo o que o Senhor lhe fez conhecer e sentir: desejou estar "a los pies de Vuestra Paternidad para que con la lengua propria diera al Padre que my Dios me ha dado una notiçia de my coraçon y de lo que en el pasa". Que coisas são essas que supõe que Deus o faz experimentar? Sempre são confirmações da origem divina do desejo que sente de ir ao Japão, confirmações, inclusive, que lhe dão a segurança de escrever não uma ou duas vezes, mas várias vezes, sempre para refrescar a memória do Padre Geral de seus desejos e, especialmente, do seu trabalho de discernimento e da certeza a que chegou.

Experiência: instrumento cognoscitivo? Ponte para aceder a Deus? Critério de identificação? Tudo isso, mas num continuum feito carne, que analisaremos a seguir, no seu dinamismo particular.

\footnotetext{
${ }^{129}$ Cf. ARSI, Indipetae Hispanae, FG 758, carta n. 329.

${ }^{130}$ Cf. ARSI, Indipetae Hispanae, FG 758, carta n. 404.
} 


\section{TERCEIRA PARTE} AS INDIPETAE NO SEU DINAMISMO 


\section{CAPÍTULO 7 Introdução}

Na leitura das Indipetae, um dos aspectos que mais salta às vistas é a recorrência de lugares-comuns ${ }^{1}$ tais como "desejo", “vocação", "martírio", “consolação", termos ou expressões que denotam "conhecimento de si”, “consideração”, “encomendar", "sentidos”,

\footnotetext{
${ }^{1}$ Entendemos por topoi ou lugar-comum o que Aristóteles define como princípios argumentativos, pressupostos ou fundamentos, que consistem numa espécie de interpretação do mundo que tem, em si mesmo, força persuasiva, devida ao fato de se constituir numa sabedoria comum, admitida e aceite em certo grupo, e em certo tempo histórico preciso. Mendes (1989) define da seguinte forma: "as técnicas discursivas do lugar-comum e da citação, ou seja, dos textos de outrem apropriados, glosados e manejados com à-vontade, traziam consigo facilidade e felicidade: proporcionavam os jogos verbais, conservavam, para melhor os saborear, os pensamentos mais engenhosos dos homens, e libertavam o orador-escritor de si próprio e da compulsão ao silêncio, ou ao retraimento, por o colocarem em contato com o tesouro de uma memória verbal sempre inteligente e selecionada, e com a potência germinativa de um cabedal de textos prévios" (p. 73). Cf. Mendes, Margarida Vieira (1989). A oratória barroca de Vieira. Lisboa: Caminho. Evidentemente que, aqui, se trata mais do uso verbal da oratória que do uso subsumido pela ars dictaminis, no entanto, como definição é absolutamente correta. Cícero (1966) fala a este respeito no seu De Oratore: "Em cada negócio a que se deve advogar, não é necessário nunca se reportar aos argumentos particulares que lhe dizem respeito; é suficiente ter em reserva lugares determinados, que se apresentarão para a causa a ser tratada, como as letras para a palavra a ser escrita. Mas esses lugares só são realmente úteis para o orador já formado, amadurecido seja pela experiência que a idade dá, seja pelas lições de outros e pela reflexão pessoal, pelo estudo atento que avança os anos. Porque vós poderíeis me trazer o homem mais instruído, dotado do pensamento mais vivo e mais penetrante jamais visto, de uma elocução fácil; no entanto se ele é estrangeiro a nossos costumes, a nossa história, a nossas instituições, aos hábitos e ao espírito públicos, estes lugares, de onde se tiram os argumentos, não lhe serão de grande ajuda. Em primeiro lugar, o orador deve buscar a natureza da causa. Ela não é nunca misteriosa: é preciso examinar se o fato aconteceu, como o qualificar, como o denominar" (XXX 130-132). Cicéron, M. T. (1966). De l'orateur. Livre deuxième. (E. Courbaud, Trad.). Paris: Société d'édition "Les Belles Lettres" (original de 55 a.C.), pp. 59-60. No nosso caso específico, os lugarescomuns presentes, se referem não apenas ao contexto histórico-cultural - o XVI-XVII ibérico - mas também ao ambiente institucional com o qual trabalhamos: trata-se de uma "gramática de uso" jesuítica.
} 
"obediência", "indignidade", sentimento de "filiação", "ad maiorem Dei gloriam" e, mesmo alguns menos freqüentes, mas bastante significativos, como "razão", "virtude", "alegria" ou “contentamento", "lágrimas”, “indiferença”, "mortificação", “desengano", “tentação", "paixões" e "experiência", entre outros ${ }^{2}$. Quase sempre estas tópicas vêm qualificadas pelos mais diversos adjetivos.

Trata-se - no caso das cartas analisadas do ponto de vista "macro-histórico" (15831609) - de um uso uniforme dos termos durante todo o período, com variações individuais, mas que não nos permite nenhuma conclusão acerca do uso ou desuso de determinado topos durante um certo período, ou em um certo colégio ou província jesuítica. Mas, é bastante evidente a recorrência das tópicas "desejo", "vocação" e "martírio", de maneira geral, e igualmente distribuídas em todo o corpo do texto das cartas.

No caso das cartas de Juan Bravo, o uso das tópicas diminui com os anos, proporcionalmente à extensão das cartas, sendo que, nas últimas, são incluídas novas tópicas como "memória" e "obrigação", sempre referidas ao desejo: seja para lembrar o superior geral de seus desejos, seja para afirmar o quão obrigado se sente de fazê-lo. Outro aspecto notável é o aumento do uso de lugares-comuns com sentido de reafirmação de seu sentimento de filiação à Companhia e ao padre geral, especialmente na última carta, que é marcadamente uma tentativa ímpar de docilização da benevolência do destinatário.

Além do uso de topoi, outro aspecto que chama a atenção é o de uma estruturaçãomodelar do texto da carta, como se pode ver mais detalhadamente no Anexo $4^{3}$ : há sempre uma salutatio, constando, na maior parte das vezes, apenas do usual Pax Christi \&c.; em seguida, a captatio benevolentiae, onde o indipetente, normalmente, a fim de docilizar a benevolência do Prepósito Geral, apresenta a motivação da escrita (a visita de um padre

\footnotetext{
${ }^{2}$ Cf. Anexo 5, a tabela com os topoi presentes nas cartas analisadas.

${ }^{3}$ Cf. Anexos 3 e 4, onde buscamos descrever tanto a estrutura argumentativa (um resumo da carta) quanto a estrutura retórica, conforme a ars dictaminis, utilizada em cada carta.
} 
procurador, uma carta lida no refeitório, o aumento do desejo, uma conversa que teve, uma pintura que viu etc.) e, sobretudo, é quando faz uso de tópicas tais como desejo, vocação, martírio, indignidade, encomendar e considerar, obediência, filiação etc. Em seguida, na narratio, o escritor declara seu desejo (ir para o Japão, trabalhar por amor a Deus, derramar o sangue em terra de hereges etc.) e conta sua história (como, quando e em que circunstâncias começou a desejar, ou porque ouviu falar de algum padre ou santo exemplar etc.), ainda aqui, aparece um relato do processo de discernimento dos espíritos ou de eleição a que se dedicou (mortificações, encomendas e considerações, oferecimentos, exercícios espirituais, jejuns, sacrifícios diversos etc., e os resultados desse discernimento: confirmouse ou não se confirmou a origem divina do desejo), os topoi mais freqüentes, portanto, são desejo, vocação, martírio, sentidos (visão e audição, sobretudo), termos e expressões que denotam "conhecimento de si”, consolação, encomendar ou considerar (oração e razão: estão quase sempre juntos), indignidade, alegria e/ou contentamento, tentação, indiferença, virtude, razão, imitação, "ad maiorem Dei gloriam" e variações deste mote jesuítico, obediência, experiência e desengano. Em uma quarta parte, a chamada petitio, o indipetente explicita seu pedido (é aí que aparecem as súplicas e humilhações, onde ele se declarando indigníssimo ou inabilíssimo, denota como conhece a si mesmo e não confia nas próprias forças, mas apenas em Deus que lhe deu o desejo); é freqüente o uso de lugares-comuns tais como desejo, consolação, vocação, obediência, "ad maiorem Dei gloriam" e variantes, martírio, encomendar ou considerar (normalmente seguidos da tópica do uso da razão, ou expressões de "conhecimento de si", como indignidade, falta de virtudes, desengano, lágrimas, sentidos ou alegria), filiação, indiferença e imitação. Finalmente, na conclusio, o jesuíta solicitante, algumas vezes, manifesta sua disposição indiferente ou obediente face à Vontade de Deus manifesta na vontade do padre geral, descreve sua situação pessoal no momento da escrita, dentro da Companhia de Jesus (idade, tempo em que se encontra na 
ordem, ofícios a que se dedica, estudos que fez ou está fazendo etc.) e se despede como de praxe (se encomendando aos santos sacrifícios e orações de Sua Paternidade), compondo uma valedictio; os topoi mais presentes nesta parte são: filiação, desejo, "ad maiorem Dei gloriam", virtude, obediência, indignidade e "conhecimento de si" (normalmente vinculado às descrições que fazem de sua situação no momento da escrita: formação intelectual, trabalhos a que se dedica, idade, saúde e outros termos) $)^{4}$.

Esta estrutura-modelar, notavelmente formal, com necessário e estudado intuito de eficácia, descreve um dinamismo ao qual devemos voltar nossa atenção. É interessante observar que esta estrutura retórica, mesmo obedecendo ao protocolo descrito acima ${ }^{5}$, deixa uma certa liberdade no uso do espaço dedicado à manifestação do desejo e à petição: trata-se de uma licença que encontra seu suporte no modelo retórico próprio da ars dictaminis, tal como regrada nos séculos XVI e XVII. Uma licença que permite sim a elaboração da experiência pessoal de desejo ${ }^{6}$, mas sem denotar o subjetivismo a que seríamos tentados a lhes imputar.

Já havíamos dito anteriormente que o conceito de "liberdade" tal como dado a entender pelos documentos analisados, bem como a categoria "experiência" nos mesmos termos, não nos eram suficientes se analisados de modo exclusivo por um ou outro daqueles pólos: o risco de um estruturalismo que destruísse a dinâmica encarnada e compreendesse tudo como esquemas estanques, de fato, nos perseguiu até aqui. É importante, por isso, que nos deparemos com a carnalidade como lugar de um dinamismo, onde a discussão filosófica e aquelas normas - seja institucional, seja espiritual (arriscamos dizer que se tratam de sinônimos) - tomam corpo e unidade.

\footnotetext{
${ }^{4}$ Cf. os Anexos 5 e 6, onde aparecem, distribuídos em quadros e tabelas, os topoi mais freqüentes, identificados na leitura das cartas, divididos seja na sua aparição nas diferentes cartas, como nas partes de cada carta.

${ }^{5}$ Cf. também o Capítulo 2.

${ }^{6}$ Cf. Massimi, Marina e Prudente, André Barreto (2002). Um incendido desejo das Índias... São Paulo: Editora Loyola.
} 
Essa carnalidade, como vimos, se manifesta nos escritos espirituais, onde é possível localizar uma a uma as influências sofridas, quase como que numa genealogia positiva: na medida em que "descreve" uma experiência, marcada por influências peculiares. Entretanto, nossa pesquisa também não pára nestes documentos, porque ainda que sintéticos, os textos de espiritualidade produzidos pela Companhia de Jesus evidenciam uma estruturação que, dado o caráter prescritivo (a virtude da descrição é a prescrição, lembremo-nos), permanecem ainda no âmbito do regrado. O que nos leva a duas hipóteses: ou a regra - seja ela institucional, espiritual ou filosófico-retórica - é um apêndice da vida e deve ser lida sob o ponto de vista estritamente formal, estrutural e árido, ou é a fonte de onde jorra a vitalidade mesma dos documentos todos com os quais trabalhamos, ou melhor dizendo, de onde jorra a vida dos homens por trás destes documentos; ou dito de outra forma: é o ponto onde o destino toma a forma de traços anotados em um vade mecum, se encarna numa companhia, num companheiro de viagem para o homo viator.

Verificaremos, neste capítulo, a segunda hipótese: há um vivido particular que pode ser identificado nas Indipetae, que nos permite mesmo descobrir a vitalidade dos demais documentos. É possível descrever um dinamismo seja no uso dos lugares-comuns elencados, seja na estrutura-modelar retórica das cartas e no fundo normativo de maneira geral. Em que medida esta é uma dinâmica de elaboração de experiência e, sobretudo, se podemos chamá-la de uma "experiência de liberdade", são questões que nos movem a partir deste ponto.

Retomemos, resumidamente, o conteúdo dos dois últimos capítulos para que possamos compor, a partir dos critérios oferecidos, uma suposta definição para essa assim chamada "experiência de liberdade".

Podemos dizer, a partir do que vimos, por um lado, que "liberdade" é uma adesão racional - não abstrata ou apenas filosófica - ao Bem e Fim últimos do homem; e é o 
outro termo para designar aquela obediência cheia de razão presente no processo de identificação com o carisma jesuítico; além de ser também uma adesão a Deus, ou mesmo identificação ou imitação, mas nunca sem obediência à sua Vontade.

É possível também descrever, por outro lado, a categoria “experiência” como uma forma de acesso à verdade que não se dá apenas no nível contemplativo-abstrato, mas também sensível; e é o que permite uma filiação definitiva, cheia de razões, uma filiação à Companhia de Jesus que define o indivíduo que obedece e segue como um cadáver - perinde ac cadaver - determinadas regras que são uma vida, ou melhor, a vida de uma "experiênciamodelo" peculiar e fundante - a de Inácio -; e, finalmente, como forma de acesso a Deus não solitária e voluntarista, mas a partir do pertencimento a uma ordem religiosa, particularmente, e à Igreja, de maneira geral.

Daqui, quem sabe, podemos tirar uma definição de "experiência de liberdade": tratar-se-ia de um conhecimento do Bem e do Fim últimos que leva a uma adesão racional, mas não abstrata ou puramente contemplativa, cujo resultado final é a felicidade; uma "obediência" cujo resultado é a identificação com o corpo institucional da Companhia de Jesus, tendo como conseqüência a experiência de ser "filho verdadeiro" da Ordem; o dinamismo de conhecimento de Deus que traz consigo um desejo de imitação, identificação ou adesão, de que se segue uma experiência de consolação.

Vejamos, agora, como aqueles topoi enumerados entrariam nesse esboço de definição, a fim de conferir status de veracidade, partindo do horizonte de produção dos documentos. Trabalharemos com três grandes conjuntos de topoi, todos evidentemente não passíveis de consideração e análise apenas do ponto de vista de um ou outro daqueles pólos, mas unidades dinâmicas filosófico-retórico-institucional-espirituais:

1. Um primeiro que agrupa todos aqueles termos que dizem respeito ao trabalho de 
"conhecimento de si” a que eram educados os jesuítas ("desejo", "vocação" e também "encomendar" e "considerar", como elementos que dizem respeito ao trabalho de discernimento dos espíritos que está intimamente ligado ao de “conhecimento de si”, assim como "dar razões” o está na medida em que implica o resultado desse trabalho; entram também os termos "experiência", "indignidade", “inspiração", "lágrimas”, “paixão”, “sentidos”, "tentação", “virtude”).

2. Num outro grupo colocamos juntos termos ou expressões que têm como horizonte a "obediência" ou dela necessitam como virtude original (por exemplo, "indiferença", “obrigação”, "mortificação”, “desengano”, “ad maiorem Dei gloriam”, “peregrinação”, assim como o termo "edificação", ou os sentimentos de "filiação" presentes nas cartas, ou o desejo de "imitação" e "martírio", sempre vinculados à vida de um outro que se torna modelo, exemplo: uma experiência-modelo de santidade e perfeição).

3. E o último ajunta todos aqueles termos que, de alguma forma, se referem ao topos “consolação" (“alegria" ou "contentamento" e "felicidade").

Por "conhecimento de si" entende-se tanto o trabalho como o resultado do trabalho pessoal de atenção aos fatores todos da realidade (internos ou externos), cuja motivação inicial é encontrar a origem do "desejo", ou seja, a fonte da "vocação". E esse trabalho se dá através dos vários instrumentos oferecidos pela Companhia de Jesus: por exemplo, os Exercícios Espirituais, as provas a que são submetidos antes da entrada, a leitura freqüente das Constituições e dos textos de espiritualidade, a confissão assídua, a oração etc. Trata-se, de qualquer maneira, de um momento imprescindível quanto ao que respeita ao processo de reconhecimento do factus a que se destina, ou seja, daquilo que será identificado como a satisfação (satis facere) última do indivíduo. Nesse sentido, toda a sua humanidade é envolvida: corpo e alma, razão e sensualidad, vontade e apetites, sem quebra de continuidade. 
“Obediência", por sua vez, como já pudemos ver, é a virtude que "nos inclina a obedecer a ordem do superior, que comanda em nome de Deus"7. A "vontade de Deus" coincide com aquele Bem "honesto, agradável e útil” a que Góis (1583) se referia no seu comentário à obra do Estagirita. De forma que podemos dizer que "vontade de Deus" e "amor de Deus" (este último objeto da inclinação do homem, segundo o texto de filosofia moral) são o mesmo, na medida em que o que Deus quer é o Bem do homem.

A “obediência” é a "mãe de todas as virtudes", conforme lembra Rodriguez (1834) em seu Ejercicio de perfeccion ${ }^{8}$ :

si sois obediente, sereis pobre, casto, humilde, callado, sufrido, mortificado, y alcanzareis todas las virtudes; y esto no es encarecimiento, sino verdad muy llana; porque las virtudes se adquieren y alcanzan con el ejercicio de sus actos, y de esa manera nos las quiere dar Dios. Pues este ejercicio nos da la obediencia: todas las reglas que tenemos, y todas las obediencias que nos mandam, son ejercicios de virtudes ${ }^{9}$.

Assim, pois, se compreenderá também a "indiferença" dentro desse âmbito da "obediência” assim entendida, como o afirma Fazio (1594):

Indifferenza al modo, che di lei si ragiona, non è propriamente altro, ch'una dispositione d'animo acquistata con lungo essercitio di Mortificatione, per laquale un'huomo havendosi determinatamente prefisso il fine della perfettione spirituale, alla quale aspira; nella determinatione poi de mezzi, che secondo lo stato suo, à tal fine s'appartengono, si rende ugualmente pronto ad abbracciare; ò lasciare qualsivoglia di essi, nel tempo, \& modo che da suoi Superiori le verrà semplicemente significativo, $\&$ imposto ${ }^{10}$.

\footnotetext{
${ }^{7}$ Sanchez, Pedro (1607). Le Royaume de Dieu, et le vray chemin pour y parvenir. Composé en Espagnol par le Pere P. Sanchez, Docteur de la Compagnie de Iesus. Traduit en François, par F. Guillaume Levite, de l'Ordre des Predicateurs. Paris: Chez Adrian Beys, p. 560, tradução nossa.

${ }^{8}$ Rodriguez, Alonso (1834). Ejercicio de perfeccion y virtudes cristianas, su autor el Padre Alonso Rodriguez de la Compañía de Jesus, natural de Valladolid. Dividido en tres partes. Parte tercera. De varios medios para alcanzar la virtud y perfeccion. Nueva Impression. Barcelona: Imprenta de D. Valero Siena y Marti, p. 214, tradução nossa.

${ }^{9}$ Ibid., pp. 214-215 ("Se és obediente, serás pobre, casto, humilde, calado, sofrido, mortificado, e alcançarás todas as virtudes; e isto não é encarecimento, mas verdade sincera; porque todas as virtudes se adquirem e alcançam com o exercício de seus atos, e dessa maneira não as quer dar Deus. Pois este exercício nos dá a obediência todas as regras que temos, e todas as obediência que nos mandam, são exercícios de virtudes").

${ }^{10}$ Fazio, Giulio (1596). Trattato utilissimo della mortificatione delle nostre passioni, \& affetti disordinati. Composto nuovamente per il molto R. P. Giulio Fatio, della Compagnia di Giesu. Brescia: Pietro Maria Marchetti, p. 140 ("Indiferença no modo como se raciocina a seu respeito não é outra coisa senão uma disposição de ânimo adquirida com longo exercício de Mortificação, pela qual um homem tendo prefixado determinadamente o fim da perfeição espiritual a que aspira, na determinação dos meios que, segundo o seu estado, a tal fim pertencem, se torna igualmente pronto para abraçar ou deixar qualquer um deles no tempo e modo que dos Superiores lhe virá significado e imposto").
} 
É na medida em que se exercita na virtude ${ }^{11}$ da obediência que o jesuíta será capaz de chegar àquela verdadeira mortificação cujo fruto principal é a "indiferença", categoria esta que coincide, do ponto de vista filosófico, com o conceito de "meio termo" aristotélico, retomado tanto por Tomás de Aquino, como pelos mais diversos pensadores da Escolástica e da Segunda Escolástica. É bem verdade que, neste ponto da discussão, nos deparamos com a interseção entre dois campos distintos de conhecimento (típico da moralização cristã dos conceitos clássicos): que a obediência seja uma virtude não o diz explicitamente a filosofia moral, que, pelo contrário, a enumera como "parte potencial" da virtude moral ou cardeal ${ }^{12}$ "justiça"13; no entanto, assim o dizem os textos de espiritualidade os mais diversos ${ }^{14}$ (sejam

${ }^{11}$ Góis (1593), discutindo o que sejam as virtudes, retoma Aristóteles para quem a "virtude é o hábito eletivo que consiste no meio termo, em relação a nós, regulado pela razão como o regularia pessoa prudente", e explica: "Esta definição, por ser própria do nosso intento presente, tem de ser explicada com clareza. É, pois, a virtude, antes de mais nada, um hábito, porque a virtude (mesmo considerada em sentido lato) é uma disposição do perfeito, como ensinou Aristóteles (....). Com o hábito dispõe-se perfeitamente para operar. Na verdade, antes de mais, necessitamos dos hábitos das virtudes para três cousas: Primeiro, para a uniformidade das acções. (...) Segundo, para que a acção se efectue prontamente. (...) Terceiro, para que a acção se complete com o prazer - o que o hábito consegue. (...) Diz-se também hábito electivo, isto é, que opera por eleição, para excluir a ciência e outros hábitos intelectuais, a cuja natureza não pertence que os hábitos nascidos deles, se façam com deleite e voluntàriamente. Acrescenta-se que consiste no meio termo para rejeitar os hábitos viciosos que se afastam do meio termo. Finalmente ajunta-se em relação a nós, regulado pela razão, para compreendermos que o meio termo, em que consiste a virtude, não é preciso ser da natureza da cousa, salvo talvez acidentalmente, mas sim relacionado com o sujeito, e por decisão e parecer de pessoa prudente". Góis, Manuel de (1593). Disputas do Curso Conimbricense sobre os livros de Moral a Nicómaco de Aristóteles em que se contêm alguns dos principais capítulos da moral. Lisboa: Oficina de Simão Lopes, pp. 209-211

${ }_{12}$ Góis (1593), divide as virtudes em intelectuais e morais. As primeiras, por suas vez, são dividas em contemplativas (intelecto, ciência e sabedoria) ou práticas (sindérese, prudência e arte). As últimas são, segundo o autor: justiça, temperança, fortaleza e prudência (sendo que esta última das virtudes morais, não está radicada no apetite, mas no intelecto). Góis (1593) também diz que as virtudes morais são também denominadas virtudes cardeais, conforme as descreveram Santo Ambrósio e São Jerônimo. Cf. Ibid., pp. 245-251.

${ }^{13}$ Quando trata da justiça, Góis (1593) a define nos termos usados por Aristóteles, dizendo que a justiça "é um bem de outro", ou seja, trata-se da virtude "que atribui a cada um o que lhe é devido" (p. 271). Em seguida, apresentando as partes da justiça [que podem ser integrantes, ou seja, são aquelas partes da virtude sem as quais torna-se difícil defini-la corretamente; sujeitas, que são as partes que dependem da virtude mesma para se definirem corretamente; ou potenciais, que são, na verdade, "virtudes adjuntas e denominam-se potenciais pelo facto de não contarem em si todo o poder da virtude principal" (p. 265)], o autor enumera como partes potenciais da justiça "religião, piedade, observância, obediência, verdade, gratidão, liberalidade, afabilidade, amizade" (p. 277). E, mais à frente, define obediência como "o acto com que a vontade se torna pronta e fácil para cumprir os preceitos do superior" (p. 279).

${ }^{14}$ Não só os textos já citados, como também o próprio Inácio, recorrendo a textos de Padres da Igreja, o afirma igualmente, por exemplo, em carta enviada aos companheiros de Gandía, no dia 29 de julho de 1547, diz: "Para além dos exemplos, a razão nos fornece os motivos [para entender o valor da obediência]. Porque se nós devemos considerar como melhor a maneira de viver onde se serve a Deus mais segundo seu bom prazer, teremos por tal aquela na qual existe para todos a obrigação da obediência, incomparavelmente mais agradável que todos os sacrifícios (a obediência é, com efeito, melhor que as vítimas, e ser dócil vale mais que oferecer a gordura de carneiros). Justamente, já que se oferece mais oferecendo seu julgamento próprio, sua vontade e sua liberdade, aquilo que há de maior no homem, que se se oferece qualquer coisa de outro. Além do mais, este gênero de vida ajuda também a adquirir toda virtude, como diz são Gregório: A obediência é menos uma virtude que a mãe de todas as virtudes". Loyola, Ignace de (1991). Écrits (M. Giuliani, dir., pres. et dir). Paris: Desclée de Brouwer/Bellarmin (Collection Christus, n. ${ }^{\circ}$ 76, Textes), p. 717, tradução nossa. 
aqueles da tradição jesuítica nascente, sejam as referências assumidas por Inácio, nos inícios da Companhia de Jesus, especialmente os textos da Patrística medieval).

Podemos, portanto, dizer que, tendo o jesuíta empregado todas as suas faculdades naquele "conhecimento de si", usa então a razão para se aplicar à "obediência de entendimento" $" 15$ e se dispõe à "indiferença" que as normas propõem, ou ao "meio termo". A "obediência" também requer do jesuíta a mortificação de seus apetites desordenados (os quais foram, antes reconhecidos e devidamente diferenciados da Vontade de Deus). Esta mortificação, que tem por objetivo "reduzir esta carne e sentido à servidão e obediência da razão e do espírito" ${ }^{\text {, }}$, se dá de diferentes formas e a partir daqueles instrumentos ordenadores, por exemplo, as provas prefiguradas no texto das Constituições (onde identificamos a "peregrinação" como uma dessas experiências).

Quanto à "consolação" podemos dizer, resumidamente, que se trata do ápice desse dinamismo, o ponto focal que se atinge após toda a trajetória de discernimento e adesão. Segundo O’Malley (1999), a “consolação” era, para o jesuíta, o resultado de uma vida receptiva em relação à Vontade de Deus.

Esse termo, descreve mais um "movimento interior da alma inflamada pelo amor de seu Criador"17, que uma sensação ou sentimento psicológico ${ }^{18}$. A “consolação" pode vir da confirmação final significada pelo Superior, ou então pela morte ou martírio desejados (que,

\footnotetext{
${ }^{15}$ Lembremo-nos que Inácio divide a obediência em três graus (ou degraus), quando escreve a famosa "Carta da Obediência", dirigida aos companheiros de Portugal, em 26 de março de 1553: o primeiro e mais imperfeito é o grau de obediência de execução; em seguida, vem a obediência de vontade; e o último e mais perfeito é o grau de obediência de entendimento. Nessa carta, ele diz: "se a obediência de entendimento não existe, é impossível que a obediência de vontade e de execução se realizem normalmente” (Ibid., p. 839, tradução nossa). Mais à frente, na mesma carta, Inácio, pela pena de Polanco, explica os meios de como se aplicar ao exercícios da virtude da obediência: "O primeiro é (...) não considerar o superior como um homem sujeito aos erros e às misérias humanas. Olhai mais para aquele a quem vós obedeceis no homem, o Cristo, a sabedoria soberana, a bondade imensa, a caridade infinita, que, vós bem o sabeis, não pode se enganar nem vos quer enganar. (...) Desta maneira, (...) vós não encontrareis nenhuma dificuldade em conformar vossas vontades e vossos julgamentos à regra que escolhestes para vossas ações" (p. 840, tradução nossa); "o segundo meio é estar prontos a buscar sempre as razões para justificar aquilo que o superior ordena (...), sem criticar" (p. 840, tradução nossa); "o terceiro meio de submeter o julgamento é também o mais fácil, o mais seguro e o mais usado entre os Santos Padres" (pp. 840-841, tradução nossa).

${ }^{16}$ Fazio, 1596, op. cit., p. 15, tradução nossa.

${ }^{17}$ Loyola, 1991, op. cit., p. 222 (EE. 316, tradução nossa).

${ }^{18}$ Cf. Massimi e Prudente, 2002, op. cit., pp. 37-41.
} 
nesse caso, são graça de Deus já que orientados para o Fim da vida: dar maior glória a Deus) e, portanto, trata-se do corolário de uma vida realizada segundo o destino do homem, segundo a liberdade que faz dos homens divinae naturae consortes, analogia de Deus, atualizada e experimentada. Esse topos conforma-se ao conceito de Felicidade ${ }^{19}$ tal como é discutido pela filosofia moral aristotélico-tomista, e àquela adesão filial à Companhia de Jesus, tal como é descrita pelo texto jurídico da ordem ${ }^{20}$.

Vejamos, a partir daqui, mais detalhadamente como esses grupos de topoi revelam-se nas cartas Indipetae e o significado que cada termo assume dentro do dinamismo particular, seja do ponto de vista macro-histórico, seja do ponto de vista micro-histórico.

${ }^{19}$ Cf. Góis, 1593, op. cit., pp. 105-136. Aqui, Góis (1593) explica o que é a Felicidade.

${ }^{20}$ Cf. por exemplo, Loyola, 1991, op. cit., pp. 559-565 (Const. \$§ 655-676). Nesta parte do texto das Constituições (a oitava parte, denominada "O que ajuda a unir com sua cabeça e entre si aqueles que estão dispersos"), se explica o papel da "obediência" para a unidade da Companhia de Jesus. 


\section{CAPÍTULO 80 "conhecimento de si" nas Indipetae}

El que ignora qué es el hombre no puede usar del hombre; y así, quien no se conoce a sí mismo no podrá usar de sí mismo, y, por consiguiente, de las demás cosas que le tocan.

Juan Eusebio Nieremberg (1645) De la diferencia entre lo temporal y eterno... ${ }^{1}$

Que os jesuítas eram formados a um trabalho de investigação acerca de si mesmos, ficou patente pelo que vimos apresentando até aqui. Mas que, dentro desse esforço possamos encontrar uma preocupação com a ordenação das paixões (apetites sensitivos), ou com a identificação da vontade de Deus como origem de um desejo (e, portanto, vocação ou inspiração divina, diferente de toda tentação ou engano), ou com a aplicação das potências humanas (os sentidos, a razão e a vontade), não é tão evidente quanto parece.

Massimi e Prudente (2002), afirmam que o termo "desejo", dada sua constante repetição nas cartas, muitas vezes faz parecer que seja ele "o verdadeiro protagonista do

\footnotetext{
${ }^{1}$ Nieremberg, Juan Eusebio (1957). Obras escogidas del R. P. Juan Eusebio Nieremberg. (E. ZepedaHenriquez, Ed.). Em E. Zepeda-Henriquez (ed.). Biblioteca de Autores Españoles, desde la formación del lenguaje hasta nuestros dias (Tomo 104). Madrid: Ediciones Atlas (originais do século XVII), p. 249.
} 
escrito, o objeto que move a pedir insistentemente" ${ }^{2}$. De fato, essa recorrência não aparece só nas Indipetae: trata-se de um termo comum à forma mentis do jesuíta ${ }^{3}$ que encontra, por exemplo, nos Exercícios Espirituais o estabelecimento de um protocolo de ordenação do desejo; ou no Relato de Santo Inácio a experiência-modelo de um desejo que saiu da desordem (desejos mundanos ${ }^{4}$ ) para chegar à ordem (desejo de imitar os santos ${ }^{5}$, desejo de ser útil $\left.^{6}\right)$ por meio da graça de Deus e do trabalho ascético; ou no Diário de Moções Interiores, onde o termo aparece de novo como experiência de aplicação dos instrumentos ordenadores com o intuito de se fazer uma eleição mais adequada à glória de Deus e ao fim da Companhia; ou mesmo nas Constituições, nas quais encontramos o "desejo" descrito, por exemplo, como um dos pontos a serem examinados no momento da entrada

\footnotetext{
${ }^{2}$ Massimi e Prudente, 2002, op. cit., p. 25.

${ }^{3}$ Mas não apenas do jesuíta: Certeau (1982) lembra como esta é uma constante no discurso espiritual dos séculos XVI e XVII. Cf. Certeau, Michel de (1982). La fable mystique, 1: XVIe - XVIIe siècle. Paris: Gallimard e também Massimi e Prudente, 2002, op. cit.. Pécora (1994) também lembra que "desejo" é um termo típicamente "humanista" e neo platônico, que, na tradição da segunda escolástica, assume um duplo valor: por um lado positivo (designado, na maior parte das vezes, pelo termo "vontade") e, por outro lado negativo (quando associado aos termos "apetite" ou "paixão"). Desejo, nesse contexto, é "ponte ascensional para Deus, com a generalidade propriamente humana que define: o desejo é natural do homem. Enquanto um dado da natureza, de sua lei e ordem, não pode constituir em si, de uma perspectiva cristã ortodoxa, um 'erro'. O desejo tão-somente anuncia uma ausência graduada do que é da ordem do Ser, uma falta real, portanto, mas nunca absoluta, após a queda. Para supri-la adequadamente, é necessário preenchê-la com uma qualidade da substância análoga ao Ser único de Deus (...): uma qualidade substancial que se desenvolve e aprimora na medida em que a criatura humana molda a existência por uma legítima vontade de assemelhar-se ao que é da ordem divina" (p. 117). Pécora, Alcir (1994). Teatro do Sacramento: a unidade teológico-retórico-política dos sermões de Antonio Vieira. São Paulo: EDUSP.

${ }^{4}$ No início do Relato, P.e Luis Gonçalves da Câmara conta como "Até os 26 anos de vida, ele foi um homem dado às vaidades do mundo; ele se deleitava sobretudo no exercício das armas, com um grande e vão desejo de ganhar honra" (Loyola, 1991, op. cit., p. 1019, tradução nossa). Mais à frente: "em seguida, outras coisas aconteciam, às quais sucediam os pensamentos do mundo (...), e ele parava também nesses pensamentos por largos momentos e esta sucessão de pensamentos tão diversos durava para ele muito tempo, e ele permanecia sempre no pensamento que se lhe apresentava, quer se tratasse de explorações do mundo que ele desejava fazer ou de outras explorações para Deus que se ofereciam à sua imaginação" (Ibid., pp. 1021-1022, tradução nossa)

${ }^{5} \mathrm{O}$ Relato conta que "os desejos de imitar os santos se apresentavam a ele, e ele considerava menos as circunstâncias que o fato de se prometer, assim, com a graça de Deus, fazer como eles tinham feito" (Ibid., p. 1022, tradução nossa).

${ }^{6}$ Assim aparece no Relato: "ora, no tempo de sua prisão em Salamanca, os mesmos desejos não lhe faltavam de ser útil às almas e, para isso, estudar primeiro, reunir alguns homens que tivessem o mesmo desígnio e guardar aqueles que ele tinha" (Ibid., p. 1055, tradução nossa). Ou então, o que acon teceu mais tarde, quando já estando em Paris, soube de um amigo que havia ficado doente em Rouen e se decidiu ir em sua ajuda: "e o desejo lhe veio de ir visitá-lo e ajudá-lo. Ele pensava também que, nessa conjuntura, poderia lhe vencer com a idéia de deixar o mundo e se consagrar inteiramente a serviço de Deus. Para poder obter esse resultado, veio-lhe o desejo de fazer as 28 milhas que separam Paris de Rouen a pé descalço, e sem comer ou beber" (Ibid., p. 1059, tradução nossa).
} 
na Ordem $^{7}$, ou como aquilo que faz do jesuíta um jesuíta de fato ${ }^{8}$.

Seja como for, nessa perspectiva particular em que aparece o termo "desejo", interessa muito que se saiba se é ordenado ou se é desordenado, se é uma inspiração vinda de Deus, ou se é fruto de uma tentação do Inimigo da natureza humana... Um desejo desordenado é um desejo que não é teleologicamente orientado, entendendo-se esse fim a que se orienta como "o Fim", ou seja, "a honra e glória de Deus nosso Senhor" e a "salvação espiritual das almas":

Para que o Criador e Senhor aja mais seguramente em sua criatura, se acontecer que esta alma esteja presa e inclinada a uma coisa de maneira desordenada, lhe convém reagir com todas as suas forças (...). Assim, por exemplo, se ela está presa à busca e posse de um cargo ou um benefício não pela honra e glória de Deus nosso Senhor nem pela salvação espiritual das almas, mas por uma sua vantagem pessoal e por seus interesses temporais, ela deve se ligar ao oposto, insistindo bastante nas suas orações e outros exercícios espirituais, e pedindo o contrário a Deus nosso Senhor; quer dizer, que ela não quer este cargo, este benefício nem nenhuma outra coisa, a menos que sua divina majestade, ordenando seus desejos, não mude nela seu primeiro vínculo; de tal maneira que o motivo para desejar ou possuir tal ou tal coisa seja unicamente o serviço, a honra e a glória de sua divina majestade 9

O desejo ordenado é, portanto, aquele que se conforma à Vontade de Deus até o ponto da identificação entre o exercitante e o Cristo, de quem ele mais se aproxima e se une na medida em que afasta o espírito das muitas coisas do mundo e se aplica totalmente a apenas uma coisa: “o serviço de seu Criador e o proveito de sua alma", usando "mais livremente suas faculdades naturais para buscar com cuidado aquilo que tanto deseja"10. E, o que o homem "tanto deseja", é

\footnotetext{
${ }^{7}$ Assim diz a letra da regra: "É preciso igualmente fazer observar àqueles que se examina, e a isso dar muita importância e preço alto diante de nosso Criador e Senhor, o quanto é uma ajuda e um proveito para a vida espiritual ter em horror, totalmente e não em parte, tudo o que o mundo ama e abraça, e aceitar e desejar com todas as suas forças tudo o que Cristo nosso Senhor amou e abraçou" (Ibid., p. 416, Const. § 101, tradução nossa).

${ }^{8}$ Massimi e Prudente (2002) assinalam como no texto das Constituições, o termo desejo aparece ligado a objetos que definem finalmente o que seja o jesuíta. Os desejos têm como objeto "a maior glória de Deus" (Const. §§ 156, 269, 602), "o serviço divino" (Const. § 33), "o bem maior e universal da Companhia"(Const. § 259), "a conversão espiritual", "a santificação e a perfeição interior", "o aumento das virtudes" (Const. § 484), "a observância das Constituições da Companhia" (Const. § 602) etc. "Ajuda-se o próximo por desejos apresentados a Deus nosso Senhor e por orações a toda a Igreja, especialmente por aqueles que, 'nela, nem mais importância para o bem comum', assim como pelos amigos e benfeitores vivos e mortos, quer eles tenham pedido ou não estas orações; farse-á essas orações também por aqueles a quem eles venham particularmente em ajuda e aos outros membros da Companhia nos diversos países, entre os fiéis e os infiéis, a fim de que Deus disponha a todos a receber sua graça, através dos frágeis instrumentos desta tão pequena Companhia" (Ibid., p. 555, Const. § 638, tradução nossa).

${ }^{9}$ Ibid., p. 56 (EE. 16, tradução nossa).

${ }^{10}$ Ibid., p. 62 (EE. 20, tradução nossa).
} 
"louvar, reverenciar e servir a Deus nosso Senhor e por meio disso salvar sua alma" ", como o afirma o Princípio e Fundamento, ao descrever a verdadeira vocação do homem.

E quanto a este termo, encontramos um sem-número de referências a ele nos mais diversos textos da Companhia de Jesus. A primeira vez em que aparece é em um dos Documentos de Fundação, quando, relatando a maneira como se instituiu a Ordem, se diz:

estávamos divididos em pareceres e opiniões que divergiam com relação ao nosso estatuto, e tínhamos um só e mesmo pensamento e vontade, que era buscar "o bom prazer e a perfeita vontade de Deus", segundo a visada de nossa vocação ${ }^{12}$.

E qual é essa “nossa vocação”? Em carta enviada aos Padres e Irmãos de Coimbra, aos

07 de maio de 1547, Inácio escreve:

Considerai o que é vossa vocação, vereis que aquilo que entre os outros não seria pouca coisa, sê-lo-ia no entanto para vós. Não somente Deus vos chamou das trevas à sua admirável luz e vos transportou ao reino de seu Filho bemamado, mas também o fez para todos os fiéis, para que vós conserveis intacta a pureza de vossa intenção e para que tenhais um amor muito forte nas coisas espirituais que são de seu serviço, ele quis vos arrancar do mar perigoso do mundo, por medo que vossa consciência estivesse em perigo em meio às tempestades que levantam seja o vento do desejo das riquezas, honras ou prazeres, seja, pelo contrário, o vento que faz temer os perder. Ainda mais, para que vosso espírito ou vosso amor não fossem pegos por esses baixos interesses (...), ele quis que vós pudésseis vos voltar e vos doar inteiramente ao fim para o qual Deus vos criou, sua honra e sua glória, vossa salvação e o socorro de vosso próximo ${ }^{13}$.

A "honra e a glória" de Deus e a "salvação das almas", em "não importa qual parte do mundo onde se espera um maior serviço de Deus e uma maior ajuda para as almas"14: eis a vocação do jesuíta, nos termos em que a define também o texto das Constituições. Nessa vocação, é pedido de um jesuíta perseverança e obediência. Porém, aquilo que interessa sobremaneira é confirmar a origem divina do chamado, como se lê no EE. 172:

É necessário (...) ver se a eleição não foi feita como se deve e de maneira ordenada, sem vínculos desordenados (...). Uma tal eleição não parece ser uma vocação divina, porque é uma eleição desordenada e tortuosa; muitas pessoas se enganam nisso, fazendo de uma eleição tortuosa e má, uma vocação divina (...). Toda vocação divina é sempre pura e nítida, sem que

\footnotetext{
${ }^{11}$ Ibid., p. 62 (EE. 23, tradução nossa).

${ }^{12}$ Loyola, 1991, op. cit., p. 277 (tradução nossa).

${ }^{13}$ Ibid., p. 695 (tradução nossa).

${ }^{14}$ Ibid., p. 468 (Const. $\$ 304$, tradução nossa).
} 
nada da carne ou de qualquer outro vínculo desordenado se misture ${ }^{15}$.

O que permite uma certeza acerca da origem da vocação é primeiramente um conhecimento seguro de si mesmo, que dá ao jesuíta a possibilidade de, atento aos movimentos da alma, distinguir o que vem de Deus daquilo que vem do Inimigo:

O próprio de Deus e de seus anjos é dar, nas suas moções, uma verdadeira letícia e alegria espiritual, afastando toda tristeza e perturbação que o inimigo suscita. O próprio deste último é lutar contra esta letícia e essa consolação espiritual, apresentando razões aparentes, sutilezas e contínuos sofismas ${ }^{16}$.

Nesse sentido, é necessária também uma atenção ao desenrolar dos pensamentos contíguos aos desejos experimentados: se, no seu prolongamento, desde o princípio se localizam bons fins e uma orientação ao Bem, "é sinal do bom anjo"17; do contrário, "é um sinal claro que isso vem do mau espírito" ${ }^{\prime 18}$. Essas exames atentos e outros tantos que se seguem no texto dos Exercícios Espirituais, têm por objetivo facilitar o caminho para a eleição. E, nesse ponto, entram, por exemplos, as tópicas “encomendar", "considerar", "dar as razões” e "desengano”.

Nas "Seis maneiras de se fazer uma sã e boa eleição", Inácio lembra que é necessário “pedir a Deus nosso Senhor que ele queira mover minha vontade e colocar na minha alma aquilo que devo fazer (...), refletindo bem e fielmente com minha inteligência"19 e, além disso, sugere que se deve "considerar, refletindo, quantas vantagens e proveitos decorrem para mim do fato de ter (...) em vista somente o louvor de Deus nosso Senhor e salvação de minha alma" ${ }^{20}$. Ao final desse trabalho, "olharei para qual lado a razão inclina mais" ${ }^{21}$ : "É, portanto, após uma maior moção da razão, e não após alguma moção dos sentidos, que é necessário tomar a decisão concernente à coisa visada",22. Ou seja, para se conhecer bem a origem de um desejo é preciso, primeiro, pedir a Deus a graça da compreensão, quer dizer, "encomendar a

\footnotetext{
${ }^{15}$ Ibid., p. 140 (EE. 172, tradução nossa).

${ }^{16}$ Ibid., p. 232 (EE. 329, tradução nossa).

${ }^{17}$ Ibid., p. 234 (EE. 333, tradução nossa).

${ }^{18}$ Ibid., p. 234 (EE. 333, tradução nossa).

${ }^{19}$ Ibid., p. 144 (EE. 180, tradução nossa).

${ }^{20}$ Ibid., p. 144 (EE. 181, tradução nossa).

${ }^{21}$ Ibid., p. 144 (EE. 182, tradução nossa).

${ }^{22}$ Ibid., p. 144 (EE. 182, tradução nossa).
} 
coisa a Deus" e, em seguida, ter claras para si as razões que o movem ${ }^{23}$.

O homem deve "se encomendar a Deus", "confiar-se a Deus" que não o engana, e

desconfiar de si mesmo, porque as paixões e os sentidos sempre podem enganar:

Dopo l'avvere esortato nel primo Trattato al profitto spirituale, sarà molto a propósito che trattiamo in questo secondo della vera diffidenza di se medesimo, perche dopo d'essere stato persuaso un'huomo Christiano ad affaticarsi nel profitto dell'anima sua, e dopo ch'egli è innamorato della bellezza, e perfezzione delle vere, e solide virtù, comincia à porre le mani nel lavoro di esse con vero disio d'impremerle nel suo cuore ${ }^{24}$.

Porém, nesse "trabalho" o homem sofre "forti, e gravi tentazionni", de tal forma que importa que "veja" e "experimente" que "da se non le può vincere, accioche cosi intenda per isperienza la necessità che hà del favore divino, e diffidi di tutte le sue forze",25. Só o "favor divino" conferirá eficácia e bons efeitos aos meios empregados em qualquer empresa à qual se dedique o homem ${ }^{26}$. E é, nesse sentido, muito importante que o homem tenha sempre presente - considere - o fim para o qual tanto ele, quanto toda a realidade, foi criada: "considerare il fine perche Dio fa tutte le buone opere, che è per onore e gloria sua"27:

Laonde havendo dichiarato, che tutte le cose le fà per gloria sua, dichiara ancora che la fece per utile dell'huomo dicendo: Se inalzando gl'occhi al Cielo vedrai il Sole, la Luna, e tutte le Stelle, non le adorare come fanno i Gentili ingannati dalla bellezza di queste creature, guarda che Dio le fece per utile dell'huomo, \&

\footnotetext{
${ }^{23}$ Nas Regras Gerais tiradas das Constituições, há um ponto que deixa bastante clara essa dinâmica: segundo o autor, antes de tratar qualquer coisa com o Superior, os jesuítas deves se recolher em oração e, "em seguida, se sentem que devem apresentar o negócio àquele que tem o cargo, que o façam. A outra coisa que devem observar: depois de ter apresentado o negócio de viva voz ou brevemente por escrito (para que não se esqueça), que abandonem todo o cuidado aos superiores e estimem que tudo o que ordenarem será o melhor. Que não repliquem nem façam instâncias, nem por eles mesmo nem por nenhuma outra pessoa, quer os superiores aceitem o que foi pedido ou não. Que todos se persuadam que aquilo que seu superior, estando informado, ordenar será aquilo que convém mais ao serviço divino e a seu maior bem em nosso Senhor" (Ibid., p. 614, tradução nossa).

${ }^{24}$ Arias, Francisco (1600). Profitto spirituale, nel qual s'insegna à fare acquisto delle virtù, \& progresso nello spirito. Del M.R.P. Francesco Arias della Compagnia di Giesu. Tradotto della lingua Spagnuola, dal Cavaliere Fra Giulio Zanchini da Castiglionchio. Milano: Stampa del q. Pacifico Pontio, Impressore Archiepiscopale (original espanhol de 1588), p. 44 ("Depois de ter exortado no primeiro Tratado ao proveito espiritual, será muito à propósito que tratemos neste segundo acerca da verdadeira desconfiança em si mesmo, porque depois de ter sido persuadido um homem cristão de dedicar-se ao proveito de sua alma, e depois que ele se enamorou da beleza e perfeição da verdadeira e sólida virtude, começa a colocar as mãos nesse trabalho com verdadeiro desejo de imprimi-lo no seu coração", tradução nossa).

${ }^{25}$ Ibid., p. 45 ("por si só não as pode vencer, de tal forma que assim compreenda por experiência a necessidade que tem do favor divino, e desconfie de todas as suas forças", tradução nossa).

${ }^{26}$ De fato, mais à frente, Arias (1600) afirma: "importa assai che l'huomo ponendo i mezzi necessari non confidi disordinadamente in essi, ma che ponga la sua confidenza perfettamente in Dio, sperando nella sua bontà, che si come gli diede la volontà e forza per porre quei mezzi, che cosi anche darà efficacia all'istessi mezzi, acciò siano di frutto, e habbiano buono effetto operando l'istesso Signore per mezzo loro" (Ibid., pp. 61-62).

${ }^{27}$ Ibid., p. 78 ("Considerai o fim porque Deus faz todas as boas obras, que é para honra e glória sua", tradução nossa).
} 
il medesimo accade di tutte l'altre opere sue, maggiormente delle buone opere che fanno i giusti, ch'essendo le più eccellenti opere di Dio, vuole, e domanda con grande affetto che coteste siano a gloria sua, e utile dell'huomo ${ }^{28}$.

Nesta mesma via, escreve, anos mais tarde, Nieremberg (1645):

El sediento, para satisfacer la sed, no ha de ir sino a una fuente de aguas; y el hombre, para alcanzar sosiego de su corazon, no ha de ir sino a buscar a Dios: el divertirse en otras criaturas, queriendo con ellas apacentar su gusto, no es mas que comer sal con que avive su sed y apetito y se abrase las entrañas ${ }^{29}$.

O trabalho do desengano ${ }^{30}-$ de ir à verdadeira fonte que mata a sede e dá sossego ao coração - é um trabalho que requer "a assistência da 'razão', potência suficiente para corrigir os enganos"31 dos sentidos. É um trabalho de reconhecimento do essencial, do Ser real de todas as coisas, escondido por trás do variável e instável de sua forma presente. Este trabalho, requer um "olhar" que se estende da origem ao destino de toda a realidade: onde origem e destino coincidem, na medida em que, num dinamismo histórico-teleologicamente-orientado - escatológico, para ser breve -, ambos os pólos remetem ao Doador do Ser, que cria a realidade ininterruptamente - tam Pater nemo - e a leva à sua perfeição final.

\footnotetext{
${ }^{28}$ Ibid., p. 79 ("Lá onde se declarou que todas as coisas foram feitas para sua glória, declara ainda que as fez para serem úteis ao homem, dizendo: Se, levantando os olhos, vede o Céu, o Sol, a Lua e todas as Estrelas, não as adorai como fazem os Gentis enganados pela beleza destas criaturas, olhai que Deus as fez para serem úteis ao homem, e o mesmo acontece com todas as outras obras suas, sobretudo com as boas obras que fazem os justos, que, sendo as mais excelentes obras de Deus, quer e pede com grande afeto que sejam para a sua glória e úteis ao homem", tradução nossa).

${ }^{29}$ Nieremberg, 1957, op. cit., p. 243 (“O sedento, para satisfazer a sede, deve ir a uma fonte de águas; e o homem, para alcançar o sossego de seu coração, deve buscar a Deus: o divertir-se com outras criaturas, querendo com elas apascentar seu gosto, não é mais que comer sal que aviva sua sede e apetite e se abrasem as entranhas", tradução nossa).

${ }^{30}$ Delumeau (2003), cita um longo trecho do livro do jesuíta alemão Jeremie Drexel (1581-1638) - Tableau des joyes $d$ u paradis - onde a questão do desengano aparece em termos bastante significativos: trata-se de um uso bastante comum da retórica, a desvalorização do terrestre para magnificar o celeste: "Quanto dará alegria e contentamento a visão da beleza soberana de tantos milhares e milhões de maravilhosos objetos que estão no céu! Ali é onde a beleza está como em seu dia e como em pleno triunfo, onde todos os bem-aventurados são sóis e milagres de beleza perfeita, onde finalmente o coro dos anjos e dos homens predestinados é tão maravilhosamente belo no templo de glória que todas as maiores belezas da terra não podem parecer, em comparação, mais que monstruosas feiúras [...]. Ide, portanto, belezas da terra, retirai-vos bem longe de mim! Pois sois apenas máscaras cobertas, corpos fétidos, carcaças podres que, sob o fino véu de pele um pouco branca e vermelha, escondeis mil misérias e mil imundícies! Ide, todo o vosso artifício e vossos disfarces paliativos me causam horror quando contemplo essa eterna e ingênua beleza dos bem-aventurados. Não, não posso suportar a visão desses corpos moribundos e hediondos, que, a pretexto de alguma beleza, são adorados na terra, quando vejo essas belas almas ou esses nobres espíritos que são bem-aventurados no paraíso". Citado por Delumeau, Jean (2003). O que sobrou do paraíso? (M. L. Machado, Trad.). São Paulo: Companhia das Letras (original francês de 2000), p. 387.

${ }^{31}$ Pécora, Alcir (1988). O demônio mudo. Em Novaes, Adauto (org.) (1988). O olhar (pp. 301-316). São Paulo: Companhia das Letras, p. 302.
} 
Havíamos dito, em outra parte, que é somente "no momento das escolhas definitivas que se observa o sucesso ou o erro",32: uma escolha definitiva - ou uma eleição feita de forma ordenada - coincide com a conformidade com "uma vocação divina",33, e a vontade divina nunca engana. Chega-se à esta escolha definitiva, chega-se a fazer uma eleição ordenada, livre dos enganos da paixão, na medida em que se aplicam adequadamente as potências da alma racional $^{34}$ : a verdadeira eleição é aquela que tem como fim último a manutenção da relação causal Criadorcriatura. O desengano é, em termos gerais, a aceitação da Graça, o reconhecimento dos "sinais do olhar de Deus, capaz de encontrar na matéria a marca do zelo da Providência"35. O desengano, enfim, pode ser descrito como aquela dinâmica de reconhecimento, no desejo, do côncavo infinito que apenas um convexo adequadamente infinito seria capaz de preencher: querer preencher a ausência com outros objetos, pelo contrário, é ficar no engano.

Nieremberg em seu De la diferencia entre lo temporal y eterno, a fim de desenganar o leitor apresentando-lhe a memória da eternidade, deixa claro: "sobre todo, la mayor calamidad de la vida humana no es la peste ni el hambre, sino las passiones no puestas en razón"36. Assim, o homem deve distinguir bem o que é temporal do que é eterno: enquanto os bens temporais são meios, o eternos são fins:

\footnotetext{
32 Pécora, Alcir (1998). Les sermons funèbres du padre Vieira. Em Mattoso, Katia de Queiroz (org.) (1998). Naissance du Brésil moderne (pp. 194-202). Paris: Presses de l'Université de Paris-Sorbonne, p. 195.

${ }^{33}$ Cf. Loyola, 1991, op. cit., p. 140 (EE. 172, tradução nossa).

${ }^{34}$ De fato, o Padre Antônio Vieira (apesar da distância temporal com nosso objeto, Vieira é um legítimo representante da formas mentis jesuítica), chega a afirmar, em dois momentos distintos - no Sermão do Demônio Mudo e no Sermão da quinta Quinta-feira da Quaresma - que as paixões desordenadas, marcadas por uma certa "preguiça da vontade" e "desatenção do olhar", são alvo certo do demônio, do Inimigo da natureza humana, que se aproveita da fraqueza da liberdade de arbítrio do homem: "Dentro da nossa fantasia, ou potência imaginativa, que reside no cérebro, estão guardadas, com em tesouro secreto, as imagens de todos as coisas que nos entraram pelos sentidos, a que os filósofos chamam espécies. E assim como nós das letras do $\mathrm{ABC}$, que são somente vinte e duas, trocando-as e ajuntando-as variamente, escrevemos e damos a entender o que queremos, assim o demónio, daquelas espécies, que são infinitas, ordenando-as e compondo-as como mais lhe serve, pinta e representa interiormente à nossa imaginação o que mais pode inclinar, afeiçoar e atrair o apetite. E deste modo mudamente nos tenta, mudamente nos persuade, e mudamente nos engana" (Vieira, apud., Pécora, 1988, op. cit., pp. 305 306). E, em outro momento, afirma: "a paixão é a que erra, a paixão a que engana, a paixão a que lhes perturba e troca as espécies, para que vejam umas coisas por outras” (Vieira, apud. Ibid., p. 306).

${ }^{35}$ Ibid., p. 313.

${ }^{36}$ Nieremberg, Juan Eusebio (1957). Obras escogidas del R. P. Juan Eusebio Nieremberg. (E. Zepeda-Henriquez, Ed.). Em E. Zepeda-Henriquez (ed.). Biblioteca de Autores Españoles, desde la formación del lenguaje hasta nuestros dias (Tomo 104). Madrid: Ediciones Atlas (originais do século XVII), p. 145 ("Sobretudo, a maior calamidade da vida humana não é a peste ou a fome, mas as paixões humanas não colocadas sob o uso da razão", tradução nossa).
} 
Es, pues, una grande diferencia entre lo temporal y lo eterno ser lo uno fin y lo outro medio; porque el eterno es el fin del hombre, y de lo temporal es el mismo hombre fin. Lo eterno es para que en ello tenga el hombre su ultima perfección y bienaventuranza perpetua; mas lo temporal es para que lo use sólo en cuanto pueda conseguir lo eterno, y así viene a ser lo temporal medio y lo eterno fin; en lo cual hay una diferencia y distancia grandísima, porque el fin se há de amar por sí mismo, y el medio no se ha de amar sino en cuanto nos ayudase a conseguir lo eterno ${ }^{37}$.

Mais à frente, no mesmo livro, o autor lembra: “Abre os olhos e repara para quê nasceste neste mundo", desengana-te e lembra-te de que "nasceste para Deus, e não para nada que seja menos que Deus e servir a Deus", foi para isto que te foi dada a vida, "para isto te tiraram do não ser ao ser e passaste do nada à qualidade de criatura racional" ${ }^{, 38}$. O homem se desenganará na medida em que "por Deus anelar somente", na medida em que não tiver “inclinação a outra coisa", e buscar a Deus com "todas as potências de sua alma e forças de seu corpo e afetos de seu coração"39.

Percebe-se daí que, não só se devem aplicar a razão e a vontade neste trabalho, mas também o sentidos - "abre os olhos" -, as potências da alma sensitiva: trata-se da aplicação dos sentidos a que se refere tantas vezes Inácio de Loyola, por exemplo, nos Exercícios Espirituais. A mesma, inclusive, que lhe permitiu, no dia 04 de março de 1544, fazer a seguinte nota no seu Diário de Moções Interiores:

Não sabendo por quem começar, e me fixando primeiramente em Jesus, me parecia que ele não se deixava ver ou sentir claramente, mas de uma certa maneira obscura; e me fixando sobre a Santíssima Trindade, me parecia que ela se deixava sentir e ver mais claramente ou luminosamente. Começando, e continuando com sua divina Majestade, cobri-me de lágrimas, soluços, amor tão intenso que eu tinha a impressão de ser extraordinariamente unido a seu amor tão luminoso e tão doce. De tal forma que esta intensa visita e amor me parecia insigne e excelente comparada às outras visitas ${ }^{40}$.

\footnotetext{
${ }^{37}$ Ibid., p. 240 (“É, pois, uma grande diferença entre o temporal e o eterno ser um o fim e o outro o meio; porque o eterno é o fim do homem, e o temporal é do homem o fim. O eterno é para que nela tenha o homem sua última perfeição e bem-aventurança perpétua; mas o temporal é para que o use somente enquanto possa conseguir o eterno, e assim vem a ser o temporal meio e o eterno fim; no qual há uma diferença e distância grandíssima, porque o fim se deve amar por si mesmo, e o meio só se deve amar enquanto conduz ao fim; pelo que fica claro que pelo eterno deveríamos suspirar, e de todo o temporal deveríamos esquecer, somente na medida em que nos ajudasse a conseguir o eterno", tradução nossa).

${ }^{38}$ Ibid., p. 240 (tradução nossa).

${ }^{39}$ Ibid., p. 242 (tradução nossa).

${ }^{40}$ Loyola, 1991, op. cit., p. 348 (§ 105, tradução nossa).
} 
Os sentidos, para que não se enganem, devem, pois, se voltar a um objeto adequado e, após sua aplicação, se deve considerar a experiência a que se chegou, se deve atingir um juízo racional acerca do sentimento experimentado finalmente.

Porém - e importa que se compreenda bem - este uso dos sentidos deve ter uma referência de perfeição, para que não se incorra no engano a que são levados naturalmente os sentidos:

Aquele que, no uso de seus sentidos, quiser imitar a Cristo nosso Senhor, se recomendará na oração preparatória, à sua divina Majestade; e após ter considerado cada um dos sentidos, dirá uma Ave Maria ou um Pai Nosso. Aquele que, no uso dos sentidos, quiser imitar Nossa Senhora, se recomendará a ela na oração preparatória para que ela lhe obtenha de seu Filho e Senhor a graça para isso; depois, após considerar cada um dos sentidos, dirá uma Ave Maria ${ }^{41}$.

Além disso, na aplicação dos sentidos, quando se considera as coisas de Deus, deve se fazer

$\mathrm{Al}$ modo de uno que entra en casa de un señor, y mira las cosas que ay en ella, y oye lo que alli se habla, y huele los suaves olores que alli ay, y gusta de los buenos manjares que se dan; y finalmente toca con las manos las cosas ricas y preciosas que alli se muéstran ${ }^{42}$.

De tal forma que, quando se fala de sentidos, nesta perspectiva, deve-se entender que não se trata de uma "vidência" como aquela da visio Dei mística, puramente contemplativa e passiva, mas de uma característica iminentemente jesuítica: o fato de que, como o diz Jerônimo de Nadal, o jesuíta é o contemplativo em ação, é o homem da militância missionária, o homem da ação; de tal forma que é na ação, que ele se conhece, é na aplicação de suas potências no contato com a realidade, que ele conhece a si mesmo e a realidade. “Aplicar os sentidos" não é por assim dizer, é concreto ${ }^{43}$.

Além disso, nesta aplicação dos sentidos, o critério para distinguir se o uso foi eficaz é o resultado a que se chega: "Quando a pessoa que se exercita [na aplicação dos sentidos] não encontra ainda o que deseja, como por exemplo lágrimas, consolações etc., é proveitoso

\footnotetext{
${ }^{41}$ Ibid., p. 178 (EE. 248, tradução nossa).

${ }^{42}$ Villanueva, Melchior de (1608). Libro de oracion mental. Compuesto por el Padre Melchior de Villanueva, de la Compañia de Iesus. Toledo: Pedro Rodriguez impressor del Rey nuestro Señor, p. 28,1 ("Como alguém que entra na casa de um senhor e olha as coisas que existe aí, e ouve o que ali se fala, e cheira os suaves odores que ali existe, e saboreia os bons manjares que se oferecem; e finalmente toca com as mãos as coisas belas e preciosas que ali se mostram", tradução nossa).

${ }^{43}$ Cf. Pécora, 1988, op. cit.
} 
fazer uma mudança na comida, no sono e nas outras maneiras de fazer penitência" ${ }^{44}$.

As "lágrimas" que se experimentam, a "indignidade" e a falta de "virtudes" suficientes para o trabalho missionário que se descobre em si mesmo não são apenas aquela falsa modéstia sentimental a que muitos seriam levados a crer, ou, quem sabe, apenas uma tentativa de persuasão sem verdade - uma pura argumentação sofista com intuito de convencimento pela moção de determinados sentimentos: há, sim, o desejo de moção de determinadas paixões no destinatário (o movere da oratória ciceroniana), mas, na medida do possível, sempre com palavra "plena animi, plena spiritus, plena doloris, plena veritatis" ${ }^{45}$.

Um outro aspecto deste "conhecimento de si" precisa, antes de avançarmos, ser bem compreendido. Se analisarmos a estrutura dos Exercícios Espirituais, veremos que ele é organizado e pensado como instrumento, grosso modo, com este fim específico: conhecer a si mesmo para bem eleger a vontade de Deus.

A partir de um trecho de Honor del gran patriarca san Ignacio, escrito por Nieremberg (1645), poderemos compreender melhor esta passagem. Neste livro, o autor, contando a história de santidade do fundador da Companhia de Jesus, chega ao ponto em que começa a descrever a vida de oração de Inácio de Loyola, e escreve:

\footnotetext{
${ }^{44}$ Loyola, 1991, op. cit., p. 100-102 (EE. 89, tradução nossa).

${ }^{45}$ Cicéron, M. T. (1966). De l'orateur. Livre deuxième. (E. Courbaud, Trad.). Paris: Société d'édition "Les Belles Lettres" (original de 55 a.C.), p. 36 ("cheia de animo, cheia de espírito, cheia de dor, cheia de verdade", tradução nossa). Cícero (1966), dando a palavra a Antonius, num diálogo com Catulus, dedica-se a uma longa crítica aos retóricos gregos. Começa por criticar a divisão dos gêneros de discurso quanto ao seu conteúdo. Depois critica o fato de os gregos tratarem a oratória como uma arte e chega ao ponto de afirmar: "Deixa-me te falar [Catulus], não como um sábio, mas, o que vale muito mais, como homem de experiência [non tam doctus quam, id quod est maius, expertus]. Todos os outros tipos de discursos, crê-me, são um jogo, quando se tem alguma vivacidade de espírito, uma certa habilidade da palavra, um grau moderado de instrução e uma cultura um pouco refinada. Mas afrontar a luta da advocacia é uma terrível empresa, e talvez a mais rude que possa tentar o espírito humano. Aí, ordinariamente, uma multidão de ignorantes aprecia o talento do orador pelo desenlace vitoriosa do processo. Aí se apresenta um adversário armado, que vós deveis bater, reprovar. Aí, freqüentemente também, o juiz mestre de vossa sorte está mal disposto, irritado, ou é mesmo amigo do adversário ou vosso inimigo. Vos é necessário instrui-lo ou desenganá-lo ou segurá-lo ou excitá-lo, governar a ele pela palavra adaptando vossos meios às circunstâncias e à causa particular (assim, mudar sua benevolência em ódio, bem como seu ódio em benevolência. É preciso, com alguma ajuda, empurrá-lo em todos os sentidos, à severidade, à clemência, à tristeza, à alegria. É preciso empregar toda a força do pensamento e toda a potência da expressão; e a tudo isso acrescentar ainda uma ação variada e veemente, cheia de fogo e de vida, cheia de patética, cheia de verdade" (XVII 72-73, p. 36, tradução do francês nossa).
} 
Para llegar a tan alto punto de oracion, de tal manera domó, y casi extinguio sus afectos san Ignacio, que no parecia hombre, con tal paz de sus passiones sujetas a la razon, tan incontrastable, que parecia espiritu puro. Cosa tan admirable (...) el perfectissimo dominio que tuvo san Ignacio sobre los movimentos dels coraçon, y todas sus passiones. Todas las regia, no para mal, sin por necessidad y razon, en quanto servian a la virtud, y que esto en tanto grado, y tan connatural en èl, que jusgaron los Medicos avia mudado totalmente el temperamento, porque como por su natural fuesse ardiente, y colerico, y como un fuego, le calificavam por frio, y flematico; y no era sino que trocò condicion, transformandose segun la condicion del cuerpo en Christo Iesus, su amado, dexando de ser colerico por ser manso, y humilde de coraçon, como de si dize el mismo Señor ${ }^{46}$.

Só chega a "domar os afetos" aquele que se conhece, que sabe como se movem suas paixões, aquele que percorreu a topografia de sua alma como quem, com a ponta do dedo, assinala num mapa, os caminhos e descaminhos que deverá percorrer. Só chega a "vencer-se a si-mesmo e ordenar sua vida sem se decidir por nenhum vínculo que seja desordenado"47 o homem que, como "princípio e fundamento", sabe que "é criado para louvar, reverenciar e servir a Deus nosso Senhor e, assim, salvar sua alma" ${ }^{\text {,48 }}$, e que, se dedicando a uma série de práticas e exercícios espirituais, conhece a si mesmo - sua alma - como a um livro aberto e como a palma de sua mão.

Numa edição dos Exercícios Espirituais, publicada na França, em 1673, pela casa editorial “chez Michael Cnobbaert, a L’enseigne de S. Pierre”, encontramos diversas ilustrações que ajudam o exercitante no trabalho de compositio loci. Entre as figuras, encontram-se as seguintes:

\footnotetext{
${ }^{46}$ Nieremberg, Juan Eusebio (1645). Honor del gran patriarca san Ignacio de Loyola, fundador de la Compañia de Iesus, en que se propone sua vida, y la de su Dicipulo el apostolo de las Indias S. Francisco Xavier. Con la milagrosa Historia del admirable Padre Marcelo Mastrilli, y las noticias de grand multitud de Hijos del mismo S. Ignacio, varones clarissimos en santidad, dotrina, trabajos, y obras maravillosas en servicio de la Iglesia. Madrid: Maria de Quiñones, pp. 40-41 ("Para chegar a tão alto ponto da oração, de tal maneira domou e quase extinguiu seus afetos santo Inácio, que não parecia homem, com tal paz de suas paixões sujeitas à razão, tão incontrastável, que parecia espírito puro. Coisa tão admirável (...) o perfeitíssimo domínio que teve santo Inácio sobre os movimentos do coração, e todas suas paixões. Regiaas todas, não para mal, sim por necessidade e razão, enquanto serviam à virtude; e que isto em tal g rau, e tão conatural nele, que julgaram os Médicos que havia mudado totalmente o temperamento, porque como por natureza fosse ardente e colérico e como um fogo, o qualificavam de frio e fleumático; e isso se devia apenas ao fato de que trocara sua condição, transformando-se segundo a condição do corpo em Cristo Jesus, seu amado, deixando de ser colérico para ser manso e humilde de coração, como de si mesmo disse o Senhor", tradução nossa).

${ }^{47}$ Loyola, Ignace de (1991). Écrits (M. Giuliani, Pres. et Dir.). Paris: Desclée de Brouwer; Bellarmin (Collection Christus, 76, Textes) (Originais do século XVI), p. 62 (EE. 21, tradução nossa).

${ }^{48}$ Ibid., p. 62 (EE. 23, tradução nossa).
} 


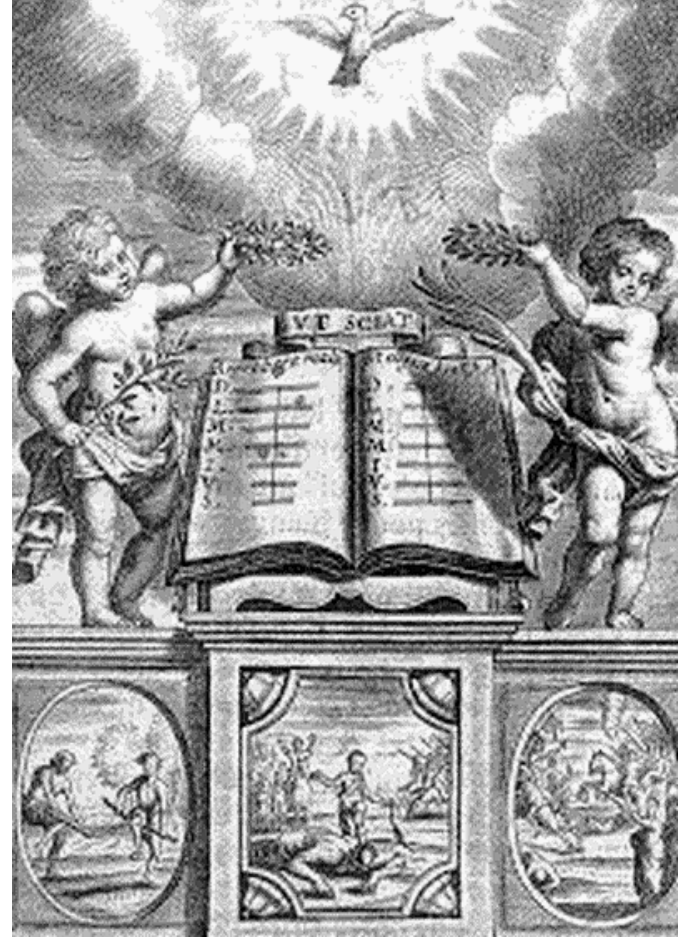

Fig. 08 - O Exame Particular.

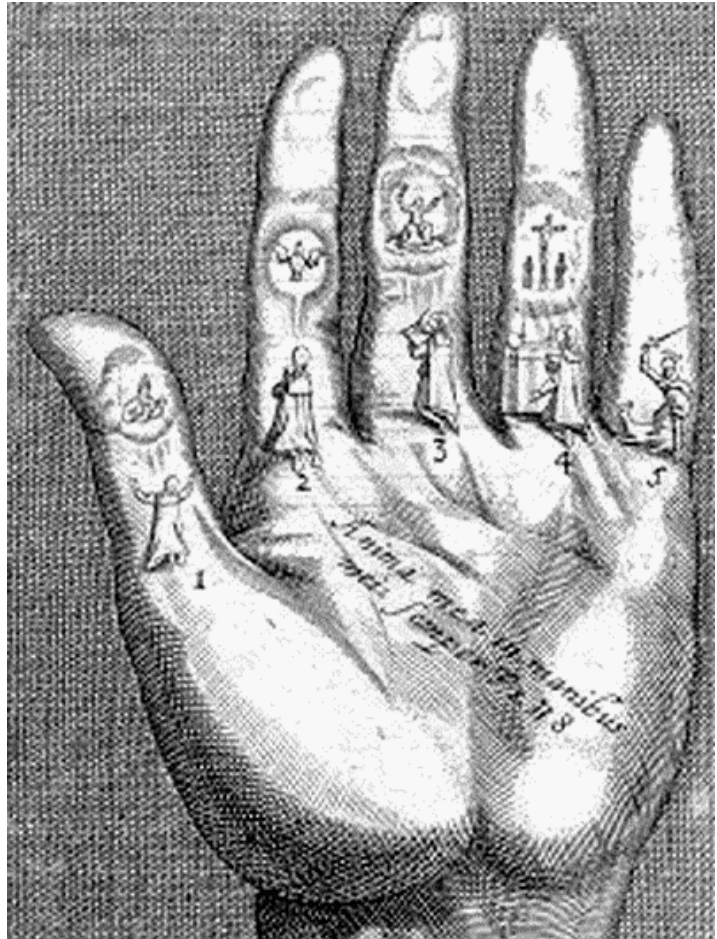

Fig. 09 - O Exame Geral ${ }^{49}$.

Ut sciat, diz o cabeçalho do livro: "para conhecer". Anima mea in manibus meis semper, diz a frase anotada na palma da mão, que representa os cinco pontos referentes à "maneira de fazer o exame geral"50. "minha alma está sempre em minhas mãos" que o Exame Particular se refere àquele cuidado cotidiano com um "pecado particular ou defeito que se quer corrigir ou emendar" ${ }^{\mathrm{5}}$, implicando a constante aplicação das faculdades todas da alma neste conhecimento - do nível vegetativo ao racional; o Exame Geral repassa, um a um, os pecados todos - do pensamento, da palavra e da ação - que se pode cometer. Conhecer-se a si mesmo quer, pois, dizer apenas conhecer sua capacidade de pecado? Não, se

\footnotetext{
${ }^{49}$ As ilustrações foram retiradas no dia 15 de janeiro de 2003 do site "The Spiritual Exercises in Pictures - Some assistance for the composition of place", no World Wide Web http:// www.faculty.fairfield.edu/ jmac/ SEPICT/ SEPICT.htm.

${ }^{50}$ Cinco são os pontos: "o primeiro ponto: dar graças a Deus nosso Senhor pelos benefícios recebidos. O segundo: pedir a graça de conhecer seus pecados e de os rejeitar. O terceiro: pedir conta à sua alma, desde a hora em que se levantar até o presente exame, hora após hora, ou período após período, primeiro dos pensamentos, depois das palavras, depois das ações, segundo a mesma ordem que foi indicada para o exame particular. O quarto: pedir perdão das faltas a Deus nosso Senhor. O quinto: formar o propósito de se emendar com sua graça" (Ibid., p. 76, EE. 73, tradução nossa).

${ }^{51}$ Sl. 119 (118), 109.

${ }^{52}$ Ibid., p. 64 (EE. 24, tradução nossa).
} 
se compreende que por meio deste conhecimento - que é o início apenas, a Primeira Semana, dos Exercícios Espirituais - o homem se purifica a fim de melhor entrar nos exercícios que serão propostos em seguida. O homem não só se purifica, mas se desengana e evita seja o excessivo amor próprio, seja a desconsideração de sua própria natureza, que "nos impede[m] a verdadeira liberdade do puro serviço divino"53. Seraphin Bonaventura Coçar, por exemplo, refere-se a isso quando relata, em Indipeta enviada no dia 02 de maio de 1583, que

ya estoy libre gloria al S.or de toda melancholia, y muy lexos della, que alfin no me era natural, y aunque algunas vezes estoy de malagana (cosa que por todos passa) pero es de tal calidad, que el exercicio corporal, y ocupacion exterior, de que ay abundancia en las Yndias, del todo me la quita ${ }^{54}$.

"Livre de toda melancolia" não-natural: é o próprio Inácio que lembra, nos Exercícios Espirituais, antes de dar entrada à Segunda Semana, que "o exame particular se fará para suprimir defeitos e negligências" ${ }^{\text {"55 }}$.

Só então, terá início a Segunda Semana, onde o jesuíta é chamado a contemplar “o apelo do (...) rei eterno" e, nesse sentido, é ajudado a fazer eleição a partir da contemplação da Encarnação e do Nascimento. Pouco antes dos exercícios desta semana, Inácio propõe a seguinte oração para aqueles que querem "se distinguir no serviço de seu rei eterno e Senhor universal" ${ }^{\prime 56}$ :

Eterno Senhor de todas as coisas, faço minha oferenda, com vosso favor e vossa ajuda, em presença de vossa infinita bondade e em presença de vossa mãe gloriosa e de todos os santos e santas da corte celeste: quero e desejo, e é minha decisão determinada, desde que seja vosso maior serviço e vosso maior louvor, vos imitar suportando todos os ultrajes, todas as repreensões e toda pobreza, tanto efetiva, quanto espiritual, se vossa santíssima Majestade quer me escolher e me receber nesta vida e neste estado ${ }^{57}$.

Um homem será capaz de eleger um modo de vida, um estado de vida mais adequado e próximo do fim, da realização, que deseja e para o qual foi feito, na medida em que

\footnotetext{
${ }^{53}$ Aquaviva, Claudio (1583). Lettera del Nostro Padre Generale Claudio Acquaviva. Sopra la Rinovatione dello spirito à Padri \& Fratelli della Compagnie. 29/09/1583. Roma, p. 5 (tradução nossa).

${ }_{54}^{5}$ ARSI, Indipetae Hispanae, FG 758, carta n. 4.

${ }^{55}$ Loyola, 1991, op. cit., p. 102 (EE. 90, tradução nossa).

${ }^{56}$ Ibid., p. 106 (EE. 97, tradução nossa).

${ }^{57}$ Ibid., p. 106 (EE. 98, tradução nossa).
} 
contemplar a vida de um Outro que, tendo se encarnado e nascido em meio a este mundo, disse de si mesmo: "Eu sou o Caminho, a Verdade e a Vida"58, fazendo de si o modelo perfeito do homem completo. Por isso também, toda a Terceira e Quarta Semanas serão marcadas pela contemplação da vida de Cristo: para que o jesuíta se converta, ele também, em figura Christi, pela incorporação daquelas imagines agentes nas quais se configuram os episódios da vida do Filho de Deus Encarnado - o Verbum caro.

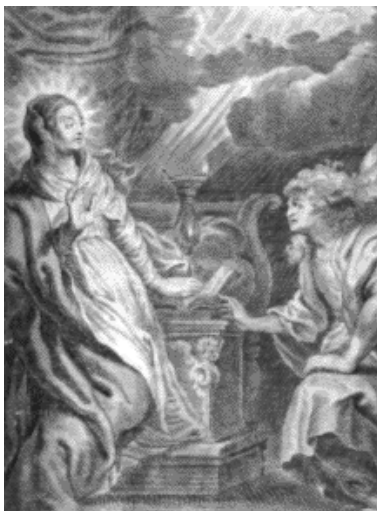

Fig. 10 - Anunciação

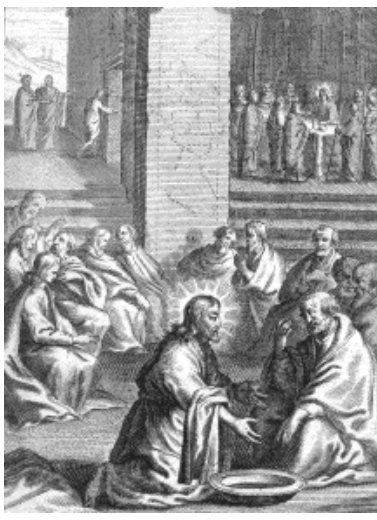

Fig. 14 - Lava-pés

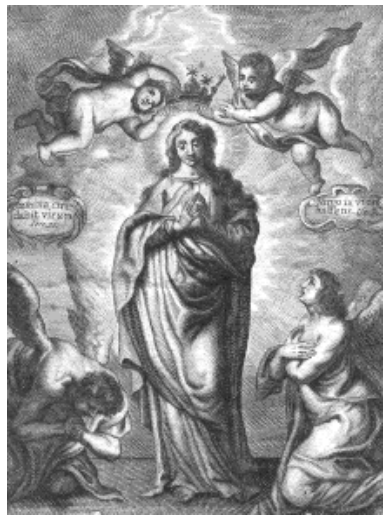

Fig. 11 - Encarnação

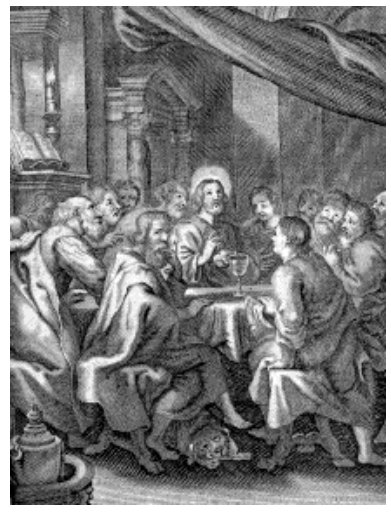

Fig. 15 - Última ceia

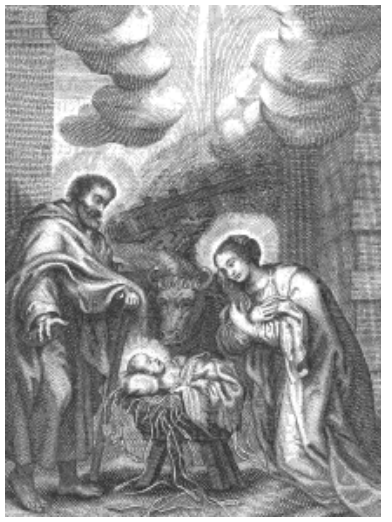

Fig. 12 - Nascimento

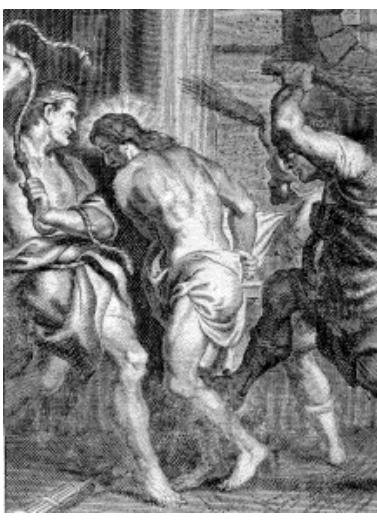

Fig. 16 - Flagelação

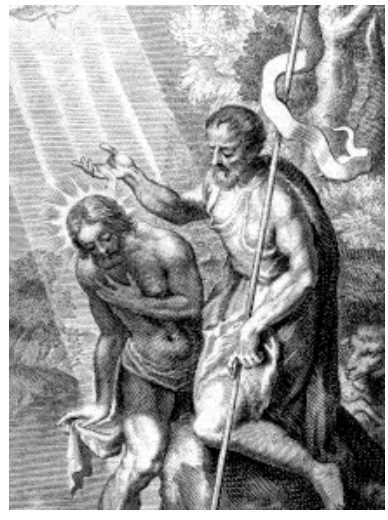

Fig. 13 - Batismo

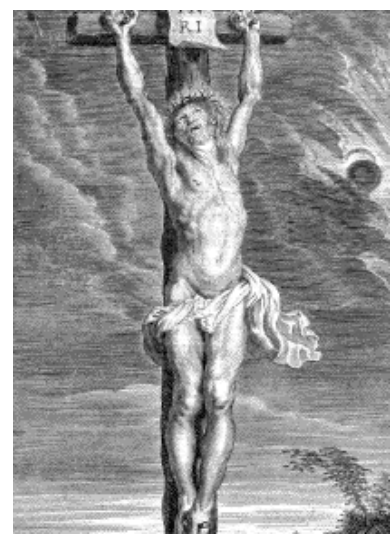

Fig. 17 - Crucifixão ${ }^{59}$

Passo a passo, Inácio - a "experiência-modelo” que é - vai conduzindo o jesuíta através de uma via cujo fim último será aquela contemplatione Dei que é a suma felicidade do homem, a consolação final, a realização definitiva, como veremos melhor no próximo capítulo.

\footnotetext{
58 Jo $14,6$.

${ }^{59}$ As ilustrações auxiliam o jesuíta a fazer a composição de lugar, aplicando, para começar, o sentido da vista. Todas foram retiradas no dia 15 de janeiro de 2003 do site "The Spiritual Exercises in Pictures - Some assistance for the composition of place", no World Wide Web http:// www.faculty.fairfield.edu/ jmac/ SEPICT/ SEPICT.htm.
} 
Sem dúvida, na leitura das Indipetae, salta às vistas, especialmente na estrutura argumentativa utilizada pela maioria dos indipetentes, a preocupação em descrever como se deu o processo de "discernimento dos espíritos" ou de "eleição". Nesse sentido, inúmeros são os exemplos de uso dos topoi aqui analisados.

A começar pela tópica do "desejo", que aparece em todas as partes das cartas, de maneira igual ao longo dos anos (no caso das cartas analisadas do ponto de vista macrohistórico), até a tópica da "inspiração" que só aparece duas vezes e sempre na captatio benevolentiae, passando pelos termos e expressões mais gerais que denotam "conhecimento de si” que quase sempre estão mais presentes na narratio, com frequiência também na petitio, quando é o caso de reafirmar a "indignidade" e a falta de "virtudes".

É bastante evidente, entretanto, a recorrência da tópica do "desejo" na narratio. O que não é de se estranhar, dado que se trata daquela parte da carta onde o indipetente relata a história do desejo e do trabalho de discernimento de sua origem. Neste relato, o jesuíta coloca ao lado do "desejo" a "vocação", que só é verificada a partir da aplicação das potências da alma (os "sentidos" e a "razão") e do conhecimento por "experiência", e a partir do constante trabalhos de "consideração" e de "encomenda" a Deus nas orações e exercícios espirituais, além de sua diferenciação com as "tentações" e com as "paixões" desordenadas que se identificam no trabalho de discernimento.

Quanto à captatio benevolentiae, ao lado do "desejo" os termos mais freqüentes, além da tópica da "vocação", são a afirmação da própria "indignidade" e do trabalho de "encomenda" a Deus, e a urgência de comunicação das "razões" da escrita da carta. Dinâmica que se repete com ligeiras diferenças na petitio e na conclusio.

Por exemplo, Seraphin Bonaventura Coçar afirma que os desejos que sente foram dados por "Nuestro Señor (...) quando me llamo por su infinita bondad a la Compañia"60.

\footnotetext{
${ }^{60}$ ARSI, Indipetae Hispanae, FG 758, carta n. 4.
} 
Segundo ele, a fim de verificar a origem divina do chamado, passou a considerar que se tratava apenas de "fervores de caçuela, y que Dios no me llama (...) y que es tentatacion" "61; as experiências que fez a partir daí lhe permitiram chegar à conclusão segura de que os desejos

como por lo mucho que me ayudan para perfecionarme en la virtud me dan tales prendas de ser llamamiento y vocacion de Dios Nuestro Señor, essa aunque no tuviesse tanta salud como tengo ni tanta virtud como para tal empresa es menester so pena de mentir al Spiritu Santo, me obligan a que confiado que sua infinita misericordia suplira lo que en mi falta quando fuere su voluntad que esto se me conceda con resignacion pida a Vuestra Paternidad me enbie al Japon ${ }^{62}$.

É interessante notar também como - não só o jovem em questão, mas praticamente todos os indipetentes insistem em expressões descritivas de sua pouca virtude, de seu pouco preparo espiritual ou de suas capacidades físicas e intelectuais, bem como dos trabalhos a que estão ou não estão preparados: “con todos me hallo bien (...) mi poca virtud la tengo bien conocida"63, afirma Coçar; "escrivi a Vuestra Paternidad lo que yo sentia de mi" ${ }^{64}$, confirma Bernardo Matias; Juan Augustin Castangia se pergunta o que Deus pode fazer "por medio deste indiño y ruin instrumento"65 que é ele mesmo; Joan Sotalell diz conhecer em sua alma "grande ventaja en mortificar los vicios y passiones desordenadas" "66; Balthasar de Torres ao descrever sua condição na Companhia diz que tem "edad de 20 a 21 años despues de cinco, que ha que entre en la Compañia, de buenas fuerças, y salud; oygo al $4^{\circ}$ año de la phylosophia" ${ }^{67}$; o irmão coadjutor Domingo Tafalla, a fim de convencer o Superior Geral acerca do quão interessante é que seja enviado, fala daquele aspecto de si mesmo que mais pode ajudar no trabalho na China:

El P.e Rogerio me ha animado mucho, ý me ha dicho que era el mejor tiempo de mi edad para ýr ý aprender la lengua china que no tengo mas de veynte o veynte un años y porque confio que Vuestra Paternidad como à Padre me ha de consolar no me alargo mas ${ }^{68}$.

\footnotetext{
${ }^{61}$ ARSI, Indipetae Hispanae, FG 758, carta n. 4.

${ }^{62}$ ARSI, Indipetae Hispanae, FG 758, carta n. 4.

${ }^{63}$ ARSI, Indipetae Hispanae, FG 758, carta n. 4.

${ }^{64}$ ARSI, Indipetae Hispanae, FG 758, carta n. 80.

${ }^{65}$ ARSI, Indipetae Hispanae, FG 758, carta n. 168.

${ }^{66}$ ARSI, Indipetae Hispanae, FG 758, carta n. 338.

${ }^{67}$ ARSI, Indipetae Hispanae, FG 758, carta n. 13.

${ }^{68}$ ARSI, Indipetae Hispanae, FG 758, carta n. 136.
} 
Este é um trecho bastante significativo dentre os diversos exemplos que poderíamos elencar: aqui o "conhecimento de si" se dá por intermédio de um terceiro a quem se confia o indipetente. Dessa forma, compreende-se como o trabalho de discernimento dos espíritos não era um trabalho solitário: o jesuíta se sabe como tal num relacionamento concreto de características muito próprias ${ }^{69}$.

Outro aspecto, já apontado por Massimi (2002), respeita às qualificações que, na maior parte das vezes, acompanha a palavra "desejo": "encendido desseo", "desseo fervoroso", “antiguos deseos”, “muy grandes deseos", “eficazes deseos”, “buenos deseos”, "deseo firme", "grande deseo", "desseos muy encendidos". Em todas as vezes é sempre qualificado de maneira a reforçar sua importância ${ }^{70}:$ o fato de serem grandes, incendidos, antigos, bons ou fervorosos, garante ao indipetente a origem divina do desejo, o que se confirma, por exemplo, no texto de Coçar que diz que Deus lhe dá um "desseo fervoroso, que como luz del cielo deshaze en mi alma aquellas tinieblas y razones, dexandome muy consolado" 71 . Também Balthasar Torres faz uso de recurso semelhante quando explica, em carta, que algumas vezes sentiu se resfriar o desejo, por medos e outras adversidades, porém, "acudia Nuestro Señor con mas ferborosos deseos delos ordinarios, prometiendome ayuda de su divina mano" ${ }^{, 72}$. Antonio Perez, por sua vez, contando "llanamente la verdad" $" 73$ da história de seus antigos desejos, confirma que se trata de vocação de Deus porque, quando estudava em Cordona, tendo ouvido a história de Francisco Xavier, viu um desejo de imitar seus passos crescer em si mesmo que em nada diminuía diante das “dificultades que se me representavan”. Outro jovem jesuíta - de 21 anos -, Juan de Avila escreve dizendo que

\footnotetext{
${ }^{69}$ Sobre esse ponto nos deteremos melhor no próximo capítulo. Porém, é interessante observar como, de fato, essa descrição, se não considerada em seu dinamismo, pode nos levar ao erro da análise estanque: como se cada um desses conjuntos de lugares-comuns fossem independentes e não descrevessem um continuиm de vivido.

${ }^{70}$ Cf. Massimi, 2002, op. cit.

${ }^{71}$ ARSI, Indipetae Hispanae, FG 758, carta n. 4.

${ }^{72}$ ARSI, Indipetae Hispanae, FG 758, carta n. 13.

${ }^{73}$ ARSI, Indipetae Hispanae, FG 758, carta n. 43.
} 
es tan grande el desseo, que de yr a padeçer por Christo y emplear mi vida en esta empresa, me da sua Magestad que quando lo pienço rebiento en lagrimas, y dame Dios dello tanta confiança, que reparando enello despaçio, lo tengo por tan cierto, como si lo viesse ya cumplido ${ }^{74}$.

De fato, esses adjetivos nada mais significam que uma confirmação de que não se tratam de desejos desordenados. O mesmo Juan de Avila, na seqüência do trecho anterior, escreve que "quando en la mortificaçion de mis passiones, y camino de la perfecçion se me offreçe alguna difficultad, el mejor remedio que tengo, y con que me animo mucho, es pensar que me voy preparando para esto" 75 . Trata-se de um desejo que remedia, que auxilia no trabalho de mortificação das paixões desordenadas. Leon Ximenes fala de grandes desejos de ir ao Peru onde se "padecen muchos trabajos y incomodidades en la comida habitacion, y cama, y que el trato mio ha de ser con gente ruda, con negros, y gente barbara"76 e continua pouco adiante, escrevendo que Deus "me dara fuerças para ello, pues el me llama y tambien espero me dara perseverancia en mi buen proposito" 77 : não fosse um chamado de Deus, desejaria tantos incômodos? Ou ainda Joan Sotalell que deseja oferecer a “Christo Nuestro Señor (...) por mi alma una perfeita obediencia y abnegacion grande en todas las cosas, y por el cuerpo, el mas horible y cruel martyrio, que hasta ahora se a padecido, ni los tyrannos an inventado" ${ }^{\text {78 }}$. Um tal desejo só se compreende quando está devidamente ordenado por uma obediência ao factus último identificado no constante exercício de discernimento a que eram educados, ordenado, finalmente, por uma obediência ao chamado de tudo "hazer por amor del mesmo Señor" 79 .

Do ponto de vista da análise micro-histórica, as cartas de Juan Bravo nos oferecem alguns aspectos interessantes a serem observados: ao longo dos três anos de escrita (apenas

\footnotetext{
${ }_{74}^{74}$ ARSI, Indipetae Hispanae, FG 758, carta n. 126.

${ }^{75}$ ARSI, Indipetae Hispanae, FG 758, carta n. 126.

${ }^{76}$ ARSI, Indipetae Hispanae, FG 758, carta n. 290.

${ }^{77}$ ARSI, Indipetae Hispanae, FG 758, carta n. 290.

${ }^{78}$ ARSI, Indipetae Hispanae, FG 758, carta n. 338.

${ }^{79}$ ARSI, Indipetae Hispanae, FG 758, carta n. 338.
} 
utilizando as cartas a que tivemos acesso), observamos uma paulatina simplificação da forma de argumentação utilizada nas cartas. Enquanto que na primeira, há um evidente cuidado com a estruturação retórica (inclusive, a captatio benevolentiae está separada do restante da carta), nas cartas seguintes, Juan Bravo, além de diminuir a extensão da carta, simplifica sua forma até o ponto de, na última, narratio e captatio benevolentiae se confundirem numa espécie de grande petitio.

Na primeira de suas Indipetae (que cremos ser, de fato, a primeira carta que escreve ao superior geral $^{80}$ ), Juan Bravo não menciona, na primeira parte da carta, nada acerca do seu desejo. Apenas iniciada a narratio, declara qual é o desejo que sente e já afirma que se trata de "vocação" comunicada por "su divina Magestad" ${ }^{21}$. Em seguida, começa a descrever todo o trabalho de discernimento dos espíritos a que se dedicou: "my acudi a la oraçion, comulgandome algunas vezes, y haziendo otras penitençias a este fin, procure tanbien ayudarme de las oraçiones de los otros" ${ }^{82}$, e mais à frente diz também que "hize refflexion sobre my mismo y vy dos cosas las quales sin pretendello me descubrieron lo que yo deseava saber" ${ }^{\prime 3}$. O aspecto mais evidente de sua narratio é a recorrência não do termo "desejo", mas do termo "vocação" e de termos semelhantes - "comunicação", "chamado" entre outros: o indipetente parece querer deixar bastante claro que está perfeitamente desenganado de o desejo é "llamamento", e de que "este llamamiento es divino". Nas duas últimas partes de sua primeira carta, nenhum lugar-comum que se relacione ao “conhecimento de si" volta a aparecer.

Será nas cartas seguintes que Juan Bravo começará, não tendo obtido resposta do padre geral, a valorizar, na captatio, o topos do "desejo": "mas he tardado en renovar a

\footnotetext{
${ }^{80}$ ARSI, Indipetae Hispanae, FG 758, carta n. 329. Logo na captatio benevolentiae ele afirma: "Con mucho consuelo myo escrivo esta a Vuestra Paternidad parte por ser la occasion con que la escrivo tal quales, parte tanbien por que me da no pequeña alegria ver que siendo la primera que a Vuestra Paternidad escrivo sea con tal occasion".

${ }^{81}$ Cf. ARSI, Indipetae Hispanae, FG 758, carta n. 329.

${ }^{82}$ Cf. ARSI, Indipetae Hispanae, FG 758, carta n. 329.

${ }^{83}$ Cf. ARSI, Indipetae Hispanae, FG 758, carta n. 329.
} 
Vuestra Paternidad la memoria de mys desseos" $" 84$, ou "mas a menudo quisiera yo refrescar a Vuestra Paternidad la memoria de mys deseos" ${ }^{85}$. Também nesta parte de suas cartas seguintes, o indipetente procura expressar com mais eficácia sua indignidade por tão "fuertes y vigorosos" desejos, "aun para quien en vez de benefficios tenia mereçidos muchos açotes y castigos". Nas pequenas narrationes que faz nesta duas cartas seguintes, o jovem jesuíta procura mais demonstrar o quão desenganado está e, portanto, o quão certo se encontra da origem divina de seu desejo, que descrevê-lo ou aos trabalhos eletivos a que se tenha dedicado.

É na última de suas cartas que encontramos o dado mais significativo: nela, a recorrência aos termos vinculados à urgência de uma experiência de "filiação" e conseqüente "identificação" com o corpo institucional da Companhia de Jesus fica evidente. Juan Bravo, como que vai, pouco a pouco, fazendo coincidir seus "deseos de yr a las Yslas del Japon para derramar en ellas el sudor y la sangre", com seu chamado à ordem religiosa fundada por Inácio de Loyola (referido na primeira carta) ${ }^{86}$ : ir em missão é mais que satisfazer um desejo pessoal, é corresponder às expectativas do "Paternal affecto y amor" do superior geral, em quem - ele confia! - reina um desejo "de fomentar, y alentar qualquier buen parto de sus espirituales hijos". Sua carta-pedido é toda ela dirigida ao prepósito a quem - ele espera! -Deus pagará "con eternos dones los dichosos trabajos que por sus hijos toma y en particular el que por este indigno tomare" ${ }^{, 87}$... e Deus pagará, por que foi Ele quem deu a Juan Bravo esses desejos: trazer para a luz os desejos e endereça-los "para mayor gloria del que se los dio" é tarefa do superior.

Abre-se, aqui, o caminho para a compreensão de outro termo deste dinamismo: a "obediência" e suas tópicas correlacionadas.

\footnotetext{
${ }^{84}$ Cf. ARSI, Indipetae Hispanae, FG 758, carta n. 404.

${ }^{85}$ Cf. ARSI, Indipetae Hispanae, FG 759, carta n. 4.

${ }^{86}$ Cf. ARSI, Indipetae Hispanae, FG 758, carta n. 329.

${ }^{87}$ Cf. ARSI, Indipetae Hispanae, FG 758, carta n. 404.
} 


\section{CAPÍTULO 9 A "obediência" nas Indipetae}

En apres ayant mis les yeux sur les regles, des religions tres-sacrees, $\mathrm{j}$ 'ay trouvé que la seule obeyssance, estoit le grand chemin Royal par où on doit marcher en la vie commune, qu'un chacun a choisie \& fait profession.

Pedro Sanchez (1607)

Le Royaume de Dieu, et le vray chemin pour y parvenir...

Lendo as Indipetae, é possível encontrar alguns dos termos relacionados ao topos da “obediência" como parte deste dinamismo chamado de "experiência de liberdade".

Por exemplo, o mote jesuítico - com ou sem as pequenas variações - se repete em praticamente todas as cartas. A tópica da "obediência", também de freqüência regular, vem quase sempre vinculada às idéias de "filiação", "imitação" e "martírio". E, apesar da importância dada até aqui a ela, o topos da "indiferença" não aparece tanto quanto se poderia pensar, mas se pode, assim como o vimos no caso do Relato de Inácio, subentendê-la em

\footnotetext{
${ }^{1}$ Sanchez, Pedro (1607). Le Royaume de Dieu, et le vray chemin pour y parvenir. Composé en Espagnol par le Pere P. Sanchez, Docteur de la Compagnie de Iesus. Traduit en François, par F. Guillaume Levite, de l'Ordre des Predicateurs. Paris: Chez Adrian Beys (original espanhol de 1594), p. iii.
} 
praticamente todas as cartas. Os demais topoi, apesar de praticamente presentes em apenas uma ou outra das cartas, nos interessam, na medida em que podem ser descritos como parte do dinamismo que vimos demonstrando até este ponto.

Quanto à freqüência desses lugares-comuns nas partes da estrutura retórica das cartas, observamos que, no caso da captatio benevolentiae, a recorrência da tópica "martírio" é bastante significativa para a conquista da benevolência do destinatário, dado seu caráter evidentemente edificante. É comum também que o indipetente use dos termos "obediência" e “filiação" com este mesmo objetivo, denotando respeito à decisão de "Vuestra Paternidad".

Será na narratio, no entanto, que o topos do "martírio" aparecerá com maior freqüência: seja vinculado à "imitação" de "experiências-modelo" particulares, seja por obediência à vocação dada por Deus, seja por "obrigação" a fim de pagar com o próprio sangue o mal cometido contra Cristo que derramou de seu sangue para salvá-lo, em todos esses casos, o "martírio" aparece como resultado de um trabalho de discernimento dos espíritos, de reconhecimento da origem divina do desejo que sente. Submeter-se a "derramar o próprio sangue" só faz sentido, nesse dinamismo, se for uma ação devidamente arrazoada e deliberada pela vontade, como o "meio-termo" no caminho para o "fim último da vida": aquela "Felicidade" a que se destina o homem.

É também nesta parte da carta que o termo "indiferença" aparece mais constantemente, demonstrando a atenção e a seriedade com que foi realizada a "eleição": lembremo-nos de que "se a vontade não eleger o meio termo, o intelecto de forma alguma impelirá para a acção", em outras palavras, se a vontade do indipetente não escolhe viver a "indiferença", sua razão não moverá a vontade para agir em direção ao destino identificado como o fim. Falar da "indiferença" é descrever para o padre geral o resultado do trabalho de eleição.

$\mathrm{Na}$ petitio, por sua vez, os três lugares-comuns que aparecem mais vezes são

\footnotetext{
${ }^{2}$ Ibid., p. $261\left(8^{\mathrm{a} D}, 2^{\mathrm{a}} \mathrm{q}, \mathrm{a} 1^{\circ}\right)$.
} 
“obediência”, “ad maiorem Dei gloriam" e "martírio". Essa tríade aparentemente paradoxal - se pensada como parte da petitio - é sinal de uma "experiência de indiferença" que se atualiza no concreto de um relacionamento hierarquicamente determinado: a Indipeta encontra seu valor de petição, “apesar” das referências várias à obediência, apenas por que, a Vontade de Deus - que não engana - é confirmada pela vontade do superior que, como cabeça da Companhia de Jesus, se esforça por levar à frente o objetivo da ordem - a "nossa vocação" a que se referem os primeiros, no documento 1539. Durante três meses - A maneira na qual se instituiu a Companhia ${ }^{3}$.

As tópicas mais presentes na conclusio, próprias deste termo do dinamismo que vimos descrevendo, são as expressões de "filiação": na maior parte das vezes para reafirmar o sentimento de identificação à ordem religiosa, no relacionamento com o padre geral.

Mas, como os termos "indiferença", "mortificação", "peregrinação", "imitação" ou "martírio" e "edificação", ou variações do mote jesuítico - "ad maiorem Dei gloriam" - e as expressões de "filiação" presentes nas cartas, podem se relacionar com - a "obediência"? Em que medida essa categoria que assumimos como mais ampla entra no dinamismo descrito como uma "experiência de liberdade"?

A fim de bem compreendermos a maior parte desses termos, especialmente a tópica da "indiferença" é preciso que nos remetamos à idéia de "meio-termo". Para tanto, retomemos o Curso Conimbricense, onde Manuel de Góis, discutindo a Ética a Nicômaco do Estagirita, lança mão deste conceito diversas vezes.

Na sétima disputa, quando trata "das virtudes em geral”, o mestre coimbrão justifica o estudo das virtudes, dizendo que "esta disputa tem grande interesse na Filosofia Moral, porque é com as virtudes que nos tornamos bons e por elas as acções ficam honestas e sem

\footnotetext{
${ }^{3}$ Cf. Loyola, 1991, op. cit., pp. 277-281.
} 
elas não se pode alcançar a felicidade, que é o alvo da ciência moral”"4. Em seguida, retomando a definição de virtude feita por Aristóteles, no segundo livro da Ética a Nicômaco, sexto capítulo, deixa aparecer, pela primeira vez, o conceito de "meio-termo": "Finalmente, a virtude moral, que Aristóteles definiu (...): Virtude é o hábito electivo que consiste no meio termo, em relação a nós, regulado pela razão como a regularia pessoa prudente ${ }^{, 5}$. Para, à frente, ainda definindo "virtude" explicar que "a virtude, de sua natureza, inclina ao acto bom e de nenhum modo ao acto que afasta do meio termo, regulado pelo juízo de pessoa prudente"6. Vai ser a partir da segunda quaestione que Góis definirá o "meio-termo":

Advirta-se que o meio termo ou é constituído segundo a natureza da cousa, ou se toma em relação a nós. Meio termo segundo a natureza da cousa, que também se chama meio da cousa, é o que dista igualmente de um e outro extremo, de maneira que o senário é o meio entre o denário e o binário, porque dista igual número de unidades, de ambos, a saber, quatro. Meio termo em relação a nós, é o que, junto a nós, nem excede nem falta; como aquela porção de alimento que convém a Sócrates, segundo o temperamento dele, diz-se meio com relação a ele. Mas, porque nem todos têm a mesma força de temperamento e de calor para cozer, muitas vezes, o que, em confronto com um, obtém o meio, com relação a outro, falta ou excede ${ }^{7}$.

Apelando a Santo Tomás de Aquino, o autor esclarece ainda que

O bem daquilo que se regula e se mede, está situado na adequação à sua regra. Por isso, como o bem da virtude moral é dirigido pela razão, também se colocará na adequação com a medida da razão. Esta adequação é igualdade ou medida entre o excesso e a falta, isto é, o meio termo ${ }^{8}$.

Na disputatio oitava - "Da Prudência" - tratando dos atos da prudência e de suas partes, diz que são três os atos da prudência: inquirir os meios para conseguir determinado fim, julgar que meios melhor podem conduzir ao fim estabelecido e "ordenar ou imperar para que se cumpra o que foi julgado" ". Góis (1593) afirma que este último ato é próprio da razão que dirige a vontade para a execução:

Para que isto melhor se perceba, adverte que, depois de feita a inquirição e

\footnotetext{
${ }^{4}$ Góis, Manuel de (1593). Disputas do Curso Conimbricense sobre os livros de Moral a Nicómaco de Aristóteles em que se contêm alguns dos principais capítulos da moral. Lisboa: Oficina de Simão Lopes, p. 207 (7ª).

${ }^{5}$ Ibid., p. $209\left(7^{\mathrm{a} D}, 1^{\mathrm{a}} \mathrm{q}, \mathrm{a} 1^{\mathrm{o}}\right)$.

${ }^{6}$ Ibid., p. $213\left(7^{\mathrm{a} D}, 1^{\mathrm{a}} \mathrm{q}, \mathrm{a} 2^{\mathrm{o}}\right)$.

${ }^{7}$ Ibid., pp. $217-219\left(7^{\mathrm{a} D}, 2^{\mathrm{a}} \mathrm{q}, \mathrm{a} 1^{\mathrm{o}}\right)$.

${ }^{8}$ Ibid., p. $213\left(7^{\mathrm{a} D}, 1^{\mathrm{a}} \mathrm{q}, \mathrm{a} 2^{\mathrm{o}}\right)$.

${ }^{9}$ Ibid., p. $261\left(8^{\mathrm{a} D}, 2^{\mathrm{a}} \mathrm{q}, \mathrm{a} 1^{\mathrm{o}}\right)$.
} 
formulado o juízo, e depois do consentimento da vontade e de eleger eficazmente o meio que parecer melhor conduzir à consecução do fim - $\mathrm{o}$ intelecto, por uma certa fala interna, denuncia e intima o que se deve fazer. Logo, a ordem consiste nesta denunciação e intimação com que o intelecto move à acção a vontade daquele a que impera. Daqui se vê, para a ordem, se requer o consentimento da vontade e a eleição eficaz e que de novo a vontade seja excitada pelo intelecto, por força deste consentimento e eleição. Se a vontade não eleger o meio termo, o intelecto de forma alguma impelirá para a acção ${ }^{10}$.

E como "lex est formaliter directio, \& regula, dirigere vero pertinet ad intellectum" 11 , esclarece-se com isto que, para a filosofia moral da segunda escolástica, quem dirige finalmente a vontade para um fim eleito antes - directio \& regula - é o intelecto: e a moção será adequada na medida em que se conformar à regra ou virtude moral que é formulada pela razão - o meio-termo, portanto.

Assim, a regra não é, de fato, apenas uma formalidade árida, já que existe uma vida por trás daquilo que regula: a vida mesma que inquiri, julga e ordena, visando um fim... que, no caso de nossos indipetentes, não é apenas "um” fim qualquer, mas coincide com o "fim último" de suas vidas e vocação.

Quanto à "indiferença", devemos dizer que, de acordo com Massimi (2002), é um ideal fundamental no perfil do autêntico jesuíta ${ }^{12}$. De fato, se nos baseamos na compreensão que o texto dos Exercícios Espirituais oferece - especialmente no Princípio e Fundamento - e nas leituras de Verhhecke (1984) e O’Malley (1999), se compreenderá que a "indiferença" é o que permite a ligação primeira do jesuíta ao fim transcendente que ele descobre no exercício de "conhecimento de si" e, nesse sentido, se opõe a toda desordem afetiva que o afaste desse fim último.

Segundo Massimi (2002), a “indiferença" é uma "virtude existencial” necessária para que os jesuítas vivessem conformes à vontade de Deus, e "consiste na mortificação do desejo imediatamente experimentado; sendo que a confiança em Deus deve ser

\footnotetext{
${ }^{10}$ Ibid., p. $261\left(8^{\mathrm{a} D}, 2^{\mathrm{a}} \mathrm{q}, \mathrm{a} 1^{\mathrm{o}}\right)$.

${ }^{11}$ Ibid., p. $263\left(8^{\mathrm{a} D}, 2^{\mathrm{a}} \mathrm{q}, \mathrm{a} 1^{\circ}\right)$.

${ }^{12}$ Massimi, 2002, op. cit., pp. 43-48.
} 
acompanhada por uma igual desconfiança de si mesmo"13. Assim, é a conformidade com a vontade de Deus que é facilitada, dinamizada ou permitida por essa a que prefiro dar o nome de "experiência do meio-termo".

Por isso, a constante insistência quanto à "indiferença", tanto nos textos normativos, quanto nos filosófico-retóricos ${ }^{14}$ ou espirituais-práticos da Companhia de Jesus: ela permite que o jesuíta se atenha àquilo que não o pode enganar - a vontade de Deus - , se afastando daquilo que, muito freqüentemente, o engana - o desejo mal ordenado ${ }^{15}$.

Em carta enviada a Isabel Roser, em 10 de novembro de 1532, Inácio usa o mesmo termo num contexto bastante significativo: respondendo a três cartas de sua amiga de Barcelona, nas quais a autora relata uma doença porque passou e algumas injúrias e calúnias que vinha sofrendo, Inácio apela para a "indiferença" para explicar que a doença ou as calúnias podem ser acolhidas de forma mais condizente com nossa humana condição, desde que vista sob a luz da vontade de Deus:

Sua segunda carta me fala da longa e penível doença pela qual passou e da grande dor de estômago que lhe resta ainda. (...) Quando penso que por meio destas provas Deus visita as almas que Ele ama mais, não posso mais sentir nem tristeza nem dor. Porque penso que um servidor de Deus sai de uma doença meio doutor na arte de dirigir e ordenar sua vida para a glória e para o serviço de Deus nosso Senhor. (...) Na sua terceira carta, você me relata as quantas malícias, armadilhas e calúnias lhe cercam de todos os lados. Nada disso me espanta. Pior que isto não me espantará. Porque o momento onde sua vontade se decidiu e onde suas forças tenderam para glorificar, honrar e servir a Deus nosso Senhor, era já declarada a guerra contra o mundo, erguido o estandarte contra o século e estava já disposta a desprezar as grandezas para abraçar a baixeza, decidida a aceitar indiferentemente elevação e abaixamento, honra e desonra, acolhida ou recusa, numa palavra, glória do mundo ou todas as injúrias do século. Não podemos fazer caso das afrontas sofridas nesta vida, quando elas não passam de palavras; todas juntas não conseguiriam arrancar-nos um cabelo. As palavras de duplo sentido, vilãs e injuriosas, não causam nem mais pena nem repouso quando as desejamos assim. Se nosso desejo é viver perfeitamente honrados e na gloriosa estima de nosso próximo, não nos será possível estar bem

\footnotetext{
${ }^{13}$ Ibid., p. 46.

14 A bem da verdade, no texto filosófico com o qual trabalhamos, o termo "indiferença" não aparece com a mesma carga semântica com a qual encontramos nos demais textos. Nos dois momentos em que aparece o termo, seu sentido é mais o vulgar do que aquele que será descrito a seguir. No entanto, outro termo bastante importante aparece no Comentário à Ética a Nicômaco: "meio-termo", que será analisado mais à frente.

15 Retomando o conteúdo do capítulo anterior, podemos dizer que a "indiferença", no nível da vontade, é o correspondente do "desengano", no nível da razão.
} 
enraizados em Deus nosso Senhor e seremos, então, infalivelmente feridos quando as afrontas se apresentarem ${ }^{16}$.

Não se trata de uma resignação ou aceitação do sofrimento per se. Mas, se trata de um olhar para tudo o que acontece - sejam honras ou desonras, sejam injúrias ou glórias, sejam palavras baixas ou não - que vê epifania onde só há inconsistência. A “indiferença”, nesse caso, é uma experiência que, nos Exercícios Espirituais, encontra seu paralelo no trecho em que Inácio distingue os "Três tipos de humildade":

$O$ primeiro tipo de humildade é necessário para a salvação eterna. Ele consiste em me abaixar e me humilhar o tanto quanto me for possível para que eu obedeça em tudo à lei de Deus nosso Senhor. De tal maneira que, mesmo que se fosse feito de mim o mestre de todas as coisas criadas neste mundo ou se se tratasse de minha própria vida temporal, eu não tencionaria transgredir um mandamento, seja divino que humano, que me obrigasse sob pena de pecado mortal ${ }^{17}$.

O segundo é uma humildade mais perfeita que a primeira. Consiste nisto: eu me encontro num tal ponto que não quero nem me ligo muito a ter a riqueza mais que a pobreza, querer honra mais que desonra, desejar uma vida longa mais que uma vida curta, sendo igual o serviço de Deus nosso Senhor e a salvação de minha alma; e além disso, mesmo diante do preço de tudo o que foi criado ou se quisessem me tirar a vida, eu não tencionaria cometer um pecado venial ${ }^{18}$.

O terceiro é uma humildade mais perfeita: é quando, incluindo a primeira e a segunda, o louvor e a glória de sua divina Majestade sendo iguais, para imitar a Cristo nosso Senhor e me parecer com Ele mais efetivamente, eu quero e escolho a pobreza com o Cristo pobre mais que a riqueza, os opróbrios com o Cristo coberto de opróbrios mais que as honras; e desejo ser tido por insensato e louco pelo Cristo que, primeiramente, foi tido como tal, mais que sábio e prudente neste mundo ${ }^{19}$.

Esses "graus" de humildade, tal como descritos, dizem respeito à progressiva realização do ideal de identificação com Cristo. Assim, humilde, o jesuíta se faz indiferente a seu desejo imediato, seu desejo mal ordenado, mal considerado; atento apenas ao horizonte último para o qual foi criado, como diz o Princípio e Fundamento, ou o Exercício 179:

É necessário notar que quando sentimos fixação ou repugnância com relação à pobreza efetiva, e quando não somos indiferentes à pobreza ou à riqueza, é bastante proveitoso, para extinguir esse afeto desordenado, pedir nos colóquios (mesmo que seja contra a carne) que o Senhor nos escolha para a

\footnotetext{
${ }^{16}$ Loyola, 1991, op. cit, pp. 635-636 (tradução nossa).

${ }^{17}$ Ibid., pp. 134-136 (EE. 165, tradução nossa).

${ }^{18}$ Ibid., p. 136 (EE. 166, tradução nossa).

${ }^{19}$ Ibid., p. 136 (EE. 167, tradução nossa).
} 
pobreza efetiva, e que nos a queiramos, a peçamos e a supliquemos, desde que seja para o serviço e o louvor de sua divina Bondade ${ }^{20}$.

A "indiferença” é fator de distinção da ordenação dos afetos: se o homem é criado para "louvar, reverenciar e servir a Deus nosso Senhor", ou "para a maior glória de Deus", é pois criado para reconhecer e ajudar às almas a também reconhecerem a Presença efetiva de Deus em toda a realidade, indiferentemente da qualidade desta. Viver a "indiferença", como o dissemos antes, é viver uma atenção à raiz da realidade, é viver um progressivo sair da ilusão de realidade na qual o homem, por seus afetos desordenados, está inicialmente imerso, para chegar à realidade mesma, que é Sinal de Deus e é ordenada a um fim glorioso ${ }^{21}$.

Ainda no texto dos Exercícios Espirituais, mas desta vez partindo para a relação entre a "indiferença" e o processo de eleição a que se dirigem os exercícios, Inácio, na "Primeira maneira para fazer uma sã e boa eleição", descreve, numa seqüência de pontos, um raciocínio acerca do modo de se eleger. Segundo ele, primeiramente, é necessário que o exercitante represente para si mesmo a coisa sobre a qual deseja fazer eleição; em seguida, atento ao fim para o qual foi criado, deve se colocar indiferente ${ }^{22}$; o passo seguinte é pedir a Deus que sua vontade se mova no sentido do que é mais justo, refletindo bem e inteligentemente sobre tudo o que se apresentar; depois, deve considerar, refletindo, as vantagens e proveitos, sempre ad maiorem Dei gloriam; para, em seguida, ver para qual lado a razão inclina mais e, então, eleger; finalmente, deverá oferecer a eleição a Deus.

Eleger, mais que fazer escolhas conforme um desejo particular, é, deliberadamente, se lançar ao continuum que, partindo do "conhecimento de si", passa pelo conhecimento da vontade de Deus, para chegar à sua atualização na vida pessoal: o jesuíta, indiferente ao modo

\footnotetext{
${ }^{20}$ Ibid., p. 144 (EE. 179, tradução nossa).

${ }^{21}$ Cf. EE. 16 (vide nota 24 deste capítulo).

22 "É necessário ter por objetivo o fim para o qual eu sou criado: louvar a Deus nosso Senhor e salvar minha alma; além do mais, devo me encontrar indiferente, sem nenhum vínculo desordenado, de tal sorte que eu não seja mais inclinado ou vinculado a ter a coisa visada que a deixá-la, nem mais a deixá-la que a tê-la. Mas que eu esteja no meio, como o centro de uma balança, para seguir aquilo que sentirei ser mais para a glória e para o louvor de Deus nosso Senhor e salvação de minha alma” (Ibid., p. 144, EE. 179, tradução nossa).
} 
e às condições de realização da vontade de Deus, se faz instrumento da glória de Deus, se torna um modelo imitável, na medida em que também imita o exemplo de realização de sua própria humanidade - o próprio Cristo -, tornando-se, finalmente, alguém em quem se pode reconhecer a "Majestade Divina" mesma: divinae naturae consortes.

Daqui provém a idéia de "imitação" ou mesmo a de "martírio" que aparecem em algumas cartas:

Como o Homem de Nazaré é o objeto adequado do desejo humano, todas as circunstâncias devem ser ordenadas na qualidade de meios voltados para a imitação da vida e da personalidade dEle. Esse é o ideal que deve nortear, segundo Inácio, o caminho histórico de cada homem e, com maior razão, a existência de um jesuíta ${ }^{23}$.

Mas, não se trata apenas de imitar a Cristo $^{24}$ : também os modelos ideais de santidade da Companhia e da Igreja são objetos desse desejo de imitação, como por exemplo o são o próprio Inácio de Loyola, Francisco Xavier, alguns missionários e mártires da Companhia, ou Santo Atanásio etc. Na medida em que esses homens não só se conformaram ao ideal jesuítico, mas também ao ideal da Igreja, suas vidas se tornam tipos perfeitos para a imitação. Nesse sentido, cabe mesmo lembrar que essa é uma tendência própria da "renascença" ${ }^{25}$, que é assumida com entusiasmo pelos jesuítas ${ }^{26}$ que encontram em suas fileiras um número cada vez mais crescente de santos mártires, no

\footnotetext{
${ }^{23}$ Massimi e Prudente, 2002, op. cit., p. 28.

${ }^{24}$ O EE. 98 diz o seguinte, a respeito da imitação de Cristo: "Senhor Eterno de todas as coisas, faço minha oferta, com vosso favor e vossa ajuda, em presença de vossa infinita bondade e em presença de vossa mãe gloriosa e de todos os santos e santas da corte celeste: quero e desejo, e é minha decisão determinada, desde que seja vosso maior serviço e vosso maior louvor, vos imitar suportando todos os ultrajes, todas as repreensões e toda a pobreza, efetiva ou espiritual, se vossa santíssima Majestade quiser me escolher e me receber nesta vida e neste estado" (Ibid., p. 106, EE. 98, tradução nossa).

${ }^{25}$ Cf. Mozzarelli, Cesare e Zardin, Danilo (orgs.) (1997). I tempi del Concilio: Religione, cultura e società nell'Europa tridentina. Roma: Bulzoni Editora. No texto de Sodano - "Il nuovo modello di santità nell'época post-tridentina" (pp. 189-205) - se afirma, por exemplo, que, no período tridentino e pós-tridentino, se assiste a uma mudança no conceito de santidade que passa ser entendida como modelo único (e não mais próprio de realidades locais e populares, como o era na idade média) e reconhecido pela hierarquia romana. É nesse período, segundo Sodano (1997) que aparece a fórmula da virtude heróica, definida como uma capacidade de executar ações difíceis, bem como se exercitar nas virtudes teologais, mesmo que com risco de morte. Assim, essa virtude heróica, assim entendida, passou a ser critério importante nos processos de beatificação, colocando o martírio na esteira dos principais motivos. Cf. também Massimi e Prudente (2002).

${ }^{26}$ Cf. Iparraguirre, Ignácio (1964). Estilo Espiritual Jesuítico (1540-1600). Bilbao: El Mensajero del Corazón de Jesús e também Guibert, Joseph (1941). Le Généralat de Claude Aquaviva (1581-1615): une place dans l'histoire de la spiritualité de la Compagnie de Jésus. AHSI, 10. Romae, 59-93.
} 
período do Generalato do Padre Aquaviva:

Deus suscitou [santos] (...) entre os jesuítas, como modelos e protetores de toda as formas de sua vida e de seu apostolado, mesmo que não nos atenhamos apenas àqueles dos quais a santidade foi proclamada pela Igreja. Os missionários primeiro e os mártires: em 1583, o Bem-Aventurado Rodolfo Aquaviva e seus companheiros são massacrados em Salsete perto de Goa; em 1597, os três santos japoneses Paulo Miki, João de Goto e Tiago Kisai são crucificados em Nagasaki e serão seguidos, pouco depois, em 1615, por toda uma plêiade de Bem-Aventurados, mártires da grande perseguição japonesa. $\mathrm{Na}$ Inglaterra encontramos os Bem-Aventurados Campion e Briant em 1581, Cottam em 1582, Cornelius em 1594, Southwell e Walpole em 1595, Page em 1602, Owen, Oldcorne et Ashley em 1606, Garnet em 1608, Ogilvie em 1615. Na França, os Bem-Aventurados Jacques Salès e Guillaume Sautemouche caem vítimas dos protestantes em $1593^{27}$.

Trata-se sempre de santos homens que levaram a termo o chamado de Deus para suas vidas, sua “vocação".

Outro aspecto importante quanto a este topos aparece na sua relação com a “obediência" propriamente dita. Em 01 de junho de 1551, escrevendo uma espécie de tratado sobre o reitorado ao então reitor do Colégio de Coimbra - Urbano Fernandez -, Inácio, pelas mãos de Polanco, lembra a importância de se ser indiferente na obediência:

Ele [Inácio] deseja, nos membros da Companhia, a renúncia de sua vontade pessoal e a indiferença para tudo aquilo que lhes será ordenado. Seu exemplo habitual é a bengala do velho, que se deixa manobrar inteiramente pela conveniência de quem a usa, ou ainda o exemplo do cadáver que vai, sem repugnância alguma, para onde o levam e não para onde quer. Tendo, sempre, o hábito de se informar acerca das inclinações (para o estudo, por exemplo, ou para uma outra maneira de servir), [a Inácio] agrada aplicar ao estudo aqueles que só tem afeição particular para a execução da vontade de Deus nosso Senhor, interpretada pela obediência, mais que aqueles que teriam um grande desejo de estudar ${ }^{28}$.

Aqui se vê como a "indiferença" é critério importante para a escolha de um jesuíta para determinado serviço: é escolhido somente aquele que tem "afeição particular para a execução da vontade de Deus nosso Senhor, interpretada pela obediência”.

Em outra carta - a conhecida "Carta da Obediência" -, de 26 de março de 1553, esta relação acima descrita aparece mais uma vez:

Se fores, em alguma coisa, de opinião diferente a do superior, ou depois de ter

\footnotetext{
${ }^{27}$ Guibert, 1941, op. cit., p. 92 (tradução nossa).

${ }^{28}$ Ibid., p. 783 (tradução nossa).
} 
rezado, julgais, sob o olhar de Deus, ser coisa boa lhe apresentar sua opinião, não podereis fazê-lo. Porém, se neste domínio desejais que vossa diligência não possa ser suspeitada de amor-próprio ou de julgamento pessoal, deveis permanecer igualmente indiferentes (...) não somente a empreender ou a abandonar a execução da coisa em questão, mas ainda a aprovar e a considerar como melhor tudo aquilo que o superior ordenar ${ }^{29}$.

Neste contexto, a "indiferença" é uma abertura, no relacionamento com a figura que ocupa o lugar de autoridade, cheia de razoabilidade e discernimento, sobretudo porque o jesuíta, quanto ao que se refere a este exercício, é educado a uma atenção à misteriosidade significada na ordem do Superior.

Vejamos agora como a "experiência-modelo" de Inácio atualiza a "experiência do meio-termo". No Diário de Moções Interiores podemos identificar algumas passagens que apontam claramente para um vivido particularmente compreendido como "indiferença"; por exemplo neste trecho escrito no dia 08 de março de 1544 :

Começando a missa, e durante todo o tempo, muita devoção interior e calor espiritual, e não sem lágrimas, e com uma persistência de devoção e disposição a chorar. Nesses intervalos de tempo, ainda que eu tivesse a intenção de não levantar os olhos da inteligência e de me esforçar por ser contente por tudo, rezando mesmo para que, à igual glória de Deus, ele não me visitasse com as lágrimas, acontecia que a inteligência ia para o alto instintivamente e me parecia ver alguma coisa do ser divino, o que, em outras vezes, quando eu o queria, não estava em meu poder $^{30}$.

Alguns dias mais tarde, nova descrição, esta do domingo, dia 16 de março de 1544 :

Antes e durante toda a missa, muitas lágrimas; a devoção e as lágrimas dirigidas a uma ou outra Pessoal [da Santíssima Trindade]; sem visões claras ou distintas. Feita a oração no quarto, antes da missa, para que me seja dada a graça do respeito, da reverência e da humildade e, quanto às visitas ou às lágrimas, que elas não me sejam dadas, se igual fosse o serviço de sua divina Majestade, ou para que eu gozasse de suas graças e visitas puramente, sem nada de meu próprio interesse ${ }^{31}$.

Nos dois trechos, podemos perceber como ao fundador interessava mais o "serviço de sua divina Majestade" que as experiências de consolação imediatas que vinha fazendo ao

\footnotetext{
${ }^{29}$ Ibid., p. 841 (tradução nossa).

${ }^{30}$ Ibid., p. 354 (§ 136, tradução nossa).

${ }^{31}$ Ibid., p. 359 (§ 159, tradução nossa).
} 
longo do processo eletivo acerca da pobreza na Companhia de Jesus ${ }^{32}$.

Nas Constituições, o termo "indiferença" também comparece. A primeira vez vem vinculado à tipologia de candidatos a ingresso na Ordem. Segundo o texto, há os que fazem profissão na Companhia e emitem quatro votos solenes (apenas os candidatos "de instrução suficiente" ${ }^{33}$ ), há os coadjutores espirituais ou temporais (que "devem fazer três votos simples de obediência, pobreza e castidade, sem fazer o quarto voto de obediência ao Papa, nem outro voto solene",34), os que são recebidos como estudantes ("quando parecem ser capazes e têm as outras qualidades que convêm aos estudos; assim, poderão, depois de terem sido instruídos, entrar na Companhia como professos ou como coadjutores, segundo se julgar conveniente" ${ }^{\natural 5}$ ), e finalmente existem aqueles que "se aceitam sem que seja determinado aquilo para que serão aptos com o tempo",36, que são os chamados "indiferente".

Na seqüência, o texto jurídico, no Capítulo 8 - "Outro exame para os indiferentes" do Exame Geral, reza o seguinte:

A fim de melhor conhecer aquele que deve ser examinado enquanto indiferente, e a fim que se aja de um lado e de outro com mais conhecimento e clareza em nosso Senhor, se lhe informará e advertirá que em nenhum momento nem por nenhum meio ele pode ou deve 'buscar ou tentar' [No entanto, quando uma coisa lhes pareça com persistência para uma maior glória de Deus nosso Senhor, eles poderão, depois de terem rezado, propor simplesmente ao superior e colocála inteiramente sob o seu julgamento, sem buscar nada diferente em seguida ${ }^{37}$ ], direta ou indiretamente, ter na Companhia um grau superior que um outro, não mais o de professo ou de coadjutor espiritual que o de coadjutor temporal ou estudante. Mas, abrindo-se a uma total humildade e a uma total obediência, deve deixar todo o cuidado de si, e a escolha de seu emprego ou de seu estado, a seu Criador e Senhor e, em seu nome, e por seu divino amor e respeito, à Companhia ou àquele que for seu Superior ${ }^{38}$.

Estando assim advertido, se lhe perguntará se é perfeitamente indiferente, calmo e preparado para servir seu Criador e Senhor em não importa qual emprego ou serviço, segundo aquilo que a Companhia ou seu superior lhe

\footnotetext{
${ }^{32}$ Como visto, sabemos que o conjunto de papéis a que temos acesso do grosso maço referente ao Diário de Inácio equivale aos dias em que, preparando o texto das Constituições, o santo procurava eleger acerca do voto de pobreza na Companhia de Jesus.

${ }^{33}$ Ibid., p. 398 (Const. § 10, tradução nossa).

${ }^{34}$ Ibid., p. 398 (Const. § 12, tradução nossa).

${ }^{35}$ Ibid., p. 398 (Const. § 14, tradução nossa).

${ }^{36}$ Ibid., pp. 398-399 (Const. § 15, tradução nossa).

${ }^{37}$ Ibid., p. 424 (Const. $\S 131$, tradução nossa). No texto utilizado, essa nota colocada entre colchetes aparece como uma Declaração acerca do "Exame Geral".

${ }^{38}$ Ibid., p. 424 (Const. $§ 130$, tradução nossa).
} 
ordenar. Se lhe perguntará igualmente, no caso em que a Companhia ou seu superior lhe queira para sempre somente em empregos baixos e humildes (ele, se devotando à salvação de sua alma), se ele está pronto a passar todos os dias de sua vida nestes empregos baixos e humildes para o bem e o serviço da Companhia, crendo, por meio disso, servir e louvar seu Criador e Senhor, fazendo todas as coisas por amor e reverência de Deus ${ }^{39}$.

Se ele está plenamente contente em nosso Senhor de tudo o que foi dito, poderse-á informá-lo e examiná-lo sobre o resto, pelo menos de alguns ou de todos os exames dos quais se falou, segundo o que parecer mais conveniente. Assim, as duas partes estarão contentes e satisfeitas, e agirão em tudo com uma maior clareza; todas as coisas estando conduzidas e ordenadas em vista de um maior serviço e de um maior louvor de Deus nosso Senhor ${ }^{40}$.

Aqui, como nos dois trechos de cartas selecionados, notamos a relação entre a "indiferença", a "humildade" e a "obediência": o candidato indiferente deverá se submeter à obediência, seguro de que sua vida será empregada "para a maior glória de Deus". A satisfação e a alegria que experimentarão as duas partes (o indiferente e a Companhia) será o critério demonstrativo da realização da vontade de Deus finalmente.

Mais à frente, no texto das Constituições, no Capítulo 3 (“Quando se vai de própria iniciativa a uma região ou a outra”), da $7^{\mathrm{a}}$ Parte (“O que concerne às relações com o próximo daqueles que já foram admitidos no corpo da Companhia, quando se os reparte na vinha de Cristo nosso Senhor"), declara-se:

Aqueles que vivem sob a obediência da Companhia não têm nenhum direito de intervir, nem direta nem indiretamente, nas missões que lhes concernem, quer sejam enviados por Sua Santidade ou pelos superiores em nome de Cristo nosso Senhor. Sempre, aquele que será enviado a um grande país tal como as Índias ou outras províncias, sem que nenhuma região lhe seja especialmente delimitada, pode parar por mais ou menos tempo num lugar ou outro, e, depois de ter considerado todas as coisas, se encontrando indiferente na sua vontade e depois de ter feito oração, pode ir a qualquer lugar onde julgue mais oportuno para a glória de Deus nosso Senhor ${ }^{41}$.

Este trecho impressiona pela liberdade de ação que é permitida ao "indiferente": "pode parar por mais ou menos tempo num lugar ou outro", "pode ir a qualquer lugar". Em última instância, livre das afeições desordenadas, o jesuíta "indiferente" se torna,

\footnotetext{
${ }^{39}$ Ibid., p. 424 (Const. $§ 132$, tradução nossa).

${ }^{40}$ Ibid., p. 424 (Const. $§ 133$, tradução nossa).

${ }^{41}$ Ibid., p. 554 (Const. $§ 633$, tradução nossa).
} 
paulatinamente, protagonista responsável da glória de Deus. Esta espécie de permissividade é outorgada àquele que de tal forma se identifica com o corpo da Companhia, de tal forma se identifica, portanto, como companheiro de Jesus, que ao fim quase se confunde com o Cristo obediente: trata-se da experiência de filiação tanto prefigurada pela norma, como querida pelo jesuíta desenganado.

Nesse sentido, o Relato do Peregrino Inácio é bastante significativo. Apesar de o topos "indiferença" não constar uma única vez sequer, é interessante notar como Inácio se portava ante o desejo que sentia e a maneira de realizar esse desejo: por exemplo, na decisão de ir a Jerusalém. Tendo encontrado dificuldade em permanecer em Jerusalém, em 1523, Inácio que andava com a certeza de que Deus queria que estivesse ali, resolve sair furtivamente do grupo de peregrinos a fim de rever a pedra de onde Cristo ascendeu aos céus. Pelo que consta, Inácio precisava ter clara a posição dos pés de Jesus (de que lado se encontrava o pé esquerdo e de que lado o direito) impressos na pedra (segundo a tradição, ficaram impressas duas marcas na pedra), a fim de ler nelas algum sinal positivo da vontade de Deus ${ }^{42}$. Mesmo que todos os sinais anteriores (a negação do Provincial dos monges responsáveis por alguns dos lugares santos e a ameaça de excomunhão, os perigos de andar sem um guia turco, a interdição de entrar no Monte das Oliveiras para ver as pegadas de Cristo etc.) mostrassem claramente a impossibilidade de permanecer e a necessidade de ir-se, Inácio manteve firme o desejo de permanecer, baseado na certeza a que chegou a partir da autorização do Papa e da chegada a Jerusalém, não obstante tudo o que havia conspirado até então para que não chegasse. Haveria para ele, portanto, algo ali que o Senhor queria lhe dizer. O que nos parece antes uma "teimosia" ou mesmo uma "desobediência", na "experiência-modelo" de Inácio pode ser entendido como "indiferença" desde que se compreenda o movente que está por trás desta atitude:

\footnotetext{
${ }^{42}$ Cf. Ibid., pp. 1038-1045.
} 
conhecer a vontade de Deus e ajudar as almas. Nesse sentido, ele se encontra verdadeiramente "indiferente", na medida em que não tem medo do que se apresenta como obstáculo, mas vai até o fim do mínimo sinal que encontrou ${ }^{43}$.

É essa mesma atitude que o move logo após sua conversão, quando decide sair como soldado em defesa de Cristo e vai se preparando desde Manresa até Paris, se dedicando aos estudos, enfrentando as acusações da Inquisição de que era um "alumbrado"44, aplicando os Exercícios Espirituais, entabulando conversas devotas e edificantes: é indiferente a maneira como realizará o desejo inicial de ajudar as almas e permitir a maior glória de Deus, o importante é que em tudo se realize esse desejo até o fim. Esse mesmo desejo que fica, dia após dia, mais claro, na atenção aos sinais que lhe são dados pela realidade: encontros que faz, intuições que tem, graças que recebe, compreensões e visões que tem etc. Em Inácio, a "indiferença" é experimentada até as últimas conseqüências, até o ponto em que, parafraseando São Paulo, se pode dizer que Inácio vive, mas não ele, é Cristo quem vive nele ${ }^{45}$. A “indiferença”, como o afirma Fernandez-Martos (1991), em Inácio, é diferenciação e identificação: diferenciação da realidade e identificação total com Cristo $^{46}$.

Entre os textos de espiritualidade, aparece, por exemplo em Nieremberg (1657) a seguinte referência ao conceito de "indiferença":

Il y a donc cette difference entre les choses qui nous appartiennent, \& celles

\footnotetext{
43 A hipótese da relação entre "indiferença" e "coragem" é desenvolvida por Barros, Mariana Leal (2004). Releituras da indiferença: um estudo baseado em cartas de jesuítas dos séculos XVI e XVII. Monografia de final de curso não publicada. Faculdade de Filosofia, Ciências e Letras de Ribeirão Preto/USP, Curso de Psicologia. 44 “Alumbrados" era o nome assumido por alguns falsos místicos espanhóis do século XVI, que diziam ter contato direto com Deus. Para eles, a alma humana poderia alcançar um tal grau de perfeição que chegaria a contemplar ainda nesta vida a essência de Deus e compreender o mistério da Trindade. Declaravam supérfluo todo rito de adoração, bem como a recepção dos sacramentos, afirmando a união completa com Deus como solução. Afirmavam também que o desejo carnal e outras más ações não manchavam a alma. A perfeição mais elevada a que deve se exercitar o cristão é, segundo esses místicos, a eliminação completa de toda a atividade, a perda da individualidade e a completa absorção em Deus. Tidos como hereges, os "alumbrados" foram perseguidos pela Inquisição. Santo Inácio também foi perseguido pela Inquisição como "alumbrado", mas conseguiu provar sua inocência.

${ }^{45}$ Na carta de São Paulo aos Gálatas $(2,20)$, encontra-se a seguinte expressão: “Já estou crucificado com Cristo; e vivo, não mais eu, mas Cristo vive em mim; e a vida que agora vivo na carne, vivo-a na fé no filho de Deus, o qual me amou, e se entregou a si mesmo por mim".

${ }^{46}$ Fernandez-Martos, 1991, op. cit.
} 
qui dépendent de la Fortune, que celles-là sont libres, \& celles-cy ne sont pas. C'est pourquoy si nous voulons nous conserver ce rare avantage de ne relever que de nous-mesmes, nous devons tenir pour indifferent ce qui n'est point en nostre puissance; autrement certes, nous sçaurions éviter de devenir esclaves; nostre passion fera nostre servitude; elle sera le titre en vertu duquel nous passerons entièrement au pouvoir d'autruy ${ }^{47}$.

Em outra de suas obras - Vida Divina e camino real de grande atajo para la perfección - Nieremberg (1957) afirma no Capítulo XX (que se chama "Como se conhecerá a vontade divina para cumpri-la em tudo, endereçando sem enganos nossas obras a Deus”):

Hemos de procurar una grand indiferencia, no inclinando el afecto más a una cosa que a otras; porque facilísimamente arrebata al juicio tras de sí cualquier afición menos ordenada, y le perturba para que conozca la verdad, o que en lugar de ella abrace un engaño (...). Para llegar a esta indiferencia se ha de proponer delante el fin para que fué uno criado, y que todas las demás cosas san medios en orden a alcanzar nuestro fin, que es la gloria de Dios y cumplimiento de su santísimo querer; y supuesto que son medios, non han de tener razón de quererse ni amarse, sino en cuanto conducen para lo que son. De donde se saca que hemos de estar indiferentes par cualesquiera cosas, y no inclinarnos a elergilas o quererlas, sino es en cuanto viéremos que nos llevan a nuestro fin y a cumplir la voluntad de Dios; porque en faltando estas falta la razón de quererse ${ }^{48}$.

Entram em jogo nesta descrição de "indiferença" topoi importantes descritos no capítulo anterior ou a eles relacionados (como "juízo", "conhecimento da verdade", "vocação"), além de um encadeamento dos termos que analisamos aqui.

Num capítulo anterior da mesma obra (denominado "Os graus da pura intenção necessários parar cumprir em tudo a vontade de Deus”), Nieremberg explica que é necessária

\footnotetext{
${ }^{47}$ Nieremberg, Juan Eusebio (1657). L'art de conduire la volonté selon les precepts de la morale ancienne \& Moderne, tirez de Philosophes Payens \& Chrestiens. Traduit du latin de Jean Eusebe de Nieremberg, Paraphrase \& de beaucoup enrichy par Loü̈s Videl, de Dauphiné. Dedié à Monsieur de Lionne, Conseiller d'Estat ordinaire \& secretaire des Commandemets de la Reyne Regente. Paris: Chez Jean Pocquet, p. 147 ("Existe portanto esta diferença entre as coisas que nos pertencem e as que dependem da Fortuna: aquelas são livres, e estas não o são. É por isso que se nós queremos nos conservar esta rara vantagem de depender apenas de nós mesmos, devemos ter por indiferente o que não está em nada sobe o nosso poder; certamente, assim, saberíamos evitar nos tornar escravos; nossa paixão será nossa servidão; ela será o título em virtude do qual passaremos inteiramente ao poder de outros", tradução nossa)

${ }^{48}$ Nieremberg, Juan Eusebio (1957). Obras escogidas del R. P. Juan Eusebio Nieremberg (E. Zepeda-Henriquez, ed.). Biblioteca de Autores Españoles, desde la formación del lenguaje hasta nuestros dias (continuación). Tomo 103. Madrid: Ediciones Atlas, p. 57 ("Temos que procurar uma grande indiferença, não inclinando o afeto mais a uma coisa que a outras; porque muito facilmente arrebata o juízo depois dele qualquer afeição menos ordenada, e o perturba para que conheça a verdade, ou que em lugar dela abrace um engano. (...) Para chegar a esta indiferença se proporá diante do fim para que foi criado, e que todas as demais coisas são meios em ordem para alcançar nosso fim, que é a glória de Deus e o cumprimento de seu santíssimo querer; e suposto que são meios, não terão razão de querer-se ou amar-se, senão enquanto conduzem para o que são. De onde se tira que temos de estar indiferentes para quaisquer coisas, e não inclinarmo-nos a elegê-las ou querê-las, senão é enquanto vermos que nos levam a nosso fim e a cumprir a vontade de Deus; porque faltando estas falta a razão de querer-se", tradução nossa).
} 
a "indiferença acerca das obras para fazer estas ou aquelas, deste modo o daquele outro" 49 , porque, segundo ele, "se o coração se apega a alguma coisa, não vai todo puro, principalmente nas obras indiferentes e que são conformes à inclinação da natureza" ${ }^{50}$. Indica, nesse sentido, a importância da "experiência do meio-termo" para uma progressiva conformidade à natureza humana, ou, nos termos por ele utilizados, uma conformidade ao "fim para que foi criado", ou seja, "o cumprimento do santíssimo querer" de Deus.

Mais à frente, tratando do "Quanto importa a obediência para a mortificação, pureza de intenção e conformidade com a vontade de Deus", num trecho anteriormente apresentado, Nieremberg descreve as boas conseqüências de uma estima pela "obediência": a “mortificação", o "aproveitamento espiritual” etc.:

De todo lo dicho hemos de sacar una incomparable estima de la virtud de la obediencia, virtud riquísima y poderosa para llenar un corazón de bienes espirituales y colmarle de grandes merecimientos; virtud poderosa para subir un alma a grande perfección en breve tiempo. Ella es una vida de ángeles que tienen por ocupación hacer la voluntad de Dios, significada por sus superiores; ella es una perfecta imitación del Hijo de Dios; ella es la quietud de las passiones; ella es el descanso del corazón; ella es el sosiego del alma, ella es el vuelo al Cielo; ella es la causa de aprovechamiento espiritual, ella es el atajo de la perfección ${ }^{51}$.

Acerca da "mortificação", em carta enviada a Urbano Fernandez no dia 01 de junho de

1551, Polanco lembra ao reitor português o quanto importa a Inácio a "obediência” e um certo cuidado com a "mortificação":

Para aqueles que já foram admitidos, lembro que o ponto para o qual ele [Inácio] vela com mais cuidado e que mais o desola quando vê que negligenciam (...), é a obediência. Ela deve não somente se estender à execução da ordem, mas também a fazer sua a vontade do superior, a ter os mesmos sentimentos que ele (...). Ele estima que é imperfeita a obediência do sujeito que se contenta em fazer e querer aquilo que se lhe ordena, sem julgar também que ele deve fazê-lo. (...) Quanto às mortificações, lembro que ele [Inácio] prefere e estima mais aquelas que tocam a honra e o amor

\footnotetext{
${ }^{49}$ Ibid., p. 56 (tradução nossa).

${ }^{50}$ Ibid., p. 56 (tradução nossa).

51 Ibid., p. 70 ("De tudo o que foi dito, temos que tirar uma incomparável estima da virtude da obediência, virtude riquíssima e poderosa para encher um coração de bens espirituais e fartá-lo de grandes merecimentos; virtude poderosa para uma alma subir à grande perfeição em breve tempo. Ela é uma vida de anjos que têm a ocupação de fazer a vontade de Deus, significada por seus superiores; ela é uma perfeita imitação do Filho de Deus; ela é a quietude das paixões; ela é o descanso do coração; ela é o sossego da alma, ela é o vôo para o Céu; ela é a causa de aproveitamento espiritual, ela é o atalho da perfeição", tradução nossa).
} 
próprio àquelas que afligem a carne, tais como jejuns, disciplinas e cilícios ${ }^{52}$.

Impressiona a moderação com que Inácio fala acerca dos exercícios de mortificação.

Por exemplo, em outra carta, enviada de Roma no dia 20 de setembro de 1548 ao ainda então duque de Gandía, Francisco de Borja, Inácio chama a atenção do amigo quanto às longas e penosas mortificações a que vinha se dedicando. O ponto de partida de Inácio é sua própria experiência, oferecendo a Borja a substância mesma de uma mística da boa medida e da ponderação interior. O tom caridoso da carta, de fato, é bastante significativo: Inácio começa apontando o valor da ascese de Borja até chegar a enumerar algumas regras que melhor norteassem as boas intenções do duque. Trata-se de uma atenção ao outro que nasce da própria atenção aos movimentos produzidos em sua alma no percurso que seguiu até chegar onde chegou. Seu primeiro pedido, na carta, é que Borja diminua pela metade o tempo dedicado aos exercícios ascéticos e dedique a outra metade ao estudo:

A partir de agora, um tal arsenal não sendo necessário para vencer o inimigo, no tanto que em nosso Senhor posso julgar por ti, preferiria que a metade do tempo seja convertida em estudo, porque a ciência, não somente a infusa mas também a adquirida, será sempre muito necessária ou útil no futuro ${ }^{53}$.

Em seguida, comentando quando escreve sobre os jejuns e abstinências, Inácio lembra que "seria necessário, 'para nosso Senhor', conservar e fortificar o estômago e as outras forças naturais e em nada as debilitar" ${ }^{, 54}$, porque "devemos, com efeito, amar e cuidar de nosso corpo na mesma medida em que ele obedece e ajuda a nossa alma",55. Quanto às macerações corporais, o fundador pede ao nobre companheiro que deixe de lado tudo o que possa "derramar uma só gota de sangue", e se ocupar mais do "Senhor de todos", buscando "uma iluminação ou bem de lágrimas, seja que se as chore sobre seus próprios pecados ou sobre aqueles de outros, seja que se as encontre nos mistérios de Cristo nosso Senhor na sua

\footnotetext{
${ }^{52}$ Loyola, 1991, op. cit., p. 783 (tradução nossa).

${ }^{53}$ Ibid., p. 735 (tradução nossa).

${ }^{54}$ Ibid, pp. $735-736$ (tradução nossa).

${ }^{55}$ Ibid., p. 736 (tradução nossa).
} 
vida terrestre e na outra, ou ainda na contemplação e amor das Pessoas divinas" ${ }^{\text {"56 }}$. E continua,

já no fim da carta:

Não importa qual desses 'dons santíssimos' deve ser preferido entre todos os atos de penitência corporal, dado que são bons na medida em que têm por objeto a obtenção desses dons ou 'uma parte' deles. Não quero dizer que devamos 'somente' os buscar para nos comprazermos neles ou neles nos deleitarmos, mas, convencidos no fundo de nós mesmos que sem eles nossos pensamentos, nossas palavras e nossas obras misturadas, frias e agitadas, para que se tornem quentes, claras e justas para o maior serviço de Deus, devemos desejar esses dons, tudo ou parte, e essas graças espirituais, na medida em que podem nos ajudar para a maior glória de Deus ${ }^{57}$.

Dessas duas cartas do fundador coligimos um importante aspecto da formas mentis do jesuíta quanto a este aspecto: a mortificação, exercício para que se alcance o verdadeiro aproveitamento e se caminhe mais diretamente no rumo do Reino dos Céus, na experiência espiritual da Companhia, tem como modelo de autoridade a vida de Inácio. Sem o exercício da virtude da obediência - forma de seguimento cheia de razões -, correr-se-ia o risco de uma dedicação a formas de mortificação humana e institucionalmente inadequadas.

De fato, o texto da Summa aponta claramente essa questão quando adverte:

Eis o que pudemos explicar sobre nossa profissão numa sorte de rascunho. Nós o fazemos agora para informar sumariamente por este texto escrito àqueles que nos interrogam sobre nosso gênero de vida e também àqueles que virão depois de nós, se Deus quer tenhamos sempre imitadores neste caminho. Tendo nós mesmos experimentado que este caminho comporta numerosas dificuldades, julgamos oportuno advertir a estes que não caiam sob pretexto de bem, nos dois perigos que evitamos. O primeiro: não impor aos companheiros, sob pena de pecado mortal, jejuns, disciplinas, ir onde quer que seja com os pés descalços ou a cabeça descoberta, vestimentas de tal cor, regimes particulares de alimentação, penitências, cilícios e outras mortificações corporais. No entanto, não impedimos isto porque o condenemos ${ }^{58}$, já que o louvamos e o admiramos bastante entre aqueles que o praticam, mas somente porque não queremos que os nossos sejam esmagados por tanto peso acumulado, ou que encontrem nisso pretexto para deixar de lado as atividades que nós nos propomos realizar. Cada um poderá, entretanto, se o Prepósito não impedir, se dedicar com devoção às mortificações que saberá lhes serem necessárias ou úteis. O segundo: ninguém seja recebido nesta Companhia a não ser depois de ter sido primeiramente longa e cuidadosamente experimentado, e quando se tiver constatado

\footnotetext{
${ }^{56}$ Ibid., p. 736 (tradução nossa).

${ }^{57}$ Ibid., p. 737 (tradução nossa).

58 Esta observação é bastante significativa, dado que, naquele período, sob o risco de serem considerados seguidores dos "alumbrados", importava sobremaneira a confirmação do respeito à tradição católica e a perfeita justificativa das opções feitas.
} 
que é prudente em Cristo e se distingue por sua doutrina ou por sua santidade de vida ${ }^{59}$.

Não obstante este aviso, Inácio, alguns anos antes da redação definitiva da Summa, escrevia a sua confidente Teresa Rejadell, aos 18 dias de junho de 1536, dizendo que, entre as armas usadas pelo "Inimigo da natureza humana", poder-se-ia localizar o medo da mortificação ou das penitências: apresentando-nos a dureza de uma vida mortificada, o "Inimigo" desvia nosso olhar "das consolações tão numerosas concedidas habitualmente pelo Senhor quando seu novo servidor ultrapassa todas estas dificuldades, escolhendo querer sofrer com seu Criador e Senhor"60.

De forma que, então, fica clara a posição de Inácio acerca do costume de se impor penitências e mortificações várias: não se trata, de fato, de um antagonismo tout court, mas de uma preocupação sincera com os possíveis resultados de tais exercícios num corpo que em tudo deveria se dispor a trabalhos tão exigentes. É, pois, preciso sim um certo desvelo no caminho da perfeição, sempre porém com um atenção a regrar-se com a ajuda da obediência ao confessor ou a um Superior:

O castigo corporal não deve ser imoderado, nem sem discernimento, nos jejuns, "vigílias", em outras penitências exteriores e nos "trabalhos" que prejudicam e que impedem maiores bens. Por esta razão convém que cada um mantenha seu confessor informado daquilo que faz neste domínio; se parecer ao confessor que existe algum excesso ou se ele tiver dúvidas a este respeito, que se leve a coisa ao superior. Tudo isso para que se proceda com mais luz e para que Deus nosso Senhor seja bastante glorificado em nossas almas e nossos corpos ${ }^{61}$.

O texto das Constituições, mais à frente, volta a afirmar que toda mortificação só será aceita na medida em que não prejudique as "capacidades psíquicas e as ocupações exteriores assumidas por caridade e obediência"62, lembrando que, para que isso se dê de forma razoável, "basta que o confessor seja sempre mantido informado e, em caso de dúvida sobre o

\footnotetext{
${ }^{59}$ Loyola, 1991, op. cit., pp. 304-306 (tradução nossa).

${ }^{60}$ Ibid., p. 643 (tradução nossa).

${ }^{61}$ Ibid., p. 468 (Const. $§ 300$, tradução nossa).

${ }^{62}$ Ibid., p. 537 (Const. § 582, tradução nossa).
} 
que convém, igualmente o superior":

Dever-se-á ter atenção a que os excessos neste domínio não enfraqueçam de tal forma as forças do corpo e tomem de tal forma o tempo, que não haja suficiente ajuda ao próximo, segundo nosso Instituto; ao invés, velar-se-á para que não haja um tal relaxamento nestas coisas que o espírito resfrie e que se aqueçam as paixões humanas e baixas ${ }^{63}$.

Também as "Adições para melhor fazer os exercícios e para melhor encontrar o que se deseja”, nos Exercícios Espirituais, retoma longamente a questão das mortificações ou penitências, diferenciando-as entre internas e externas: as primeiras, aquelas que permitem ao exercitante uma atenção aos movimentos da alma durante a oração, bem como uma aflição pelos próprios pecados, até o ponto de se dar “o firme propósito de não cometer nem este nem outros quaisquer" ${ }^{\prime 64}$; as segundas, aquelas que respeitam aos movimentos das paixões e da sensibilidade, e consistem num "castigo pelos pecados cometidos"65. Quanto às últimas, Inácio dedica três exercícios para descrevê-las: 1) as penitências que concernem à alimentação $^{66}$; 2) as que concernem ao sono $^{67}$ e 3 ) as que concernem ao castigo da carne, infligindo "dor sensível"68. Em seguida, sublinha:

As penitências exteriores se fazem principalmente em vista de se obter três efeitos: 1. Para a satisfação dos pecados passados. 2. Para vencer-se a si mesmo, quer dizer para que a sensibilidade obedeça à razão e que todas as partes inferiores sejam bastante submissas às superiores. 3 . Para buscar e encontrar alguma graça ou algum dom que se queira o se deseje; como, por exemplo, se se deseja ter uma contrição interior de seus pecados, ou chorar abundantemente sobre eles ou sobre as penas e dores que Cristo nosso Senhor suportou na sua Paixão, ou resolver alguma dúvida na qual se encontra ${ }^{69}$.

É interessante, antes de avançarmos, verificarmos como na vida de Inácio, de fato, se deu o caminho na "mortificação". No Relato, P.e Luis Gonçalves da Câmara, quando narra a peregrinação do Fundador rumo a Montserrat, escreve:

Neste caminho lhe aconteceu uma coisa que será bom escrever para que se

\footnotetext{
${ }^{63}$ Ibid., p. 537 (Const. § 582, tradução nossa).

${ }^{64}$ Ibid., p. 98 (EE. 82, tradução nossa).

${ }^{65}$ Ibid., p. 98 (EE. 82, tradução nossa).

${ }^{66}$ Ibid., p. 98 (EE. 83, tradução nossa).

${ }^{67}$ Ibid., p. 98 (EE. 84, tradução nossa).

${ }^{68}$ Ibid., p. 98 (EE. 85, tradução nossa).

${ }^{69}$ Ibid., p. 100 (EE. 87, tradução nossa).
} 
compreenda como nosso Senhor se comportava com esta alma que era ainda cega, se bem que desejasse O servir em tudo que ela pudesse conhecer. E assim ele decidiu fazer grandes penitências, tendo em vista apenas o desejo de satisfazer seus pecados sendo o mais agradável possível a Deus (...). E assim, quando se lembrava de alguma penitência que os santos haviam feito, ele se propunha de fazê-la e, às vezes mesmo, mais. E ele encontrava toda sua consolação nestes pensamentos, não considerando nenhuma coisa interior e não sabendo o que eram humildade, caridade, paciência ou discernimento para regrar e medir estas virtudes. Mas toda sua intenção era de fazer grandes obras exteriores porque os santos haviam-nas feito para a glória de Deus, sem considerar nenhuma circunstância mais particular ${ }^{70}$.

No percurso de conversão de Inácio, nesse primeiro momento, o exercício das

mortificações era ainda pouco regrado pela razão, mas suficientemente marcado pela imitação,

o que, de alguma forma impedia que incorresse em erro grave ou que causasse a si mesmo dano

grave a sua saúde física e mental. No entanto, sabe-se que, durante toda a sua vida, Inácio se preocupou em penitenciar-se de uma ou outra forma (seja interior como exteriormente). No

Diário de Moções Interiores, por exemplo, relata, no dia 13 de fevereiro de 1544:

Tomada a consciência de ter cometido uma grande falta negligenciando a vigília das Pessoas divinas no tempo de ação de graças. Quis me abster de dizer a missa da Trindade em lugar de dizê-la como havia tido a intenção, e tomar por intercessores a Mãe e o Filho para que me seja perdoado e que eu seja recolocado na graça anterior, abstendo-me das Pessoas divinas para não me aproximar delas imediatamente no que concerne às graças e oblações anteriores. Pensei também de não dizer essas missas durante toda a semana, fazendo dessa privação minha penitência. Entrei numa grande devoção e bastantes lágrimas muito intensas, durante a oração ou quando me vestia, e com soluços. Sentindo que a Mãe e o Filho intercediam, senti uma inteira segurança que o Pai Eterno me recolocava no estado anterior. Em seguida, antes, durante e depois da missa, devoção muito grande, e lágrimas muito abundantes, vendo e sentindo os Mediadores, com uma grande segurança de reencontrar o que tinha perdido. E em todos estes tempos, tanto na quarta-feira quanto na quinta-feira, tendo por firme a oblação feita e sem nada contra ela ${ }^{71}$.

Na carta que Polanco enviou ao P.e Ribadeneira e a todos os superiores da Companhia

de Jesus para comunicar a morte de Inácio, entretanto, destaca-se esta passagem:

Nosso Pai tendo deixado este mundo, pareceu conveniente, a fim de conservar seu corpo, retirar-lhe as entranhas e embalsamar-lhe de alguma forma. Isto foi também uma ocasião de grande edificação e admiração, porque encontrou-se o estômago e os intestinos completamente vazios e ressecados, de onde os expertos nesta arte concluíram que se devia às grandes abstinências que havia feito outrora, bem como à sua grande constância e à sua força de alma, do fato que apesar de uma tal fragilidade ele trabalhasse tanto, e com um rosto tão

\footnotetext{
${ }^{70}$ Ibid., pp. 1025-1026 ( $\$ 14$, tradução nossa).

${ }^{71}$ Ibid., pp. 332-333 ( $\$ 23$, tradução nossa).
} 
alegre e tão igual. Viu-se também que ele tinha três cálculos no fígado, devidos à mesma abstinência, que endureceu o fígado. Quanta verdade havia no que dizia o bom velho Don Diego de Eguia (que está na glória): que nosso Pai vivia desde muito tempo por milagre, porque com um fígado assim, eu não sei como ele poderia viver naturalmente, senão porque, como ele era necessário à Companhia, Deus nosso Senhor supria a deficiência dos órgãos corporais e the conservou a vida ${ }^{72}$.

Enfim, toda "obediência", toda "indiferença", toda "mortificação" e penitência, todo exercício de ordenação das paixões visa o fim do Instituto da Companhia de Jesus expresso no inúmeras vezes repetido mote jesuítico ad maiorem Dei gloria.

Apenas no texto das Constituições, a expressão e suas variantes aparece 177 vezes, sempre lembrando o fim da Ordem, como diz o Prólogo:

E ainda que o que é primeiro e tem mais importante seja, na nossa intenção, tudo o que concerne o corpo universal da Companhia da qual se procura principalmente a união, o bom governo e a conservação em seu bom estado para uma maior glória divina, no entanto, porque este corpo é constituído de seus membros e que, na execução, o que concerne às pessoas vem em primeiro lugar, bem como para aquilo que é importante para os admitir, fazer progredir e os repartir na vinha de Cristo nosso Senhor, é por isso que começaremos, com a ajuda que a Luz eterna dignará nos comunicar para sua honra e seu louvor ${ }^{73}$.

E assim comenta a Anotação do Prólogo das Constituições:

O fim das Constituições é ajudar a conservação e o crescimento do corpo inteiro da Companhia e de seus membros, para a glória divina e o bem da Igreja universal; não somente todas estas Constituições e cada uma delas, tomadas em si mesmas, devem ser conformes a este fim ${ }^{74}$.

Uma a uma, as referências ao mote retomam a "experiência-modelo" de Inácio, o homem que, atento primeiramente a si, se coloca diante do concreto da multiplicidade humana, para propor a cada um dos jesuítas o fim mesmo de suas vidas; ou, para usar a expressão de Nadal, o "contemplativo em ação", desejoso de amar e servir em tudo a "su divina Majestad", que, obediente ao real, se dispunha com a mesma obediência à Vontade de Deus, que tantas vezes pediu e se empenhou para conhecer; o homem disponível ao que o Papa, Vigário de Cristo na terra, exigisse; sempre atento a que se cumprisse um verdadeiro

\footnotetext{
72 Ibid., p. 1079 ( $\$$, tradução nossa).

${ }^{73}$ Ibid., p. 428 (Const. $§ 135$, tradução nossa).

74 Ibid., p. 427 (Const. $\$ 136$, tradução nossa).
} 
serviço de colaboração com a missão de Cristo, de forma a poder ser mais útil ao bem dos homens e, assim, dar maior glória a Deus.

Antes de passarmos às cartas, vejamos o que Arias (1600) diz acerca dos frutos que a obediência traz para a vida de uma pessoa:

Di qui viene che la persona obbediente hà gran sicurtà (quella peroche in questa vita ordinariamente si può havere) per trovare il cammino della virtù, e liberarsi da innumerabili lacci, \& inganni de Dimoni (...). Dicovi in verità che mai nostro signore Giesu Cristo darà la sua grazia (senza la quale non possiamo niente che gli sia grato) a quell'huomo che havendo chi lo struisca, e governi $\&$ guidi per la via della virtù, \& vita spirituale, non vuole essere governato, \& retto da altri (...), ma si regge secondo la sua volontà, credendo d'essere sufficiente per reggersi da se stesso, \& intendere da se le cose per la sua salute (...). Se due persone desiderano digiunare per loro divozione, e l'una che sta in sua libertà digiuna in fatto, riceve una paga per quel digiuno. E l'altra, che è sotto l'obbedienza non digiuna perche il suo superiore li ordina cosi, questa riceve paga doppia, l'una perche volontariamente desiderò digiunare, l'altra perche negò la sua volontà e desiderio \& obbedì. Tutto questo frutto cosi ammirabile nasce da che obbedendo si fa la volontà di Dio (...). Di qui viene eziandio la gran pace e quiete che possiede l'anima di colui che è vero obbediente, perche la cagione d'ogni inquietudine e turbazione dell'anima è la propria volontà ${ }^{75}$.

A "paga” da obediência é uma quietude e paz da alma, que praticamente corresponde àquela experiência descrita por Nieremberg (1657), quando fala da alegria como "um certo silêncio do apetite", "uma modéstia da ambição", "uma prisão da cobiça, que não tem mais o poder de se elevar contra a autoridade soberana da Razão", "uma satisfação do coração", "o casamento do amor com seu objeto; um feliz encontro daquilo que se busca, a presença

\footnotetext{
${ }^{75}$ Arias, Francisco (1600). Profitto spirituale, nel qual s'insegna à fare acquisto delle virtù, \& progresso nello spirito. Del M.R.P. Francesco Arias della Compagnia di Giesu. Tradotto della lingua Spagnuola, dal Cavaliere Fra Giulio Zanchini da Castiglionchio. Milano: Stampa del q. Pacifico Pontio, Impressore Archiepiscopale (original espanhol de 1588), pp. 400-403 ("Daqui advém que a pessoa obediente tenha grande segurança (aquela que se pode ter nesta vida ordinariamente) para encontrar o caminho da virtude, e libertar-se dos inúmeros laços e enganos dos Demônios (...). Digo-vos, em verdade, que nunca nosso senhor Jesus Cristo dará sua graça (sem a qual não podemos nada fazer que lhe seja grato) àquele homem que tendo quem lhe instrua e governe e guie pela via da virtude e vida espiritual, não quer ser governado e regido por outros (...), mas se rege segundo a sua vontade, crendo ser suficiente para reger-se a si mesmo, e pretender por si mesmo as coisas de sua salvação (...). Se duas pessoas desejam jejuar por devoção pessoal, e uma, que está na sua liberdade, jejua de fato, recebe o pagamento por aquele jejum. E a outra, que está sob a obediência não jejua porque o seu superior lhe ordena assim, esta recebe pagamento duplo, um porque voluntariamente desejou jejuar, e outro porque negou sua vontade e desejo e obedeceu. Todo este fruto assim admirável nasce do fato de que, obedecendo, se faz a vontade de Deus (...). Daqui advém também a grande paz e quietude que possui a alma daquele que é verdadeiro obediente, porque o motivo de toda inquietude e turbação da alma é a própria vontade", tradução nossa).
} 
daquilo que se ama; a realização da esperança, o efeito do desejo; a possessão do bem" ${ }^{\text {76 }}$. O que, nos abre as vias para o que será desenvolvido no próximo capítulo: a experiência de “consolação", que, nas cartas, também vêm descrito como "alegria" ou "contentamento" e, em outros documentos - aqueles filosófico-retóricos - como "felicidade".

Estes termos, como vimos no início do capítulo, estão presentes, com a mesma vitalidade descrita por Nieremberg (1657), de forma bastante uniforme ao longo dos anos, quando fazemos uma análise macro-histórica.

Juan Augustin Castangia, por exemplo, tendo visto a representação do martírio do padre Rodolfo Aquaviva e seus companheiros, sentiu o mesmo "impulso" de "padecer en servicio de su divina magestad", de "perder la vida, o por mejor dezir, ganarla muriendo en servicio de su magestad"77. Relata, em seguida, que no trabalho de "desengano" a que foi incentivado, encomendou-se "a Nuestro Señor pidiendole gracia para hazer lo que fuere a sua maior gloria", oferecendo comunhões, disciplinas, mortificações e trabalhos ordinários a Deus durante cinco anos consecutivos. O resultado deste longo exercício de discernimento dos espíritos foi que os desejos "han crecido tanto y de tal modo que me pareçe hechar con esto leña al fuego". Com este relato, Juan justifica seu pedido:

Y lo que mas me empuja para escribir esto es ver que pareçe Dios Nuestro Señor me ha dado la graçia de entrar en la Compañia despertandome para ello con la vista de aquellos sanctos martires, para le servir en esse exercicio y aunque para esto se requiera mucho espiritu de que yo caresco, es verdad; pero confio en aquel que por su misericordia se digna darme los desseos, se diñara tambien con su divina gracia suplir lo que en mi falta de spiritu y otras cosas y assi humilmente por las entrañas de Christo Nuestro Señor supplico a Vuestra Paternidad no me prive deste consuelo, graçia y misericordia que Dios Nuestro Señor me quiere hazer de padecer por su divino amor y reverencia de su sanctissimo nombre para que assi alcance el fin para el qual he sido criado y he entrado en la Compañia el qual sera

\footnotetext{
${ }^{76}$ Nieremberg, Juan Eusebio (1657). L'art de conduire la volonté selon les precepts de la morale ancienne \& Moderne, tirez de Philosophes Payens \& Chrestiens. Traduit du latin de Jean Eusebe de Nieremberg, Paraphrase \& de beaucoup enrichy par Louÿs Videl, de Dauphiné. Dedié à Monsieur de Lionne, Conseiller d'Estat ordinaire \& secretaire des Commandemets de la Reyne Regente. Paris: Chez Jean Pocquet (original latino de 1631) pp. 118-119 (tradução nossa).

${ }^{77}$ ARSI, Indipetae Hispanae, FG 758, carta n. 168.
} 
possible que Su Magestad aia guardado para que por medio destos trabajos, o muerte lo alcanse ${ }^{78}$.

Encontram-se também, nas demais cartas, expressões tais como: "la resignacion que en todas las cosas y obediencias pide Nuestro Santo Instituto"79 é o que espera o mesmo Juan Augustin do trabalho de desapego da "aficion de las cosas"; Balthasar de Torres, por sua vez, diz que "sera muy gran consuelo todos los dias de mi vida, y a la hora de mi muerte, aver travajado siempre solo por obediencia" ${ }^{\prime 80}$; Antonio Perez afirma que está disposto a "obedecer plenamente en todo. Estando con la indiferençia que mi Instituto me pide, y tiniendo por mas acertado lo que se me mandare, pues ser ordenaçion cierta de Dios, que no quiere ni puede engañarme" ${ }^{81}$; em outra carta, o indipetente roga "a Nuestro Señor me haga obediente y hijo verdadero de la Compañia" ${ }^{\circ 2}$; Joseph de Sepulveda afirma querer ir para o Japão ou para "otra qualquiera parte que la obediençia ordenase" ${ }^{\text {83 }}$; outro afirma estar confiando que o superior "mirara mis deseos como de hijo que desea obedecer en todo Nuestro Señor" ${ }^{\text {" }}$; há aquele que espera mostrar em sua Indipeta sua "determinadissima indifferensia a eso o a qualquier otra cosa que a la obediencia pareciesse"; na carta de 1599, o jovem jesuíta, afirma que desde pequeno ouvia as histórias edificantes dos padres da Companhia de Jesus e, a partir de então, "aficioneme tanto a imitar a los Padres" no que se referia aos padecimentos por eles sofridos. Poderíamos ainda citar um grande número de exemplos de uso desses lugares-comuns, porém, mais que enumerá-los, interessa-nos que fique clara a sua participação num continuum que, partindo do "conhecimento de si", chega até uma experiência de "consolação", tantas vezes prefigurada nas cartas.

\footnotetext{
${ }^{78}$ ARSI, Indipetae Hispanae, FG 758, carta n. 168

${ }^{79}$ ARSI, Indipetae Hispanae, FG 758, carta n. 4.

${ }^{80}$ ARSI, Indipetae Hispanae, FG 758, carta n. 13

${ }^{81}$ ARSI, Indipetae Hispanae, FG 758, carta n. 43.

${ }^{82}$ ARSI, Indipetae Hispanae, FG 758, carta n. 73.

${ }^{83}$ ARSI, Indipetae Hispanae, FG 758, carta n. 116

${ }^{84}$ ARSI, Indipetae Hispanae, FG 758, carta n. 188.
} 
Com relação às cartas de Juan Bravo, no capítulo anterior, descrevemos como na última carta, o indipetente valoriza a experiência de filiação à ordem religiosa, na pessoa do padre geral. Esta mesma característica já aparece na primeira Indipeta escrita, no entanto nesta, este sentimento tem muito mais o valor de captação da benevolência do destinatário e edificação que de afirmação da coincidência entre "missão" e "pertencimento".

Além deste aspecto evidenciado especialmente pela leitura da última carta ${ }^{85}$, podemos verificar também uma mudança de postura bastante significativa: enquanto que na primeira, Juan Bravo, que pede explicitamente o Japão, declara, na narratio, sua indiferença como claro sinal da origem divina de seu desejo ${ }^{86}$, a partir da segunda, a indiferença muda de posição na carta, sendo declarada na petitio, indicando mais uma tentativa de persuasão pela docilização dos afetos do superior que o resultado de um trabalho ${ }^{87}$; esse movimento chega ao seu ápice, na terceira carta, quando Juan Bravo não mais se declara indiferente, apelando para uma argumentação cheia de humilhações e súplicas que contam com o "Paternal affecto y amor" do padre geral.

Ainda na esteira deste sentimento de "filiação", as cartas de Juan Bravo interessam sobremaneira pela valorização desta experiência: em todas as Indipetae a que tivemos acesso, o jovem jesuíta faz questão de lançar mão desta tópica em alguma parte da carta: na primeira, ele utiliza na captatio benevolentiae e na conclusio; na segunda, aparece na narratio e na

\footnotetext{
${ }^{85} \mathrm{O}$ que chama a atenção, no caso da última carta, é que dada a liberdade de Juan Bravo no uso da estrutura retórica, esta Indipeta é marcada por uma forma de argumentação onde é bastante valorizado o sentimento de "filiação". No entanto, este é um topos que aparece em todas as suas cartas. Entendemos que o indipetente não seja um inepto, dado a demonstração do contrário nas duas primeiras cartas - muito bem estruturadas -, mesmo que a segunda seja marcada por uma certa sobrevalorização da captatio benevolentiae.

${ }^{86}$ Cf. ARSI, Indipetae Hispanae, FG 758, carta n. 329. Nela, Juan Bravo afirma: "asseguralo est una hambre grande que siento de convertir peccadora cosa a Dios Nuestro Señor. De todo esto claramente colijo que Dios me llama para servirle enel Japon. Y mas que todo me çertifica que esto llamamiento es divino la indifferençia que en my siento, porque junto con llamarme Nuestro Señor para servile en aquellas partes tan remotas, siento indifferençia grande para lo que es yr, o quedar sin perder por esto un punto el fervor y desseo de servile aca en Europa, antes creçiendo mas".

${ }^{87}$ Cf. ARSI, Indipetae Hispanae, FG 758, carta n. 404. O termo "indiferença" aparece, nesta carta, no seguinte contexto: "Ni por esto me despido de hazerla en Europa pues con sufficiente indiferençia me hallo para lo que Vuestra Paternidad escogiere, que alli con el favor divino espero o, en Japan, o en Europa procurar ser hijo de Nuestra Santa Compañia y para que yo desde agora lo açierte a ser supplico a Vuestra Paternidad como al Padre de ella y myo me lo alcançe del Señor".
} 
petitio (partes que quase se confundem); e na terceira, aparece em toda a carta que, como já dissemos, é marcada por uma aparente inaptidão, dado que captatio e narratio não se distinguem e, como conteúdo, se confundem também com a petitio, ficando claramente delimitáveis apenas a salutatio e a conclusio.

Um outro aspecto presente nas cartas deste indipetente é uso do termo "obrigação" sobretudo na segunda Indipeta. Lembremo-nos que, nesta, Juan Bravo começa dizendo que pretende apenas "renovar a Vuestra Paternidad la memoria de mys desseos" e, neste sentido, o faz por obrigação:

Siento ser tan grande esta merced $^{88}$, y liberalidad del Señor, que quando no uviera acarreado a my alma otros bienes (que si ha hecho tanto en remediar costumbres, como en renovar alientos, segun en las otras ${ }^{89}$ apunte a Vuestra Paternidad) ella por si sola bastantemente me obligava a no desistir de hazer lo que con esta hago, y supplicar instantemente a Vuestra Paternidad se dignasse hechar los ojos a lo que embado del Señor (segun pienso) le llego a pedir ${ }^{90}$.

Mais à frente, na mesma carta, ele se serve outra vez desta tópica e num contexto bastante semelhante, à diferença que, neste segundo momento, narra como o desejo tem lhe sido útil desde que o sente: explicando o quão difícil é escrever tudo o que sente e lhe foi dado conhecer, diz que gostaria de estar "a los pies de Vuestra Paternidad" para dizer de voz aquilo que se passa em seu coração; porém não é possível fazer isso, dada a distância, por este motivo ele espera que Deus se sirva de

Declarar a Vuestra Paternidad lo mucho que me tiene obligado a hazerle este sacrifiçio, que tanto mejor lo podra hazer su Magestad, quanto mejor conoçe my indignidad, y la mucha merced que en darme este deseo me ha hecho ${ }^{91}$.

Com este uso, Juan Bravo demonstra o quão seguro se encontra de que vem de Deus o desejo que sente e que, portanto, nada mais justo que lhe ser concedida esta missão. Ainda que "el demonio mas ladre y me de en los ojos mys espirituales miserias", sua segurança se

\footnotetext{
${ }^{88}$ A mercê a que se refere Bravo é de ter recebido tantos benefícios a partir dos desejos, ele que "tenia mereçidos muchos açotes y castigos". Cf. ARSI, Indipetae Hispanae, FG 758, carta n. 404.

${ }^{89}$ Esta nota é interessante: entre a carta de 20 de janeiro de 1603 - que é a primeira, como já vimos - e esta de 29 de julho de 1604, Juan Bravo afirma ter escrito outras.

${ }^{90}$ ARSI, Indipetae Hispanae, FG 758, carta n. 404.

${ }^{91}$ ARSI, Indipetae Hispanae, FG 758, carta n. 404.
} 
sustenta no desengano que lhe permite confiar "de su bondad", de tal forma que "podria rematar una cruz", a fim de cumprir a promessa de "una vengança general [en aquella Region] de las muchas [miserias] con que he deservido a my Dios" 92 .

Voltando à primeira carta, lemos, na captatio benevolentiae, algumas referências que neste contexto analisado, são significativas: nesta, Juan Bravo fala da consolação e alegria que sente em escrever ao padre geral numa "tal occasion" 93 e acrescenta: "creo que no sera de menos consuelo a Vuestra Paternidad como a quien tanto desea el bien espiritual de sus hijos el verla, pues por ella descobriramos quan grande sea la bondad de Vuestra Paternidad. Pues se estiende hasta my con tanta largueza". A combinação entre experiência de "consolação" e de "filiação" deste trecho ou aquela entre "filiação" e "mortificação" e sentimento de segurança que aparece no final desta mesma carta ${ }^{94}$, apontam para uma questão importante neste dinamismo a que vimos dando o nome de "experiência de liberdade": em que medida termos tão distintos, descritivos de experiências tão diversas, podem significar uma "consolação" ou uma "alegria"? O que sustentaria a passagem desta dinâmica de “obediência", "mortificação", "pertencimento" e "filiação" para a conquista da "Felicidade”?

Eis que devemos dar lugar ao terceiro termo deste dinamismo: a "consolação" e as demais tópicas correlatas.

\footnotetext{
${ }^{92}$ ARSI, Indipetae Hispanae, FG 758, carta n. 404.

93 ARSI, Indipetae Hispanae, FG 758, carta n. 329.

94 Na conclusio, Juan Bravo comenta: "Entretanto que estoy esperando la respuesta he determinado entrar muy en my mismo y procurar dar me al exerçicio de la mortificaçion porque me da a entender Nuestro Señor que ella es una de las mayores alas con que puede un verdadero hijo dela Compañia atravesar el imenso occeano, y andar seguro entre los mayores trabajos que en la Gentilidad se offreçen”. Cf. ARSI, Indipetae Hispanae, FG 758, carta n. 329.
} 


\section{CAPÍTULO 10 A "consolação" nas Indipetae}

Ainsi donc, quiconque ayme la paix \& desire acquerir le repos; quiconque pretend à la felicité,

dont le rare avantage est d'estre immuable \& eternelle, doit constamment aymer la Verité, qui en est la base $\&$ le fondement immobile. Nous avons appris qu'elle se trouve dans la source; dans la Raison épurée des erreurs, \& pour ainsi le dire, de la lie $\&$ des ordures de l'Opinion.

Juan Eusebio Nieremberg (1657) L'art de conduire la volonté...

Enfim, chegamos ao topos final do dinamismo a que vimos denominando "experiência de liberdade". Verifiquemos, inicialmente, como as tópicas relacionadas à "consolação" aparecem nas Indipetae, para então descobrir como se apresentam na forma mentis do jesuíta; e, sobretudo, certifiquemo-nos da veracidade do percurso até aqui desenvolvido.

$\mathrm{Na}$ análise das Indipetae do ponto de vista macro-histórico, encontraremos um uso

\footnotetext{
${ }^{1}$ Nieremberg, Juan Eusebio (1657). L'art de conduire la volonté selon les precepts de la morale ancienne \& Moderne, tirez de Philosophes Payens \& Chrestiens. Traduit du latin de Jean Eusebe de Nieremberg, Paraphrase \& de beaucoup enrichy par Loü̈s Videl, de Dauphiné. Dedié à Monsieur de Lionne, Conseiller d'Estat ordinaire \& secretaire des Commandemets de la Reyne Regente. Paris: Chez Jean Pocquet (original latino de 1631), p. 475.
} 
freqüente e bem distribuído em todo o período estudado de termos relacionados à tópica da “consolação" tal como descrita até aqui.

Partindo para uma análise da freqüência de aparecimento em cada uma das partes da estrutura retórica das cartas, encontraremos uma relação bastante significativa: enquanto que na captatio benevolentiae e na conclusio os lugares-comuns tais como "consolação", "alegria" e "contentamento" praticamente não comparecem, ou, se sim, apenas quando o indipetente, por exemplo, descreve a consolação que o desejo lhe traz, ou a consolação que quer dar ao padre geral, relatando a ele a história de um desejo tão eficaz etc; ou, ainda, quando, na conclusio, retomando brevemente o conteúdo de sua carta, refere-se ao "consolo" que sentiu quando descobriu no mata-borrão o conteúdo da carta que havia escrito anteriormente ${ }^{2}$.

Será portanto na narratio e na petitio, onde os termos vinculados ao topos da “consolação" aparecerão mais vezes, sendo que na primeira a freqüência é mais evidente. Nesta parte da carta, o jesuíta deve, ao narrar a história de seu desejo e do discernimento dos espíritos, mostrar ao padre geral as razões que o fazem crer que o processo eletivo a que se dedicou está correto, e serão a "consolação" e "alegria" que experimentou os critérios para o julgamento de veracidade, assim como Inácio diz, em negativo, em carta enviada à sua amiga Teresa Rejadell, no dia 18 de junho de 1536:

Quando a alma se encontra sem consolação, (...) quero dizer que nosso antigo inimigo acumula todas as dificuldades possíveis para nos desviar da rota na qual começamos a caminhar. Ele nos vexa violentamente e (...) não pára de jogar em nós a tristeza, sem que saibamos por quê. Não experimentamos mais a menor devoção em rezar, em contemplar; não mais o menor sabor e o menor gosto interior em falar ou escutar falar das coisas de Deus nosso Senhor. E ainda mais, se ele nos encontra fracos, abatidos por esses pensamentos funestos, ele nos coloca na cabeça que somos totalmente esquecidos por Deus nosso Senhor (...). Ele se esforça assim de nos fazer perder totalmente a confiança. É preciso que nós vejamos bem de onde provêm este temor e esta fraqueza tão grandes; nós consideramos demais nossas misérias e nos deprimimos sob estes pensamentos enganosos. É por isso que aquele que inicia o combate deve tomar guarda. É a consolação? Nós nos abaixaremos, nós nos humilharemos sonhando que a prova da tentação não tardará. É a tentação, a obscuridade, a tristeza que vêm? Iremos contra elas sem ressentir pena, esperando pacientemente

\footnotetext{
${ }^{2}$ Cf. ARSI, Indipetae Hispanae, FG 758, carta n. 116.
} 
a consolação do Senhor que dissipará para fora todas estas perturbações e todas estas trevas exteriores ${ }^{3}$.

Se ao contrário de "consolações", o indipetente sentisse "tristeza", "abatimento", "fraqueza", "pensamentos funestos e enganosos", "perda de confiança", poderia estar certo de que se tratava de tentação e engano do Inimigo da natureza humana. Portanto, falar de “consolações", “alegrias", "contentamentos", "gozo" nesta parte da indipeta, denota sempre certeza sobre a origem divina dos desejos que sente.

Quando aparece na petitio por sua vez, os termos em questão, na maior parte das vezes, vêm ligados à súplica de que o superior permita o "consolo" solicitado, permita que se cumpra a vontade de Deus na sua vida, seja qual for esta vontade. Nesse sentido, usar tais topoi aqui acaba tendo, às vezes, uma estreita vinculação com a experiência de indiferença: se interessa a "consolação", independente da maneira como ela se dará, o homem se encontra naquela perfeita "indiferençia que mi Instituto me pide".

Bernardo Matias, por exemplo, inicia sua carta de petição comentando da “consolação" que experimentou quando soube "de las muertes o por mejor desir de la nueva vida de tantos martires" ${ }^{\circ 5}$ nas Índias orientais. Interessante observar que seja na captatio benevolentiae a comentar: lembremo-nos que, como correspondência epistolar produzida no âmbito da Companhia de Jesus, as cartas deveriam trazer conteúdo edificante, de forma que falar da "consolação" que sentiu quando soube do martírio de tantos jesuítas, Bernardo Matias propõe um tema edificante que, certamente, docilizará a intenção do prepósito geral. Em sua carta, ele só voltará a falar deste lugar-comum na petitio, quando diz - quase na mesma dinâmica de captação da benevolência - que "cierto yo me aconsolaria mucho de

\footnotetext{
${ }^{3}$ Loyola, 1991, op. cit., p. 645 (tradução nossa).

${ }^{4}$ Cf. ARSI, Indipetae Hispanae, FG 758, carta n. 43.

${ }^{5}$ ARSI, Indipetae Hispanae, FG 758, carta n. 80.
} 
saber el rescibo de alguna mia por no enfadar a Vuestra Paternidad" 6 .

Outro indipetente a fazer uso desta tópica na primeira parte da carta é Alonso Cortes que explica, logo no início, que pretende manifestar ao padre geral os desejos que sente, a fim de que, sabendo destes desejos, "este yo contento con lo que de mi ordenare, y piense aver hecho lo que de mi parte en razón de cumplir aquello, a que la divina Voluntad me llama"7. Trata-se de um uso diferenciado daquele empregado por Bernardo Matias: aqui, o “contentamento" aparece vinculado à tópica da obediência, descrevendo exatamente aquilo que dizia Arias (1600) quando enumerava entre os frutos da obediência a segurança, a liberdade e a quietude da alma ${ }^{8}$.

Seraphin Bonaventura Coçar, por sua vez, quando narra o trabalho de discernimento dos espíritos, escreve que experimenta um desejo que o deixa "muy consolado, y con tal alegria que me parece bastante para arrostrar a qualquiera dificultad y trabajo que por entonces se me podria ofrecer, y de hecho se me haze todo suave"": um desejo que o ajuda a resistir às dificuldades que se imponham no caminho de sua realização só pode ser uma experiência que o leve a dizer com todas as letras de que se trata de "llamamiento y vocacion de Dios Nuestro Señor" ${ }^{\prime 10}$.

Também Balthasar de Torres, diz ter o coração incendido de tal maneira após ter se dedicado, durante 5 ou 6 meses, nos exercícios “delas cosas de el Japon”, que, se naquele dia o "embiasen, interrumpiendo mis estudios, me partiera con grande consolacion de mi spiritu" ". Aqui, a "consolação" não é uma experiência que fez e que elabora no momento da escrita, mas uma promessa e uma certeza produzida pelos "grandes deseos" que sente de

\footnotetext{
${ }^{6}$ Cf. ARSI, Indipetae Hispanae, FG 758, carta n. 80.

${ }^{7}$ Cf. ARSI, Indipetae Hispanae, FG 759, carta n. 13.

${ }^{8}$ Cf. Arias, Francisco (1600). Profitto spirituale, nel qual s'insegna à fare acquisto delle virtù, \& progresso nello spirito. Del M.R.P. Francesco Arias della Compagnia di Giesu. Tradotto della lingua Spagnuola, dal Cavaliere Fra Giulio Zanchini da Castiglionchio. Milano: Stampa del q. Pacifico Pontio, Impressore Archiepiscopale (original espanhol de 1588).

${ }^{9}$ ARSI, Indipetae Hispanae, FG 758, carta n. 4.

${ }^{10}$ Cf. ARSI, Indipetae Hispanae, FG 758, carta n. 4.

${ }^{11}$ ARSI, Indipetae Hispanae, FG 758, carta n. 13.
} 
imitar aos padres que trabalham no Japão, um desejo de imitação que nasceu depois de haver lido e visto "con mas attention, que otras veçes solia, lo que nuestros padres hacen en las Indias orientales, specialmente en el Japon" "12 a "consolação" da "imitação" daqueles que, por suas vidas, se tornam experiências modelares para toda a Companhia de Jesus, para a Igreja e para o mundo, cumprindo o factus de todo homem - dar maior glória a Deus, permitir que o mundo reconheça a Deus através de sua própria vida entregue, como a de Cristo, pelo bom destino, pelo bem e felicidade da humanidade (gloria Dei vivens homo, vita autem hominis visio Dei, dizia Santo Irineu ${ }^{13}$ ). Tanto é assim que, em sua petitio, Balthasar escreve: "sera muy gran consuelo todos los dias de mi vida, y a la hora de mi muerte, aver travajado solo por obediencia, y bien de las animas; sin mescla de propria Voluntad"14.

Uma tal expectativa de "consolação" que, para nós modernos, parece tão estranha a qualquer experiência de felicidade, não pode, no entanto, ser entendida como simples recurso retórico de convencimento e persuasão: é bem verdade que o aspecto filosófico-retórico é inseparável deste dinamismo, porém isto não implica uma leitura cindida deste texto, mas devemos sempre nos remeter àquela unidade filosófico-retórico-espiritual-intitucional que sustenta essa elaboração de experiência. Se não partirmos da certeza desta unidade, arrisco a dizer que nunca seremos capazes de descrever a "experiência" contida nas Indipetae: a fragmentação do documento significa secar a fonte.

Em outras cartas o termo aparece algumas vezes com o mesmo sentido presente na carta deste último indipetente: "yre con summo gozo a ello entendiendo ser la voluntad de Nuestro Señor"15, escreve Joseph de Sepulveda; ou Domingo Tafalla que garante que "porque confio que Vuestra Paternidad como à Padre me ha de consolar no me alargo mas" ${ }^{\text {; }}$; também

\footnotetext{
${ }^{12}$ ARSI, Indipetae Hispanae, FG 758, carta n. 13.

${ }^{13}$ Irineu, Adversus Haereses, IV 20,7.

${ }^{14}$ ARSI, Indipetae Hispanae, FG 758, carta n. 13.

${ }^{15}$ ARSI, Indipetae Hispanae, FG 758, carta n. 116.

${ }^{16}$ ARSI, Indipetae Hispanae, FG 758, carta n. 136.
} 
Pedro Ruiz em sua carta, na qual a petitio precede a narratio, pede "tenga por bien (...) concederme esta peticion q sin duda ninguna sera para mi de mucho consuelo si por orden de Vuestra Paternidad Nuestro Señor me hiciese esta Merced"17; outro a repetir o mesmo uso do termo é Leon Ximenes que espera ser enviado pela obediência, porque assim ira "consolado"18; também Cosme Hatter diz que seus desejos se incenderam depois de ter ouvido umas "nuevas de Indias que han venido, ý con un aviso que por orden de Vuestra Paternidad se ha dado en general que todos los que piden ýr a las Indias esten con buen animo, ý se pongam a punto por que Vuestra Paternidad en esta sazon los consolarà” ${ }^{19}$. Em todas estas cartas, o termo vem marcada por uma expectativa, esperança, confiança ou certeza: sempre uma experiência futura, sobre a qual eles sustentam a argumentação... aquela mesma beatitudine final descrita anteriormente.

Em outras, no entanto, este topos vem descrito como uma experiência presente. A mais interessante das Indipetae em que o uso do termo é este, é a de Alonso Crespo: trata-se de uma Indipeta sem captatio benevolentiae. A correspondência, de texto bastante curto, chama a atenção não só pela ausência desta parte, mas por sua argumentação que parece não se preocupar em convencer o superior geral, mas dá quase por óbvio o envio:

\section{JHS}

Muy Reverendo Padre Nuestro en Christo

Los dias passados escrivi a Vuestra Paternidad no entendiendo que biera yo al Padre Pedro Ortigosa que viene de mexico yo le he hablado y me he consolado mucho con el y como va hablar a Vuestra Paternidad no pude dexar de escrivir siquiera para que sirva de acordar a Vuestra Paternidad la charidad que he pedido mucho ha a Vuestra Paternidad y agora se lo pido por amor de Nuestro Señor que no me lo niegue por que es justa petiçion y assi el Padre Pedro Ortigosa podra dar particular Relaçion de mi y sabido Vuestra Paternidad esto y Vuestra Paternidad juzgar que vaya yre de muy buena voluntad. Y sino yo Ruego a Nuestro Señor me haga obediente y hijo verdadero de la Compañia para quedado queira que este cumpla su sancta Voluntad, y yo de mi parte mediante su favor y ayuda me disponre en todo lo que pudiere sin hablar mas dello teniendo entendido que

\footnotetext{
${ }^{17}$ ARSI, Indipetae Hispanae, FG 758, carta n. 188.

${ }^{18}$ Cf. ARSI, Indipetae Hispanae, FG 758, carta n. 290.

${ }^{19}$ ARSI, Indipetae Hispanae, FG 759, carta n. 49.
} 
saviendo ya Vuestra Paternidad mis desseos lo que fuere de mi sera lo que mas me conviene ${ }^{20}$.

A intervenção do Padre Pedro Ortigosa parece, neste caso, haver definido a situação do indipetente. Porém, esta hipótese só se poderá verificar a partir do acesso aos catálogos da Companhia de Jesus, conservados no ARSI.

A carta, porém, com maior número de referência a topoi vinculados à “consolação" é a de Diego de Salcedo. Nela, o autor descreve o consolo que sentia quando ouvia a leitura das "cartas de Japon y otras partes": "me consolava mucho de oyelas, y me regozijava interiormente pareciendome que yo me hallaria alla con ellos [los Padres] conviviendo"21. Aqui, "gozo" e "consolação" são experiências do presente de tal forma fortes e vivas que se parecem com aquelas que sentiria caso o desejo que sente encontrasse espaço de realização. À frente, Salcedo escreve que "si me viniera una suia sola, que me significase que me fuese, me fuera luego sin duda muy contento y regozixado",22, mais uma vez naquele sentido de alegria futura. Em seguida, na petitio, se refere ao fato de que sua ida significaria a "cosa que mas contento [y] alegria me poderia traer aora en la tierra"23. As referências à "consolação" não param na elaboração de sua experiência pessoal, mas se ampliam até o ponto de falar acerca da "consolação" que sua história produziu em outros e que ele espera poder produzir também no padre geral: "El Padre Esteban Paez me escrebio que yo le embie aquellas cartas que e dicho que se consolara harto de que estubiera en su mano el cumplimento de mi deseos"24.

Joan Sotalell se refere também à "consolação" e "grande ventaja" que sente "cuando siento hablar de las Indias" $" 25$ :

Y tengo experimentado que muchas vezes, quando alguna tentacion o otra cosa alguna me aflige, el medio para vencella, es pensar que si la como con

\footnotetext{
${ }^{20}$ ARSI, Indipetae Hispanae, FG 758, carta n. 73.

${ }^{21}$ ARSI, Indipetae Hispanae, FG 758, carta n. 191.

${ }^{22}$ ARSI, Indipetae Hispanae, FG 758, carta n. 191.

${ }^{23}$ ARSI, Indipetae Hispanae, FG 758, carta n. 191.

${ }^{24}$ ARSI, Indipetae Hispanae, FG 758, carta n. 191.

${ }^{25}$ ARSI, Indipetae Hispanae, FG 758, carta n. 338.
} 
paciencia yr a las Indias, luego se deshaze como humo, y siento despues grande consuelo y facilidad en hazer lo que antes me parecia muy pesado.

(...) me dio Nuestro Señor tan grandes consuelos, y muestras de lo mucho que me amava que no pude ofrecer en pago de tan grande amor, como pedirle, que muera yo por su amor, una muerte cruel, y estos despues de muchos y grandes trabajos en las mismas Indias padecidos ${ }^{26}$.

Revela, assim, o dinamismo bastante peculiar da pedagogia jesuítica, que tem como fundamento aquela antropologia filosófica aristotélico-tomista, onde o processo de modificação dos temperamentos não parte imediatamente da razão e da vontade, mas dos sentidos que "escutam" e "experimentam" certas coisas que, quando passam pela ratio particularis (após a percepção pelos sentidos externos e uma primeira assimilação pelo senso communes e pela transformação em imagem na potência imaginativa, com as espécies adequadas à "conversão" ou o "aproveitamento espiritual"), atingem mais facilmente o intelecto, que mobiliza a vontade a escolher de forma virtuosa, ou seja, de forma a conduzir à felicidade.

Com relação às cartas de Juan Bravo, apenas na primeira delas aparece o termo "consolação" ou similares, e sempre na captatio benevolentiae, o que explica o duplo uso: um primeiro onde Bravo fala do consolo que sente por escrever ao superior geral: "Con mucho consuelo myo escrivo esta a Vuestra Paternidad parte por ser la occasion con que la escrivo tal quales parte tanbien por que me da no pequeña alegria ver que siendo la primera que a Vuestra Paternidad escrivo sea con tal occasion" 27 . E um segundo, onde o indipetente fala da “consolação" que espera provocar no prepósito: "Y creo que no sera de menos consuelo a Vuestra Paternidad como a quien tanto desea el bien espiritual de sus hijos"28.

Nas cartas seguintes, toda a referência a tópicas de "consolação" são eliminadas e o texto vai ficando cada vez mais carregado de "impaciencia"29, "indignidad",30, "miserias"31,

\footnotetext{
${ }^{26}$ ARSI, Indipetae Hispanae, FG 758, carta n. 338.

${ }^{27}$ ARSI, Indipetae Hispanae, FG 758, carta n. 329.

${ }^{28}$ ARSI, Indipetae Hispanae, FG 758, carta n. 329.

${ }^{29}$ ARSI, Indipetae Hispanae, FG 758, carta n. 404.

${ }^{30}$ ARSI, Indipetae Hispanae, FG 758, carta n. 404.

${ }^{31}$ ARSI, Indipetae Hispanae, FG 758, carta n. 404.
} 
"açotes y castigos"32, "imperfecçiones"33, "resignaçion"34, descrevendo mais uma experiência de desolação que do contrário. Porém, como indicam os Exercícios Espirituais - "aquele que se encontra em desolação considerará como o Senhor o deixou nesta provação a suas faculdades naturais, a fim de resistir às diversas agitações e tentações do inimigo" ${ }^{\text {35 }}$, este jesuíta parece, sobretudo na última carta, demonstrar como está se dedicando ao trabalho de mudança desta condição de desolação em consolação: ele diz que

Me asegura y da confiança el deseo grande que reyna en Vuestra Paternidad de fomentar, y alentar qualquier buen parto de sus espirituales hijos. Y asi espero en el Señor, que este myo [deseo], aunque contrastado del demonio, y de mys imperfecçiones, Vuestra Paternidad con el calor de su Paternal affecto y amor le ha de sacar a luz ${ }^{36}$.

Com o que apresentamos até aqui, temos elementos suficientes para pensar acerca da experiência de consolação: se corolário ou não de uma vida vivida como adesão à vontade de Deus; se termo ou não de uma vida de busca, de constante "peregrinação", de incessante trabalho de desengano do mundo, de olhar para o fundo da realidade; se resposta decisiva à expectativa de uma visão "beatífica", quando "então, veremos face a face" 37 e seremos infinitamente felizes e transfigurados; se satisfação, se perfeição conquistada finalmente; se algo apenas do além-vida ou experiência possível no aqui-agora; são hipóteses que se verificarão na medida em que compreendermos adequadamente o significado do uso deste lugar-comum entre os jesuítas do XVI-XVII, na medida em que descrevermos, com os elementos apropriados, a "gramática" que sustenta esse uso particular da tópica em questão.

Havíamos dito no capítulo anterior que a educação do homem, na perspectiva inaciana, é pensada como guia que conduz o jesuíta através da realidade, objetivando aquela consolação

\footnotetext{
${ }^{32}$ ARSI, Indipetae Hispanae, FG 758, carta n. 404.

${ }^{33}$ ARSI, Indipetae Hispanae, FG 759, carta n. 4.

${ }^{34}$ ARSI, Indipetae Hispanae, FG 759, carta n. 4.

${ }^{35}$ Loyola, 1991, op. cit., p. 226 (EE. 320, tradução nossa).

${ }^{36}$ ARSI, Indipetae Hispanae, FG 759, carta n. 4.

${ }^{37} 1$ Cor 13,12
} 
final em direção à qual se movem originalmente todos os homens. Na edição ilustrada dos Exercícios Espirituais (1673), encontramos uma figura que descreve bem esta experiência (e a descreve tomando como referência, mais uma vez, a "experiência-modelo" de Inácio de Loyola que relata ter contemplado a corte celeste, na Glória, com a Santíssima Trindade ${ }^{38}$ ).

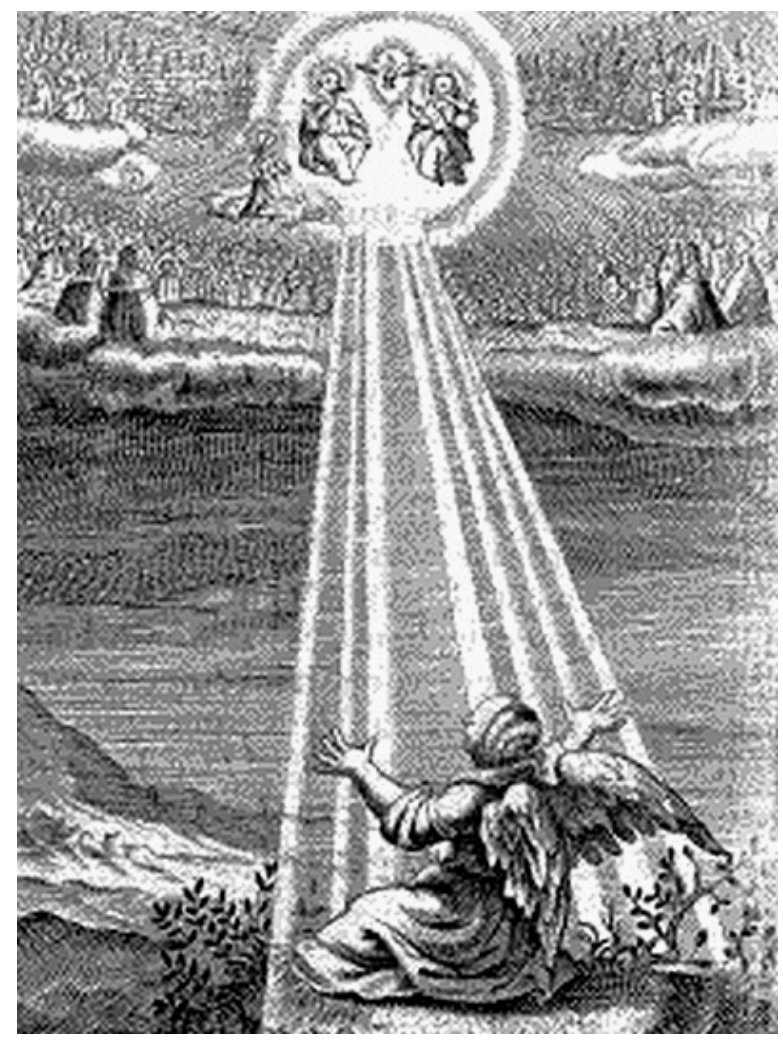

Fig. 18 - A alma do homem contempla a Glória celeste: a Santíssima Trindade e toda a corte de santos e santas ${ }^{39}$.

Poder-se-ia refutar que esta “consolação" perfeita, que só virá quando “veremos face a face", obsta o dinamismo descrito até aqui, protelando a "experiência de liberdade", impingindo-a para um futuro tão distante quanto o próprio fim da vida, ou tão distante quanto as Índias além-mar. No entanto - e são os jesuítas, mais uma vez, a nos dizer o contrário -, esta é uma experiência hic et nunc, "já e ainda não": o gosto, aqui e agora, da eternidade futura, como o dizem Pedro Ruiz ${ }^{40}$ e Diego de Salcedo ${ }^{41}$ em suas Indipetae:

\footnotetext{
${ }^{38}$ Cf. Loyola, 1991, op. cit., p. 348.

${ }^{39}$ As ilustrações foram retiradas no dia 15 de janeiro de 2003 do site "The Spiritual Exercises in Pictures - Some assistance for the composition of place", no World Wide Web http:// www.faculty.fairfield.edu/ jmac/ SEPICT/ SEPICT.htm.

${ }^{40}$ ARSI, Indipetae Hispanae, FG 758, carta n. 188.

${ }^{41}$ ARSI, Indipetae Hispanae, FG 758, carta n. 191.
} 
Y para que mas clara noticia tenga Vuestra Paternidad de mis deseos me parecio convenir dar quenta asi de la perseverancia en ellos tanto tiempo a como del consuelo que Nuestro Señor me comunica en renovarlos a menudo que cierto es grande y asi todas las veces que oygo tratar destas cosas y especialmente de persecuciones y trabajos que padecen los nuestros en aquellas partes siento en mi un nuevo fervor y una nueba alegria y me confirmo mucho mas en mis deseos $^{42}$ - escreve Ruiz, no dia 29 de julho de 1593.

Desde el principio, que entre en la Compañia me dio Nuestro Señor siempre deseos de ir alas Indias, tanto que quando estava enel noviciado y se leian las cartas de Japon y otras partes de los Padres, me consolava mucho de oyelas, y me regozijava interiormente pareciendome que yo me hallaria alla con ellos conviviendo, y me crecian los deseos, y aora que esta movida el agua son muy grandes $^{43}$ - relata Salcedo, em carta que escreve no dia 31 de maio de 1594.

Vejamos, então como esta tópica aparece no restante de nossa documentação.

Se recorremos à filosofia moral - que, lembremo-nos, é a ciência que trata do "homem enquanto atua livremente e se pode aperfeiçoar com os bons costumes e alcançar a felicidade humana"44 -, encontraremos, na Terceira Disputa do Curso Conimbricense (Da Felicidade), importantes distinções. Por exemplo, já na discussão inicial, Góis (1593) declara que beatitudinem nihil aliud esse, quam summum hominis bonum ${ }^{45}$. E se pergunta, então, de que se trataria esse Sumo Bem: dos bens externos? dos bens do corpo? ou dos bens da alma?

À primeira questão - são os bens externos a felicidade do homem? -, o mestre coimbrão responde que "não", e argumenta contra, um a um, os bens externos - a riqueza ${ }^{46}$, o poder $^{47}$, a honra ${ }^{48}$ e a glória ${ }^{49}$.

\footnotetext{
${ }^{42}$ Cf. ARSI, Indipetae Hispanae, FG 758, carta n. 188 (tradução nossa).

${ }^{43}$ Cf. ARSI, Indipetae Hispanae, FG 758, carta n. 191 (tradução nossa).

${ }^{44}$ Góis, Manuel de (1593). Disputas do Curso Conimbricense sobre os livros de Moral a Nicómaco de Aristóteles em que se contém alguns dos principais capítulos da moral. Lisboa: Oficina de Simão Lopes, p. 61.

${ }^{45}$ Ibid., p. 105.

${ }^{46}$ Ele, de fato, diz que a felicidade não consiste nas riquezas: "Prova-se primeiro, porque o sumo bem do homem não está sujeito à fortuna. Com efeito, os bens fortuitos, como são as riquezas, advêm sem aplicação da razão. Porém, o sumo bem do homem é tal que não se atinge senão por meio da razão, que no homem mantém o melhor lugar" (Ibid., p. 107).

${ }^{47}$ Assim argumenta Góis (1593) contra o poder: "Prova-se, porque o poder humano é instável nem está dependendo da vontade humana e tanto cai nas mãos de bons como de maus" (Ibid., p. 109).

${ }^{48}$ Segundo Góis (1593) a felicidade não consiste na honra porque, "como Aristóteles disputa no livro I da Moral, cap. 5, a felicidade deve estar no feliz; a honra, porém, está naquele que faz a honra e não naquele a quem se faz" (Ibid., p. 109).

${ }^{49}$ Contra a glória, Góis (1593) argumenta assim: "Com efeito, a felicidade é um bem sólido e verdadeiro. Acontece, porém, muitas vezes que a glória e a fama são fingidas e alcançadas com falsos rumores do povo, visto que muitas vezes os homens se enganam e espalham o que lhes apetece a respeito do próximo. Também, porque a glória torna os homens orgulhosos e insolentes. A isto diz respeito a sentença de Séneca: Qui vixit notus omnibus, moritur ignotus sibi”(Ibid., p. 109).
} 
Na sequiência da disputatione, Góis (1593) se pergunta se entre os bens do corpo se encontraria o Sumo Bem do homem. Segundo ele, "os bens do corpo são principalmente os prazeres dos sentidos, a saúde, a formosura e a força" ${ }^{\text {"50 }}$. Com a mesma linha de argumentação desenvolvida anteriormente, o filósofo opõem-se também a esta hipótese, trazendo como último argumento o seguinte desenvolvimento:

A suma felicidade exclui toda a afronta de deshonestidade e a miséria. De outro modo, miserável e feliz seria o mesmo ao mesmo tempo. Ora, os bens do corpo podem encontrar-se simultâneamente com a deshonestidade e a infâmia dos vícios. Logo, a felicidade não reside nestes bens ${ }^{51}$.

A terceiro quaestio discute as "operações da alma":

Como convém assentar a felicidade no que se diz feliz, e conste da anterior disputa que a felicidade não reside nos bens do corpo, conclui-se que se situa nos bens da alma. E mais: como os bens da alma, se falarmos de um modo geral, são potências, hábitos e operações, e os dois primeiros se ordenam para a operação, e a felicidade é desejada por si mesma - deve-se afirmar, por consequência, que a felicidade consiste na operação da alma ${ }^{52}$.

Estabelecem-se, então, três objeções a esta hipótese e três soluções são dadas, ficando demonstrada a parte afirmativa. Em seguida, no artigo segundo, o conimbricense diferencia "felicidade sobrenatural" e "felicidade natural" e divide cada uma delas: duas podem ser as felicidades sobrenaturais - da outra vida ou desta vida - e duas podem ser as felicidades naturais prática ou contemplativa. Quanto à primeira, ele afirma: “A felicidade sobrenatural que se alcança na outra vida, consiste na contemplação intuitiva da natureza divina" ${ }^{, 53}$, e completa o argumento dizendo que "a felicidade formal não é outra cousa que a aquisição e posse do fim último. Ora, só a clara visão de Deus exige isso. Logo, só ela é felicidade" $" 54$; e continua, dizendo ainda que "a suma felicidade consiste na mais perfeita de todas as operações. Ora, a contemplação intuitiva da divina essência é dessa natureza. Logo, a suma felicidade consiste nela"55.

\footnotetext{
${ }^{50}$ Ibid., p. 111.

${ }^{51}$ Ibid., p. 115.

${ }^{52}$ Ibid., p. 119.

${ }^{53}$ Ibid., p. 123.

${ }^{54}$ Ibid., p. 123.

${ }^{55}$ Ibid., p. 125.
} 
Quanto à felicidade sobrenatural desta vida, Góis (1593) a compara à virtude teologal da caridade, ao hábito caridoso, afirmando que, “como esta felicidade é uma tendência para aquela (...) suprema de que há pouco falámos, (...) é preciso confiná-la sobretudo na acção da caridade sobrenatural, porque tal tendência faz-se principalmente por meio de actos meritórios que a caridade em parte produz em parte ordena" ${ }^{, 56}$.

A felicidade natural prática, como deve estar situada na ação "da vida prática", “consiste inteiramente na operação segundo a virtude moral, principalmente a prudência, que é a regra das virtudes e entre elas obtém o principado" 57 A felicidade natural contemplativa, por sua vez, "está situada na contemplação, preferentemente de Deus e também de outras substâncias isentas de matéria. Com efeito, esta é a mais nobre operação do intelecto especulativo" ${ }^{, 58}$.

Ao final da disputatio, Góis (1593), partindo da definição de Aristóteles, segundo a qual "felicitas est operatio animae per rationem, aut non sine ratione, secundum virtutem in vita perfecta",59, deixa claro que a felicidade é uma operação intelectiva, prescrita e regulada pelo intelecto, uma operação honesta e conforme à reta razão, praticada no decurso de uma vida inteira ou por longo tempo. Explicita também que, nesta vida, nem a felicidade ativa nem a felicidade contemplativa, são perfeitas; e que a simples contemplação não está acompanhada da pureza dos costumes. Mas, isso não tira à contemplativa o grau de felicidade mais perfeita que a ativa.

Nesse sentido, o conimbricense segue, perfeitamente, as vias traçadas por santo Tomás de Aquino, que dissertou longamente, e em várias ocasiões, sobre a felicidade da visão "beatífica”. Segundo Aquino, o desejo mais profundo do homem é ver Deus, pois

o desejo natural de conhecer não pode apaziguar-se em nós antes que conheçamos a causa primeira, não de uma maneira qualquer, mas em sua essência. Ora, a causa primeira é Deus [...]. O fim último de uma criatura

\footnotetext{
${ }^{56}$ Ibid., p. 125.

${ }^{57}$ Ibid., p. 127.

${ }^{58}$ Ibid., p. 127.

${ }^{59}$ Ibid., p. 129.
} 
intelectual é, portanto, ver Deus por sua essência ${ }^{60}$.

Também na Suma Teológica, Tomás diz: "Segundo a fé, sustentamos que o fim último da vida humana é a visão de Deus [...]. A claridade de Deus [...], embora seja agora invisível, não o será mais então"61. Não é por acaso que o Doutor Angélico faz essa afirmação; trata-se de uma convicção que se baseia na autoridade de são João e são Paulo. O primeiro, em sua primeira carta, escreve: “Amados, desde já somos filhos de Deus, mas o que seremos ainda não se manifestou. Sabemos que por ocasião desta manifestação seremos semelhantes a ele porque o veremos tal como ele é" ${ }^{62}$. Enquanto que Paulo de Tarso, na primeira carta enviada aos cristãos de Corinto, afirma que, agora, "nosso conhecimento é limitado (...). Agora, vemos em espelho e de maneira confusa, mas depois veremos face a face" ${ }^{, 63}$.

Na mesma linha da segunda escolástica do mestre coimbrão e, portanto, dentro da tradição tomista, o teólogo jesuíta Francisco Suarez (1548-1617) ensina que a "bemaventurança" - um outro termo para a felicidade (beatitudine) - é o resultado da mobilização da inteligência e da vontade de uma só vez ${ }^{64}$ : a inteligência que ilumina e reconhece o Bem e a vontade que move as demais potências na conquista deste Bem. Podemos dizer portanto que, nesta perspectiva, a felicidade não pode ser compreendida apenas como um bem reconhecido em si mesmo e alcançável somente por uma visio Dei mística - mesmo que se tenha compreendido que a contemplação é a atividade mais perfeita no caminho para a felicidade -, porém é exigido do homem um trabalho, um esforço, um hábito que configuram, "nesta vida", uma busca ativa do bonum arduum 65 . Aqui, entendemos, inclusive, que não só as faculdades da alma racional entram nesta dinâmica,

\footnotetext{
${ }^{60}$ Cf. Delumeau, Jean (2003). O que sobrou do paraíso? (M. L. Machado, Trad.). São Paulo: Companhia das Letras (original francês de 2000), p. 198. (Delumeau cita Tomás de Aquino, Compedium theologiae, Paris, Vrin, 1984, p. 179).

${ }^{61}$ Ibid., p. 198 (Delumeau cita Tomás de Aquino, Summa Theologica, qq. 87-88, pp. 227-231)

${ }^{62} 1 \mathrm{Jo} 3,2-3$.

${ }^{63} 1$ Cor $13,9-12$.

${ }^{64}$ Cf. Ibid., pp. 384-386.

${ }^{65}$ Cf Summa Th. I-II, q. 40, a. 1, c.; I-II, q. 34, a. 2, ad 1.
} 
mas as paixões da alma, os apetites concupiscível (aquele que se move pelo simples reconhecimento do bem) e irascível (aquele que se move em direção da apreensão do bem árduo) são necessários também ${ }^{66}$.

Se voltarmos nossa atenção para a maneira como se configuraram as normas da vida espiritual na Companhia de Jesus, identificaremos, imediatamente, estas mesmas categorias descritas pelo universo filosófico-retórico jesuítico, denunciando, mais uma vez, aquela unidade a que vimos nos referindo nesta Terceira Parte do trabalho. Por exemplo, nos Exercícios Espirituais, mais especificamente nas "Regras para sentir e reconhecer de alguma maneira as diversas moções que se produzem na alma, as boas para as receber e as más para as rejeitar", Inácio descrevendo o que chama de "consolação" escreve:

Chamo consolação quando se produz na alma alguma moção interior pela qual a alma se inflama no amor de seu Criador e Senhor; e em seguida quando ela não pode mais amar nenhuma coisa criada sobre a face da terra por ela mesma, mas somente no Criador de todas as coisas. Da mesma forma, quando ela versa lágrimas que levam ao amor de seu Senhor, seja por causa da dor por seus pecados ou pela Paixão do Cristo nosso Senhor, seja por outras coisas virtuosamente ordenadas para o seu serviço e seu louvor. Enfim, chamo consolação todo crescimento da esperança, da fé e da caridade, e toda alegria interior que chama e atrai às coisas celestes e à salvação própria da alma, dando-lhe repouso e paz em seu Criador e Senhor ${ }^{67}$.

Assim descrita, a "consolação" coincide com o que se disse acerca da "felicidade", no sentido de que se trata de um reconhecimento do Sumo Bem - o "Criador e Senhor" do homem - ao mesmo tempo em que carrega consigo um empenho de "amor", um se deixar mover em direção às "coisas celestes e à salvação própria da alma", e também o conseqüente corolário - a "alegria interior" e o "repouso e paz" - de todo esse dinamismo de contemplação no real dos sinais da misteriosa presença do Criador, e de ação ordenada ao serviço e louvor

\footnotetext{
${ }^{66}$ Cf. Massimi, Marina (2001b). A Psicologia dos Jesuítas: Uma Contribuição à História das Idéias Psicológicas. Psicologia Reflexão e Crítica, 3(14), 625-633.

${ }^{67}$ Loyola, Ignace de (1991). Écrits (M. Giuliani, Pres. et Dir.). Paris: Desclée de Brouwer; Bellarmin (Collection Christus, 76, Textes) (originais do século XVI), pp. 222-224 (EE. 316, tradução nossa).
} 
desta mesma Presença - tudo isso parte do reconhecimento da vocação última do homem ${ }^{68}$.

Já ao final dos Exercícios Espirituais, quando dá algumas regras "Para o sentido verdadeiro que devemos ter na Igreja militante" - Inácio faz um chamado de atenção bastante significativo para o contexto histórico em que vivia. Ele diz:

Nós não devemos, habitualmente, falar muito da predestinação. Mas se, de alguma maneira, se fala às vezes, que se fale de tal modo que as pessoas simples não caiam em algum erro, como acontece às vezes, dizendo: "Que eu deva ser salvo ou condenado, já está decidido; e, que eu aja bem ou mal, não pode nada modificar". E assim, se relaxando, negligenciam as obras que conduzem à salvação e ao progresso espiritual de suas almas ${ }^{69}$.

A preocupação manifesta por Inácio, aqui, revela não só o empenho contra as heresias

modernas, especialmente contra o protestantismo então emergente e sua valorização da predestinação em detrimento da liberdade ${ }^{70}$, mas, na medida mesma em que revela sua adesão à tradição escolástica segundo a qual a felicidade é um objetivo que se alcança pelo aperfeiçoamento do homem livre nos bons costumes, é afirmação de uma confiança no homem (nesse sentido, em nada distante do "humanismo" de então), como ser capaz de cuidar das “obras que conduzem à salvação [sua e do próximo] e ao progresso espiritual” também de sua alma e da do próximo.

\footnotetext{
${ }^{68}$ Inácio lembra também, no EE. 177, falando dos "Três tempos para fazer, em cada um deles, uma sã e boa eleição" que "o terceiro tempo é tranqüilo: considerando inicialmente porque o homem nasceu, quer dizer para louvar Deus nosso Senhor e salvar sua alma, e desejando isso, escolhe-se, como meio, uma vida ou um estado que se situa no interior da Igreja, a fim de encontrar nisso uma ajuda para o serviço de seu Senhor e a salvação de sua alma. Digo um tempo tranqüilo: quando a alma não está agitada por diversos espíritos e usa de suas faculdades naturais, livre e tranqüilamente" (Ibid., p. 142, tradução nossa).

${ }^{69}$ Ibid., p. 252 (EE. 367, tradução nossa).

${ }^{70}$ Marías (1998) explica: "Precisamente ante a situação dramática da vida humana - que, evidentemente, desembocará na salvação ou na condenação -, a idéia de predestinação adquire um papel decisivo: muito mais no protestantismo, mas também no catolicismo: os teólogos dos séculos XVI e XVII imaginaram muitas teorias - algumas muito agudas - para conciliar a onipotência de Deus com a liberdade humana (os dominicanos, tendendo mais a enfatizar a onipotência à custa da liberdade; os jesuítas, mantendo mais vivamente a liberdade seus adversários pensavam que com isto se prejudicava a onipotência -; a doutrina da scientia media etc.). $\mathrm{O}$ fato é que houve uma tendência a afirmar a predestinação, que no protestantismo tem muito mais força e, especialmente no calvinismo, há uma restrição à liberdade. Especialmente no calvinismo, mas não se esqueçam de que Lutero era um adversário da liberdade e, precisamente por isso, Lutero rompe com Erasmo. Erasmo tinha interesse numa reforma da Igreja e, em princípio, não via com maus olhos o movimento reformista, mas o $D e$ servo arbitrio de Lutero lhe pareceu absolutamente intolerável e o ponto de ruptura entre ambos foi justamente o problema da liberdade". Marías, Julián (1998). Liberdade e Responsabilidade: Conferência proferida em Madrid, em 22-4-98, como parte do curso, no qual o conhecido filósofo analisou a perspectiva cristã, isto é, o modo como, independentemente da fé, o cristianismo informou a visão de mundo característica do Ocidente. (L. J. Lauand, Trad. e Ed.). International Studies on Law and Education, 2. Retirado em 27/10/2003, do World Wide Web www.hottopos.com/harvard2/liberdade_e_responsabilidade.htm, s/p.
} 
Também quando lemos o Diário de Moções Interiores de Inácio, podemos encontrar ali relatos da experiência de um modelo. Ele escreve, por exemplo, no dia 21 de fevereiro de 1544, que sentia, na oração, uma devoção contínua que o levava a experimentar uma certa elevação. Na missa celebrada, naquele dia, derramou muitas lágrimas e sua voz se paralisou algumas vezes. Sentiu “inteligências espirituais” acerca da Santíssima Trindade e, após considerar bem a questão, descobriu que a razão consistia nisso:

quando, antes, eu queria encontrar a devoção na Trindade, eu não queria buscá-la nem encontrá-la dizendo as orações ao Pai, e não me dispunha a isso, porque me parecia que não havia aí consolação ou visita na Santíssima Trindade. Mas, durante esta missa, eu conhecia, eu sentia ou via, Dominus scit, que falar ao Pai, ver que ele era uma Pessoa da Santíssima Trindade, me levava a amá-lo inteiramente, além das outras Pessoas que estavam nele essencialmente. Eu experimentava a mesma coisa durante a oração ao Filho, a mesma coisa durante a oração ao Espírito Santo, gozando indiferentemente de uma ou outra Pessoa enquanto sentia as consolações, relacionando-as a todas as três, e encontrando meu júbilo no fato de que elas pertenciam a todas as três. Parecia-me tão importante resolver este nó ou este algo deste gênero que eu não parava de me dizer, falando a mim: "Quem és tu? De onde? Etc. Que mereces? Ou: de onde vem isso? Etc."71.

Podemos perceber neste trecho da "experiência-modelo" de Inácio a maneira como ele se move no real, aplicando cada uma de suas potências numa unidade indissolúvel: o fundador da Companhia relata a experiência de uma familiaridade com a Santíssima Trindade que não pode ser descrita apenas como um misticismo passivo.

Este mesmo tipo de experiência de relacionamento com o Sagrado aparece na "autobiofonia" de Inácio. Por exemplo, Câmara, quando escreve sobre o período de convalescença de Inácio, relata que

já se iam para o esquecimento os pensamentos de antes, graças aos santos desejos que ele tinha, os quais lhe foram confirmados por uma visita, da seguinte maneira. Estando desperto uma noite, ele viu claramente uma imagem de Nossa Senhora com o santo Menino Jesus: desta visão, que durou um espaço de tempo notável, ele recebeu uma grandíssima consolação e permaneceu com um tal desgosto de toda a sua vida passada, e especialmente das coisas da carne, que lhe parecia que se havia retirado de sua alma todas as imagens que estavam nela pintadas antes. Assim, desde esta hora até agosto de 1553, onde isto é escrito, ele

\footnotetext{
${ }^{71}$ Loyola, 1991, op. cit., pp. 340-341 (\$63, tradução nossa).
} 
não teve jamais o menor consentimento às coisas da carne. E por este efeito, se pode julgar que a coisa era de Deus ${ }^{72}$.

Há um outro trecho do Relato, em que o fundador confirma, por suas palavras, aquela dinâmica que aparece descrita no Diário. Falando do período em que esteve em Manresa (1522-1523), o biógrafo conta que Inácio sentia que Deus se comportava com ele como um "mestre escola" - Ele o ensinava. Segundo Inácio, isso se poderia verificar, por exemplo, no seguinte relato:

Primeiramente. Ele tinha muito devoção pela Santíssima Trindade; e assim ele fazia, cada dia, oração às três Pessoas separadamente. E como ele fazia também à Santíssima Trindade, um pensamento lhe veio: como ele poderia fazer quatro orações à Trindade? Mas este pensamento só era trabalhado pouco ou quase nada, como sendo uma coisa de pouca importância. E um dia que, sobre os degraus do mesmo mosteiro, ele estava dizendo as horas de Nossa Senhora, seu entendimento começou a se elevar, como se ele visse a Santíssima Trindade sob a figura de três toques, e isto com tantas lágrimas e soluços que ele não podia se dominar. Enquanto ele seguia, nesta manhã, uma procissão que saia do mosteiro, ele não pôde em nenhum momento reter suas lágrimas até a hora da refeição. E depois da refeição ele não podia parar de falar da Santíssima Trindade, e isso com a ajuda de comparações numerosas e muito diversas, com muito júbilo e consolação. De tal forma que durante toda a sua vida ficou impresso nele o fato de sentir uma grande devoção quando faz oração à Santíssima Trindade ${ }^{73}$.

É interessante notar como essa “devoção pela Santíssima Trindade” que, aqui, aparece num período de sua vida anterior à data da escritura das notas no Diário de Moções Interiores (1544), que correspondente ao início do percurso de "conversão" por que passou, provoca em Inácio desde então a mesma experiência de consolação. Inácio se torna uma "experiênciamodelo" não porque viveu, em apenas um momento de sua vida, uma certa experiência extraordinária qualquer, mas porque se aplicou na virtude todos os dias, em toda o resto de sua vida, neste relacionamento, nesta familiaridade com a Trindade, a fim de atingir um grau de perfeição e de felicidade que se torna exemplo de realização da vida não só para os companheiros, mas para a Igreja e para o mundo.

É interessante notar, neste sentido, como as Constituições descrevem as qualidades de

\footnotetext{
72 Ibid., pp. 1022-1023 (§ 10, tradução nossa).

${ }^{73}$ Ibid., pp. 1033-1034 ( $\$ 28$, tradução nossa).
} 
quem será Prepósito Geral da Ordem: tratam-se das mesmas qualidades verificadas em Inácio.

Na Nona Parte do texto - O que concerne à cabeça e ao governo que dele descende -,

Capítulo Segundo (Quem deve ser o prepósito geral), aparece:

Quanto às qualidades que se deve desejar no prepósito geral, a primeira é que ele seja unido a Deus nosso Senhor e que tenha uma grande familiaridade com Ele na oração e em todas as suas atividades, a fim de que obtenha de Deus, como fonte de todo bem, uma abundante participação de seus dons e de suas graças em favor de todo o corpo da Companhia, assim como uma grande força e uma grande eficácia para todos os meios que se utilizará para ajudar as almas. O segundo: será um homem que, pelo exemplo de todas as virtudes, ajuda os outros membros da Companhia. Nele deve especialmente resplandecer a caridade para o próximo, seja quem for, e muito particularmente pela Companhia, assim como uma humildade verdadeira, que o torna muito amável a Deus nosso Senhor e aos homens. Ele deve também ser livre de todas as paixões, as mantendo domadas e mortificadas, a fim de que interiormente elas não perturbem o julgamento da razão; e que ele seja exteriormente tão mestre de si, e especialmente tão medido nos seus propósitos, que ninguém possa notar nele uma coisa ou uma palavra que não edifique, tanto aqueles da Companhia, que devem olhá-lo como um espelho e um modelo, quanto aqueles de fora ${ }^{74}$.

Essa “união a Deus nosso Senhor", essa "familiaridade com Ele", esse "exemplo de todas as virtudes", essas "caridade", "humildade", "mortificação das paixões" e "senhorio de si” a que se refere o texto jurídico-espiritual da Companhia de Jesus, são não só a descrição de qualidades gerais, mas a prescrição de um "modelo" - o de Inácio - que deverá ser o espelho de todo o jesuíta e de todos aqueles que se encontram com um jesuíta, a fim de que se cumpra “o fim desta Companhia", que é "não somente se empregar, com a graça divina, à salvação e à perfeição da alma de seus membros mas, com a mesma graça, buscar intensamente ajudar à salvação e à perfeição da do próximo"

Estas mesmas características se repetem quando o texto, na Terceira Parte $-A$ conservação e o progresso daqueles que estão em provação -, reza acerca dos instrumentos que esta ordem religiosa deve utilizar para conservar a alma e promover o avanço nas virtudes de seus membros (Capítulo Primeiro):

Será útil ter alguém de fiel e, tendo as qualidades suficientes, que instrua e ensine como se deve comportar interior e exteriormente, que o incite a isso,

\footnotetext{
${ }^{74}$ Ibid., p. 580 ( $\S$ 723-726, tradução nossa).

${ }^{75}$ Ibid., p. 396 ( $\$ 3$, tradução nossa).
} 
que o lembre e que o repreenda com amor; alguém que seja amado de todos aqueles que estão em provação, e a quem eles possam recorrer nas suas tentações e se abram com confiança, esperando dele em nosso Senhor consolação e ajuda em todas as coisas. Advertir-se-lhes-á que eles não devem guardar em segredo nenhuma tentação, sem a dizer a este, ou ao confessor, ou ao superior, feliz de que sua alma seja inteiramente conhecida. E eles não dirão apenas seus defeitos, mas também as penitências, ou as mortificações, ou as devoções e todas as suas virtudes, com uma pura vontade de serem recolocados no caminho certo em tudo aquilo que, em algum ponto, foram desviados, sem querer se conduzir por seu próprio julgamento se este não se junta ao parecer daquele que ocupa para eles o lugar de Cristo nosso Senhor ${ }^{76}$.

A "consolação" é o fruto seguro de um relacionamento objetivo com alguém que “ocupa (...) o lugar de Cristo nosso Senhor”, com quem o jesuíta em provação - ou seja, o que está percorrendo o caminho necessário para se tornar um verdadeiro companheiro de Jesus, como o foi Inácio de Loyola e tantos santos e mártires da ordem - se mede, ao se abrir com confiança, aprendendo paulatinamente a conhecer a si mesmo.

Em outro momento - O que ajuda a unir com sua cabeça e entre eles aqueles que estão espalhados (Oitava Parte) -, o texto das Constituições, ao descrever "o que pode ajudar à união dos corações" (Capítulo Primeiro) lembra que

O principal vínculo entre as duas partes, para a união dos membros entre eles e com a cabeça, é o amor de Deus nosso Senhor. Com efeito, quando o superior e os inferiores são muito unidos à divina e soberana Bondade, eles se unirão muito facilmente entre eles, pelo mesmo amor que descerá dela e se espalhará sobre todos os homens, e particularmente sobre o corpo da Companhia. É assim que a caridade, e em geral toda bondade e todas as virtudes que nos fazem agir segundo o espírito ajudarão, de uma parte a outra, neste união; e, conseqüientemente, ajudará também a todo o desprezo das coisas temporais que são habitualmente uma ocasião de desordem para o amor próprio, principal inimigo desta união e do bem universal. A uniformidade pode também ajudar bastante: que ela seja interior, na doutrina, nos julgamentos, nas vontades, tanto quanto for possível, ou exterior, nas vestimentas, nas cerimônias da missa e no resto, tanto quanto permitem as diversas sortes de pessoas, de lugares etc. ${ }^{77}$.

Em seguida, no parágrafo 673, quando prescreve a troca de correspondências como auxílio nesta união, o texto das Constituições lembra também que fica a encargo dos superiores e provinciais fazer saber às demais comunidades da Companhia de Jesus aquilo

\footnotetext{
${ }^{76}$ Ibid., pp. 460-461 (\$263, tradução nossa).

${ }^{77}$ Ibid. pp. 564-565 (§ 671, tradução nossa).
} 
que for conteúdo de "consolação e edificação mútuas no nosso Senhor"78.

Notemos que a experiência de "consolação" não é concebida como uma experiência isolada, fruto de uma graça especial destinada a poucos, ou fruto de uma ascese estóica individual, mas está intimamente relacionada à experiência de unidade entre os membros dispersos e entre eles e seus superiores: uma unidade que se expressa na uniformidade tanto interior, quanto exterior; uma unidade que, aqui, coincide perfeitamente com identidade, tal como aparece no Evangelho de são João, quando Cristo convoca os seus discípulos a se amarem mutuamente:

Filhinhos: vou ficar convosco só mais um pouco. Ireis me procurar, e eu vos digo agora o que eu já disse aos judeus: para onde eu vou, vós não podeis ir. Dou-vos um mandamento novo: amai-vos uns aos outros. Assim como eu vos amei, vós deveis vos amar uns aos outros. Se tiverdes amor uns para com os outros, todos reconhecerão que vós sois os meus discípulos ${ }^{79}$.

Outro aspecto importante da experiência de "consolação", que já apareceu acima e sobre o qual Inácio já insistia desde os começos da Companhia de Jesus é o que vem expresso em carta enviada ao então Duque de Gandía, Francisco de Borja, em fins de 1545:

Eu não devo vos esquecer em minhas orações e devo vos visitar espiritualmente por minhas cartas. Posso vos assegurar: tendo continuado, como o faço cada dia, a rezar por vós, e esperando em nosso Senhor que, se obtendes algum favor, ele virá unicamente do alto, descerá da bondade divina; considerando apenas sua eterna e soberana liberalidade, assim como vossa devoção e vossa santa intenção, acreditava, tendo-vos assim cada dia presente em espírito diante de mim, ter respondido ao desejo que experimentastes de ser consolado por minhas cartas. Considerando que as pessoas que saem de si mesmas e entram em seu Criador e Senhor conhecem o recolhimento assíduo, a atenção, a consolação, que elas vêem como todo nosso bem eterno se encontra em todas as criaturas às quais ele dá existência e que ele conserva nele por seu ser e sua presença infinitas, eu creio de boa vontade que estes pensamentos e muitos outros vos consolam mais que minhas cartas ${ }^{80}$.

Aqui, fica evidente a necessidade daquele "desprezo das coisas temporais" a que se referem as Constituições, pois além de serem "ocasião de desordem" - "principal inimigo da união e do bem universal" - , são elas também a impedirem a "consolação". Este "desprezo"

\footnotetext{
${ }^{78}$ Ibid., p. 565 (§673, tradução nossa).

${ }^{79}$ Jo $13,33-35$

${ }^{80}$ Ibid., p. 682 (tradução nossa).
} 
será eficaz quando o homem sai de si mesmo e preza todas as criaturas na medida em que elas indicam "seu Criador e Senhor". Apenas quem fixa "seus dois olhos sobre os bens celestes" não está dividido em si mesmo, não se engana e está unido à Cristo - “o único necessário" 82 , na Igreja e na Companhia de Jesus, experimentando, finalmente, aquela felicidade de

Não tendo nada, tudo possuir. Tudo, eu posso dizê-lo, tudo o que o Senhor prometeu dar por acréscimo àqueles que buscam antes o Reino de Deus e a sua justiça. Se tudo é dado em acréscimo àqueles que buscam antes o Reino de Deus e a sua justiça, poderá faltar alguma coisa àqueles que buscam unicamente a justiça do Reino e o Reino ele mesmo ${ }^{83}$

A fim de conquistar essa felicidade da união e da familiaridade com o "único necessário", é preciso que o homem inteiro se decida por isso. Assim Inácio se expressa, em carta enviada no dia 30 de março de 1556, a Alphonso Ramirez de Vergara:

O meio para saborear pelo coração e para executar com suavidade o que a razão dita como sendo o maior serviço e a glória de Deus, o Espírito Santo vos ensinará melhor que qualquer outro. É verdade que, para elevar-se às coisas melhores e mais perfeitas, a moção da razão é suficiente; no entanto, a da vontade, não precedendo em nada nem a decisão nem a execução, não deixaria de as seguir, porque Deus nosso Senhor recompensa a confiança que se tem em sua Providência, o inteiro abandono de si mesmo e a renúncia às consolações pessoais, atribuindo muito contentamento, gosto e uma consolação espiritual mais abundantes que se pretenda, e que se busque puramente sua glória e seu bom prazer. Agrada a sua infinita e soberana bondade conduzir tudo o que vos concerne segundo o que ela verá como mais conveniente a este fim $^{84}$.

O movimento iniciado pela "razão é suficiente", mas pela vontade renuncia-se a si mesmo e adere-se ao chamado de Deus, recebendo um "gosto e uma consolação espiritual mais abundantes" que se esperava e pretendia. Também Pedro Sanchez (1607), quando enumera as quatro vocações dos homens - à vida, a ser filho de Deus, à perfeição e ao trabalho na vinha do Senhor - diz que este é um dom precioso e completa:

Et c'est une chose fort merveilleuse de voir, comme sans forcer nostre volonté, il nous attire quelquefois, nous invitant avec moyens \& contentements: autres

\footnotetext{
${ }^{81}$ Carta enviada em agosto de 1537 a Pietro Contarini. Cf. Ibid., p. 654 (tradução nossa).

${ }^{82}$ Ibid., p. 654 (tradução nossa).

${ }^{83}$ Ibid., p. 654 (tradução nossa).

${ }^{84}$ Ibid., p. 984 (tradução nossa).
} 
fois nous menassant, \& nous donnant de craintes \& espouvantes, a fin de ramasser ses esleuz avec toute doucer dans son Royaume ${ }^{85}$.

Se a vontade é forçada, o homem perde a liberdade ${ }^{86}$ : apenas aplicando-a livremente, numa obediência de entendimento, cheia de razões, o homem (cor)responderá adequadamente ao chamado de Deus para a sua vida e alcançará sua realização e "consolação" definitivas, experimentando-as ainda nesta vida ${ }^{87}$. Somente oferecendo seu entendimento, liberdade e vontade a Deus, o homem pode chegar a dizer aquele fiat ergo voluntas tua em todas e em cada coisa e gesto, de todos e em cada modo em que agir, sempre visando o "único necessário".

E no que consiste esta liberdade do homem? Nieremberg (1957) responde assim: "En esto está la libertad de los hijos de Dios: el desprecio del mundo, la tranquilidad del ánimo, la conformidad con la voluntad divina, la verdadera prudencia; y es fundamento de toda virtud mirar que no nacimos sino para servir a nuestro Creador solamente" ${ }^{\natural 8}$. O que mais poderia descrever este estado de liberdade, em que o homem, enfim, está constantemente amando a

\footnotetext{
${ }^{85}$ Sanchez, Pedro (1607). Le Royaume de Dieu, et le vray chemin pour y parvenir. Composé en Espagnol par le Pere P. Sanchez, Docteur de la Compagnie de Iesus. Traduit en François, par F. Guillaume Levite, de l'Ordre des Predicateurs. Paris: Chez Adrian Beys (original espanhol de 1594), p. 171 ("E é uma coisa muito maravilhosa ver como, sem forçar nossa vontade, Ele nos atrai algumas vezes nos convidando com meios e contentamentos; outras vezes nos ameaçando e nos dando medos e espantos, a fim de ajuntar seus eleitos com toda a doçura no seu Reino", tradução nossa).

${ }^{86}$ Cf., por exemplo, Nieremberg, 1657, op. cit.. Também Rodrigues (1834) explica que a obediência e os demais votos não tiram a liberdade, apenas a aperfeiçoam e completa dizendo, com Santo Anselmo, que "peccare non est libertas, nec pars libertatis; peccare est potius non posse, quam posse: quincumque enin facit, quod sibi non expedit, quantò magis hoc potest, tantò magis adversitas, et perversitas possunt in illum: Poder pecar, y poder usar mal de la libertad, no es perfeccion, sino imperfeccion y miseria; ese no es poder, sino flaqueza y enfermidad" ("pecar não é liberdade, nem parte da liberdade; pecar é mais não possuir que possuir: de fato sempre que faz quem não o impede, quanto mais este pode pecar, tanto mais adversidade e perversidade haverá nele: poder pecar e poder usar mal da liberdade não é perfeição, mas imperfeição e miséria; isso não é poder, mas fraqueza e enfermidade", p. 100, tradução nossa). Rodriguez, Alonso (1834). Ejercicio de perfeccion y virtudes cristianas, su autor el Padre Alonso Rodriguez de la Compañía de Jesus, natural de Valladolid. Dividido en tres partes. Parte tercera. De varios medios para alcanzar la virtud y perfeccion. Nueva Impression. Barcelona: Imprenta de D. Valero Siena y Marti (original espanhol de 1609).

${ }^{87}$ Em um outro trecho da mesma obra, Sanchez (1607) diz que, diante do chamado de Deus, o homem deve dizer como Santo Agostinho "Senhor dai-me o que me pedis, e vos peço o que vos agrada" (Cf. Ibid., p. 226, tradução nossa). Este "querer o querer de Deus" é o que faz com que Ele "nos guie para onde é mais necessário" (Ibid., p. 226, tradução nossa) e experimentar o cêntuplo prometido no aqui e agora de sua vida.

${ }^{88}$ Nieremberg, Juan Eusebio (1957). Obras escogidas del R. P. Juan Eusebio Nieremberg. (E. ZepedaHenriquez, Ed.). Em E. Zepeda-Henriquez (ed.). Biblioteca de Autores Españoles, desde la formación del lenguaje hasta nuestros dias (Tomo 104). Madrid: Ediciones Atlas (originais do século XVII), p. 249 ("Nisto está a liberdade dos filhos de Deus: o desprezo do mundo, a tranqüilidade do ânimo, a conformidade com a vontade divina, a verdadeira prudência; e é fundamento de toda virtude olhar que só nascemos para servir a nosso Criador somente", tradução nossa).
} 
Verdade (que é "a base e o fundamento imóvel" 89 de toda felicidade que anseia)? Segundo Nieremberg (1657), deve-se enumerar também o uso mesmo da "Razão", que dá "Ser à Verdade", "vem do Céu", "procede de Deus, como de sua primeira e natural Origem"90; a "Razão" que traz repouso e facilidade, que "transforma todos seus espinhos em rosas", sempre porém com a "assistência do Céu", pois ela "sem dúvida tem necessidade da Graça; de onde deve lhe vir seu maior e mais seguro socorro" $"$.

A experiência de "consolação" - presente, passada ou futura (experiência, memória ou esperança) -, nas cartas Indipetae, parece ser a indicação daquela felicidade a que se destinam todos os homens, segundo esta antropologia filosófica. A experiência de "consolação", como termo deste dinamismo que vimos descrevendo, é o feliz resultado de uma vida de atenção à realidade tanto do mundo que rodeia o jesuíta - um mundo "sacramental"92 -, quanto do mundo que esconde dentro de si - a analogia com o Mistério, o Alfa e Ômega. A experiência de "consolação" é o efeito daquela "obediência", que nada mais é que adesão ao fim último, identificado no trabalho de "conhecimento de si" e de atenção ao mundo e aos demais homens.

\footnotetext{
${ }^{89}$ Nieremberg, 1657, op. cit., p. 475 (tradução nossa).

${ }^{90}$ Ibid., p. 473 (tradução nossa).

${ }^{91}$ Ibid., pp. 377-378 (tradução nossa).

${ }^{92}$ Cf. Pécora, Alcir (1994). Teatro do Sacramento: a unidade teológico-retórico-política dos sermões de Antonio Vieira. São Paulo: EDUSP.
} 


\section{CONSIDERAÇÕES FINAIS}

Basicamente, no trabalho de demonstração da hipótese inicial de uma "experiência de liberdade" presente às Litterae Indipetae, buscamos responder à três perguntas: o que são estes documentos? Como as categorias "experiência" e "liberdade" aparecem na forma mentis de um jesuíta? E, qual o dinamismo que, nas cartas, poderia comprovar aquela hipótese?

De início, buscando descrever as fontes primárias com as quais trabalhamos. Assim, ficou-nos evidente que se trata de um gênero particular de correspondência epistolar, produzida no âmbito da Companhia de Jesus, entre os anos de 1581 e 1770: as cartas visam exclusivamente a petição de envio em missão nas Índias; que são escritas conforme um protocolo formal, próprio da tradição da ars dictaminis, com incontestável estrutura retórica. De fato, estão presentes, no corpo das cartas, as partes da correspondência epistolar, tal como, classicamente, foi concebida: salutatio, captatio benevolentiae, narratio, petitio, conclusio com valedictio, local, data e assinatura. Além disso, mostramos como esta forma, estudada e controlada, não impede que o conteúdo seja fruto da 
elaboração de uma experiência pessoal de eleição; onde os autores, antes da escrita, certamente passaram por um trabalho de investigação pessoal acerca de si mesmos.

Não deixamos de mencionar também algumas das inúmeras outras motivações subjacentes à produção destes documentos - políticas missionárias dos várias colégios da Companhia de Jesus, questões econômicas dos Estados Nacionais, interesses religiosos, políticos e econômicos da Cúria Romana, interesses pessoais quanto a relacionamentos familiares e de amizade etc. - e esclarecemos que, não obstante este universo amplo de investigação, a nós interessava analisar as fontes do ponto de vista da "elaboração de experiência" nelas presente, dado que era este o aspecto a nos permitir, no diálogo entre história e psicologia, investigar elementos do "dinamismo psíquico" tal como compreendido nos séculos XVI e XVII, especificamente na Companhia de Jesus.

Em seguida a esta apresentação geral das fontes primárias, partimos para uma descrição canônica detalhada de cada uma daquelas que selecionamos para nosso corpus documental: 26 cartas, sendo 23 de diferentes autores, escritas entre os anos de 1583 e 1609, e 3 de um mesmo autor, escritas entre 1603 e 1605. Explicamos também, neste sentido, a escolha do recorte histórico (1581-1615) - o generalato do Padre Claudio Aquaviva: primeiro, porque se trata de um período fundamental na história da Companhia de Jesus, na medida em que é neste governo que a ordem começa a se uniformizar e assumir um "rosto" propriamente jesuítico (corresponde, por exemplo, à aprovação da Ratio Studiorum, que unifica o ensino nos colégios e universidades dirigidas pelos jesuítas, e do Diretório dos Exercícios Espirituais, que unifica a regra espiritual e a maneira de viver a espiritualidade, com características em tudo semelhantes às de Inácio); depois, porque Aquaviva assume o governo num momento de grande crescimento da ordem, de forma que se faz necessária uma política missionária adequada à magnitude a que se foi chegando. 
No passo seguinte, mostramos como os termos "liberdade" e "experiência" são usados no âmbito da Companhia de Jesus.

Antes de partirmos para esta análise, procuramos evidenciar como o conceito "experiência", no universo histórico, cultural e institucional com o qual trabalhamos, era importante e determinante para a seqüência da investigação: o XVI-XVII como momento de uma importante cisão entre experientia e experimentum, onde o primeiro conceito se vê, paulatinamente, reduzido ao segundo, tanto no ponto de vista da filosofia, quanto no da produção científica de então. Ainda neste ponto, mostramos como a Companhia de Jesus, apesar de influenciada pela mentalidade "renascentista" e "humanista", cultivou, por vários anos, a tradição escolástica.

Indicamos também, como critérios de análise, três fundamentos básicos do modus vivendi jesuítico, a que demos o nome de pólos. Para cada um destes pólos estudamos um conjunto de fontes diferenciado, assim: para o scholicorum, descritivo do modus cogitandi próprio dos jesuítas, trabalhamos com um manual de filosofia moral e com alguns dos textos clássicos de retórica por eles utilizados; para o pólo chamado ratio spiritualis, descritivo do modus operandi, no nível da espiritualidade desta ordem religiosa, analisamos vários documentos responsáveis pela regulação espiritual; e, finalmente, para aquele a que demos o nome de ratio institutorum, que ajuntava os documentos descritivos do modo de agir, no nível institucional, característico da Companhia de Jesus, estudamos basicamente os textos jurídicos fundantes. Além destes três pólos, analisamos e descrevemos um quarto gênero de documentos: escritos espirituais produzidos no período do referido generalato. Este último conjunto de documentos, conforme sugerimos, seria a referência encarnada do cogitare e do operari identificados nos outros três agrupamentos de fontes secundárias, dada a sua característica de ser produto de um conhecimento per experientia daquilo que, até este nível, permanecia pura regra de ação ou puro pensamento. 
Em seguida, tendo como ponto de partida estes pólos, descrevemos, uma a uma, aquelas duas categorias - "liberdade" e "experiência". Compreendemos, neste sentido apesar do risco constante de um estruturalismo que poderia destruir a dinâmica própria das Indipetae - que ambos os conceitos deveriam ser entendidos dentro de uma unidade filosófico-retórico-institucional-espiritual. De tal maneira que, por exemplo, não era possível nos limitarmos apenas ao desenvolvimento filosófico dado aos termos nos manuais de casuística da Companhia de Jesus, tampouco poderíamos descrever um ou outro deles a partir apenas da regra espiritual ou institucional. Verificamos que há uma unidade de compreensão que, vimos, baseia-se na carnalidade de uma "experiência-modelo" fundante: a de Inácio de Loyola que, como modelar que é, inspira tanto a "experiência" dos padres espirituais, quanto a dos jovens indipetentes.

Num terceiro momento, tendo identificado nas Indipetae uma série de lugares-comuns peculiares ao gênero de documento que são e, evidentemente, ao universo cultural e institucional em que foram produzidos, propusemos uma leitura do dinamismo presente no corpo das cartas, mostrando primeiramente como essas tópicas poderiam ser agrupadas em três grandes conjuntos de termos - o "conhecimento de si", a "obediência" e a "consolação" para, em seguida, descrever cada um desses grupos. Essa descrição deu-se, como acompanhamos nos últimos capítulos, sempre buscando colocar em evidência a vitalidade de seu uso nas correspondência de petição de nossos jovens jesuítas, mas também mostrando sua origem "gramatical" na tradição a que pertencem, no modelo de experiência que imitam.

Assim, pudemos ver como o "conhecimento de si" - um dos três vértices fundamentais para a compreensão do que seja uma "experiência de liberdade" - é momento fundamental no trabalho de eleição a que são educados e formados os jesuítas. Mas, mais do que isso, verificamos como esta tópica pressupõe uma unidade indissolúvel entre corpo e 
alma, de forma que, falar de "conhecimento de si" não significa apenas uma cognição estanque de estruturas psíquicas ou de capacidades físicas isoladamente: trata-se, sempre, de uma unidade não apenas na pessoa, mas da pessoa com a realidade espaço-temporal que o circunda, de modo que o mundo e as criaturas todas, se tornam realidades sacramentais.

Vimos também que a "obediência" e suas tópicas correlatas não são um jugo ou uma constrição irracional, mas o passo necessariamente consecutivo ao trabalho de "conhecimento de si”, na medida em que, tendo compreendido a que é vocacionado na vida, o jesuíta, atento ao desejo ordenado que experimenta, adere às condições de realização que o desejo mesmo impõe. "Escravo" de quem lhe deu o desejo, submete-se, indiferentemente, às vias de perfectibilidade que o próprio Doador fornecerá, por meio daquele a quem, imediatamente, o jesuíta deve obedecer, no caso específico da petição que escreve - ao Superior Geral. Tudo isso, com o trabalho da constante retomada das razões, tendo sempre na memória o objetivo final ad maiorem Dei gloriam.

Quanto à "consolação", pudemos nos certificar de como esta é a conseqüência necessária deste dinamismo. Vivida não apenas como uma esperança, a “consolação", nas cartas Indipetae, aparece também como uma confirmação da veracidade do desejo, ou melhor dizendo, da origem divina do desejo e, por conseguinte, de sua ordenação.

Juntos, estes topoi e seus correlatos, lidos no dinamismo que descrevem - e apenas aí -, apontam precisamente para uma "liberdade" entendida não como categoria abstrata, ou como conceito estanque, mas como uma "experiência". E somente se partimos deste pressuposto, será possível ler nas cartas - nas quais, ficou patente, o termo "liberdade" não comparece uma única vez sequer - a descrição de uma "experiência" à qual necessariamente deveremos dar o nome “de liberdade". Não se trata, manifestamente, de uma experiência que se reduza a um ou outro daqueles conjuntos de lugares-comuns: não podemos, por exemplo, dizer que a liberdade 
coincida com o "conhecimento de si", dado que este é apenas um dos vértices dessa geometria que, somente ela - tomada em sua totalidade -, é capaz de representar aquela "experiência de liberdade" que supomos presente em nossas fontes primárias.

Sem dúvida que estas são categorias filosóficas, antropológicas e existenciais fundamentais e, por isso mesmo, devem ter sua compreensão muito bem delimitada, para que não se incorra no erro de dar por óbvia ou inexistente sua influência sobre determinadas práticas. No caso estudado, inclusive, elas podem ser consideradas partes da "psicologia filosófica" produzida no âmbito da própria Companhia de Jesus, na época. Trata-se de uma maneira de "intervir" sobre o "psiquismo" que tem como base um certo olhar sobre o humano muito específico e bastante eficiente, visto que tendida à conversão. E uma conversão que deve ser entendida do ponto de vista da moralidade, mais que do moralismo: quer dizer, devemos buscar entendê-la sob a perspectiva do amor à Verdade Última de si mesmo, do mundo e de toda realidade criada. Para usar a gramática da época, estamos falando da tópica do "desengano": o jesuíta era educado a viver a realidade como sinal, eliminando todo o amor à imagem - grande ou pequena demais - de si mesmo, do mundo e de toda a realidade criada, a imagem construída pelo engano e pela não ordenação de suas potências ao télos - que é, ao mesmo tempo arché - de toda a vida.

Podemos concluir, portanto, que as Indipetae, entre os muitos outros elementos que podem oferecer ao pesquisador interessado por este documento seguramente rico em matériaprima para investigação, descrevem uma "experiência de liberdade", com todos os conseqüentes e necessários aspectos de uma maneira peculiar de compreensão do "dinamismo psíquico" humano.

A “experiência de liberdade" que procuramos trazer a público, bem como a estrutura subterrânea que tentamos fazer vir à tona, descrevendo-a com o máximo de elementos de uma gramática de uso específica, não é um "sentimento interior", ou um "substantivo" que sabe a 
abstração, nem mesmo pode ser considerada como uma "experiência mística".

Vista da perspectiva da forma mentis e do modus vivendi descritos, essa "experiência de liberdade" que identificamos nas Litterae Indipetae aponta alguns aspectos basilares para a constituição da psicologia moderna. Senão, vejamos.

Se lançamos um olhar breve sobre a história da psicologia moderna, saltará às vistas a influência de uma certa concepção de "experiência" que é, em tudo, devedora daquela idéia emergente na Idade Moderna, segundo a qual a veracidade de qualquer pressuposto teórico será conquistada à custa somente da experimentação.

Estamos, portanto, nos confins de uma questão historicamente determinante: a das opções metodológicas assumidas pela psicologia moderna. Nas suas origens como disciplina autônoma - no século XIX -, a psicologia científica, tendo rompido com toda uma tradição anterior que já elaborara saberes acerca do "dinamismo psíquico", assume o método experimental como caminho unívoco para chegar a tocar e desvendar o psiquismo humano e todos os fenômenos a ele relacionados. Esta opção de método está claramente fundada sobre os elementos oferecidos pelo empirismo inglês, segundo o qual a "experiência" se reduz ao aspecto sensorial. Trata-se da mesma matéria-prima que sustentará, nos seus inícios, por exemplo, o conceito de "experiência imediata" wundtiano, que fez da psicologia experimental um análogo das ciências físicas: a definição do objeto se limitou a elementos básicos gerais, como "sensações", "sentimentos" e "mente" (entendida, esta última, como aquele conjunto de fenômenos mentais que se podem apreender pela "experiência imediata").

Assim, não é de se estranhar que, hodiernamente, entre os extremos de uma psicologia de bases biológicas e uma metapsicologia, seja uma mesma premissa a priori a se aplicar indistintamente, de forma a fundamentarem pretensões éticas e epistemológicas sobre uma concepção de homem, na maior parte das vezes mecanicista e estruturalista. 
Além disso, se pensarmos do ponto de vista do "alvo" dessas concepções, nos depararemos com outros problemas: ante a pergunta “qual o objeto da psicologia?", cada um responderá conforme o instrumental que já possui - o método determinando o objeto. É perturbador ver que, no mais das vezes, há um grande desentendimento a este respeito: enquanto que uns reduzem o objeto às estruturas profundas do funcionamento cerebral, outros se contentam com comportamentos manifestos social ou individualmente; enquanto que outros ainda se ocupam em formulações acerca de traumas do passado determinantes de atitudes presentes ou futuras, há os que encerram a questão afirmando o pragmatismo. Brevemente: acabamos, de alguma forma, sempre absolutizando um ou outro dos fatores que - é verdade - constituem este "objeto", mas numa atitude que, na maior parte das vezes, mais divide que unifica, mais contribui ao isolamento que ao diálogo.

Evidentemente que, com estas descrições simplistas, não queremos dar a palavra final acerca de tudo o que se produziu em psicologia desde sua "fundação". Porém, atentemos ao fato que, com este horizonte assim desenhado, com esta ausência de certeza acerca do objeto, com esta fragmentação, parcialidade e isolamento dos fatores particulares que impõe a tudo aquilo sobre o quê se ocupa, a psicologia sofre uma grave crise epistemológica, já denunciada por muitos antes de nós.

O trabalho de escavo das origens, o trabalho de apresentação, de emersão do "período gestacional" desta ciência só terá valor se contribuir a repensar o que, há muito tempo, vimos dando por óbvio. Ou a experientia, tal como aprendemos dos jesuítas, serve de resposta à evidente exigência de unidade para uma constituição, sobre bases sólidas, do estatuto epistemológico da psicologia, ou será apenas fruto de uma curiosidade ou erudição. Este estudo histórico nos aponta a necessidade de se aplicar a noção de experientia para além do que historicamente vimos assumindo como opção metodológica. 
Faltam-nos, talvez, elementos para compreender aquela "experiência de liberdade" que descrevemos exatamente porque nos falte uma concepção de "experiência" adequada, ou melhor e mais fundamentalmente, porque nos falte uma apropriada visão de homem. Mas, como chegar a um conceito de homem mais adequado? Que critério utilizar na escolha de um e não de outro?

Aprendamos per experientia, por que não?

Na visão de homem que sustenta aquele "dinamismo psíquico” descrito nas Indipetae, o aspecto mais surpreendente é a consideração da totalidade dos fatores que compõem a pessoa: corpo, sensações, afetos, juízos, tudo é levado em conta... e nenhum deles é considerado fora da indissolubilidade da unidade da pessoa em si e com a realidade. Através da experientia, este homem assim concebido, lança mão de tudo o que é - desde as faculdades da alma vegetativa até as da racional -, gerando um saber sobre si e sobre o mundo, que o permite de se arriscar no desconhecido do "além-mar".

A experientia é, portanto, fator cognoscitivo aplicável a todo o espaço que se estende do micro ao macrocosmos, tal como eles os concebiam: a realidade inteira e o homem na sua relação com ela e com seus iguais. Segundo esta concepção, o homem é aquele nível da criação que é capaz de uma consciência de si e do todo que o circunda; é, pois, aquele ponto da natureza que colhe, para além dos dados sensíveis, o sentido acerca do que coligiu, elaborando um necessário juízo da razão.

A “experiência de liberdade”, que nasce desta dinâmica, nada mais é que a experiência de reconhecimento em si mesmo daquele movimento que impinge à felicidade, e adesão sincera e simples Àquele de quem, por analogia, se é imagem e semelhança, no infinito do desejo. Porém, esta mesma "experiência de liberdade" que, nas cartas tantas vezes aparece, como dissemos, apenas como expectativa, se realiza já no cotidiano e no ato mesmo da escritura da Indipeta, quando o jesuíta afirma um relacionamento objetivo - a que todos eram 
educados a viver - com o Absoluto, na realidade sacramental de uma companhia.

Todo esse dinamismo é, sim, radicalmente dirigido ao Absoluto, mas não numa espera passiva de um tempo que virá... Será o drama de tensão entre o reconhecimento da própria finitude e do desejo infinito que sinaliza o Mistério, a mobilizar este homem entendido como unidade indissolúvel - corpo e mente - numa busca incessante: será livre aquele que não pára e, não estando parado, pede, num gesto de pura e humana filiação e pertença.

Esperamos, tendo dado voz a esta realidade tão distante de nós no tempo e na mentalidade, ter contribuído mais para uma experiência de familiaridade e de reconhecimento que de estraneidade. Deixemo-nos provocar pelas perguntas que nascerão, com certeza, da progressiva amizade com esta realidade outra.

Ribeirão Preto, dia de Finados, 


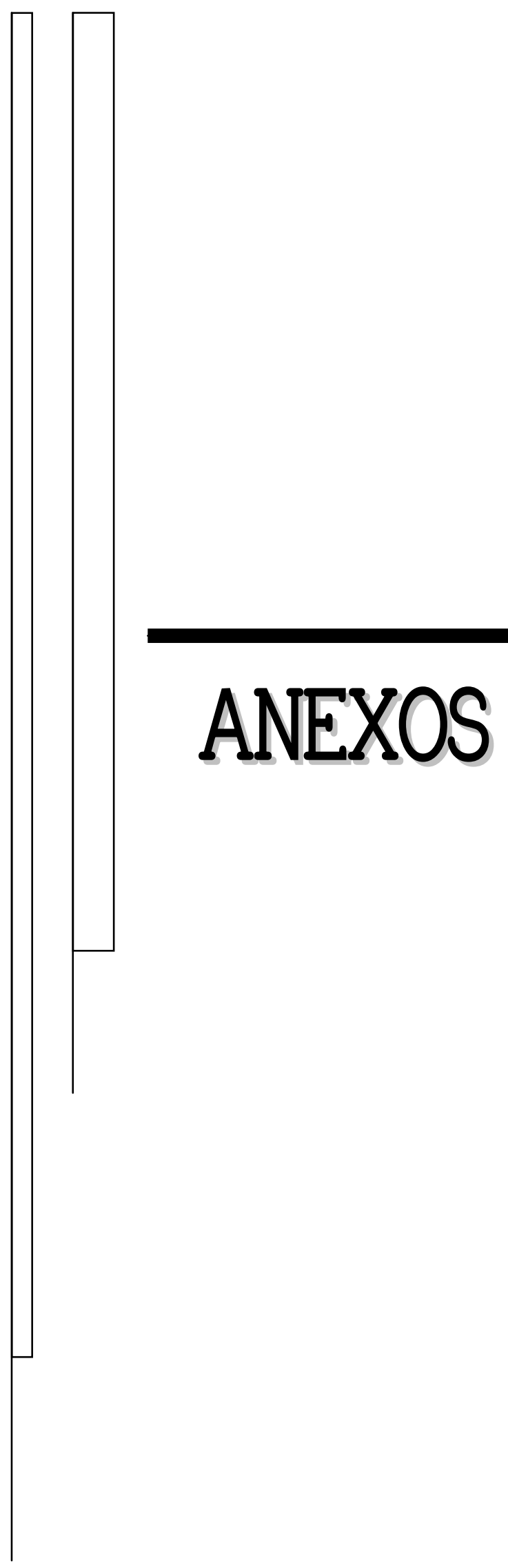




\title{
ANEXO 1 Indipetae Hispanae (1583-1609)
}

\author{
ARSI, Indipetce Hispance, FG 758, carta n. 4 \\ Muy R.do en Chr.o P.e N.ro ${ }^{1}$ \\ Pax Chri. etc. ${ }^{2}$
}

Los desseos de yr al Japon, que como V.P. ${ }^{3}$ sabe, años ha tengo, de tal manera crecen, que tengo por tentacion dexar de proponerlos a V.P. segunda vez, y haviendolos consultado con el Padre Hieronimo Domenech, ha sido de parecer escriviesse esta, dando cuenta a V.P. de ellos. Son tales, quales y quan fervorosos fueron, los que N.ro S.or ${ }^{4}$ me dava, quando me llamo por su infinita bondad a la Compañia: y uno de los motivos que para entrar en ella tuve, fue un encendido desseo de yr al Japon, y esse ahora me es grande espuela ${ }^{5}$ para caminar ala perfeccion. Porque quando se me ofrecen trabajos y dificultades en el camino de la virtud, se me allanan ${ }^{6}$ con la memoria, de que Dios N. S. ${ }^{7}$ me llama para mayores. Lo qual me ayuda en grande manera, para tener paciencia y mortificarme interiormente muchas vezes al dia, para desapegar la aficion de las cosas, que pueden impidir mi aprovechamiento espiritual, y para la resignacion que en todas las cosas y obediencias pide N.ro S.to Instituto. He querido, quando siento estas aldavadas ${ }^{8}$ en mi anima de yr a las indias, hazer el sordo y as vezes actos contrarios, hablando conmigo mismo, y diziendome, que son fervores de caçuela, y que Dios no me llama, y que lo mejor es estar resignado y no pedirlo, y que es tentacion, y que mas me conviene estar en estas partes: haziendome para esto las razones, que podrian ser causa, para

\footnotetext{
${ }^{1}$ É muito comum o uso de abreviações no texto das Indipetae. Aqui, o autor escreve: Muy Reverendo en Christo Padre Nuestro (Muito Reverendo em Cristo Padre Nosso).

${ }^{2}$ Saudação inicial comum a quase todas as cartas.

${ }^{3}$ V.P. = Vuestra Paternidad . Modo como os jesuítas se referiam ao Superior Geral da Companhia. No caso de nossas cartas, os indipetentes se referirão sempre ao P.e Cláudio Acquaviva.

${ }^{4}$ N.ro S.or $=$ Nuestro Señor $=$ Nosso Senhor.

${ }^{5}$ Espuelas $=$ esporas. Aqui é usado no sentido de incentivo.

${ }^{6}$ Allanar $=$ sujeitar, pacificar. Aqui é usado no sentido de trazer paz.

${ }^{7}$ N. S. = Nuestro Señor.

${ }^{8}$ Aldabada = batida na porta. Aqui é usado no sentido de toques.
} 
que V.P. no me lo concediesse; como que ahora dos años tuve algunas melancholias, y que a ratos viu enfermizo, y que si pidiendolo yo me lo concediessen, podria tener sospecha de que me movio amor proprio a pidirlo, y por consiguiente, que sera de ningun fruto mi yda, assi para mi, como para los yndios. Pero en semejante caso experimento dos cosas. La una es, que ades hora me da devero Dios N. S. un desseo fervoroso, que como luz del cielo deshaze en mi alma aquellas tinieblas y razones, dexandome muy consolado, y con tal alegria, que me parece bastante para $\operatorname{arrostrar}^{9}$ a qualquiera dificultad y trabajo que por entonces se me podria ofrecer, y de hecho se me haze todo suave. La otra es, que por quanto estas razones me causan seguedad y inquietud entretanto que duran, y restriban en mis fuerças y proprias comodidades, juzgo ser del Demonio; y por quanto no me agotan el desseo, ni satishazen, ser de poco momento y eficacia. Principalmente, que ya estoy libre gloria al S.or de toda melancholia, y muy lexos ${ }^{10}$ della, que alfin no me era natural, y aunque algunas vezes estoy de malagana (cosa que por todos passa) pero es de tal calidad, que el exercicio corporal, y ocupacion exterior, de que ay abundancia en las Yndias, del todo me la quita. Y para concluyr no ay exercicio, por demas trabajo, y baxo que sea, que no me lo encomienden los Superiores a mi, como a qualquier hermano coadiutor, y con todos me hallo bien, por todo sea Dios bendito. De manera que solo puede ser estorvo desto mi poca virtud, la qual tengo bien conocida; pero como quiera que los desseos, que de la perfeccion, y de yr al Japon me da D. N. S. lleguen a este punto, que los unos me causan grande cuydado en la observancia de las regras, y siempre, que se ofrece haver de poner en execucion alguna, actualmente ofrezco aquel acto a N. S. y siempre que me han advertido de alguna falta, grande o pequeña, o me he emmendado luego, o lo he procurado hasta haverlo hecho gloria al S.or: y los otros, parte por los muchos años que ha los tengo, haviendolos encomendado a N. S. con perseverancia; como por lo mucho que me ayudan para perficionarme en la virtud me dan tales prendas de ser llamamiento y vocacion de D. N. S., essa que aunque no tuviesse tanta salud como tengo ni tanta virtud como para tal empresa es menester so pena de mentir al Sp.tu S.to, me obligan a que confiado que su infinita misericordia suplira lo que en mi falta quando fuere su voluntad que esto se me conceda con resignacion pida a V.P. me enbie al Japon buscando en esto la mayor honra y gloria de su divina Magestad a quien humilmente suplico con desseo de mi aprovechamiento y de aquellos indios inspire a V.P. lo que fuere mas para su S.to Servicio. Amen. En los S.tos Sacrificios y oraciones de V.P. muy deveras me encomiendo.

De Valencia a 2 de mayo 1583.

D.V.P. servo indigno y hijo en el Señor

Copia de otra de 11 de Abril

Seraphin Bonaventura Coçar.

\section{ARSI, Indipetce Hispance, FG 758, carta n. 13 $\mathrm{JHS}^{11}$ \\ Muy R.o P.e N.ro en Xpo ${ }^{12}$ \\ Pax Xpi etc.}

Por averse offrecido tan buena occasion como esta, con la venida de el padre Procurador de el Japon me parecio no dexarla pasar, sin dar parte a V.P.ad de los deseos que N.ro S.or ha sido servido communicar a este su siervo indignisimo: y aunque lo pudiesse hacer por tercera persona; mas confiado de el amor, que V.P.ad a todos nos tiene, como comum padre de toda la Comp. ${ }^{13}$ y particular de cada uno de nosotros; lo quise hacer por mi, para confirmar mas

\footnotetext{
${ }^{9}$ Arrostrar $=$ resistir.

${ }^{10}$ Lejos $=$ distante.

${ }^{11} J H S=$ Iesus Hominibus Salvator = Jesus Salvador dos Homens.

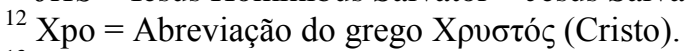

${ }^{13}$ Compañía.
} 
mis deseos, con la autoridad de V.P.ad y hacer lo que sentia ser obligado, para corresponder a las inspirationes de N.ro S.or. Abra dos años poco mas, o menos; que leyendo, y mirando con mas attention, que otras veçes solia, lo que n.ros p.es hacen en las Indias orientales, specialmente en el Japon; y los travajos, que pasan por Christo N.ro S.or en la conversion de las animas; sentia em mi grandes deseos de imitarles en lo que tanto N.ro S.or se sirve: como es padescer travajos por aquellos, por quien el se puso en una cruz: pero cesavan aquellos deseos, parte por verme tan inhabil (como ahora) por mi poca virtud; parte por no tener certidumbre bastante de la voluntad de Nuestro Señor. Despues abra 5 o 6 meses perseverando en el mesmo exercicio delas cosas de el Japon; se ençendia mi coraçon de tal suerte en deseo, que si aquel dia me embiasen, interrumpiendo mis estudios, me partiera con grande consolacion de mi sp.tu: y los deseos que antes eran interpollados, y a ratos; ya eran casi continuos, unas veces con mas intension, que otras. He sentido algunas veces diminuçion, y resfriamiento en mis deseos; la causa era, no el aver de dexar la tierra natural, y los parientes; sino al verme tan falto de las virtudes necesarias para tal impresa. Mas ordinariamente despues de esta adversidad acudia N.ro S.or con mas ferborosos deseos delos ordinarios, prometiendome ayuda de su divina mano. Quando me pongo a dexar las raçones, que ay de una parte, y de otra; apenas hallo una, que me lo impida, y esa de muy poca fuerça, $\left({ }^{14}\right.$ tiniendo siempre travajo en desapasionarme, para jusgar bien, quales sean de mayor probabilidad. De muchas causas, que me mueven a hacerlo, algunas embio a parte al padre Francisco Antonio, con quien he communicado este negocio; que creo escribira a V.P.ad o a alguno de los p.es asistentes ${ }^{15}$. Los mas principales es los deseos, que N.ro S.or ha sido servido de darme; que son semejantes a aquellos con que su Divina Mag. ${ }^{16}$ me llamo a la Comp.a y a veçes mas ferborosos; creo ser llamammiento de N.ro S.or porque estos deseos me son espuelas, y ayuda, para aprovechar en virtud.

Esto es lo que se me offrece escrevir a V.P.ad no para pedir esta mision, sino para declarar llanamente $^{17}$ lo que por mi a.i.a ${ }^{18}$ pasa. Y si a V.P.ad le pareciere expediente en el ${ }^{19}$ de la Divina Mag.t se cumplan mis deseos; por que me sera muy gran consuelo todos los dias de mi vida, y a la hora de mi muerte, aver travajado siempre solo por obediencia, y bien de las a.i.as; sin mescla de propria Voluntad. Terme edad de 20 a 21 años despues de cinco, que ha que entre en la Comp.a, de buenas fuerças, y salud; oygo al $4^{\circ}$ año de la phylosophia; que quando el padre procurador buelva de Roma abra ya dias, que abre acabado con el ayuda de N..ro S.or. En los Sanctos Sacrificios y ora.nes de V.P.ad mucho me encomiendo.

De Huete y Agosto 14, año de 1584

De V.P.ad hijo muy indigno

Balthasar de Torres ${ }^{20}$

\section{ARSI, Indipeta Hispance, FG 758, carta n. 43}

Pax X. etc.

Los eficazes deseos que la Mag.t de Dios me da, de emplearme en serviçio de mi relligion, en todas las cosas a mis fuerças posibles, pareçe que no me dan lugar para descuidarme en representar de nuevo lo que en el principio de mi entrada en la Comp.a hize, pues veo que N.ro Señor aviva en mi los deseos que tengo ya representados. Abra dos annos que estando yo noviçio en Montilla, se publico un mandato de V.ra P.d que quien tuviesse deseos de ir al

\footnotetext{
${ }^{14} \mathrm{O}$ indipetente abre o parêntese, mas não o fecha no texto original.

${ }^{15} \mathrm{O}$ indipetente inclui uma palavra nesse ponto, no entanto é ilegível.

${ }^{16}$ Magestade.

${ }^{17}$ Llanamente $=$ sinceramente.

${ }^{18}$ Anima (?) = alma.

${ }^{19}$ Neste trecho existem palavras ilegíveis.

${ }^{20}$ Há no canto da carta uma nota com outra letra: tiene 21 de edad, çinco de Comp.a, esta en el cuarto de artes, buena salud, pide Japon.
} 
Japon, lo representase, lo qual cumpli entonçes con las veras que pude, representandoselo a su R. ${ }^{21}$ el P. Provincial. Pero por ser negotio tam grave, y tam deseado de mi, con algum temor de mi proprio afecto en esto, lo he ido pensando todo este tiempo con mas veras, y perseverando mis motivos, juntando con esto una confesion general que hize de toda mi vida para el tiempo de los votos: pidiendo consejo al confesor si servia proponer este negoçio, y de su pareçer lo hago. Y ansi de nuevo resuelto en ello, con las veras que la obediencia me permite, pido a V.ra P.d sea io uno de los que mereçen ser senãlados para la mission del Japon. Y para que se conozcan los antiguos deseos, que de esto Dios me ha dado, propondre llanamente la verdad dello. Abra diez annos que me llamo Dios a esta relligion, estudiando artes en Cordona, y lo que en aquel tiempo acrecento mis deseos, fue la leccion de la vida del P. Xavier ${ }^{22}$, deseando yo con summo afecto seguir sus pasos, no apartandome de tales deseos, las dificultades que se me representavan. Y como fui detenido casi ocho annos (por justos respectos de la soledad de mi madre por ser unico, hasta que siendo sacerdote con su beneplacito fui admitido en la Comp.a) todo este tiempo vivio en mi un eficaz deseo de este trabajoso viaje, costandome hartas lagrimas por verme privado de el y temiendo perdello. Mucho he deseado siempre en este negoçio, ser embiado sin peticion mia; pero pues es tan permitido el representar los deseos, me determine a hazerlo. V.ra P.d como verdadero P. vea si esto me conviene, que io estoi dispuesto con el favor de Dios, para obedeçer plenamente en todo. Estando con la indiferençia que mi Instituto me pide, y tiniendo por mas acertado lo que se me mandare, pues sera ordenaçion cierta de Dios, que no quiere ni puede engañarme. Antes que tratara se escrevir esta, se lo encomende a Dios, en la oraçion y missa con todas las veras posibles, juntando oraciones y grandes yhesnos ${ }^{23}$, cinquenta dias continuos, y mas de otros tantos, desfines de escrita: pidiendo ordenase esto, como convenir a su maior honrra y gloria. En los sanctos sacrificios y oraciones de V.ra P.d mucho me encomiendo.

De Granada y de Abril 4 de 85.

D.V.P.d Hijo indigno

Antonio Perez

\section{ARSI, Indipetce Hispance, FG 758, carta n. 73 \\ JHS}

Muy R.do P.e N.ro en Xo.

Pax X \&c.

Los dias passados escrivi a V.P.d no entendiendo que biera yo al P.e P.o ${ }^{24}$ Ortigosa que viene de mexico yo le he hablado y me he consolado mucho con el y como va hablar a V.P. no pude dexar de escrivir siquiera para que sirva de acordar a V.P.d la charidad que he pedido mucho ha a V.P.d y agora se lo pido por amor de N.ro S.or y que no me lo niegue por que es justa petiçion y assi El P.e P.o Ortigosa podra dar particular Relaçion de mi y sabido V.P.d esto y V.P.d juzgar que vaya yre de muy buena voluntad. Y sino yo Ruego a N.ro S.r me haga obediente y hijo verdadero de la Comp.a para quedado quiera que este cumpla su sancta Voluntad, y yo de mi parte mediante su favor y ayuda me disponre en todo lo que pudiere sin hablar mas dello teniendo entendido que saviendo ya V.P.d mis desseos lo que fuere de mi sera lo que mas me conviene.

De Madrid a 20 de diziembre de 1586

D.V.P. Indigno Hijo y Siervo en Xo.

Al.o Crespo

\footnotetext{
${ }^{21}$ Reverencia.

${ }^{22}$ Refere-se a São Francisco Xavier.

${ }^{23}$ Esta palavra encontra-se grifada no documento.

${ }^{24}$ Pedro.
} 


\section{ARSI, Indipeta Hispance, FG 758, carta n. 80 \\ JHS}

Al muy R.do P.e N.ro en Chro.

Pax Xpi. \&c.

Por dos vezes he escrito a V.P. los muy grandes deseos que N.ro Señor me da de que le vaya a servir a las indias y de nuevo cada dia se me van aumentando y muy particularmente con tan buena nueva como estes dias tenemos por aca de las muertes o por mejor desir de la nueva vida de tantos martires que cierto ha sido para mi una nueva de tanta Consolacion que cierto no lo podria declarar con palabras, yo he tratado estos mis deseos con el P.e Provincial y con el P.e Rector y con algunos P.es de casa y todos me han aconsejado que lo pidiesse, el P.e Provincial ya me dixo que lo avia escrito a V.P., tanbien me dixo el P.e Morales ablandole yo desto que si ningun H.o coadiutor avia de yr que seria yo uno dellos yo confio en N.ro Señor que si ha de ser a mas honra y gloria de su divina Magestad como yo cada dia selo pido que el me dara gracia para que yo vaya ha emplear los buenos deseos que en esto N.ro Señor me da, tambien escrivi a V.P. lo que yo sentia de mi Mas contado esso me ha parescido bolver lo apuntar por no saber si V.P. ha rescebido ninguna mia lo qual me da alguna pena por que cierto yo me aconsolaria mucho de saber el rescibo de alguna mia por no enfadar a V.P. ,, yo soy obrero de villa se leer y escrivir tanbien soy platico en la mar por que puedo dizir que la mitat de mi vida me he criado en ella tanbien tengo buenas fuerças y sanidad, soy de condicion alegre esto escrivo quanto lo exterior y quanto a lo interior no digo nada por que si quiziere escrivir alguna virtud tendria en que entender de hallarla en mi mas yo confio en el que me da estos deseos me dara lo que es menester para cumplirlos y por esta no mas sino que en los santos sacrificios y oraciones de V.P. mucho me encomiendo.

De tarragona y março a los 17 de 1587.

D.V.P.

Indigno hijo en el Señor

Bernardo Matias

En la outra escrivi a V.P. en que indias N.ro Señor me dava deseos de ir mas por no saber como tengo dicho si V.P. ha rescebida ninguna mia lo buelvas apuntar aqui y ansi digo que en donde N.ro Señor mas deseos me da y yo mas me inclino es de yr al Japon o la china al fin a la India de Portugal,

\section{ARSI, Indipetce Hispance, FG 758, carta n.116}

Pax Xi. etc.a

Los dias pasados escrevi a V.P. una carta y segun entiendo se perdio, en esta pondre lo que aquella contenia, que es dar a V.P. parte de los desseos que N.ro S.r desde que entre en la Comp.a y no se si antes me ha dado de yr al Japon, o a otra qualquiera parte que la obediençia ordenase, donde pudiese servir mas a su Mag.d y padeçer algo por su nombre, y amor. Y esto hagolo despues de averlo encomendado por algunos dias a N.ro S.r el qual aunque es verdad que me ha dado estos deseos tan de atras, con todo esso no los he declarado hasta agora porque al principio desechavalos ${ }^{25}$ como tentacion, pareciendome que no era para mi tan noble empresa, pues, ni tengo, virtud, ni otras muchas partes que para ella se requieren; despues quando oya deçir de yr a essas partes reyame de los que o tratavan, no mostrando ninguna voluntad, aunque interiormente siempre me quedava no se que escocim.to ${ }^{26}$. Todas estas difficultades quito el buen exemplo de los h.os ${ }^{27}$ que deste collegio han ido este año, uno al Japon, y quatro al Mexico, y desde que se fue el primero

\footnotetext{
${ }^{25}$ Desechar $=$ expelir, afastar, menosprezar, afastar de si.

${ }^{26}$ Escocimento $=$ escozar $=$ sentimento penoso, difícil.

${ }^{27}$ Hijos.
} 
determine encomendar a Dios este negocio, y no resistir a su Magestad si de mi se quisiese servir, y assi lo e hecho, y de cada dia se me an ydo augmentando los desseos, holgando me, de pensar, tratar, hablar, y leer cosas de aquellas tierras, inclinandome siempre a yr donde mas trabajos ay, y porque e oydo ay mas en el Japon alli parese me llama n.ro S.r y me da gusto particular. Con todo, si esto no meresco alcançar, y V.P. me ordenare vaya al Peru, o a otra qualquier parte lo tendre por mejor, y yre con summo gozo a ello entendiendo ser la voluntad de N.ro S.r por quien aunque indigno querria padecer mucho, que esso es lo que me mueve a proponer mis desseos, no tiniendo como he dicho partes ningunas para ello, pero esta nonada ${ }^{28}$ que soy la offresco a su mag.d puniendola en manos de V.P. que es mi Dios en la tierra para que de mi disponga como mejor a V.P. pareciere. No se mas que Gramatica aqui la leo en este collegio, ando en veynte, y un años, y tengo medianas fuerças, y salud buena hasta agora. Esto escrebia a V.P. en la otra, y e lo sacado de un borrador ${ }^{29}$ con que me quede para mi consuelo gustando de estar ya obligado a Dios. El qual nos guarde a V.P. muchos años para que obedeciendole en todo lo que nos embiare a mandar, seamos mas agradable a su di.na Magestad que yo para mi assi lo espero, desse collegio de Belm.te ${ }^{30}$, Junio 211588.

Joseph de Sepulveda

\section{ARSI, Indipetce Hispance, FG 758, carta n.126 \\ JHS}

Pax Chri ett.

Un año a escrivi a V.P. proponiendo los desseos que N. S.or me dava de yr a las Indias, a trabajar por amor de X.o y a consejo me mi superior deste Colleg.o aunq tenia ya escrita otra para V.P. q bastava haver escrito una vez, y que entre tanto lo encomendasse a Dios y hiziese alforja; yo lo he dissimulado solo por ello asta agora, que con la venida del P.e Pro.al $^{31}$ a este Colleg.o con quien lo comuniq, lo he hecho por pareçerle a su R.a ser conveniente, dar razon de lo que el Señor me a comunicado en esta parte, desde q escribi a V.P. y esto solo a sido para mi de tanto alivio, quanto era el dolor, q rescebia por haverseme quitado el acudir a V.P. con carta. Es tan grande el desseo, que de yr a padeçer por X.o y emplear mi vida en esta empresa, me da su Mag.d q quando lo pienço rebiento en lagrimas, y dame Dios dello tanta confiança, q reparando enello despaçio, lo tengo por tan cierto, como si lo viesse ya cumplido: y quando en la mortificaçion de mis passiones, y camino de la perfecçion se me offreçe alguna difficultad, el mejor remedio que tengo, y con q me animo mucho, es pensar que me voy preparando para esto: lo que con mas fervor encomiendo a Dios en la or.on ${ }^{32}$, es, la conversion de la Gentilidad, en particular de la China, q tengo metida en lo intimo de mi coraçon. Mueveme tambien para esto, la mucha necesidad q hay de obreros en aquella ven.ma ${ }^{33}$. el pesado tributo q cobra el Dem.o cada dia de muchos millanares de almas, redemidas con la sangre de X.o q lleva a sus Infernales moradas. Por todo lo qual y por amor de Dios supplico a V.P. con lagrimas, q no quiera negar este consuelo, a este su minimo hijo (pues estos suelen ser mas tiernamente amados y regalados) acordandose de mis desseos, aunq las obras, no lleguen a mereçerlo. Yo estoy agora en Girona cuidad de Catalunya, con mas salud y fuerças q hasta aqui, acabando mi curso de artes, cumplo los 21 años, con desseo de emplear los q me

\footnotetext{
${ }^{28}$ Arcaísmo de "nada".

${ }^{29}$ Mata-borrão.

${ }^{30}$ Belmonte.

${ }^{31}$ Provincial.

32 Oración.

${ }^{33}$ Vendima.
} 
quedan en padeçer por X.o lo qual si ha de ser para su gl.a ${ }^{34}$ confio en su Mag.d me lo concedera presto, y dexara ver a V.P. enel Cielo, como yo se lo supplico.

De Girona y octubre a 2 de 1589

Juan de Avila

\section{ARSI, Indipetce Hispance, FG 758, carta n. 136 \\ JHS}

Pax Christi ettc.

Esta sera para suplicar à V.P. me haga charidad de consolarme con esta tan buena occasión de la venida del P.e Rogerio, en q yo sea uno de los muchos q se han offrescido de ýr a la China, q creo sera para q yo mas sirva à N.ro Señor con tan buena ventura como me cabería en q yo fuesse escogido para tal empressa, porq esta occasión me haria ýr mas solicito ý cuydadoso en el servicio de Dios ý me haria mas llegar à su divina bondad el haverle en este particular menester tanto. N.ro Señor ordene aquello, q fuere para su sancto servicio para q en todo se cumpla su sancta voluntad. Yo me hallo bendito sea el Señor muý bueno, ý con hartas fuerças ý encendidos desseos de ver effetuado este negocio, ý creo q son menester tambien para la China no solo los Padres y Hermanos estudiantes, pero tambien los Hermanos Coadjutores. El P.e Rogerio me ha animado mucho, ý me ha dicho q era el mejor tiempo de mi edad para ýr ý aprender la lengua china q no tengo mas de veynte o veynte un años ý porq confio q V.P.d como à Padre me ha de consolar no me alargo mas, sino en pedir humilmente ser encomendado en los santos sacrificios y oraciones de V.P.d

De Val.a ${ }^{35}$ a 23 de Março 1590.

Domingo Tafalla ${ }^{36}$

\section{ARSI, Indipetce Hispance, FG 758, carta n.168}

JHS

Pax Christi \&c.

Por estar dudoso si V.P. ha recebido una que con el P.e Superior escrivi a 29 de Noviembre de 1590 repitire con esta lo mismo que en aquella dezia por lo qual ha de saber V.P. como antes que yo entrasse en la Comp.a se pusieron en el Collegio de Caller unos papeles onde estava pintado el dichoso martirio del P.e Rodolfo Aquaviva con sus companeros, y aviendo yo antes pedido de entrar en la Comp.a y resfriadome fue N. S. servido con la vista de aquellos sanctos martires darme tan grande y vehemente impulso sinto con reprehenderme mi consciencia de la negligencia y descuido que avia tenido en perseverar en pedir la Comp.a que desde entonces iuntamente con darme Dios N.ro Señor deseo firme de entrar en la Comp.a, me le dio de padecer por su divino amor entre gentiles, moros, o ereges, y de padecer en servicio de su divina mag.d los trabajos y fatigas que en tales missiones se suelen padecer, y $\operatorname{aun}^{37}$ si se ofreciere ocasión perder la vida, o por mejor dezir, ganarla muriendo en servicio de su mag.d. Ni por entrar en la Comp.a se menguaran en mi estos deseos y gana de padecer; antes con las exortaciones ordinarias, lectiones, y otros exercicios spirituales mas crecian, tanto que dudando no fuesse alguna tentacion, me fui al P.e maestro de novicios y le dixe muy largam.te ${ }^{38}$ todo. El qual aviendome oido dixo entre otras cosas que no me dexasse llevar desse espiritu, porque assi como parecia bueno por de fuera podria ser que naciesse de mala raiz siendo alguna tentacion y que para esto era menester mucha virtud y pero que con todo lo

\footnotetext{
${ }^{34}$ Gloria.

${ }^{35}$ Valencia.

${ }^{36}$ No verso: Pide enbio a la China.

${ }^{37}$ No documento original, encontram-se cortadas as seguintes palavras: la vida.

${ }^{38}$ Largamente.
} 
encomendasse a N.ro Señor pidiendole gracia para hazer lo que fuere a sua maior gloria y para conocer si esta era alguna tentacion y hizo yo todo lo que me fue dicho ofreciendo para ello muchas comuniones, diciplinas mortificaciones y trabajos ordinarios a N.ro Señor, lo qual no hizo por solo un mês, o, dos; sino por espacio de cinco años que ha que estoi en la Comp.a con todos los quales exercicios no solamente no se han disminuido y afloxado en mi estos desseos; pero aun han crecido tanto y de tal modo que me pareçe hechar con esto leña al fuego. por lo qual iuzgando que lo avia tenido mucho tiempo encerrado escriviselo a V.P. a quexado de algunos escrupulos de aver perdido este tiempo en que con la divina gracia Dios N. S. se diñara hazer por medio deste indiño y ruin instrumento, algun pequeño fructo en aquel proximo tan necessitado de quien le aiude en lo que toca a su salvacion, y temiendo no me pida dello cuenta Dios N.ro Señor; me ha pareçido no dilatarlo mas, sino dar dello razon a V.P. rogandole por las llagas de Chr.o N.ro Señor mande darme licencia para tan gloriosos trabajos y muerte si iuzgare N.ro S.or que conviene para mi salvacion y provecho spiritual. $\mathrm{Y}$ pues agora esta aquí el P.e Visitador (el qual conoce mui bien a todos, y con cuia presencia nos alegramos tanto; quanto con la partida del P.e Spiga tuvimos alguna pena). Podra V.P. si fuere servido informarse de Su R.a al qual yo he hablado desto y lo que me ha respondido es que sin particular orden de V.P. no puede en estas missiones hazer nada que lo avisasse a V.P. y que haria lo que se le ordenaria. Y lo que mas me empuja para escribir esto es ver que pareçe Dios N. S. me ha dado ${ }^{39}$ la graçia de entrar en la Comp.a despertandome para ello con la vista de aquellos sanctos martires, para le servir en esse exercicio y aunq para esto se requiera mucho espiritu de que yo caresco, es verdad; pero confio en aquel que por su misericordia se digna darme los desseos; se diñara tambien con su divina gracia suplir lo que en mi falta de spiritu y otras cosas y assi humilmente por la entrañas de Chr.o N. S. supp.co $^{40}$ a V.P. no me prive deste consuelo, graçia y misericordia que Dios N. S. me quiere hazer de padecer por su divino amor y reverencia de su sanctiss.o nombre para que assi alcance el fin para el qual he sido criado y he entrado en la Comp.a el qual sera possible que Su Mag.d aia guardado para que por medio destos trabajos, o muerte lo alcanse. Y N.ro Señor sea servido que se aga en todo su sanctiss.a y divina voluntad y de a V.P. mucha vida quanta sus hijos tenemos menester.

De Sacer y Agosto a 30 de 1591.

Juan Augustin Castangia.

\section{ARSI, Indipetce Hispance, FG 758, carta n.179 \\ JHS}

Pax Christi \&c.

Sintome tan movido de cadaldia mas, que no me sufre el animo que dexe passar la occassion que se offresce de escribir a V.P. es me testigo Dios que no pretendo en escribir tantas vezes a V.P. sino descubrir ${ }^{41}$ mi pecho con toda resignacion como es verdad, que me siento con ella por la misericordia del Señor. Son muchas vezes tantos los desseos que siento de ser embiado a las Indias especialmente al Japon, o, a la China que offresco mis pobres lagrimas con grande esperança, quel Señor se servira de mi vida miserable en lo que fuere de maior gloria suya. Ha como seis años e medio, que movido con oyr el exemplo de los n.ros en Japon empece a pedir esto aca a los superiores, y con su orden despues escrivi a V.P. Hasta agora me han ido cresciendo los desseos y van de cadaldia, y he rescebido en este tiempo muchos beneficios de Dios por medio dela sacratissima Virgen muy necessarios para este fin. Y en esta Señora tengo puesta mi esperança. Y en

\footnotetext{
${ }^{39} \mathrm{O}$ indipetente cortou no texto as seguintes palavras: algunas cosas naturalm.te.

40 suplico.

${ }^{41}$ Estão cortadas as seguintes palavras: sino descubrir
} 
ella me consuelo disponiendome para si el Señor quisiere servirse de mi en otro que en cumplirme mis desseos. Tengo 23 años cunplidos y ocho en la Comp.a estoy en el segundo año de theologia con muy cumplida salud.

Deste Collegio de Valencia a 16 de Abril 1592

Balthasar Mas ${ }^{42}$

\section{ARSI, Indipetce Hispance, FG 758, carta n.188 \\ JHS}

Pax X. ett.

El año pasado escrebi a V.P. dandole quenta de los deseos q Nuestro Señor por su misericordia me hacia merced de dar de pasar a indias o a otras partes de infieles donde pudiese padecer algo por su amor y por durar todavia essos deseos y mas intensos y no ser deseos de dos dias sino de mas de seis años y comunicados con los que Nuestro Señor a puesto para q me endereçen y encaminen asi superiores como confisores me parecio guiado por su parecer escrebir segunda vez a V.P. y pedirle con todas las veras q puedo tenga por bien si juzgare ser para maior servicio y gloria de Dios concederme esta peticion q sin duda ninguna sera para mi de mucho consuelo si por orden de V.P. Nuestro Señor me hiciese esta Merced, y para q mas clara noticia tenga V.P. de mis deseos me parecio convenir dar quenta asi de la perseverancia en ellos tanto tiempo a como del consuelo q Nuestro Señor me comunica en renovarlos a menudo q cierto es grande y asi todas las veces q oygo tratar destas cosas y especialmente de persecuciones y trabajos q padecen los n.ros en aquellas partes siento en mi un nuevo fervor y una nueba alegria y me confirmo mucho mas en mis deseos, y los oficios en q. me a occupado ordinariamente la obed.a y en q puedo servir en aquellas partes a la comp.a son Ropero, enfermero y cocinero tanbien suelo acudir a los otros quando es menester, yo quedo muy confiado en la paternal charidad de V.P. q mirara mis deseos como de hijo q desea obedecer en todo N.ro Señor guarde a V.P.

De este collegio de Cadiz a 29 de julio de 93.

Pedro Ruiz

\section{ARSI, Indipetce Hispance, FG 758, carta n.191}

Jesus

Sabra V. Paternidad como yo el Her.o ${ }^{43}$ Salçedo uno delos minimos desta Comp.a ha ya muchos dias que he deseado ir alas Indias, y tambien aora que se avia ofrecido ocasion lo he pedido al P.e Esteban Paez Provincial, y offrecidome a ello con mucha promptitud a hazerlo. Mas el aviendo le yo escrito dos cartas sobre esto me respondio que el bien tenia conoçido mi deseo y animo de ir alla, pero que no podia llevarme sin orden particular de V.P. porque todos los que avian de ir venian señalados de alla, y asi me dixo que escriviese a V.P. y mostrase los deseos que Dios N.ro S.or me avia dado, y que N.ro S.or lo negociaria. Hase me offrecido aora con esta ocasion representar mis deseos, que ponerme en manos de V.P., para que haga, lo que viere que ha de ser para maior servicio de Dios N.ro S.or. Yo soy Herm.o estudiente de edad de 19 años poco mas de buena salud gracias a Dios que hasta aora no e tenido enferm.d alguna, ha que entre en la Comp.a 3 años y dos meses, estoy aora leyendo menores en este Collegio de Belm.te. Desde el principio, que entre en la Comp.a me dio N.ro S.or siempre

\footnotetext{
${ }^{42}$ No pé dessa carta há uma nota de outra mão: A aunque no sea carta por no saber la voluntad de V.P. ni gustar los padres de aca que yo escriva desta materia no dexare siquiera de avisar a V.P. de mis deseos de las indias ser los mismos y maiores no se que es, uviera hecho voto de nunca cessar de pedirlo hasta que tuviesse edad para ello por apretarme los deseos, mas por no tener enesto tanta claridad no lo e hecho. Yo siento en mi que aunq lea 3 y 4 anos mas de theologia y despues me embiaren que sera mi deseo cumplido, pero no pienso que V.P. aguardara tanto pues haze ya 9 o 10 años que pido estos y la differencia de estados en la Comp.a no me han mudado mis deseos. V.P. ara lo que conviene que esso sera mi gloria. Hernando Ponçe

${ }^{43}$ Hermano.
} 
deseos de ir alas Indias, tanto que quando estava enel noviciado y se leian las cartas de Japon y otras partes de los P.es, me consolava mucho de oyelas, y me regozijava interiormente pareciendome que yo me hallaria alla con ellos conviviendo, y me crecian los deseos, y aora que esta movida el agua son muy grandes quisiera que por amor de Dios V.P. lo mirase, y hiciese conmigo aquello que viere que mas me conviene. Si me viniera una suia sola, que me significase que me fuese, me fuera luego sin duda muy contento y regozixado, y si lo contrario no se si quedaria tan contento, pero alo menos procurara conformarme con la voluntad de N.ro S.or entendiendo ser aquello lo que mas conviene. Promptiss.o estoy P.e para ir deseoso en grande manera, no ay cosa que mas contento, ni alegria me poderia traer aora en la tierra. Asi yo supp.co y pido humilm.te a V.P. hincadas las rodillas, que aunque bien apartado, con todo eso lo pido como si estubiera muy cerca, que si no hallare que ay algun grande inconven.te en mi ida, o que si sirviere mas Dios N.ro S.or de que me quede por aca, que aiude a mis deseos, y me los cumpla, pues esta en sus manos, si como he dicho no viere ser otra la voluntad de Dios. El P.e Esteban Paez me escrebio que yo le embie aquellas cartas que e dicho que se consolara harto de que estubiera en su mano el cumplim.to de mi deseos, que procura darme el contento que era rason, por estas mismas palabras. Pido otra vez muy encarecidam.te a V.P. que pues es P.e N.ro, que mire qual sera de las dos cosas, la de mas servicio del S.or. Porque sín duda lo que hiziesen mas por acertado, y expediente, y asi yo me pongo en las manos de V.P. y le dexo y remitto la disposicion de mi muy ${ }^{44}$ ala parte que mas quisiere, que esa sera el querer del S.or. Plega a Dios N.ro S.or y a sus santos que en esto vaya muy acertado, y conforme con su voluntad.

De Belm.te, a ultimo de Mayo de 1594.

Diego de Salcedo.

\section{ARSI, Indipetce Hispance, FG 758, carta n.200 \\ JHS}

Pax Christi etc.

Muchos dias ha que N.ro Señor me a dado deseo de servirle en la Compañia y juntamente me le dio que fuese en las indias aun antes que entrase en ella, por estar mas desarraigado de mundo, lo primero me lo concedio su magestad abra tres años en esta provincia de castilla, y porq todavia siento en mi que me despierta el deseo para lo segundo. Y agora se a ofrecido buena ocasion que el p.e procurador de la Nueva España a de llevar algunos, me parecio representarlo a V.P. para que me de licençia que vaya con el y me lleve con los demas. Bien veo que no tengo las partes que se requieren, mas confio en la divina bondad que ofreciendome yo a los trabajos que se an de padeçer en la navegaçion y por alla, me dara su fabor y ayuda para que en aquellas partes sea de algun probecho en lo que se me mandare, mediante el ser embiado por V.P. y por las or.ones de V.P. a quien N. S.or nos guarde por largos años. De Medina del Campo 4 de mayo de 1597.

Juan de Ortega

\section{ARSI, Indipetce Hispance, FG 758, carta n.204 \\ JHS}

Pax X. \&c.a

Muchos años ha me da N.ro Senor deseos de ser empleado por la obed.a en alguna extraordin.a mission donde se offreciessen mill trabajos deshonrras y peligros por amor de N.ro Señor y la salv.on de las almas y aunque lo he significado a los padres Provinciales q he tenido no los he pedido en particular el ir a índias, sino solam.te mostrandoles de palabra y por escrito una determinadiss.a indifferensia a eso o a qualquier otra cosa q a la obed.a

\footnotetext{
${ }^{44}$ Trecho ilegível.
} 
pareciesse. Ahora mas en particular pido y supp.co humillm.te a V.P.d que ora sea para el Japon ora para alguna parte delas regiones septentrionales donde reyna la heregia ora en qualquier otra del mundo donde mas aya que padeçer por amor de JesuXpo. V.P.d por amor de el se sirva de mi en la prim.a occasion q se offresca que esta tengo yo aguardando cada dia de aqui a la muerte esperando en su divina mag.d que asi como me ha dado gracia para lo desear me la dara mas abundante para lo cumplir. Y porq el P.e Xpoval ${ }^{45}$ de los Cabos dar relacion a V.P.d de mi en particular no digo mas sino q a lo que N.ro Señor mas me inclina es a lo que menos tiene desso mas sobretodo a lo que fuera mas voluntad suya el qual nos guarde a V.P.d como sus hijos yndignos lo deseamos y cada dia rogamos.

De obiedo y oct.b 23 de 1598

Andres Porta

\section{ARSI, Indipetce Hispance, FG 758, carta n.227 \\ JHS Maria}

Pax Chri \&c.

Por la grande confiança que tengo del paternal pecho de V.P., me atrevo a escribir estos breves ringlones, dando razon de mis antiguos deseos; que por ser tan antiguos, y aver hechado tan hondas raizes en mi coraçon; me parece averme de quedar grande escrupulo si no los propongo a V.P. Mas de diez años ha que deseo yr a las Índias para ayudar en lo que fuere bueno a la salvacion de las almas que alli biven; no espantandome trabajos por graves y peligrosos que sean; antes animandome mas quanto mas trabajos dizen padecer Nuestros Padres que en esto se emplean. Causara por ventura a V.P. alguna admiracion que deseo yo ir a las Indias de diez años a esta parte, no aviendo mas de quatro años e medio que estoy en la Comp.a: pero lo que passa en realidad de verdad es; que comence a pedir la Comp.a seis años antes que entrasse en ella; y luego que me determine de entrar en la Comp.a mi principal motivo fue para yr a las Indias a emplearme en lo que alli se emplean los nuestros; y de entonces aca no se ha apartado de mi coraçon un punto este deseo. Tenia yo no mas de treze años quando Dios me començo à dar un grande deseo desta peregrinacion; porq como mis Padres (por aver sido mi Aquela hermana del P.e Hieronimo Nadal) me criaron toda mi vida en la Compañia; luego desde pequeño oyendo que los Padres referian cosas de edificacion que en las Indias acontecian, y lo que alli los Nuestros padeciam; aficioneme tanto a imitar a los Padres en esta parte; y era tanto este mi deseo estando aun el siglo que me acontecio muchissimas vezes hazer muchos actos de Martirio, y de padecer gravissimos trabajos, por amor de Dios quando encomendava a Dios esta mi entrada en la Comp.a, diziendo con estas o con semejantes palabras hablando con mi Señor JesuChro: O mi Dios si yo entrasse en la Comp.a para padecer mucho por Vuestro amor en la India dando mi sangre si fuere menester por Vuestro amor; y por la salvacion de los Indios; yo no lo meresco mi Dios. Esto dezia yo porque me parecia que en aviendo entrado en la Comp.a me seria muy facil alcançar de los superiores me embiassen esta peregrinacion. Despues que huve entrado en la Comp.a a cabo de pocos meses propuse este mi deseo al P.e Provincial, y al P.e Maestro de Novicios que agora es Provincial desta Provincia: aviendolo propuesto simplemente, siendo Novicio, y despues otras vezes particularmente quando se fue de aqui el P.e Procurador la ultima vez; nunca he osado hazer mucha instancia, antes, despues de averlo propuesto simplemente, no me curava mas; teniendo esto por mas perficion; y procurando de ponerme con indiferencia antes y despues de averlo propuesto; a lo qual me movio la indiferencia que pide y desea N.ro bienaventurado P.e Ignacio para uno de la Comp.a. Con todo esso aviendo yo comunicado estos mis deseos con mi P.e confesor le ha parecido ser muy justo que yo lo representasse a V.P. para que entendiendo mis antiguos deseos disponga de mi V.P. como mas fuere a gloria

\footnotetext{
${ }^{45}$ Cristobal.
} 
de Dios; porque nil mihi gratia quam vivere in est mundi plaga ubi maius Dei obsequium at animarum auxilium speratur ${ }^{46}$.

De Çaragoça 30 de Agosto 1599.

Geronimo Moranta

\section{ARSI, Indipetce Hispance, FG 758, carta n.290 \\ JHS}

Pax Xpi \&c.a

Muchos dias ha que andaba con grandes deseos de que N.ro S.or me diera gana de ir a las indias y animo para por ello por obra, y aora es tan extraordinaria la mudança que en mi siento para ir a esta mision, que no me parece ay que dudar sino que esta novedad es Vocacion de Dios N.ro S.or por que oyendo decir que en el Piru (adonde N.ro Señor me muebe particularmente mas que a outra parte ninguna) se padecen muchos trabajos y incomodidades en la comida habitacion, y cama, y que el trato mio ha de ser con gente ruda, con negros, y gente barbara, estoy tan lejos de espantarme con estas cosas, que antes lo que me muebe con mas efficacia es verme en ocasion de padecer, de tal manera que no la pueda huir, aunque quiera, y el ayudar a aquella gente, que por ser pobre y vaja ay menos que quieran tratar con ellos. Y confio en la divina bondad que me dara fuerças para ello, pues el me llama, y tambien espero me dara perseverancia en mi buen proposito, de tal suerte que no me aparten del ni las difficultades de alla, ni la navegacion larga y peligrosa, ni tampoco el riesgo de caer enel camino en mano de los hereges o gentiles, por que entendese que qualquiera cosa que sucediese biene registrada por la mano piadosa de Dios N.ro S.or. Y asi digo que si a V.P.d le pareciere sera para mayor gloria de Dios N.ro S.or que yo vaya al Piru, el si de V.P. lo tomare como si fuera dela voca del mismo Xpo., y como por obediencia suya, y asi pido por las llagas de JesuXpo, que si se me concede esto que pido, sea mandandomelo, para que el acto sea mas meritorio por ser de obediencia, y yo con esto vaya consolado, que lo ire sumamente. Guarde N.ro S.or muchos años a V.P.d en cuyas oraciones y santos sacrificios este su minimo hijo muy deveras se encomienda.

De Alcala y Junio a 15 de 1602.

Leon Ximenes

\section{ARSI, Indipetce Hispance, FG 758, carta n.338 \\ JHS}

Pax Christi ett.

Aunque por via delos P.es Gaspar Moro, y Diego Torres procurador de las Indias Occidentales escrivi a V.P. tambien por otra via escrivieron por mi desde Val.a ${ }^{47}$, todavia el desseo grande que mi alma tiene de ir a las Indias, hora sean orientales, hora occidentales, me fuerça a que buelva a escrivir, ahora por tener tan buena occasion, como es el q P.e procurador desta Provincia, a V.P. lo que Dios N.ro S.or por su infinita clemencia y bondad fue servido comunicarme, en los Exercicios espirituales que tuve el año 1602 por el mes de Agosto, en los quales mi alma, como el Aguila se renovo, y se vencera de cada dia, en los quales estuve (e lo estoy siempre) desseando el martyrio, assi como el ciervo herido las aguas, por lo qual estoy persuadido passar de aqui adelante qualquier trabajo aunque de alcançallo. Y tengo experimentado q muchas vezes, quando alguna tentacion, o otra cosa alguna me aflige, el medio para vencella, es pensar que si la como con paciencia yr a las Indias, luego se deshaze como humo, y siento despues grande consuelo y facilidad en hazer lo que antes me parecia muy pesado. Como me acontecio el Domingo y Viernes antes del dia de San

\footnotetext{
${ }^{46}$ nil mihi gratia quam vivere in est mundi plaga ubi maius Dei obsequium at animarum auxilium speratur = nada me é de maior graça do que viver neste mundo buscando o maior obséquio de Deus e esperando seu auxílio para a alma. ${ }^{47}$ Valencia.
} 
Bartholome $^{48}$, en los quales tuve grandissimas tentaciones a cerca de lo que me mandavan mis superiores, pero enpesando que avia de yr a las Indias, y q alli padeceria mayores trabajos, se deshizieron como el humo; pero el dia de S. Bartholome deste mismo año de 1602, estando ayudando a Missa, despues de aver comulgado me dio N.ro S.or tan grandes consuelos, y muestras de lo mucho que me amava que no pude ofrecer en pago de tan grande amor, como pedirle, que muera yo por su amor, una muerte cruel, y estos despues de muchos y grandes trabajos en las mismas Indias padecidos. Desde el Mayo passado del dicho año de 1602, dia en que su divina magestad me dio los desseos, sin que yo los buscasse, conosco en mi alma grande ventaja en mortificar los vicios y passiones desordenadas solo con la memoria dellas Indias. Cuando siento hablar de las Indias, y yo hablo con algunos, es muy grande el consuelo q mi alma recibe con aquella platica, y esto en qualquiera hora del dia, lo qual me sirve para que yr fervor en todas las cosas que hago. En todos los exercicios espirituales no tengo mejor medio ni mas official, para siquiera satisfaser algun poquito a lo que Christo N.ro S.or a padecido por mi, como ofrecerle por mi alma una perfeita obediencia y abnegacion grande en todas las cosas, y por el cuerpo, el mas horible y cruel martyrio, q hasta ahora se apadecido, ni los tyrannos an inventado, y esto por entender ser el acto mas heroico que uno puede enesta vida hazer por amor del mesmo S.or, al qual con todos los improperios de la passion tenia por obiecto quando esto ofreci, con condicion que esto fuesse despues de aver entre los gentiles, o infieles padecido tales y tantos trabajos como S. Athanasio ${ }^{49}$. Pero davame grande molestia el ver que no podia ser luego, pero conforme me con la voluntad de Dios N.ro S.or que fuesse quando el quiziesse. Por lo qual yo, aunque indigno, ruego a V.P. quan humilmente puedo, que pues su Divina Magestad usa con este siervo indigno, de tales y tantas misericordias, que V.P. me quiera oyrme lo mas presto que fuere possible, por que para mi sera el mayor beneficio que yo en esta vida puedo alcançar. Plegue a su divina Magestad quiera declarar a V.P. lo demas que por mi alma passa, que creo que si yo fuera tan dichoso de poder de palabra dezir todo lo demas, sin duda ninguna V.P. me daria luego licencia, pero yo continuamente selo supplicare como le hecho hasta aqui con mis pobres oraciones. Una cosa no puedo dexar de escrivir a V.P. y es q siendo seglar tuve este sueño, y fue que me parecia que me enbiaron a las Indias a predicar, y a los que no se querian convertir a nuestra S.ta fe, yo con mi propia mano les dava la muerte. Guarde Dios N.ro S.or a V.P. por muchos años, como este hijo indigno de V.P. lo dessea.

De Gandia y mayo a 201603.

Joan Sotalell

\section{ARSI, Indipetce Hispance, FG 758, carta n.379 \\ JHS}

Pax Chri etc.

Con gana grande he estado mas de un año, de escrivir esta a V.P. y dalle en ella a entender lo q passa por mi coraçon, pero no lo he hecho porque me ha parecido era necessario q antes de escrivir considerasse muy bien lo q pretendia comunicar con V.P., ý lo encomendara deveras al S.or para cumplir con la Regla q a esto me obliga ${ }^{50}$, ý esto por algun espacio de tiempo, por

\footnotetext{
${ }^{48} \mathrm{O}$ dia de São Bartolomeu é celebrado tradicionalmente no dia 24 de Agosto.

49 Santo Atanásio, monge de personalidade forte, nasceu em Alexandria, no Egito, em 295. É uma figura dramática e polêmica da Igreja. Em sua vida, cinco exílios (a maior parte vivido no deserto com alguns monges que o acompanhavam) lhe foram impostos pelos seguintes imperadores: Constantino, Constâncio, Juliano e Valente. Escreveu além da Apologia pela Fuga uma biografia de Santo Antão.

${ }^{50}$ De fato, em carta enviada no dia 26 de maio de 1555, Inácio adverte: "Quem for tratar com algum Superior leve as coisas bem mastigadas e estudadas pessoalmente ou consultadas com outros, segundo forem de maior ou menos importância" (Cardoso, Armando (org.). Cartas de Santo Inácio de Loyola. Volume 2. São Paulo: Ed. Loyola, 1990, p. 137). Posteriormente, esta carta, denominada Modo de Tratar ou Negociar com qualquer Superior, será incluída nas Constituições sob o número 7292.
} 
ser el negocio grave; agora despues de haverlo bien considerado, ý encomendado al S.or con esta, llana ý brevemente; por no ser fastidioso a V.P.; descubrire lo que el S.or me ha comunicado; ý es que siento un muý encendido desseo de emplear mis fuerças sirviendo al S.or en la Conversion de las Almas del Japon; este desseo, no aparta, ni quita de mi el desseo de emplearme en el aprovechamiento de las almas, q moran en qualquiera otra parte del mundo, sean de fieles, o de infieles, antes mas presto le augmento, ý retamente me siento inclinado á abraçar los trabajos de alla; los quales entiendo que ha muý grandes, q juntamente al desseo de aquellos experimento facilidad grandissima para todos los trabajos de corazon, que me paracen en comparacion de aquellos, muý pequeños. No nace este desseo q tengo de ver en mi algo delo q han de tener los Predicadores evangelicos q andan por aquellas partes, porque antes me hallo inhabilissimo para todo quanto es de mi cosecha pero entiendo, q el desseo nace de sola la immensa bondad de Dios, q en mi lo despierta y me tira sin ýo mereçello ni pretendello. Con este desseo le acompaña el desseo de dar la vida por amor del S.or q aunque indigno de tan grande merced con todo el ser Dios tan liberal en concederla a los q por aquellas partes andan, me despierta en gran manera ý enciende para pretender y enprender esta empresa, ý desta manera; si el S.or fuere servido; con alguna occasion de derramar la sangre por mi Dios porque haviendole yo sumam.te offendido ý con mis peccados sido occasion para q su sagrada sangre se derramara no me tendre por coreto por mas q trabaje en su servicio hasta q llegare a tanto, q por serville me custe la sangre, si se me diere lugar para ello. Una de las cosas q mas me mueven a pedir esto a V.P. es el entender q serviendo al S.or deste modo, le agradare muchiss.o ý passando por obediencia a partes tan remotas en algu.a manera me assemejare mas a mi dulce Jesus q por obed.a hace de la Region de la vida, hasta esta n.ra Region de muerte. Supplico a V.P. q no desprecie estos mis desseos, antes como Piadoso P.e buelva los ojos á este su hijo minimo, ý disponga dello en esto, o en qualquier otra cosa segun juzgare ser mayor gloria ý honra del S.or que esta sola es la q pretendo, demas desto supplico a V.P. q para q estos mis desseos se mejoren, me tenga encomendado en sus S.tos sacrificios ý oraciones.

De Caller ý Março a los 10 de 1604.

Gabriel Mayo

\section{ARSI, Indipetce Hispance, FG 759, carta n.5}

Pax Christe

Yo he tratado y dado cuenta de mi counciencia al P.e Luice de la Puente y al P.e F.co Lavata antes y dispues que entre en la Compañia, y de los desseos que Nuestro S.r me a dado y ellos me dizen que conviene, y que sera bien dar quenta a V. Pa.d de todo. Suplicando a V.Pd. me pardone el atrevemiento, y la respuesta tendra conmigo la condicion del manà. Mis desseos son estos tres. El primero es que yo desseo derramar mi sangre por la fee. El segundo que desseo la conversion de mis parrientes y deudos. El tercero que yo desseo de tener una muerte buena y segura. En quanto a lo primero digo que quando yo era deesa secta y no conoçia la fee verdadera desseava si fuera en mi mano de matar y acabar con todos los Catolícos de una vez. Y en recompensa de aquellos malos desseos no puedo yo menos que ofrecer y restituir con todos mis desseos en pago, mi vida y sangre. En quanto al segundo digo que en toda mi vida aunque yo siempre vivi hasta tener 17 años de edad entre mis parrientes y algunos dellos eran catollicos y caze todos los demais son sismatticos, los qualles nunca me hablaria de remediar la necessidad que yo tenia en quanto a la fee y la misma necessidad que yo tenia tendran ellos sin sin quien los remedie y como yo tento confianza y esperanza en Dios de remediarlos o procurar su remedio si estuviera alla. Y si V. Pa. mi quisiera consolar tanto de imbiarme a servir a algun Padre alli yo me tendria por dichoso y si yo no fuera de provecho yo me contentarè de volver luego que fuere llamado. En quanto al terçero digo que temo mucho de morrir en la cama, que con la enfermedad los sentidos son muertos, los potencias 
del Alma turbados, los dones del Espiritu Santo endormecidos. Porque yo he visto muchos morrir y entre ellos alguns Religiosos siervos de Dios, por lo qual yo no me atrevo de confiar de mis fuerças en tal passo y por la otra parte tengo tanto amor propio que desseo tener los sentidos bivos, los potencias asentados, los dones del Espiritu Santo dispiertos para morir constantemente y offrecer con fervorosos desseos mi Alma al S.r. Y en el tiempo que yo fui seglar yo dessearia mucho de ir a ocuparme en lo que agora desseo y el P.e John Blacfan prometio de levarme consigo y despues yo le diche que yo tenia desseos de entrar en la Compania en Inglatierra y el me acosejo de escrevir a V.Pd. sobre esta materia y el hizo lo mismo y V.Pd. en una carta respondio al P.e que el y su dissipulo avia de ir juntos a Inglatierra y que me avian de recebir alla en la Compania y de alli a pocos dias vino orden que el P.e J.n Blacfan avia de esperar otros 6 meses y entonces el, y el P.e Joseph Cresvvello y el P.e Luis de la Puente y el P.e F.co Lavata todos 4 me aconsejaron de entrar aquí, segurandome que me imbiaria el P.e Cresvvello con el P.e Blacfan o con los primeros Pa.es que fuessen y ya ha yido 3 ó quatro y á passado quasi 3 años y no me imbian y muchos vezes yo lo ha pedido del P.e Cresvvello y el me responde que no conviene porque yo no soy sacerdote; entonces me dixeron una cosa y agora otra. Qualquira cosa que V.Pd. respondiere para mi sera grande consuello.

De Valladolid en el año del Siñor de 1605 y 12 de março.

Hijo obediente de V. Pd.

Thomas Hhavvard.

\section{ARSI, Indipetce Hispance, FG 759, carta n.13}

Pax Christi ett.a

El deseo de corresponder a los deseos y inspiraciones que yo no dudo ser de Dios Nro. S.or, me fuerza a manifestarlos a V.P. para que sabiendolos V.P. este yo contento con lo que de mi ordenare, y piense aver hecho lo que de mi parte en razón de cumplir aquello, a que la divina Voluntad me llama. Algunos añnos ha que N.ro S.or me ha dado deseo de emplearme en la ayuda de la conversion de los infieles, y aunque yo he dado parte deste mi deseo a N.ro P.e Provincial, no he sido digno de que por medio de su R.a se me cumpliesse. Pienso sin duda ha guardo Dios N.ro S.or este negotio, (que espero sera para gloria de su divina Mag.d,) para que V.P. le ponga en exequution, y recibe yo tan señalada charidad de mano de V.P. Y aunque es verdad que me hallo indigno de tan alta empresa, assi por no merezer que Dios N.ro S.or se quiera servir de mi; como tambien por mi poca sufficiencia; con todo espero en la divina bondad suplira en mi lo mucho que de virtud y letras para ella me falta. Y porque V.P. tenga mas entera notitia de mi, para ver lo que mas conviene; yo tengo veinte y un años, de los quales los siete ha que estoy en la Comp.a he senido seminario, y oido a los tres años de artes acostumbrados, y este es el primero de Theologia; y hazeme N.ro S.or m.d de darme entera salud; y si V.P. juzgare convenir que la emplee en ayudar a n.ros hermanos que con tantas ansias estan deseando ser ayudados en Japon, y mucho mas aquellas almas de aquellos nuevos christianos, recibira mucha m.d mayor que yo se la pueda esplicar a V.P. En que sea presto, y agora se ofreze buena ocasión, questa enessa S.ta ciudad el P.e Procurador de Portugal, el qual pienso se lo pedira a V.P., y facilitara la difficultad que puede aver de parte de Portugal. Todo esto, y todas mis cosas pungo en manos y voluntad de V.P. a quien se digne Dios N.ro S.or guardarnos por muchos años; como yo lo deseo y se lo suplico.

De Salamanca y otubre 24 de 1606.

Alonso Cortes. 


\section{ARSI, Indipeta Hispance, FG 759, carta n.24/2}

Pax X. etc.

Desde que entre en la Compañía a que avra dos años y medio me ha dado Nuestro Señor muy grandes y fervorosos deseos de ir a las indias sin diferenciar parte ninguna dellas sino que de muy buena gana ire a qualquiera parte donde V.P. me mandare ir y en los dos años de noviciado por pareçerme que no se me concederia lo que tanto deseo no he representado esto a V.P. pero ahora que ya por la bondad de Nuestro Señor he hecho los votos y he encomendado este negocio muy deveras a Dios y me siento cada dia mas dispuesto y con mas deseo pido a V.P. me haga caridad de concederme que y a alas indias, porque entiendo según es el fervor que siento quando pienso en esso que Nuestro Señor se quiere servir de mi enllas indias y el deseo de servirle me mueve a pedirlo con grande instancia y no reparar en dificultad ninguna de las que se pueden ofrecer. Yo soy natural de los arcos de Valdevez arçobispado de Braga en Portugal, de edad de 24 años poco mas o menos sientome gracia a Dios con muy buenas fuerças para trabajar el officio que se es de carpintero y este he usado casi todo el tiempo que he estado en la compañía y avra tambien ${ }^{51}$ y por que entiendo que V.P. como padre acudira a dar me contento en esto y quedo con grande confiança que lo tengo de alcançar ${ }^{52}$ mas largo por ${ }^{53}$ sar a V.P. a quien Nuestro Señor guarde muchos años.

Granada 13 de otubre de 1607.

Francisco Gonzales

\section{ARSI, Indipetce Hispance, FG 759, carta n.49 \\ JHS}

Pax Xpi. \&c.

Algun tiempo ha que N.ro Señor se ha dignado hazerme merçed de darme unos desseos muy encendidos de ýr a las Indias para en ellas emplear mi salud, fuerças, y vida en la conversion a n.ra Santa fé de aquellas almas que estan tan arrinconadas, tan solitarias, ý tan desamparadas de socorro; ý no para esso solamente, mas aun para dar la vida, ý derramar la sangre de mis venas en servicio de N.ro buen Jesus, por la predicacion de su sagrado Evangelio, si el mismo Señor se dignasse concederme essa merçed de merçedes tan singular, aun que ýo soý indignissimo dessa. Ahora con la occasíon de unas nuevas de Indias que han venido, ý con un aviso que por orden de V.P. se ha dado en general que todos los que piden ýr a las Indias esten con buen animo, ý se pongam a punto por que V.P. en esta sazon los consolarà, se han encendido mucho mas mis desseos, ý con ellos se han ayuntado unas ancias grandes, de salir esta vez con la empresa si fuesse possible. Hamese offrecido despues de hacerlo bien considerado, ý encomendado al Señor que era bien dar dello razon a V.P. como con esta lo hago, supplicando humildissimam.te ý con toda resignacion, que V.P. siempre que iusgare ser assi conveniente a maýor gloria divina, ý provecho de mi Alma, me conceda esto que pido; Causas para persuadir esto a V.P. no se me offrecen mas, que el sentir mi coraçon estimulado del Señor, ý encendido con desseos desso; ý en esto solo me fando sin que baste a hazerme desmaýar el ser Hoceieio de pocos meses sin caudal alguno de letras, ý meceho menos de virtud, por entender que el Señor que me llama, dará para esta jornada tan larga todo el maralocaje que será minester. Entretanto procuraré de mi parte atender al estudio de todas virtudes; ý para que mejor lo haga supplico ultimamen.te a V.P. que me tenga por encomendado en sus Santos Sacrificios, ý oraciones. De Caller ý enero a los 29 de 1608.

Cosme Hatter

\footnotetext{
${ }^{51}$ Ilegível na carta

${ }^{52}$ Ilegível na carta

${ }^{53}$ Ilegível na carta
} 


\section{ARSI, Indipeta Hispance, FG 759, carta n.58/1}

Pax Christi ett.a

Ahora experimento una cosa que hasta aquí no avia podido alcançar, que es la merçed tan señalada que N.ro S.or hase a un religioso, en darle superiores con yo pareçer y mandato se endereçado, y regido en aquello que ${ }^{54}$ de mayor provecho suyo y gloria de su divina magestad: por lo qual me quiero aprovechar della dando a V.P. parte delos desseos que N.ro S.or me da, para que jusgando V.P. que son tales los endereçe y guia aquello que sea de serbiçio de N.ro S.or. Muchos dias ha que tengo deseos de ir ala India Oriental a las partes del Japon o Etiopia a ayudar con mi corto caudal aquella gentilidad, pero las grandes dificultades que $^{55}$ jeron avia enconcederse esto, melos entibiaron, y aun me apartaron aqu ${ }^{56}$ afastasse dello: aora he sabido no ay ninguna ${ }^{57}$ loqual an merecido mis ${ }^{58}$ desseos, y tanto que me an obligado a que los represente a V.P. y supplique me lo conçeda si es cosa en que N.ro S.or a de ser serbido y sino hagasse la voluntad de V.P. que esa entendere es la de Dios. Las raçones que me an mobido a pedir a V.P. esto son que como entre en la Compañía no solo para me aprobechar a mi sino tambien a otros; pareçeme que en ninguna parte podre yo tambien alcançar esto como en la India supuesto el grande fruto que los de la Compañía haçen en aquellas partes, y los grandes trabajos que padecen: La segunda como los religiosos, yran los de la Compañía, ande estar despegados y desavidos de todas las cosas temporales para estar mas dependentes de Dios, alli me pareçe estare mas que aquí, pues soy apartidonde no tengo ningun consuelo temporal. La terçera y la que me mueve a yr ala India Oriental es por aver abierto N. P. Francisco Jabier la puerta para que entrase en aquella ciega gentilidad la luz de S.to Evangelio; a quien yo desseo mucho ymitar por la particular y entrañable devoçion que le tengo. Algunas otras seme offrecian pero porque entiendo podra V.P. hechar deber por estas si mi vocaçion es de Dios quiero dejar

. Haçerca de mi persona notengo cosa en particular de que avisar a V.P. estoy al presente en dia oyendo un curso de artes que se empeço el año passado, soy natural de Valderas diocesi de Leon. Solamente he tratado esto con el P. Ricardo Haller el qual entiendo que escribe a V.P. acerca de lo mismo. N.ro S.or guarde a V.P. muchos años como sus hijos de V.P. deseamos. De Scg.a y Agosto 29 del 609.

Hernando dela Torre.

\footnotetext{
${ }^{54}$ Ilegível na carta

${ }^{55}$ Ilegível na carta

${ }^{56}$ Ilegível na carta

${ }^{57}$ Ilegível na carta

${ }^{58}$ Ilegível na carta
} 


\section{ANEXO 2 Indipetae Hispanae - Juan Bravo (1603-1605)}

\section{ARSI, Indipetce Hispance, FG 758, carta n.329}

Pax Xpti. \&c.

Con mucho consuelo myo escrivo esta a V.P.d parte por ser la occasion con que la escrivo tal quales, parte tanbien por que me da no pequeña alegria ver que siendo la primera que a V.P.d escrivo sea con tal occasion. Y creo q no sera de menos consuelo a V.P.d como a quien tanto desea el bien espiritual de sus hijos, el verla pues por ella descobriramos quan grande sea la bondad de V.P.d. Pues se estiende hasta my con tanta largueza, haziendome con desmerecim.to proprio muchas y grandes m.r.des ${ }^{59}$. Una delas quales es, y nota menor la que aqui refirire a V.P.d.

Ha sido pues su div.a Mag.d servido de comunicarme un ençendido deseo de emplear mys pocas fuerças en ayuda de la Gentilidad de Japon, y conseguir desta suerte el fin glorioso de my vocaçion con derramar si su Mag.d se dignase conçedermelo, la sangre por la predicaçion de su palabra. Al prinçipio çertifico a V.P.d q tuve este desseo por tan ageno de my que mi veya pensando que era disparate por verme tan para poco, y tan ageno de lo que esse espiritu requiere. Pero despues poco a poco fui escarvando y considerando en particular que siempre Dios en empressas grandes se sierve de instrumentos viles dando su Mag.d todo lo q es menester para q alcançe lo q con ellos pretende ut non glorietur omnis caro ${ }^{60}$. Desta suerte me persuadi que ya podia entrar en el numero de los de esta empressa, solo me arredrava el no saber tan a la descubierta si era voluntad de Dios, y para descubrirla, y çertificarme de lo q Dios queria de my acudi a la oraçion, comulgandome alg.as vezes, y haziendo otras penitençias a este fin, procure tanbien ayudarme de las oraçiones de los otros, y despues de alg.os meses q esto se continuo entendi q el mejor medio para conseguir lo q yo pretendia era dar parte a V.P.d por que siendo interesse general de la voluntad divina podia assegurarme façilm.te en este neg. ${ }^{61}$. Estando enesto hize refflexion sobre my mismo y vy dos cosas las

\footnotetext{
${ }^{59}$ Mercedes.

${ }^{60}$ Ut non glorietur omnis caro $=$ quando não se orgulhar de toda carne.

${ }^{61}$ negocio.
} 
quales sin pretendello me descubrieron lo q yo deseava saber. La p.a ${ }^{62}$ fue experimentar muy a la clara q este desseo q me ha dado el S.r hasta agora ha sido como una lima con la qual gran parte de mys imperfecçiones han desapareçido, y melhorandose my vida notablem.te fruta $\mathrm{q}$ es argum.to claro de q es rayz divina la de donde mana. Lo segundo es un conoçim.to de la nova grande q Dios me ha hecho en llamarme a la Comp.a y conservarme enella (lo qual antes conoçia como en sueño) y un firmarme mas y como arraygarme en el estado donde Dios me ha puesto, descubriendo mucho mas q antes quan alto y quan soberano es, y quan bien me viene para salvarme, y esto en tanto grado q aun alg.as cosas de Instituto q antes me pareçian niñerias agora las tengo en mucha veneraçion, y me siento tan firme enellas como peña dura entre las olas del mar. No creo q rayz de donde brotan tales ramas puede ser o malas, o antojadiza. Aseguralo esto una hambre grande q siento de convertir peccadora cosa a Dios N. S. De todo esto claram.te colijo q Dios me llama para servirle enel Japon. Y mas q todo me çertifica q este llamamiento es divino la indifferençia grande que en my siento, porque junto con llamarme N. S. para servile en aquellas partes tan remotas, siento indifferençia grande para lo q es yr, o quedar sin perder por esto un punto el fervor y desseo de servile aca en Europa, antes creçiendo mas. Por onde supp.co a V.P.d q mirando este neg.o con ojos de P.e disponga de my segun juzgare ser mas conveniente para la gloria del S.r y bien de my alma. Entretanto q estoy esperando la respuesta he determinado entrar muy en my mismo y procurar dar me al exerçiçio de la mortificaçion, porq me da a entender N. S. q ella es una de las mayores alas con q puede un verdadero hijo dela Comp.a atravesar el imenso occeano, y andar seguro entre los mayores trabajos q en la Gentilidad se offreçen. Supp.co a V.P.d q para q yo enesta virtud aproveche tanto quanto he menester se acuerde de my en sus s.tos sacrifiçios y fervorosas oraciones en las quales mucho confio.

De Caller y Enero a los 20 de 1603

Juan Bravo

\section{ARSI, Indipetce Hispance, FG 758, carta n.404}

Pax Xpti. \&c.

Mas he tardado en renovar a V.P.d la memoria de mys desseos; de emplearme en la empressa que n.ra Comp.a ha emprendido en los Rey.os del Japon; de lo que ellos davan lugar, por haver sido en este tiempo; bendito sea el S.r; no menos fuertes y vigorosos q en qualquier otro, q tales la liberalidad de N.ro Dios, aun para quien en vez de beneff.os tenia mereçidos muchos açotes y castigos: q no dexare de confessar esta verdad delante sus criaturas para q ellas con alabarle satisfagan en parte, a lo que yo no podre en toda my vida. Siento ser tan grande esta m.r.d ${ }^{63}$, y liberalidad del S.r, que quando no uviera acarreado a my alma otros bienes (que si ha hecho tanto en remediar costumbres, como en renovar alientos, segun en las otras apunte a V.P.d) ella por si sola bastantem.te me obligava a no desistir de hazer lo que con esta hago, y supplicar instantem.te a V.P.d se dignasse hechar los ojos a lo que embado del Señor (segun pienso) le llego a pedir. Es muy diffiçil con renglones explicar lo que el hombre siente, y lo que el Señor le da a conoçer a ratos, lo qual ha sido causa que alg.as vezes con una, como impaciencia de ello, me haya desseado a los pies de V.P.d para que con la lengua propria diera al P.e que my Dios me ha dado una notiçia de my coraçon y de lo que en el pasa. Pero pues esto no me es conçedido por la distançia servirase su div.a Mag.d declarar a V.P.d, lo mucho que me tiene obligado a hazerle este sacrifiçio, q tanto mejor lo podra hazer su Mag.d, quanto mejor conoçe my indignidad, y la mucha m.r.d q en darme este deseo me ha hecho. Solo dire yo q me prometo con el favor div.o; aunq el demonio mas ladre y me de en los ojos mys espirituales miserias; en aquella Region una vengan cagural de las muchas con que he deservido a my Dios, y aun no dexo de confiar de su bondad q la podria rematar una

\footnotetext{
${ }^{62}$ Primera.

${ }^{63}$ Merced.
} 
cruz. Ni por esto me despido de hazerla en Europa pues con sufficiente indiferençia me hallo para lo que V.P.d escogiere, q alli con el favor div.o espero o, en Japon, o en Europa procurar ser hijo de n.ra S.ta Comp.a y para q yo desde agora lo açierte a ser supp.co a V.P.d como al P.e de ella y myo me lo alcançe del S.r.

Sacer a 29 de julio 1604.

Juan Bravo

\section{ARSI, Indipetce Hispance, FG 759, carta n. 4 \\ Pax Xpti \&c.}

Mas a menudo quisiera yo refrescar a V.P.d la memoria de mys deseos, de yr a las Yslas del Japon para derramar en ellas el sudor y la sangre si pudiese por el buen Jesus, que tan bien me lo tiene mereçido, si las occupaçiones, q se me representa tiene V.P.d, me dieran animo para hazello. Aunq de otra parte me asegura y da confiança el deseo grande que reyna en V.P. de formentar, y alentar qualquier buen parto de sus espirituales hijos. Y asi espero en el Señor, que este myo, aunq contrastado del demonio, y de mys imperfecçiones, V. P.d con el calor de su Paternal affecto y amor le ha de sacar a luz, y emplear esto que offrezco, que aunq poco, va con mucho animo, y resignaçion, y con senzilla voluntad, y deseo de acertar a agradar a my Dios, y offreçermele en sacrificio y verdadero holocausto. El pague a V.P.d, como yo se lo supp.co, con eternos dones los dichosos trabajos q por sus hijos toma, y en particular el q por este indigno tomare, en endereçar sus deseos para mayor gloria del q se los dio. Sacer y Março a 5 de 1605.

Juan Bravo 


\section{ANEXO 3 Quadro 01 - Estrutura argumentativa}

Quadro 01 no qual se apresentam o número de codificação da carta no ARSI, os topoi presentes em cada carta, o número de palavras utilizadas (a contagem de palavras foi realizada com o uso do contador de palavras do editor de texto Word 97) e uma descrição da estrutura argumentativa utilizada nas $\operatorname{cartas}^{64}$.

\begin{tabular}{|c|c|c|c|}
\hline $\mathbf{N}^{\mathbf{o}}$ & TOPOI & $\begin{array}{c}\mathbf{N}^{\circ} \\
\text { PALAVRAS }\end{array}$ & ESTRUTURA DA ARGUMENTAÇÃO \\
\hline $\begin{array}{r}4 \\
(758)\end{array}$ & $\begin{array}{l}\text { Tentação } \\
\text { Vocação } \\
\text { Desejo } \\
\text { Memória } \\
\text { Mortificação } \\
\text { Obediência } \\
\text { Experiência } \\
\text { Consolação } \\
\text { Razão } \\
\text { Liberdade } \\
\text { Encomendar } \\
\text { Alegria } \\
\text { AMDG } \\
\text { Conhecimento de si } \\
\text { Virtude }\end{array}$ & 791 & $\begin{array}{l}\text { 1) DESEJOS E CONSEQÜÊACIAS: Os desejos crescem. Tem a tentação de não os propor } \\
\text { uma segunda vez ao P.G. Consultou o P.e Jerônimo Domenech. Pede Japão/Índias. Os desejos } \\
\text { são os mesmos que sentiu quando quis entrar na C.J., e os sente como incentivo para caminhar à } \\
\text { perfeição, à virtude, ou seja, viver a paciência, a mortificação, o desapego das coisas, a } \\
\text { resgnação e a obediência pedidos pela C.J. 2) DISCERNIMENTO DOS ESPÍRITOS: Faz-se de } \\
\text { surdo ante as "batidas" que o desejo dá em sua alma, por pensar que seja tentação e que, na } \\
\text { verdade, Deus não o chama. Dá razões para não ser enviado: melancolia, doenças recentes, } \\
\text { amor próprio. Experimenta duas coisas: a) o desejo é como luz que desfaz as trevas da alma e as } \\
\text { razões falsas, deixando-o consolado; b) quando verifica que causa cegueira e diminui as forças, } \\
\text { julga ser do demônio. 3) SITUAÇÃ̃O ATUAL: Agora, está livre de toda melancolia e muito } \\
\text { longe dela, porque não lhe era natural. Os exercícios corporais e a ocupação exterior são } \\
\text { suficientes para afastar toda má vontade (e disso as Índias estão cheias). Desejos de perfeição e } \\
\text { de ir ao Japão: desejo de perfeição lhe causa cuidado na observância das regras e lhe faz } \\
\text { oferecer cada execução da regra a Deus, e lhe faz se emendar logo das faltas; desejo de ir ao } \\
\text { Japão (que tem há anos) é encomendado com perserverança e o ajuda a se aperfeiçoar na } \\
\text { virtude, por isso sabe que é de Deus que vem. Esses dois argumentos são suficientes para } \\
\text { obrigá-lo a pedir, confiando no Espírito Santo que o suprirá do que lhe falta, o envio, para seu } \\
\text { proveito pessoal e dos índios. 4) DESPEDIDA }\end{array}$ \\
\hline
\end{tabular}

\footnotetext{
${ }^{64}$ Os itens internos utilizados nesta descrição são meramente enunciativos. Não têm que ver com uma estrutura retórica, que será apresentada, na verdade, no próximo anexo.
} 


\begin{tabular}{|c|c|c|c|}
\hline $\begin{array}{r}13 \\
(758)\end{array}$ & $\begin{array}{l}\text { Desejo } \\
\text { Vocação } \\
\text { Indignidade } \\
\text { Filiação } \\
\text { Inspiração } \\
\text { Obrigação } \\
\text { Sentidos } \\
\text { Imitação } \\
\text { Conhecimento de si } \\
\text { Virtude } \\
\text { Consolação } \\
\text { Razão } \\
\text { Paixão } \\
\text { Obediência }\end{array}$ & 620 & $\begin{array}{l}\text { 1) MOTIVAÇÃO DA ESCRITA/OCASIÃO: Aproveita a visita do P.e Procurador do Japão } \\
\text { para manifestar seu desejo pessoalmente. Está obrigado a falar do desejo, a pedir, para } \\
\text { corresponder às inspirações de Deus. Pede Japão/IIndias orientais. 2) HISTÓRIA DO DESEJO: } \\
\text { Leu cartas do Japão e sentiu desejo de imitar aqueles padres jesuítas. Os desejos cessavam ante } \\
\text { a sua inhabilidade e pouca virtude e por não ter certeza da vontade de Deus. 3) } \\
\text { DISCERNIMENTO DOS ESPIRITOS: Para ter certeza, se exercitou nas "coisas do Japão"; os } \\
\text { desejos se incenderam e começaram a ser contínuos. 4) SITUAÇÃO ATUAL: Não tem apego à } \\
\text { terra natal nem aos parentes. Deus lhe promete ajuda. Diz que trabalha para mortificar suas } \\
\text { paixões, afim de bem jugar. 5) RESUMO: Os desejos que tem são semelhantes àqueles que } \\
\text { Deus lhe deu quando foi chamado à C.J., e às vezes até mais fervorosos. Crê que sejam desejos } \\
\text { dados por Deus, porque são um incentivo para se aproveitar em virtudes. Não escreve para } \\
\text { pedir a missão, mas para declarar sinceramente o que se passa em sua alma. Espera que o P.G. o } \\
\text { empregue naquilo que for de mais expediente no serviço de Deus; e isso será motivo de grande } \\
\text { consolação: ter trabalhado sempre por obediência e bem das almas, sem mistura de vontade } \\
\text { própria. Diz que tem boas forças. Não diz exatamente para onde quer ser enviado, mas há nota } \\
\text { no verso da carta dizendo "pide Japon". 6) DESPEDIDA }\end{array}$ \\
\hline $\begin{array}{r}43 \\
(758)\end{array}$ & $\begin{array}{l}\text { Desejo } \\
\text { Vocação } \\
\text { Obediência } \\
\text { Vocação } \\
\text { Imitação } \\
\text { Lágrimas } \\
\text { Indiferença } \\
\text { Desengano } \\
\text { AMDG }\end{array}$ & 488 & $\begin{array}{l}\text { 1) INTRODUÇÃO/MOTIVAÇÃO: Quer se empregar a serviço da C.J. por inteiro. 2) } \\
\text { HISTÓRIA DO DESEJO E DOS PEDIDOS: O desejo já havia sido representado quando entrou } \\
\text { na C.J. Fala de um decreto publicado em } 1583 \text { que pede que se escreva pedindo as missões. } \\
\text { Escreveu dois anos antes, ao P.e Provincial. 3) DISCERNIMENTO DOS ESPÍRITOS: A } \\
\text { gravidade do negócio e a força do desejo o fizeram temer que fosse afeto próprio. Fez confissão } \\
\text { geral e pediu conselhos ao padre confessor. 4) PEDIDO: Pede por obediência. 5) HISTÓRIA } \\
\text { DO DESEJO: Foi ouvindo a vida de Xavier que sentiu desejo de "seguir sus pasos", sem temer } \\
\text { qualquer dificuldade. Os desejos são eficazes. Chorou por medo de peder o desejo ou por ver-se } \\
\text { privado de satisfação. 6) DISPOSIÇÃO INDIFERENTE: Quer ser enviado sem petição. Pede } \\
\text { que o P.G. verifique a conveniência do pedido, para que assim possa obedecer plenamente. Fala } \\
\text { de obediência e indiferença pedidas pela C.J. Confia que Deus não o enganará. 7) } \\
\text { DISCERNIMENTO DOS ESPÍRITOS: Encomendou o desejo nas orações e nas missas, fez } \\
\text { orações e jejuns por } 50 \text { dias contínuos, pedindo que Deus ordenasse o que fosse para sua "maior } \\
\text { honrra y gloria". Há uma nota no verso que diz "pide Japon". 8) DESPEDIDA }\end{array}$ \\
\hline $\begin{array}{r}73 \\
(758)\end{array}$ & $\begin{array}{l}\text { Consolação } \\
\text { Memória } \\
\text { Obediência } \\
\text { Filiação } \\
\text { Desejo }\end{array}$ & 196 & $\begin{array}{l}\text { 1) MOTIVAÇÃO DA ESCRITA: Já havia pedido e, agora, aproveita o P.e Pedro Ortigosa para } \\
\text { dar notícias do seu pedido anterior. 2) PEDIDO: É petição justa, por isso pede por amor de } \\
\text { Deus que não lhe seja negada. 3) NOTíCIAS SUAS/SITUAÇÃO ATUAL: Será informado, } \\
\text { pelo P.e Ortigosa sobre sua situação atual. 4) DISPONIBILIDADE: Irá de boa vontade se o } \\
\text { P.G. quiser; e se não for, pede a Deus que lhe faça obediente e "hijo verdadero de la } \\
\text { Compañía". Espera que se cumpra a santa vontade de Deus. Não falará mais dos seus desejos, } \\
\text { sabendo que se o P.G. já sabe, será feito o que mais lhe convém. }\end{array}$ \\
\hline $\begin{array}{r}80 \\
(758)\end{array}$ & \begin{tabular}{|l|} 
Desejo \\
Vocação \\
Martírio \\
Consolação \\
AMDG \\
Conhecimento de si \\
Virtude \\
\end{tabular} & 439 & $\begin{array}{l}\text { 1) INTRODUÇÃO/MOTIVAÇÃO DA ESCRITA: Terceira vez que escreve. Aproveita as } \\
\text { novidades que se tiveram acerca dos padres e irmãos da C.J. para escrever outra vez. Seus } \\
\text { desejos vêm aumentando. 2) DISCERNIMENTO DOS ESPÍRITOS: Tratou já dos desejos com } \\
\text { o P.e Provincial, com o Reitor da casa e com outros padres. 3) DISPONIBILIDADE } \\
\text { VOCACIONAL: Confia em Deus que será para Sua maior glória a sua ida. 4) SITUAÇÃO } \\
\text { ATUAL: É trabalhador da cidade, sabe ler e escrever, e é prático no mar. É alegre, mas não diz } \\
\text { nada sobre o interior porque não tem o que dizer sobre virtudes. 5) DESPEDIDA. }\end{array}$ \\
\hline $\begin{array}{r}116 \\
(758)\end{array}$ & $\begin{array}{l}\text { Desejo } \\
\text { Vocação } \\
\text { Obediência } \\
\text { Encomendar } \\
\text { Tentação } \\
\text { Virtude } \\
\text { Sentidos } \\
\text { Imitação } \\
\text { Consolação } \\
\text { Indignidade } \\
\text { Conhecimento de si } \\
\text { Obrigação }\end{array}$ & 468 & $\begin{array}{l}\text { 1) INTRODUÇÃO/MOTIVAÇÃO DA ESCRITA: Segunda vez que escreve, porque lhe parece } \\
\text { que a primeira carta se perdeu. Menciona Japão e Peru, mas se diz indiferente. Que servir a } \\
\text { Deus e padecer por seu amor. 2) DISCERNIMENTO DOS ESPÍRITOS: Encomendou-se a } \\
\text { Deus antes de pedir. Achava ser tentação, pois não tem as virtudes que se requerem para tal } \\
\text { empreitada. Ria de quem pensava em ir ao Japão. O exemplo de outros irmãos do Colégio onde } \\
\text { se encontra o fez mudar de posição: agora, folga em ouvir, pensar, tratar, falar, ler coisas do } \\
\text { Japão. 3) DISPONIBILIDADE INDIFERENTE: Vai para o onde o P.G. ordenar, pois tudo o } \\
\text { que quer é padecer muito por Nosso Senhor. Oferece o nada que é para o trabalho a Deus. 5) } \\
\text { SITUAÇÃO ATUAL. 6) COMENTÁRIO FINAL E DESPEDIDA. Copiou essa carta do mata- } \\
\text { borrão, onde estava marcado o texto da primeira carta enviada. }\end{array}$ \\
\hline $\begin{array}{r}126 \\
(758)\end{array}$ & $\begin{array}{l}\text { Desejo } \\
\text { Vocação } \\
\text { Encomendar } \\
\text { Razão } \\
\text { Lágrimas } \\
\text { AMDG } \\
\text { Martírio } \\
\text { Mortificação } \\
\text { Consolação } \\
\text { Filiação }\end{array}$ & 419 & $\begin{array}{l}\text { 1) INTRODUÇÃO/MOTIVAÇÃO: Segunda vez que escreve. Quer trabalhar por amor de Cristo. P.e } \\
\text { Superior lhe indicou que escrevesse uma vez ao P.G. e que encomendasse o assunto a Deus. O P.e } \\
\text { Provincial, no entanto, em visita ao Colégio onde mora, sugeriu que escrevesse outra vez dando a } \\
\text { razão do que Deus lhe comunicou. 2) DESEJO E DISCERNIMENTO DOS ESPÍRITOS: O desejo é } \\
\text { grande, tanto que se arrebenta em lágrimas quando pensa. Quando sente alguma dificuldade na } \\
\text { mortificação das paixões e no caminho da perfeição, pensando que está se preparando para ir em } \\
\text { missão, imediatamente se anima; é remédio. Tem a China guardada no coração. 3) PEDIDO: Pede a } \\
\text { graça da consolação nesse negócio, ainda que não mereça. Quer empregar o que lhe resta da vida por } \\
\text { Cristo. 4) SITUAÇÃO ATUAL. 5) DESPEDIDA. }\end{array}$ \\
\hline $\begin{array}{r}136 \\
(758)\end{array}$ & $\begin{array}{l}\text { Consolação } \\
\text { Desejo } \\
\text { Filiação } \\
\text { Encomendar }\end{array}$ & 235 & $\begin{array}{l}\text { 1) PEDIDO: Pede a caridade de ser consolado pelo P.G., aceitando-o como voluntário para ida } \\
\text { à China. 2) DISCERNIMENTO DOS ESPÍRITOS: Sendo escolhido, irá mais solícito e } \\
\text { cuidadoso, sabendo que estaria, então, cumprindo a vontade de Deus. 3) SITUAÇÃO ATUAL. } \\
\text { 4) MOTIVAÇÕES E ARGUMENTOS EM SEU FAVOR: Tem o beneplácito de P.e Rogério, } \\
\text { que acredita que ele tenha idade suficiente para começar a aprender chinês. 5) DESPEDIDA. }\end{array}$ \\
\hline
\end{tabular}




\begin{tabular}{|c|c|c|c|}
\hline $\begin{array}{r}168 \\
(758)\end{array}$ & $\begin{array}{l}\text { Sentidos } \\
\text { Martírio } \\
\text { Desejo } \\
\text { Imitação } \\
\text { Desengano } \\
\text { AMDG } \\
\text { Virtude } \\
\text { Encomendar } \\
\text { Mortificação } \\
\text { Indignidade } \\
\text { Conhecimento de si } \\
\text { Razão } \\
\text { Alegria } \\
\text { Vocação }\end{array}$ & 779 & $\begin{array}{l}\text { 1) INTRODUÇÃO: Não sabe se o P.G. recebeu a carta enviada em 29/11/1590, por isso volta a } \\
\text { escrever. 2) HISTÓRIA DO DESEJO: Motivou-se pelo martírio de Rodolfo Aquaviva e seus } \\
\text { companheiros. Quer ganhar a vida, dando-a em serviço a Deus. Antes de entrar na C.J., havia pedido } \\
\text { vária vezes, mas o desejo de entrar foi resfriando nele. Com a visão dos "papeles" (onde estavam } \\
\text { representados os martírios), viu o desejo novamente incendido. Desejos, depois de entrado, só } \\
\text { cresceram. 3) DISCERNIMENTO DOS ESPÍRITOS: Mestre de noviços pediu para ter atenção: } \\
\text { discernir os espíritos e encomendar o negócio a Deus. Há cinco anos se encomenda e os desejos só } \\
\text { aumentam dia após dia. 4) MOTIVAÇÃO DA ESCRITA: Se diz instrumento ruim e indigno. Porém, } \\
\text { teme que Deus cobre dele o dilatar no pedido, por isso escreve ao P.G. pedindo que lhe dê licença } \\
\text { para "tan gloriosos trabajos y muerte". 5) RESUMO E PEDIDO: Deus lhe deu a graça de entrar na } \\
\text { C.J., através da visão dos martíres; sabe que não tem o necessário, mas confia que Deus, que lhe deu o } \\
\text { desejo, há de lhe dar o que falta. 6) DESPEDIDA. }\end{array}$ \\
\hline $\begin{array}{r}179 \\
(\mathbf{7 5 8})\end{array}$ & $\begin{array}{l}\text { Desejo } \\
\text { Lágrimas } \\
\text { Indignidade } \\
\text { Conhecimento de si } \\
\text { AMDG } \\
\text { Sentidos } \\
\text { Imitação } \\
\text { Consolação }\end{array}$ & 230 & $\begin{array}{l}\text { 1) INTRODUÇÃO: Diz que não pretende escrever outras vezes. 2) MOTIVAÇÃO DA ESCRITA: } \\
\text { Quer "descobrir seu peito" para o P.G. 3) DESEJO: Quer ser enviado ao Japão ou China. Diz oferecer } \\
\text { lágrimas, com esperança, de que o Senhor vai usar de sua vida miserável para Sua maior glória. 4) } \\
\text { HISTÓRIA DO DESEJO: O desejo nasceu ouvindo falar dos jesuítas que estão no Japão. 5) } \\
\text { DISCERNIMENTO DOS ESPÍRITOS: Encomenda-se a Nossa Senhora. 6) SITUAÇÃO ATUAL. }\end{array}$ \\
\hline $\begin{array}{r}188 \\
(758)\end{array}$ & $\begin{array}{l}\text { Desejo } \\
\text { Vocação } \\
\text { Martírio } \\
\text { AMDG } \\
\text { Alegria } \\
\text { Filiação } \\
\text { Consolação } \\
\text { Obediência } \\
\end{array}$ & 297 & $\begin{array}{l}\text { 1) INTRODUÇÃO E DESEJO: Segunda vez que escreve. Quer padecer por amor de Cristo. } \\
\text { Tem Superiores a quem se dirigir, por isso escreve de novo. 2) PEDIDO: Pede que o P.G. } \\
\text { julgue o que ser para a maior glória de Deus. 3) DISCERNIMENTO DOS ESPÍRITOS: Fala da } \\
\text { perseverança dos desejos e dos consolos que sente. Sente fervor e alegria quando ouve falar dos } \\
\text { padecimentos em terra de missões. 4) SITUAÇÃO ATUAL. 5) DESPEDIDA. }\end{array}$ \\
\hline $\begin{array}{r}191 \\
(758)\end{array}$ & $\begin{array}{l}\text { Indignidade } \\
\text { Desejo } \\
\text { Vocação } \\
\text { AMDG } \\
\text { Sentidos } \\
\text { Consolação } \\
\text { Alegria } \\
\text { Razão }\end{array}$ & 578 & $\begin{array}{l}\text { 1) INTRODUÇÃO, RESUMO, MOTIVAÇÃO: Havia pedido ao P.e Provincial, mas este lhe } \\
\text { respondeu que só quem autorizava era o P.G., por isso escreve ao P.G., mesmo sabendo que o } \\
\text { P.e Provincial já comunicou o seu desejo. Deus negociaria com o P.G., desde que ele lhe } \\
\text { comunicasse o desejo. 2) MOTIVAÇÃO/ OCASIÃO DA ESCRITA. 3) SITUAÇÃO ATUAL. } \\
\text { 4) HISTÓRIA DO DESEJO: Deseja desde que entrou na C.J. No noviciado, quando se liam as } \\
\text { cartas do Japão ou de outros lugares, se consolava muito. 5) PEDIDO: Se o P.G. responder } \\
\text { "sim", ficaria muito consolado. Se "não", procuraria coformar-se à vontade de Deus. 6) } \\
\text { COMENTÁRIO SOBRE P.E ESTEBAN PAEZ. 7) NOVO PEDIDO E DESPEDIDA: Pede } \\
\text { humildemente para ser enviado, caso o P.G. não encontre inconveniente na sua ida ou que não } \\
\text { encontre motivos para permanecer. }\end{array}$ \\
\hline $\begin{array}{r}200 \\
(758)\end{array}$ & $\begin{array}{l}\text { Vocação } \\
\text { Desejo } \\
\text { Desengano } \\
\text { Indignidade }\end{array}$ & 195 & $\begin{array}{l}\text { 1) DESEJO E HISTÓRIA DO DESEJO: Deseja desde antes de entrar na C.J., quando era mais } \\
\text { desarraigado do mundo. Deus concedeu-lhe entrar na C.J. há três anos, e agora lhe despertou de } \\
\text { novo o desejo das Índias. 3) MOTIVAÇÃO/OCASIÃO DA ESCRITA: Aproveita a ocasião da } \\
\text { visita do P.e Procurador da Nova Espanha para fazer seu pedido. 3) DISCERNIMENTO DOS } \\
\text { ESPÍRITOS E CONFIANÇA: Não tem as qualidades necessárias, mas confia na divina } \\
\text { bondade que lhe dará o que é necessário, desde que seja enviado pelo P.G. 4) DESPEDIDA. }\end{array}$ \\
\hline $\begin{array}{r}204 \\
(758)\end{array}$ & $\begin{array}{l}\text { Vocação } \\
\text { Desejo } \\
\text { Obediência } \\
\text { Indiferença } \\
\text { Martírio }\end{array}$ & 248 & $\begin{array}{l}\text { 1) HISTÓRIA DO DESEJO E HISTÓRIA DOS PEDIDOS/DISCERNIMENTO: Deseja há muitos } \\
\text { anos. Já falou com P.es Provinciais, não para pedir-lhes, mas para mostrar-lehs o quão indiferente se } \\
\text { encontrava. 2) PEDIDO: Pede Japão ou norte da Europa. 3) PEDIDO DE DISCERNIMENTO: } \\
\text { Espera de Deus o discernimento para cumprir Sua vontade. Deus deu graça para desejar, dará para } \\
\text { cumprir o que faz desejar. Está inclinado para o que seja padecimento e morte e para o que for a } \\
\text { vontade de Deus. 4) SITUAÇÃO ATUAL: Diz que o P.G. será informado sobre a seu respeito por } \\
\text { vias do P.e Cristóbal de los Cabos. 5) DESPEDIDA. }\end{array}$ \\
\hline $\begin{array}{r}227 \\
(\mathbf{7 5 8})\end{array}$ & \begin{tabular}{|l|} 
Filiação \\
Razão \\
Desejo \\
Martírio \\
Peregrinação \\
Sentidos \\
Edificação \\
Imitação \\
Indignidade \\
Indiferença \\
AMDG \\
Encomendar \\
\end{tabular} & 568 & $\begin{array}{l}\text { 1) INTRODUÇÃO: Escreve para dar a razão dos antigos desejos que sente. Os desejos já têm } \\
\text { profundas raízes em seu coração, e sente escrúpulos em não os propor ao P.G. 2) HISTÓRIA } \\
\text { DO DESEJO E DISCERNIMENTO DOS ESPÍRITOS: Quer salvar as almas nas Ïndias. Nada } \\
\text { lhe assusta, pelo contrário, tudo o anima. Está há quatro anos na C.J. Durante } 6 \text { anos pediu o } \\
\text { ingresso, mas lhe foi negado por causa da idade. Seus pais eram amigos da C.J. (conheciam o } \\
\text { P.e Jerônimo Nadal). Desejava tanto entrar que, algumas vezes, fez muitos atos de martírio e } \\
\text { trabalho duro por amor de Deus. Quer dar o sangue por Cristo. Depois da entrada, pediu ao P.e } \\
\text { Provincial e ao Mestre de noviços, porém nunca insistiu muito (por medo de ousadia). Antes e } \\
\text { depois de propor os desejos, procurava a indiferença. 3) PEDIDO/DISPOSIÇÃO/DESPEDIDA: } \\
\text { O P.e Confessor lhe indicou que escrevesse ao P.G. Quer viver por Deus, por seu favor. }\end{array}$ \\
\hline $\begin{array}{r}290 \\
(758)\end{array}$ & $\begin{array}{l}\text { Desejo } \\
\text { Vocação } \\
\text { Conhecimento de si } \\
\text { Vocação } \\
\text { Sentidos } \\
\text { Martírio } \\
\text { AMDG } \\
\text { Obediência }\end{array}$ & 352 & $\begin{array}{l}\text { 1) INTRODUÇÃO: Há muitos dias sente desejo de ir às Índias. 2) DISCERNIMENTO DOS } \\
\text { ESPÍRITOS: Desejo traz mudanças extraordinárias em si. 3) HISTÓRIA DO DESEJO E DO } \\
\text { DISCERNIMENTO: Diz que ouviu contar que no Peru se sofrem vários incômodos e trabalhos } \\
\text { difíceis e que quer isso de tal forma que nada o espanta. 4) SITUAÇÃO ATUAL E } \\
\text { CONFIANÇA: Confia na mão piedosa de Deus, que lhe dará as forças necessárias, pois Ele o } \\
\text { chama. 5) PEDIDO E OBEDIÊNCIA: }\end{array}$ \\
\hline
\end{tabular}




\begin{tabular}{|c|c|c|c|}
\hline $\begin{array}{r}338 \\
(\mathbf{7 5 8})\end{array}$ & $\begin{array}{l}\text { Desejo } \\
\text { Vocação } \\
\text { Martírio } \\
\text { Conhecimento de si } \\
\text { Experiência } \\
\text { Tentação } \\
\text { Consolação } \\
\text { Memória } \\
\text { Sentidos } \\
\text { Paixões } \\
\text { Mortificação } \\
\text { Encomendar } \\
\text { Obediência }\end{array}$ & 733 & $\begin{array}{l}\text { 1) INTRODUÇÃO: Enviou duas outras cartas por via dos P.es Gaspar Moro e Diego Torres (P.e } \\
\text { Procurador das Índias Ocidentais), além de ter enviado uma quando estava em Valência. No entanto, } \\
\text { escreve outra vez porque se sente forçado pelo "desejo grande que minha alma tem de ir às Îndias". 2) } \\
\text { HISTÓRIA DO DESEJO: Começou a desejar depois dos Exercícios Espirituais que fez em 1602. } \\
\text { Deseja o martírio desde então. Relata que faz experiência de, quando tem alguma tentação, ela logo se } \\
\text { desfaz como fumaça e se sente consolado, com a simples memória dos desejos. 3) DUAS } \\
\text { HISTÓRIAS: Relatando dois exemplos, diz que sente consolação grande e acha que só pode pagar } \\
\text { com a própria morte e padecimento os bens recebidos. 4) DISCERNIMENTO DOS ESPÍRITOS: } \\
\text { Mortifica-se com a memória das Índias. Oferece uma perfeita obediência a Deus e a abnegação de } \\
\text { corpo e alma. 5) SITUAÇÃO ATUAL E PEDIDO: Descreve sua atual situação na C.J. e pede ao P.G. } \\
\text { que lhe alcance a realização do desejo de ser enviado às Índias. 6) RELATO DE UM SONHO: } \\
\text { Sonhou, quando ainda era secular, que matava com as próprias mãos os "índios" que não se } \\
\text { convertiam. 7) DESPEDIDA. }\end{array}$ \\
\hline $\begin{array}{r}379 \\
(758)\end{array}$ & $\begin{array}{l}\text { Encomendar } \\
\text { Vocação } \\
\text { Desejo } \\
\text { Conhecimento de si } \\
\text { Indignidade } \\
\text { Imitação } \\
\text { Filiação } \\
\text { AMDG } \\
\text { Experiência } \\
\text { Martírio }\end{array}$ & 532 & $\begin{array}{l}\text { 1) INTRODUÇÃO: Esperou por um ano para escrever ao P.G. E, nesse tempo, considerou bem } \\
\text { o desejo. 2) NECESSIDADE DE DISCERNIMENTO: Mostra como a Regra da C.J. exige que } \\
\text { se encomende a Deus os negócios graves, antes de pedir. 3) HISTÓRIA DO DESEJO E DO } \\
\text { DISCERNIMENTO: Encomendou-se a Deus. Junto com o desejo tem experimentado facilidade } \\
\text { para todos os trabalhos de coração. Deseja dar a vida, porque ofendeu muito a Cristo e sente } \\
\text { que só será correto quando puder derramar o snage por amor dEle. 4) MOTIVAÇÃO DA } \\
\text { ESCRITA: Escreve obedecendo como Cristo obedeceu. 5) PEDIDO E DESPEDIDA: Suplica } \\
\text { ao P.G. que disponha dele para ser enviado ao Japão. }\end{array}$ \\
\hline $\begin{array}{r}5 \\
(759)\end{array}$ & $\begin{array}{l}\text { Conhecimento de si } \\
\text { Desejo } \\
\text { Martírio } \\
\text { Consolação } \\
\text { Sentidos }\end{array}$ & 622 & $\begin{array}{l}\text { 1) INTRODUÇÃO: Relata que conversou, antes de entrar na C.J., com dois padres e ambos } \\
\text { disseram que ele deveria falar de seus desejos com o P.G. 2) PEDIDO DE DESCULPAS: Pede } \\
\text { desculpas pelo atrevimento de escrever. E diz que a resposta do P.G. será como o maná. 3) } \\
\text { DESEJOS E DISCERNIMENTO DOS ESPÍRITOS: Diz que tem três desejos: a) derramar o } \\
\text { sangue pela fé; b) a conversão dos parentes e "deudos"; c) ter morte boa e segura. E explica a } \\
\text { motivação e maneira como trabalhou no discernimento. Relata que, antes de entrar para a C.J. } \\
\text { era sismático, como toda a sua família. Teme a doença, porque morrem os sentidos, turbam-se } \\
\text { as potências, adormecem os dons do Espírito Santo. 4) HISTÓRIA DO PEDIDO E } \\
\text { CHAMADO DE ATENÇÃO: Há três ou quatro anos espera a resolução de um envio para a } \\
\text { Inglaterra. Diz, ao final, que "entonces me dixeron una cosa y agora outra". }\end{array}$ \\
\hline $\begin{array}{r}13 \\
(759)\end{array}$ & $\begin{array}{l}\text { Desejo } \\
\text { Inspiração } \\
\text { Alegria } \\
\text { Razão } \\
\text { Vocação } \\
\text { Indignidade } \\
\text { AMDG } \\
\text { Conhecimento de si } \\
\text { Virtude }\end{array}$ & 379 & $\begin{array}{l}\text { 1) MOTIVAÇÃ̃O DA ESCRITA: Desejo de corresponder aos desejos e inspirações que certamente } \\
\text { vêm de Deus. 2) HISTÓRIA DO DESEJO: Sente desejo de se empregar na ajuda da conversão dos } \\
\text { infiéis, há alguns anos. Falou do desejo com seu P.e Provincial. 3) EXPECTATIVAS: Esperava que o } \\
\text { P.G. realizasse seus desejo e lhe concedesse "tão assinalada caridade". 4) DISCERNIMENTO DOS } \\
\text { ESPIIRITOS E CONFIANÇA: Relata o resultado do trabalho de discernimento, dizendo-se indigno de } \\
\text { tal empreitada e insuficiente. Espera que Deus o supra do que lhe falta. 5) SITUAÇÃO ATUAL. 6) } \\
\text { PEDIDO: Pede o Japão. 7) MOTIVAÇÃO DA ESCRITA: Escreve aproveitando a passagem do P.e } \\
\text { Procurador de Portugal em Salamanca. 8) DESPEDIDA. }\end{array}$ \\
\hline $\begin{array}{r}24 / 2 \\
(759)\end{array}$ & $\begin{array}{l}\text { Vocação } \\
\text { Desejo } \\
\text { Indiferença } \\
\text { Encomendar } \\
\text { Filiação }\end{array}$ & 269 & $\begin{array}{l}\text { 1) HISTÓRIA DO DESEJO E INDIFERENÇA: Deseja desde que entrou na C.J. É indiferente } \\
\text { quanto ao lugar das Índias. 2) MOTIVAÇÃO DA ESCRITA E DISCERNIMENTO DOS } \\
\text { ESPIIRITOS: Não pediu antes, porém pede agora porque fez os votos e encomendou o negócio } \\
\text { a Deus, sentindo-se, agora, com mais desejo que antes. 3) PEDIDO: Pede que o P.G. faça a } \\
\text { caridade de conceder-lhe ir às Índias. E diz que não reparará em nenhuma dificuldade que } \\
\text { aparecer. Quer cumprir a vontade de Deus. 4) SITUAÇÂO ATUAL. 5) DESPEDIDA. }\end{array}$ \\
\hline $\begin{array}{r}49 \\
(759)\end{array}$ & $\begin{array}{l}\text { Vocação } \\
\text { Desejo } \\
\text { Martírio } \\
\text { Indignidade } \\
\text { Sentidos } \\
\text { Encomendar } \\
\text { Virtude } \\
\text { Razão } \\
\text { AMDG } \\
\text { Conhecimento de si }\end{array}$ & 350 & $\begin{array}{l}\text { 1) HISTÓRIA DO DESEJO: Tem desejo de empregar toda a vida pela conversão das almas das } \\
\text { Índias, há algum tempo. 2) MOTIVAÇÃO DA ESCRITA E PEDIDO: Tendo ouvido algumas } \\
\text { notícias das Índias, e sabido da ordem do P.G. que "todos os que pedem para ir às Îndias } \\
\text { estejam com bom ânimo e se ponham disponíveis", se motivou a escrever e pedir humilde e } \\
\text { resignadamente para ser enviado. 3) DISCERNIMENTO DOS ESPÍRITOS: Diz que examinou, } \\
\text { considerou e encomendou o negócio ao Senhor. Por isso dá, agora, razão do seu pedido: que } \\
\text { seja para a maior glória de Deus. 4) SITUAÇÃO ATUAL E ARGUMENTO EM SEU FAVOR: } \\
\text { Descreve sua situação na C.J. e diz que quer persuadir o P.G. com o fato de que "sente o } \\
\text { coração muito estimulado pelo Senhor". Diz que não tem muitas virtudes, mas que estudará e } \\
\text { que confia que o Senhor proverá no que lhe falta. 5) DESPEDIDA. }\end{array}$ \\
\hline $\begin{array}{r}58 / 1 \\
(759)\end{array}$ & $\begin{array}{l}\text { Experiência } \\
\text { AMDG } \\
\text { Desejo } \\
\text { Conhecimento de si } \\
\text { Razões } \\
\text { Consolação } \\
\text { Imitação } \\
\text { Vocação } \\
\text { Martírio }\end{array}$ & 435 & $\begin{array}{l}\text { 1) INTRODUÇÃO E DECLARAÇÃO DE OBEDIÊNCIA: Experimenta a graça de se saber } \\
\text { sob a obediência de um Superior, sobretudo no que concerne ao que seja para a maior glória de } \\
\text { Deus. 2) HISTÓRIA DO DESEJO: Sente, há muitos dias, desejo de ser enviado à Índia } \\
\text { Oriental (Japão ou Etiópia), para ajudar os gentios. Por isso suplica ao P.G. que lhe conceda o } \\
\text { envio, desde que isso "seja coisa na qual Nosso Senhor seja servido, e signifique fazer a } \\
\text { vontade de V.P., que essa entenderei como a de Deus". 3) DISCERNIMENTO DOS } \\
\text { ESPÍRITOS: Nada o afasta do desejo que sente. Não entrou na C.J. para se aproveitar } \\
\text { pessoalmente apenas, mas para aproveitar a outros também. Além do mais, acha que ir para as } \\
\text { Îndias servir-lhe-á para se desapegar de tudo o que é temporal. Finalmente, diz que quer imitar } \\
\text { Xavier. 4) SITUAÇÃO ATUAL. 5) DESPEDIDA. }\end{array}$ \\
\hline
\end{tabular}




\begin{tabular}{|c|c|c|c|}
\hline $\begin{array}{r}329 \\
(758)\end{array}$ & $\begin{array}{l}\text { Consolação } \\
\text { Desejo } \\
\text { Vocação } \\
\text { Martírio } \\
\text { Conhecimento de si } \\
\text { Experiência } \\
\text { Indiferença } \\
\text { AMDG } \\
\text { Mortificação }\end{array}$ & 752 & $\begin{array}{l}\text { 1) INTRODUÇÃO: Fala da boa ocasião que é para ele escrever, pela primeira vez ao P.G., para } \\
\text { tratar do que pretende. 2) HISTÓRIA DO DESEJO E DO DISCERNIMENTO: Deseja } \\
\text { derramar o sangue no Japão, para conseguir realizar o fim de sua vocação. Achava que o desejo } \\
\text { não era verdadeiro, porque não tem o que se requer. Mas, considerou como é verdade que Deus } \\
\text { usa de instrumentos vis para grandes empresas. Não sabia, porém, se era mesmo vontade de } \\
\text { Deus. Encomendou-se a Deus e às orações de amigos. Finalmente, resolveu pedir a P.G.; sendo } \\
\text { interesse geral da vontade divina, seria assegurado neste negócio. 3) DISCERNIMENTO DOS } \\
\text { ESPÍRITOS E INDIFERENÇA: Refletiu sobre si mesmo e descobriu duas coisas: a) o desejo é } \\
\text { como uma lima que acaba com suas imperfeições; sinal da origem divina do desejo; b) a } \\
\text { grandeza de ter sido chamado e ser ainda conservado na C.J. Sente-se firme nas coisas do } \\
\text { Instituto como pedra entre as ondas do mar. Não crê que "a raiz de onde brotam tais ramos } \\
\text { possam ser más, ou vontades infantis". Está certo de que Deus o chama, o que se comprova pela } \\
\text { indiferença grande que sinto. 4) PEDIDO E DISPONIBILIDADE: Pede que o P.G. disponha } \\
\text { dele segundo o que for mais conveniente e para a maior glória de Deus. Enquanto espera uma } \\
\text { resposta do P.G., promete que irá se mortificar, porque assim terá as mais seguras asas para que } \\
\text { um filho da C.J. atravesse o "imenso oceano". 5) DESPEDIDA. }\end{array}$ \\
\hline $\begin{array}{r}404 \\
(758)\end{array}$ & $\begin{array}{l}\text { Memória } \\
\text { Vocação } \\
\text { Experiência (?) } \\
\text { Indiferença }\end{array}$ & 432 & $\begin{array}{l}\text { 1) INTRODUÇÃO: Escreve para renovar a memória de seus desejos ao P.G. Desejos estes que, } \\
\text { neste tempo, não deixaram de ser fortes e vigorosos. Fala de como isto é uma mercê grande } \\
\text { para ele que é tão indigno. Por isso quer louvar a Deus diante de todas as criaturas. 2) } \\
\text { MOTIVAÇÃO DA ESCRITA E PEDIDO DE DESCULPAS: Essa grande mercê o obriga a } \\
\text { escrever de novo. Diz que escreveu já outras cartas ao P.G. (no entanto, esta consta como sendo } \\
\text { a segunda carta de Juan Bravo). Pede, então, que o P.G. feche os olhos para a sua impertinência. } \\
\text { 3) JUSTIFICATIVA: Porque ele sabe o quão difícil é escrever em tão poucas linhas aquilo que } \\
\text { o Senhor lhe dá a conhecer aos poucos e que o coração sente. Gostaria, portanto, de lhe } \\
\text { comunicar pessoalmente, à voz. Nesse sentido, espera, então, que o Senhor comunique ao P.G. } \\
\text { as tão grandes mercês que lhe tem feito. 4) PROMESSA E DISPONIBILIDADE } \\
\text { INDIFERENTE: Promete uma vingança sobre si mesmo para remedir todas as vezes que não } \\
\text { serviu ao Senhor, quem sabe até morrendo na cruz por Ele. Diz-se indiferente. 5) DESPEDIDA. }\end{array}$ \\
\hline $\begin{array}{r}4 \\
(759)\end{array}$ & $\begin{array}{l}\text { Memória } \\
\text { Martírio } \\
\text { Desejo } \\
\text { AMDG }\end{array}$ & 203 & $\begin{array}{l}\text { 1) INTRODUÇÃO: Refresca a memóia do P.G. de seus desejos de martírio no Japão. 2) DESEJO } \\
\text { E PEDIDO/CONFIANÇA NO PADRE GERAL: Sente-se seguro da paternidade do P.G., por isso, } \\
\text { espera, no Senhor, que o P.G. o empregue naquilo que mais agradar a Deus, ainda que seu desejo } \\
\text { esteja tão contrastado pelo demônio e por suas imperfeições. 3) DESPEDIDA. }\end{array}$ \\
\hline
\end{tabular}




\section{ANEXO 4 Quadro 02 - Estrutura retórica (ars dictaminis)}

Quadro 02 no qual se apresentam o número de codificação da carta no ARSI e a estrutura retórica, conforme a ars dictaminis.

\begin{tabular}{|c|c|}
\hline $\mathbf{N}^{\circ}$ & $\begin{array}{l}\text { DIVISÃO INTERNA CONFORME A ARS DICTAMINIS } \\
\end{array}$ \\
\hline $\begin{array}{r}4 \\
(758)\end{array}$ & $\begin{array}{l}\text { 1) SALUTATIO: Muy R.do en Chr.o P.e N.ro / Pax Chri etc. } \\
\text { 2) CAPTATIO BENEVOLENTIAE: Los desseos de yr al Japon (...) y obediencias pide N.ro S.to Instituto (desejo, tentação, } \\
\text { vocação, memória, mortificação, obediência, virtude). } \\
\text { 3) NARRATIO: He querido, quando siento (...) por todo sea Dios bendito (vocação, tentação, razão, experiência, desejo, } \\
\text { consolação, alegria, livre de, conhecimento de si). } \\
\text { 4) PETITIO: De manera que solo puede ser estorvo (...) lo que fuere mas para su S.to Servicio (virtude, conhecimento de si, desejo, } \\
\text { obediência, encomendar, vocação, amdg). } \\
\text { 5) CONCLUSIO: Amen. (...) Coçar. }\end{array}$ \\
\hline $\begin{array}{r}13 \\
(758)\end{array}$ & $\begin{array}{l}\text { 1) SALUTATIO: Muy R.o P.e N.ro en Xpo / Pax Xpi etc. } \\
\text { 2) CAPTATIO BENEVOLENTIAE: Por averse offrecido tan buena (...) a a las inspirationes de N.ro S.or. (desejo, vocação, } \\
\text { indignidade, filiação, obrigação, inspiração). } \\
\text { 3) NARRATIO: Abra dos años poco mas (...) para aprovechar en virtud (sentidos, desejo, imitação, conhecimento de si, virtude, } \\
\text { consolação, razão, paixão, vocação). } \\
\text { 4) PETITIO: Esto es lo que se me offrece (...) sin mescla de propria Voluntad (desejo, consolação, obediência). } \\
\text { 5) CONCLUSIO: Terme edad de } 20 \text { a } 21 \text { años (...) Torres. }\end{array}$ \\
\hline $\begin{array}{r}43 \\
(758)\end{array}$ & $\begin{array}{l}\text { 1) SALUTATIO: Pax X. etc. } \\
\text { 2) CAPTATIO BENEVOLENTIAE: Los eficazes deseos (...) que tengo ya representado (desejo, vocação). } \\
\text { 3) NARRATIO: Abra dos annos que estando (...) de el y temiendo perdello (desejo, obediência, vocação, imitação, lágrimas). } \\
\text { 4) PETITIO: Mucho he deseado (...) no quiere ni puede engañarme (desejo, obediência, indiferença, desengano). } \\
\text { 5) CONCLUSIO: Antes que tratara se escrevir (...) Perez (amdg). }\end{array}$ \\
\hline $\begin{array}{r}73 \\
(758)\end{array}$ & $\begin{array}{l}\text { 1) SALUTATIO: Muy R.do P.e N.ro en Xo. / Pax X. \&c. } \\
\text { 2) CAPTATIO BENEVOLENTIAE: Los dias passados (...) que viene de mexico. } \\
\text { 3) NARRATIO: yo le he hablado (...) mucho ha a V.P.d (consolação, memória). } \\
\text { 4) PETITIO: y agora se lo pido (...) muy buena voluntad. } \\
\text { 5) CONCLUSIO: Y sino yo Ruego (...) Crespo. (obediência, filiação, desejo) }\end{array}$ \\
\hline $\begin{array}{r}80 \\
(758)\end{array}$ & $\begin{array}{l}\text { 1) SALUTATIO: Al muy R.do P.e N.ro en Chro. / Pax Xpi \&c. } \\
\text { 2) CAPTATIO BENEVOLENTIAE: Por dos vezes he escrito (...) no lo podria declarar con palabras (desejo, vocação, martírio, } \\
\text { consolação). } \\
\text { 3) NARRATIO: yo he tratado estos mis deseos (...) lo que yo sentia de mi (desejo, amdg, vocação). } \\
\text { 4) PETITIO: Mas contado esso me ha parescido (...) por no enfadar a V.P. (consolação). } \\
\text { 5) CONCLUSIO: yo soy obrero de villa (...) Matias (conhecimento de si, virtude, desejo). }\end{array}$ \\
\hline
\end{tabular}




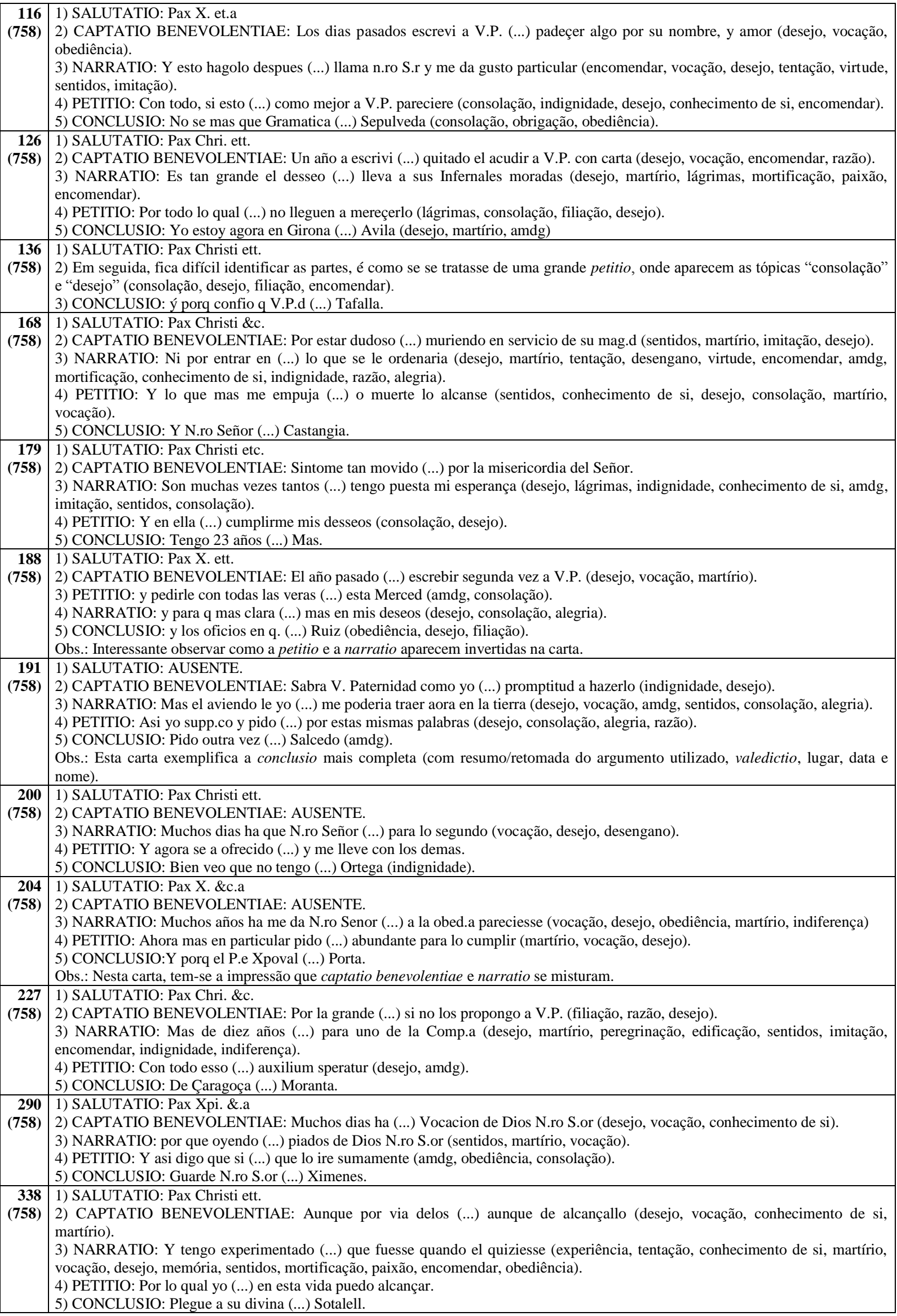




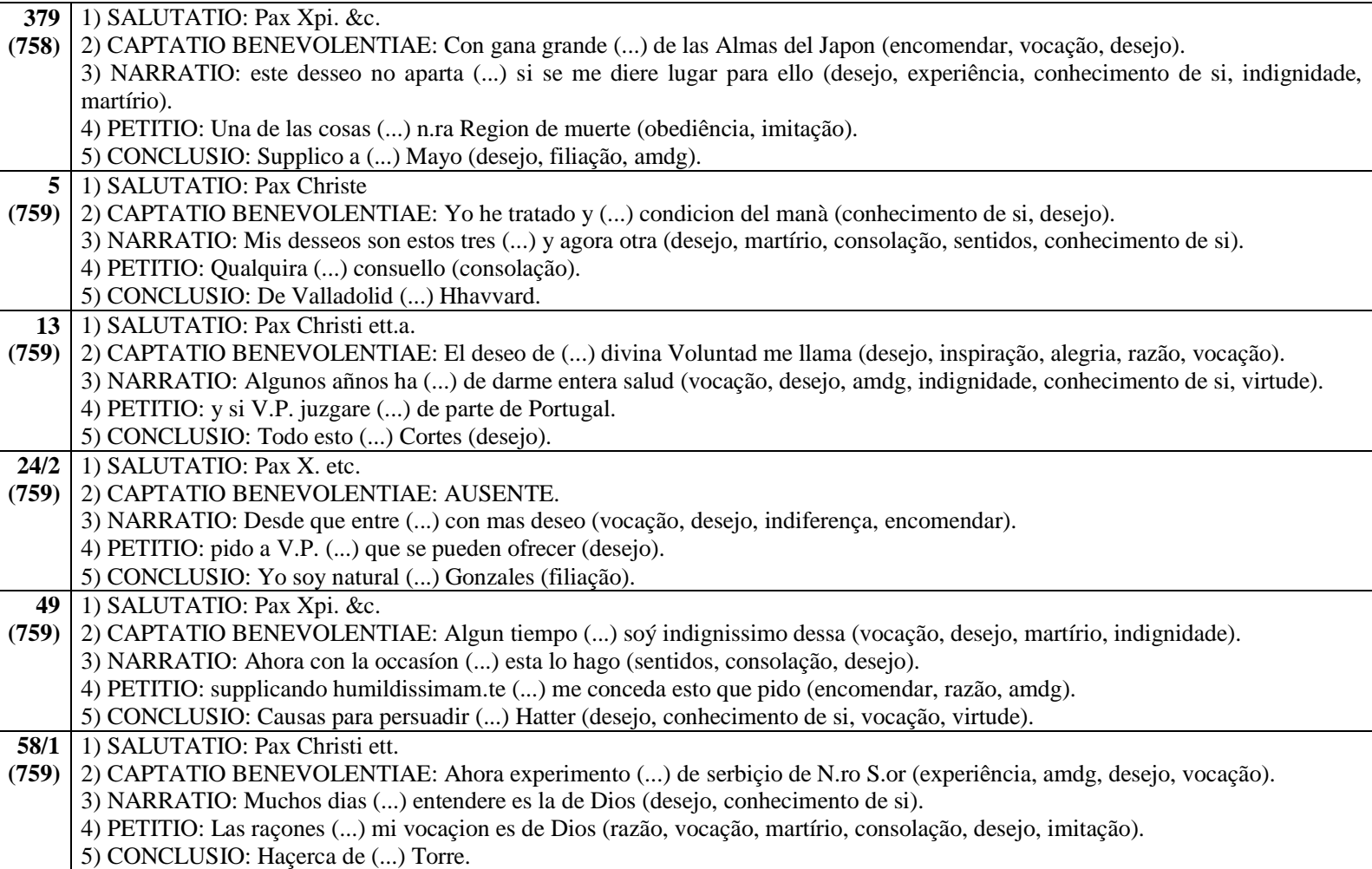

\begin{tabular}{r|l|}
$\mathbf{3 2 9}$ & 1) SALUTATIO: Pax Xpti \&c.a. \\
$\mathbf{( 7 5 8 )}$ & 2) CAPTATIO BENEVOLENTIAE: Con mucho consuelo (...) refirire a V.P.d (aparece nesta parte apenas a tópica da \\
"consolação"). \\
3) NARRATIO: Ha sido pues (...) antes creçiendo mas (onde aparecem os seguintes topoi: desejo, vocação, martírio, conhecimento \\
de si, experiência, vocação e indiferença). \\
4) PETITIO: Por onde supp.co (...) de my alma (estando presente apenas a tópica do ÄMDG”). \\
5) CONCLUSIO: Entretanto q estoy (...) Bravo (aparece nesta parte a tópica da "mortificação"). \\
\hline $\mathbf{4 0 4}$ \\
1) SALUTATIO: Pax Xpti \&c.a. \\
2) CAPTATIO BENEVOLENTIAE: Mas he tardado (...) le llego a pedir (aparecem as tópicas da memória e do desejo). \\
3) NARRATIO: Es muy diffiçil (...) rematar na cruz (estando presentes apenas as tópicas do desejo e da experiência). \\
4) PETITIO: Ni por esto (...) me lo alcançe del S.r (onde aparece a tópica da "indiferença"). \\
5) CONCLUSIO: Sacer (...) Bravo. \\
(759) \\
1) SALUTATIO: Pax Xpti \&c.a. \\
2) CAPTATIO BENEVOLENTIAE: AUSENTE. \\
3) NARRATIO: Mas a menudo (...) de sus espirituales hijos (estão presentes os seguintes topoi: memória, martírio e desejo). \\
4) PETITIO: Y asi espero (...) y verdadero holocausto (estando presente a tópica do “desejo"). \\
5) CONCLUSIO: El pague a V.P.d (...) Bravo.
\end{tabular}




\section{ANEXO 5 Tabelas 03 e 04 - Lugares-comuns nas Indipetae Hispanae}

Tabela 03 na qual se apresentam os topoi mais freqüentes encontrados nas cartas analisadas e a quantidade total de uso de cada topos, nas cartas do recorte macro-histórico.

\begin{tabular}{|c|c|c|c|c|c|c|c|c|c|c|c|c|c|c|c|c|c|c|c|c|c|c|c|c|}
\hline & 1583 & 1584 & 1585 & 1586 & 1587 & 1588 & 1589 & 1590 & 1591 & 1592 & 1593 & 1594 & 1597 & 1598 & 1599 & 1602 & 1603 & 1604 & 1605 & 1606 & 1607 & 1608 & 1609 & TOTAL \\
\hline Alegria & 1 & 0 & 0 & 0 & 0 & 0 & 0 & \begin{tabular}{|l|}
0 \\
\end{tabular} & 1 & 0 & 1 & 6 & 0 & 0 & 0 & 0 & 0 & 0 & 0 & 1 & 0 & 0 & 0 & 10 \\
\hline AMDG & 1 & 0 & 1 & 0 & 1 & 0 & 1 & 0 & 1 & 1 & 1 & 2 & 0 & 0 & 1 & 1 & 0 & 1 & 0 & 1 & 0 & 1 & 2 & 16 \\
\hline Conhecimento de si & 2 & 1 & 0 & 0 & 1 & 1 & 0 & 0 & 2 & 1 & 0 & 0 & 0 & 0 & 0 & 1 & 3 & 1 & 3 & 2 & 0 & 1 & 1 & 20 \\
\hline Consolação & 1 & 2 & 0 & 1 & 2 & 2 & 1 & 1 & 2 & 2 & 2 & 2 & 0 & 0 & 0 & 1 & 3 & 0 & 2 & 0 & 0 & 1 & 1 & 26 \\
\hline Desejo & 5 & 10 & 10 & 1 & 4 & 4 & 4 & 1 & 4 & 3 & 5 & 9 & 2 & 2 & 9 & 1 & 3 & 9 & 11 & 5 & 4 & 3 & 4 & 113 \\
\hline$\overline{\text { Desengano }}$ & 0 & 0 & 1 & 0 & 0 & 0 & 0 & 0 & 4 & 0 & 0 & 0 & 1 & 0 & 0 & 0 & 0 & 0 & 0 & 0 & 0 & 0 & 0 & 6 \\
\hline Edificacão & 0 & 0 & 0 & 0 & 0 & 0 & 0 & 0 & 0 & 0 & 0 & 0 & 0 & 0 & 1 & 0 & 0 & 0 & 0 & 0 & 0 & 0 & 0 & 1 \\
\hline Encomendar & 1 & 0 & 0 & 0 & 0 & 3 & 2 & 1 & 2 & 0 & 0 & 0 & 0 & 0 & 1 & 0 & 1 & 4 & 0 & 0 & 1 & 2 & 0 & 18 \\
\hline Experiência & 1 & 0 & 0 & 0 & 0 & 0 & 0 & 0 & 0 & 0 & 0 & 0 & 0 & 0 & 0 & 0 & 1 & 1 & 0 & 0 & 0 & 0 & 1 & 4 \\
\hline Filiação & 0 & 1 & 0 & 1 & 0 & 0 & 1 & 1 & 0 & 0 & 1 & 0 & 0 & 0 & 1 & 0 & 0 & 2 & 0 & 0 & 1 & 0 & 0 & 9 \\
\hline Imitação & 0 & 1 & 1 & 0 & 0 & 1 & 0 & 0 & 1 & 1 & 0 & 0 & 0 & 0 & 1 & 0 & 0 & 1 & 0 & 0 & 0 & 0 & 1 & 8 \\
\hline Indiferença & 0 & 0 & 1 & 0 & 0 & 0 & 0 & 0 & 0 & 0 & 0 & 0 & 0 & 1 & 2 & 0 & 0 & 0 & 0 & 0 & 1 & 0 & 0 & 5 \\
\hline Indignidade & 0 & 1 & 0 & 0 & 0 & 1 & 0 & 0 & 1 & 1 & 0 & 1 & 1 & 0 & 1 & 0 & 0 & 3 & 0 & 2 & 0 & 1 & 0 & 13 \\
\hline Inspiração & 0 & 1 & 0 & 0 & 0 & 0 & 0 & 0 & 0 & 0 & 0 & 0 & 0 & 0 & 0 & 0 & 0 & 0 & 0 & 1 & 0 & 0 & 0 & 2 \\
\hline Lagrimas & 0 & 0 & 1 & 0 & 0 & 0 & 2 & 0 & 0 & 1 & 0 & 0 & 0 & 0 & 0 & 0 & 0 & 0 & 0 & 0 & 0 & 0 & 0 & 4 \\
\hline Livre de & 1 & 0 & 0 & 0 & 0 & 0 & 0 & 0 & 0 & 0 & 0 & 0 & 0 & 0 & 0 & 0 & 0 & 0 & 0 & 0 & 0 & 0 & 0 & 1 \\
\hline Martírio & 0 & 0 & 0 & 0 & 1 & 0 & 3 & 0 & 10 & 0 & 1 & 0 & 0 & 2 & 4 & 2 & 5 & 3 & 3 & 0 & 0 & 2 & 1 & 37 \\
\hline Memória & 1 & 0 & 0 & 1 & 0 & 0 & 0 & 0 & 0 & 0 & 0 & 0 & 0 & 0 & 0 & 0 & 1 & 0 & 0 & 0 & 0 & 0 & 0 & 3 \\
\hline Mortificação & 1 & 0 & 0 & 0 & 0 & 0 & 1 & 0 & 1 & 0 & 0 & 0 & 0 & 0 & 0 & 0 & 1 & 0 & 0 & 0 & 0 & 0 & 0 & 4 \\
\hline Obediência & 2 & 1 & 2 & 1 & 0 & 2 & 0 & 0 & 0 & 0 & 2 & 0 & 0 & 2 & 0 & 2 & 1 & 2 & 0 & 0 & 0 & 0 & 0 & 17 \\
\hline Obrigação & 0 & 1 & 0 & 0 & 0 & 1 & 0 & 0 & 0 & 0 & 0 & 0 & 0 & 0 & 0 & 0 & 0 & 0 & 0 & 0 & 0 & 0 & 0 & 2 \\
\hline Paixão & 0 & 1 & 0 & 0 & 0 & 0 & 1 & 0 & 0 & 0 & 0 & 0 & 0 & 0 & 0 & 0 & 1 & 0 & 0 & 0 & 0 & 0 & 0 & 3 \\
\hline Peregrinação & 0 & 0 & 0 & 0 & 0 & 0 & 0 & 0 & 0 & 0 & 0 & 0 & 0 & 0 & 2 & 0 & 0 & 0 & 0 & 0 & 0 & 0 & 0 & 2 \\
\hline Razão & 3 & 1 & 0 & 0 & 0 & 0 & 1 & 0 & 1 & 0 & 0 & 1 & 0 & 0 & 1 & 0 & 0 & 0 & 0 & 1 & 0 & 1 & 1 & 11 \\
\hline Sentidos & 0 & 1 & 0 & 0 & 0 & 2 & 0 & 0 & 3 & 1 & 0 & 2 & 0 & 0 & 1 & 1 & 1 & 0 & 4 & 0 & 0 & 1 & 0 & 17 \\
\hline Tentação & 2 & 0 & 0 & 0 & 0 & 1 & 0 & 0 & 3 & 0 & 0 & 0 & 0 & 0 & 0 & 0 & 2 & 0 & 0 & 0 & 0 & 0 & 0 & 8 \\
\hline Virtude & 2 & 2 & 0 & 0 & 1 & 1 & 0 & 0 & 1 & 0 & 0 & 0 & 0 & 0 & 0 & 0 & 0 & 0 & 0 & 1 & 0 & 2 & 0 & 10 \\
\hline Vocação & 4 & 5 & 2 & 0 & 2 & 3 & 1 & 0 & 1 & 0 & 1 & 2 & 2 & 2 & 0 & 3 & 3 & 1 & 0 & 2 & 1 & 2 & 3 & 40 \\
\hline
\end{tabular}


Tabela 04 na qual se apresentam os topoi mais freqüentes encontrados nas cartas analisadas e a quantidade total de uso de cada topos, nas cartas do recorte micro-histórico.

\begin{tabular}{l|c|c|c|c}
\hline & $\mathbf{1 6 0 3}$ & $\mathbf{1 6 0 4}$ & $\mathbf{1 6 0 5}$ & TOTAL \\
\hline Alegria & 1 & 0 & 0 & 1 \\
\hline AMDG & 1 & 0 & 1 & 2 \\
\hline Conhecimento de si & 2 & 0 & 0 & 2 \\
\hline Consolação & 2 & 0 & 0 & 2 \\
\hline Desejo & 4 & 3 & 2 & 9 \\
\hline Desengano & 1 & 1 & 1 & 3 \\
\hline Encomendar & 2 & 0 & 0 & 2 \\
\hline Experiência & 1 & 0 & 0 & 1 \\
\hline Filiação & 2 & 0 & 3 & 5 \\
\hline Indiferença & 2 & 1 & 0 & 3 \\
\hline Indignidade & 1 & 2 & 1 & 4 \\
\hline Martírio & 1 & 0 & 2 & 3 \\
\hline Memória & 0 & 1 & 1 & 2 \\
\hline Mortificação & 1 & 0 & 0 & 1 \\
\hline Obrigação & 0 & 2 & 0 & 2 \\
\hline Sentidos & 1 & 1 & 0 & 2 \\
\hline Vocação & 7 & 0 & 0 & 7
\end{tabular}




\section{ANEXO 6 Quadros 03 e 04 - Lugares-comuns nas Indipetae Hispanare}

Quadro 03 no qual se apresentam os topoi mais freqüentes encontrados nas cartas analisadas e a quantidade total de uso de cada topos, divididos a partir da estrutura retórica própria da ars dictaminis.

\begin{tabular}{|c|c|c|c|c|}
\hline & CB & $\mathbf{N}$ & $\mathbf{P}$ & $\mathbf{C}$ \\
\hline 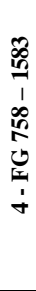 & $\begin{array}{l}\text { Desejo } 2 \\
\text { Tentação } 1 \\
\text { Vocação } 1 \\
\text { Memória } 1 \\
\text { Mortificação } 1 \\
\text { Obediência } 1 \\
\text { Virtude } 1\end{array}$ & $\begin{array}{l}\text { Vocação } 1 \\
\text { Tentação } 1 \\
\text { Razão } 3 \\
\text { Experiência } 1 \\
\text { Desejo 1 } \\
\text { Consolação } 1 \\
\text { Alegria 1 } \\
\text { Liberdade 1 } \\
\text { Conhecimento de si } 1\end{array}$ & $\begin{array}{l}\text { Virtude } 1 \\
\text { Conhecimento de si } 1 \\
\text { Desejo } 2 \\
\text { Obediência } 1 \\
\text { Encomendar } 1 \\
\text { Vocação } 2 \\
\text { AMDG } 1\end{array}$ & \\
\hline & CB & \begin{tabular}{|c|}
$\mathbf{N}$ \\
\end{tabular} & $\mathbf{P}$ & $\mathbf{C}$ \\
\hline 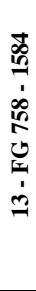 & $\begin{array}{l}\text { Desejo } 2 \\
\text { Vocação } 1 \\
\text { Indignidade } 1 \\
\text { Filiação } 1 \\
\text { Obrigação } 1 \\
\text { Inspiração }\end{array}$ & $\begin{array}{l}\text { Sentidos 1 } \\
\text { Desejo 7 } \\
\text { Imitação 1 } \\
\text { Conhecimento de si } 1 \\
\text { Virtude 2 } \\
\text { Consolação 1 } \\
\text { Razão 1 } \\
\text { Paixão 1 } \\
\text { Vocaçãa 2 }\end{array}$ & $\begin{array}{l}\text { Desejo } 1 \\
\text { Consolação } 1 \\
\text { Obediência } 1\end{array}$ & \\
\hline & CB & $\mathbf{N}$ & $\mathbf{P}$ & $\mathrm{C}$ \\
\hline 党 & $\begin{array}{l}\text { Desejo } 2 \\
\text { Vocação } 1\end{array}$ & $\begin{array}{l}\text { Desejo } 6 \\
\text { Obediência } 1 \\
\text { Vocaçãa } 1 \\
\text { Imitação } 1 \\
\text { Lágrimas } 1\end{array}$ & $\begin{array}{l}\text { Desejo } 2 \\
\text { Obediência } 1 \\
\text { Indiferença } 1 \\
\text { Desengano } 1\end{array}$ & AMDG 1 \\
\hline
\end{tabular}




\begin{tabular}{|c|c|c|c|c|}
\hline & CB & $\mathbf{N}$ & $\mathbf{P}$ & $\mathbf{C}$ \\
\hline 总 & & $\begin{array}{l}\text { Consolação } 1 \\
\text { Memória } 1\end{array}$ & $\begin{array}{l}\text { Obediência 1 } \\
\text { Filiação 1 } \\
\text { Desejo 1 }\end{array}$ & \\
\hline & CB & $\mathbf{N}$ & $\mathbf{P}$ & $\mathbf{C}$ \\
\hline D. & \begin{tabular}{|l|} 
Desejo 1 \\
Vocação 1 \\
Martírio 1 \\
Consolação 1
\end{tabular} & $\begin{array}{l}\text { Desejo } 2 \\
\text { AMDG 1 } \\
\text { Vocação } 1\end{array}$ & Consolação 1 & $\begin{array}{l}\text { Conhecimento de si } 1 \\
\text { Virtude 1 } \\
\text { Desejo } 1\end{array}$ \\
\hline & & & & \\
\hline 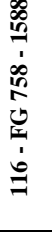 & $\begin{array}{l}\text { Desejo } 1 \\
\text { Vocação } 1 \\
\text { Obediência } 1\end{array}$ & $\begin{array}{l}\text { Encomendar 2 } \\
\text { Vocação 2 } \\
\text { Desejo 2 } \\
\text { Tentação 1 } \\
\text { Virtude 1 } \\
\text { Sentidos 2 } \\
\text { Imitação 1 } \\
\end{array}$ & $\begin{array}{l}\text { Consolação 1 } \\
\text { Indignidade 1 } \\
\text { Desejo 1 } \\
\text { Conhecimento de si } 1 \\
\text { Encomendar 1 }\end{array}$ & $\begin{array}{l}\text { Consolação } 1 \\
\text { Obrigação } 1 \\
\text { Obediência } 1\end{array}$ \\
\hline & CB & $\mathbf{N}$ & $\mathbf{P}$ & $\mathbf{C}$ \\
\hline 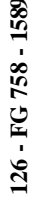 & $\begin{array}{l}\text { Desejo 1 } \\
\text { Vocação 1 } \\
\text { Encomendar 1 } \\
\text { Razão 1 }\end{array}$ & $\begin{array}{l}\text { Desejo 1 } \\
\text { Martírio 2 } \\
\text { Lágrimas 1 } \\
\text { Mortificação 1 } \\
\text { Paixão 1 } \\
\text { Encomendar 1 }\end{array}$ & $\begin{array}{l}\text { Lagrimas 1 } \\
\text { Consolação 1 } \\
\text { Filiação 1 } \\
\text { Desejo 1 }\end{array}$ & $\begin{array}{l}\text { Desejo 1 } \\
\text { Martírio 1 } \\
\text { AMDG 1 }\end{array}$ \\
\hline & & & PTO & \\
\hline D. & $\begin{array}{l}\text { Consolação 1 } \\
\text { Desejo 1 } \\
\text { Filiação 1 } \\
\text { Encomendar 1 }\end{array}$ & & & \\
\hline & CB & $\mathrm{N}$ & $\mathbf{P}$ & C \\
\hline 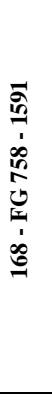 & \begin{tabular}{|l|} 
Sentidos 2 \\
Martírio 6 \\
Imitação 1 \\
Desejo 1
\end{tabular} & $\begin{array}{l}\text { Desejo } 2 \\
\text { Martírio 2 } \\
\text { Tentação } 3 \\
\text { Desengano } 1 \\
\text { Virtude 1 } \\
\text { Encomendar 2 } \\
\text { AMDG 1 } \\
\text { Mortificação 1 } \\
\text { Conhecimento de si } 1 \\
\text { Indignidade 1 } \\
\text { Razão 1 } \\
\text { Alegria 1 }\end{array}$ & $\begin{array}{l}\text { Sentidos } 1 \\
\text { Conhecimento de si } 1 \\
\text { Desejo 1 } \\
\text { Consolação 2 } \\
\text { Martírio 2 } \\
\text { Vocação 1 }\end{array}$ & \\
\hline & CB & $\mathbf{N}$ & $\mathbf{P}$ & $\mathbf{C}$ \\
\hline 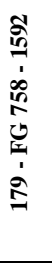 & & $\begin{array}{l}\text { Desejo } 2 \\
\text { Lágrimas } 1 \\
\text { Indignidade 1 } \\
\text { Conhecimento de si } 1 \\
\text { AMDG 1 } \\
\text { Imitação 1 } \\
\text { Sentidos 1 } \\
\text { Consolação 1 } \\
\end{array}$ & $\begin{array}{l}\text { Consolação } 1 \\
\text { Desejo } 1\end{array}$ & \\
\hline & CB & $\mathbf{P}$ & $\mathbf{N}$ & C \\
\hline 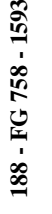 & $\begin{array}{l}\text { Desejo 2 } \\
\text { Vocação } 1 \\
\text { Martírio } 1\end{array}$ & $\begin{array}{l}\text { AMDG 1 } \\
\text { Consolação } 1\end{array}$ & $\begin{array}{l}\text { Desejo 2 } \\
\text { Consolação } 1 \\
\text { Alegria } 1\end{array}$ & $\begin{array}{l}\text { Obediência } 2 \\
\text { Desejo 1 } \\
\text { Filiação } 1\end{array}$ \\
\hline
\end{tabular}




\begin{tabular}{|c|c|c|c|c|}
\hline & CB & $\mathbf{N}$ & $\mathbf{P}$ & $\mathbf{C}$ \\
\hline 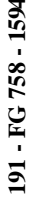 & $\begin{array}{l}\text { Indignidade } 1 \\
\text { Desejo } 1\end{array}$ & $\begin{array}{l}\text { Desejo 6 } \\
\text { Vocação } 2 \\
\text { AMDG 1 } \\
\text { Sentidos 2 } \\
\text { Consolação 1 } \\
\text { Alegria } 5\end{array}$ & $\begin{array}{l}\text { Desejo } 2 \\
\text { Consolação } 1 \\
\text { Alegria 1 } \\
\text { Razão } 1\end{array}$ & AMDG 1 \\
\hline \multirow[b]{2}{*}{ 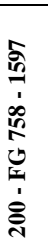 } & CB & $\mathbf{N}$ & $\mathbf{P}$ & C \\
\hline & & $\begin{array}{l}\text { Vocação } 2 \\
\text { Desejo } 2 \\
\text { Desengano } 1\end{array}$ & & Indignidade 1 \\
\hline \multirow[b]{2}{*}{ 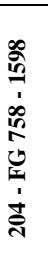 } & \multicolumn{2}{|c|}{$\mathrm{CB} / \mathbf{N}$} & $\mathbf{P}$ & C \\
\hline & \multicolumn{2}{|l|}{$\begin{array}{l}\text { Vocação 1 } \\
\text { Desejo 1 } \\
\text { Obediência } 2 \\
\text { Martírio 1 } \\
\text { Indiferença 1 }\end{array}$} & $\begin{array}{l}\text { Martírio } 1 \\
\text { Vocação } 1 \\
\text { Desejo } 1\end{array}$ & \\
\hline \multirow[b]{2}{*}{ 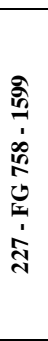 } & CB & $\mathbf{N}$ & $\mathbf{P}$ & $\mathbf{C}$ \\
\hline & $\begin{array}{l}\text { Filiação } 1 \\
\text { Razão } 1 \\
\text { Desejo } 1\end{array}$ & $\begin{array}{l}\text { Desejo 6 } \\
\text { Martírio } 4 \\
\text { Peregrinação } 2 \\
\text { Edificação } 1 \\
\text { Sentidos 1 } \\
\text { Imitação 1 } \\
\text { Encomendar 1 } \\
\text { Indignidade 1 } \\
\text { Indiferença 2 } \\
\end{array}$ & $\begin{array}{l}\text { Desejo } 2 \\
\text { AMDG } 1\end{array}$ & \\
\hline \multirow[b]{2}{*}{ 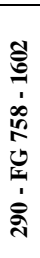 } & CB & $\mathbf{N}$ & $\mathbf{P}$ & $\mathbf{C}$ \\
\hline & $\begin{array}{l}\text { Desejo } 1 \\
\text { Vocação } 2 \\
\text { Conhecimento de si } 1\end{array}$ & $\begin{array}{l}\text { Sentidos } 1 \\
\text { Martírio } 2 \\
\text { Vocação } 1\end{array}$ & $\begin{array}{l}\text { AMDG 1 } \\
\text { Obediência } 2 \\
\text { Consolaçãa 1 }\end{array}$ & \\
\hline \multirow[b]{2}{*}{ 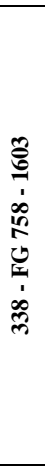 } & $\mathbf{C B}$ & $\mathbf{N}$ & $\mathbf{P}$ & $\mathbf{C}$ \\
\hline & $\begin{array}{l}\text { Desejo } 2 \\
\text { Vocação } 1 \\
\text { Conhecimento de si } 1 \\
\text { Martírio } 1\end{array}$ & $\begin{array}{l}\text { Experiência } 1 \\
\text { Tentação } 2 \\
\text { Conhecimento de si } 2 \\
\text { Consolação } 3 \\
\text { Martírio } 4 \\
\text { Vocação } 2 \\
\text { Desejo 1 } \\
\text { Memória 1 } \\
\text { Sentidos 1 } \\
\text { Mortificação } 1 \\
\text { Paixão 1 } \\
\text { Encomendar 1 } \\
\text { Obediência 1 } \\
\end{array}$ & & \\
\hline \multirow[b]{2}{*}{ 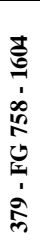 } & CB & $\mathbf{N}$ & $\mathbf{P}$ & $\mathbf{C}$ \\
\hline & $\begin{array}{l}\text { Encomendar } 4 \\
\text { Vocação } 1 \\
\text { Desejo } 1\end{array}$ & $\begin{array}{l}\text { Desejo } 7 \\
\text { Experiência } 1 \\
\text { Conhecimento de si } 1 \\
\text { Indignidade } 3 \\
\text { Martírio } 3\end{array}$ & $\begin{array}{l}\text { Obediência } 2 \\
\text { Imitação } 1\end{array}$ & $\begin{array}{l}\text { Desejo } 1 \\
\text { Filiação } 2 \\
\text { AMDG } 1\end{array}$ \\
\hline \multirow[b]{2}{*}{ 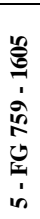 } & CB & $\mathbf{N}$ & $\mathbf{P}$ & $\mathbf{C}$ \\
\hline & $\begin{array}{l}\text { Conhecimento de si } 1 \\
\text { Desejo } 1\end{array}$ & $\begin{array}{l}\text { Desejo } 10 \\
\text { Martírio } 3 \\
\text { Consolação } 1 \\
\text { Sentidos } 4 \\
\text { Conhecimento de si } 2\end{array}$ & Consolação 1 & \\
\hline
\end{tabular}




\begin{tabular}{|c|c|c|c|c|}
\hline & CB & $\mathbf{N}$ & $\mathbf{P}$ & $\mathrm{C}$ \\
\hline 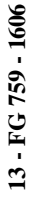 & $\begin{array}{l}\text { Desejo } 2 \\
\text { Inspiração } 1 \\
\text { Alegria 1 } \\
\text { Razão 1 } \\
\text { Vocação } 1\end{array}$ & $\begin{array}{l}\text { Vocação } 1 \\
\text { Desejo } 2 \\
\text { Indignidade } 2 \\
\text { AMDG } 1 \\
\text { Conhecimento de si } 2 \\
\text { Virtude } 1\end{array}$ & & Desejo 1 \\
\hline \multirow[b]{2}{*}{ 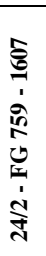 } & CB & $\mathbf{N}$ & $\mathbf{P}$ & $\mathbf{C}$ \\
\hline & & $\begin{array}{l}\text { Vocação } 1 \\
\text { Desejo } 3 \\
\text { Indiferença } 1 \\
\text { Encomendar } 1\end{array}$ & Desejo 1 & Filiação 1 \\
\hline \multirow[b]{2}{*}{ 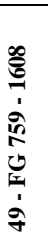 } & CB & $\mathbf{N}$ & $\mathbf{P}$ & $\mathbf{C}$ \\
\hline & $\begin{array}{l}\text { Vocação } 1 \\
\text { Desejo 1 } \\
\text { Martírio } 2 \\
\text { Indignidade } 1\end{array}$ & $\begin{array}{l}\text { Sentidos 1 } \\
\text { Consolação } 1 \\
\text { Desejo 1 }\end{array}$ & $\begin{array}{l}\text { Encomendar } 2 \\
\text { Razão } 1 \\
\text { AMDG } 1\end{array}$ & $\begin{array}{l}\text { Desejo } 1 \\
\text { Conhecimento de si } 1 \\
\text { Vocação } 1 \\
\text { Virtude } 2\end{array}$ \\
\hline \multirow[b]{2}{*}{ فئ } & CB & $\mathbf{N}$ & $\mathbf{P}$ & $\mathrm{C}$ \\
\hline & $\begin{array}{l}\text { Experiência } 1 \\
\text { AMDG } 2 \\
\text { Desejo 1 } \\
\text { Vocação } 1\end{array}$ & $\begin{array}{l}\text { Desejo } 2 \\
\text { Conhecimento de si } 1\end{array}$ & $\begin{array}{l}\text { Razão 1 } \\
\text { Vocação } 2 \\
\text { Martírio 1 } \\
\text { Consolação } 1 \\
\text { Desejo 1 } \\
\text { Imitação 1 }\end{array}$ & \\
\hline
\end{tabular}

\begin{tabular}{|c|c|c|c|c|}
\hline & CB & $\mathbf{N}$ & $\mathbf{P}$ & C \\
\hline 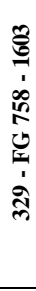 & $\begin{array}{l}\text { Consolação } 2 \\
\text { Alegria 1 } \\
\text { Desejo 1 } \\
\text { Filiação 1 } \\
\text { Indignidade 1 }\end{array}$ & $\begin{array}{l}\text { Vocação } 7 \\
\text { Desejo } 3 \\
\text { Martírio 1 } \\
\text { Conhecimento de si } 2 \\
\text { Encomendar 2 } \\
\text { Sentidos 1 } \\
\text { Experiência 1 } \\
\text { Desengano 1 } \\
\text { Indiferença 2 }\end{array}$ & AMDG 1 & $\begin{array}{l}\text { Mortificação } 1 \\
\text { Filiação } 1\end{array}$ \\
\hline \multirow[b]{2}{*}{ 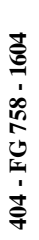 } & CB & $\mathbf{N}$ & $\mathbf{P}$ & $\mathbf{C}$ \\
\hline & $\begin{array}{l}\text { Memória } 1 \\
\text { Desejo } 1 \\
\text { Indignidade } 1 \\
\text { Obrigação } 1\end{array}$ & $\begin{array}{l}\text { Sentidos 1 } \\
\text { Desejo } 2 \\
\text { Obrigação 1 } \\
\text { Indignidade 1 } \\
\text { Desengano 1 }\end{array}$ & $\begin{array}{l}\text { Indiferença } 1 \\
\text { Filiação } 2\end{array}$ & \\
\hline \multirow[b]{2}{*}{ 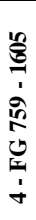 } & \multicolumn{2}{|c|}{$\mathrm{CB} / \mathrm{N}$} & $\mathbf{P}$ & C \\
\hline & $\begin{array}{l}\text { Memória } 1 \\
\text { Desejo } 2 \\
\text { Martírio } 1 \\
\text { Filiação } 1\end{array}$ & & $\begin{array}{l}\text { Desengano } 1 \\
\text { Filiação } 1 \\
\text { Martírio } 1\end{array}$ & $\begin{array}{l}\text { Filiação } 1 \\
\text { Indignidade } 1 \\
\text { AMDG } 1\end{array}$ \\
\hline
\end{tabular}


Quadro 04 no qual se apresentam os topoi mais freqüentes encontrados nas cartas analisadas e a quantidade total de uso de cada topos, em cada uma das partes da estrutura retórica própria da ars dictaminis.

\begin{tabular}{|c|c|c|c|}
\hline \multicolumn{2}{|c|}{ CAPTATIO BENEVOLENTIAE } & \multicolumn{2}{|c|}{ NARRATIO } \\
\hline Experiência & 1 & Edificação & 1 \\
\hline Imitação & 1 & Filiação & 1 \\
\hline Indiferença & 1 & Liberdade & 1 \\
\hline Mortificação & 1 & Obrigação & 1 \\
\hline Tentação & 1 & Peregrinação & 2 \\
\hline Virtude & 1 & Lágrimas & 3 \\
\hline Alegria & 2 & Memória & 3 \\
\hline AMDG & 2 & Mortificação & 3 \\
\hline Inspiração & 2 & Paixão & 3 \\
\hline Obrigação & 2 & Desengano & 4 \\
\hline Sentidos & 2 & Experiência & 4 \\
\hline Conhecimento de si & 3 & Obediência & 4 \\
\hline Consolação & 3 & AMDG & 5 \\
\hline Memória & 3 & Imitação & 5 \\
\hline Razão & 3 & Razão & 5 \\
\hline Filiação & 4 & Virtude & 5 \\
\hline Obediência & 4 & Indiferença & 6 \\
\hline Encomendar & 5 & Tentação & 7 \\
\hline Indignidade & 5 & Alegria & 8 \\
\hline Martírio & 13 & Indignidade & 9 \\
\hline Vocação & 15 & Encomendar & 10 \\
\hline Desejo & 28 & Consolação & 11 \\
\hline \multicolumn{2}{|c|}{ PETITIO } & Conhecimento de si & 14 \\
\hline Alegria & 1 & Sentidos & 16 \\
\hline Indignidade & 1 & Martírio & 23 \\
\hline Lagrimas & 1 & Vocação & 24 \\
\hline Sentidos & 1 & Desejo & 73 \\
\hline Virtude & 1 & \multicolumn{2}{|c|}{ CONCLUSIO } \\
\hline Desengano & 2 & Consolação & 1 \\
\hline Imitação & 2 & Martírio & 1 \\
\hline Indiferença & 2 & Mortificação & 1 \\
\hline Conhecimento de si & 3 & Obrigação & 1 \\
\hline Filiação & 3 & Vocação & 1 \\
\hline Razão & 3 & Conhecimento de si & 2 \\
\hline Encomendar & 4 & Indignidade & 2 \\
\hline Martírio & 5 & Obediência & 3 \\
\hline AMDG & 6 & Virtude & 3 \\
\hline Obediência & 8 & AMDG & 5 \\
\hline Vocação & 8 & Desejo & 6 \\
\hline Consolação & 12 & \multirow{2}{*}{ Filiação } & \multirow{2}{*}{6} \\
\hline Desejo & 17 & & \\
\hline
\end{tabular}




\section{REFERÊNCIAS BIBLIOGRÁFICAS}

\section{1) DOCUMENTOS HISTÓRICOS}

\section{- Originais}

Aquaviva, Claudio (1583). Lettera del Nostro Padre Generale Claudio Acquaviva. Sopra la Rinovatione dello spirito à Padri \& Fratelli della Compagnie. 29/09/1583. Roma. BCS W12/441.

Aquaviva, Claudio (1586). Lettera del Nostro Padre Generale Claudio Acquaviva. Dello studio della perfettione, \& carità fraterna. 19/05/1586. Roma.

BCS W12/441

Arias, Francisco (1600). Profitto spirituale, nel qual s'insegna à fare acquisto delle virtù, \& progresso nello spirito. Del M.R.P. Francesco Arias della Compagnia di Giesu. Tradotto della lingua Spagnuola, dal Cavaliere Fra Giulio Zanchini da Castiglionchio. Milano: Stampa del q. Pacifico Pontio, Impressore Archiepiscopale (original espanhol de 1588).

BNF D-23722 
ARSI, Indipetae Hispanae, FG 758, carta n. 4.

ARSI, Indipetae Hispanae, FG 758, carta n. 13.

ARSI, Indipetae Hispanae, FG 758, carta n. 43.

ARSI, Indipetae Hispanae, FG 758, carta n. 73.

ARSI, Indipetae Hispanae, FG 758, carta n. 80.

ARSI, Indipetae Hispanae, FG 758, carta n. 106.

ARSI, Indipetae Hispanae, FG 758, carta n. 116.

ARSI, Indipetae Hispanae, FG 758, carta n. 126.

ARSI, Indipetae Hispanae, FG 758, carta n. 136.

ARSI, Indipetae Hispanae, FG 758, carta n. 168.

ARSI, Indipetae Hispanae, FG 758, carta n. 179.

ARSI, Indipetae Hispanae, FG 758, carta n. 188.

ARSI, Indipetae Hispanae, FG 758, carta n. 191.

ARSI, Indipetae Hispanae, FG 758, carta n. 200.

ARSI, Indipetae Hispanae, FG 758, carta n. 204.

ARSI, Indipetae Hispanae, FG 758, carta n. 227.

ARSI, Indipetae Hispanae, FG 758, carta n. 290.

ARSI, Indipetae Hispanae, FG 758, carta n. 329.

ARSI, Indipetae Hispanae, FG 758, carta n. 338.

ARSI, Indipetae Hispanae, FG 758, carta n. 379.

ARSI, Indipetae Hispanae, FG 758, carta n. 404.

ARSI, Indipetae Hispanae, FG 759, carta n. 4.

ARSI, Indipetae Hispanae, FG 759, carta n. 5.

ARSI, Indipetae Hispanae, FG 759, carta n. 13. 
ARSI, Indipetae Hispanae, FG 759, carta n. 24/2.

ARSI, Indipetae Hispanae, FG 759, carta n. 49.

ARSI, Indipetae Hispanae, FG 759, carta n. 58/1.

Fazio, Giulio (1596). Trattato utilissimo della mortificatione delle nostre passioni, \& affetti disordinati. Composto nuovamente per il molto R. P. Giulio Fatio, della Compagnia di Giesu. Brescia: Pietro Maria Marchetti.

BCS W12/274.

Gusmão, Alexandre (1720). Eleyçam entre o Bem e o Mal Eterno, Lisboa: Officina da Musica.

Nieremberg, Juan Eusebio (1645). Honor del gran patriarca san Ignacio de Loyola, fundador de la Compañia de Iesus, en que se propone sua vida, y la de su Dicipulo el apostolo de las Indias S. Francisco Xavier. Con la milagrosa Historia del admirable Padre Marcelo Mastrilli, y las noticias de grand multitud de Hijos del mismo S. Ignacio, varones clarissimos en santidad, dotrina, trabajos, y obras maravillosas en servicio de la Iglesia. Madrid: Maria de Quiñones.

\section{BCS 55600/5}

Nieremberg, Juan Eusebio (1657). L'art de conduire la volonté selon les precepts de la morale ancienne \& Moderne, tirez de Philosophes Payens \& Chrestiens. Traduit du latin de Jean Eusebe de Nieremberg, Paraphrase \& de beaucoup enrichy par Loü̈s Videl, de Dauphiné. Dedié à Monsieur de Lionne, Conseiller d'Estat ordinaire \& secretaire des Commandemets de la Reyne Regente. Paris: Chez Jean Pocquet (original latino de 1631).

BNF R-6222. 
Rodriguez, Alonso (1834). Ejercicio de perfeccion y virtudes cristianas, su autor el Padre Alonso Rodriguez de la Compañía de Jesus, natural de Valladolid. Dividido en tres partes. Parte tercera. De varios medios para alcanzar la virtud y perfeccion. Nueva Impression. Barcelona: Imprenta de D. Valero Siena y Marti (original espanhol de 1609).

BCS W10/141

Sanchez, Pedro (1607). Le Royaume de Dieu, et le vray chemin pour y parvenir. Composé en Espagnol par le Pere P. Sanchez, Docteur de la Compagnie de Iesus. Traduit en François, par F. Guillaume Levite, de l'Ordre des Predicateurs. Paris: Chez Adrian Beys (original espanhol de 1594).

BCS W12/259

Villanueva, Melchior de (1608). Libro de oracion mental. Compuesto por el Padre Melchior de Villanueva, de la Compañia de Iesus. Toledo: Pedro Rodriguez impressor del Rey nuestro Señor.

BCS W12/267.

\section{- Seleção e edições modernas}

Borja, San Francisco de (1997). Diario Espiritual (1564-1570) (M. R. Jurado, ed.). Bilbao: Ediciones Mensajero/Sal Terrae (original espanhol de 1578).

Cardoso, Armando (1977). Introdução. Em: Loyola, Inácio (1977). Diário Espiritual (A. Cardoso, org. e trad.). São Paulo: Ed. Loyola (original espanhol de 1544 e 1545).

Cardoso, Armando (org.) (1988). Cartas de Santo Inácio de Loyola. Volume 1. São Paulo: Ed. Loyola.

Cardoso, Armando (org.) (1990). Cartas de Santo Inácio de Loyola. Volume 2. São Paulo: Ed. Loyola. 
Cardoso, Armando (org.) (1993). Cartas de Santo Inácio de Loyola. Volume 3. São Paulo: Ed. Loyola.

Cicéron, M. T. (1985). De l'orateur. Livre premier. (E. Courbaud, Trad.). Paris: Société d'édition "Les Belles Lettres" (original latino de 55 a.C.).

Cicéron, M. T. (1966). De l'orateur. Livre deuxième. (E. Courbaud, Trad.). Paris: Société d'édition "Les Belles Lettres" (original latino de 55 a.C.).

Cicéron, M. T. (1968). De l'orateur. Livre deuxième. (E. Courbaud, Trad.). Paris: Société d'édition "Les Belles Lettres" (original latino de 55 a.C.).

Cicéron, M. T. (1934). Correspondance. Tome I. (L.-A. Constans, Trad.). Paris: Les Belles Lettres (original latino do séc. I a.C.).

Cicéron, M. T. (1935). Correspondance. Tome II. (L.-A. Constans, Trad.). Paris: Les Belles Lettres (original latino do séc. I a.C.).

Cicéron, M. T. (1936). Correspondance Tome III. (L.-A. Constans, Trad.). Paris: Les Belles Lettres (original latino do séc. I a.C.).

Cicéron, M. T. (1950). Correspondance Tome IV. (L.-A. Constans, Trad.). Paris: Les Belles Lettres (original latino do séc. I a.C.).

Góis, Manuel de (1593). Disputas do Curso Conimbricense sobre os livros de Moral a Nicómaco de Aristóteles em que se contêm alguns dos principais capítulos da moral. Lisboa: Oficina de Simão Lopes.

Loyola, Ignace de (1991). Écrits (M. Giuliani, Pres. et Dir.). Paris: Desclée de Brouwer; Bellarmin (Collection Christus, 76, Textes) (Originais do século XVI).

Nieremberg, Juan Eusebio (1957). Obras escogidas del R. P. Juan Eusebio Nieremberg. (E. Zepeda-Henriquez, Ed.). Em E. Zepeda-Henriquez (ed.). Biblioteca de Autores Españoles, desde la formación del lenguaje hasta nuestros dias (Tomo 103). Madrid: Ediciones Atlas (originais do século XVII).

BNF 4-Z-3501 (103). 
Nieremberg, Juan Eusebio (1957). Obras escogidas del R. P. Juan Eusebio Nieremberg. (E. Zepeda-Henriquez, Ed.). Em E. Zepeda-Henriquez (ed.). Biblioteca de Autores Españoles, desde la formación del lenguaje hasta nuestros dias (Tomo 104). Madrid: Ediciones Atlas (originais do século XVII).

\section{BCS W17/121}

Raffo, Giuliano (a cura di) (1989) La "ratio studiorum": il metodo degli studi umanistici nel collegi dei gesuiti alla fine del secolo XVI. Milano: Gesuiti San Fedele (original latino de 1598).

Surin, Jean-Joseph (1990). Triomphe de l'Amour divin sur les puissances de l'Enfer en la possession de la Mère Supérieure des Ursulines de Loudun, exorcisée para le Père Jean-Joseph Surin, de la Compagnie de Jésus et Science expérimentales des choses de l'autres vie. Grenoble: Jérôme Millon (originais de 1653 e 1660, respectivamente).

\section{2) ESPIRITUALIDADE}

\section{- Geral}

Certeau, Michel de (1982). La fable mystique, 1: XVIe - XVIIe siècle. Paris: Gallimard.

Giussani, Luigi (2000). O Senso Religioso (P. A. E. Oliveira, Trad.). Rio de Janeiro: Nova Fronteira (original italiano de 1997).

Meslin, Michel (1988). L'expérience humaine du divin: fondements d'une anthropologie religieuse. Paris: Les éditions du cerf.

O livro das horas (1998). São Paulo: Companhia Ilimitada.

\section{- Jesuítica}

Bergamo, Mino (1994). L'anatomie de l'âme: de François de Sales à Fénelon (M. Bonneval, Trad.). Paris: Jérôme Millon (original italiano de 1991). 
Du Jourdin, Michel Mollat (1991). Saint Ignace et les pèlerinages de son temps. In: Plazaola, Juan (Ed.) (1991). Ignacio de Loyola y su tiempo: Congresso Internacional de Historia. Bilbao: Mensajero e Universidad de Deusto.

Fabre, Pierre-Antoine (2000). "Ils iront en pèlerinage...": 1'“expérience" du pèlerinage selon 1'“Examen général" des Constitutions de la Compagnie de Jésus et selon les pratiques contemporaines. Em Boutry, Philippe; Fabre, Pierre-Antoine et Julia, Dominique (2000). Rendre ses voeux: les identités pèlerines dans l'Europe moderne (XVIe-XVIIIe siècles) (pp. 159-188). Paris: EHESS.

Fernández-Martos, José Maria (1991). La incorporación de la realidad como clave del cambio en los Ejercicios Espirituales. Em Alemany, Carlos e Garcia-Monge, José A. (ed.) (1991). Psicologia y Ejercicios Ignacianos (vol I): la transformación del yo en la experiencia de Ejercicios Espirituales. Bilbao: Mensajero e Sal Terrae.

García Mateo, Rogelio (2000). Ignacio de Loyola: su espiritualidad y su mundo cultural. Bilbao: Instituto Ignacio de Loyola/Universidad de Deusto/Ediciones Mensajero.

García-Mateo, Rogelio (1998). Fuentes filosófico-teológicas de los ejercicios según el currículum académico de su autor. Em: Plazaola, Juan (ed.) (1998). Las fuentes de los Ejercicios Espirituales de San Ignacio. Actas del Simposio Internacional (Loyola, 1519 septiembre 1997). Bilbao: Ediciones Mensajero.

Gilmont, Jean-François (1961). Les écrits spirituels des premiers jésuites: inventaire commenté. Em Subsidia ad Historiam Societatis Iesu (Vol. 3). Romae: IHSI.

Guibert, Joseph (1941). Le Généralat de Claude Aquaviva (1581-1615): une place dans l'histoire de la spiritualité de la Compagnie de Jésus. AHSI, 10, 59-93.

Guibert, Joseph de (1953). La spiritualité de la Compagnie de Jésus: esquisse historique. Em Bibliotheca Instituti Historici Societatis Iesu (Vol. IV). Romae: IHSI. 
Iparraguirre, Ignácio (1961). Répertoire de Spiritualité Ignatienne: de la mort de S. Ignace à celle du P. Aquaviva (1556-1615). Em Subsidia ad Historiam Societatis Iesu (Vol. 4). Romae: IHSI.

Iparraguirre, Ignácio (1964). Estilo Espiritual Jesuítico (1540-1600). Bilbao: El Mensajero del Corazón de Jesús.

Madrid, Jairo H. Cifuentes (2002). Momentos de decisión: reflexiones sobre tres momentos en la vida de Ignacio de Loyola. Retirado em 02/05/2002 da Pontificia Universidad Javeriana, no World Wide Web http://www.puj.edu.co/pedagogia/seminario

Marin, Louis (1996). Le Récit, réflexion sur un testament. Em Marin, Louis (1999). L'écriture de soi: Ignace de Loyola, Montaigne, Stendhal, Roland Barthes (pp. 137-155). Paris: Presses Universitaires de France.

Melloni, Xavier (2002). Los Ejercicios en la Tradición de Occidente. Cuadernos EIDES, 23. Retirado em 01/02/2002, do site Cristianisme i Justícia, no World Wide Web: http://www.fespinal.com/espinal/castellano/eides/eies23.htm

Pousset, Edouard (1992). Foi et liberté: présentation des Exercices spirituels de saint Ignace de Loyola. Paris: Vie Chrétienne/CERF.

Ruiz Jurado, Manuel (1976). La espiritualidad de la Compañía de Jesús en sus Congragaciones Generales. AHSI, XLV(90), 233-290.

\section{3) FILOSOFIA}

\section{- Geral}

Agostinho, Santo (1994). A Trindade (A. Belmonte, Trad.). São Paulo: Editora Paulus (original latino de 416).

Agostinho, Santo (1991). A cidade de Deus (2 vols.). Lisboa: Fundação Calouste Gulbenkian (original latino de 426). 
Aquino, Tomás de (1947). Suma Teológica, I Parte, Questões 75-83: Do homem considerado na sua alma (A. Correa, Trad.). São Paulo: Gráfica Siqueira (original latino de 1473).

Baccarini, E. (2002). La soggettività dialogica. Roma: Aracne.

Lauand, Jean (2003). Razão, Natureza e Graça - Tomás de Aquino em Sentenças: Estudos introdutórios e tradução. Mirandum Plus, 3. 1-51. Retirado em 12/08/2003, do World Wide Web http://www.hottopos.com/mp3/sentom.htm.

Marías, Julián (1998). Liberdade e Responsabilidade: Conferência proferida em Madrid, em 22-4-98, como parte do curso, no qual o conhecido filósofo analisou a perspectiva cristã, isto é, o modo como, independentemente da fé, o cristianismo informou a visão de mundo característica do Ocidente. (L. J. Lauand, Trad. e Ed.). International Studies on Law and Education, 2. Retirado em 27/10/2003, do World Wide Web www.hottopos.com/harvard2/liberdade_e_responsabilidade.htm

Reale, Giovani e Antiseri, Dario (1990). História da Filosofia: Antigüidade e Idade Média (L. V. Borda e A. M. Montoya, Trad.s). São Paulo: Paulus (Coleção Filosofia, vol. 1) (original italiano de 1966).

Rittier, Joachim e Gründer, Karlfried (1998). Historisches Wörterbuch der Philosophie. Vol. 10. Berlin: Wissenschaftliche Buchgesellschaft Darmstadt.

\section{- Séculos XVI e XVII}

Chacon, Vamireh (1998). O humanismo ibérico: a escolástica progressista e a questão da modernidade. Lisboa: INCM.

Monteiro, Miguel Corrêa (1998). Finalidade Teística e Humanismo no Primitivo Ideal Pedagógico Jesuítico. Millenium Internet, 12, Outubro. Retirado em 01/02/2002, da Revista Eletrônica Millenium, no World Wide Web: http://www.ipv.pt / millenium / pers12_jesuit.htm. 
Rodrigues, Manuel Augusto (1981). Do Humanismo à Contra-Refoma em Portugal. Revista de História das Idéias, 3, 125-176.

Schmitt, Charles B. (1992). Aristote et la Renaissance (L. Giard, trad.) Paris: PUF (original inglês de 1983).

Schmitt, Charles Bernard (1969). Experience and Experiment: a comparison of Zabarella's view with Galileo's in De motu. Studies in the Renaissance, 16, 80-138.

Tavares, Severiano (1948). O Colégio das Artes e a Filosofia em Portugal. Revista Portuguesa de Filosofia, 4(3), 227-238.

\section{4) HISTÓRIA DA COMPANHIA DE JESUS}

\section{- Produção de conhecimento}

Brizzi, Gian Paolo (org.) (1981). La "Ratio Studiorum”: modelli culturali e pratiche educative dei gesuiti in Italia tra Cinque e Seicento. Roma: Bulzoni Editore

Caeiro, Francisco da Gama (1989). El Problema de las raíces historicas. In: Barba, Enrique M. et al. (dir.) (1989). Ibero-américa, una comunidad. Tomo I. Separata. Madrid: Ediciones de Cultura Hispánica.

Carvalho, José Vaz de (1991). Jesuítas portugueses com obras filosóficas impressas nos séculos XVI-XVII. Revista Portuguesa de Filosofia, 47, 651-659.

Diego, Rafael Maria Sanz de (1991). La novedad de Ignacio de Loyola ante un mundo nuevo. Em Plazaola, Juan (Ed.) (1991). Ignacio de Loyola y su tiempo: Congresso Internacional de Historia. Bilbao: Mensajero e Universidad de Deusto.

Dinis, Alfredo (1991). Tradição e transição no Curso Conimbricense. Revista Portuguesa de Filosofia, 47, 535-560.

Dominique, Pierre (1965). La politique des jésuites. Paris: CAL. 
Fabre, Pierre-Antoine e Romano, Antonella (1999). Presentation. Revue de synthèse 2-3(120), 247-260.

Giard, Luce (dir.) (1995). Les jésuites à la Renaissance: système éducatif et production du savoir. Paris: PUF.

Lewalter, Ernst (1998). Metafisica ispanico-gesuitica e tedesco-luterana del XVII secolo: un contributo alla storia dei rapporti culturali ibero-tedeschi e alla preistoria dell'idealismo tedesco. Em: Mozzarelli, Cesare (org.) (1998). Chiesa romana e cultura europea in Antico Regime. Roma: Bulzoni Editore.

Lohr, Charles H. (1995). Les jésuites et l'aristotelisme du XVIe siècle (81-91). Em Giard, Luce (dir.) (1995). Les jésuites à la Renaissance: système educatif et production du savoir (pp. 251-308). Paris: PUF.

Martins, António Manuel (1989). Verbete “Conimbricense”. Enciclopédia Logos II, 11121126.

Martins, António Manuel (1996). O conimbricense Manuel de Góis e a eternidade do mundo. Revista Portuguesa de Filosofia, 52, 487-499.

Massimi, Marina (1999a). Conhecimentos psicológicos e experiência religiosa na história da cultura luso-brasileira: um sermão de Antônio Vieira. Em Massimi, Marina e Mahfoud, Miguel (orgs.) (1999). Diante do Mistério: psicologia e senso religioso (pp. 47-55). São Paulo: Ed. Loyola.

Massimi, Marina (1999b). O lugar dos conhecimentos psicológicos na cultura luso-brasileira, do século XVI ao século XVIII. Em Guedes, Maria do Carmo e Campos, Regina Helena de Freitas (orgs.) (1999). Estudos em História da Psicologia (pp. 97-117). São Paulo: Editora da PUC. 
Massimi, Marina (2001a). Identidade, Tempo, Profecia na visão de Padre Antônio Vieira. Memorandum, 1, 13-32. Retirado em 10/10/01, do World Wide Web: http:// www.fafich.ufmg.br/ memorandum/ artigos01/ massimi01.htm.

Massimi, Marina (2001b). A Psicologia dos Jesuítas: Uma Contribuição à História das Idéias Psicológicas. Psicologia Reflexão e Crítica, 3(14), 625-633.

Massimi, Marina; Mahfoud, Miguel; Silva, Paulo José Carvalho da e Avanci, Sílvia Helena Sarti (1997). Navegadores, colonos e missionários na Terra de Santa Cruz: um estudo psicológico da correspondência epistolar. São Paulo: Edições Loyola

Massimi, Marina e Silva, Paulo José Carvalho da (orgs.) (2001). Os olhos vêem pelo coração: conhecimentos psicológicos das paixões na cultura luso-brasileira dos séculos XVI e XVII. Ribeirão Preto: Holos

Mir, Gabriel Codina (1968). Aux sources de la pédagogie des jésuites: le "modus parisiensis ”. Romae: IHSI.

O’Malley, John W. (1999a). The Jesuits: Culture, Sciences and the Arts. 1540-1773. Toronto/Buffalo/London: University of Toronto Press.

Silva, Paulo José Carvalho da (2000). A tristeza na cultura luso-brasileira: os sermões do padre Antônio Vieira. São Paulo: EDUC/FAPESP

Silva, Paulo José Carvalho da e Massimi, Marina (1987). A construção do conhecimento psicológico na obra História do Predestinado Peregrino e seu irmão precito (1682) de Alexandre de Gusmão S.J. Sociedade Brasileira de História da Ciência, 17, 71-80.

Spadaro, Antonio (1991). Alle radici della pedagogia dei gesuiti: il rapporto dell'uomo con il mondo e la storia alla luce della spiritualità di Ignazio di Loyola. Em Guerello, F., Schiavone, P. (ed.) (1991). La pedagogia della Compagnia di Gesù. Atti del Convegno Internazionale. Messina 14-16 novembre 1991, 579-588. 
Zanlonghi, Giovanna (2003). La psicologia e il teatro nella riflessione gesuitica europea del Cinque-Seicento. Memorandum, 4, 61-85. Retirado em 12/08/2003, do World Wide Web: http://www.fafich.ufmg.br/ memorandum/ artigos04/ zanlonghi.htm.

- Geral

Abad, Camilo Maria (1957). Vida y escritos del V.P. Luis de la Puente de la Compañía de Jesus (1554-1624). Comillas: Universidad Pontificia.

Astrain, Antonio (1905). Historia de la Compañía de Jesús en la Asistencia de España. Tomo II: Laínez-Borja (1556-1572). Madrid: Est. Tipográfico “Sucesores de Rivadeneyra”. Astrain, Antonio (1909). Historia de la Compañía de Jesús en la Asistencia de España. Tomo III: Mercurian-Aquaviva (Primera Parte) (1573-1615). Madrid: Est. Tipográfico "Sucesores de Rivadeneyra".

Astrain, Antonio (1913). Historia de la Compañía de Jesús en la Asistencia de España. Tomo IV: Aquaviva (Segunda Parte) (1581-1615). Madrid: Est. Tipográfico "Sucesores de Rivadeneyra".

Bangert, E. V (1990). Storia della Compagnia de Gesú. Genova: Marietti

Fouqueray, Henri (1910). Histoire de la Compagnie de Jésus en France - Vol 1: Les origines et les premières luttes (1528-1575). Paris: A. Picard et fils.

Giard, Luce et Vaucelles, Louis de (1996). Les jésuites à l'âge baroque (1540-1640). Grenoble: Jérôme Millon.

Guerra, Alessandro (2003). Un generale fra le milizie del papa. La vita di Claudio Acquaviva. AHSI, 72, 199-203.

Institucion de Estudios Complutenses (s.d.). La Compañía de Jesús en Alcalá de Henares (1546-1989). Alcalá de Henares: IEC.

Lacouture, Jean (1994). Os jesuitas: 1. Os conquistadores. Porto Alegre: L\&PM (original francês de 1988). 
Lamalle, Edmond (1981-1982). L'archivio di um grande Ordine religioso: L'Archivio Generale della Compagnia di Gesù. Archiva Ecclesiae, 24-25, 89-120.

Lamalle, Edmond (2004). Compagnia di Gesú. Retirado em 15/04/2004, da Totus Tuus Network - Pagine cattoliche, no World Wide Web: http://www.paginecattoliche.it/ CompagniaDiGesù.htm.

Leite, Serafim (1938-1950). História da Companhia de Jesus no Brasil, 10 vols. Lisboa-Rio de Janeiro: Portugália-Civilização Brasileira.

Loomie, A. J. (1994). Fr Joseph Creswell's Informacion for Philip II and the Archduke Ernest ca August 1594. Recusant History, 22, 465-481.

Mendes, Margarida Vieira (1989). A oratória barroca de Vieira. Lisboa: Editorial Caminho.

O’Malley, John W. (1999b). I primi gesuiti (A. Schena, Trad.). Milano: Vita e Pensiero. (original inglês de 1993).

Pécora, Alcir (1988). O demônio mudo. Em Novaes, Adauto (org.) (1988). O olhar (pp. 301316). São Paulo: Companhia das Letras.

Pécora, Alcir (1994). Teatro do Sacramento: a unidade teológico-retórico-política dos sermões de Antonio Vieira. São Paulo: EDUSP.

Pécora, Alcir (1998). Les sermons funèbres du padre Vieira. Em Mattoso, Katia de Queiroz (org.) (1998). Naissance du Brésil moderne (pp. 194-202). Paris: Presses de l'Université de Paris-Sorbonne.

Pécora, Alcir (2001). Máquina de gêneros: novamente descoberta e aplicada a Castiglione, Della Casa, Nóbrega, Camões, Vieira, La Rochefoucauld, Gonzaga, Silva Alvarenga e Bocage. São Paulo: Editora da Universidade de São Paulo.

Rodrigues, Francisco (1938). História da Companhia de Jesus na Assistência de Portugal. Tomo II, Vol. II. Porto: Livraria Apostolado da Imprensa. 
Rondon, Víctor (1997). Música jesuita en Chile en los siglos XVII y XVIII: primera aproximación. Revista musical chilena [online], 188(51), 7-39, jul/1997. Retirado no dia 13/06/2003, do World Wide Web: http://www.scielo.cl/ scielo.php? script=sci_arttext\&pid=S0716-27901997018800001\&lng=es\&nrm=iso.

Ruiz Jurado, Manuel (1980). Origenes del noviciado en la Compañía de Jesus. Em Bibliotheca Instituti Historici Societatis Iesu (Vol. XLII). Romae: IHSI.

Scaduto, Mario (1964). Storia della Compagnia di Gesù in Italia. Vol III: L'epoca di Giacomo Laínez (1556-1565) - Il governo. Roma: Edizioni “La civiltà cattolica"

Scaduto, Mario (1974). Storia della Compagnia di Gesù in Italia. Vol IV: L'epoca di Giacomo Laínez (1556-1565) - L’azione. Roma: Edizioni “La civiltà cattolica"

Scaduto, Mario (1992). Storia della Compagnia di Gesù in Italia. Vol V: L'epoca di Francesco de Borgia (1556-1565). Roma: Edizioni "La civiltà cattolica".

\section{- Missões}

Groupe de Recherches sur les Missions Religieuses Ibériques Modernes (1999). Politique missionaire sous le pontificat de Paul IV: un document interne de la Compagnie de Jésus en 1558. Mélanges de l'École Française de Rome: Italie et Méditerranée, 111(1), 277-344.

Imbruglia, Girolamo (1992). Ideali di civilizzazione: la Compagnia di Gesù e le missioni (1550-1600). Em: Prosperi, Adriano e Reinhard, Wolfgang (ed.) (1992). Il nuovo mondo nella coscienza italiana e tedesca del Cinquecento: Annali dell'Istituto storico italo-germanico. Quaderno 33 (pp. 287-308). Bologna: Il Mulino.

Massimi, Marina e Prudente, André Barreto (2002). Um incendido desejo das Índias... São Paulo: Ed. Loyola.

Pizzorusso, Giovanni (1997). Le choix indifférent: mentalités et attentes des jésuites aspirants missionnaires dans l'Amérique française au XVIIe siècle. Mélanges de l'École 
Française de Rome: Italie et Méditerranée, 109(2), 881-894.

Sánchez, Javier Burrieza (2003). La recompensa de la eternidad. Los fundadores de los colegios de la Compañía de Jesús en el ámbito vallisoletano. Revista de Historia Moderna Anales de la Universidad de Alicante, 21, 7-74.

\section{5) HISTÓRIA GERAL}

Andrés-Avelino, Esteban Romero (1960). San Diego de San Nícolás. Em: Año Cristiano, IV. Madrid: Ed. Católica (BAC 186).

Azaña, D. Esteban (1882). História de la Ciudad de Alcalá de Henares (Antigua Compluto). Adicionada con una reseña histórico-geográfica de los pueblos de sua partido judicial. Tomo I. Alcalá de Henares: Imprenta de F. Garcia C.

Azaña, D. Esteban (1883). História de la Ciudad de Alcalá de Henares (Antigua Compluto). Adicionada con una reseña histórico-geográfica de los pueblos de sua partido judicial. Tomo II. Alcalá de Henares: Imprenta de F. Garcia C.

Beeching, Jack (2000). La Battaglia di Lepanto (A. Audisos, trad.). Milano: Bonpiani (original inglês de 1982).

Chartier, Roger (dir.) (1991). La correspondance: les usages de la lettre au XIXe siècle. Paris: Fayard.

Da Cás, Danilo (1996). A universidade luso-brasileira: universidade de fato (1572-1822). Tese de Doutorado não publicada, Universidade Estadual Paulista, Marília, SP.

Hébrard, Jean (1990). La correspondance au XIXe siècle: approche historique. Extrait du Colloque "L'Épistolarité a travers les siècles: geste de communication et/ou d'écriture. Centre Culturel International de Cerisy la Salle France. Stuttgart: Franz Steiner Verlag.

Kristeller, Paul Oskar (1995). Tradição clássica e pensamento do Renascimento. Lisboa: Edições 70 (original inglês de 1954). 
Le Goff, Jacques (dir.) (1989). O Homem Medieval (M. J. V. de Figueiredo, Trad.). Lisboa: Editorial Presença (original francês de 1989).

Longo, Nicola (1981). De epistola condenda: L'arte di “componer lettere” nel Cinquecento. Em: Quondam, Amedeo (org.) (1981). Le “carte messaggiere”: retorica e modelli di comunicazione epistolare: per un indice dei libri di lettere del Cinquecento. Roma: Bulzoni Editor.

Mayeur, Jean-Marie et col. (dir.s) (1994). Histoire du Christianisme: des origines à nos jours. Tome VII - De la Réforme à la Réformation (1450-1530). Sèvres: Desclée.

Mendiola, Alfonso (2003). Un nuevo reto a la interpretación de las crónicas de la conquista: historzar el concepto de experiencia. Ciudad de Mexico: mimeo.

Morse, Richard McGee (1988). O espelho de Próspero: cultura e idéias nas Américas (P. Neves, Trad.). São Paulo: Companhia das Letras (original inglês de 1988).

Mozzarelli, Cesare e Zardin, Danilo (orgs.) (1997). I tempi del Concilio: Religione, cultura e società nell'Europa tridentina. Roma: Bulzoni Editora.

Pécora, Alcir (1999). Cartas à Segunda Escolástica. Em: Novaes, Adauto (org.) (1999). A outra margem do Ocidente (pp. 373-414). São Paulo: Companhia das Letras.

Prosperi, Adriano (1996). Tribunali della coscienza: inquisitori, confessori, missionari. Torino: Giulio Einaudi editore.

Tin, Emerson (2003). "Familiar del Universo": arte epistolar e lugar-comum nas cartas familiares (1664) de d. Francisco Manuel de Melo. Dissertação de Mestrado, Curso de Teoria Literária do Instituto de Estudos da Linguagem da Universidade Estadual de Campinas, UNICAMP, Campinas, SP.

Torgal, Luís Reis (2001). Nota Histórica. Retirado em 09/08/2001, da Universidade de Coimbra, no World Wide Web http:/ www.ci.uc.pt/ sdp/ prospecto9798/ his.historia.html. 
Tormo y Monzó, Elías (s.d.). Alcalá de Henares. Madrid: Gráficas Marinas.

World Wide Web http://www.magma.ca/ gcsfred/ cap3.html, retirado em 01/02/2002.

Yates, Frances A. (1975). L'Art de la mémoire (D. Arasse, trad.). Paris: Gallimard (original inglês de 1966).

\section{6) HISTORIOGRAFIA}

Bloch, Marc (1999). As transformações das técnicas como problema de psicologia coletiva. Signum 1, 169-181

Braudel, Fernand (1989). Gramática das civilizações (T. Costa, Trad.). São Paulo: Martins Fontes (original francês de 1963).

Boureau, Alain (1989). Propositions pour une histoire restreinte des mentalités. Annales 6(44), 1491-1504

Cardini, Franco (1993). História, História Social, História Oral, Folclore. Psicologia USP 4(1/2), 319-328.

Certeau, Michel de (2002). A escrita da história. (M. L. Menezes, Trad.). São Paulo: Forense Universitária (original francês de 1975).

Debus, Allen G. (1991). A ciência e as humanidades: a função renovadora da indagação histórica. Revista da SBHC, 5, 3-14.

Delumeau, Jean (2003). O que sobrou do paraíso? (M. L. Machado, Trad.). São Paulo: Companhia das Letras (original francês de 2000).

Marrou, Henri-Irinée (1978). Do conhecimento histórico (R. C. de Lacerda, Trad.). Rio de Janeiro: Zahar Editora (original francês de 1954).

Massimi, Marina (1995). Descoberta, ação, conhecimento e poder no Brasil Colonial: estudos histórico-psicológicos. Tese de Livre Docência, Faculdade de Filosofia, Ciências e Letras de Ribeirão Preto, Universidade de São Paulo, São Paulo, SP. 
Massimi, Marina (2000). A história das idéias psicológicas: uma viagem no tempo rumo aos novos mundos. Em Biasoli Alves, Zélia Maria Mendes e Romanelli, Geraldo (orgs.) (2000). Diálogos Metodológicos sobre prática de pesquisa (pp. 11-30). Ribeirão Preto: FFCL-RP.

Massimi, Marina e Mahfoud, Miguel (1997). Abordagens psicológicas à experiência religiosa: traçando uma história. Em A Psicologia e o Senso Religioso: anais do seminário Ribeirão Preto/SP - 14 e 15 de março de 1997 (pp. 43-58). Ribeirão Preto: USP/Salus.

Vainfas, Ronaldo (1997). História das mentalidades e história cultural. Em: Cardoso, Ciro Flamarion S. e Vainfas, Ronaldo (orgs.) (1997). Domínios das História: ensaios de teoria e metodologia (pp. 127-164). São Paulo: Campus. 